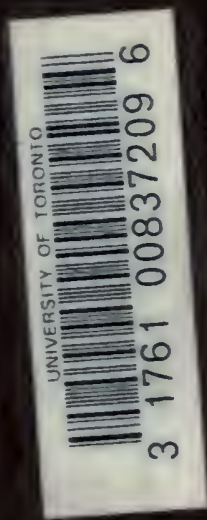




$$
82 k
$$





\section{Digitized by the Internet Archive in 2008 with funding from Microsoft Corporation}

http://www.archive.org/details/surveysofnatureh02tayluoft 


\section{TAYLOR, CHARLES III \\ SURVEYS of NATURE,}

$$
\begin{aligned}
& \text { IISTORICAL, MORAL, } \\
& \text { and } \\
& \text { ENTERTAISIAG } \\
& \text { exhibiting the }
\end{aligned}
$$

PRINCIPLES of NATURAL SCIENCE

in various Branches

by

FRANCIS FITZGERALD Efg:

Stuther of the Lechures in the Urtististichository.

$$
\text { VOL:II. }
$$

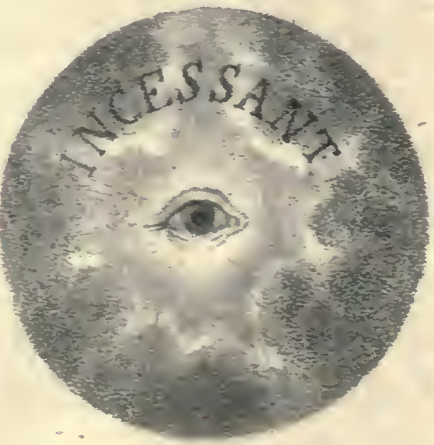

London, Publisheat by. C. Tuylur ATo Holborn. 


$$
\begin{gathered}
Q H \\
45 \\
T 3 \\
V .2 \\
695893 \\
\hline 27.2 .59
\end{gathered}
$$




\section{$\begin{array}{lllllll}\mathrm{P} & \mathrm{R} & \mathrm{F} & \mathrm{A} & \mathrm{C}\end{array}$ TO THE \\ SECOND VOLU M E.}

JATURAL Hiftory is a fubject very extenfive in itfelf, 1 and which has been treated by many writers in a manner fo voluminous, that its information is now rather a ftudy than an accomplifhment, and much beyond the retention of the memory. In fact, on fome articles it offers much that fcarce deferves retention, while its accounts of others are very limited.

This divifion of our work is an attempt to prefent a general view of the fubject, as little encumbered by foreign matter, or by idle tales, as poffible: offering the chief fpecimens of each kind, and enabling the reader to acquire a knowledge of moft particulars which are interefting. It was neceffary in this intent to avoid the fhackles of fyftem, yet, firmly adhering to order, to group what feemed allied, and to fate thofe apparent relations which indicate fimilarity, to avoid repetition and redundance, to affint the memory by concifenefs, perfpicuity, and relevancy.

Want of fubject has been no difficulty, but to determine on a judicious felection, and to regulate their introduction, 


\section{$P \quad R \quad E \quad F \quad A \quad C$ E.}

has often been embarraffing, and occupied much reflection: We prefume to think that no work of only equal bulk contains more information of general and familiar ufe, nor completer or more compendious manual of natural knowledge : whether its merit be equal to the labour it has coft, or its utility be equal to the wifhes of its author, muft now be fubmitted to the determination of a candid and indulgent public; from whom, in the courfe of publication, we have received the moft liberal teftımony, and to whom we return our grateful acknowledgments, for numerous inftances of approbation, and numerous marks of kindnefs and conf, dence. 


\section{O N T E N T S}

\section{SE C O N D V OL U M E.}

\section{SUR VEYS OF NATURE.}

$$
\text { PART THE THIRD. }
$$

MN the firt in rank on the globe-yariation-by climate-manners I 1 of life-cuftoms-food - his original colour - of one original.

\section{VARIETIES OF THE HUMAN SPECIES.}

Laplanders, \&c. page I.-Tartars, \&c. page 2.-Chinefe, \&c. page 3.-Negroes, page 3.-Americans, page 3.-Europeans, page 4.

$$
\text { QU A D R U PEDS. }
$$

The HORSE $P A G E$

PAGE

The Ass

VoL. II.

The Mule

The $Z_{E B}$ RA 


\section{O N T E N T S.}

\section{RUMINATING ANIMALS,}

The Cow kind

The Urus

The Bifon

The Buffalo page 12.
PAGE
I3

15

15

$x 6$
Chinefe Stag

Corfican Stag.

Tragelaphus

Axis

Mexican Stags

The Fallow DeEr

The Ros-Buck

The ELK

The REIN-DEER

$P_{A G E}$

Sheep and Goat T- 18

Iceland Sheep

Broad-tailed Sheep - - $\quad 20$

Strepficheros - - 20

Guinea Sheep - - $\quad 20$

The Mouffion = - $2 \mathrm{I}$

The Goar

Angora Goat

Syrian Goat

American Goak of Good Hope Goat Whida Goat

IBEX

Chamors

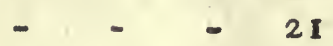

22

22

22

23

23

23

23
The J_ama

The BOAR

The PECCARY

The Musk Animal

PAGE

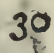

31

$3 \mathrm{I}$

$3 I$

$3 I$

$3 \mathbf{I}$

PAGE

The CAMEL and Dromedary

39

THE HOG KIND.

PAGE

The AFRICAN WILD BOAR

43

The BABYROUESSA

45

46

48

GAZELLES, or ANTELOPES.

Tive PAGE

Tiwelve varieties $\quad 26-27$

The Bubalus . - 27

The Condoma - $\quad-\quad 327$

The GUIB - - 27

African wild Goat . . : $\quad 27$

Chevrotin

27

THE DEER KIND.

PAGE

The Stag

28

\section{THE DOG KIND.}

$A G E$

The Doc

His varieties

The Wolf

Wolf of America

The Fox

His varieties

The JACKAL

The ISATIS

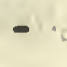

The Hyena

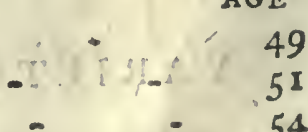

54

57

$5^{8}$

60

60

$6 I$

62

THE 


\section{O N T E N T S.}

THE CAT KIND. PAGE

The Domestic Cat wild Cat

Its varieties

The Lios

The TIGer

His varieties

The Cougar

The Panther

The Lépard

The Jaguar

The Ounce

The TIGER-CAT

The Lysx

The SYAGUSH

The SERval .

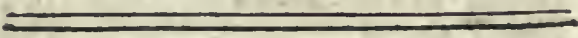

THE WEASEL KIND. PAGE

The Weaser

The ERMine

The FERRET

The Polecat

The Martin

The SABLE

The ICHNEUMON

The STINKARDS

The Squarh

'The Skunk

The Conepate

The Zorille

The Gexette

The Ciyet

The Glutros

12

83

84

84

84

85

86

87
THE HARE KIND.

64 The HARE

65 The RABBIT

65

66

70

71

72

73

73

73

74

4

75

76

The Syrian Rabbit

The Marmotte

The Agours

The PAca

The Guinea-Pio

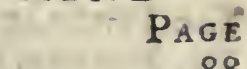

88

-90
$-\quad 91$

92

94

95

96

PAGE

The Szutrael

97

Its varieties

97

The Flying Squirrel

99

\section{THE RAT KIND.}

The great RAT

PAGE

The black Rat - - 100

The black Water Rat - 100

The Mouse - roI

The long-tail'd Field Moufe IOr,

The Shrew Moufe

The Dormouse

The Musk Rat

The Hamster

The LEMING

IOI

The Mole

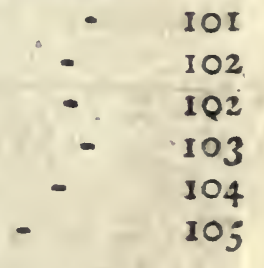

The HEDGe-Hog

The TANrec

1 


\section{C $\quad 0, N-T-E \quad N \quad T$.}

\section{PAGE}

The TENDRAC

The Porcupine 108

The Couando

The UrJon

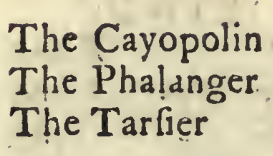

PAG 120 120

120

THE, MONKEY KIND.

Apes.
The Ouran Outang -

The Pongo

The Ape

The long-armed

The Magot

PAGE

The BaBOoN

B A B̧ O, ONs.

The $W$ anderow

The Pigtail

MON KEYS.

The Ouarine

African. American.

Their varieties.

SAPAJOUS

SAGOINS

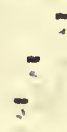

II I

II 3

II 3

II 3

113

113

II 4

114

115

116

117

117

\section{A MPHIBIOUS QUA- DRUPEDS.}

PAGE

The Otter

The Beaver

I 2 I

123

The SEAL Or PHOCA :

The MORSE

125

The Manati

126

I 26

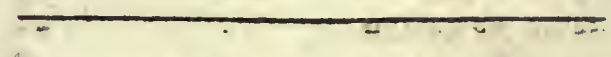

PAGE

The Hippopotamos - 127

The Tapili - 128

\section{SCALY AND SHELLY} QUADRUPEDS.

PAGE

The Pangolin

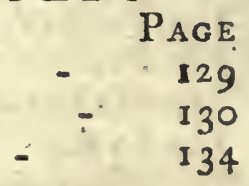

The Armadilug

Its varieties

PAGE:

The Mococo

The Mosgooz

The VARI

The Lori

$\begin{array}{rr}\because & \text { PAGE } \\ - & 118 \\ - & 118 \\ - & \text { II9 } \\ - & 119\end{array}$

QUADRUPEDS that will not range under any of the foregoing divifions.

The Elephas T

OP POS SU M s.

The Oppqssum

The RHINOCEROS

The MAR wose

PAGE

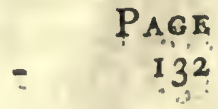

: 135

The 


\section{C, O N T E N $\mathrm{N}$ T S.}

\section{PAGE}

The Giraffe, or Camelopar- The Sloth

DALIS

The Bear

Its varietics

The RAcoon

The Coatrmond
135 Its varieties

136 The Grrboa

137

${ }_{13} 8$

The Kangaroo

The Bat

139 Its varieties
PAGE

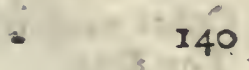

- 145 142
ANT-EATERS Their varieties

\section{SURVEYS OF NATURE. \\ PART THE FOURTH.}

$$
\text { B } \quad I \quad R \quad D \quad S \text {. }
$$

THEIR external thape - their feathers - wings-mahner of rifing-

1 toes-bones-refpiration-length of life-moulcing-incubation -paffage-varieties.-Distinctions, page 10.

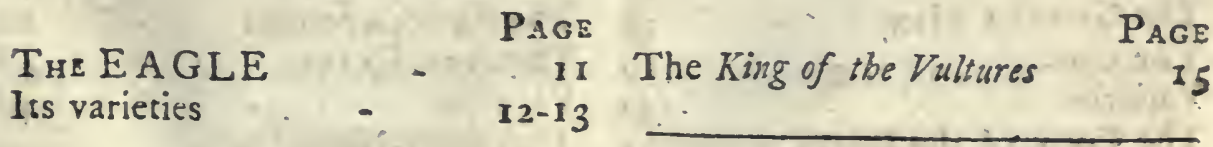

The VULTURE Its varieties

\section{PAGE}

13

14
The Falcon

The gyr Falcon

Falcon-gentle
PAGE

16
$-\quad 16$
16

Other 


\section{C $O N \quad \mathrm{~N} E \mathrm{~T} E \mathrm{~N}$ S.}

Other varieties

The Kite

The Buzzard

Its varietits
PaGE

I 6

17

17

I7

The PARTRIDGE

PAGE

Varieties

34

The QuaIb

Varieries

The Butcher-Birds PAge Their varieties 18

The great HORNED OW L The common Horned OwI The Howlet Varieties

\section{THE OWL KIND.}

PAgE

19

20

20

20
THE POULTRY KIND.

PAGE

The Bustard

Varieties

The Tinamous

The Turkey

The PEAcock.

The Hoccos

The Pheasant

Varieties

The Guinea Hen

The Cock

Varieties

The Cock of the Rocks

The Agami

The Grous

The black Cock

Varieties

Red Cork
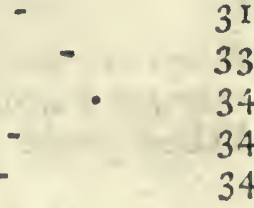

$3 \mathrm{x}$
24

25

26

$3 \mathrm{I}$
The PIE KIND.

The Raven

The Crow

The JACKDAW

The Chovgh

The Rook

The Calaos

The Toucan

The Magpie

The Cbatterer

The Roller

The Nutcr a CKer
PAOE

38

39

39

40

40

40

$4 \mathrm{I}$

43

44

44

44.

THE WOODPECKERS.

The green Woodpecker

PAGe

The Crenpers

45

The HOOPOES

The Promerops

The BEr-EATERS

The FLY-CATCHERS

The Ant,Eaters

Varieties

48

The WRY-NECK

49 .

The ANis

The Ux-Pecker

N ES T S.

Varieties 


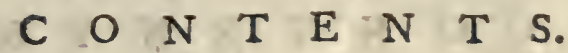

The BIRD OF PARADISE.

Varieties

THE CUCKOo.

Varieties

$$
\text { - 53:54 }
$$

PARROTS.

The Cockatoo

ParRots

LORIES

Long-tailed Parroguets

Sbort-tailed Parroquets.

Mackaws -

Amazons

CRIKS

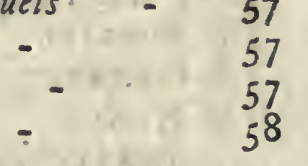

THE PIGEON.

The Stock-Dove

Domeftic Pigeon

The Ring Dove

The Turtle Dove

The Peacock Pigeon

The Crown Fowl

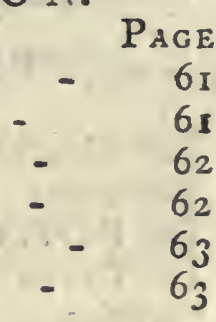

THE SPARROW KIND.

PAGE

The THRUSH

The Black Bird

The BLUE BIRD

VoL. II.
PAgE

55

56

56

56

57

57

57

The CANARY BIRDS - 70

The BULl-Finch - 7 I

The GROS-BEAK - 72

The Cross-BILl $\quad-72$

The BLUE-BREAST - 69

The Black-CaP - 70

The WREN 70

The Golden-crefted Wren 70

The Goat-sucker, or Night-

SWALLOW

The House-Swallow - 74

The MARTIN $\quad-, \quad 74$

The SWIFT.

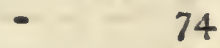

$P_{1 G E}$

ThE S W A L L O W.

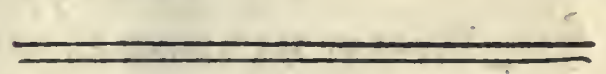

THE HUMMING BIRDS.

Varieties

PAGE
W A T E R B I R D S.

C R A N ES.

The Crani

$\mathrm{b}$
PAge

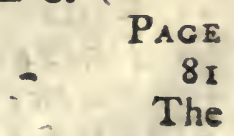


C O N T E N T S.

The STORk

Varieties

PAGE

The Inis

Variety

The JABIRU

The Nandopoa

The KamichI

The Secretary

The Cariama

Crowned African Crane

Numidian CRANE

SPOON-BILL

Flamingo
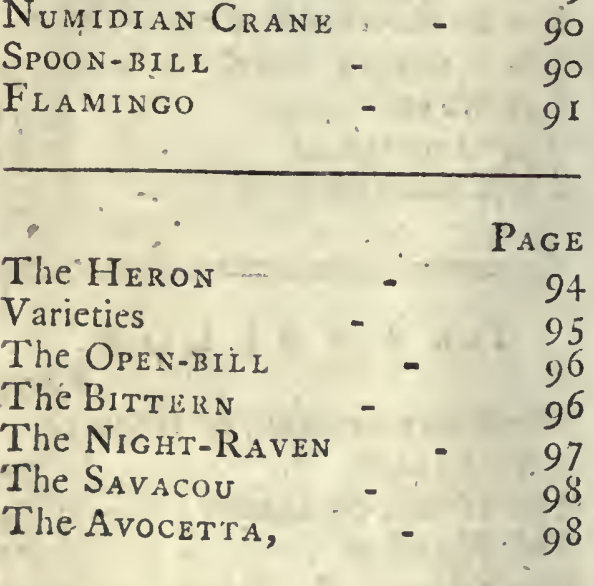

Small BIRDS of the CRANE KIND.

Varieties

The Woodcock

The SNipe.

The COMBATAN T

The LAPWING

The Oyster-Cátciter - 103

The TURNSTONE

The WATER-OUZEL

The Rails

The JACANA

The. PORPHY RION

The KING-FISIER
PAge $99,-100$ 101 102

103

105

$-105$

.106

107

-107
$-\quad 108$

- 108
The WATER-HEN

PAGE

The Coot *

109

110

PAge

The GREBE

I I I

Varieties

The ANHINGA

I I 2

The PILICAN

PAGE

The Cormorant

The Alis a tross

Gulls and Petrels

The FrIgate Bird

I I 2

The Boobles

I 5

I 6

The GANNET

I I 7

II 7

II 8

The NODDY

I 20

Sea-Swallows

I 2 I

Tropic Birds

12 I

122
The PENGUIN.KIND.

P'AGE

The Magellanic Penguin 124 The Auk

The Puffin

I 24

The Diver

124

$V$ arieties

The Goofander

125

I 25

I 26

\section{THE GOOSE KIND.}

The SWAN

The Goose

Varieties
PAGE.

127

128

129

The 
C O N T E N T S.

Page Page

The Duck $\quad 129$

Varieties

BIRDS that will not range under any of the foregoing divilions.

The Ostrich

The Tourou

The Cassowary

The Dodo

SURVEYS OF NATURE.

PART THE FIFTH.

Oviparous Cuadupeds.

The Tor torse

$\begin{array}{ll}\text { Land Tortoife } & \text { I } \\ \text { Frefh-water Tortoife } & \text { I }\end{array}$

Sea-Tortoifes, or Turthe I 45

Trunk Turte-

Loggerhead Turcle " - 148

Hawkßill Turtle - $\quad 148$

Mediterranean Turtle - $\quad \mathbf{1 4}_{48}^{8}$

\section{Lizards}

The Crocodile

The Whip-TaIL

130
PAGE

I 31

133

$\therefore \quad 13.5$

PAGE

The FORKED-TONGUEDLIZARDI 55

The IGUANA * -

The BASILISK

The Galeote

The GREY Lizard

The Green Lizard

The CAMELEON

The WOOD-SLAVER

The Gecko

The Sers

The ChALCIDE

The Dragon

The SALAMANDER

The flat-tailed Salamander

I 55

156

I 57

I 57

158

158

161

I 6 I

163

163

164 164 165

The three-fingered Salamander 167

OVIPAROUS QUADRUPEDS without -
TAILS

The Frog

The Bull Frog

Tree Frogs

The Toad

The brown Toad

The Calamite

The PIIAL
PAgE. I67

I 68

172

172

174

177

177

177
B I P E R E P T I E S.
P.GE
The FlUted - -
The SHELTOPUSICK

149

$-\quad 150$

OF SERPEN TS, P. Is

Their Diftinetions

185

154

Of venonous Sempenis 


\section{C $O \mathrm{O} N \mathrm{~T} E \mathrm{E}: \mathrm{T} S$.}

The VIPER

The Viper of Egypt

The AMMODYTES

The Cerastes

The NAJA

The YELLOW SERPENT

The Whip Snake, \&cc.

The SNAKE

'The Black Snake

The LADIES' SNAKE

The Dabore

The Borguacu

The RatrLe SNAKE

The BIIND Worm

The AMPHISBEN 2 .
PAGE

189 Huso

19.1

I9I

191

192

193

195

194

195

195

I 96

I 97

198

201

201

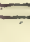

\section{OF FISHES}

Cetaceous Fishes

The WHALE

The NARWHAL

The Cachaiot

The Dolpins,

GRAMPUS and PORPESSE
PAgE 203 208

209

214

215

$-217$

(1)

CARTILAGINOUS FISHES,

The SHARK

The RAY lind

$P_{\Lambda G E} 218$

SKatr

RAY

Rough RAY

Fire-hlare

TORPEDO

The LAMPREY

The Sturgeon

219

222

222

223

22.3

224

224

225

226
Anomalous Cartilaginous Fishes.

The Mole

The. Fishing Frod

$P_{\text {AGE }}$ 228

The LuMP Fish

The SEA SNAIL

The Pipe Fish

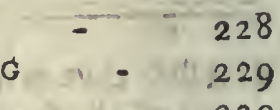

The Hippocampus

The SEA OrB

Varieties

The Galdey

229

229

230

230

230

230

231

.SPINOUS FISHES PAGE 231

The SALMON

233

The EeL

233

The CoD

The HADDOCK,

WHITING,

Mackarel

23.

HIIRRING - - 235

PILCHARD

STICKLEBACK

236

DORADO

FIYING FISH

PIKE

234.

236

238

238

238

SHELL FISH.

The LOBSTER

The CRAB

The Land Crab

The Violet Crab

The Soldier Crab

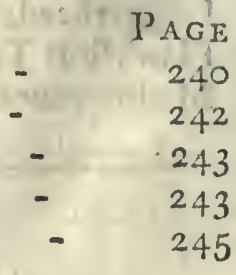

Testaceous Fishes and their Shells 
$C O O N$ T E N T S.

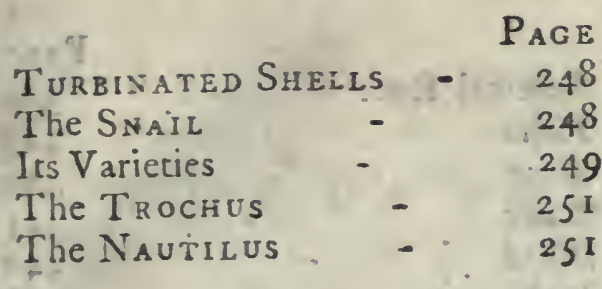

BIVALVE SHELLS.

PAGE

Thie Mussel

The Oyster

- 253

The Scallop

The Razor Shell

Pearls

MULTIVALVE SHELLS.

PAGE

The SEA URCHIN O - $\quad 257$

ACOR N, \&C.

257

Phold ates

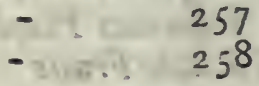

PART THE S I X T H. I N S E C T S:

WINGLESS INSECTS, Page 263

The SPIDER

Houfe Spider

Garden Spider

264

Water Spider

Tarantula

The FLEA

The Louse

The Leaf Loufe and Varieries 27

The Bug

The WOOd Louse

The Monoculys

The Scorpio:s

The SCOLORENDRA 265

267

268
The GaluY WORM

PAGE

277

INSECTS which acquire WINGS.

The Dragon Fly - $\quad \therefore 278$

The Lion Axt , - 280

The GRAsSHOPPER,

Locuft,

Cricket,

Mole Cricket - $2 \mathrm{~S}_{2}$

The EARwiG - - 289

The Cuckow-Spit - 289

The Wacer Tipula - 290

Water FLY

Water SCORPION

The EPHEMERA

290

290

290

CATERPILLARS, SC. 293

The SILK-WORM - - 3OI

The BEE

The Humble Bee . - 309

The Wood Bee

The Mafon Bee

The Ground Bee

The Leaf-cutring Bee -

The Wall Bee

266 The WAsP

The Solitary Wafp

The ICHNEUMO: FLy

268 The ANT

269. African Ants

304

jog

310

310

310

311

sis

314

315

317

272 BEETLES, \& . 318

273 The May Bug - $\quad 3$ IS

274 The Tumble Dung _. . 3 39

274 The Elephant Beetle . - 319

277 The Glow Wr crm - 320 
$C O N$ T E N T S.

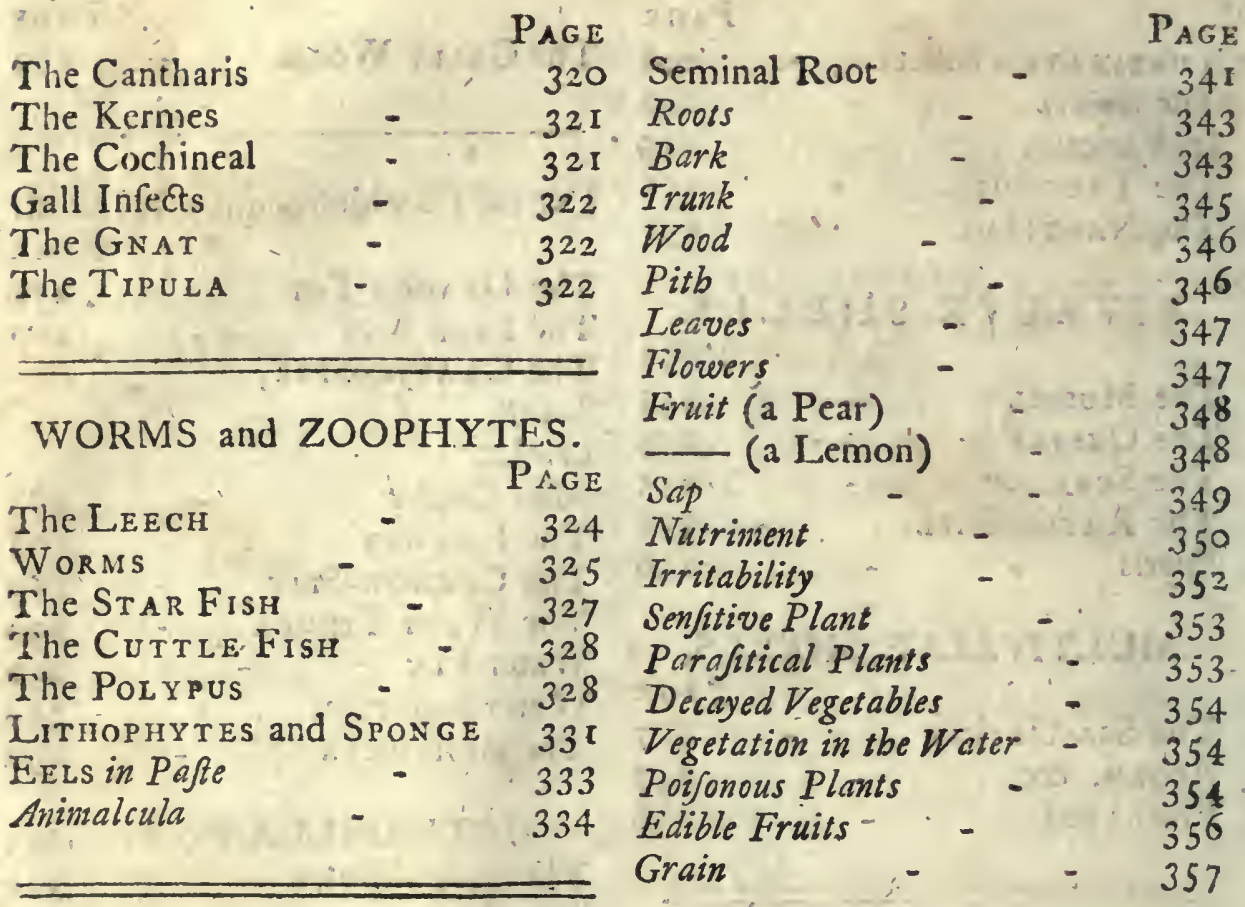

Principles of Vegetation.

\section{Propagation}

Grafting

Seeds
PAGE

339

340.

$34 \mathrm{I}$
Cliasses of Plants according to $\begin{array}{ll}\text { the Sexual Syftem. } & \text { p. } 35^{8}\end{array}$
$34 \mathrm{I}$

343

343

345 346 346

347

348

348

349

350

$55^{2}$

35

354

354

354

356

357 


\section{SURVEYS OF NATURE:}

\section{PART THE THIR D.}

$\mathrm{N}$ confidering the inhabitants of the globe, we muft doubt1 lefs place Man the firft, in rank, and confequence, if we regard merely the animal part of his compofition, wherein, neverthelefs, in common with animals of all kinds, he is fubject to variations, arifing from local circumftances, climate, manner of life, cuftoms, and nutriment; thefe variations are not fo diftinct, or indelible, as may induce us to difallow one common origin; yet they are fufficiently ftriking, to juftify particular notice. We proceed therefore to offer fuch remarks as occur on this fubject, and fuch general information on the nature of animals, and their manners, as may juftify our principles.

It thould feem, that, according to the rank of creatures in the fcale of life, was their fubjection to variation : thofe of the lower degrees changing moft from their priftine ftock, thofe of greateft fecundity changing fomething at each generation, while creatures of greater bulk, longer life, or fuperior fa: culties, lefs affected by thefe caufes, maintained a nearer refemblance to the forms, manners, and properties of their parental origin. According to this idea we may expect plants to vary greatly froin fimilar plants in their native climates (efpecially in their powers), Infeets, Reptiles, fmaller PART III.

Quadrupeds, 


\section{$(2)$}

Quadrupeds, and Birds; and this we find to be fact, not only in external appearance, but alfo in internal conformation, though the latter is noticed only by the curious-for inftance, animals which with us have four ftomachs, have in Africa only two; the reafon we guefs to be, becaufe the African grafs is more fucculent, and fooner gives out its nutritive particles than ours, confequently requires lefs compreffion, and preparation, which is the office of thefe ftomachs. In external form, very: Atrange changes occur: fowls fent from Europe to Virginia, quickly lofe their rumps, and by this lofs become as it were metainorphofed: nor need we go fo far for proofs; it is well known, our bull-dogs degenerate on the continent, and no art can maintain their race in perfection; fo do our theep. If in the fame latitudes this occurs, no wonder difference of latitude hould have great effect : creatures which réquire an ardent fun muft be very much enfeebled in northern climates. This is happy for us ; efpecially, if it be true, that we have in our own country moft of thofe venomous infects (if not the reptiles) which beneath the Equator are fo mifchievous, and deadly; but with us they are fo weak and diminutive, that they require the microfcope to afcertain them. Our frakes are doubtlefs of the fame nature as equatorial ferpents, but of how different powers! how feeble their thifs! how diminifhed their terrors! Larger animals (as the horfe) preferve more of their native properties, and manners, though they vary in fize and frength; but no creature is capable of inhabiting the globe at large, of occupying diftant and contradictory climates, like man, who 

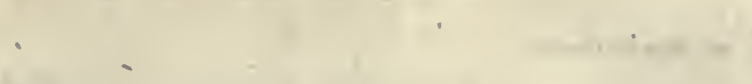

nes

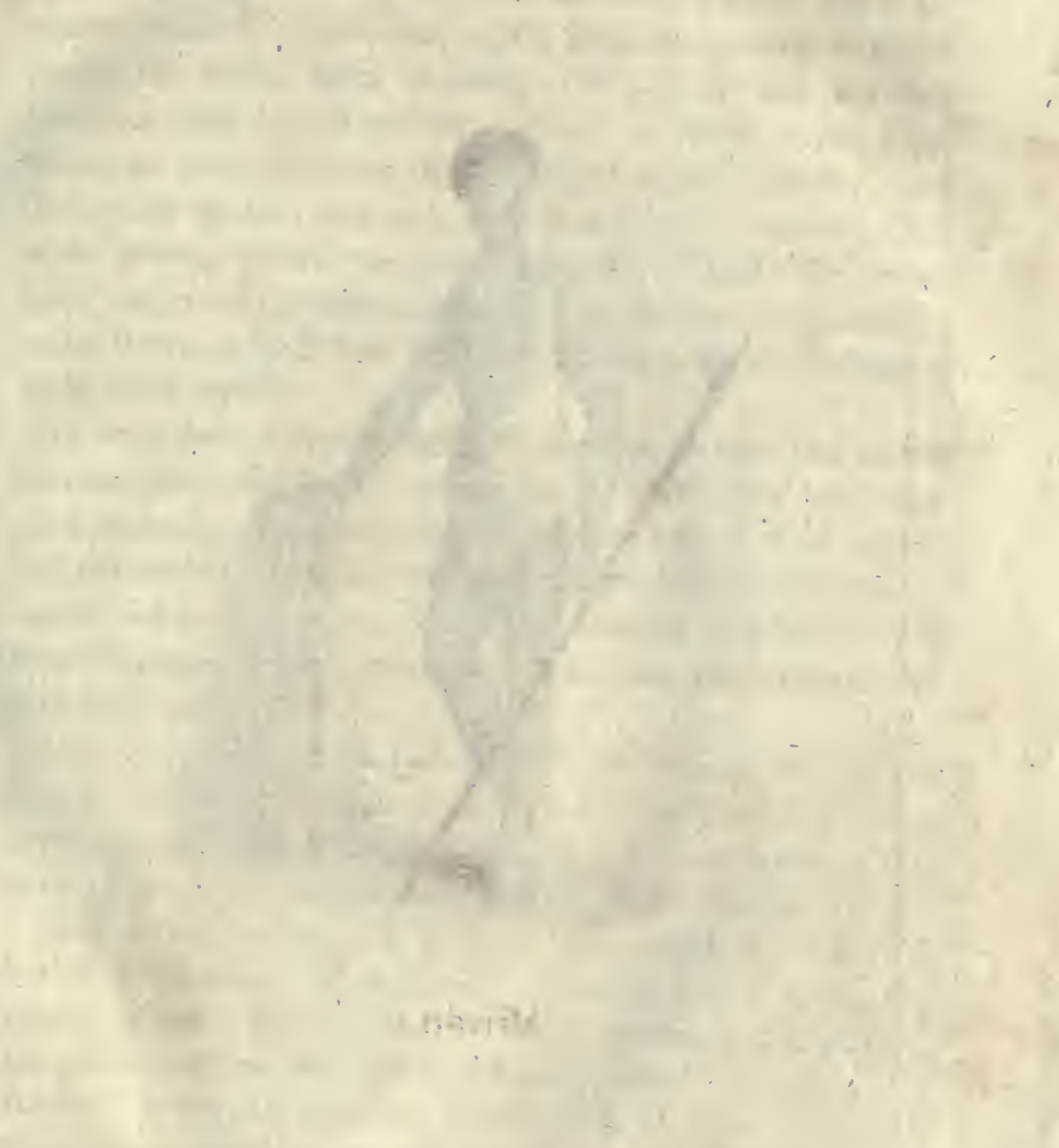


Varriefy of the Utuman . Species

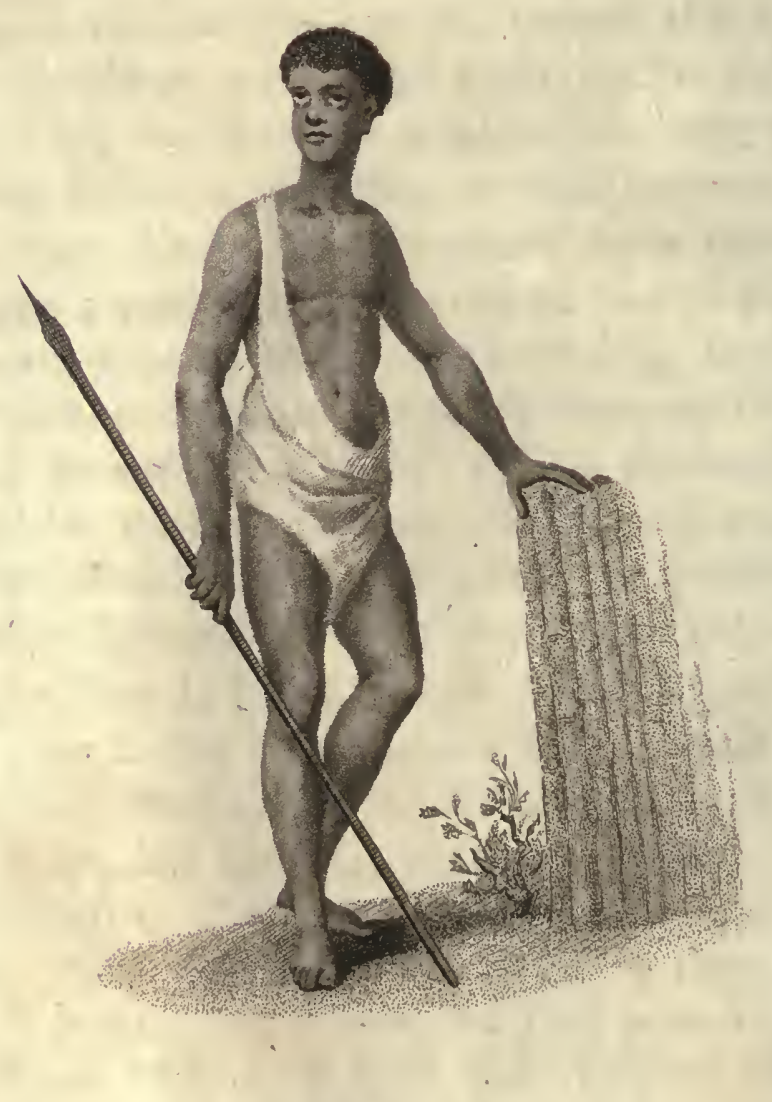

African. 


\section{$(3)$}

iwhó every where maintains his erect figure', his commanding tifpect, and his dominion over all creatures around his habitation; thofe he felects for fervice he domefticates; thofe he chafes fly before him; dreading his power; and expelled (more or lefs) by his enmity: Even monfters of the deep, which in their profound receffes might expect fecirity, even thefe yield to his arts; and; difturbed in their retreats, feek other Ahores; where to attain maturity. Thus the whale is no longer of the amazing dimenfions he once was, or if he teach them, it is diftant from where the prow of navigation molefts his repofe.

If then man be leaft fubject to changes, yet we find in the humaii race confiderable varieties : we may juftly infer very great diverfity among animals of the fame tribe; their refemblances are lefs marked, and their approaches to other fpecies thearer and more frequent: we thall however chiefly advert to the differences among mankind, and leave the inference to reflection and good fenfe.

We have fuggefted as the caufes of variety among the human fpecies, climate, manner of life, cuftoms, and nutriment; we conclude that the ere are principal caufes of this variety, becaufe if thefe be changed the effect changes alfo.

Climate is not only, in general, hot or cold, moift or dry, but in fome places in the fame countries; hotter or colder, moifter or drier, than in others: Upon mountains, in valleys, the action of the fun differs; confequently heat differs alfo. Around lakes and marihes, by the fides of great rivers, we expect fuperabundant humidity, more watery air is breathed 


\section{(4)}

(acting internally), or affects the fkin, the hair, \&cc. (acting externally); mineral particles alfo impregnate the air, and have confequent influence not only on health, but on appearance.-This caufe might be traced ad infinitum.

MANNERS OF LIFE vary fo greatly among mankind, that much muft be attributed to them. Cleanlinefs permits free perfpiration, and a clear fkin; upon this Europeans value themfelves; while Hottentots clothe themfelves in greafe, and of tawny make foot-black complexions. Thofe al ways in fmoke muft needs be fmoke-dried; thofe always fedentary feeble and inactive, thofe always fcorched by the fun thrivelled, thofe expofed to the feafons weather-beaten; thefe effects are fo evident in the various claffes of people which compofe our own nation, that little imagination is neceffary, to allow their full force among thofe tribes of mankind whofe days are paffed in conftant fubjection to any one of them.

Customs and MANNERS follow clofely on modes of life: what was at filft arbitrary becomes at length national, what has been efteemed a beauty determines the withes of all, and by degrees their features; the power of imagination is not eafily calculated. Religious rites, tyrannical impofition, local difeafes, conftant depreflion of mind, fuperftition (which is always gloomy) and uther habitual manners, greatly influence the expreffion of the ceuntenance.

FOoD, above all, is the caufe of variety, by its quantity or its quality. If little and ill fupplied, can it afford nutriment adequate to the confumption of the body? Can it fill the parts, and furnith throughout the whole, thofe juices requifite 


\section{(5)}

to general iricreafe? If now enjoyed in abundance, is there no danger of indifpofition by repletion? If now withheld, is not weaknefs and debility likely to enfue ? The quality of food is confeffedly different, as well animal as vegetable: if coarfe and refufe, or in good condition; if juicy, or dry in its nature ; if frefh, or preferved by artificial means, falt, or fmoke, correfpondent effects on thofe who live on it may naturally be expected. And to this muft be added, the very great variety of liquors; fermented or fimple, water, milk, beer, wire, fap of trees, fpirits from corm, rice, vinous fermentations, and what anfwers the fame end; opium. Thefe are many of them daily noticed by us, and from what we actually fee, we may readily conclude their influence elfewhere.

Thefe caufes branch out into almolt innumerable effects and vary in the fame kingdom, or country. To trace them further is rather the province of the Geographer than the Naturalift; though it muft be owned that whatever concerns our race, interefts fomething in us fuperior to curiofity.

What was the original colour of mankind, has long divided the learned. Upon the whole, I acquiefce in the opinion that the lighter Afiatics are the neareft to it; for in our owly country, which ftands firt in fairnefs of complexion, the tints of thofe among us expofed to the air, Sxc. are little different from many Afiatics. That expofure to air is our matural ftate; I am perfuaded: and thus circumftanced, the cleareft fkin acquires a tint of brunette. The deviation of colour has been toward fairnefs in Europe,-towards blacknefs in Africa. Not but that the upper $\mathbb{k}$ in of a Negro is colourlefs as our 


\section{( 4 )}

(acting internally), or affects the 1 kin, the hair, \&cc. (acting externally); mineral particles alfo impregnate the air, and have confequent influence not only on health, but on appearance.-This caufe might be traced ad infinitum.

MANNERS of LIFE vary fo greatly among mankind, that much muft be attributed to them. Cleanlinefs permits free perfpiration, and a clear fkin; upon this Europeans value themfelves; while Hottentots clothe themfelves in greafe, and of tawny make foot-black complexions. Thofe always in fmoke muft needs be fmoke-dried; thofe always fedentary feeble and inaclive, thofe always fcorched by the fun thrivelled, thofe expofed to the feafons weather-beaten; thefe effects are fo evident in the various claffes of people which compofe our own nation, that little imagination is neceffary, to allow their full force among thofe tribes of mankind whofe days are paffed in conftant fubjection to any one of them.

Customs and manners follow clofely on modes of life: what was at firft arbitrary becomes at length national, what has been efteemed a beauty determines the wifhes of all, and by degrees their features; the power of imagination is not eafily calculated. Religious rites, tyrannical impofition, local difeafes, conftant depreffion of mind, fuperftition (which is always gloomy) and uther habitual manners, greatly influence the expreffion of the countenance.

FOOD, above all, is the caufe of variety, by its quantity or its quality. If little and ill fupplied, can it afford nutriment adequate to the confumption of the body? Can it fill the parts, and furnith throughout the whole, thofe juices requifite 


\section{(5)}

to general increafe? If now enjoyed in ábundarice, is there no danger of indifpofition by repletion? If now withheld, is not weaknefs and debility likely to enfue? The quality of food is confeffedly different, as well animal as vegetable: if coarfe and refufe, or in good condition; if juicy, or dry in its nature ; if frefh, or preferved by artificial means, falt, or fmoke, correfpondent effects on thofe who live on it may naturally be expected. And to this muft be added, the very great variety of liquors, fermented or fimple, water, milk, beer, wirie, fap of trees, fpirits from corn, rice, vinous fermentations, and what anfwers the fame end, opium. Thefe are many of theni daily noticed by us, and from what we actualiy fee, we may readily conclude their influence elfewhere.

Thefe caufes brancli out into almoft innumerable effeets and vary in the fame kingdom, or country. To trace them further is rather the province of the Geographer than the Naturalift; though it muft be owned that whatever concerns our race, interefts fomething in us fuperior to curiofity.

What was the original colou $\mathrm{R}$ of mankind, has long divided the learned. Upon the whole, I acquiefce in the opinion that the lighter Afratics are the nearent to it; for in our owil country, which ftands firt in fairnefs of complexion, the tints of thofe among us expofed to the air, \&x. are little different from many Afiatics. That expofure to air is our natural ftate; I am perfuaded: and thus circumftanced, the cleareft $f$ kin acquires a tint of brunette. The deviation of colour has been toward fairnefs in Europe,-towards blacknefs in Africa. Not but that the upper $\mathrm{fkin}$ of a Negro is colourlefs as our oívil : 


\section{(6)}

own: the feat of blacknefs is faid to be the reticular membrane, between the $\mathrm{fkins}$; and thistint probably arifes from fome fecretion thrown more plentifully on that part by the heat of the country, and coloured by heat, by exhalations from minerals and vegetables, and by vapours of various kinds, not omitting the dry and fultry winds of Africa.

We conclude thefe introductory remarks, by obferving the wifdom evident in difpofing each nation of inen to think highly of their own country, notwithftanding the inconveniencies apparent to Atrangers. The African enjays his heat, the Laplander his cold, the Afiatic his indolence, the European his activity. Each find a fomething peculiarly agreeable in his native climate, and is condemned by his own mouth if ungrateful to the univerfal Benefactor: nor is it lefs proper that each fhould admire his national complexion, fhould depict beauty as charming black, and feel the Mafts of love thot from delightful jet; or engage rofes and lilies in feeble comparifon with the object of admiration, and defcribe her complexion as whiter than fnow. Were it otherwife, and that our native land difpleafed us, we fhould feek foreign thores, and encounter thoufands of ufelefs perils, and unprofitable difficulties: we fhould mingle, without benefit, the tawny with the fair, the light with the duky, the white with the black, which though it may be done, and thereby proves the common nature and common origin of mankind, yet feems to promife little happinefs and comfort, little pleafure and folace, little domeftic fatisfaction, and perfonal enjoyment : without which, what is climate, complexion, manners, or even life itfelf ! 


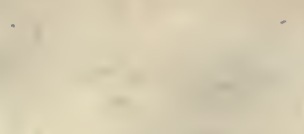

$\checkmark$

$7=$
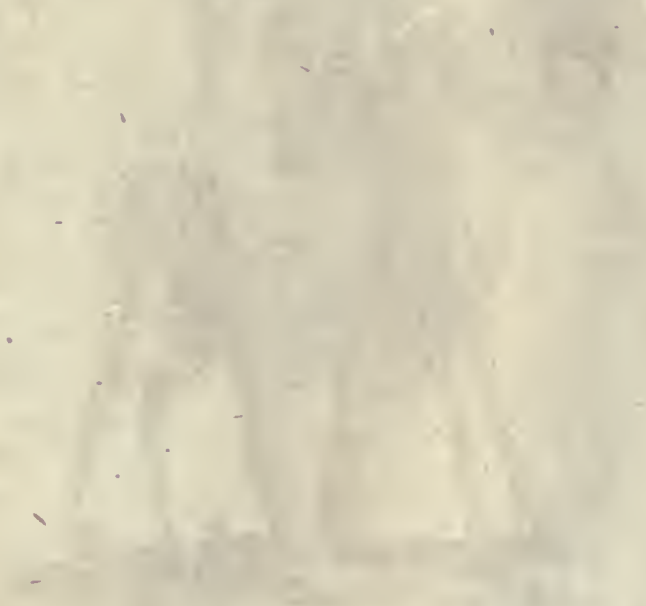

1. 


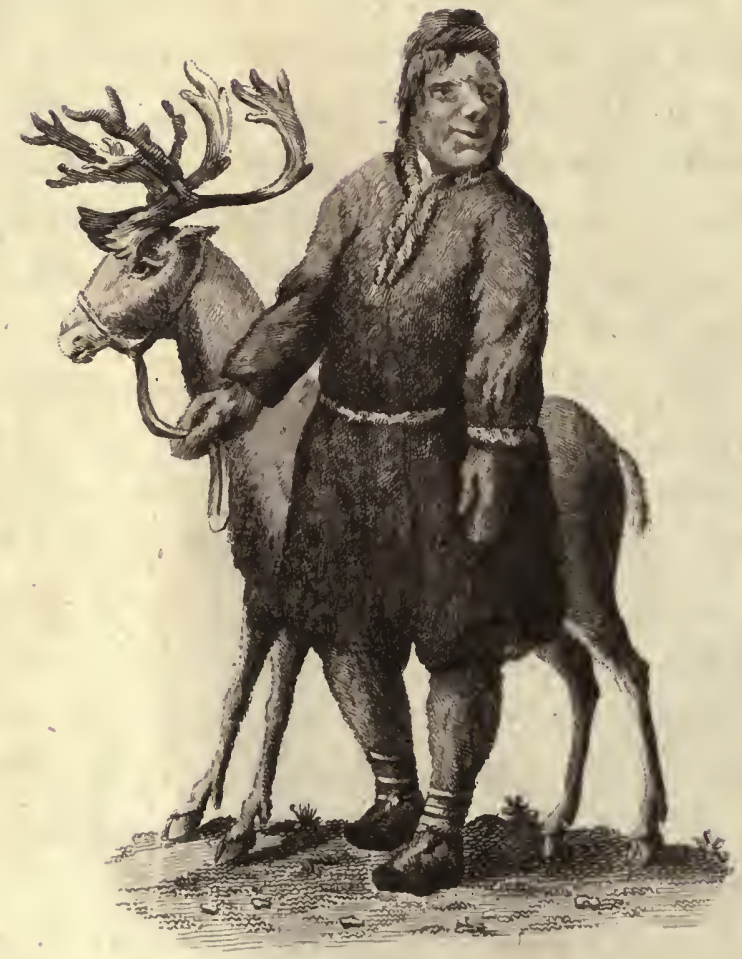

Iaplander. 


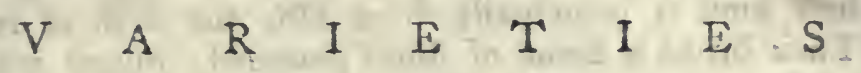

OF THE

\section{$H \cup M A N \quad S \quad P \quad E, C A$ I}

THERE feem to be about fix varieties in the human fpecies, 1 each ftrongly marked, and indicating little mixture.

The firt around the polar regions. The Laplanders, the Efquimaux Indians, the Samoeid Tartars, the inhabitants of Nova Zembla, the Borandians, the Greenlanders, and Kamfkatkadales, may be confidered as one race of people, refembling each other in itature, complexion, and-cuftoms. Under a tigotous climate, of few productions, and coarfe provifions and fcanty, their bodies have been ftinted, and their complexions changed, by cold, to a deep brown, often inclining to blacknels. Thefe people, in general, are of hort ftature, and odd thape, with countenarices favage, and manners barbarous. Their vifage is large and broad, the nofe flat and fhort, the eyes yellowinh brown inclining to black, the eye-lids drawn toward the temples, the cheekbones extremitly high, the mouth very large, the lips thick and turned outwards, the voice thin and fqueaking, the head large, the hair black and ftraight, the colour of the fkin dark greyilh. The generality are about four feet high, the talleft five. The woinen refemble the men fo nearly that one cannot, at firft, diftinguinh the fexes.

Stupidity, fuperfition, and cowardice, belong equally to thefe people: yet they are dexterous in Nkaiting, in conftructing their nedges, - wherein they are drawn over the frow, in the ufe of the bow, and the dart, in the management of their rein-deer; and thofe near the coaft, in fining. They have few wants, wlich they eafily fupply, and Linnaus fays tiney have more content and enjoyment than nations which efteem them barbarous; and which in return they do not hefitate to contemn as ill-bred and unpolite.

No. 2 I. 
They are all hunters, and purfue the ermine, the fox, the ounce, and the-martin, for their fkins. Thefe they barter, with their fouthern neighbours, for brandy and tobacco; of both which. they are fond to excefs. Their food is principally dried fifh, the fle?h of rein-deer and of bears. Their bread is bones of fifhes pounded, mixed with the inner bark of the pine tree. Their drink is train-oil, or brandy; when deprived of thefe, water, in which juniper berries have been infufed.

The fecond great variety, in the human fpecies, is the Tartar race; whofe country comprehends great part of Afia; confequently, includes a number of nations, of various forms and complexions. But, however different from each other, they agree in being unlike any other people. Thefe have the upper part of the vifage very broad, and wrinkled even in youth; their nofes thort and flat, their eyes little and funk in their heads; in fome of them, five or fix. inches afunder; their cheek-bones high, the lower part of the vifage narrow, the chin long and prominent, their teeth large and apart, their eye-brows thick, and hanging, their eye-lids thick, the face broad and flat, the complexion olive, and hair black. They are of a middle fize, extremely ftrong and robutt. They have little beard, ftraggling on the chin. They have large thighs, and fhort legs. The uglieft are the Calmoucks, whofe appearance is frightful. They lead an erratic life, dwelling in tents of hair, or fkins. They live upon flefh of horfes or camels, raw, or fodden between the horfe and the faddle; alfo filh dried in the fun. Their ufual drink is mare's milk, fermented with millet ground into meal. They thave the head, except a lock of hair, on the top, which they form into treffes, on each fide the face. The women, counterparts to the men, wear their hair, which they ornament with bits of copper and other finery.

Irreligious, immoral, indecent, dihoneft, and filthy, for the moft part characterizes thefe nations: yet among them are exceptions: but all are dexterous at plunder, traffic in laves, can endure great hardhips, and travel long without reft: are very fond of horfes, and expert in their management : receive from this animal clothing and food.

To this race is referred the Chinefe and the Japanefe, however different they feem. The Chinefe have broad faces, fmall eyes, flat nofes, and fcarce any beard; are broad and fquare-houldered, and rather lefs in ftature than Europeans. Thefe are marks common to them and the Tartars. 
Toriety of the Human Specias

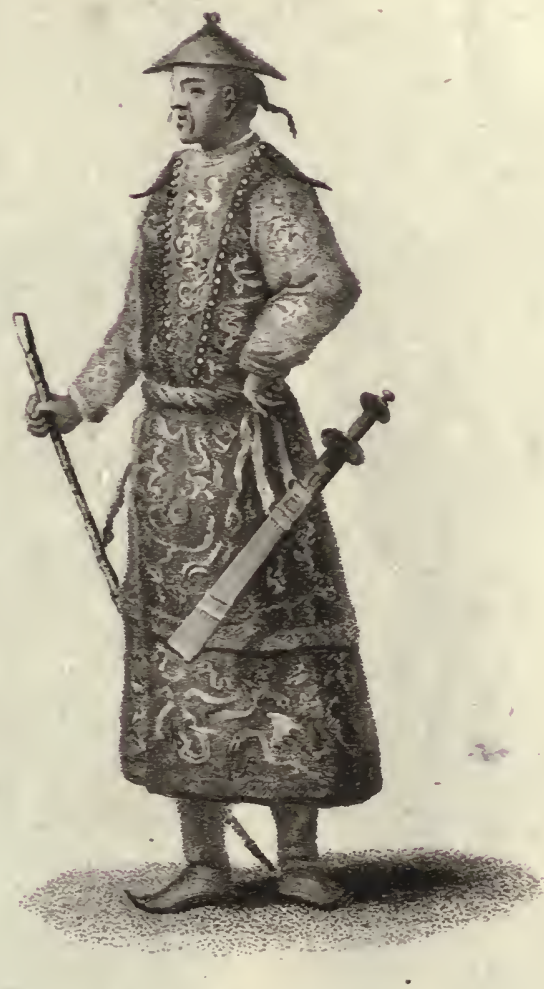

Chinefe. 




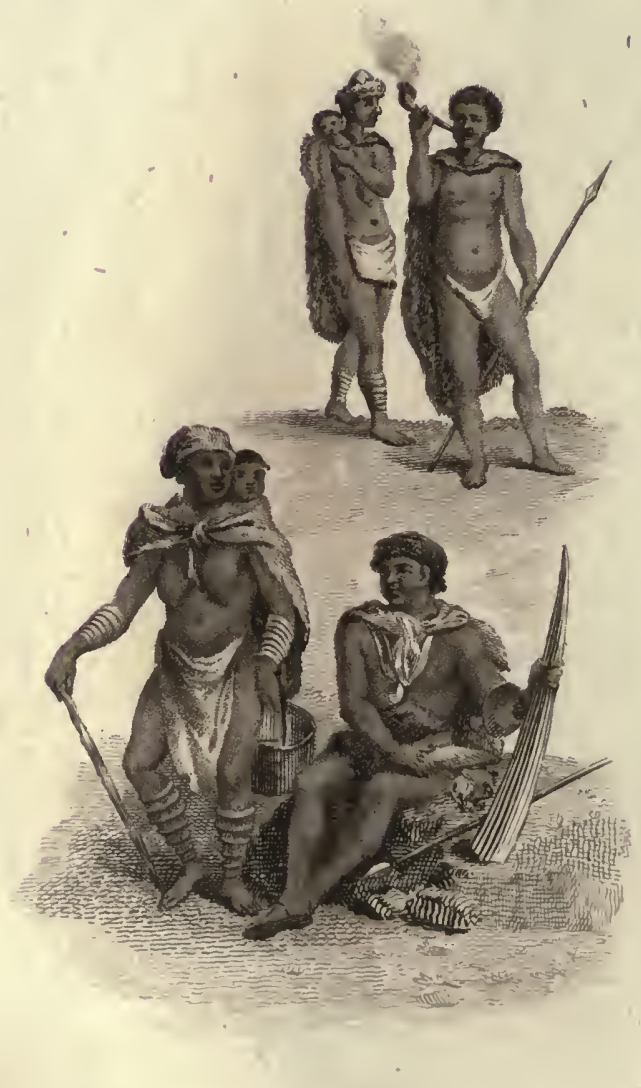

Hottentots. 


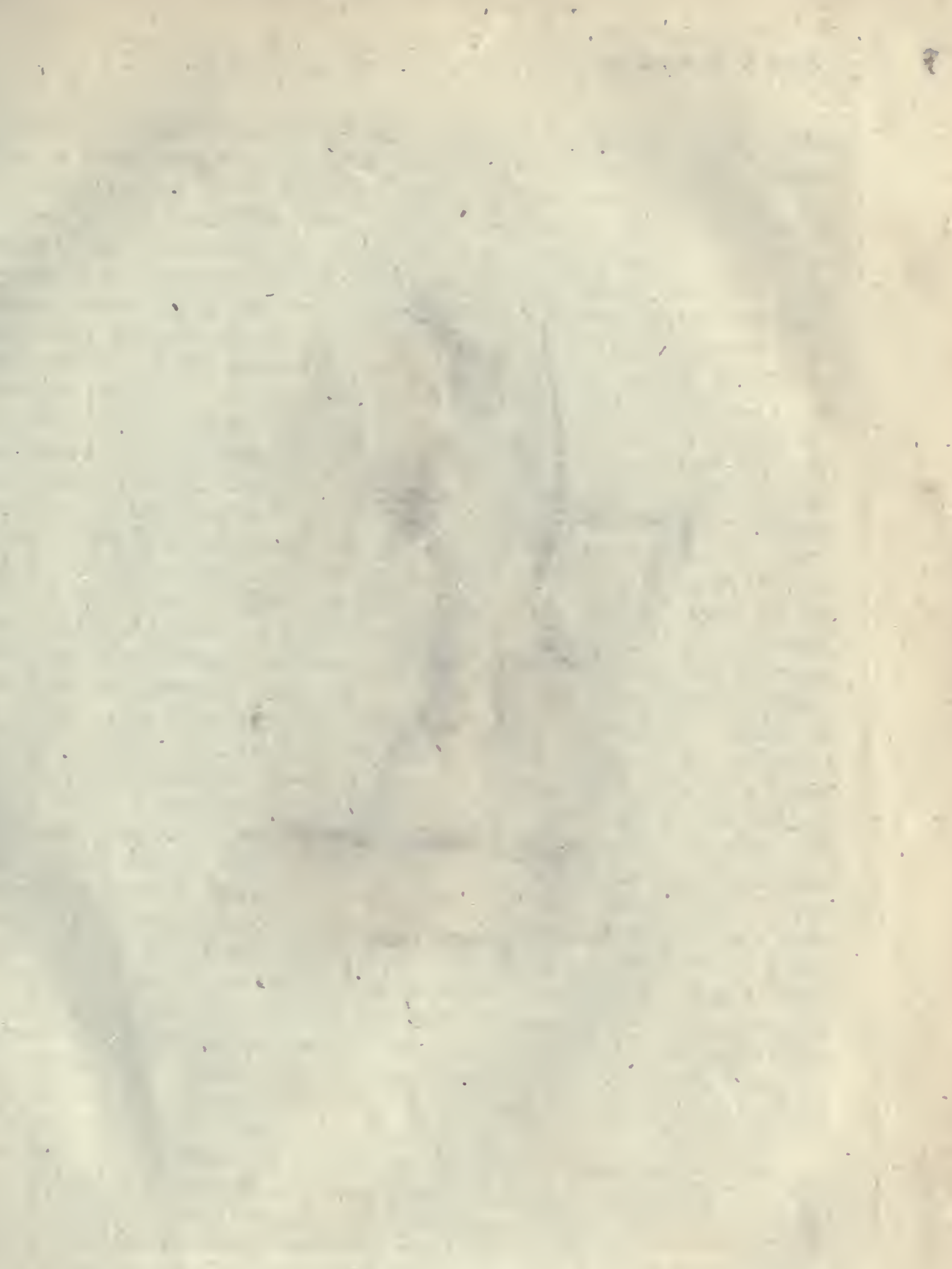




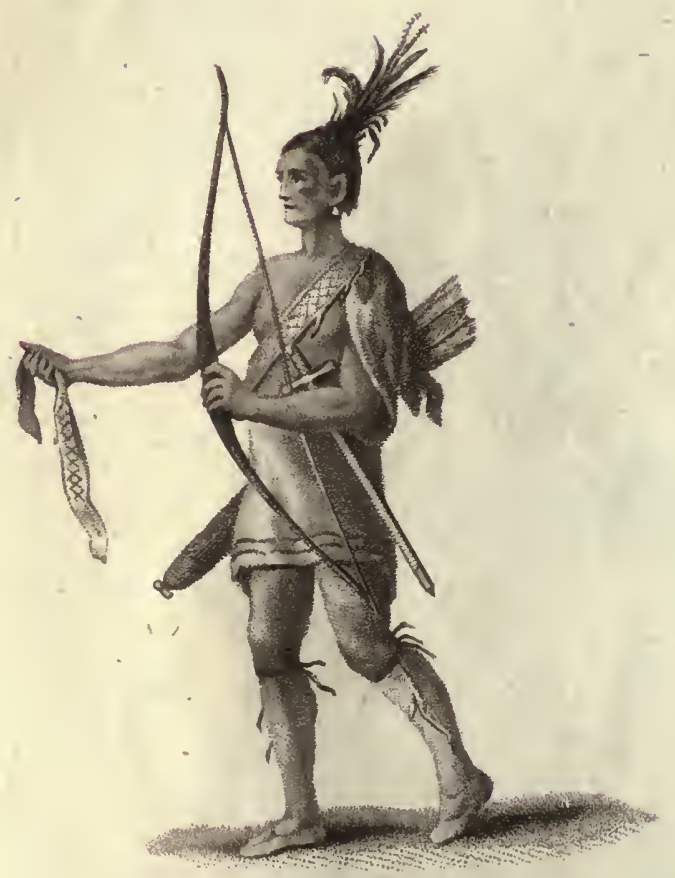

North American. 
The Japanefe refemble the Chinefe, and rank in the fame clafs. They differ in being rather browner, as they inhabit a more fouthern climate.

A third variety in the human fpecies, is the fouthern Afratics. The nations of the Peninfular India, feem to be the ftock whence the inands fcattered in the Indian ocean, have been peopled. They are, in general, of a nender Thape, with long ftraight black hair, and often Roman nofes. Thus they refemble Europeans in ftature and features; but greatly differ in colour, and habit of body. The Indians are of an olive colour, in the more fouthern parts, quite black; the women are extremely delicate. The Indians are cowardly and effeminate; the warmth of their climate influences their manners; nothful, fubmiffive, luxurious; fatisfied with fenfual happinefs without mental pleafure; contented with navery, they readily obey any mafter. Many tribes among them eat nothing that has life; but are fearful of killing the meanelt infect. To this class we nay refer the Perfians and Arabians.

The fourth variery in the human fpecies, is the. Negroes, which blacken the fouthern parts of Africa, from is degrees north to the Cape of Good Hope. The Caffres, indeed, who inhabit the fouthern extremity of that large continent, differ fomewhat in colour and features, but may be grouped together. Negro nations alfo differ: peculiar countries, as in Europe, pride themfelves on their beauty. Thofe of Guinea are ugly, and of ill fcent; thofe of Mofambique are reckoned beautiful, and have no ill fmell. Negroes, in general, are of a black colour, with a foft fmooth Ikin, proceeding from the downy foftnefs of the hair growing on it. The hair of their heads is foft, woolly, and fhort. The beard, alfo, partakes of the fame qualities; but foon turns grey, which the hair rarely does; fo that white beards, and black hair occur together. Their eyes are generally a deep hazle; their nofes flat and fhort; their lips thick and tumid; their teeth of ivory whitenefs. The climate feems alfo to relax their mental powers; they are, in general, ftupid, indolent, and mifchievous.। The many colonies of Arabians who migrated fouth into Africa, have become fcarce diftinguifhable from the original natives. As alfo the Portuguefe, who, about two centuries ago, fettled along this coaft, are become almoft as black as the Negroes, and equally barbarous.

A fifth race, different in colour, as diftinct in habitation, is the natives of America (except in the northern extremity, where they refemble the Laplanders): thefe are of a red or copper colour; nearly all of one colour; have black, thick, ftrait hair; and thin black beards; which they 


\section{OF THE HUMAN SPECIES.}

pluck out by the roots, They have, in general, flat nofes, high cheekbones, and fmall eyes; and thefe deformities they increafe by art. They paint the body and face of various colours, and confider hair, except upon the head, as a deformity to be eradicated. Their limbs are generally Mighter than thofe of Europeans. Their frequent wants make them furprifingly patient; diftrefs by familiarity becomes lefs terrible; they poffefs rather apathy than fortitude. They have a ferious air, but feldom think; are improvident; but though indolent, capable of great exertions. They live by the chace; are cruel to their enemies, but kind and juft to each other.

The fixth variety of the human fpecies, is the Europeans, and bordering nations, including the Georgians, Circaffians, and Mingrelians, the inhabitants of Afia Minor, and the northern parts of Africa, with part of the countries north-weft of the Cafpian fea. Thefe differ much, but generally agree in the colour of their bodies, their complexions, their largenefs of limbs, and vigour of underitanding. It is natural to fuppofe, that fome intermixtures muft have taken place, even among the moft fecluded nations; vifitants, whether friends or foes; fome traffic, though but little, and fome removes, though feldom, muft have had their effect. Hence mixtures, and hence thofe leffer branches, which poffefs not folely the likenefs of any unmingled race. 


\section{$(5)$

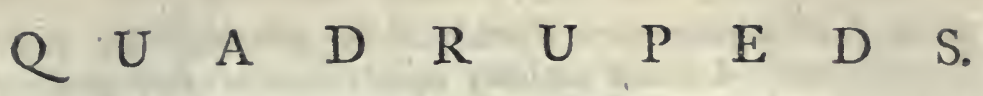

\section{TH E H O R S. E.}

$\mathrm{F}$ all quadrupeds, the horfe is moft beautiful; his noble form, his gloffy fmonthnefs of tkin, his graceful eafe of motion, and exact fymmetry of hape, have induced us to regard him as the firft of animals, and as the moft perfectly formed; yet, his internal ftrusture differs more from the human than that of all other quadrupeds.

The horfe, like other animals, is naturally wild, and domefticated by the art of man; his enemies of the foreft are but few, none but the greater kinds will venture to attack him; thefe he is able to overcome fingly, but is content to find fafety in fociety; wild horfes herding together, often in droves of five or fix hundred. As they are never attacked but at a difadvantage, when they neep in the forefts, one among their number ftands as centinel, and this office they take by turns. If a man approaches them while feeding by day, the centinel walks boldly near him, as if to examine, or to intimidate him; as the man approaches within piftol hot, the centinel alarms his fellows, by a loud kind of fnorting, upon which all fly off with the fpeed of the wind; their faithful centinel bringing up the rear. They will not admit of ftrange animals among them, even of their own kind. If a tame horfe attempts to affociate with them, they foon oblige him to feek fafety by Hight.

Arabia produces the moft beautiful breed of native horfes, the moft generous, fwift and perfevering. They are found wild, though not in great numbers, in the defarts of that country; and the natives ufe every itratagem to take them. They are active and beautiful, yet not fo large as thofe bred up tame; are of a brown colour ; their mane and tail very fhort, and the hair black and tufted. Their fwiftnefs is incredible; to purfue them with dogs is fruitlefs. By their rapid fight, they are inftantly out of view, and dogs themfelves give up the purfuit. They are taken by traps, hidden in the fand, which entangle their feet. If the horfe thus caught be young, he is confidered as a great delicacy, and affords a feaft; but if he promifes to be ferviceable in his nobler capacity, he is tamed by the ufual methods, fatigue and hunger, and foon becomes an ufeful dometic. 
The manner of trying their fpeed is by hunting the oftrich: the horfe is the only animal whofe rapidity equals that of this creature, which inhabits the fandy plains of thofe countries. When the oftrich perceives itfelf aimed at, it makes to the mountains, while the horfeman purfuing with all poffible fwifnefs, endeavours to cut off its retreat. The cliace then continues along the plain, the oftrich ufrng both legs and wings to affitt its motion; only a horfe of the firft fpeed is able to outrun it: and if, in a trial of this kind, he is not readily tired, his price becomes proportionably great; fome horfes are valued at a thouland ducais. Horfes thus caught, or thus trained, are at prefent rare.

The Arabians preferve pedigrees of their horfes with great care, for ages. They know their alliances and gencalogies; they diftinguins rheir races by different names, and divide them into three claties. I. The nobles, the ancient breed, unadulterated on either fide. II. The horfes of the ancient race, but adulterated. 111. Thofe common and inferior. They know, by experience, the race of a horfe by his appearance; and can tell the name, the furname, the colour, and the marks properly belonging to each. The moft ordinary mare of the firft race fils for 500 crowns; many for 1000 , and fome for 14 or 1500l. As the Arabians live in tents, they alfo ferve them for ftables; fo that the mare, the foal, the hußband, the wife, the children, lie torether indifcriminately; the little children are often aftride on the body, or neck of the mare, which permits their careffes without injury. The Arabians never beat their horfes; but treat them gently; fpeak to them, and feem to difcourfe with them as friends; never attempt to increafe their fpeed by the whip, or fpur them but in cafes of necefficy. When thus urged, they fet off with amazing fwiftnefs; they leap over obftacles with as much agility as a buck; and, if the rider happens to fall, are fo manageable, that they ftand ftill in the midft of their moft rapid career. The Arabian horfes are of a middle fize, eafy in their motions, and rather inclined to leannefs than fat. They eat nothing during the day ; only drink once or twice; at fun fet a bag is hung to their head, containing about half a bufhel of clean barley, which they eat during night. When the fpring is patt, they are taken from pafture, and barley is their only food during the reft of the year, except now and then a little fraw. They are. always kept ready faddled at the tent door from morning till fun-fet, in order to be prepared againft furprife.

From Arabia the molt generous race of horfes has been, tranfmitted to many parts of the world, to Egypt, to Barbary among the Moors, 
and from them into moft parts of Africa. Europe alfo, and even America, highly prize Arabian herfes. America had not originally this noble animal; but now has plenty, not only domeftic, but wild alfo. At this time, almoft all nations have their refpective breeds of horfes, and according to their foil, climate, or management, the animal improves or degenerates.

By great affiduity, application, and management in their breeding, Englifh horfes are now fuperior to all others for fize, ftrength, fiviftnefs, and beauty. By judicious mixture of foreign original kinds, the happy difference of our foils, and our fuperior fkill, we have brought this animal to its higheft perfection. An Englin horfe excels the Arabian, in fize and fwiftnefs; is more durable than the Barb, and more hardy than the Perfian. Our racers go at the rate of a mile in two minutes : and we had one inftance, in the admirable Childers, of ftill greater rapidity. He has been frequently known to move above eighty-two feet and a half in a fecond, or almoft a mile in a minute: and he has run round the courfe of Newmarket, which is little lefs than four miles, in fix minutes and forty feconds.

\section{T H E A S S.}

THE horfe and the afs, though nearly approaching in form, are of difinct kinds, and of different natures : were there but one of each kind, botb races would probably be extinguifhed. Their thapes and habits may refemble; but there is fomething in every animal, befide conformation, or way of life, that determines its fpecific nature.

The onager, or wild afs, abounds more than the wild horfe; and the peculiarities of its kind are more diftinctly marked than amorig the tame. Had it been a horfe degenerated, or were a horfe an afs improved, the wild animals of both kinds would refemble each other, much more than thofe domefticated, on whom art has long been employed in producing new habits and alterations. The contrary however obtains, and the wild afs is even more afsine, than that bred in fervitude; and has a natural averfion to the horfe.

This animal is found wild in many inands of the Archipelago, particularly in that of Cerigo: alfo in the defarts of Lybia and

No. 21 . 
Numidia: they run with fuch amazing fwiftnefs, fcarce even the courfers of the country can overtake them. When they fee a man, they fet up a horrid braying, and ftop fhort all together, till he approaches near them; then fly off with great fpeed; and on fuch occafions generally fall into traps which are previouny prepared. The narives take them chiefly on account of their flesh, which they efteem delicious eating; and for their fkins, of which that kind of leather is made which is called thagreen.

The afs was originally imported into America by the Spaniards. That country feems to have been peculiarly favourable to this race of animals; and, where they have run wild, they have multiplied in fuch numbers, that in fome places they are become a nuifance. They have the fwiftnefs of horfes; neither declivities nor precipices retard their career. When attacked, they defend themfelves with their heels and mouth with fuch activity, that, without lackening their pace, they often maim their purfuers. But the molt remarkable proferty in thefe creatures is, that after carrying their firft load, their celerity leaves them, their dangerous ferocity is loft, and they foon contract the ftupid look and dulnefs peculiar to their fpecies. It is alfo obfervable, that thefe creatures will not permit a horfe to live among them. They always feed together; and if a horfe happens to ftray where they graze, without giving him the liberty of Aying, they bite and kick him till they leave him dead on the fpot.

But the afs, in a ftate of tamenefs, is the mont gentle and quiet of animals. He fuffers, without refiftance, the ill treatment of his owners : he is temperate with regard to the quantity and quality 'of his provifon; and makes his humble repaft on what the horfe and other animals leave behind: he prefers the plantane among herbs; is delicate with refpect to his water; drinks only at the cleareft brooks, and chiefly thofe to which he has been accuftomed. He drinks as foberly as he eats; and never, like .the horfe, dips his ..ofe into the ftream: he never rolls, like the horfe, in the mud; he even fears to wet his fcet; and turns out of his way to avoid dirt.

When over-loaded, the afs hangs down his head, and lowers his ears; when too hard preffed, opens his mouth, and draws back his lips in a very difagreeable manner. If his eyes are covered he will not ftir a ftep; if he is laid down in fuch a manner that one eye is covered with the grafs while the ocher is hidden with a ftone, or whatever is next at hand, he continues in the fame fituation, and will not 


\section{T}

attempt to rife to free himfelf from thofe night impediments. $\mathrm{He}$ walks, trots, and gallops like a horie; but though he lets out very freely at firt, yet is foon tired; and no beating will make him mend his pace.

We have good reafons to believe that, were the fame care beftowed on the afs as on the horfe, and the fame induftry ufed in croffing the breed and improving it, we hould fce the als become from his prefene mean ftate, a very portly and ferviceable animal; we hould find him rival the horfe in fome of his perfections, and exceed him in oihers. The afs, bulk for bulk, is ftronger than the horfe; is more furefooted; and, though nower in kis motions, is much lefs apt to fart out of the way.

Though now common in England, the afs was loft among us during the reign of Queen Elizabeth. Holingfhed informs us that our land did yield no affes : but we have accounts of their being frequent in England before that time. In Sweden and the north, they are a fort of rarity. The hotter climates are the original of this ferviceable creature. In Guinea, they are larger and more beautiful than their horfes. In Perfia, they have two kinds; one ufed for burthens, being now and heavy; the other for the faddle, being fmooth, ftately, and nimble. They are managed as horfes, and they are taught to amble like them; but the rider fits nearer the crupper. They generally cleave their noftrils to give them more room for breathing, and many of thefe are fold for forty or fifty pounds.

Of all animals covered with hair, the afs is the leaft fubject to vermin, for he has no lice, probably owing to the drynefs and hardnefs of his fkin : he is three or four years in coming to perfection; lives till twenty or twenty-five; neeps much lefs than the horfe; never lies down for that purpore, unlefs very much tired. The the-afs goes above eleven months with young; never brings more than one at a time.

The MuLs may be engendered either between a horfe and a ihe-afs, or between a jack-afs and a mare. The latter breed is larger, ftronger, and better fhaped. The common mule is healthy, and will live above thirty years, being very ferviceable in carrying burthens, particularly in mountainous and ftony places, where horfes are not fo fure-footed. The mule is not totally and neceffarily barren : befide the authority of Ariftorle long ago, modern obfervation furnifhes facts in proof of this affertion; but as the inftances are very rare, the mule may be confi-

C 2

dered 
dered as an animal generally barren, confequently, contrary to the order of nature, who has confined fertility within certain bounds, that intermixture of fpecies might not prevail, nor inftead of regular defcendants, broods of mifhapen forms and manners.

\section{T H E}

T chiefly a native of the fouthern parts of Africa; whole herds of them feed in thofe extenfive plains that lie towards the Cape of Good Hope. By their watchfulnefs they fuffer nothing to come near them; and by their fwiftnefs, they leave every purfuer far behind. The zebra, in thape, refembles the mule rather than the horfe, or the afs ; is rather lefs than the former, yer larger than the latter; its ears not fo long as the afs, nor fo fmall as the horfe. Like the afs, its head is large, its back ftraight, its legs finely placed, and its tail tufted at the end; like the horfe, its $\mathrm{kin}$ is fmooth and clofe, its hind quarters round and flefhy. But the amazing regularity and elegance of its colours is its greateft beauty. In the male, they are white and brown; in the female, white and black, difpofed in alternate ftripes over the whole body, like fo many ribbands, narrow, parallel, and exactly feparated from each other; every ftripe is perfectly diftinct, and preferves its colour round the body (or the limb) without diminution. The head, body, thighs, legs, tail, and ears, are thus beautifully ftreaked.

The head of the male zebra is ftriped with bands of black and white, which center in the forehead. The ears variegated with white and dufky brown. The neck has broad ftripes of the fame dark brown running round it, leaving narrow white ftripes between. The body is ftriped acrofs the back with broad bands, leaving narrower fpaces of white between them, ending in points at the fides of the belly, which is white, except a black line pectinated on each fide, from between the fore-legs, along the middle of the belly, two thirds of its length. There is a line of reparation between the trunk of the body and the hinder quarters, on each fide; behind which, on the rump, is a plat of narrow ftripes, joined togecher, by a ftripe down the middle, to the end of the tail. The colours differ in the female; the ftripes vary fometimes, but are always equally diftinet; the hair equally finooth 
and fine; the white Thining and unmixed; and the black, or brown, thick, and luftrous.

Such is the beauty of this creature, by nature feemingly fitted for the pleafure and fervice of man. Hitherto, however, it has difdained fervitude, and neither force nor kindnels has fubdued its native independence and ferocity. Yet probably this animal, by time and affiduity, might be brought under fubjection. As it refembles the horfe in form, without doubt it has a fimilitude of nature, and only requires the efforts of an induftrious and fkilful nation, to be added to the number of our domeftics. Nor is its extraordinary beauty the only motive for withing this animal among our dependents : its fwiftnefs is faid to furpafs that of all others; fo that the fpeed of a zebra is become a proverb among the Spaniards and Portuguefe. It ftands better upon its legs alfo than a horfe; and is confequently ftronger in proportion.

The zebra is chiefly a native of the Cape of Good Hope. It is alfo found in the kingdom of Angola; and, as we are affured by Lopez, in feveral provinces alfo of Barbary.

This animal, which is peculiar to Africa, is eafily fed. That which came over into England fome years ago, would eat almoft any thing, bread, meat, tobacco, or hay. As it fo nearly refembles the horfe and the afs in ftructure, it probably brings forth annually as they do. "Their noife is neither like that of a horfe nor an afs, but more refembling the confufed barking of a maftiff dog. In fome the fkin hangs loofe upon the neck, in a kind of dewlap, which takes away much from their general beauty. 


\section{RUMINATING ANIMALS.}

A NIMALS that chew the cud are mott harmles, and moft A eafily tamed. As they live on vegetables, they feldom defire to change their paftures, while furnifhed with a proper fupply of food; and fearing nothing from each other, they generally go in herds for mutual fecurity. The fierceft of the carnivorous kinds feek their. prey in folitude; thefe, on the contrary, range together, and unite in mutual defence; the hare itfelf is gregarious, in countries where it has no enemies but the beafts of the foreft.

Ruminant animals feem naturally more indolent and lefs artful than the carnivorous; their appetites more fimple, and their inftincts more confined. As it requires a tedious procefs to tranfmute grafs into flefh, Nature has, generally, furnithed grafs-eaters with four ftomachs, through which the food fucceffively paffes, to undergo the proper feparations.

I. The paunch, which receives the food after a night chewing. II. The honeycomb, properly a continuation of the former. Thefe two, which are very capacious, the animal fills as falt as it can, then lies down to ruminate, which is a kind of vomiting without effort or pain. The food, by chewing a fecond time, is rendered more foft and moift, and at laft liquid enough to pafs into the third ftomach, where it undergoes ftill farther comminution. In this fto mach, called the manyfold, from the number of its leaves (all which promote digeftion), the grafs appears like boiled (pinage : in the fourth ftomach, it is completely macerated, and ready to be turned into. chyle.

The ftomach of ruminant animals is ftrong and mufcular, the more readily to act on its contents ; their inteftines fat, the better to preferve their warmth; and extended to a great length, fo as to extract the whole nourifhment which their vegetable food fupplies.

The cow, the heep, and the deer being furnifhed with four ftomachs, may properly be called the ruminant kinds; though many others 
have this quality in a fmall degree. Among animals, the rhinoceros, camel, horfe, rabbit, marmotte, and fquirrel. Among birds, the pelican, ftork, heron, pigeon, and turtle, have a power of difgorging their food (chiefly to feed their young). Among fifhes, lobfters, crabs, and one or two others. Among infects, the mole, cricket, wafp, drone, bee, grahopper, and beetle. All thefe animals either actually or feemingly chew the cud. Their ftomachs are compoled of murcular fibres, by means whereof their food is ground up and down, in the fame manner as in thofe dittinguifhed by the appellation of ruminants.

\section{OF THE \\ G O W $\mathrm{K}$ I $\mathrm{N}$ D.}

F all ruminant animals, thofe of the cow kind deferve the firt rank, for their fize, their beauty, and their fervices.

The climate and pafture of Great Britain are excellently adapted to this animal's moderate nature; our verdant and fertile plains perfectly fuit its manner of feeding; for wanting the upper fore teeth, it loves to graze in a high rich pafture, little regarding the quality of its food, if fupplied in abundance. In no part of Europe the tame animal grows larger, yields more milk, or more readily fattens, than with us.

Our paftures fupply them with plenty; they in return enrich the pafture; for of all animals, the cow feems to give back more than it takes from the foil.

This animal is furnifhed with eight cutting teeth in the lower jaw ; at the age of ten months, the two middlemoft fall out, and are replaced by others not fo white, but broader; at fixteen months, the two next milk-white teeth fall out, and others appear: thus changing every fix months, till all the cutting teeth are renewed, which then are long, pretty white and equal; but as the animal advances in years, they become irregular and black, their inequalities fmoother, and the animal lefs capable of chewing its food. The cow often declines from this caufe; for, being obliged to eat a great deal to fupport life, the fmoothnefs of its teeth renders chewing difficult, and the quantity chewed inadequate ta fupply the ftomach.

No. 2 I. 
At three years old; the cow heds its horns, and new ones arife, which are permanent; at four years of age, the cow has fmall pointed neat fmooth horns, thickeft near the head; at five they become larger, and are marked round with the former year's growth; and every year produces a new ring at the root; fo that allowing three years before their appearance, and adding the number of rings, we have the animal's age. Some cows have horns, others have none; this feems a kind of caprice of nature, for which we can affign no reafon.

Of all quadrupeds, the cow feems molt liable to alteration from its pafture. In our own country, we perceive great varieties, produced by the variation of foil. In fome they grow very large; in others, they are very diminutive. The breed of the Ine of Man, and moft parts of Scotland, is much lefs than that of England or Ireland.

The cow kind is found in moft parts of the world, large or fmall in proportion to the richnefs of the pafture. Africa is remarkable for the largeft and the finalleft cattle of this kind; as is India; alfo, Poland, Switzerland, and feveral other parts of Europe. Among the Eluth Tartars, where the paftures are remarkably rich, the cow becomes fo large, that he muft be a tall man who can reach the tip of its fhoulder. Almolt every where the cow is found in fome of its varieties; large, like the urus, or humped as the bifon; with ftrait horns, or bending, inverted backwards, or turning fideways to the cheek, like thofe of the ram; and, in many countries, without horns, as in Iceland. The cattle of the Ukraine, where the pafture is excellent, become very fat, and are confidered as one of the largeft breeds of Europe. In Switzerland, among the mountains, are large; in France fmall; very fmall in Barbary. The famous bulls of Spain are by no means comparable to our own; nor is a Spanifh bull fight worthy the applaufe beftowed on it by their writers, requiring no great bravery, and little more addrefs, than to take advantage of the bull's miftaking the cloak for the cavalier, and of his fhutting his eyes (as this animal is faid to do) before he ftrikes with his horns.

But the differences in fize of this animal are not fo remarkable as thofe of its form, its hair, and its horns. Thefe are fo very extraordinary, that they have been confidered as contituting different creatures, and names have diftinguihed what in reality is the fame. The urus and the bifon have been regarded, from the variety in their make, 
as diftinct in their production; but they have a certain mark of one common ftock; they breed among each other, and confequently form one kind, notwithftanding the extreme bulk of the urus, or the hump on the back of the bifon: their breed is fruitful, and among their defcendants, the hump belonging to the bifon is foon worn away.

The URUS, or wild bull, inhabits chiefly the province of Lithuania; and grows to a lize farce equalled, except by the elephant; is quite black, except a ftripe mixed with white, that runs from the neck to the tail, along the top of the back; the horns are fhort, thick and ftrong; the eyes fierce and fiery; on the forehead is a kind of garland of black curled hair, and fome have beards of the rame; the neck is fhort and ftrong, and the fkin has an odour of mulk. The female, though lefs than the male, exceeds the largeft of our bulls; neverthelefs, her udder and teats are fo fmall, that they can fcarcely be perceived. Upon the whole, however, this animal refembles the tame one. Gefner, in his Icon. Anim. 34, fays he faw a horn, he fuppofed, of an urus, hung in the Straburg cathedral, which was fix feet long.

The Brson differs in having a lump between its fhoulders. Thefe animals are fome very large, others diminutively little. This creature, in front, has fomewhat the look of a lion, a long fhaggy mane, a beard under his chin; his head little, his eyes red and fiery, with a furious look; his forehead large, and horns fo big, and fo far afunder, that three men might often fit between them. On the middle of the back grows a bunch almoit as high as that of a camel, covered with hair, and which is confidered as a great delicacy by the hunters. There is no purfuing him with fafety, except in forefts where are trees large enough to hide the men. He is generally taken by pitfals; the hunters dig holes in the ground, and covering them with boughs of trees and grafs, provoke the bifon to purfue them: they get on the oppofite fide of the pitfall, while the furious animal, running head foremoft, falls into the pit, and is quickly overcome.

The breed of the urus, or thofe without a hump, chiefly occupies the cold and temperate zones; the breed of the bifon, or thofe with a hump, the fouthern parts of the world; throughout India, and throughout Africa, from Mount Atlas to the Cape of Good Hope. In thefe countries, the bifon feems to prevail; where they have imooth, foft hair, are very nimble of foot, and in fome meafure fupply the want of horfes. The bifon breed is expert and docile; many of them 
bend their. knees to take up, or fet down burthens; and are treated by their mafters with much tendernefs and care, which in India has degenerated into fuperftition, Thefe animals are, among the Hottentots, chicfly efteemed. The bull is at once their protector and fervant, attends the flocks, guards them, herds in the ftraying fheep, and fhews no mercy to robbers, or even ftrangers, who attempt to plunder. Thefe backeleys (as they are called) are taught to combat even the enemies of the kraal. Every Hottentot army is furninhed with a herd of them, which is let loofe againt the enemy. The backeley lives in the fame hut with its mafter, and, by habit, gains an affection for him. When a backeley dies, a fuccefior is chofen by a council of the old men of the kraal; he is then joined with a veteran of his own kind, from whom he learns his art, becoms focial and diligent, and is taken for life into human friendihip and protection.

The humps of the bifons are of different fizes, fome weighing from forty to fifty pounds, others lefs; it is not to be confidered as a part indifpenfable to the animal; it refembles a griftly fat; and is faid to cut and tafte fomewhat like udder.

The American bifon is rather lefs than that of the ancient continent; its hair is longer and thicker, its beard more remarkable, and its hide more luftrous and foft. They breed with the tame kinds, brought from Europe; and thus produce a race peculiar to that country.

The cow kind feems an ancient inmate in every climate, domeftic and tame in civilized countries, favage and wild in wild countries, but capable of being ufeful in all : able naturally to defend itfelf againt every enemy of the foreft; and only fubordinate to man : taken from the dam in a favage ftate, either in Africa or Afia, foon becomes humble, patient and familiar; and man may be confidered, in thofe countries, as almolt helplefs without their affiftance.

\section{T H E B U F F A L O,}

J F we campare the buffalo wịth our common cow, no two animals can be more alike, either in form or nature; equally fubmiflive to the yoke, often living under the fame roof, employed in the fame domeftic fervices; the make and turn of their bodies greatly alike, yet no two animals can be more diftinct. Such is the fixed averfion between 
between thefe creatures, that the cor refufes to breed with the buffalo, while it is known to propagate with the bifon, to which it has; in point of form, but very diftant fimilitude.

The buffalo is by no means fo beautiful as the cow; his figure is" more clumfy and aukward; his air wilder; and he carries his head lower and nearer the ground; his limbs are lefs flethy, his tail more naked of hair; his body fhorter and thicker; his legs higher; his head fmaller; his horns fometimes ten feet long, not fo round; but black and compreffed, with a bunch of curled hair hanging down between them; his Ikin is alfo, harder, thicker, blacker, lefs furnifhed with hair; bis flefh is hard, blackin, difagreeable to the tafte and fmell. The milk of the female much inferior to that of the cow, but abundant. In the warm countries; cheefe and butter are made of buffalo milk. The leather made of its hide is well known for its thickriefs, foftnefs, and impenetrability. Being, in general, very much larger and ftronger than the cow, the buffalo is employed in agriculture; ufed alfo in drawing burthens; fometimes in carrying them; being guided by a ring thruft through the nofe. Two buffaloes yoked in a waggon are faid to draw more than four ftrong horfes; as their heads and necks are naturally bent downward, they are better fitted for the draught, and the whole weight of their bodies is applied to the carriage.

Wild buffaloes are very dangerous animals, often gore travellers, and trample them with their feet, until they have mangled the whole body : in woods not equally to be feared as in plains, becaufe in purfuit, their large horns become entangled in the branches, which gives time to efcape. There is fcarce any other method of avoiding their purfuit; they run with great fwiftnefs; overturn a tree of moderare growth; and are fuch fwimmers, as to crols the largelt rivers without difficulty. Like all large animals of the torrid zone, they are very fond of the water; and, during their purfuit, often plunge in to cool themfelves.

In Italy, they make the food and riches of the poor. The female produces but one at a time, in the fame manner as the cow; but the cow, as we know, goes nine months; whereas the buffalo continues pregnant twelve. They, are afraid of fire; and, perhaps, in confequence, have an averfion to red colours, that refemble the colour of flame : it is faid, that in thofe countries where they are found in plenty, no perfon dares to drefs in farlet. 
Thefe are regarded as the only real varieties of the cow kind; others have been fuppofed by naturalifts to fo many as eight or ten fpecies; but after proper allowances. for climate, pafture, \&c. there feems no need to conlider others, as permanently or effentially different. Some are faid to grunt like a hog, others to fmell of mufk. In Surat, a fmall kind, not bigger than a dog, draw the children in carts.

\section{OF THE}

\section{SHEEP AND GOAT.}

$7 \mathrm{HE}$ goat and the Theep differ, in the form of their bodies, their covering, and their horns; and may be confidered as two kinds, with regard to domeftic purpofes; but their internal conformation is alike; their feet, their four ftomachs, their fuet, their appetites, are the fame; and they propagate with each other. The produce of the buck goat with the ewe in two or three generations returns to the theep. The theep and the goat, therefore, belong to one family; and were their races reduced to one of each, they would replenifh the earth with their kinds.

Their internal ftructure is not very remote from that of the cow kind, which they refemble in their hoofs, and in chewing the cud. But the differences between thefe animals are fufficiently apparent by their form and fize; they are alfo diftinguifhed from deer, by never thedding their horns, which draws a line between the kinds; fo that we may regard the fheep and goat as ruminant animals of a fmaller fize, having permanent horns.

Thefe harmlefs and ufeful animals have been long reclaimed from the foreft, and brought into a ftate of domefticity. The fheep is the more ferviceable creature in moft places; but the goat has more fenfibility and attachment. In the earlieft ages, the goat feemed rather the greater favourite; and continues fuch, in fome countries, among the poor. But the theep has long become the principal object of human care; efpecially in our country and climate.

The fheep, in its prefent domeftic ftate, is of all animals the moft defencelefs and inoffenfive; and, if expofed in its prefent ftate to ftruggle with its natural enemies of the foreft, would foon be extirpated. 


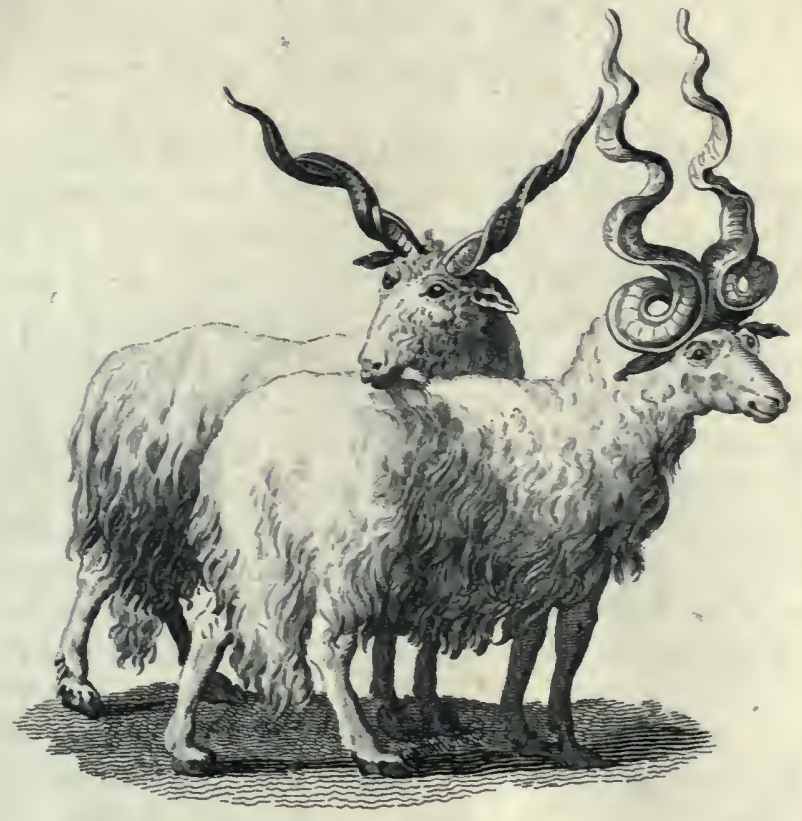

Wallachian Sheep. 

Loaded with a heavy fleece, incapable of defence by its horns, heavy, now, and feeble, it can have no fafety but from man. Thofe without horns are moft dull and heavy; thofe whofe fleeces are longeft and fineft, are moft fubject to diforders; whatever changes have been wrought in this animal being by human induftry, are intirely calculated for human advantage. A fucceffion of ages could fcarce reitore the theep to its primitive ftate, fo as to become a match for its foes of the foreft.

The goat is much its fuperior; has its particular attachments, fees danger, and generally contrives to efcape it; but the fheep is timid without caufe, and fecure in real danger.

It does not appear, from early writers, that the fheep was bred in Britain; nor till feveral ages after this animal was cultivated, that the woollen manufacture was carried on among us. That valuable branch of bufinefs lay for a confiderable time in foreign hands; and we were obliged to import the cloth, manufactured from our own materials.

No country, however, produces fuch theep as England; with larger fleeces, or better adapted for the loom. Thofe of Spain, indeed, are finer, and we generally require fome of their wool to work up with our own; but the weight of a Spanith fleece is much inferior to one of Lincoln or Warwick?hire : where it is no uncommon thing togive fifty guineas for a ram.

Sheep, like other ruminant animals, want the upper fore teeth; have eight in the lower jaw : two of thefe drop, and are replaced at two years old; four of them are replaced at three years old; and all at four. The new teeth are diftinguifhed by their frefhnefs and whitenefs. Some breeds in England never change their teeth; thefe the Thepherds call leather-mouthed cattle; and they are generally fuppored to grow old a year or two before the reft. Sheep bring one or two at a time; fometimes three or four. They bear five months; and, by being houfed, bring forth at any time of the year.

If we look for this animal in its nobleft ftate, we muft feek it in the African defart, or the extenfive plains of Siberia. Its defcendants have fuffered fo many changes, as entirely to difguife the kind, and often to minlead the obferver. Scarce any two countries has theep alike, in fize, covering, fhape, or horns.

The woolly theep is found only in Europe, and fome of the temperate provinces of Afia. When tranfported into hotter countries, it affumes a covering fitted to the climate, hairy and rough lofes its Iro. 2 I. 
fertility, and its flefh no longer has the fame flavour. In very cold countries, it feems equally a ftranger; requires unceafing attention to preferve it; and though fubfifting as well in Greenland as in Guinea, yet it feems a natural inhabitant of neither.

The Iceland theep refembles ours in form; but differs in the number of horns, having four, fometimes eight, growing from different parts of the forehead. Thefe are large and formidable; and the animal feems fitted for a ftate of war: yet, is equally mild, gentle, and timid. Its wool is long, fmooth, and hairy. Its colour a dark brown; and under its outward coat, it has a covering, rather refembling fur than wool, being fine, thort, and foft.

A fecond variety is the broad-tailed iheep, of Tartary, Arabia, Perfia, Barbary, Syria, and Egypt. This broad and heavy tail often weighs from twenty to thirty pounds : fometimes grows a foot broad, and muft be fupported by a fmall kind of board, that goes upon wheels. This tail is not woolly underneath like the upper part, but bare; and the natives, who confider it as a great delicacy, are very careful in preferving it from injury. Their fleeces, in the temperate climates, are foft and woolly; in the warmer latitudes hairy; yet in both thefe theep preferve the enormous fize of their tails.

A third variety is the theep called ftrepficheros, native of the inands of the Archipelago, which differs from our theep, in having ftrait horns, furrounded with a fpiral furrow.

Another variety is the Guinea Theep, generally found in the tropical climates. They are large, with a rough, hairy fkin, fhort horns, ears hanging down, with a kind of dewlap under the chin. They differ greatly in form from others; but breed with them. Thefe, of all the domeftic kinds, feem to approach neareft the ftate of nature : are larger, ftronger, and fwifter than others; confequently better fitted for foreft life. However, they feem to rely, like the reft, on man for fupport; being entirely of a domeftic nature, and fubfifting only in warm climates.

Thefe varieties are capable of producing among each other; their peculiarities of form refult from climate and cultivation. While man thus cultivates the domeftic kinds, he drives away the favage race, which is lefs beneficial, and more headftrong. This is found in fmall numbers in uncultivated countries, where they have fubfifted by fwiftnefs or ftrength. In Greece, Sardinia, Corfica, and particularly in the deferts of Tartary, the moufflon is found, that is thought by 
M. Buffon to have been the primitive race; and that has been known to breed with the domertic animal.

The moufflon, (or mufimon,) though covered with hair, bears ftrongeft fimilitude to the ram: like the ram, has the eyes placed near the horns : its ears are fhorter than thofe of the goat: refembles the ram in the contours of its form. The horns alfo are alike; are yellow; have three fides, as in the ram, and bend backwards in the fame manner behind the ears. The muzzle, and infide of the ears, are whitin, tinctured with yellow; the other parts of the face, brownilh grey. The general colour of the body is brown, approaching that of the red deer. The infide of the thighs and belly are white, tinctured with yellow. The mufimon is found in a favage ftate, and maintains itfelf, by force or fwiftnefs, againt all animals that live by rapine. From its extreme fpeed, many have inclined to rank it among deer: but the mufimon never theds its horns. Thefe fometimes grow to a furprifing fize; many of them meafuring, in their convolutions, two ells. From yellow, the horns become the darker as the animal grows older; fometimes are found broken off in fuch a manner, that the fmall animals of the foreft creep into the cavity for fhelter. The female refembles the male, but is lefs, and her horns never grow to fuch prodigious fize as thofe of the ram.

N. B. The mufimon is reckoned a goat by thofe who divide the kinds, but if, as afferted, breeds with the fheep, evidently belongs to both kinds.

The Goat feems better fitted for a life of liberty than the fheep: is naturally more lively, and of keener inftinct: eafily attaches itfelf to man, and feems fenfible of his careffes : is ftrong and fwift, courageous, playful, lively, capricious, and vagrant : not eafily confined to its llock; but choofes its pafture, and loves to ftray from others: delights in climbing precipices; in going to the very edge of danger; on rocks hanging over the fea, and on a very narrow bafe, often neeps in fecurity. Nature has fitted it for traverfing declivities; the hoof being hollow underneath, with tharp edges. This hardy animal is eafily fultained, and choofes the heathy mountain, or the fhrubby rock; prefers the tops of boughs, or the tender bark of young trees; neeps expofed to the fun; and feems to enjoy its heat : fears not ftorm, or rain; but immoderate cold is faid to affict it with a vertigo. The inconftancy of its nature is perceivable in their regularity of its gait; it goes forward, ftops, runs, approaches, flies, merely from caprice, and extreme vivacity of difpofition. 
The goat produces two at a time; three at moft. But in warm climates, though the animal degenerates, and grows lefs, it becomes more fruitful, bringing three, four, or five. The goat, like the fheep, continues five months with young; and, in fome places, bears twice a year.

The goat's milk is fweet, nourihing, and medicinal; not fo apt to curdle on the ftomach as that of the cow; and, therefore, preferable for thofe of weak digeftion. T'he milk differs in flavour from that of the cow or the Theep; the fhrubby paftures, and heathy mountains, imparting an agreeable wildnefs to its tafte. In Ireland and Scotland, on mountains almoft naked, the goat gleans a living; and fupplies the hardy natives with comforts. Beds are made of its $\mathrm{R}$ kins; its milk is food; furnilhes alfo butter and cheefe; and the flem (efpecially of the kid) is a delicacy, ranked by fome as not inferior to venifon.

We find this animal in moft parts of the world. In the north, where the pafture is coarfe and fcanty, the goat finds a fubfiftence; between the tropics, the goat is adapted to the heat of the climate, and its flefh improves.

A remarkable variety of the goat is that of Natolia or Angora in Syria, which has ears longer and broader than ours. The horns of the inale are black, iffue horizontally on each fide the head, and are twifted like a cork-fcrew. The horns of the female are fhorter, and encircle the ear fomewhat like thofe of a ram. Their colour is a dazzling white; their hair very long, thick, fine, and gloffy; but degenerates at the diftance of a day's journey from this peculiar neighbourhood. It is fold into all parts of Europe; and is the bafis of the beautiful ftuffs known among us by the name of camlet.

The Syrian goat is a fecond variety, fomewhat larger than ours, with ears hanging down almoft to the ground; broad in proportion; fometimes fo troublefome, that the owners cut off one to enable the animal to feed. The horns not above two inches and an half long; black, and bending a little backwards; the hair of a fox colour; under the throat are two excrefcences, like the gills of a cock : chiehy kept round Aleppo for their milk.

A third variety is the little goat of America, the fize of a kid, but the hair as long as that of the ordinary breed. The horns, which do not exceed a finger's length, are thick, and bend downwards fo clofe to the head, that they almoft enter the fkin. 
The blue goat of the Cape of Good Hope, may be ranked as a fourth variety: is in Thape like the domeftic, but nearly the fize of a ftag. Its hair very thort, of a delightful blue; which it lofes greatly when dead : has a very long beard; horns not fo long in proportion as in others; turned fpirally: has very long legs, but well proportioned; the fle? is well tafted, but lean; therefore chiefly killed for its $\mathrm{kin}$ : abounds in the uncultivated parts; where are found others, beautifully fpotted with red, white, and brown.

The Juida (or Whida) goat refembles ours, except in fize, being much fmaller : is common in Guinea, Angola, and along the coaft of Africa : is not much larger than a hare, but extremely fat, and its flefh admirably tafted : is in that country univerfally preferred to mutton.

The foregoing are certainly known to belong to the goat kind; there are others nearly refembling the goat, whofe kindred is not equally evident : for being found in a ftate of nature, they have not been fufficiently fubjected to obfervation. Thefe are the $\mathrm{C}_{\text {Hamols }}$ and the IBEX; both approach the goat in figure, and have horns that never thed; but, at the fame time, differ more from each other than from the animal in queftion.

They are both natives of the Alps, the Pyrenees, and the mountains of Greece; there they continue to exift in valt numbers, in fpite of hunters and bealts of prey that inceffantly purfue them.

The IBEx refembles the goat in Thape; but the horns are much larger; are bent backward, full of knots; and it is generally afferted that a knot is added every year. Some of thefe are found two yards long. The male ibex has a large black beard, is of a brown colour, with a thick warm coat of hair; a ftreals of black runs along the top of the back; the belly and back of the thighs are of 2 fawn colour.

The Cuamors, though wild, is docile, and eafily tamed; is abous the fize of a domeftic goat, which it much refembles; is agreeable, lively, and active beyond expreflion. The chamois' hair is mort; in fpring is afh coloured; in autumn dun, inclining to black; in winter, blackith brown: abounds in the mountains of Dauphiny, of Piedmont, Savoy, Switzerland, and Germany: is peaceful, gentle, and lives in fociety, in flocks of from four to fourfcore, or an hundred, difperfed on the crags of the mountains. The large males feed detached, except when they approach the females, and drive away the young; which is during October and November: bring forth in March and April. The young keep with the dam five months, or longer, if not 
leparated; they live between twenty and thirty years. Their flem is good. The chamois has fcarce any cry; at moft a kind of feeble bleat, by which the parent calls its young: But to warn the reft of the flock, ufes a hiffing noife, which is heard at a great diftance. This creature is extremely vigilant, and has a quick ear, and fcent, and a moft piercing eye. When it lees its enemy, it ftops for a moment; and inftantly flies off. Its fmell difcovers a man at half a league diftance if to windward. When alarmed, the chamois begins his hifing note with fuch force, that the rocks and the forefts re-echo to the found. The firft hils continues as long as the time of one infpiration. In the beginning it is very tharp; deeper towards the clofe. Having repoled a moment, he again looks round, and continues to hirs by intervals, till the alami has fpread to a very great diftance. During this time, it feems in the mof violent agitation; ftrikes the ground with its fore-foot, and fometimes with both; bounds from rock to rock; turns and looks round; runs to the edge of the precipice; and flies with all its fpeed. The hifling of the male is much loudent and Tharpeft; it is performed through the nofe ; and is properly a very ftrong breath, driven violently through a fmall aperture. The chamois feeds on the beft herbage, and choofes the mott delicate parts of plants, and of aromatic herhs, which grow on the fides of the mountains : drinks little while feeding on fucculent herbage; chews the cud in the intervals of feeding. This animal is greatly admired for the beauty of its eyes, which are round and fparkling: has two fmall horns, of a beautiful black, rifing from the forehead almont between the eyes, and jetting out forward; at their extremities they bend a little backward, in a fmall circle, and end in a very tharp point. The ears are placed near the horns: on each fide of the face are two ftripes of black; the reft being a whitin yellow. Thefe animals are incommoded by heat, and never found in fummer, except in caverns of rocks, amid unmelted ice, under the rhade of fpreading trees, or of rough and hanging precipices, which keep off the rays of the fun. They feed early in the morning, and late in the evening. During winter, lodge in the hollows of rocks to avoid the avelanches, or fnow-rolls, and dig through the fnow for food. They run along the rocks with eafe, and leap from one to another, fo that no dogs can purfue them. They mount or defcend in an oblique direktion; throw themfelves down a rock of thirty feet, and alight fecurely on fome excrefcence, or fragment, on the fide of the precipice, which is juft large enough to receive their feet : in their defcent, they 
frike the rock with their feet, three or four times, to ftop'the velocity of their mocion; and, when arrived on their bafe below, are at once fixed and fecure. When jumping in this manner, they feem rather to have wings than legs. Their hinder legs are rather longer than their fore-legs, and bend fo that, when they defcend upon them, they break the force of the fall. Hunting the chamois is very laborious, and difficult. The ufual way is to hide behind the clefts of rocks and thoot them. Dogs are quite ufelefs in this chace, as they rather alarm than overtake. Nor is it without danger to men; for often when the animal finds itfelf over-preffed, it drives at the hunter with its head, and tumbles him down the neighbouring precipice, unlefs he has time to lie down, and let the chamois pals over him. This animal cannot go upon ice when fmooth; but if there be the leaft inequalities on its furface, it bounds along, and evades purfuit.

Such are the quadrupeds that belong to the goat kind. It is hard to difcover where the theep ends and the goat begins; ftill harder to determine the boundaries between the goat and the deer, But in tranfitions from one kind to another, is generally a middle race, that partakes of each, and can precifely be referred to neither. Such are the gazelles, properly neither goat nor deer, yet poffeffing many marks of both.

\section{T H E G A Z E L L E S, \\ O $R$}

\section{A $N$ N T E L L O P P E S,}

IKE the goat, have hollow permanent horns, a gall bladder, and feed rather upon fhrubs than pafture. But they refemble the roe-buck in fize and form; in having deep pits under the eyes; in the colour and nature of their hair; in the bunches upon their legs, which differ in being on the fore-legs in thefe, on the hind-legs in the other.

They differ from both goat and deer by their horns, which are annulated (or ringed) with longitudinated deprefions running from the bottom to the point; by having bunches of hair on their forelegs; and by a ftreak of black, red, or brown, running along No, 21 . 
the lower part of their fides; and three ftreaks of whitin hair in the internal fide of the ear. Of all animals in the world, the gazelle has the mott beautiful eye, extremely brilliant, yet fo meek that eaftern poets compare the eyes of their miltreffes to thofe of this animal, as the highelt compliment. The gazelle is moft delicately and finely limbed; its hair thort, fine, and gloffy. Its hinder legs are longer than thofe before; is extremely fwift; runs along in an even, uninterrupted courfe. Moft are brown on the back, white under the belly, with a black ftripe, feparating thofe colours between. The tail of various lengths, but in all covered with pretty long hair; and the ears beautiful, well placed, and terminating in a point; hoofs cloven.

Of thefe animals, M. Buffon makes twelve varieties; which is much fewer than other naturalifts have made them. Firft, the GAZEI.LA, properly fo called, the fize of a roe-buck, and much refembling it; but differing in the horns, which are black, hollow, (like thole of the ram, or goat) and never fall. The fecond, the Y.Evel, rather lefs than the former; its eyes larger; its horns flatted on the fides. The third, the CorIn, ftill lefs; its horns fmaller, fmoother, and their annular prominences fcarce difcernible. Some of thefe animals are often feen ftreaked like the tiger. The fourth, the ZEIRAN, which he fuppofes to be a larger kind of gazelle, found in India and Perfia. The fifth, the Кова; the fixth, the Ков : thefe differ only in fize, the former being much the largett. The feventh he calls after its Egyptian name, the ALGAzEL; the horns very long, being generally three feet. The eigbth, the PAzAN ; called by fome, the bezoar goat. As the algazel feeds on the plains, this is only found in the mountains, of Egypt, Arabia, and Perfia. This is the animal famous for that concretion in the inteftines or Atomach, called the Oriental Bezoar, which was once in fuch repute all over the world for its medicinal virtues. The nintb is the Nanguer, a native of Senegal; differs fomewhat in fhape and colour; but particularly in its horns, which are Atrait to near the points, where they crook forward, pretty much as in the chamois they crook backward. The tenth is the ANTelope, fo well known to the Englin, who have given it the name; is the fize of a roe buck; refembles the gazelle, but difiers in having deeper eyepits; the horns differ alfo, being about fixteen inches long, almoft touching at the bottom, fpreading as they rife, fo as at their tips to be fixteen inches afunder. They have annular prominences, but not fo 
diftinguinable as in the gazelle. A very remarkable double flexure diftinguifhes them : at the root, a tuft of very long hair. The antelope is brown on the back, and white under the belly; but thefe colours are not feparated by the black Atreak which belongs to the gazelle kinds. The eleventb variety $M$. Buffon calls the LiDME, which has very long horns. The twelftb and laft, he calls the Indian ANTELOPE, whofe horns are very fmall.

To thefe may be added three or four varieties, which equally refemble both the goat and the gazelle. Firft, the BubALus, that feems allied to the cow, the goat, and the deer: like the ftag in fize and figure, particularly its legs; but has permanent horns, like the goat ; and refembling thofe of the gazelles; while the make of its head is exactly like the cow in the length of its muzzle, and in the difpofition of the bones of its fcull. Has a narrow, long head; eyes placed very high; forehead fhort and narrow; horns about a foot long, black, thick, annulated; Thoulders very high, a kind of bunch on them, terminating at the neck; tail about a foot long, and tufted. The hair of this animal remarkable, being thicker at the middle than at the root; the only inftance, except the elk. Common in Barbary. Seems with mont propriety reckoned among the antelopes.

The fecond anomalous animal, M. Buffon calls the Condoma; fuppofed equal in fize to the largeft ftag, with hollow horns, and varied flexures above three feet long; at their extremities, two feet afunder. Along the back runs a white lift, another of the fame colour croffes this, at the bottom of the neck, which it furrounds: two more run round the body, one behind the fore-legs, the other parallel to it before the hinder. The general colour of the body greyin; the belly white: has a long grey beard; legs long, but well proportioned; native of Africa.

A third is the Guis : refembles the gazelles, except the colour of the belly, which is white in them, but in this of a deep brown. Its horns alfo are fmooth and polinhed; is remarkable for white lifts, on a brown ground, difpofed along the animal's body, as if it were covered with harnefs : is native of Africa.

The African wild goat is a fourth : of a dark an colour : in the middle of the head a hairy tuft, ftanding upright; on both fides, between the eyes and the nore, are very deep cavities, which contain a yellow oily. liquor, (coagulating into a black fubftance, with a fmell berwen mulk and civet): if.taken away, again runs out. 
To the we may add the CHEvrotix, or little Guinea deer, the leatt of all cloven-footed quadrupeds; its legs, at the fmalleft part, little thicker than the thank of a tobacco-pipe; is about feven inches high, twelve from the point of the nofe to the infertion of the tail; is completely formed like a ftag in miniature; except that its horns, when it has any (as in Guinea only), are of the gazelle kind, hollow and annulated : has two canine teeth in the upper jaw; in which it differs from the goat or deer, and makes a fingular fpecies. The hair, which is thort and gloffy, is in fome a bezutiful yellow, except the neck and belly, which is white. Native of India, Java, Ceylon, Guinea, and the tropics. They may be eafily tamed, and become familiar and pleafing; but are of fuch delicate conftitutions, they can bear no climate but the hotreft.

Such are the gazelles, or antelope kinds: of warm climates, ex-. tremely fwift, thy, fure-footed, though among rocks or precipices, impracticable but to themfelves: birds only can follow, and overtake them : for this purpofe the falcon is trained throughout the eaft; and their chace forms a principal amufement and employment of thofe countries.

\section{T H E}

\section{E E R , K I N D.}

THE Atag feems made to embellin the foreft, and animate its folitudes. His eafy elegance 'of form, and lightnefs of motion; his large branches, rather the ornament than defence of his head; his fize, ftrength and fwiftnefs, rank him among the nobleft quadrupeds.

The firt year, a flag has no horns, but a horny excrefcence, fhort, rough, and covered with a thin hairy fkin. The fecond year, his horns are fingle and ftraight; the third year, they have two antlers; the fourth, three; the fifth, four; the fixth, five (this number is not certain): After the fixth year, the antlers do not always increale.

Thefe horns are thed yearly. They are firm and folid, and employed in making knife-handles, \&c. While young, they are foft and tender. "The animal, on thedding his horns, hides himfelf in thickets, never venturing out to pafture, except by night." This ufually hapis 
pens in fpring; the new horns are very painful, and of quick fenfibility. When the old horn is fallen, the bones of the fkull are bare, being covered only with a tranfparent periofteum, which covers all bones. After a thort time, this fkin begins to fwell, and forms a fort tumour, containing a great deal of blood, and is gradually covered with a downy fubftance that feels like velvet. This tumour buds from the point like the graft of a tree; and, rifing by degrees, fnoots out the antlers on either fide, fo that fpeedily, in proportion to the animal's condition, the head is completed : but at firft is very foft, and has a fort of bark, which is a continuation or integument of the Rull. It is velveted and downy; every where furnithed with bloot-veffels, that nourih the growing horns. As thefe creep along the branches, they imprint the whole furface. The horns begin to harden at botton while the upper part remains foft, and continues growing. Hence it appears they grow differently from thofe of fheep or cows; in which they increafe from the bottom. When the whole head has received its full growth, the extremities begin to acquirc folidity; the velvet covering, or bark, with its blood-velfels, dry up, and begin to fall; this the animal haftens and completes, by rubbing its anders againft every tree.

If a ftag be caftrated when its horns are fallen, they will never return; if when they are on, they will never fall. If partialiy, he will want the horn on that fide. Plenty or fcarcity of provifion, fatigue and diteafe, greatiy affect the growth of the horns. It feldom happens that the branches on both fides fall off together, there being two or hiree chas interval. The old ftags ufually thed their horns firft, the latter end of February, or in March; thofe of the fecond head (between five and fix years old) about the latter end of March; thofe younger, in April; the youngeft of all, in May : they generally thed them in pools of water, and this has given rife to the opinion of their hiding them.

The horns generally increafe in thicknefs and in height from the fecond year to the eighth, but fee! the impreffions of age, and flrink like the reft of the body. The horns alfo partake of the nature of the fuil; in fercile paftures they are large and tender; in barren foils they are hard, ftunted, and brittle, correfpondent to the ftate of the creature himle!f.

When ftags have thed their horns, they are utterly unable to defend themfelves. They walk with their heads ftcoping, to kecp them from ftriking againft the trees above. Thus they continue near three monchs before their heads acquire their full growth and folidity. About the end 
of Augut, they return to the mountain to feek the hind, to whom they call with a loud tremulous note. At this time their neck is fwollen; they appear bold and furious; fly from country to country: and butt with their horns. At the end of this period of madnels, the creature that was before fat, neek, and gloffy, becomes lean, feeble, and timid. As he is above five years coming to perfection, he lives about forty years.

The ufual colour of the ftag in England was red; neverthelefs, the greater number in other countries are brown. Some few are white; but thefe perhaps obrained this colour in a former ftate of domefticity. Of all animals in this climate, none have fo beautiful an eye as the ftag: it is fparkling, foft, and fenfible. His fmelling and hearing are in perfection. When alarmed, he lifts his head and erects his ears. Man is not the enemy he molt fears; he feems delighted with the fhepherd's pipe; and the hunters fometimes ufe that infrument to allure him.

The ftag eats flowly, and is delicate in his choice of pafture. He retires to covert to chew the cud in fecuricy. His rumination feems performed with difficulty; not without much ftraining, and a kind of hiccup, which is eafily perceived the whole time. Some years ago, William Duke of Cumberland caufed a tiger and a ftag to be inclofed in the fame area; the ftag made fo bold a defence, that the tyger was at laft obliged to fly.

The cry of the hind, or female, is not fo loud as that of the male, and never excited but by apprehenfion for herfelf or her young. She has no horus. The time of geftation is between eight and nine months; generally produce but one about May, or June : they take great care to. hide their young, fince almoft every creature is then a formidable enemy. What is more unnatural, the ftag himfelf is a profeffed enemy, and the is obliged to ufe all her arts to conceal her young from him as from the mot dangerous of her purfuers. At this feafon, the courage and arts of the male feem transfersed co the female. The calf (as the young ftag is called) accompanies the dam the whole fummer; in winter, the hind, and young males affemble in herds, which are numerous in proportion as the feafon is fevere.

The ftags of China are no taller than a common houfe-dog; hunting them is a principal diverion of the great. Their fleth, while young, is good; ar maturity, hard and tough: the tongue, the muzzle, and the ears, are in particular efteem among that luxurious people. Their manner of taking them is fingular: they carry a head of the female ftulf̧ed, and exactly imitate her cry; upon this the male appears, and perceiving 
perceiving the head (which is all that the hunter, who is himfelf concealed, difcovers) advances, the company then rife, furround, and often take him alive.

There are very few varieties in the red deer of this country. But in different parts of the world, they differ in form, fize, horns, and colour.

The Corfican ftag is a very fmall animal, not above half the fize of ours. His body is fhort and thick, his legs fnort, and his hair a dark brown.

In the forefts of Germany is a kind of ftag, named by the ancients the Tragelaphus, which the natives call the Bran, or Brown Deer; is of a darker colour than the common ftag, of a lighter thade upon the belly, and long hair upon the neck and throat, by which it appears bearded, like the goat. The Hippelaphus is of the fame race.

The Axis (of Pliny), between the ftag and the fallow deer, is a beautiful ftag inhabiting the banks of the Ganges, Ceylon and Java; are very tame, and, though they readily eat bread, will refufe a piece that has been breathed on.

Although there are but few varieties of the deer kind, yet the deer feems generally diffufed over the earth. America produces ftags, and deer. The Mexicans have a breed of white ftags in their parks, which they call. Stags Royal. The Americans are faid to have brought the ftag to the fame domeftic tamenefs as our heep, goats, or cattle. They fend them forth in the day-time to feed in the forefts; and at night they return home with the herdfman who guards them.

\section{THE FALLOW DEER.}

7 HE Alag and the fallow deer are alike in form, in difpofition, in 1 the furniture of their heads, in fwiftnefs and timidity; yet they never herd together, or form a mixed breed; and where the ftag is common, the buck feems a franger. The fallow deer are lefs robut, and favage than the ftag; are, in general, bred in parks, and kept for their venifon. The horns of the buck are broad and palmated; whereas thoie of the ftag are in every part round; they are fhed yearly and take the ufual time for repairing. The fallow deer is eafily tamed, and feeds upon many things which the ftag refures. By this means it preferves its venifon better. The doe goes with young above eight months, commonNo. 21 . 
ly brings one : the buck comes to perfection at three, and lives till fixteen years. The ftrength, cunning and courage of this animal, is inferior to the ftag; being lighter, and not tracking fo deeply, it leaves a lefs powerful and lafting fcent, and the dogs in purfuit are more frequently at a fault.

We have in England two varieties of the fallow deer, which are faid to be of foreign origin. The beautiful fpotted kind, fuppofed to have been brought from Bengal; and the very deep brown fort, introduced by King James the Firft, from Norway. From having obferved their hardineis, and that they could endure the winter, even in that fevere climate, without fodder, he brought over fome of them into Scotland, and difpofed of them among his chaces. Since that time, they have multiplied in many parts of the Britifh empire ; and England is now become more famous for its venifon, than any other country. Found in molt parts of Europe, in Greece, Syria, and the north of China.

\section{T H E R O E - B U C K}

TS the fmalleft of the deer kind in our climate, and is almoft extinct, except in fome of the highlands of Scotland. Exceeds three feet long, and two feet high; horns from eight to nine inches long, uprighr, round, divided into only three branches, and are deciduous. Body covered with very long hair, well adapted to the rigour of its mountainous abode. The lower part of each hair is alh-colour; near the ends is a narrow bar of black, and the points are yellow. The hairs on the face are black, tipped with ath-colour. The ears are long, their infides a pale yellow, and covered with long hair. The fpaces bordering on the eyes and mouth, are black. The cheft, belly, legs, and infide of the thighs, are yellowith white; the rump, pure white; the tail very thort. This animal is very elegant, and fwift.

The roe-buck courts the fhady thicket, and the rifing nope. Its hair is always fmooth, clean, and glofiy; it frequents only the drielt places, and the pureft air. Though but a little animal, yet, when its young is attacked, it faces even the flag himfelf, and often comes off victorious. It is cunning, difficult to purfue, and, though its fcent is much ftronger than that of the fag, more frequently makes good a recreat. The ftag never ufes art till his ftrength declines; but when the 


\section{THE DEER KIIN D.}

the roe finds its firft efforts to efcape without fuccefs, it returns on its former track, again goes forward, and again returns, till by its various windings, the fcent is entirely confounded, and the laft emanations joined to thofe of its former courfes. It then, by a bound, goes to one fide, lies flat on its belly, and permits the pack to pafs by without offering to ftir.

Thefe animals live in families; the fire, the dam, and the young ones; and never admit a ftranger. All the deer kind are inconftant but the roe-buck, who never leaves its mate; as they have been generally bred up together from fawns, their attachment is ftrong, permanent, and mutual. The femaie fawns in May; goes with young five months ard an half; which diftinguimes this animal from all others of the deer kind, that continue pregnant more than eight.

The female retreats to the thickeft woods, being not lefs apprehenfive of the buck than of the wolf, the wild cat, and other ravenous animals; generally produces two, very rareiy three. In about ten or twelve days thefe are able to follow their dam, except purfued. On fuch occafions, the tendernefs of the dam is extraordinary; leaving them in the deepeft thickets, The offers herfelf to the danger, and flies before the hounds, to millead them from the retreat of her little ones. Such animals as are not beyond her power, the boldly encounters; attacks the ftag, the wild cat, and the wolf; enemies, which, in corjungtion with mankind, have diminifhed the fpecies.

The fawns follow the deer eight or nine months. They fhed their horns the latter end of autumn, and renew them during winter. When they fall, and new ones appear, the roe-buck does not forfake its ufual haunts, but keeps down its head to avoid ftriking its horns againft the branches of trees, the pain of which it feems to feel with exquifite fenfibility. It feldom is found to live above twelve or fifteen years; if kept tame, not above fix or feven. They may be fubdued, but never domefticated, or be made familiar: inhabits mofi parts of Europe, in Tartary and China, not Africa. Uncertain whether an American animal of this kind is of this fpecies, or one refembling it, that is very numerous, as well in Louifiana as in Brafil. 


\section{T H $\quad$ E $\quad$ E $\mathrm{L} \quad \mathrm{K}$.}

7 HE Elk is rather of the buck than the ftag kind, as its horns are flatted toward the top; but far exceeds in ftature, being often ten feet high: is called in Europe the Elk, and in North America the Moofe-deer. It is timorous and gentle; content with its pafture, and never willing to difturb any other animal, when fupplied itfelf.

The hair is very long and coarfe : the ears a foot and an half long. The upper jaw longer by fix inches, than the lower; and almoft divided by a deep hollow : has a fort of beard under the throat, hanging from a finall excrefcence, and a prominence in the middle of the forehead. The noftrils four inches long on each fide the mouth; nofe very broad; it ufes its fore feet, which are very tharply hoofed, to ftrike down its enemies; hind-legs much fhorter than the fore-legs; hoofs very much cloven; colour of the body in general a hoary black, and grey about the face.

There are two kinds, the common grey moofe, which is not very large, and the black moofe; all have flat palmated horns, the palm very large, having a hort trunk at the head, and immediately fpreading above a foot broad, with a kind of fmall antlers, like teeth, on one of the edges.

The grey moofe-deer is about the fize of a horfe; as in all of this kind the upper lip is much longer than the under, it is faid they go backward as they feed. Their noftrils are fo large that a man may thrutt his hand in a confiderable way.

Joffelyn, the firft Englith writer who mentions the black moofe, fays, it is a goodly creature, twelve feet high, with exceeding fair horns, that have broad palms, two fathoms from the top of one horn to another: that it is a creature, or rather a monfter of fuperfluity, and many times bigger than an Englifh ox. This Dudley confirms, but gives to the horns only thirty-one inches between tip and tip: however, that fuch an extraordinary animal as Joffelyn defcribes, has actually exilted, we cannot doubt, fince horns twelve feet from tip to tip have often been found in a foffil ftate, as well in Ireland as in America.

Thefe animals delight in cold countries, feeding on grafs in fummer, and bark of trees in winter. The natives prepare to hunt them when the fun begins to melt the'fnow by day, which is frozen again at night; for then the icy crutt which covers the fnow, ufually four feet deep, is too weak to fupport fo great a bulk, and retards the creature's motion. The 
timorous animal, by its endeavours to efcape, finks at every ftep it takes. Still it purfues its way through a thoufand obftacles: the fnow yields to its weight; the harp ice wounds its feet; and its lofty horns are entangled in the branches as it paffes : thefe are broken down with eafe; and where the moofe-deer runs, is traced by the fnapping off branches of trees, as thick as a man's thigh, with its horns. The chace lafts thus a whole day; fometimes two, or three days. The moofe trots on (for that is its ufual pace), till its purfuers come up; after repeated wounds, and repeated exertions, quite tired, and fpent, it finks, like a ruined building, and thakes the earth beneath its fall.

The flem is well tafted, and faid to be very nourithing. The hide is ftrong, and fo thick, that it has been often known to turn a mufket ball. The fur, when viewed through a microfcope, appears fpongy like a bulruh, and is fmaller at the rcots and points than in the middle; for this reafon, it lies very flat and fmooth, and though beaten and abufed never fo much, always returns to its former ftate.

\section{THE RE I N-D E E R}

FS a native of the polar regions, and incapable of futtaining more temperate climates. From it the natives of Lapland and Greenland fupply moft of their wants; like a horfe, it conveys them and their fcanty furniture from mountain to mountain; like a cow it gives milk; and like the heep, it furnifhes a warm, though homely clothing: the milk affords cheefe, the flefh, food; the tendons, bowftrings; and when fplit, thread; the horns, glue; the bones, fpoons.

The rein-deer fomewhat refembles the elk in its horns, has browantlers, very large, and hanging over the eyes, palmated toward the top, and bending forward. The rein-deer is much fmaller, lower, and fronger built than the ftag; its legs thorter and thicker, its hoofs much broader, its hair much thicker and warmer, its horns much larger, as alfo its ears; its pace is rather a trot than a bounding, and this it can continue for a whole day; its hoofs are cloven and noveable, fo that it fpreads them abroad as it goes, to prevent finking in the fnow, which, when it raifes its feet again, occafions them to ftrike together with an audible crack: the elk has the fame peculiarity. The female rein- 
deer has horns as well as the male, by which the fpecies is diftinguifhed from every animal of the deer kind.

When the rein-deer firft thed their coat they are brown; but, as fummer approaches, their hair grows whitih; and at laft, nearly grey. They are, however, always black about the eyes. The neck has long. hair, hanging down, and coarfer than other parts. The feet, at the infertion of the hoof, are furrounded with a ring of white. The hair in general ftands fo thick over the body, that if one hould attempt to feparate it, the fkin will no where appear uncovered: when it falls, it feems broken fhort near the bottom; fo that the lower part of the hair remains.

The horns of the female are like thofe of the male, but they are fmaller and lefs branching. As in other deer, they fprout from the points; and alfo are furnilhed with an hairy bark, which fupports the blood-veffels, of molt exquifite fenfibility. The rein-deer thed their horns, at the latter end of November; and are not completely furnithed again till towards autumn. The female retains hers till the brings forth.

In Lapland this animal is of the greateft advantage, where it forms the riches of the inhabitants, fome of whom poffers herds of a thoufand: their great enemies are the innumerable fwarms of gnats which infeft the lower grounds in fummer, and even drive them from their paftures to the mountains, where the gnats fear to come becaufe of the cold.

Befides the gnat, there is a gadfly, no lefs formidable and often fatal, This fly is bred under their fkins, where the egg has been depofited the preceding fummer; and is no fooner produced than it endeavours to depofite its eggs in a place fimilar to that from whence it came. Whenever, therefore, this fly appears over an herd of rein-deer, it terrifies the whole body; they know their enemy; and by tofing their horns, and running among each other, endeavour to avoid it, or run for fhelter to the mountains; they have alfo enemies in the beafts of the forent, and have difeafes fome of which are fudden, contagious, and incurable.

The female brings forth in the middle of May, and gives milk till about the middle of October. Every morning and evening, during fummer, the herdfman returns to the cottage with his deer to be milked, where the women have previounly kindled a moky fire, which drives off the gnats, and keeps the rein-deer quiet. The female yields about a pint, then the herdfman drives them back to feed; neither folds nor houfes them, neither provides their fubfiftence, nor cultivates their pafture, 


\section{THE DEER KIN D.}

Their chief, and almoft their only food, in winter, is the mofs, which, from its being fed on by this animal, obtains the name of the rein-deer lichen (lichen rangiferinus). This is of two kinds; one white, which covers almoft all the defert parts of the country like fnow; the other black, which covers the branches of the trees. The deer purfue their food, though covered in the deepeft fnow, even though its furface be frozen: They turn it up with their nofes, like fwine, for the hide by ufe is hardened in that part.

The rein-deer of this country are of two kinds, wild and tame. The wild are larger and ftronger, but more mifchievous than the others. No creature can be more active, patient, and willing than the tame; when hard pufhed, they will trot nine or ten Swedih miles, or between fifty and fixty Englith miles, at one ftretch: but the poor obedient creature fatigues itfelt to death. In general, they can go about thirty miles without halting, and without danger.

They go with young about eight months and generally bring two. The dam is fond of her young, and often, when they are feparated from her, returns from palture, keeps calling round the cottage for them, and will not defitt, till they are brought and laid at her feet. They are at firt of a light brown, but become darker with age. The old ones almoft approach to blacknefs. The young follow the dam two or three years; do not acquire their full growth till four; are then troke in, and managed for drawing the netge, and continue ferviceable four or five years longer. Live about fifteen or fixteen years.

\section{OF THE}

\section{$M U S K A N I M A$ L.}

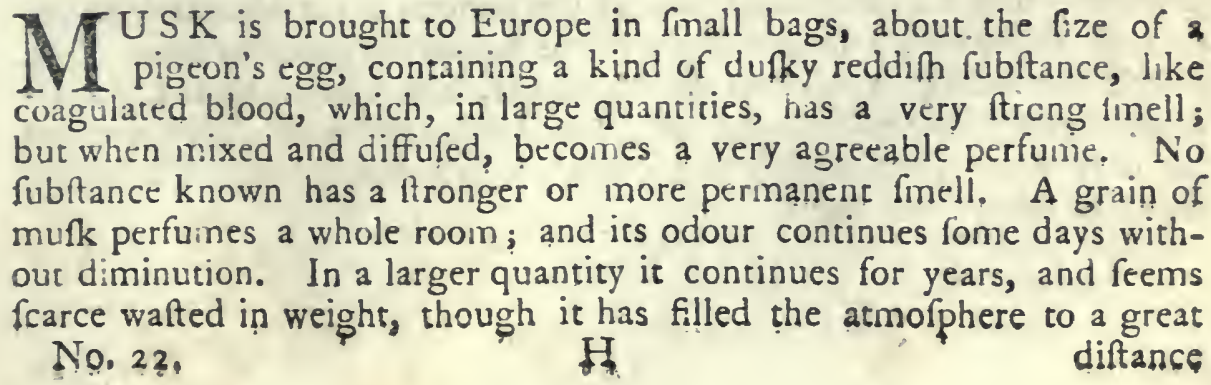


diftance with its particles. In nervous and hyfteric diforders, it is found a powerful remedy. The animal that furnilhes this admirable medicine, is known but imperfectly.

The Munk animal has no horns; wants fore teeth in the upper jaw, the fame as ruminating animals; but has two tufks haneying out exprfed. Eight fmall cutting teeth in the lower jaw. 'It is three feet fix 'inches in length, about two feet three or four inches high. The head is above half a frot long; the fore part of the head is fomewhat like a greyhound; ears long and narrow, infide pale yellow, outfide deep brown, partly ercet, like thofe of a rabbit; the tail not two inches; is cloven-footed; hoofs nender and black; hair is erect, on the head and legs half an inch long, on the belly an inch and half, on the back and buttocks three inches, and proportionably thicker than in any other animal; is waved brown and white alternately, from the root to the point; on the head and thighs brown, under the belly and tail white, a little curled, efpecially on the back and belly. On each fide of the lower jaw, under the corners of the moutl, is a tuft of thick hair, which is fhort and hard, about three quarters of an incli long. The hair of this animal is foft and fine; but what dittinguifhes it are the tuiks, which are near two inches long, and turn back in the form of a hook; and, more particularly, the muik bag, which is about the fize of a hen's egg, on the belly of the male only: It has two fmall orifices; one naked, the other hairy. It is a very fearful animal; has the fenfe of hearing fo quick, that it can difcover an enemy at a great diftance.

The female is lefs than the male, nofe tharper, wants the swo tunks, and has two fmall teats. Inhabits the kingdom of Tibet, Cbina, Tonquin, and Bontan, from lat. 6o to 45 or 44 ; but never wanders fo far fouth, except forced by feverity of the fealon, when they feek corn or rice newly grown. Inhabits naturally mountains covered with pines; loves folitude; if purfued, feeks inaccefible fummits. It is extremely probable, that the mufk-bags fold by the hunters are adulterated, as the greateft plenty of the animal could fcarce fupply the quantity fold. The ferh of the animal is infeeted with the fcent, but is eaten by the Mufcovites. The Tibet mufk is the beft; the Ruflian the worft. This is not the only animal refembling the deer, yet without horns. There are. others in Brazil and India. 


\section{( 39$)$}

T H E

\section{CAMEL AN D THE DROMEDARY.}

7 HEsE animals are in all refpects the fame, except that the camel has but one bunch on his back; the dromedary has two. The camel alfo is the ftrongeft and largeft. The two races produce with each other, and the mixed breed formed between them is confidered the beft, the moft patient, and moft indefatigable.

The camel has a bunch on the back, fmall head, little ears, long neck and bending; about fix feet fix inches to the top of his bunch; foft hair, lnngeft about the neck, throat, and bunch; tail long, hoofs fmall, divided, but not entirely; the foal exceffively tough and pliant; has fix callofities on the legs, one on each knee, one on the infide of each fore-leg on the upper joint, one on the infide of the hind-leg at the bottom of the thigh, another on the lower part of the breaft, being the places on which the animal refts when lying down.

The camel is by far the moft numerous, and is fpread over the defarts of Arabia, Africa, Perfia, Tartary, and great part of the eaftern Indies, but cannot fubfift, or propagate, in the variable climates towards the north; they feem formed for countries where Thrubs are plenty; and water fcarce; where they can travel along the fandy defart, without being impeded by rivers, and find food at expected diftances; fuch a country is the defart of Arabia, and feems inott adapted to this animal. They have been tranfported to Spain, to America, to Barbadoes, but without effeet.

The camel is the moft temperate of animals, and can travel feveral days without drinking. Its feet are formed for travelling upon fand, and utierly unfit for moift or marhy places; the Arabians, therefore, find a moft ufeful affiftant in this animal, where no other could fubfift, and by its means crof's thofe defarts with fafery, which would be unpaffable by any other method of conveyance. If the camel hould nip, as in moitt places it might, it would fplit afunder under a burden.'

The natives could neither fubfift, traffick, or travel without the camel; its milk and flefh make part of their nourifhment; its hair, which it fheds yearly, their clothing; and if they fear an invading enemy, their camels convey them in a fingle day above an hundred miles. All' the 
armies upon earth might be loft in purfuit of a flying fquadron mounted on camels.

The camel is eafily inftructed in the methods of taking up and fup. porting his'burthen; their legs, a few days after they are produced, are bent under their belly; they, are then loaded, and taught to rife; their burthen is daily infenlibly increafed. Equal care is taken in making them patient of hunger and thirft: while other animals receive their food at ftaced times, the camel is reftrained for days together, and thefe intervals of fcarcity are increafed in proportion as the animal feems capable of fuftaining them. Their fomach is admirably formed by nature for long abfinence : befides the four ftomachs, common to animals that chew the cud (and the camel is of the number), it has a fifch ftomach, which ferves as a refervoir, to hold a greater quantity of water than the animal has immediate occafion for. Here the fluid remains without corrupting, or being adulterated by other aliments: when the camel finds itfelf thirly, it throws up a quantity of this water by a fimple contraction of the mufcles, into the other ftomachs, and thus macerates its food.

In Iurkey, Perlia, Arabia, Barbary, and Egypt, all commerce is carried on by camels. Mierchants and travellers unite in a body, to fecure themfelves from robbers. This affemblage is called a caravan; fometimes confifting of above ten thoufand perfons, and the number of camels often greater. Thefe animals are loaded according to their ftrength, and of this each is fo fenfiole, that when overloaded, he remains on his belly, refufing to rile, till his burthen be leffened. Large camels are capable of carrying a thoufand weight, and fometimes twelve bundred; the dromedary from fix to feven. In trading journeys, they feldom go above thirty, or five and thirty miles a day. Every evening, when they arrive at a fage, which is ufually fome fpot of verdure, they feed at liberty, and eat as much in an hour, as will fupply them for twenty four; they prefer coarfe weeds, the thiftle, nettle, cafia, and other prickly vege:ables; but their drivers fupply them with balls of meat, of barley, or beans, as more permanent nourihment. Thefe animals, having often gone the fame track, are faid to know their way. precifely, even when thrir guides are bewildered. When they come within a few miles of their bairing-place, in the evening, they fagaciounly inçreafe their fpeed, and often trot with vivacity to their ftagre. Ihey can difcover water by their fcent at half a league ditance, and will haften towards it, long before their drivers perceive it: They are enlivened 
enlivened by the pipe and mufic, and this always forms part of their drivers' profeflion.

The humps on the back grow large in proportion as the animal is well fed, and are in fubftance not unlike the udder of a cow. The female goes with young about a year, and produces but one at a time. Camel's milk is abundant and nourifhing; and mixed with water makes a principal part of the beverage of the Arabians. They ordinarily live from forty to fifty years.

There is a kind of dromediry which is fwift, and ufed only to ride on, is trained for running matches, and to carry couriers, who travel an hundred miles a day for nine days together over burning fands. The African camels are very hardy, and pafs dreadful delarts from Numidia to Ethiopia.

\section{T H E L A M A.}

r PHE Lama may be confidered as the camel of the new world, and is every way fmaller than that of the old. Refembles the camel, not only in its natural mildnefs, but its aptrefs for fervitude, its moderation, and its patience. The Americans early availed themfelves of its ufeful qualities.

They belong entirely to the new continent; nor are they fpread over all America, but chielly among the Andes. They inhabit the higheft regions of the globe, and feem to require the pureft air. In Potofi, and other provinces of Peru, where they are numerous, titey make the chief riches of their mafters, Indians and Spaniards : their fleth is excellent food; their hair, or rather wool, forms clothing; and, in the moft rugged and dangerous ways, they carry burchens of a hundred weighe with fafety. They go about fifteen miles a day; their tread is heavy, but fure; they defcend precipices, and find footing among craggy rocks where men can fcarce accompany them. After four or five days latour, they are obliged to repofe for a day or two. They are chithy ufed in carrying the riches of the mines of Potofi ; and we are told that these are above three hundred thoufand of thefe animals in actual employ. Were ufed to plough the land before the introduction of mules. 
This animal is about the fize of an afs, fome four or four and half feet high, and fix in length; the neck three feet long, the head is fmall, its face refembling a camel, eyes large, nofe long, lips thick, the upper divided, the lower a little depending; like all animals that feed on grafs, wants the upper cutting teeth; the ears four inches long, move with great agility; the tail fmall, ftrait, a little turned uo at the end; is cloven footed, like the ox, but has a kind of fpear-like appendage behind, which affints it in moving over precipices and rugged ways; the wool on the back. is. Thort, but long on the fides and the belly; has fmooth hair when tame, rough when wild; are moftly brown, but fome white, black, or fpotted.

The lama is extremely moderate in what it drinks, and exceeds even the camel in temperance. Indeed, of all creatures, it feems to require water leaft, as it is fupplied by nature with faliva in fuch large quantities, that it fpits it out on every occafion, and this faliva is its only offenfive weapon; wherever it falls on the kkin, it caufes an itching and reddifh fpot.

Thêfe animals are found wild in very great numbers, and exhibit marks of very great force and agility; are in mape delicare and ftrong; colour tawney, wool thort; in their native forelts are gregarious animals, often feen in flocks of two or three hundred. When they perceive a ftranger, they regard him with aftonifhment, without marking fear or furprife; but thortly, as if by common confent, they fnuff up the air, fomewhat like horfes, and take refuge on the tops of the mountains : are fonder of the northern than the fouthern fide of the Andes; often climb above the fnowy tracts of the mountain, and feem vigcrous in proportion to the coldnefs of their fituation,

The lama feems to be the largeft of the camel kind in America; there are others, called guanacoes and pacos, that are fmaller and weaker, of the fame nature and forms. The woul of the paco is formed into ftuffs, not inferior to filk, either in price or beauty. The natural colour of the paco is that of a dried rofe-leaf, or dull purple; the manufacturers feldom dye its wool, but form it into quiles and carpets. 


\section{$(43)$ \\ O F T H E \\ $\begin{array}{lllllll}H & O & G & K & I & N & D\end{array}$}

7 HE hog kind feem to unite thofe diftinetions by which others are feparated. They refemble the horfe in the number of their teeth, which anount to forty-four, in the length of their head, and in having but one ftomach. They refemble the cow in their apparently cloven hoofs, and the pofition of their inteftines; and they refermble the rapacious kind in their appecite for flefh, in their not chewing the cud, and in their numerous progeny. Like them they have thort inteftines; their hoofs alfo, though apparently cloven, on anatomical infuection, appear formed with bones like beafts of prey; and the number of their tears ine creafes the fimilitude.

The wild Boar is by no means fo ftupid nor fo filthy, as that reduced to tamenefs; he is fmaller; his colour an iron grey, inclining to black; his fnout is much longer than that of the tame hog; ears thorter, rounder, and black. He roots up the ground like a furrow, and does irreparable damage in cultivated lands. The turks of this animal are large, fome of them almoft a foot long. Thefe grow from both the under and upper jaw, bend upwards circularly, and are exceeding fharp; they never fall; all the hog kind never thed their teeth. The turks of the lower jaw are moft to be dreaded, and give very terrible wounds.

The wild boar can properly be called neither folitary nor gregarious. The three firt years the litrer follows the fow, and the family lives together. They are then called beafts of companv, and unice their forces againt beafts of prey, calling to each other with a very loud and fierce note; the ftrongeft face the danger, and the weakeft fall into the centre. In this pofition tew ravenous beafts dare attack tnem. When the wild boar is mature, and confcious of his Atrength, he walks the foreit alone, and fearlefs.

The hog, in a natural ftate, feeds chiefly on roots and vegetables; feldom atracks other aninals; but if an animal die in the furclt, or is fo wounded that it can make no refintance, it becomes a prey to the hog, who feldom refules animal food, how putrid foever, though rever at the pains of taking or procuring it alive. In A tierica, feeds upon rattle-fnakes with fafety, and is in that refpect very ufeful.

It is of all quadrupeds moit delicate in the choice of vegrtables, and rejects a greater number than others. The cow, we are alfured by LinNo. 22, 
næus, eats two hundred and feventy-fix plants, and rejects two hundred and eighteen; the goat eats four hundred and forty-nine, and rejects an hundred and twenty-fix; the theep eats three hundred and eighty-feven, and rejects an hundred and forty-one; the horfe eats two hundred and fixty-two, and rejects two hundred and twelve; but the hog eats only feventy-two plants, and rejects an hundred and feventy-one. The indelicacy of this animal is, therefore, rather in our apprehenfions than in its nature; for, where it finds variety, it rejects the worlt with as diftinguifhing a tafte as any other quadruped whatfoever. In the orchards of peach-trees in North-America, where the hog has plenty, it will rejęt the fruit that has lain a few hours on the ground, and continue on the watch hours together for a frefh windfall.

The hog is ftupid, inactive, and drowfy; would fleep half its time; but is frequently awaked by the calls of appetite, which having fatisfied, goes to reft again.. Its whole life is leep and gluttony, in enjoyment of which it foon grows unfit even for exiftence; its flefh becomes a greater load than its legs are able to fupport, and it continues to feed lying down, or kneeling, an helplefs inftance of indulged fenfuality. Is keen of fmell; its fat difpofed different from other animals in a regular coat over the whole body. When the wind blows with vehemence, is greatly agitated, runs violently to its fty, fcreaming horribly, which feems to indicate that it is naturally fond of a warm climate. It appears alfo to forefee bad weather, bringing ftraw in its mouth, preparing a bed, and hiding itfelf from the impending ftorm. When it hears any of its kind in diftrefs, gathers round it, to lend fruitlefs afiftance, and to fympathize with its fufferings. They have been known to gather round a dog that had teazed them, and kill him on the fpot. Neverthelefs, is fo brutal, as to eat its own offspring, and fometimes infants.

Moft difeafes of this animal arife from intemperance; meanes, impothumes, and fcrophula. It is thought by fome that they wallow in the mire to deftroy a fort of loufe that infefts them; rather, perhaps, to cool their furfeited body. They generally live eighteen or twenty years; and the females produce till fifteen. As they produce from ten to twenty at a litter, twice a year, they would thortly become exceedingly numerous, if not diminithed. In the wild ftate, the fow brings forch but once a year.

The wild boar was formerly native of our country, as appears from the laws of Hoel Dda, the famous Welch leginator, who permitted his grand huntfinan to chace that animal from the middle of November to 
the beginning of December. William the Conqueror alfo punifhed fuch as were convicted of killing the wild boar in his forefts, with the lofs of their eyes. At prefent the wild breed is extinct; but no country makes greater ufe of the tame.

This animal is native of almoft every country, except in the frigid zones and Kamtchatka, and where the cold is very fevere. Since introduced into America by the Europeans, abounds to excefs in the hot and remperate parts. The Eaft-India breed is lower, lefs furnifhed with hair, ufually black, and has the belly almolt touching the ground; it is now common in England.

There is a remarkable variety of this animal about Upfal, which is fingle-hoofed, like the horfe; but in no other refpect differing from the common kinds. The Guinea hog differs alfo in fome things from our own.

I have feen in the poffeffion of an officer, who had ferved in the EaftIndies, drawings of a pair of creatures exactly refembling hogs, except that they had only two legs, their hinder parts being held up in the air, as it were. They are natives of Ceylon, and were fent from thence to a Rajah (I believe) of Tarjore, where they were drawn. They walk with difficulty, and are not eafily induced to rife.

Thefe we confider as of the hog kind; there are other quadrupeds refembling this fpecies, but very diftinct, notwithftanding their general form or habits.

\section{T H E}

\section{A F R I A N W I L D B $\odot$ A R}

IFFERS from that of Europe, efpecially by its head; which is large in the upper, rifing almoft perpendicular, near feven inches long. The under tufks exactly meet the upper when the mouth is thut. The head is flat in front, and ends in a confiderable breadth of fnout, almoft of a horny hardnefs, with which he roots the earth; no fore teeth; his eyes are placed on the fore part of his head, to that he can only fee before him. Beneath them is a very wrinkled kind of hollow, formed of loofe fkin; fomewhat lower, the fkin rifes, and forms on each fide an excrefcence, which at a little diftance refembles ears in fize and figure, broad, flat, rounded at the end, lying almoft in the fame direction as the face, intercepting the view of every thing below from the animal; 
between the excrefcences and the tufks, is a large callous protuberance on ench fide the face; ears large and tharp pointed, well lined with long whirim hairs; tail naked, nender, and flat, not very long; hrołs divided; general colour blackin; grows to an enormous fize; capable of tamenefs, in fome degree at leaft, but irritable and capricious; naturally very fwift and fierce; will not breed with the common fort; inhabits the hotteft parts of Africa; little of its native manners known.

\section{T H E}

\section{P E G C A R Y, O R T A J A C U.}

MHE Peccary, or Tajacu, is native of America and the Antilles, found in herds of feveral hundreds together, grazing among the wonds; inoffenfive except when offended.

The peccary refernbles a fmall hog in the form of its body, the fhape of its head, the length of its fnout, and the form of its legs; bur the body is not fo bulkv, its lews not fo long, its briftles much thicker and ftronger than thofe of the hog, lefs refembling hair than the quills of a porcupine, but are not near fo thick; are aifo variegated like the porcu-pine's. Inftead of a tail, it has only a little flefhy protuberance, which does not even cover its pofteriors. It differs from all other quadrupeds by having on its back a lump refembling the navel in other animals, which feparates a liquor of a very ftrong finell. This lump, fituated on the hirider part of the back, is, in general, fo covered with long briftles, that it cannot be feen except they be drawn afide. A fmall fpace then appears, only befet with a few thore fine hairs. In the middle it rifes, and has an orifice capable of receiving a goofe quill, about an inch in depth; round it, under the fkin, are fituated a number of fmall glands, which diftil a whition liquor, in colour and fubftance refembling that obtained from the civet animal; but offenfive. While forne creatures have thefe glands under the belly, of under the tail, the peccary has them on its back.

The belly is slmof bare ; the briftles on the fides gradually increafe in length, as they approach the ridge of the back, where fome are five inches lo g. On the head, between the ears, is a large tuft of briftles, chiefly black; ears are about two inches and a half long, ftanding upfight; the eyes refenble thofe of a common hog, but fmaller; the inout 
is like a hog's, though fmall. One fide of the lower lip is generally fmooth, by the rubbing of the turk of the upper jaw. The feet and hoofs are perfectly like thofe of a common hog.

The peccary may be tamed like a hog, and has pretty nearly the fame habits and ratural inclinations; feeds upon the fame aliments; its fle h, though drier and leaner than that of the hog, is pretty good eating; and, when killed, not only the parts of generation mutt be taken inftantly away, but alfo the lump on the back, with all the glands that contribute to its fupply. If this operation be deferred only half an hour, the flefh becomes utterly unfit to be eaten.

They are particularly fierce when their young are affaulted; they furround the plunderer, attack him boldly, and frequently make his life pay the forfeit of his rafhnefs. When any of the natives are purfued by a herd, they climb a tree to avoid them; the -peccaries gather round it; by threatening with their tufks, and erecting their rough biiftles (as hogs) they affume a very terrible appearance. Thus they remain at the foot of the tree hours together; while the hunter is obliged to wait patiently, and not without apprehenfions, till they retire.

The peccary is fond of mountain-forelts (not of marhes or the mud, like our hogs); it fubffits on wild fruits, roots, and vegetables ; is an unceafing enemy to the lizard, toad, and ferpent, with which thefe uncultivated forefts abound. As foon as it perceives a ferpent, it feizes it with its fore hoofs and teeth, fkins it in an inftant with great dexterity, and devours the flefh. The jaguar is its mortal enemy, but often feels the force of their union. It is faid there are two forts of peccary; one large-the other fmall, and no enemy to marfnes or mud, ous of which it draws worms and infects.

The peccary is very prolific; the young ones follow the dam till they come to perfection. If taken at firft, foon lofe their natural ferocity; never thew any remarkable figns of docility, but continue ftupid and rude, without attachment, or feeming to know the hand that feeds them. They feldom ftray far from home; recurn of themfelves to the fty; and do not quarrel among each other, except when fed in common. At fuch times have an angry kind of growl, much ftronger and harher than that of an hog, but are feldom heard to fcream like the former; fometimes, when frighted or irritated, they have an abrupt angry manner of blowing like the boar.

The peccary is very diftinct from the hing, and will not mix with it.

The Warree is the European hog, degenerated into a wild ftate in the foretts of America, 


\section{B A B Y ROUESSA, OR INDIAN HOG.}

THIS animal's figure, on the whole, moft refembles that of tle hog; has four cutting teeth in the upper, fix in the lower jaw. Its legs are longer, its body more fiender than a hog; its hair is finer, bla'ck:h, rather refembling wool than briftles, but along its back are fome weak briftles; its tail is long, and alfo tufted with the fame, often twifted; ears fmall, erect, fharp pointed. What principally diftinguith it, are four tufks; the two largeft (about twelve inches long) from the upper; the two finalleft (about eight inches) from the under jaw. The jaw-bones of this extraordinary animal are very thick and ftrong, from whence thefe monftrous tufks proceed; they bend circularly, the two lower like thofe of the boar, the two upper rife from the upper jaw, rather like horns than teeth; and, bending upwards and backwards, fometimes have their points directed to the animal's eyes, and fometimes grow into them. The tunks in both jaws are of a very fine ivory, fmonther and whiter than that of the elephant, but not fo hard or ferviceable.

Thefe enormous turks give this animal a very formidable appearance; yet it is thought to be much lefs dangerous than the wild boar. They go together in herds; often in company with the wild boar, with which, however, they are never known to engender; have a very ftrong fcerit, which difcovers them to the hounds; and, when purfued, they growl dreadfully, often turning bacis upon the dogs, and wounding them with the tuiks of the lower jaw, for thofe of the upper are rather an obftuctiun than a defence. They run much fwifter than the boar; have a more exquifite fcent, winding the men and the dogs at a great diftance. When hunted clofely, they generally plunge themfelves into the fea, where they fwim with great fwiftnefs and facility, diving, and rifing again at pleafure; fierce when offended; peaceable and harnilefs when unmolefted. They are eafily tained; their flefh gocd, but faid to putrefy in a very thort time. They repofe themfelves by hitching one of their upper tuns on the branch of a tree; live upon vegetables and the leaves of trees; never break into gardens, like other liwine; inhabit ñear Amboyna and Celebes. 
TH E

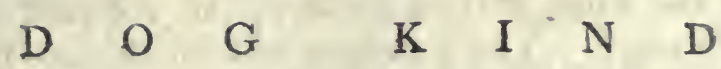

M A be diftinguifhed by their claws, which have no theath, like thofe of the cat kind, but are insapable of extenfion or retraction; nofe and jaw long; body ftrongly made, covered with hair inftead of fur; the intertines much longer in the dog than in the cat kind; the eye not formed for nighe vifion; the olfactory nerves diffufed on a very extenfive membrane within the fcull. They cannot, like cats, purfue their prey up trees, and among the branches, as their claws cannot ftick in the bark ; but their proper prey are animals like themfelves, unfitted for climbing; the hare, rabbit, gazelle, or roebuck. By their fenfe of fmelling, they purfue their prey with certainty, wind it through all its mazes, and tire it down by perfeverance. When driven to extremity, the dog kinds can live for fome time on fruits and vegetables.

Of all the tribe, the Doc claims the preference, as the moft intelligent of quadrupeds, and our acknowledged friend. Independent of his beauty, vivacity, force, and fwiftnefs, the dog poffeffes internal qualifications to conciliate our efteem. To pleafe feems to be his ambition; he comes crouching to lay his force, courage, and talents, at the feet of his mafter; waits his orders, to which he pays implicit obedience; confults his looks, and a fingle glance puts him in motion; he is faithful and conftant; friendly and grateful; much more mindful of benefits than of injuries; is not driven off by unkindnefs; he licks the hand jutt lifted to ftrike him, and difarms refentment by fubmiffive perfeverance; docile and obedient, lie is quickly initructed, and conforms to the difpofitions and manners of his mafters; like the domeftics, is difdainful among the great, churlifh among clowns: afliduous in ferving his mafter, and only a friend to his friends; knows a heggar by his clothes, his voice, or his geftures, and forbids his approach. When at night the guard of the houle is committed to his care, feems proud of the charge; continues a watchful centinel, goes his rounds, fcents ftrangers at a diftance, and gives them warning of his being upon dury. If they affault his territories, he becounes fierce, - Alies at them, threatens, fights, and, when he has conquered, quietly abftains from what he has deterred others from abufing : at once an example of courage, temperance, and fidelity. No.22. 
Without the dog, how could man have been able to conquer and domefticate other animals? How could he difcover and chafe thofe noxious to him? The firft art of man was to conciliate the favour of the dog; and the fruits of this art were, the conqueft and peaceable poffeffion of the earth. The generality of animals bave fuperior agility, fwiftnefs, or arms, than man; their fenles, particularly fimelling, are fuperior. The acquifition, therefore, of an affiftant, efpecially one whofe fcent is fo exquilite, was gaining a fenfe which before was wanting.

The dog, thus taken into office, exerts a fuperiority over all animals under human protection. The flock and the herd obey him; he conducts them, guards them, and confiders their enemies as his own. When the found of the horn, or the voice of the huntfman, calls him to the field, he purfues with pleafure and perfeverance. All animals that live on fleth hunt by nature ; the lion and the tiger, fure to conquer, hunt alone; the wolf, the fox, the wild dog, hunt in packs; but the domeftic dog, when he has been taught by man, hunts with method, and with fuccers.

The wild dog is at prefent unknown; yet there are many that, from a domeftic ftate, have returned to wildnefs (or rather are without mafters), and entirely purfue the dictates of nature; of thefe it is afferted, that when they have run down an animal, they ftill preferve fo much refpect for mankind, as to fuffer part to be taken away without growling. Multitudes wild in Africa and South-America; they unite in large bodies, and attack the moft formidable animals of the foreft, the cougar, the panther, and the bifon; even man himfelf does not pafs without infult. But they are eafily tamed; when taken home, and treated with kindnefs and lenity, they quickly become fubmiffive and familiar, and continue faichfully attached to their mafters. Different in this from the wolf or the fox, who, though taken never fo young, are gentle only while cubs, and, as they grow older, obey their natural appetites of rapine. In thort, the dog is the only animal whofe fidelity is unfhaken; who knows his manter and his friends; who inftantly diftinguifhes a ftranger; who knows and anfwers to his name; who feems to underftand the nature of fubordination, and feeks affintance; who, when he miffes his mafter, teftifies his lofs by complaints; who, carried to a diftance, can find the way home. The only animal whofe natural talents are always fuccefsfully improved by educacion.

The varieties of this animal are too many for the moft careful defrriber to mention. Climate, food, education, produce alterations in. 
fhape, colour, hair, fize, and in every thing but its nature. Nothing appears conftant, but internal conformation, and a capacity of pros ducing among each other, through all their varieties, which determines the identity of the fpecies, and approximates forms that at firt fight: feem never made for conjunction.

Which is the original animal is a queftion not eafily folved. Probably that which moft nearly approaches the wolf or the fox externally; for as the dog nearly refembles them internally, his external refemblance may naturally approach them alfo, except where art or accident has altered his form.

On this principle, we felect that which is called the Shepherd's Dog, with long coarfe hair, except on the nofe, a long nofe and pricked ears; which is common among us, and ufed in attending on fheep. If we examine countries ftill favage, or but half civilized; where the dog, like his mafter, has received few imprefions from art, we find this dog, or one very like him, prevailing among them. Dogs that have run wild in America, and in Congo, approach this form. The dog of Siberia; Lapland, and Iceland, of the Cape of Good Hope, of Madagafcar, Madura, Caiicut, and Malabar, refembles the Repherd's dog. In Guinea, the dog fpeedily takes this form; and, at the fecond or third generation, forgets to bark, his ears and his tail become pointed, his hair drops off, and a coarfer thinner kind fucceeds it. Notwithftanding this creature's melancholy and favage air, he is fuperior to all of his kind in inftinct; and, without teaching, naturally takes to tending flocks, with affiduity and vigilance.

The fhepherd's dog, in temperate climates, and among people entirely civilized, will lofe his favage air, his pricked ears, his rough, long, and thick hair, and by the influence of climate and food become either a Matin, a Maftiff, or a Hound.

The Hound, the Harrier, and the Beagle feem of one kind; for in the litters of a bitch covered by one, are found puppies refembling all three. This animal, tranfported into Spain or Barbary, where the hair of all quadrupeds becomes foft and long, will be converted into the land-fpaniel and the water-fpaniel.

The Grey Matin Hound (the fecond branch) tranfported to the north, becomes the great Danifh dog; this, fent into the fourh, becomes the grey-hound of different fizes; tranfported into Ireland, the Ukraine, Tartary, Epirus, and Albania, becomes the great wolf-dog. 
The Maftiff (the third branch) chiefly a native of Engiand, when tranfported into Denmark, becomes the little Danifh dog; which, in tropical and warm climates, becomes the Turkin dog without hair. Thefe races, with their varieties, are produced by the infuence of climate, food, and education.

Mixed kinds are fo extremely numerous, and different in different countries, it would be endlefs to mention them.' In our own country the varieties are very great, and daily increafing. In the time of queen Elizabeth, Dr. Caius attempted their natural hiftory. Some he mentions are no longer found among us, many others are fince introduced.

He divides dogs into three kinds. Firft, the generous kind, including the tarrier, the harrier, and the blood-hound; the gaze hound, the greyhound, the leymmer, and the tumbler; thefe are ufed for hunting. The fpaniel, the fetter, the water-fpaniel, or finder, for fowling; and the fpanit gentle; or lap-dog, for amufement. 'Secondly, the farm kind, confifting of the fhepherd's dog and the maftiff. Thirdly, the mongrel kind, confifting of the wappe, the turn-fpit, and the dancer. To thefe we may now add, the bull-dog, the Dutch maftiff, the harlequin, the pointer, and the Dane, 'with a variety of ufelefs lap-dogs.

The Tarrier is a fmall kind of hound, with rough hair, uled to force the fox or the badger out of their holes; or rather to give notice by their barking, in what part of their kennel the fox or badger refides, when the fportfmen intend to dig them out.

The Harrier, as well as the Beagle and the Fox-hound are ufed for hunting; of all animals, they have the acuteft fenfe of fmelling.

The Blood-hound was of great ufe, and high efteem among our anceftors, for recovering game that had elcaped wounded, or had been killed, and ftolen; and for hunting thieves and robbers by their footfteps.

The Gaze-hound hunted, like our grey-hounds, by the eye only; chafed the fox, hare, or buck; would felect the fatteft and faireft, and, if loft, recover it again with amazing fagacity. This fpecies is now unknown.

The Grey hound, well known at prefent, was formerly the peculiar companion of a gentleman; who, in the times of femi-barbarifm, was known by his horfe, his hawk, and his grey-hound.

The Leymmer is a fpecies now unknown. It hunted both by feent and fight, and was led in a leyme or thong, from whence it received its name. 


\section{THE DOG K I ND.}

The Tumbler, lefs than the hound, fcraggy, and had pricked ears, e ems to anfwer to the lurcher. This took its prey by mere cunning. The Land-Spaniel (probably named from Spain, where it might acquire the foftnefs of its hair) is well known. There are two varieties; the Starter, ufed in hawking to fpring game, and the Setter, that crouches down when it fcents the birds, till the net be drawn over them, an amufement known only in England.

The Water-Spaniel was another fpecies ufed in fowling.

The Shepherd's Dog has been mentioned, and the Maftiff is too cominon to require defcription:

The Bull-Dog, Mr. Buffon fuppofes, is bred between the fmall Dane and the Englim maftiff. The large Dane is the talleft dog gerierally bred in England.

Of thofe of the foreign kinds, the Lion Dog greatly refembles that animal, in miniature. The hair on the fore part of the body is extremely long; on the hinder part Mhort. The nofe is fhort, the tail long and tufied. In thefe particulars entirely like the lion. It comes originally from Malta, where it is fo fmall, that women carry it about in their חeeves.

That falfely called the Turkin Dog, differs in being entirely without hair. The $\mathrm{kin}$ is of a flefh colour, with brown fpots, and their figure at firft view rather difgufting. They are extremely chilly, unable to endure our climate, and in the midft of fummer always hivering; in winter their fpots entirely difappear.

The Great Irin Wolf-Dog may be confidered as the firft of the fpecies in regard to fize, being fomerimes four feet high, or as tall as a calf of a year old; made like a greyhound, but rather more robuft.

In China are dog-butchers, and Thambles appointed for felling their fleth. In Canton particularly; and wherever a dog-butcher appears, all the dogs of the place follow him in full cry, and perfecute him as far as they are able.

The dog, when whelped, is not complete, the eyes being clofed by a kirid of thin membrane, which is torn as foon as the upper eye-lid becomes ftiong enough to raife it, which in general requires ten or twelve days. Duting that time, the bones of the fcull are not completed, the body is fufied up, and the nofe fhort. In lefs than a month the puppy begins to ufe its fenfes, and makes hafty advances. At the fourth month the dog lofes fome of his teeth, which are renewed by fuch as never fall. Thefe amcunt to forty-two. The teeth of the dog being his 
great and only weapon, are formed in the moft ferviceable manner. He cuts with his incifors, or fore-teeth, he holds with his four great canine teeth, and he chews with his grinders; thefe are fourteen in number, and fo placed that, when the jaws' are fhut, there remains a diftance between them, fo that the dog, by opening his mouth ever fo wide, does not lofe the power of his jaws. The bitch goes nine weeks with young; lives to about twelve years. Will not eat many, kinds of birds; is voracious, yet can bear hunger long; drinks often, though not abundantly; and it is' commonly believed, that when abridged in water, he runs mad; but perhaps not fo often as has been afferted.

\section{T H E W O L F.}

THE Dog and the Wolf are very much alike internally, and ex1. ternally fome dogs rather refemble the wolf than each other.

The wolf is about three feet feven inches long, and about two feet five inches high; which thews him to be larger than our mattiffs. His colour a mixcure of black, brown, and grey, extremely rough and hard, mixed toward the roots with a kind of afh-coloured fur. He appears Atronger chan the dog; and the length of his hair contributes to this effect. The wolf's eye opens nantingly upwards, in the direction of the nofe; whereas, in the dog, it opens more at right angles with the nofe, as in Inan; his tail alfo is long and buhy, and he carries it rather more between his hind legs than the dog. The wolf's eye-balls are fiery green, and add to the fierce and formidable air of his vifage.

The wolf's appetite for animal food is molt vehement. Nature has furnithed him with ftrength, cunning, agility, and all requifites for purfuing, overtaking, and conquering; yer, wich all the fe, the wolf moik frequently dies of hunger, for he is the declared enemy of man. He is naturally dull and cowardly; bue, frequently difappointed, and reduced to famine, he becomes ingenious from want, and courageous from-necefficy. When preffed with hunger, he fallies forch over the country, keeps peering round the villagies, carries off fuch animals as are not under protection, attacks the theep-folds, fcratches up and underminines the, threlholds of doors where they are houfed, and deftroys all before he fixes on and carries off his prey; When thefe fallies fail, the returns to the thickest part of the forelt to purfue finallef animals, which, when taken, 


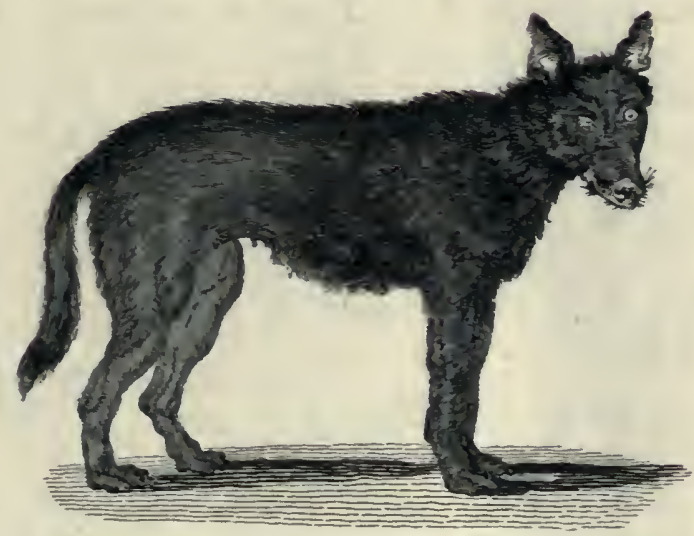

The Black Wolf 
N.

1

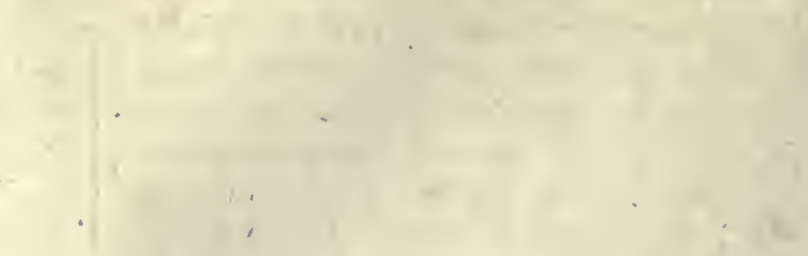

, 
taken, afford him but a fcanty fupply. He there goes regularly to work, follows by the fcent, opens to the view, ftill keeps following, if hopelefs himfelf of overtaking, expecting that fome other wolf will come to his affiftance, and then content to thare the fpoil. At laft, when his neceflities are very urgent, he boldly faces certain deftruftion; he attacks women and children, fometimes men; becomes furious by continual agitation, and ends his life in madnefs.

The wolf apparently refembles the dog s yet only offers the reverfe of the medal. If his form be like, his nature is different; he preferves the ill qualities of the dog, without any of his good ones. No two animals can have a more perfect antipathy to each other. A young dog thudders at the fight of a wolf; he even huns his fcent, which, though unknown, is fo repugnant to his nature, that he comes trembling to take protection near his mafter. A dog who is ftronger, and knows his ftrength, briftles up and teftifies his animofity, attacks him with courage, and exerts his abilities to rid himfelf of a hateful preferce. They never meet without animofity, fighting for life and-death, and without mercy on either fide. If the wolf is the ftronger, he devours his prey: the dog contents himfelf with victory, leaving his enemy, when he falls, as food for birds of prey, or for other wolves, fince they devour each other; when one wolf is defperately wounded, the reft track him by his blood, and complete his difafter.

Dogs, of the dulleft kinds, feek company; but the wolf is the enemy of all fociety, even among thofe of his kind; their affociation is not fociety, but a combination for war : their loud howlings and fiercenefs difcover a project for attacking fome great animal, a ftag or a bull, or fome more redoubtable watch-dog. The inftant their military expedition is completed, their fociety ends, and each returns in filence to his folitary retreat. There are but night attachments between the male and female; they feek each other but once a year, and remain together but a few days; they couple in winter; feveral males often follow one female, and this affociation is ftill more bloody than the former; they difpute moft cruelly, growl, bark, fight, and tear each other; and fometimes the majority kill that wolf which has been chiefly preferred by the female.

The time of pregnancy is about three months and a half; young wolves are found from the latter end of April to the beginning of July: The long continuance of the wolf's pregnancy adds a diftinction between it and the dog. They generally bring five or fix, fometimes nine No: 22, 
cubs, with the eyes clofed; the dam fuckles them fome weeks, and teaches them betimes to eat flefh, which the prepares for them, by chewing it firt herfelf. Some time after the brings them ftronger foot, hares, partridges, and birds yet alive. The young wolves begin by playing with them, and end by killing them. The dam then ftrips them of their feathers, tears them in pieces, and diftributes them. They do not leave the den till they are fix weeks or two months old. When they are about ten or twelve months old, have fhed their firft teeth, and completed the new, the thinks them able to thift for themfelves. She hides the place of her retreat from the male, left he fhould devour her cubs.

The wolf grows grey by age, and his teeth wear by ufing. He neeps when fatisfied or fatigued, rather, by day than night; and always is very eafily waked. He drinks frequently; though very voracious, fupports hunger for a long time, and often lives four or five days without food, provided he be fupplied with water; to allay hunger will eat mud. He carries off a theep in his mouth without letting it touch the ground, and runs with it much fwifter than the fhepherds who purfue him; fo that only the dogs can overtake and oblige him to quit his prey. $\mathrm{He}$ bites cruelly, always with greater vehemence in proportion as he is - leaft refifted; for he ufes precautions where he meets defence. He is ever cowardly, and never fights but by neceffity. When wounded by a bullet, he fcreams; yet, when furrounded by the peafants, and attacked with clubs, he defends himfelf in filence, and dies as hard as he lived.

He travels, runs, and plunders, days and nights together; is indefatigable; and perhaps of all animals the moft difficult to be hunted down. If caught in a pit-fall, he is for fome time fo frightened and aftonithed, that he may be killed, or taken alive, without much danger; may be collared, muzzled, and dragged along fafely. At all other times he has his fenfes in great perfection; his eye, his ear, and (particularly) his fmelling. He fmells a carcafe at more than a league's diftance. When he leaves the wood, he takes care to go out againft the wind; at its extremity, he examines, by his fmell, on all fides, emanations of his enemy or his prey, which he nicely diftinguifhes. He prefers animals which he kilis himfelf, to thofe he finds dead; yet he does not difdain thefe when without better. He is particularly fond of human flefh, and perhaps, were he fufficiently powerful, would eat no other. Gefner sells us of a friar, a woman, and a wolf, being taken in a pit-fall in the 
the fame night. The woman lott her fenfes with the fright, the friar his reputation, and the wolf his life.

King Edgar is faid to be the firft who attempted to rid this kingdom of fuch difagreeable inmates, by commuting the punifhment for certain crimes into the arceptance of a number of wolf's tongues or heads from each criminal. However, fome centuries after, thefe animals were again increafed to fuch a degree, as to become a public nuifance. Edward the Firft iffued out his mandate to Peter Corbet to fuperintend and affift in their deftruetion. They are faid to have infefted Ireland long after they were extirpated in England.

Befide the common wolves in France and Germany, there are others with thicker hair, inclining to yellow.' Thefe are more favage and lefs noxious, neither approaching the flocks nor habitations, and living rather by the chace than rapine. In the northern climates are found fome quite black, and fome white all over. The former are larger and ftronger than thofe of any other kinds.

The fpecies is very much diffufed in every part of the world, being found in Afia, Africa, and in America, as well as Europe. The wolyes of Senegal refemble thofe of France, except that they are larger and much fiercer than thofe of Europe. They prey in company with the lion. Thofe of Egypt are fmaller than thofe of Greece. In the Eaft, the wolf is trained up for a thew, being taught to dance and play tricks; one thus educated often fells for four or five hundred crowns. It is faid, that in Lapland the wolf will never attack a rein-deer that is haltered; the wary animal, being well acquainted with the nature of a trap, fufpects one wherever he perceives a rope. However, when he fees the deer at liberty, he feldom fails to deftroy it.

The wolf of North-America is blacker and much lefs than others, and approaches nearer to the dog. In fact, they were ufed as fuch by the natives, till the Europeans introduced others; and even now, on the remoter fhores, or the more inland parts, they ufe thefe aniunals in hunting. They are tame and gentle; and the wild ones of this kind neither fo large nor fierce - as an European wolf, nor do they attack mankind. They go in large packs by night to hunt the deer, which they do as well as any dogs in England; and it is confidently afferted that one of them can run cown a deer; do not bark, but ufe a kind of howl. Catefby fays, they have engendered with the European dogs, and that their breed has become prolific; which proves them to be of the fame fpecies. Similar facts have occurred in London. 
The Mexican wolf has a very large head, great jaws and teeth, and is a voracious animal.

Wolf's ferh is very indifferent, and feems to be diniked by all other animals, no creature being known to eat it, except a wolf. He breathes a moft fœtid vapour from his jaws, as his food is indifcriminate, often putrid, and feldom cleanly. In fhort, every way offenfive, by a favage afpect, a frightful howl, an infupportable odour, a perverfe difpofition, and fierce habits, he is hateful while living, and ufelefs when dead.

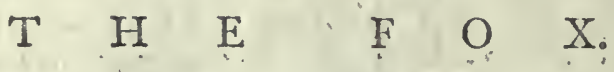

THE Fox is nenderer than the wolf, and not near fo large; about 1. two feet three inches high. The tail of the fox is longer in proportion, and more bufhy; its nofe fmaller, and hair fofter; its eyes hazel, obliquely fituated like thofe of the wolf, and its ears are directed in the fame manner; its head is equally large in proportion to its fize. It has a ftrong offenfive fmell peculiar to the fpecies, and often the caufe of their death.

The fox has ever been famous for cunning and art, not without meriting his reputation. Not attempting to oppofe the dogs or the fhepherds, neither attacking the flock, or alarming the village, he gains by his addrefs what is denied to his ftrength or courage. Patient and prudent he waits opportunity, and varies his conduct. His ftudy is felf-prefervation; nearly as indefatigable, actually fwifter than the wolf, he does not truft to thefe qualities, but retires, in cafe of neceflity, to an afylum, where he avoids danger, ard brings up his young.

A home fuppofes a fuperior degree of inttinet; the choice of fituation, the art of making it convenient, of fecuring and concealing it, are marks of fuperior fkill. - The fox generally keeps his kennel, which is often a badger's hole, at the edge of a wood, within an eafy journey of fome neighbouring cottage. "Thence he liftens to the crowing cock and the cackling fowls. He fcents them, feizes his opportunity, conceals his approaches, creeps nyly "along, and feldoms returns without his booty. In a yard he levels all the poultry; carries off part of the fpoil, hides it at forme convenient diftance, and again returns to the charge. He hides others alfo, but not in the fame place; and this for feveral 
times together. When le tinds birds entangled in fpringes, the fox is beforehand,-very expertly takes the bird out of the fnare, hides it three or four days, and knows exactly when and whe to return to his hidden treafure. He is equally alert in feizing young hares and rabbits, and if old ones are wounded or fatigued, he is fure to profit by their moments of diftefs. He finds out birds netts, feizes the partridge and the quail fitting, and deftroys a large quantity of game. In fhort, nothing comes amifs; rats, mice, ferpents, ioads, and lizards. When urged by hunger, he will eat vegetables and infects. Thofe rear the feacoatts eat crabs, fhrimps, and fhell-filh. The hedge-hog vainly rolls itfelf into a ball; this determined glutton teizes it till it unrolls, and then devours it. He attacks the wafp and the wild bee with equal fuccefs; at firtt they oblige their invader to retire, but in a few minutes he has rolled himfelf on the ground, and crufned fuch as ftick to his $f_{\mathrm{K}} \mathrm{in}$, he then returns to the charge, and by perfeverance, obliges them to abandon their combs, which he greedily devours, both wax and honey.

His fcent is ftrong, but foon evaporated. His hifts to efcape, when retreat is cut off to his kernel, are various and furprifing. He choofes the moft woody country, and takes the paths moft embarraffed with thorns and briars; flies in a direct line before the hounds, though at no very great diftance; manages his frength; takes to the low and plafhy grounds, where the fcent will leaft lie; and, when overtaken, defends himfelf with a defperate obftinacy, and fights in filence to the very laft.

The fox's litter is generally from four to fir. The female goes with young about fix weeks, feldom ftirs out while pregnant, but makes a bed for her young, and ufes every preparation. If her retreat is difcovered, and her yourg difurbed during her abfence, fhe remeves them one after the other in her mouth. The cubs are born blind, are eighteen months or two years in coming to perfection, and live about twelve or fourteen years.

The fox makes and fuffers general war. The dog hunts him with peculiar acrimony; the wolf purfues him to his very retreat; the birds attend his excurfions, and give warning of their approaching danger. The daw, the magpye, and the black-bird, perching on the hedges as he creeps below, with their cries apprize other animals; a caution which they perfectly underftand and practife.

The generality of the foxes are red; but there are fome, though not in England, greyin. 
The greyhound fox is the largeft, talleft, and boldeft, and will atrack a grown fheep. The maltiff fox is less, but more ftrongly built. "The cur fox is the leaft and moft common; he lurks about hedges and outhoufes, and is the moft pernicious.

Around the pole, the foyes are of all colours; black, blue, grey, iron-grey, filver-grey, white, white with red legs, white with black heads, white with the tip of the tail black, red with the throat and belly entirely white, and lanty with a ftripe of black running along the back, and another crofing it at the fhoulders. The common kind is generally diffufed, being found in Europe, in the temperate climates of Afia and America; but rarely in Africa, and under the torrit zone. Blue fox Ikins are bought with avidity from their fcarcenefs; but the black fox thin is moft efteemed, a fingle fkin of en felling for forty or fifty crowns. The hair of thefe is fo difpofed, that it is impoffible to tell which way the grain lies; if we hold the fkin by the head, the hair hangs to the tail; if we hold it by the tail, it hangs down equaily fmooth to the head.

\section{T}

T S faid to be the fize of a middling dog, refembling the fox in the 1 hinder parts, particularly the tail; and the wolf in the fore-parts, efpecially the nofe. Its legs are fhorter than thofe of the fox, and its colour a bright yellow or forrel.

The fpecies is diffufed over Afia and Africa, as it were a fubftitute for the wolf, where that is not common. There feem to be many. varieties; thofe of the warmeft climates are largeft, and their colour rather a reddifh brown, than that beautiful yellow of the fmaller jackall.

Its cry is a howl, mixed with barking, and a lamentation refembling that of human diftrefs, It is noify and yoracious; goes always in is pack of forty or fifty, fometimes two hundred; hunt from evening to morning; nothing can efcape them; they deftroy the fmaller animals, yet united, have courage to face the largeft. Very little afraid of mankind, they puriue their game to the very doors, and will deltroy children. They enter the fheep-folds, yards, and itables, when they can find nothing elfe, deftroy leather harnefs, boots, and hoes, and run off with what they have not time to fwallow: They fçatch up with theic 
feet new-made graves, and devour the corpfes how putrid foever; to prevent which, the earth over the graves is mixed with thorns. While they are at this dreary work, they exhort each other by a cry, refembling that of children under chaftifement. When they have dug up a body, they thare it. When they have once tafted human $\mathrm{fle}$, ever after purfue mankind : They watch burying-grounds, follow armies and caravans. To thefe vultures of quadrupeds, every thing that once had life leems equally agreeable.

The jackall that firft fcents fome larger beaft, gives notice by a howl, which it repeats as it runs; while all within hearing join the chace and cry, which is fo loud, people can farce hear each other fpeak. Often the lion, the tiger, or the panther, follow in filence at fome diftance : The jackall purfues the whole night, keeps up the cry, and with perfeverance tires down its prey; juft at that moment in comes the lion or the leopard, and the jackall muft be content with the remnant he leaves. Between the jackall and dog is an irreconcileable antipathy, and they, never part without an engagement. The jackall is as ftupid as impudent; if one has ftoien filently into an out-houfe, to feize the poultry, hearing others at a diftance, it anfwers the call, and betrays its own depredations.

T H E

\section{S A T I S, OR A R C T I C F O X,}

$\mathbf{M}^{\mathrm{s}}$

AY be confidered as between the diog and the fox. Refembles a fox in its form and length of tail; and a dog, in its head, the pofition of its eyes, and its barking. The hair is foft, fome blue, fome white at one feafon, at another ruffet brown. Its hair is two inches long, thick, tufted, and gloffy, yet the under jaw is bare and without any.

This animal can bear only the coldeft climates, the coafts of the Icy fea, and the great rivers around it; is moftly found in the mountainous and naked regions of Norway, Siberia, and Lapland. Burrows like the fox; fometimes two or three in a hole, in Groenland; when with young, the female retires to her kennel in the fame manner. Thefe holes, which are very narrow and extremely deep, have many outlets, are kept very

No. 22. $\mathrm{M}$ clean, 
clean, and bedded with mols. Its time of geftation and number of young are fimilar to the fox ; brings forth in May or June.

Its moft ftriking peculiarity remains to be mentioned, namely, its change of colour, being at one time brown, at another white; the blue never change colour, but fome are, when brought forth, of a yellow hue, which, in the beginning of September, gradually changes to whice; its fur is then two inches long; in May this begins to fall, and about the middle of July the ifatis again becomes brown.

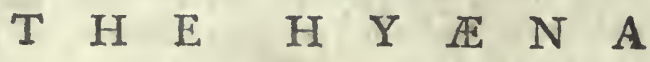

TS nearly the fize of a wolf, and has fome fimilitude to that animal in Thape. The head at firft fight agrees, except that its ears are longer and more bare of hair ; obferving clofely, we find the head broader, the nofe flatter, and not fo pointed; nor are the eyes placed obliquely; fore legs longer than the hinder; the feet different from all other quadrupeds, in having but four' toes, as well before as behind. Its coarfe hair is a dirty greyifh, marked with black, difpofed in waves down its body. Its tail is hort, with pretty long hair; immediately under it, above the anus, is an opening into a kind of glandular pouch (which feparates a fubftance of the confiftence, but not the odour, of civet), in which it is refembled only by the badger. It holds its head fomewhat like a dog purfuing the fcent, with the nofe near the ground, by which the back appears elevated, which is augmented by a long briftly band of hair that runs down it.

Savage and untameable, ever in a ftate of rage or rapacity, ever growling; except when receiving food; then its eyes gliften, the briftles of its back ftand upright, its head hangs low, and yet its teeth appear; a moft frightful afpect, heightened by a dreadful howl, which is very peculiar: its beginning refembles the voice of a man moaning, its conclufion a violent effort to vomit, or a kind of grofs guttural laughing haw! haw! It feems the moft untractable of quadrupeds; its courage equals its ferocity; it defends itfelf againft the lion, is a match for the panther, attacks the ounce, and feldom fails to conquer.

Is a folitary animal; native of the moft defolate and uncultivated parts of the torrid zone; refides in caverns of mountains, clefts of rocks, in dens formed by itfelf. Though taken young, cannot ufually be tamed; 


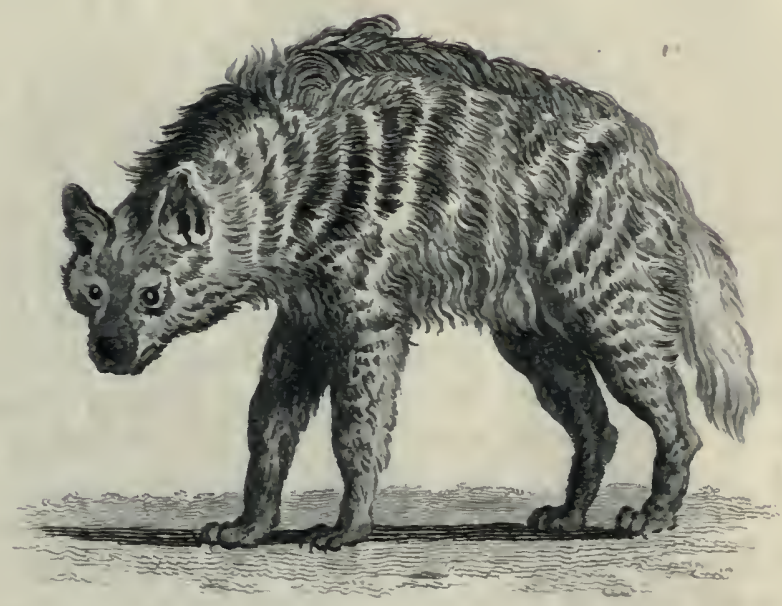

The Hyrena. 


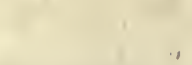

$-\quad 1$ 
it lives by depredation, fometimes attacks man, carries off cattle, follows the flock, breaks open the fheep-cots by night, and ravages with infatiable voracity. Its eyes fhine by night; and it is afferted, not wichout great appearance of truth, that it fees better by night than by day. When deftitute of other provifion, it fcrapes up the graves, and devours the dead bodies, how putrid foever.

Befide the ftriped hyæna, there is alfo a fpotted hyæna, of congenial form and manners.

T H E

\section{$\begin{array}{lllllll}\text { C } & \mathrm{A} & \mathrm{T} & \mathrm{K} & \mathrm{I} & \mathrm{N} & \mathrm{D} \text {. }\end{array}$}

$7 \mathrm{HE}$ Cat kind are diftinguifhed by their claws, which they can hide or extend at pleafure. They feek their food alone : and, except at certain feafons, are enemies to each other. They devour nothing but flefh, and ftarve on other provifion; ever fierce, rapacious, fubtle, and cruel; unfit for fociety among each other, and unprofitable were they added to our lift of domeftics. Lions have been tamed fo far as to become pageants of favage ftate; and tigers have been fubdued, but'ac too great trouble and rifque to encourage the practice.

Though differing in fize or colour, they are nearly allied, and one is a fpecimen of the whole. All the kind are inflexible in their forms, and wear the print of their natural wildnefs ftrong upon them. The cat kind are alfo remarkable for their fharpneis and ftrength of claws (whofe gripe is extremely tenacious), their fhortnefs of fnout, their roundnets of head, and their large whilkers on the upper lip. Their teeth, in number thirty, are very formidable, but rather calculated for tearing their prey than for chewing. They feed.but nowly, and while eating, growl, to deter others. Their hinder parts are much weaker than thofe before, and feem lefs made for ftrength than agility. Nor are they fwift, but rather furprife their prey than hunt it. They feize it with a bound, expreffing their fierce pleafure with a roar; timid and cowardly, they feldom attack without advantage, but lly when the force oppofing them is fuperior or equal. The lion himfelf will not venture a fecond attempr, where he has been once repulfed. 
The Cat, the only one of the kind taken under human protection, is a faithlefs friend, oppofed to a more infidious enemy. The fervices of the cat alone equal the trouble of raifing it; and its ftrength is not fufficient to render its anger formidable. The lion or the tiger, if tamed, are dangerous by their ftrength. The cat has only the appearance of attachment, as may eafily be perceived by its timid approaches, and fide-long looks.

The cat goes with young fifty-fix days; brings five or fix at a time. The female ufually hides her retreat from the male, who would devour her kittens. She fuckles them fome weeks, and accuftoms them betimes to rapine. Lives about ten years; is extremely vivacious, and holds out long ere it dies. Kittens are playful and amufing; but their fport fcon becomes malice. They early thew a difpofition to cruelty; often look wiffully towards the bird-cage, or fit centinels at the mouth of a moufe-hole, and fhortly become expert hunters.

We are told of the Greek monks of the inle of Cyprus, teaching cats to hunt the ferpents with which the inand is infefted. Birds, rabbits, hares, rats, mice, bats, moles, toads, frogs, are equally purfued, though not, perhaps, equally acceptable. The moufe feems to be the favourite. The cat has the fenfe of fmelling but meanly. Of all the marks by which the cat difcovers its natural malignity, that of playing and fporting with its little captive, before killing it outright, is the moft flagrant.

In the eyes of cats, the contraction and dilatation of the pupil, is fo confiderable, that the orifice, which by day appears narrow, by night expands over the whole furface of the eye-ball, and their eyes feem or fire. By this conformation, they fee beft in darknefs.

The cat is particularly fearful of water, of cold, and of ill fmells; loves to keep in the fun, to enjoy the fire, and to rub itfelf againt thofe who carry perfumes; is excefluely fond of fome plants (valerian, marum, and cat-mint); thefe it fmells at a diftance, rubs againft them, and, if they be planted in a garden, wears them out. It loves fin, as well boiled as raw; it neeps very lightly; often feems to neep, the better to deceive its prey; treads very foftly, and without noife; is cleanly to the laft degree. Its fur is ufually neek and gloffy; cafily. electrified, fending forth fparks if rubbed in the dark.

The wild cat breeds with the tame; is larger than the houfe cat; its fur being-longer, gives it a greater appearance than it really has; its head is bigger, and face flatter; the teeth and claws much more formidable; 
dable; its mufcles very ftrong, as being formed for rapine; the tail of a moderate length, very thick and flat, marked with alternate bars of black and white, the end always black; the hips, and hind part of the lower joints of the leg, always black; the fur very foft and fine : the general colour of thefe animals, in England, is a yellowih white, mixed with a deep grey. Thefe colours, though apparently blended, yet are difpofed like the ftreaks of the tiger, pointing from the back downwards, rifing from a black lift that runs from the head along the middle of the back to the tail. This animal is the molt deftructive of the carnivorous kinds in this kingdom; inhabits mountainous and woody parts, living moftly in trees, and feeding by nighr. It fhould feem that thefe are not original inhabitants of this kingdom, but from a domeftic ftate, became wild by ill ufage or neglect. By the laws of Howel, the Welch prince, the price of a kitten, before it could fee, was a penny; then two-pence; when it commenced moufer, four-pence: it was required, befides, that it hould be of perfect hearing and fight, be a good moufer, have the claws whole, and be a good rurfe. If it failed in any of thefe qualities, the feller was to-forfeit to the buyer the third part of its value. If any one ftole or killed the cat that guarded the prince's granary, he was to forfeit a milch ewe, its fleece and lamb, or as much wheat as, when poured on the cat fufpended by the tail (the head touching the floor) would form an heap high enough to cover the tip of the tail.

In our climate we know but of one kind of wild cat : there are but few differences in this quadruped. Of all quadrupeds the wild cat has inteftines fmalleft and fhortelt. Thofe of the theep, for inftance, unravelled and meafured, will extend thirty times the length of its body; whereas the wild cat's inteftines will not be found above three times the length of its body, and are, by one third, fhorter than thofe of the tame. If we fay the domeftic cat has inteftines enlarged to the quantity of its food, this obfervation is contradicted in the wild boar and the wolf, whofe inteftines equal thofe of the hog or the dog, though, like the wild cat, fed by precarious fubfiftence.

Wild cats were common alfo in Peru before its difcovery, though not domeftic. They abound in Africa, and many parts of Afia. Some are of a peculiar colour, inclining to blue. Pietro della Valle informs us, there is a kind of cat, particularly in the province of Chorazan, in Perfia, of the form of the ordinary one, but infinitely more beautiful in the luftre and colour of its $\mathrm{kin}$, which is grey blue, as foft and flining as filk; tail very long, covered with hair lix inches long, which the animal throws 
QU A D R U P D S.

throws upon its back like a fquirrel. Thefe cats are well known in France; and have been brought into England, under the name of the blue cat, which ill expreffes their colour.

Another variety is the cat of Angora; larger than the common cat; their hair is much longer, hangs about their head and neck; fome white, others dun. There are other varieties in this animal, but rather in colour than form, as the tortoife-Thell cat, and others.

\section{T H E $\mathrm{H}$ L I $\mathrm{O}$ N.}

7 THE Lion, produced under the burning fun of Africa, is the moft 1 terrible, the moft undaunted of animals; but thofe bred in more temperate climates, or on the upper parts of lofty mountains, are far lefs dangerous, and have neither the ftrength nor ferocity of the lions of Biledulgerid or Zaara, where the plains are covered with burning fands. Happily the fpecies is not very numerous, and feems to be diminifhing as well in Lybia, as in Turkey, Perfia, and the Indies, occafioned by the increafe of mankind, the only animal in nature capable of effectually contending againt thefe tyrants of the foreft. The arms, even of an Hottentot or a Negro, render them more than a match for this powerful creature. This fuperiority ferves alfo to alarm and difcourage him, for he is brave only in proportion to his former fuccefs. The habit of conquering renders him intrepid and terrible. Thofe which never experienced the power of man, have no apprehenfions. 'They boldly face him, and feem to brave the force of his arms. Wounds rather provoke their rage, than reprefs their ardour. A fingle lion of the defert will attack an entire caravan, and, after an obftinate conteft, when overpowered, inftead of Aying, he continues to combat, retreating, and facing the enemy till he dies. Whereas the lions which inhabit the peopled countries of Murocco or India, acquainted with human fuperiority, have loft their courage, are fcared with a hout, and feldom attack any but focks or herds, which women and children are fuficient to protect.

When the lion is bred with domeftic animals, he will play innocently and familiarly among them; and feldom exerts his natural ferocity againft his benefactors. His anger is noble; his courage magnanimous; his difpofition grateful. He defpifes contemptible enemies, and neglects their infults when he might punifh them. He has been feen to fpare the lives 
lives of fuch as were thrown to be devoured by him, to live peaceably with them, to afford them a part of his fubfiftence, and fometimes to want food himfelf, rather than deprive them of that life his generofity had fpared. The lion is not cruel, fince he never kills more than he confumes. When fatiated, he is gentle; while the tiger, the wolf, the fox, and others, kill without remorfe, are fierce without caufe, and, by their indifcriminate naughter, feem rather to fatisfy their malignity than their hunger.

His figure is ftriking, his look confident and bold; his gait proud, his voice terrible. His ftature is compact, well proportioned, and fizeable; a perfect model of ftrength, joined with agility; mufcular and bold, not charged with unneceffary fac or flefh. It is fufficient to fee him, to be affured of his fuperior force. His large head, furrounded with a dreadful mane; his mufcles, fwelling with the nighteft exertions; the great breadth of his paws, and the thicknefs of his limbs, evince that no animal in the foreft can oppofe him. He has a very broad face that, as fome have imagined, refembles the human; furrounded with long hair, which gives it a very majeftic air. The top of the head, the temples, the cheeks, the under jaw, the neck, the breatt, the fhoulder, the hinder part of the legs, and the belly, are furnithed with it, while all the reft of the body is covered with very thort hair, of a tawny colour. The hair about the neck and brealt differs from the reft only in length; nor is each hair pointed as in moft other animals, but of equal thicknefs throughout. The neck has feven joints, which is univerfal to all quadrupeds. The tongue is rough, befet with prickles as hard as a cat's claws; their grain turned backwards, fo that fhould a lion attempt to lick a man's hand, as we are told, it might tear off the fkin. The eyes are always bright and fiery; nor even in deach does this terrible look forfake them. The ftructure of the paws, teeth, eyes, and tongue, are the fame as in a cat; and the inward parts of thefe animals fo nearly refemble, that the anatomift's chief diftinction arifes merely from the fize: The lion's mane grows longer as the animal grows older : the lionefs is without this ornament. This mane is not coarfe or rough, but of the fame hair with the body, lengthened and fhining. The lion's colour is yellow or tawny throughout the fpecies.

The lion has not the fenfe of fmelling equal to mort other animals; and too ftrong, light greatly incommodes him. His eyes, like thofe of the cat, feem fitted for feeing beft in the dark; he therefore feldom appears in open day, but ravages chiefly by night. All animals of the cat No. 22. $\mathrm{N}$ 
kind are kept off by fires, whereby the inhabitants preferve their herd's and flocks. The bright flame dazzles them, and they fear to venture blindly among their enemies. They hunt rather by fight than fmell.

The lion, when hungry, boldly attacks all animals; but as all avoid him, he is often obliged to hide, in order to furprife them. He crouches on his belly in fome thicker, or among the long grafs of the foreft, with patient expectation, till his prey comes within diftance; then he fprings fifteen or twenty feet, and often feizes it at the firft bound. If he miffes, and in two or three reiterated fprings cannot feize his prey, he continues motionlefs for a time, feems very fenfible of his difappointment, and waits for a more fuccefsful opportunity. In the deferts and forefts, his ufual prey are the gazelles and the monkeys, with which the torrid regions abound. The latter he takes when on the ground, for he cannot climb trees. He devours a great deal at a time, and generally fills himfelf for two or three days. His teeth are fo ftrong, that he eafily breaks the bones and fwallows them. It is reported that he fuftains hunger long, but not thirft, his temperament being extremely hot; fame have afferted that he is in a continual fever. He drinks water, lapping it like a cat. He generally requires about fifteen pounds of raw fleth daily; prefers that of live animals; feldom eats what begins to putrefy, and choofes rather to hunt for frefh fpoil, than to return to what he had half devoured. His breath is very offenfive, and his urine infupportable.

The roaring of the lion, when heard in the night, and re-echoed by the mountains, refembles diftant thunder. This roar is his natural note; when enraged he has a different growl; thort, broken, and reiterated. The roar is a deep hollow growl, which he fends forth particularly before rain. His cry of anger is much louder, and more formidable. This is excited by oppofition. When the lion fummons up all his terrors, nothing can be more terrible. He lahes his fides with his long tail, which alone is able to knock down a man; his mane rifes ftiflly round his head; his face is all agitation; his huge eye-brows half cover his glaring eye-balls; he fhews his teeth, formed for deftruction, his tongue covered with points, and his claws almoft as long as a man's fingers. Thus prepared, few animals will venture an engagement; and the boldeft of the human kind are daunted. The elephant, the rhinoceros, the tiger, and the hippopotamos, are the only animals that fingly dare oppofe him. The leopard and the wild boar, if provoked, will fometimes abide his approach, and wait his onfer, which he feldom makes, unlefs compelled by hunger; they are fometimes fuccefsful. Thefe inftances are 
rare; for the lion is in general undifputed lord of the foreft. Man only attacks him with fuccefs, by the affittance of dogs and hories trained to the purfuit. Thefe animals, that naturally would have fled from the lion in an agony, confcious of human aid, purfue in turn, and boldly hunt their tyrant. The dogs are of the large breed; and the horfes, as Gefner affures us, of that fort called cbarofle, or lion-eyed; all others flying the fight of a lion, and endeavouring to throw their riders. The lion, when roufed, recedes fowly, never goes off direct, but takes an oblique courfe, going from fide to fide, and bounding rather than running. $\mathrm{He}$ is very vivacious, never killed at once, but fights defperately, even after he has received his mortal blow. He is alfo taken by pit-falls. The ufual manner of taking this animal is while a cub; the place near the den of the lionefs is generally well known by the greatnefs of her depredations on that occafion. The natives watch the abfence of the lionefs, and, aided by a fwift horfe, carry off her cubs, which they fell to their great men or to ftrangers.

The lion feldom quits the foreft while able to fubfift by his activity; but when old, and unfit for furprife, he boldly comes down into places more frequented; attacks the flocks and herds, notwithftanding the habitation of their keeper, and depends on his courage for fupport. If he finds men and quadrupeds in the fame field, he only actacks the latter, unlefs the men provoke an engagement. He prefers the flefh of camels and of young elephants, which he often attacks before their trunks are grown.

The lionefs brings forth in fpring; the goes with young about five months; brings never more than two, abcut the fize of a large pug dog, harmlefs, pretty, and playful; they continue the teat twelve months, and the animal is five years in coming to perfection.

The great lion, called Pompey, which died in the year I 760 , was known to have been in the Tower above feventy years; and another, which was brought from the river Gambia, died aged about fixty-three.

The lionefs, though lefs ftrong, lefs courageous, and lefs mifchievous than the lion, becomes terrible when the has cubs. She then roams with fearlefs intrepidity; throws herfelf indifcriminately among men and animals; deftroys without diftinction; and loads herfelf with rpoil, and carries it reeking to her cubs, whom the accultoms betimes to flaughter. She ufually brings forth in inacceffible places; when the fears a difcovery of her retreat, often hides her tracks, by running back her ground, or by brufhing them out with her tail; fometimes alfo tranfports them to 
another place, and, if obfructed, defends them with determined courage to the laft.

The lion can fubfift in temperate climates; and formerly even the fouth of Europe was infefted by him. He is only found now in Africa and the Eaft-Indies, where he grows to an enormous height. The lion of Biledulgerid is faid to be nearly five feet high, and between nine and ten feet from the tip of the nofe to the tail. The ordinary fize is about four feet; the female being about one third lefs than the male.

The author of the QEconomy of Nature gives a wonderful relation of the inftinct of lions. Amid the burning heat of Africa the pelican makes her neft; and in order to cool her brood, and accuftom them to an element with which they muft afterwards be familiar, the brings from afar, in her great gular pouch, fufficient water to fill the neft : the lion (and other wild bealts) approach and quench their thirft; yet never injure the unfledged birds, as if confcious their deftruction would ftop thofe grateful fupplies.

\section{$\begin{array}{llllllll}\mathrm{T} & \mathrm{H} & \mathrm{E} & \mathrm{T} & \mathrm{I} & \mathrm{G} & \mathrm{E} & \mathrm{R}\end{array}$}

THE ancients had a faying, That as the peacock is the moft beautiful 1 -among birds, $\int_{0}$ is the tiger among quadrupeds. No quadruped can be handfomer. The gloffy fmoothnefs and brigntnefs of his hair, the extreme blacknefs of its ftreaks, the bright yellow ground they diverfify, are all eminently beautiful. To this is added an extremely elegant form, flender and delicate, expreffing fingular fwiftnefs and agility. But this animal's difpofition is as mifchievous, as its form is admirable: fierce and favage beyond meafure; neither can correction terrify, nor indulgence tame it. The careffes of its keeper have no influence on its manners, and correction only increafes its fiercenefs and malignity. The tiger fnaps at the hand that feeds it; feems to confider every object as its proper prey, which it devours with a look; and, though confined by bars and chains, makes fruitlefs efforts, as if to demonftrate its ferocity, though it cannot exert its power.

The principal diftinction of the tiger, is the hape of its ftreaks, which run in the fame direction as his ribs, from the back down to the belly, differing from the leopard, panther, and ounce, which are fpotted. The tiger is often found bigger than the lion himfelf; is much nenderer 
alfo, its legs fhorter, and its neck and body longer. It refembles almolt exactly the cat in fhape, efpecially the male; and, if we conceive a he-cat fufficiently magnified, he will afford a very apt idea of the tiger. Mr. Buffon was affured by one of his friends, that he faw a tiger, in the Eaft-Indies, fifteen feet long, including the tail, for which allowing four feet, this animal muft have been eleven feet from the tip of the nofe to the infertion of the tail. Such is the royal tiger!

The tiger is fierce without provocation, and cruel without neceffity; though gluted, is not fatisfied with faughter, but continues the carnage; its courage only inflamed by not meeting refiftance. Among a flock or herd, levels all, and fcarce finds time to appeafe its appetite, while intent on fatisfying its malignity. The fcourge of a country! it fears not mankind; beafts wild and tame experience its infariable fury ; often the young elephant and the rhinoceros, and fometimes the lion himfelf.

The tiger is found in Malabar, in Siam, in Bengal, and other Afratic countries inhabited by the elephant or the rhinoceros. They frequent the fides of lakes and rivers, compelled by the thirtt which in that torrid climate they often endure; and it is likely the tiger finds this a conveniert fituation to furprife many of thofe animals which refort thither from the fame motives. It generally lurks where it has repeated opportunity of prey. When it has killed one, it often attacks others, fwallowing their blood at large draughts, and feeming rather glutted than fatiated with its abundance, it plunges its head up to the eyes in the body of its prey, and exhaults the corple of blood, before it devours the fler.

Ceptain Hamilton informs us, that in the Sundah Raijha's dominions are three forts of tigers in the woods; the fmalleft is the fiercent, not above two feet high, extremely cunning, and fond of human fleth; the fecond about three feet high, hunts deer and wild hogs; the largeft fort is above three feet and a half high, but not equally rapacious:

A peafant in that country, fays this traveller, had a buffalo fallen into a quagmire; while he went for affittance, there came a large tiger, that alone drew forth the animal. When the people returned, the firlt object they beheld was the tiger, which had thrown the buffalo over its Thoulder, as a fox does a goofe, and was carrying it' away, feet upward, towards its den; it had killed the buffalo, and fucked its blood. As fome Ealt-Indian buffaloes weigh a thoufand pounds, we may from 
hence form a conception of the enormous ftrength of this rapacious animal. As to its agility, we may guefs at it, by obferving the diftance a cat can leap, which is feveral feet; and doubtlefs the tiger, being ten times as long, can fpring proportionably. They are alfo fleet in running, but feldom exert this quality, preferring to take their prey by furprife, rather than chafing.

This fpecies is extremely fcarce; of the number of its young we have no certain accounts; it is faid to bring four or five at a time; the female, ever furious, then exceeds her ufual rapacity. If her young be taken from her, the purfues the fpoiler with incredible rage; if She overtake him, he drops one cub, with which the immediately returins to her den, and again purfues him; he drops another, and by the time fhe has returned with that, efcapes with the remainder.

The tiger expreffes its refentment much like the lion; moves the mufcles and fkin of its face, thews its teeth, and Ahrieks frightfully. Its note is very different from that of the lion, being rather a fcream than a roar. The Indians fometimes eat its $\mathrm{Al} \mathrm{H}_{2}$, and find it neither difagreeable nor unwholfome.

There is an American animal, ufually called the Red or Brown Tiger (by Mr. Buffon, the Cougar), which; though very different from the true tiger, yet refembles it except in colour, being equally flender, and fmaller necked, than others of the panther kind.

Thefe are common in South-America, and extremely deftructive, carrying off fowls, dogs, and other domeftic creatures. The Negroes and Indians are very dexterous in encountering them; and fome, for a fmall reward and their fkins, feek their retreats. Their arms in this combat are a lance of two or three yards long, of heavy wood, the point hardened in the fire; and a kind of fcymitar, about three quarters of a yard in length. They wait till the tiger affaults the left-hand, which holds the lance, and is wrapped in a fhort cloak of baize. Sometimes the animal; aware of danger, declines the combat; but is provoked with a night touch of the lance, which, when it feels, it grafps with one paw, and with the ocher ftrikes at the arm which holds it. At this moment the perfon, with his other hand, nimbly aims a blow with his fcymitar, and hamftrings the creature, which immediately draws back enraged, but inftantly returns to the charge, and by another ftroke on the other paw, is deprived of the power of motion, and becomes an eafy conqueft. 
Thefe animals are common in Guiana. They formerly fwam over in great numbers to the inand of Cayenne, to ravage the flocks and herds, and were a terrible fcourge to the infant colony; but, by degrees, were repulfed. They are found in Brazil, in Paraguay, in the country of the Amazons, and in other parts of South-America. They often climb trees in queft of prey; or to avoid their purfuers.

\section{$\begin{array}{lllllllll}T & H & E & P & A & N & T & H & E\end{array}$}

7 HE Panther has been by many naturalitts miltaken for the tiger, which it approaches in fize, fiercenefs, and beauty; but is diftinguilhed by being Spotted, not frealed. The panther is to Africa, what the tiger is to Afia; with this alleviation, that it prefers the Refh of brutes to that of man; but when hungry, makes no diftinction. Irs manner of taking its prey is equally infidious as the tiger, by furprife, crouching in thickets, creeping on its belly till it can fpring at once on its mark. Will climb up trees in purfuit of monkeys and leffer animals. The Romans exhibited this creature and the leopard in their public thews: Pompey thewed four hundred and ten; Auguftus, four hundred and twenty. But they ftiil fwarm from Barbary to Guinea.

Next to the great panther, is the LEOPARD, which is often called the Leopard, or Panther of Senegal, where it is chiefy found. 'Their principal differences are as follow: The large panther is often fix or leven feet long, from the tip of the nofe to the infertion of the tail; the leopard of Senegal is not above four. The panther is marked with five or fix fpots, making a kind of circle, and a large one in the middie; except on the face and legs. The leopard is more beautiful, his yellow coat more brilliant, his fpots fmaller, not difpofed in rings, but in clufters. They are both whitih under the belly; the tail of the firft three feet, of the fecond two and a half, confequently rather longeft in proportion.

The JAGUAR, or PANTher of South-America, refembles thefe two, except in the difpolition of its fpots, and that its neck and head are rather ftreaked than fpotted; and the creature is faid to be lower on its legs. There is fornetimes feen a combat between this animal and the crocodile, which is extraordinary. When the jaguar comes to drink, the crocodile, who has been long watching to furprife any animal that No. 23 .

approach- 


\section{QUA D R UPEDS.}

approached, raifes its head above the water; the jaguar inftantly ftrikes its claws into the eyes of the crocodile (its only penetrable part), who, diving direetly, pulls his enemy with him, and commonly both perifh.

Thefe three animals we may rank wogether, as they agree pretty nearly in their robe, their fize, their difpofitions, and their ferocity.

The OUNCE is at moft three feet and a half long; its tail often longer than the reft of its body; its colour rather inclining to a cream. colour, deeper on the back, whiter towards the belly. The hair on the back an inch and a half long; that on the belly, two inches and a half, which is much longer than that of the panther. Its fpots are difpofed like thofe of the panther; but on the haunches it has-rather ftripes than fpots.

The ounce is remarkable for being camed; and is employed in the Eaft for the chace. A fmall kind of panther is fometimes ufed for this purpofe; yet never thoroughly fubdued, but ufually brought to the field in a carriage, and kept chained and caged till thewn their prey. This they purfue by three or four great fprings. If it efcape from, their firt effort, they appear quite cunfounded, and fometimes are fo much enraged at it, that they attack their employer, and his only refource to avoid their fury, is to throw them fome fmall pieces of meat which he has brought with him for that purpofe.

The ounce is treated with more confidence, and brought to the field hood-winked behind a horfeman. When the game appears, the ounce is inftantly uncovered, and shewn where it lies; on which the fierce creature darts like an arrow, and feizes it at once, or, miffing it, remains motionlers in the place. It runs badly, and has no fcent. Scent indeed is nearly, if not totally, ufelefs in tropical climates; for their extreme heat produces fuch univerfal putrefaction, fuch various and powerful odours, that dogs themfelves are firft bewildered, and at laft deprived of the delicacy of their fcent.

Among fmaller animals of this kind is the Catamountain, or TIGER CAT of moft who exhibit it. It is a Mexican animal, about two feet and a half in length, from the nofe to the infertion of the tail. It is extremely like a cat, but larger and nenderer; its colours more beautiful, and its tail rather fhorter. The fur is reddin, beautified with black fpots, and ftreaks, long on the back, and round on the belly and paws. On the ears are black ftripes, which run acrofs; but, in other refpects, they entirely refemble thofe of a cat. Thefe colours are not permanent, but differently difpofed in difierent fpecimens. 
The Catamountain, or Tiger Cat, one of the fierceft, and, for its fize, one of the moft deftructive animals in the world, is a native of SouthAmerica. Two of thefe, from which Mr. Buffon has taken his defcription, were brought over from Carthagena, and having been taken from the dam very young, were fuckled by a bitch. But, before they were three months old, they had Itrength and ingratitude fufficient to kill and devour their nurfe. Their fucceeding fiercenels and malignity feemed to correfpond with their firt efforts; no arts could tame or foften them; they teftified an unceafing difpofition for Maughter: When food was given them, the male always ferved himfelf before the female ventured to touch a bit, and not till after he was fatisfied the orher began. In their favage ftate, they are lighly deftructive; having great ftrength and agility, they eafily overtake their prey, which they purfue among the tops of the trees, as well as on the ground. They fuck the blood with avidity, and frequently leave the carcafe untouched, to purfue other animals for their blood. They generally continue on trees, like our wild cais, where they often bring forth their young. When an animal paffes beneath them, they dart down upon it with inevitable exactnefs.

From this tribe of the cat kind, with fpotted nkins and a long tail, we come to another with Rins diverfified in like manner, but with a thorter tail. The principal of thefe is the LYNX.

The firft ftriking diftinetion of the lyns, from the panther kind, is its tail, which is barely half as long in proportion, and black at the extremity. Its fur is much longer, its fpots lefs vivid, and confufedly mingled; its ears long, tipped at the points with a black tuft of hair; colour round the eyes white, the phyfiognomy inore placid. Each hair of this animal is of three different colours : the root a greyilh brown, the middle red or afh-coloured, the ends white. This whitenefs makes the body appear as if filvered over; the hair in the fpots has no white at the ends. This animal equals the ounce in fize, but is ftronger built, and it has but twenty-eight teeth; whereas all of the cat kind already mentioned have thirty.

The lynx inhabits chiefly the north of Germany, Lithuania, Mufcovy; Siberia, and North-America. Thofe of the new continent are rather fmaller than thofe of Europe. It exactly refembles the cat, except that, being nearly two feet long, it is bolder and fiercer. Like the cat, it climbs trees, feeks its prey by furprife, is delicate and cleanly, covering 
its urine with its paws (but it refembles the wolf in cry, which often deceives the hunters). Having once feafted on its prey, will not return 1 to it, but hunts for another : Whence may have arifen the common report of the lynx having the fhorteft memory of all quadrupeds.

The SYAGUSH is native of the Ealt-Indies, and refembles the lynx in fize, in form, and in being tufted at the tips of the ears; but differs in not being mottled. Its hair is rougher and fhorter, its tail longer, its muzzle more lengthened, its phyfiognomy more fierce, and its nature more favage. Leaps on its prey, and creeping on their necks, fcratches their eyes out.

The SERVAL is native of Malabar, refembling the panther in its fpots, but the lynx in the fhortnefs of its tail, in its fize, and in its ftrongbuilt form.

Thefe feem to be the principal diftinctions of this kind. From the Jarge panther to the domeftic cat, which is the fmalleft of all, their nature feems the fame, fierce, fubtle, cruel, and cowardly. The panther, the leopard, and the jaguar, as they are the largent, are alfo the moft dangerous; but all are rapacious in proportion to their power.

The whole race may be confidered as the inveterate enemy of mankind; others are ftronger, but gentle ; more numerous, but more feeble; and rather expect fafety by concealment, than by oppofition; while thefe maintain their ground, and may be faid to keep certain diftricts of the earth in their own poffeffion.

\section{W E A S E L $\quad K \quad I \quad N \quad D$}

A RE diftinguifhed by their length and nendernefs of body, by A which they pars through very fmall crevices. They bear the name of vermin from this fimilitude to the worm. Their claws can neither be drawn in nor extended at pleafure (as cats). They are cloched rather with fur than hair; and have glands near the anus, opening into, or beneath it, furnifhing a fubftance, in fome the moft offenfive fmell in nature, in others a pleafing perfume; cruel, voracious, cowardly, thievinh, and now ; fupported by their patience, affiduity, and cunning; live long without food; but if they meet with plenty, deftroy all before they fatisfy their appetite, and fuck the blood, before they touch the flefh.

The 
The WEASEL is in length barely feven inches, from the nofe to the infertion of the tail; its height not above an inch and a half, confequently is near five times as long as high. The burhy tail, of two inches and a half, adds to the animal's apparent length. Colour pale tawny brown on the back and fides, white under the throat and belly; has whifkers like a cat, and thirty-two teeth (two more than the cat), and thefe better adapted for tearing and chewing than the cat's. Eyes little and black; ears thort, broad, and rounded, have a fold at the lower part, which makes thein feem double. Beneath the corners of the mouth, on each jaw, a brown fpot.

This animal inhabits the temperate parts of Europe, farce in the North and in Barbary; is very formidable to quadrupeds an hundred times its fize. Where theep or lambs are bred, the weafel is detefted and deftroyed as noxious; where agriculture is followed, is confidered as a friend, being deftructive to fuch vermin as live on corn. One of the moft untameable and untractable of animals. When kept in a cage, will not touch its victuals while looked at; is continually agitated; and frighted fo much at the fight of mankind, that it will die, if not permitted to hide itfelf in a fuficient quantity of wool or hay, whereto it may carry its food; paffes three parts of the day in neep; night its time of exercife and feeding. Is feen ftealing from its hole at the approach of evening, and creeping about the farmer's yard for prey. If it enters among poultry, immediately aims at the young ones; does not eat its prey on the place, but killing it by a fingle bite near the head, with a wound fcarcely perceivable, carries it off; is a great devourer of tggs; is remarkably active; in a confined place, fcarce any animal can elcape it; runs up the fides of walls with facility, and winds through a very imall hole. In winter, chiefly confines itfelf in barns and farm yards, till fpring, where it brings forth, and makes war on rats and mice, with greater fuccefs than the cat, purfuing them into their holes. A gentleman once found eighty-five, newly killed, in one weafel's hole. Creeps alfo into pigeon holes, deftroys the young, catches fparrows, and fmall birds; and, if it has young, hunts with great boldnets and avidity. In fummer, ventures farther from the houle, to where the rat, its chief prey, precedes it; is found in low grounds, by the water-fide, near mills, and often hides its young in the hollow of a tree.

The female takes every precaution to make an eafy bed; lines her hole with grafs, hay; leaves, and nofs; brings from three to five, with cloled eyes; but foon ftrong enough to follow their dam, and affift in 
her rapine. The weafel does not run, but bounds; when it climbs a tree, gets high from the ground by a fingle fpring; jumps on its prey; and, having an extremely limber body, evades the attempts of much ftronger animals to feize ir.

This animal has a very ftrong peculiarly foetid fmell; the glands which furnifn this foetid fublance (which is of the confiftence of fuet) open directly into the anus, and taint the excrement, more ftrongly in fummer than in winter; and when irritated or purfued, than when at eafe. Always preys in filence; when ftruck, by a rough kind of fqueaking, at once expreffes refentment and pain; never lofes its appetite for animal food, and feems to enjoy the vicinity of putrefaction. Mr. Buffon tells us of one found, with three young ones, in the carcals of a wolf that was putrid, and had been hung up, by the hind legs, as a terror to -others.

\section{THE}

\section{E R M I N E, OR S T O A T.}

THE Stoat, or Ermine, ufually exceeds nine inches long; the tail - five inches and a half, tipped with black; edges of the ears and ends of the toes yellowilh white; general colour lightin tawny brown; in winter, becomes white or cream-coloured; yet always retains the black tip of the tail. Sometimes found white in Great-Britain. Haunts woods, hedges, and meadows, by brook fides; rarely barns, \&rc.

The ermine is remarkable for the foftnels, clofenefs, and warmth of its fur. Mr. Daubenton had one with its winter fur, which he kept to obferve its manner of moulting. He received it in the beginning of March; very hortly it began to fhed its coat, and a mixture of brown variegated the white; at the ninth of the month its head was nearly a reddin brown; this colour daily extended along the neck and back, like a tripe of half an inch broad. The fore-part of the legs then affumed the fame colour; part of the head, the thighs, and the tail were the laten, but all changed by the end of the month. This little animal, when confined, was very wild and untractable, ever violently agitated except when aneep, which often occupied three parts of the day. Except for its difagreeable licut, was an extremely pretty creature, its 


\section{THE W E A S E K I N D.}

eyes fprightly, its phyfiognomy pleafant, motions fwift. It ate eggs or flen, but always let them firt putrify: As fome of this kind are fond of honey, it was tried with fuch food, of which it ate, and died Shortly after.

In the north of Europe and Siberia, their fkins make a valuable article of commerce; are there abundant; fome in Newfoundland and $\mathrm{Ca}$ nada; burrcw in the fields, or in birch forefts, never in thofe of fir or pine; are thot with blunt arrows, or taken in traps made of two flat ftones; one propped with a ftick, to which is faftened a baited ftring; when the animals attempt to pull this away, the ftone drops, and crufhes them,

\section{$\begin{array}{llllllllllllllll} & \mathrm{T} & \mathrm{H} & \mathrm{E} & \mathrm{F} & \mathrm{E} & \mathrm{R} & \mathrm{R} & \mathrm{E} & \mathrm{T}\end{array}$}

IS above one foot long, of nender body and Mhort legs; its nofe Tharp; is commonly of a cream colour, but are found white, blackin, brown, and party-coloured. The whition have red eyes, as is almoft general with animals entirely of that colour. The hair on its tail is much longer than in the weafel; tail five inches.

This animal is native of the torrid zone, from whence it was fetched into Spain to free that country from rabbits, which over-run it; cannot bear our climate, without care and fhelter; kept for its ufe in the warren; is naturally fuch an enemy of the rabbit, that if a dead rabbit be be prefented to a young ferret, though it has never feen one before, it inftantly attacks it. If the rabbit be living, the ferret eagerly feizes it by the neck, winds itfelf round it, and fucks its blood. In warrens they enter the holes, and drive the rabbits into nets at the mouth. The ferret is always muzzled, left it fhould continue at the bottom of the hole. If it difengages itfelf of its muzzle, inftead of returning, it leads a rapacious folitary life during fummer, and dies with the cold of winter; unlefs fmoked from his hole.

The female is lefs than the male; they neep almoft continually; the inftant they wake, feem eager for food, which is ufurally bread and milk; they breed twice a year, bring five, fix, to nine at a lirter. Some of them devour their young. The ferret is ufeful, but difagreeable and offenfive; fortid, voracious, tame without attachment; blood-thirfty, No. 23 . 
even to the killing children in the cradle; eafily irritated, then efpecially its fnell offenfive; its bite very difficult of cure.

To the ferret kind, we may refer an animal which $\mathrm{Mr}$. Buffon calls the VANSIRE, the 1 kin of which was fent him ftuffed from Madagalcar; thirteen inches long; much refembling the ferret, but having twelve grinding teeth, whereas the ferret has but eight. In colour, a darkbrown throughout.

\section{$\begin{array}{lllllllllllllll}T & \mathrm{H} & \mathrm{E} & & \mathrm{P} & \mathrm{O} & \mathrm{L} & \mathrm{E} & \mathrm{C} & \mathrm{A} & \mathrm{T}\end{array}$}

TS one foot five inches long; fo much refembles the ferret, that fome have thought them the fame; but is larger, not fo flender, has a blunter nofe; differs internally, having but fourteen ribs, whereas the ferret has fifteen; wants one breatt bone of the ferret. Warreners affert, that they will mix, and this is promoted to improve the breed of ferrets, which, by long confinement, fometimes abates its rapacious difpolition. The produce moft refembles the polecat, being darker than the ferret.

The polecat is principally a deep chocolate colour; white about the mouth; ears thort, rounded, and tipt with white; a little beyond the mouth a ftripe begins, which runs backward, partly white, partly yellow : its hair (like that of all this clafs) is of two forts; the long, and the furry; of different colours; the longeft black, the Ahorter yellowin ; the throat, feet, and tail are blackeft; the claws white underneath, brown above; tail about fix inches. Is very deftructive to young game of all kinds; but the rabbit feems its favourite prey; a fingle polecat will often deftroy a warren; it kills much more than it can devour. Refides in woods or thick brakes, making holes under ground of two yards deep, ending among roots of large trees for fecurity. In winter, frequents houfes, robs the hen-rooft and the dairy; is particularly deftructive among pigeons; difpatches each with a fingle wound in the head : after killing many, and fatiating itfelf with their blood, carries them one by one to its hole; but if the opening by which it entered the dove-houfe be too fmall for the body of the pigeon to pafs, contents itfelf with carrying away the heads, and feafts on the brains, Is fond of honey, attacks the hives in winter, and forces the bees away. 
The female brings forth in fummer, five or fix at a time; thefe the foon trains to rapacity, fupplying the want of milk (of which no carnivorous quadruped has plenty) by the blood of animals. The fur is foft and warm; bur its offenfive fmell can never be removed or fuppreffed. The polecat inhabits temperate climates; is rare in the north and in warm latitudes.

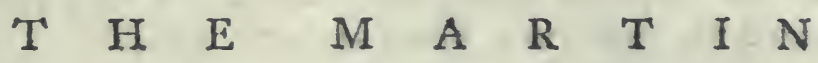

TS generally eighteen inches long; 'the tail ten, and burhy at the end; its cry harp and piercing; its nofe Aatter than the polecat; its colours more elegant; -its feent not offenfive, but confidered as a perfume; the moft beautiful of all Britih bealts of prey; its head fmall and elegant; eyes, lively; ears, broad, rounded and open; back, fides, and tail, covered with a fine thick downy fur, with longer hair intermixed; the roots afh colour, the middle bright chefnut, the points black; the head is brown, with a night calt of red ; the legs, and upper fides of the feet, chocolate colour; the palms, or under fides, covered with a thick downy fur ; the feet broad; claws white, large and Mharp, well adapted for the purpoles of climbing, but incapable of being theathed or unTheathed; throat and breaft, white; belly of the fame colour with the back, but rather paler; hair on the tail very long, efpecially at the end, where it appears much thicker than near the infertion.

There is a yellow-breafted martin; differs only by its yellow breaft; the colour of the body is darker, and its fur more valuable, beautifu! and glofy; is much more common in France than in England; yet even there is much fcarcer than that with the white breaft.

Of all the weafel kind, the martin is the molt pleafing; its motions are graceful and agile; fcarce an animal in our woods will oppofe it : the wild cat itfelf, though much ftronger, is not its match, and feldom meets it without a combat; has been kept partly tamed, in which ftate it ate every thing except fallad or herbs; was remarkably fond of honey; drank often; often nept two days together, and often paffed two or three days without neep. Before it nept, drew itfelf into a round, and hid its head by its tail.

When the martin finds irfelf purfued by dogs (for which there is a peculiar breed) it makes to its retreat, which is generally the hollow of 
fome tree, toward the top, which to come at, it muft be cut down. Their neft is generally the original tenement of the fquirrel. It brings three or four, to fix; their eyes clofed. The dam compenfates her deficiency of milk, by bringing them eggs (which fhe often carries whole) and live birds, accuftoming them early to rapine, When fhe' leads them into the woods, the birds difcover and attend them, threatening and infulting her, alarming every thicket, and often directing the hunter.

The martin is more common in North-America than in Europe; but is found in all the northern parts, from Siberia to China and Canada, They are hunted for their furs, which are very valuable.

\section{T $\mathrm{H} \quad \mathrm{E} \quad \mathrm{S}$ A $\mathrm{B}$ I $\mathrm{E}$.}

ABLE fur is held in the higheft efteem; is brownifh black; the $\$$ darkeft moft valuable. A fingle $\mathrm{kin}$, not above four inches broad, is often valued at 10 or $15 l$. The fur has no grain; every way equally fmooth and unrefifting.

The fable refembles in form the martin, and the weafel in the number of its teeth; is eighteen inches long, tail twelve; very large whinkers about the mouth; its feet broad, five claws on each foot. Some are dark brown over the body, except the ears and throat, where the hair is rather yellow; others yellowith, their ears and throat paler. Thefe are their winter colours, which they change in fpring; the former becoming: a yellow brown, the latter a pale yellow; fometimes found fnow-white. They refemble their kind in vivacity, agility, and inquietude; in fleeping by day and preying by night, and in their difagreeable odour. Live on fmaller animals, ermines, weafels and fquirrels, but efpecially hares: in autumn on berries; bring forth in A pril from three to tive.

Inhabit the banks of rivers, in fhady places, and the thickeft woods, beneath the roots of trees, or holes in the earth; leap eafily from tree to tree, and are faid to fear the fun; are moftly found in Siberia, very few elfewhere; but fuppofed, in one of its varieties, to be found in America, where it grows large. Sable hunting is chiefly followed by condemned exiles fent from Ruffia into thefe wild and extenfive forefts, that, great part of the year, are covered with fnow. They are obliged to fhoor with only a fingle ball, or with crofs-bow and blunt arrows, ta avoid fpoiling the Ikin. 


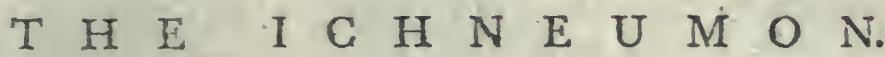

THE ichneumon, which fome have injudiciouny denominated the Cat of Pharaoh, is the boldeft and mo:t ufeful of the weafel kind; in Egypt is ufed as the cat in Europe, and is more expert in catching mice. Differs in fize from twenty-four to forty-two inches; refembles the martin in appearance, but the hair is of a grifly black, much rougher and lefs downy; the tail is not fo buthy at the end, and each hair has three or four colours, which thew in different difpofitions of its body. Under its rounher hairs is a fort brownith fur; the rough hair is about two inches long, on the muzzle extremely fhort, as on the legs and paws. Being long fince domefticated, has many varieties.

The ichneumon, to the ftrength of a cat, unites more inftinct and agility, more univerfal appecite for carnage, and greater variety of powers to procure it; purfues equally rats, mice, birds, ferpents, lizards, infects, every living thing which it can overcome. Its courage equals its appetite. It fears neither dog, cat, vulture, nor viper; attacks all kinds of ferpents with avidity, feizes and kills them how vefomous foever, even the cobra di capello, fkilfully feizing them by the throat to avoid injury. It difcovers and deftroys the eggs of crocodiles, and kills the young ones ere they reach the water; generally refides on the banks of rivers, in times of inundation approaching inhabited places, in queft of prey. Advances filently and cautiouny, changing its manner according to circumftances : fometimes carries its hẹd high,' Thortens its body, and raifes itfelf on its legs; fometimes lengthens itfelf, and creeps along the ground, or fits on its hind legs, like a dog when begging ; or will feign itfe!f dead; loves filh; darts like an arrow on its prey, and feizes it with inevitable certainty. Its eyes are fprightly and full of fire; its phyflognomy fenfible, its body nimble, tail long, hair rough and various. Like all of its lind, has glands that open behind, and furnifh an odorous fubftance. Its nofe is too tharp, and its mouth too linall, to feize large things; eafily ftranglez a cat, and fights with dogs; takes the water like an otter, and is faid to continue under it much longer; grows fait and dies foon.

Is found plentifully in the fouth of Afra, from Egypt to Java; in Africa, at the Cape of Good Hope; is incapable to fupport the rigour of our winters. 
This animal was formerly worhipped by the Egyptians. If we confider the number of eggs which the crocodile lays, often three or four hundred, we have reafon to admire this animal's ufefulnefs, as well as induftry, in deftroying them, fince otherwife the crocodile might be produced in fufficient numbers to over-run the whole earth; befide which, his fervices in deftroying the various kinds of ferpents, place his utility much above that of many deities adopted among that fuperntitious people.

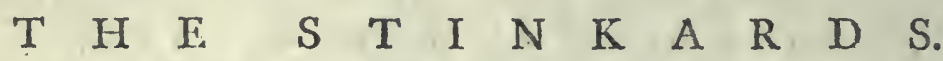

A the weafel kind have glands furnifhing an odorous matter, A rear the anus. The fubftance they furnifh is in fome a perfume; in ochers, as the weafe five; but the fmell of thefe is fragrance itfelf, when compared to that of the Squaßs and the Skunk, which are found in America, alfo in the fouth of Africa, and denominated by our failors THE STINKARDS. The glands in thefe animals are much larger, and furnifh a matter fublimed to a degree of putrefcence truly amazing. A fingle grain of mufk or civet will diffufe itfelf over a houfe, and continue for months; but this is nothing, either for ftrength or duration, to this infupportable odour. It is ufually voided wich their excrement; and if but a fingle drop happens to tcuch a man's garment, it is fearce poffible he thould wear any part of it more. This ejection of their excrement defends them againt their purfuers; nor is employed, except when enraged or affrighted. They are often kept tame about houfes in America, without being very offenfive.

The Squafs is about the fize of a polecat, its hair a deep brown, but differs in having only four toes on the feet before, whereas all other weafels have five. The Skunk refembles a polecat, but differs in the length of its hair and colour. The hair is above three inches and a half long, at the end of the tail above four inches. Colour is partly black, parrly white, variouny difpofed, very gloffy, long and beautiful.

The Conepate and the Zorille feem variecies. The conepate refembles the fkunk, except in fize, being fraller, and in the difpofition of its colours, which are more exact, having five white ftripes on a black ground, running longitudinally from the head to the tail. The zorille refembles 


\section{THE WEA SEL K I N D.}

refembles the fkunk, but is rather fmaller and more beautiful; its ftreaks of black and white more diftinet; and its tail black at its infertion, and white, at the extremity; whereas in the fkunk they are all grey.

The SeUash burrows in the clefts of rocks, where it brings forth; fteals into farm-yards, and kills the poultry, eating only their brains. If purfued, calls up all its fcents, which reach half a mile round, and near are ftilling. If purfued, endeavours to efcape by getting up a tree, or by fome fuch means; driven to extremity, lets fly on the hunters; Thould a drop of this fotid difcharge fall in the eye, the perfon runs the rifque of being blinded for ever. The dogs inftantly abate of their ardour, turn tail, and leave the animal, rubbing their nofes in the grafs. In 1749, fays Kalm, one came near the farm where I lived, in winter time, during the night; the dogs on the watch purfued it, until it difcharged againft them: though I was in bed a good way off, I thought I thould have been fuffocated; and the cows and oxen, by their lowings, fhewed their fulferings by the ftench. Another crept into our cellar, but did not exhale the fmallent fcent; till a foolifh woman, who perceived it at night, by the fhining of its eyes, killed it. That moment its ftench began; the cellar was filled with it to fuch a degree, that the woman kept her bed feveral days, and all the provifions were fo infeeted, that they were obliged to be thrown out of doors.

\section{$\begin{array}{llllllllll}T \cdot H & \mathrm{E} & \mathrm{G} & \mathrm{E} & \mathrm{N} & \mathrm{E} & \mathrm{T} & \mathrm{T} & \mathrm{E}\end{array}$}

TS rather lefs than the martin; refembles the weafel kind, in its length, compared to its height, in having a foft beautiful fur, its feet armed with claws that cannot be fheathed, and its appetite for petty carnage. It differs in having the nofe much fmaller and longer, the tail alfo tapers to a point, and is much longer; its ears are larger, and its paws fimaller; is fpotted with black, on a ground mixed with red and grey; has two forts of hair, one fhorter and fofter, the other longer and ftronger, half an inch long; longer on the tail; its fpots diftinet and feparate on the fides, unite towards the back, forming black ftripes, which run longitudinaliy from the neck backwards; has along the back a kind of mane or longifn hair, which forms a black ftreak from head to tail; tail marked with rings, alternately black and white, its whole length. Like all the weafel kinds, has glands; thefe feparate a kind of perfume; open differently 
from thofe of other animals of this kind, under the anus, fo that the male feems, on fuperficial obfervation, to be of two fexes.

Belon affures us, that he has feen them in the houfes at. Conftantinople as tame as cats, and employed in fimilar purpofes. The fpecies is not much diffufed; is found in Spain and Turkey, and part of France; requires a warm climate; yet is not found in India or Africa.

\section{$\begin{array}{llllllll}\mathrm{T} & \mathrm{H} & \mathrm{E} & \mathrm{C} & \mathrm{I} & \mathrm{V} & \mathrm{E} & \mathrm{T} .\end{array}$}

HE civet is found above thirty inches long. Mr. Buffon diftin1 guifhes this fpecies into two kinds, the civet and the zibet. The latter differs in being longer, nenderer, the nofe fmaller, the ears longer and broader; no mane or long hair running down the back; the tail longer and better marked with rings of different colours.

The civet refembles the weafel kind in fendernefs of body, fhortnefs of legs, the odorous matter from the glands behind, the foftnefs cf its fur, the number of its claws, and their incapacity of being theathed. It differs in being larger, the nofe lengthened, the tail long and tapering to a point, and its ears ftrait like thofe of a cat. Is commonly anh-coloured, fpotted with black (the female is whiter, tending to yellow); and the fpots are much larger, like thofe of a panther; on the belly, and under the throat, is black; the body black or ftreaked with grey; is fometimes ftreaked, as tabby cats; has whifkers; its eye is black and beautiful.

The bag, which is the receptacle of the civet, opens under the anus. There is another opening lower down, but of what ufe is not known. The bag is about two inches and a half broad, and two long, covered with fhort hair, large enough to hold a fmall pullet's egg. In this are fmall glands, furnifhing a ftrong perfume, of the colour and confiftence of pomatum.

Is bred among the Turks, Indians, and Africans; alfo in Holland, where they make no fmall gain of its perfume, being reckoned the pureft. It gives in proportion as it is delicately and abundantly fed. Eats raw flefh hafhed fmall, eggs, rice, birds, young fowls, and parricularly fifh. Drinks but rarely, yet urines frequently. The perfume of the civet communicates itfelf to all parts of the animal; the fur and the ikin preferve the odour long. If a perfon be thut up with one of them in a clofe room, he cannot fupport the perfume. When irritated, its 


\section{THE. WEASEL KIN D.}

icent is violent; if it be made to fweat, this alfo is a ftrong perfume, and ferves to adulterate or increafe what is otherwife obtained from it.

The civet is faid to be wild and fierce; though fometimes tamed; never familiar. Its teeth ftrong and cutting; its claws feeble. Light and active; it purfues birds and fmall animals. Their eyes thine in the night; probably they fee beft in the dark. They breed very faft in their native climates.

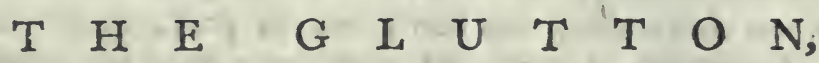

THICH Linnæus places among the weafels, from the fimilitude of its teeth; to this agrees its length of body, its thortnefs of legs, the foftnefs of its fur, its difagreeable fcent, and its infatiable appetite for animal food. Mr. Pennant, however, ranks it among the bears.

Is about twenty-eight inches from nofe to tail; the fore legs about one foot from the extremity of the nails to the body; the hind legs fomewhat longer ; the tail eight inches, including four inches of hair at the end; the muzzle black to the eye-brows; from the eye-brows to the ears, white mingled with brown; ears one inch long; front of its body fpotted with white; the legs, tail, belly, and back, black; fides of a yellowin brown; interior fur or down, white ; five very crooked claws, better fitted for climbing trees than for running along the ground; is found in the north of Europe and Siberia, and in North-America, where it is named the Carcajou.

In America, this voracious creature lurks among the thick branches of trees to furprife the deer. Endued with patience equal to its rapaci$t y$, fingles out trees marked by the teeth or the antlers of deer, and there remains watching. When the elk or the rein-deer pals, -it darts down upon them, fticks its claws between their fhoulders, and there remains. In vain the frighted animal increares its fpeed, or threatens with its horns; drives rapidly among the thickeft woods; and ftrikes againft the largeft trees. It never feizes without bringing down its prey, unlefs it plunges into water, which the glutton fears. The deer, feeble with lofs of blood, falls, and the glutton compenfates former $a b$ ftinence, by prefent voracity. It is indeed amazing how much one of thefe animals can eat at a time! That feen by Mr. Klein, though in captivity, ate thirteen pounds of flen daily, yet remained unfatisfied. 
Mr. Buffon fays, one he had, ate four pounds daily, but fwallowed it fo fatt as to rifque choaking. After a long faft it gorges till incapable of motion; it lies torpid two or three days by the animal it has killed, protected even from the wolf and bear by its horrid fmell. Thus eating and neeping till its prey be devoured, bones and all, then returning to its poft of expectation. Seems to prefer putrid flefh; is fo now, that moft quadrupeds efcape it, except the beaver, which it frequently purfues on land; but the beaver generally makes good its retreat by taking to the water; often examines the traps laid for other animals; fteals on the retreats of the rein-deer, whofe flem it prefers; feeks animals wounded by the hunters; purfues the ifatis while hunting for itfelf; when that animal has run down its prey, comes in and feizes the whole; fometimes devours its provider; digs up graves, and devours the bodies.

Is a folitary animal, never feen in company except with its female in the midlt of winter; goes with young about four months, and brings two or three; burrows in holes. Male and female are generally found together, and equally refolute in defence of their young. Linnaus informs us, that it is very difficult to be fkinned.

\section{O F TH E \\ $\begin{array}{lllllllllllllll}H & A & R & E & K & I & N & D\end{array}$}

A NIMALS of the hare kind, like all that feed on vegetables, are inA offenfive and timorous. Abundantly fupplied by nature, they have not that ravenous appetite remarkable in fuch as are often ftinted in provifion.

The hare, the rabbit, and the fquirrel, are placed by Pyer among thofe that chew the cud; neverthelefs they chew their meat very much before they fwallow it. They ufe their fore-paws like hands; are fo very prolific, that were they never molefted, they would quickly overrun the earth.

The HARE is the largeft, the moft perfecuted, the moft timorous; its mufcles and its fenfes feem given only for flight; by its large prominent eyes, placed backward in the head, it can almolt fee behind it as it runs. Thefe are never wholly clofed; but the watchful animal neeps with them 
open. The ears are remarkably large, are moveable to every quarter, and readily receive the finalleft founds; the hinder feet are longer than the fore, which augments its rapidity, efpecially up hill.

The hate multiplies exceedingly; the females go with young thirty days; generally bring three or four. They are alio fitted in an extral ordinary manner for multiplying their kind; the conformation of the womb permits pregnancies of different conceptions, after one delivery retaining another : being divided, fo that one fide may be filled, while the other remains empty.

The young are brought forth with their eyes open; the dam fuckles them twenty days, after which they: leave her, but feldom feparate far from their native place, but make each a form at fume difance, having a predilection rather for the place than each other's fociety. They repofe by day, feed during night, choofe the tender grafs, quenching their thirft with dew; eat alfo roots, leaves, fruits, and corn; prefer fuch plants as have milky juice; ftrip the bark of trees during wincer, except the lime or the alder; are fond of birch, pinks, and parney. In February, the male purfues the female by the fagacity of his nore. They are then feen, by moon-light, playing, fkipping, and purfuing each other; but the leaft alarm diturbs their revels; they inftantly Aly, each a feparate way.

In running, they eafily outitrip all other animals at firtt ; could they preferve their fyeed, it would be impoffible to overtake them; but their tirft efforts exhaut their ftrength, and they double back to the plact shey were ftarted from. Their motions are filent, the fole of their foot being furnifhed with hair; and they feem fingular in having hair within their mouths; live feven or eight years; come to perfection in a year. It is faid the females live longer than the males; are feldom heard to cry, except when feizeo or wounded; their voice is not tharp; are of a complying nature, and fuiceptible of a kind of education; eafily tamed, but incapable of attachment. If taken never fo young, regain their narive freedom the firt opportunity. They have a remarkable good ear, can fit on their hind legs, ufe their fore-paws as hands, and have been taught to beat the drum, to dánce to mufic, and perform the manual exercife.

They make their form in places where the colour of the grafs moft refembles them; open to the fouth in winter, to the north in fummer. The hare, when it hears the hounds at a diftance, files by impulfe: Haviig at:ained fome hill, and left the dogs far behind, it ftops, rears 
on it's hinder legs, and looks back. Sometimes will ftart a frefh hare, and fquat in the fame form; fometimes will creep under the door of a fheep-cot, and hide among the theep; will enter holes; will go up one fide of the hedge, and come down the other; run a good way thereon; take to furze bufhes, leap from one to another, by which the dogs are frequently milled. Young hares tread heavier, and leave a ftronger fent, than the old. The more this creature tires, the heavier it treads, and leaves the ftronger fcent. In moift weather, they hold by the highways moft, becaufe the fcent is then ftrongeft on the grafs.

When the male and female keep one fpot, they fuffer no ftrange hare to make its form in the fame quarter. They live in woods and thickets, but are naturally fonder of the open country. Hunted, thot, fnared by men; deftroyed by dogs, birds, cats, ants, fnakes, and adders; perfecuted by fleas; it feldom reaches even that thort term to which it is limited by nature.

Around the north-pole, they become white in winter, and run in troops of four or tive hundred on the banks of the Irtiph, or the Jenifca, as white as fnow. Their fur forms a confiderable article in the hat manufacture.' A few are entirely black.

The hares of hot countries are finaller than ours. This animal is found from the torrid zone to the polar circle. The Jews, the ancient Bricons, and the Mahometans, all rejected it as unclean, and religiouny abftained from its Aleh; mott other people, at prefent, confider it as agreeable. The ancient Romans fo much admired it, as to call it the food of the wife.

\section{T}

THE rabbit, though nearly refembling the hare in form and manners, is diltinct in kind. In fecundity the rabbit exceeds the hare; breeds feven times in a year; brings eight young. Should this happen regularly during four years, the progeny would exceed a million. The rabbit makes a hole, where it continues great part of the day, and breeds in fecurity; but it loves the funny field and open pafture; feems to be a chilly animal; is continually out when without fear; often brings forth at a diftance from the warren, in a hole a foot deep; fuckles about a month, covering its young with mols and grafs. 
In the warren, always brings forth in a hole feparate from the male, more intricate and more ample than ordinary ; fue pulis off her belly a good quantity of hair, with which the makes a bed. The two finlt days the does not ftir out but for nourinnent; fuckles her young near five weeks; the male feldom vifits them, but when grown up, he feems to acknowledge them as his offspring, takes them between his pavs, fmooths their fkin, and licks their eyes, beftowing on each alternately an equal thare of carefres.

When a frefh warren is ftocked with tame rabbits, unaccuftomed to the art of fcraping a hole, they continue expofed to the weather and accidents without burrowing; and not till after two or three generations begin to find the neceflity and convenience of an afylum.

Rabbits are of various colours; white; brown, black, and moufe-colour. The black are the fcarceft. Mont wild rabbits are brown; in every neft of rabbits, whether the parents be black or white, are fome brown.

A gentleman who bred rabbits for amufement, fays, "the defcendants were furprifingly obedient and fubmifive to their common parent, who was eafily diftinguined by his fuperior whitenefs; when they quarrelled among each otlier, he ran directly up, and all was inftantly reduced to peace. If he caught any of them in the fact, he punified them. Having accuftomed them to come to me with the call of a whiftle, when this fignal was given, I faw him marfhalling them, leading them foremott, then fuffering them all to file off before him." The rabbit, though lefs than the hare, generally lives longer. Are generaliy fatter than the hare, but their fleh much lefs delicate.

The rabbit is native of the warmer climates, and originally imported from Spain. In that country, and its inands in the Mediterranean, they once multiplied to the greateft nuifance. At firft military aid was demanded to deftroy them; foon after they called in the ferict from Africa, which, with much more eafe and expedition, leffened the calamity. Rabbits love a warm climate; are incapable of bearing the cold of the north; in tropical climates feldom burrow.

The Syrian rabbit, like other animals of that country, is remarkable for its length of hair, which falls along the fides in wavy wreaths, in fome places curled like wool ; is thed yearly in large malies, the rabbir often dragging a part of its robe on the ground. No rabbits naturally in America; thofe rarried from Europe multiply in she Weft-Indiz inands in greąt abundance,

No. 23 . 


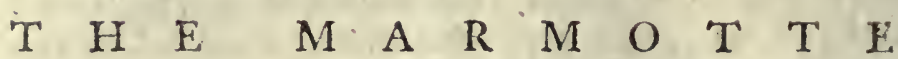

K $\mathrm{S}$ almoft as big as a hare, corpulent and fhort-legged; its head reI fembies a hare, but its ears are much fhorter ; is clothed with very long hair, and fhorter fur beneath, black and grey. This length of hair increafes its appearance of corpulence, fo that its belly leems to touch the ground. Tail tufted, well furnifhed with hair, carried Itraight with the body; five claws behind, only four before. Thefe it ufes as the fquirrel does, to carry its food to its mouth; and often fits on its hinder parts to feed.

Is chiefly native of the Alps; when taken young, eafily tamed, taught to dance, to wield a cudgel, and to obey the voice of its mafter; has an antipathy to the dog; has great Atrength, joined to great agility; has four large cutting teeth, which are formidable weapons of defence; is, in general, inoffenfive, and, except its enmity to dogs, feems to live in friendhip with every creature, unlefs provoked; runs much fwifter up hill than down; climbs trees with great eafe, and runs up the clefts of rocks, or the contiguous walls of houfes, with great facility; eats indifcriminately flefh, bread, fruits, herbs, roots, pulfe, and infects; is particularly fond of milk and butter; will fteal into a dairy, lap the milk like a cat, purring all the while, as an expreffion of pleafure. Milk is the only liquor they like; felclom drink water, and refufe wine. When pleafed, yelp like puppies; when irritated, have a piercing note that hurts the ear. Are very cleanly animals, but have a difagreeable fcent, particularly in fummer. Their flefh, being fat and firm, would be very good, were not this flavour predominant.

The marmotte, though native of the higheft mountains, where the fnow is never wholly melted, feems efpecially to feel the influence of cold, and its faculties are benumbed in winter. This extraordinary fulpenfion of life and motion deferves our attention.

The marmotte, in September or October, prepares its habitation for winter refidence, and does not quit it till April. It is a deep hole on the fide of a mountain, fpacious at bottcm, wherein feveral can refide without crowding or injury. It refembles the letter $\mathrm{Y}$; the two branches being two openings, which unite and terminate in their general apartment at the bottom. One branch floping downwards, and ferving as a kind of fink or drain; the other noping upwards, ferving as 2 door. The 


\section{T.HE H A R E IND.}

a partment at the end is warmly ftuccoed with mofs and hay. This work is very laboriou's, and performed in common. Here they pafs three parts of their lives; in ftormy weather; while it rains, and during danger; they never ftir out except in fine weather, nor ever go far from home. When abroad, one is a centinel; and when an enemy, a man, a dog, or a bird of prey, approaches, apprifes its companions with a whiftle. They ftore up no food; at the approach of the winter, they clofe the two entrances of their habitation with fuch folidity, that it is eafier to dig up the earth any where elfe. At this time they are very fat, and fome weigh above twenty pounds; they continue fo long, but by degrees begin to wafte, and are ufually very lean by the end of wirter. When this retreat is opened, the family is difcovered, each rolled into a ball, and covered under the hay, apparently lifelefs; they may be taken away, and even killed, without teftifying any great pain. Gradual and gentle warmth revives them; but they die if too fuddenly brought near the fire.

This torpor is produced by congelation of their blood, which is naturally cold (not above $10^{\circ}$ of heat); their internal heat feldom exceeds that of the air. There animals, therefore, become torpid, when the external cold is too powerful for the fmall quantity of heat in their bodies, i.e. when the thermometer equals ten degrees above congelation: This $\mathrm{Mr}$. Buffon experienced in the bat, the dormoufe, and the hedgehog, and with great juftice extends the analogy to the marmotte; extreme cold would kill them (if the heat of the air be above ten degrees, thefe animals revive). In this ftate, the blood fcarcely moving, or only in the greater veffels, they want no nourihment to repair what it wears away; they become leanier in proportion to the now attrition of their fluids, but not perceptibly, till after fome months, having juft fufficient motion in their luids to keep off putrefaction, and juft fufficient nourifhment to fupply the wafte of their languid circulation, they continue rather feebly alive than neeping.

Thefe animals produce once a year; bring three or four; they grow very faft; live nine or ten years; are chiefly found in the Alps, where they prefer the brow of the higheft mountains, and the funny fide. The inhabitants, when they obferve the hole, generally ftay till winter before they open it; for if they begin too foon, the animal wakes, and, having a furprifing faculty of digging, makes its hole deeper in proportion as they follow. 
This animal is found in Poland under the name Bobak, entirely refembling that of the Alps, except that the latter has a toe more upon its fore-foot than the former; alfo in Siberia under the name of the Jevranka, but rather fmaller. In Canada it is called the Monax, differing in having a blueifh fnout, and a longer tail.

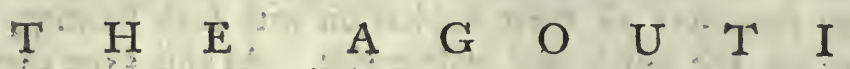

TS abundant in South-America, and has by fome been called a rab1 bit, which it refembles in fize and head, but its ears are fhort; alfo in the arched form of its back, in the hind legs being longer than the fore, and in having four great cutting teeth, two above and two below; but differs in that its hair is hard and briftly like that of a fucking pig, of a reddifh brown colour; alfo its tail is fhorter than the rabbit's, and without hair; and in the number of its toes, having but three on the hinder-feet, whereas the rabbit has five. With the hair of a hog, it has its voracioufnefs ; when fatiated, hides the remainder fo: a future ocicaflon; gnaws every thing if comes near. When irritated, its hair ftands erect along the back, and, like the rabbit, it ftrikes the ground violently with its hind-feet. It burrows in the hollows of trees; eats roots, potatoes, yams, and fallen fruits in autumn; ufes its fore-paws to carry its food to its mouth ; and its hind being longer than the fore, runs very fwiftly up hill. Its fight and hearing are good; when whiftled to, it fops to hearken. The French drefs it like a fucking pig; the Englin with a pudding in its belly, like a hare, It is hunted by dogs; in a fugar ground, where the canes cover the place, it is eafily overtaken; in the open country, it runs with great fwiftnefs to its retreat, and nothing but fmoke can force it out. When forced by the dogs, it turns on the hunters, and with its hair briftling like a hog, and ftanding upon its hind feer, defends itfelf very obitinately. Sometimes it bites the legs of thofe that attempt to take it, and will take out the piece where it fixes.

Its cry, when difturbed, reímbles that of a fucking pig; taken. young, is eafily tamed; plays harmlefsly about the houfe, and goes out and returns of its own accord; when wild, continues in the woods; the female generally choofes the moft obfcure parts to bring forth; prepares a bed 
2 bed of leaves and dry grass, and generally brings two; breeds twice or thrice a year, and carries her young from one place to another in the manner of a cat; lodges them when three days old in the hollow of a tree, fuckling them but a very fhort time; they quickly co:ne to perfection, and probably are not long lived.

\section{T $\mathrm{H} \quad \mathrm{E} \quad \mathrm{P} \quad \mathrm{A}$ G $\mathrm{A}$}

Y about the fize of a hare, or larger; fomewhat referribles a fucking L pig in its grunting and its manner of cating; is covered with coarfe hair, but beautifully marked along the fides with fmall afh-coloured fpots, upon an amber-coloured ground; is rather more thick and corpulent than the agousi; its nofe fhorter, and its hind feet have five toes; the ears are naked, and fomewhat tharp; the lower jaw fomewhat longer than the upper; the teeth, the fhape, and fize of the head, are like thofe of the rabbit; has a Thort tail, not tufted, and its hinder legs longer than the fore; burrows like a rabbit; does not ufe its fore-paws to carry food to its mouth, but hunts for it on the ground, and roots like a hog; frequents the banks of rivers in the moift and warm countries of South-America; is very fat; is eaten, fkin and all, like a young pig, is a great delicacy ; defends itfelf to the laft extremity, and is feldom ta'sen alive. Not only man, but every beaft and bird of prey watches its motions; but though its race is thus continually deftroyed, it finds refuge, and breeds in great numbers.

The TAPETr, or Brafilian rabbit, refembles our Englifh ones, but is much lefs; is reddin on the forehead, and a little whitifh under the throat; has no tail; has long ears, with whinkers, like our rabbits, and black eyes; does not burrow.

The APEREA, called by fome the Brafilian rabbit, feems to partake of the nature of a rabbic and a rat. The ears are like thofe of a rat, fhort and round; the other parts like a rabbit, except that it has but three toes on the hinder-legs. 


\section{TH E G U I N E A - P I G}

H AS been fo long rendered domeftic, that it is now become comH mon in every part of the world; is lefs than a rabbit; its legs Ihorter, fcarce feen, except when it moves; and the neck alfo is nhort; ears Rort, thin, and tranfparent; has no tail; in moving its body, lengthens like a rabbit; when at reft, it gathers up in the fame manner; has the rabbit lip, but its noftrils much farther afunder; fome are white, fome are red, others red and white; has four toes on the feet be fore, and but three on thofe behind; ftrokes its heact with the fore-feet like the rabbit; and, like it, fits upon the hind-feet; for which purpofe has a naked callous fkin on the back of the legs and feet.

Thefe animals are perfectly helplefs, fcarce poffeffed of courage to defend themfelves againft a moufe, but will often fight each other very obftinately; are devoured by cats, without refiftance; the female fees her young deftroyed without attempting to proiect them. . Eat bran, parney, cabbage, and moft cultivated vegetables. The carrot-top is a peculiar dainty, and fallad. They drink by lapping; are fond of new milk; but contented with water. When confined in a room, feldom crofs the floor, but generally keep along the wall; the male ufually driving the female before him; the following treading in the footfteps of the preceding. Seek the darkeft retreats, where they neep together, and venture out with caution; ftop at the entrance, liften, look rourd; if they fufpect danger, run back. In very cold weather, run about to keep themfelves warm.

If the young ones fall into the dirt, the fermale takes an averfion to them; her employment feems to confift in fmoothing their kkins, in difpofing their hair, and improving its glofs. The male and female taise this office by turns; when they have brufhed up each other, they attend to their young, taking care to make their hair lie fmooth, and biting them if refractory.

When anleep, they lie flat on their bellies; love to have their fore-feet higher than their hinder; turn themfelves round feveral times before they lie down; neep with their eyes half open. The male and female never Ieep at one time; while he enjoys his repofe, fhe guards him, her head turned toward the place where he lies.- When fhe fuppofes he has had his turn, the awakes him with a kind of murmuring noife, goes to him, 


\section{THE SQUIRREL.}

him, forces him from his bed, and lies down in his place. He does the fame good office for her, and continues watchful till the awakes.

Goes with young five weeks; brings from three to five; becomes again pregnant immediately, fo that their mulciplication is aftonihing; fuckles about twelve or fifteen days; does not feem to know her own, but fuffers the young of others to drain her, to the difadvantage of her own offspring; are produced with the eyes open, and in about twelve hours equal the dam in agility; fhe has but two teats, yet plenty of milk; they feed on vegetables very early; they contend for the moft agreeable food, or the warmeft place, very obftinately. Their manner of eating is fomething like the rabbit; they appear alfo to chew the cud; they feldom drink, yet make water every minute; they grunt fomewhat like a young pig; and exprefs pain by a more piercing note; their fleth is indifferent food.

\section{$\begin{array}{llllllllllll}T & H & \mathrm{E} & \mathrm{S} & \mathrm{Q} & \mathrm{U} & \mathrm{I} & \mathrm{R} & \mathrm{R} & \mathrm{E} & \mathrm{L} .\end{array}$}

WEW wild animals have fo many varieties as the fquirrel. The common fquirrel is of a reddih brown; belly and breatt are white; ears beautifully ornamented with long tufts of hair, of a deeper colour than the body; eyes large, black and lively; legs are. fhort and mufcular, like thofe of the rabbit; the toes longer, and claws fharper, fit for climbing. When eating, or dreffing itfelf, fits erect, like the hare or rabbit, ufing its fore-legs as hands; chiefly refides in trees.

The grey Virginian fquirrel is larger than a rabbit; greyilh body and limbs thicker than the common fquirrel; ears Morter, without tufts; upper part of the body, and external part of the legs, a fire whitifn grey, with a beauriful red ftreak on each fide lengthways; tail covered with very long grey hair, variegated with black and white towards the extremity; feems to be common to both continents; in Sweden changes colour in winter.

The Barbary fquirrel is a mixed colour, between red and black. Along the fides are white and brown lines, very becutiful; the belly a fky blue, furrounded with white. Some of thefe hold the tail ereet; others throw it forward over their body.

The Siberian wbite Squirrel in fize equals a common fquirrel. The Carolina black fquirrel is much bigger, fometimes tipt with white at all No. 23. the 
the extremities. The Braflian fquirrel is a beautiful animal, remarkable for its variety of colours; belly bright yellow; head and body variegated with white, black, brown and orange colour; wants the tufts at the ears; does not climb trees, as moft of the kind do. The little ground Squirrel of Carolina is reddith, with blackifh ftripes on each fide; alfo not delighting in trees. The fquirrel of Ner Spain is of a deep irongrey, with feven longitudinal whitifh ftreaks along the fides of the male, and five along thofe of the female.

This animal is diffured over all parts of the world, yet few animals are fo tender. Thofe of the tropical climates will only live near a warm fun; while the Siberian fquirrel fcarce endures our temperature; fome live on the tops of trees, others feed, like rabbits, on vegetables below.

The fquirrel is neither carnivorous nor hurtful; eat fruits, nuts and acorns; is cleanly, nimble, active, and induftrious; its eyes fparkling; its phyfiognomy lively; generally fits on its hinder-legs, and ufes the fore-paws as hands; thefe have five toes, one of them feparated from the reft like a thumb; neftles among the large branches of a great tree, where they fork off into fmall ones; begins by making a kind of level between the forks, bringing mors, twigs, and dry leaves, binds them together with great art, fo as to refift the moft violent ftorm. This is covered on all fides, except a fingle opening at top, juft large enough to admit the little animal, which is itfelf defended by a kind of conical canopy, to throw off rain. The neft is very commodious below; foft, well united, convenient and warm; and Thelters its inhabitant from the heat of the fun, which it feems to fear, and from the inclemency of winter, which it is lefs capable of fupporting. Its ftores are feldom in its neft, but in the hollows of the tree, and never touched but by neceffity. They bring about four or five young once a year in May. Their time of geftation is about fix weeks.

Seldom defcends to the ground, but jumps from branch to branch; if alarmed, travels thus throughout the foreft. It moves by bounds from one tree to another, at forty feet diftance; if obliged to defcend, runs up the next tree with amazing facility; has an extremely fharp piercing note, expreffive of pain, another not totally unlike the purring of a cat when pleafed; feeds in fpring on buds and young thoots; in fummer on fruits, particularly the young cones of the pine-tree; in autumn, on the acorn, philberd, chefnut, and the wilding; gathers now its provifions for winter, and forefees the feafon of fcarcity. 


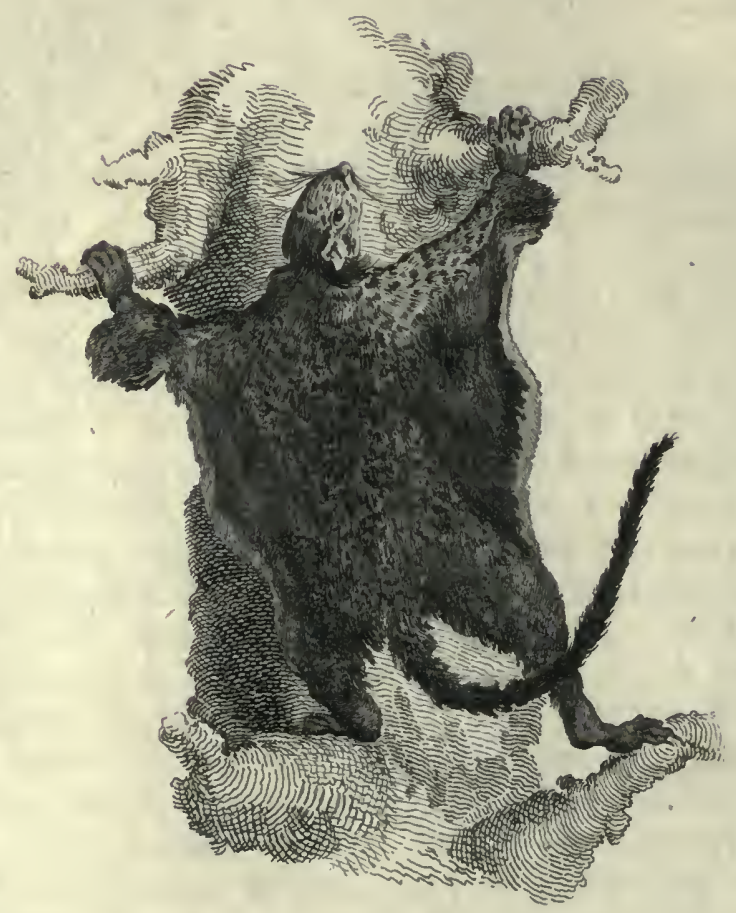

Great Flying Squirrel. 
In Lapland and the north, fquirrels remove by thoufands from one country to another, travelling directly forward, neither rocks, forefts, nor waters can ftop them: We are told by Klein and Linnzus, that on approaching a breadth of water, they return into the neighbouring foreft, each in queft of a piece of bark, which as a boat may waft him over; then boldly committing their little fleet to the waves, each fits on its own piece of bark, fanning the air with its tail to drive it forwards. In this orderly manner they often crofs lakes feveral miles broad; often too the poor mariners are not aware of the dangers of their navigation, for if the edge of the water be calm; the middle is more turbulent. There the fighteft additional guft of wind overfets the little failor and his veffel, ruins the whole navy, and Mipwrecks two or three thoufand fail, to the great joy of the Laplander on Shore, who gathers up the dead bodies thrown in by the waves, eats the flem, and fells the fkins.

The fquirrel is eafily tamed, and becomes very familiar; loves to lie warm, and will often creep into a pocket or the bofom.

\section{THE FL Y I N G, S QUIR R E L}

TS lefs than a common fquirrel, its $\mathrm{k}$ kin very foft, elegantly adorned with dark and light-grey fur; has large prominent black and very parkling eyes, fmail ears, and very tharp teeth. When not leaping, its tail lies clofe to its back; but when fpringing, is moved from fide to fide.

It is amazing to fee it at one bound dart many yards, from one tree to another, in which they are affifted by a peculiar formation of the Rin, extending from the fore-feet to the hinder; when the animal ftretches its fore-legs forward and its hind-legs backward, this fkin is fpread out between them, fomewhat like that between the legs of a bat; by this increafe of furface, the little animal floats in the air till the force of its firft impulfe ceafes, then gradually defcends. This Kin, when at reft, is wrinkled up on the fides; when the limbs are extended, forms a kind of web between them of above an inch broad on either fide. Though thus fitted for leaping, feldom exerts its powers; is eafily tamed, but apt to break away; not fond of nuts or almonds, like other fquirrels, but chiefly pleafed with the fprouts of birch and cones of the pine. 
O. F TH E

\section{R A $\quad \mathrm{A} \quad \mathrm{K} \quad \mathrm{I} \quad \mathrm{N}, \mathrm{D}$.}

F thefe the moft mifchievous is the Great Rat, a new comer, but has taken too fecure poffeffion to be removed; fometimes called the Rat of Norway, but is unknown beyond the Baltic; probably came. from the Eaft-Indies.

This animal is in length about nine inches; its eyes large and black; colour of the head, and the whole upper part of the body, a light brown, mixed with tawny and an colour; the end of the nofe, the throat and belly, are a dirty white, inclining to grey; the feet and legs almoft bare, of a dirty pale fleth colour; the tail as long as the body, covered with minute dufky fcales, mixed with a few hairs. It is chiefly in the colour that this animal differs from the Black Rat, or the Common Rat; as it was once called; but now common no longer. 'This new invader, in a few years after its arrival, deftroyed almoft the whole fpecies: the frog alfo, which had been introduced in Ireland, has been extirpated by it.

It burrows in the banks of rivers, ponds, and ditches, and does great damage to mounds raifed to conduct ftreams, or confine rivers; molefts farm-houfes; burrows in corn, eats much, and damages more; nothing eatable efcapes its voracity. It deftroys rabbits, poultry, and game; fwims with great eafe, and thins the filh-pond.

Produces from fifteen to twenty, three times a year; happily for us, eat each other. The large male rat generally keeps in a hole by itfelf, dreaded by its own fpecies, as the moft formidable enemy. Dogs and cats, but not without exception, deftroy them, but the weafel moft effectually.

The Black Rat is in length about feven inches; the tail, near eight; colour, a deep iron-grey, almott black, except the belly, which is of a dirty cinereous hue. Over-run America, being introduced from Europe, and are now noxious there.

The Black Water-Rat is about the fame fize, has a larger head, a blunter nofe, leis eyes, fhorter ears, and the tip of its.tail a little white. Never frequents houfes; but the banks of rivers, ditches, and ponds, where it burrows; feeds on filh, frogs, and infects; and, in fome countries, is eaten on faft-days. 


\section{THE RAT KIND.}

\section{T $H \quad E \quad M \quad O \quad U$ S E.}

TTIMID, cautious, and active, fearful by nature, familiar from nèceffity, it attends on mankind an unbidden gueft; it never leaves its hole but to feek provifion, and feldom ventures above a ferw paces; does not leave a houfe unlefs forced. The moft feeble of quadrupeds; except the guinea-pig; never, though tamed, familiar; and, though fed in a cage, fufpicious. Surrounded by enemies, the owl, the cats the fnake, the hawk, the weafel, and the rat, it only fubfints by its amazing fecundity.

The moufe brings forth feveral times in the year from fix to ten; thefe, in a fortnight thift for themfelves; are feldom found in ricks or corn much inferted with rats; generally choofe that fide of the ricks from whence moft rain is expected; and thence venture forth to drink the little drops of rain or dew at the extremities of the ftraw; feldom live above two or three years; found almoft throughout the ancient continent, and exported to the new; afraid of human fociety, yet clofely attending it; enemies to man, but only found where he has fixed his habitation.

The long-tailed field-moufe is larger than the former; in colour, nearly refembling the Norway rat; chiefly found in fields and gardens. The flort-tailed freld-moufe, about fix inches long, has a tail not above an inch and a half long, ending in a fmall tuft Its colour inclines to that of the domeftic moufe. This, and the former, remarkable for laying up provirion againft winter, fometimes above a buhel.

The fbrew-monfe is about the fize of the domeftic moufe, but differs greatly in the form of its nofe, which is very long and nender. The teeth alfo are fingular in form, and twenty-eight in number; whereas. the number of the rat kind is but fixteen. The two upper fore-teeth are very tharp, and on each fide is a kind of wing or beard, like an arrow, fcarcely vifible, but on clofe infpection. The other teeth placed clofe together, are very fmall, and feemingiy fcarcely feparated. As it lives chiefly in the fields, and feeds more on infects than corn, it may be confidered rather as a friend than an enemy. It has a ftrong difagreeable fmell; is faid to bring four or five young at a time. 


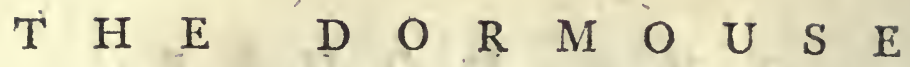

AY be diftinguiked into three kinds; the greater, the mid1 dle, and the lefs; the largeft being equal to a rat, the leaft no bigger than a moufe. They differ from the rat in having the tail tufted with hair, round, refembling a bruh. All have black fparkling eyes, and whilkers, partly white and partly black; are ftupified like the marmotte during winter, and hoard provifions in cale of revival by a funny day.

They inhabit woods or very thick hedges, neftling in the hollow of fome tree, or near the bottom of a clofe fhrub; form magazines of nuts, beans, or acorns, and thut themfelves up with it for the winter, rolling themfelves up in a ball. Their nefts are lined with mofs, grafs, and dead leaves; ufually bring forth three or four young in fpring.

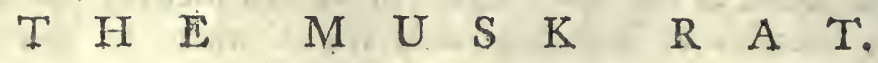

F thefe are three diftinctions: the Ondatra, the Defman, and the Pilori. The ondatra is native of Canada, the defman of Lapland, the pilori of the Weft-India inlands. The ondatra differs in having the tail flatted and'carried edge-ways. The defman has a long extended fnout like the threw-moufe; the pilori a thort tail, as thick at one end as the other. They refemble each other in being fond of the water, and in that mufky odour from whence they are named.

The ondatra is the moft remarkable; about the fize of a fmall rabbit; has the hair, the colour, and tail of a rat, but flatted on the fides; can contract and enlarge its body at pleafure. It has a mufcle like that of horfes, by which they move their hides, lying immediately under the fkin, fo powerfully contractile, and fuch an elafticity in the falfe ribs, that it can creep into an hole where others, feemingly much lefs, cannot follow. The female is remarkable alfo for two difinct apertures. Their mufky fmell is much ftrongeft at one feafon of, the year; and the marks of the fex feem to appear and difappear in the fame manner.

The ondatra fomewhat refembles the beaver in nature; lives in fociety during winter; forms houfes of two feet and a half wide, in which reficle 
refide feveral families to Thelter themfelves from the feafon; but they do not lay up magazines of provifion. They form a kind of covert way to and round their dwelling, from whence they iffue to procure water and roots, upon which they fubfift. During winter their houfes are eight or ten feet deep in fnow. During fummer they feparate two by two, and feed on roots and vegetables. They then become extremely fat, and are fought after, as well for their flen as their $\mathrm{Nins}$,

\section{T H E}

Reatly refembles the water-rat in fize, fmall eyes, and the fhortI nefs of its tail ; is rather browner, the belly and tegs a dirty yelJow; is diftinguifhed by two pouches on each fide its jaw, under the Rkin, into which it crams provifion, which it carries home for winter ftore. There are oblong, the fize of a large walnut. They open into the mouth.

Its hole is generally on an inclining ground, always has two entrances, one perpendicular, the other oblique; (if there be many in a family, there are fo many perpendicular holes.) The perpendicular hole is the door. Within about $\mathrm{z}$ foot of this are two more, containing provifions. There is another apartment warmly lined with grafs and ftraw, where the female brings forth. Thefe communicate with each other, and all together take up a fpace of ten or twelve feet in diameter. Thefe animals ftore up dry corn well cleaned, or in the ear, beans and peas in the pod. They begin to ftore in Auguft; as each magazine is filled, they carefully cover it with earth, fo neatly, that it is not eafy to difcover where the earth has been moved; their retreats are found by obferving the oblique entrance, which generally has a fmall quantity of earth before it; and this, though often feveral yards from their home, conducts the fkilful to the difcovery. Mariy German peafants make a Jivelihood by thefe hoards, which, in a fruitful feafon, often furnifh two bufhels of good grain each.

They produce twice or thrice a year, and bring five or fix. In moift feafons, their devaftations produce a famine. Like the reft of their kind, deftroy each other. Their fur is valuable; the natives are invited by revards to deftroy them, and the weafel kind feconds their efforts. 


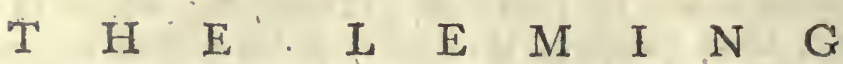

F 5 a native of Scandinavia, larger than a dormoufe, with a bufhy tail, half an inch long; covered with thin hair; the upper part of the head, the neck and Thoulders, black; the reft of the body reddin, with fmall black fpots to the tail; eyes little and black; ears round, inclining toward the back; the legs before fhort, thofe behind longer, which renders it very fwift.

In wet feafons, all the rat kind multiply; but this fpecies fo remarkably, that the Laplanders believe they drop from the clouds; they quit their native mountains in troops of millions, moving by night, in a fquare often more than a mile broad, covering the ground, the hindmoft touching its leader. They generally move in lines, about three feet apart, and parallel, from north-weft to fouth-eaft. They go forward, directed by fome ftrange impulfe. If extenfive water' interrupt their progrefs, they fwim over it; if a fire, or a deep. well, they plunge into the flames, or leap down the well; if a boat acrofs a river, while they are fwimming, they mount directly up its fides; if a ftack of hay or corn, they gnaw their way through it; if a houfe through which they cannot get, they continue there till they die. Happily they eat nothing ftored for human fubfiftence; but confume roots and vegetables. If they pafs through a meadow, they deftroy it quickly, and give it an appearance of being burnt up and ftrewed with afhes. If a man fhould venture to interrupt one of them in its courfe, the little animal furiounly flies up at its opponent, barking fomewhat like a puppy, and, wherever it faftens, does not eafily quir the hold. If the leader be forced out of its line, which is very rare, it expreffes its grief by a plaintive cry, and is faid not to furvive it. Even their breeding does not hinder their march; for fome have been obferved to carry one young in their mouth, another on their back. Their rapacity, at laft, impel's them to devour each other. After committing incredible devaltations, they feparate into two armies, along the coafts of the larger lakes and rivers. The Laplanders, who obferve them thus drawn up to fight, confider their combats as prefages of war, and expect invafion from Ruffia or Sweden, as the fides next thofe kingdoms happen to conquer. They fight till one party overcomes, and from that time difappear, most probably being entirely. devoured, either in rage, or as food. Often 



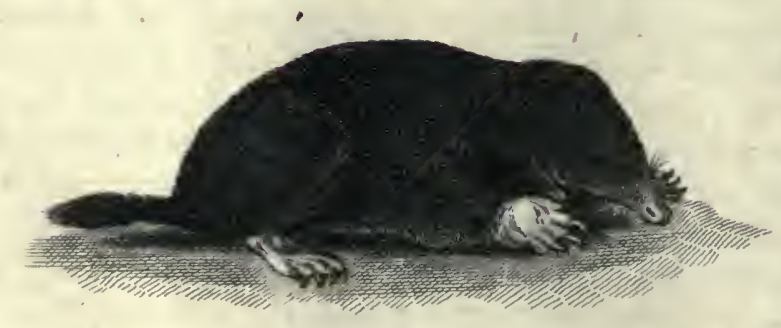

The Mole 
they are found dead by thoufands, and taint the air for miles, producing malignant diforders. They feem alfo to infect the plants they have gnawed, for cattle often die that afterward feed where they paffed.

To the Swedes and Norwegians, who live by hưbandry, fuch an invalion is terrible; but the Laplanders are happy when vifited by an army of lemings; they feaft on their flefh, though horrid food even to dogs and cats, and always expeet plenty of game the year following, among thofe fields which the lemings have deftroyed.

\section{T $\mathrm{H}=\mathrm{E} \quad \mathrm{M} O \mathrm{O}$ L $E$.}

THE mole is formed to live wholly under the earth, that no place fhould be left untenanted. Is fat, fleek, and gloffy, and, though denied many advantages of other animals, enjoys fome of which they are but fcantily poffeffed.

Lefs than a rat and bigger than a moufe, with a coat of fine, thort, gloffy, black hair; its nofe, long and pointed; its eyes fcarce poffible to be difcerned. Inftead of ears, has only holes. Its neck fhort; body thick and round; fmall hoort tail; legs alfo very fhort; aз it refts on its belly, the feet appear growing out of its body. The ancients, and fome moderns, thought the animal utterly blind; but Derham, by a microfcope, difcovered all the parts of an eye. The , fore-legs are very fhort and ftrong, furnifhed with five claws each, turned outwards and backswards, the hind-legs are longer and weaker than the fore; the teeth are like thofe of a hrew moufe, five on each, fide the upper jaw, which ftand out; thofe behind, divided into points. The tongue is as large as the mouth will hold.

By the breadth, ftrength, and Thortnefs of the fore-feet, which incline outwards, throws back the earth with eafe; had they been longer, the falling in of the earth would have prevented the quick repetition of their ftrokes, and they would have required a larger hole for their exertion. The fore-part of the body being thick and very mufcular, gives great ftrength to the action. of the fore-feet, enabling it to dig its way with amazing force and lapidity.

Little vifion is fufficient for a creature who lives in darknels; had the organ been larger, it would have been perpetually liable to injury by 
falling earth; that inconvenience is avoided by its being very fmall, and very clofely' covered with hair. Anatomifts mention alfo a certain mufcle, by which the animal can advance or draw back its eyes at pleafure.

Perfectly fitted to the animal's fituation, are alfo the fenfes of hearing and fmelling; by the firft it receives notice of diftant danger, by the other, is directed, in the midft of darknefs, to its food. Buried in the earth, it feldom ftirs out, unlefs forced by violent rains, or when in purfuit of prey it gets into the open air, which is hardly its natural element : it choofes the loofer fofter grounds, beneath which it can travel with greater eafe; where alfo it finds molt worms and infects, on which it chiefly preys. It is moft active, and cafts up mott earth, immediately before rain; and, in winter, before a thaw : at thofe times worms and infects being, in motion, and approaching the furface. In dry weather, the mole feldom forms hillocks, but penetrates deeper after its prey.

Their greatert calamity is an inundation; notwithftanding every effort to reach the higher grounds, many perih, as well as their young, which remain in their holes. Without fuch accidents, their great fecundity would render them extremely troublefome; and as it is, in fome places they are confidered by the farmer as his greateft peft. They couple toward the approach of fpring, and their young are found about the beginning of May, four or five at a time. It is eafy to diftinguin that mole-hill in which the female has brought forth, by its fize. To form this retreat, the begins by erecting the earth into a tolerably fpacious apartment, fupported by partitions, to prevent the roof from falling; the beats the earth very firm, to render it tight againft the molt violent rain, and raifes it above nlight inundations. She then procures grafs and dry leaves, as a bed for her young. All around this hill, are holes diverging into the earth, from the middle apartment, extending about fifteen feet in every direction, into which the animal makes her fubterraneous excurfions, and by which, as the is very quick of hearing, the inftant the perceives her habitation attacked, the and her young always make good a retreat, unlefs the earth be dug away by feveral men at once.

The mole is fcarcely found, except in cultivated countries : its varieties are but few. That of Virginia refembles the common mole, except in colour, which is black, mixed with a deep purple. There are fometimes white moles, particularly in Poland, rather larger than the former: 


\section{( 107$)$}

\section{O F T H E}

\section{PRICKLY, OR HEDGE-HOG KIND.}

7 HE Hedge-hog, apparently formidable, is yet harmlefs. Armed with a thoufand points, for defence, not invafion. Deftitute of force, cunning, or fwiftnels, this animal finds protection by one expedient. When attacked, it rolls itfelf up, and prefents nothing but a ball of defenfive thorns to the enemy.

Thisanimal is of cwo kinds; one with a nofe like a hog, the other, more fhort and blunt. The latter is moft common; is about fix inches from the tip of the nofe to the tail. The tail is little more than an inch long, concealed by the fpines; the head, back, and fides, covered with prickles; the nofe, breaft, and belly, with fine foft hair; legs fhort, of a dufky colour, almoft bare; five toes on each foot, long and feparated; the prickles are about an inch in length, very fharp pointed; their lower part white, middle black, and points white : the eyes are fmall, and placed high in the head; the ears are round, pretty large, and naked; the mouth is fmall, well furnifhed with teeth for chewing its food.

On occalions of danger, it alters its whole appearance; bends its back, lays its head on its breaft, fhuts its eyes, rolls down the Rin of its fides toward the legs, draws thefe up, and tucks them in on every fide, by drawing the fin clole; refembles now not an animal, but a roundin mafs of prickles, not unlike a chefnut in the hufk; having, on one fide, a kind of flat, where the head and legs are tucked in. Thus rolled up, it waits till its enemy is fatigued by fruitlefs attacks. The car, the weafel, the ferret, the martin, quickly decline the combat ; the dog himfelf feldom fucceeds. If iis affailant attempt to bite, he more frequently feels than inficts a wound; enraged and barking, he rolls it along with his paws; but the hedge-hog patiently fubmits, in fecurity, to every indignity, and, to difguft its enemy, fheds its urine. The fox, by preffing it with its weight, often obliges the hedge-hog to put out its nofe, which he inftantly feizes, and foon becomes mafter of the whole body: when danger is paft, the hedge-hog peeps out from its ball, and creeps flowly to its retreat.

The hedge-hog feeps by day, and ventures out by night; refides in fmall thickets or hedges; makes a hole fix or eight inches deep, lies 
well wrapped up in.mofs, gxafs, or leaves; eats roots, fruits, worms, and infects.

Mr. Buffon accufes them of tricks, not a little mifchievous. "I have often," fays he, "had the female and her young brought me about the beginning of June; from three to five in number.; white in the beginning, and hewing only the marks of their fpines; willing to rear fome of them, 1 put the dam and her young in a tub, with abundant provifion; but the old animal, inftead of fuckling her young, devoured them all, one after another. On another occafion, a hedge-hog, that had made its way into the kitchen, difcovered a little pot, in which was meat prepared for boiling; the mifchievous animal drew out the meat, and left its excrements in the ftead. In the garcien they did very little damage, and it was fcarcely perceivable that they were there : they lived on fruits that fell from the trees; they dug the earth into fhallow holes; eat caterpillars, beetles, and worms; were alfo very,fond of fleth, boiled or raw."

They neep during winter; at no time eat much, and can remain very long without food. Their blood is cold, like all other torpid,animals.

\section{T H E}

\section{T A N R E C A N D T E N D R A C,}

A. RE two little animals, defcribed by Mr. Buffon, of the hedgeA hog kind, yet different; like the hedge-hog, covered with prickles, but mixed with more hair; unlike that animal, they do not defend themfelves by rolling up in a ball. Found only in the EaftIndies, where the hedge-hog exifts alfo.

The TANREC is about the fize of a mole; the TendRac ftill lefs, defended only with prickles on the head, neck, and fhoulders; being elfewhere covered with a coarfe hair, refembling hog's briftes. Having very fhort legs, they move nowly; grunt like a hog, and wallow in the mire. Are chiefly in creeks and harbours of falt water; multiply greatly; make holes in the ground, and neep for feveral months. During this torpid ftate, their hairs, perhaps alfo their prickles, fall, and are renewed on their revival; are ufually very fat; their fle $\mathrm{h}$ infipid, fof, and ftringy, yet the Indians confider it as a delicacy. 
-

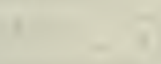

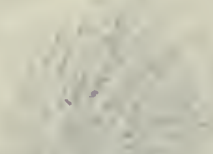

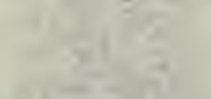

$-1+\frac{1}{2}=0$

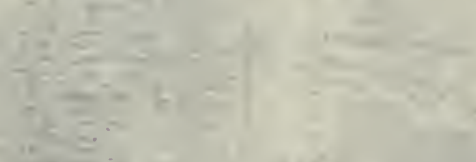




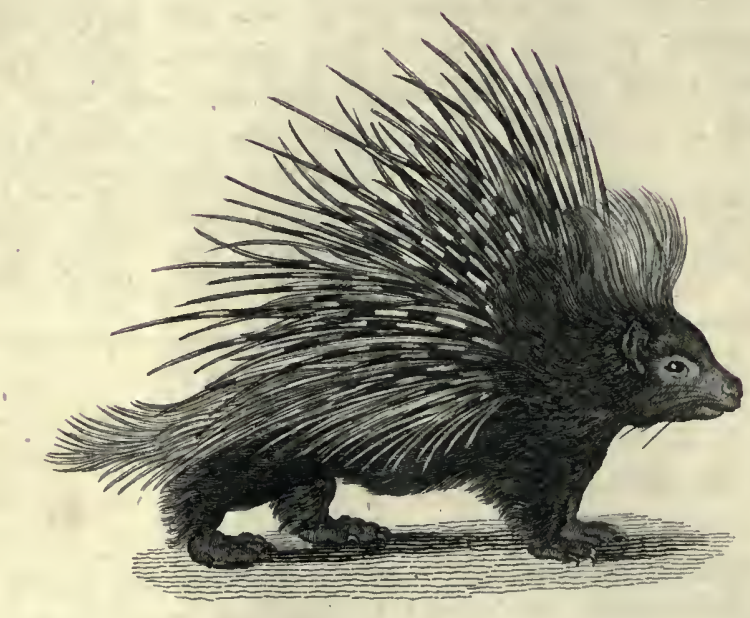

The Porcupine 


\section{THE HEDGE.HOG.KIN D.

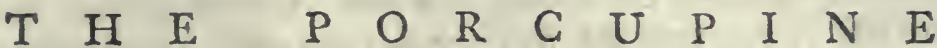

$\operatorname{IOg}$

TS about two feet long, and fifteen inches high; covered with quills, from ten to fourteen inches long, refembling a goofe-quill in thicknefs, but tapering and fharp, thickeft in the middie, and inferted like feathers into birds; within fpongy, like the top of a goofe-quill; white and black alternately from end to end; fome fifteen inches long, and a quarter of an inch in diameter; harder than common quills, difficult to be cut, and folid at the point : others long, flexible, and nender, grow here and there among the former; fome near the tail are white and tranfparent. Thefe quills incline backward, like the briftles of a hog; when the animal is irritated, they ftand upright, like briftes.

The muzzle fomewhat refembles a hare, but is black; the legs very Short, each foot has five toes; the belly, head, and body, are covered with fhort hair, like prickles, except the ears and the fole of the foot; the ears are thinly covered with very fine hair, in Thape are like the human; the eyes fmall, only one-third of an inch in length. When Akinned, there appear a kind of paps where the large quills grew, the fize of a fmall pea, anfwering to as many holes on the furface of the nkin, which are about half an inch deep, wherein the quills are fixed. This formidable armour is entirely defenfive; the quills never quit the fkin, except. when the animal moults them, as birds do their feathers. Their ufual manner of defence is to lie on one fide, and when the enemy approaches very near, by fuddenly rifing, to wound him with the points on the other, always directing their quills ta the enemy: thus amply protected, even the lion fears to attack the porcupine. Hunts ferpents and reptiles. Traveliers affure us that, between the ferpent and the porcupine, exifts irreconcileable enmity, and that they never meet without mortal engagement. The porcupine is faid to roll itfelf on the ferpent.

Thofe brought to this country are ufually fed on bread, milk, fruits, and meat. The porcupine is extremely hurtful to gardens, and does incredible damage. Lives from twelve to fifteen years; couples in September; the males become very fierce, and often deftroy each other with their teeth. The female goes with young feven months, brings forth one, fuckles it about a month, accuftoms it betimes to vegetables and the bark of trees; the is very fierce in its defence; at other feafons, No. 23 . 
is fearful, timid, and harmlers. The porcupine never bites or injures its purfuers: if hunted by a dog or a wolf, climbs a tree, and continues there till it has wearied out the patience of its adverfary. The Indians eagerly purfue it to make embroidery of its quills, and to eât its fiefh.

The porcupines of America differ from that of the ancient continent, and may be confidered as different fpecies. Thefe are principally,

The Couando, much lefs than the porcupine; its quills about a quarter the length of the porcupine's; its fnout little like a hare; irs tail is long, catches the branches of trees, and holds by them ; may be eafily tamed; inhabits chiefly the fouthern parts of America, yet is not wanting in the northern.

The URson is native of Hudfon's Bay. The body of this animal fomewhat refembles a pig; is covered with long brifty hair, with a fhorter hair underneath; under this the quills lie concealed very thick; 'they are white, with a brown point, and bearded, and the longeft do not exceed four inches; they ftick to the hand when the animal is ftroked - on the back, fometimes fo faft as to follow it. They neftle under the roots of great trees, neep very much, chiefly feed on the bark of the juniper. In winter, the fnow ferves'them for drink; in fummer, they lap water like a dog; are very common in the country lying eaft of Hudfon's Bay; and feveral of the trading Americans depend on them for food, at fome feafons of the year.

O F

\section{$\begin{array}{llllllllllll}M & O & N & \text { K } & \text { E } & \text { Y } & \text { K } & \text { I } & \text { N } & \text { D. }\end{array}$}

A N I MALS of this clafs have hands inftead of paws; ears, eyes, A eye-lids, lips, and breafts like mankind; their internal conformation bears partial likenefs; in fome nearer, in others more diftant. May be divided into three claffes, viz.

The Ape kind; thefe exhibit ftrongly the human likeners; walk upright, want a tail, have flefhy pofteriors, calves to their legs, and feet fomewhat like ours. 
The Baboon kind is a more diftant approach to the human form, the quadruped mixing in every part: go on all fours; when upright, fome are as tall as a man, have fhort tails, long fnouts, and are brutally fierce.

The Monkey kind are removed further, are much lefs, tails as long or longer thán their bodies; flattin faces.

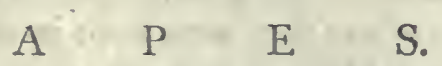

THE Ouran Outang, of all animals, neareft approaches the human race; is of different fizes, from three to feven feet high. In general, is lefs than a man; but its ftrength and agility much greater. T Travellers, who have feen them in their native folitudes, give furprifing relations of their force, fwiftnefs, addrefs, and ferocity. Naturalifts at home have been-equally ftruck with their patient, pliane, imitative difpofitionso; their appearance and conformation. That obferved by Dr. Tyfon is beft known, having been defcribed with the greateft exactnefs. It was brought from Angola in Africa; the body was covered with coal black hair, refembling human, and longeft where it is longeft on the human fpecies. The face was like that of a man, the forehead larger, the head round; the jaws were not prominent, as in monkies, but fiat; the ears were like human in moft refpects; and the teeth, as alfo the bending of the arms and legs.

The differences were the flatnefs of the nofe, the lowners of the forehead, the want of chin; the ears were too large, the eyes too clofe, the nofe and mouth too diftant, the thighs too fhort, the arms too long, the thumb too little, and the palm of the hand too narrow. The feet were more like hands than feet, and the animal bent ton much on its haunches. It differed in the number of its ribs, having thirteen; whereas, in man, are but twelve. The tongue, and the organs of voice, were the fame, yet the animal was dumb; the brain was the fame, yet he wanted reafon.-Profeffor Camper has fince obferved a nit in the gullet of this animal, through which the air, neceffary to form a voice, efcapes in a whifte.

This animal was very hairy behind; but before, the hair was much thinner, the fkin appeared, and in fome places was almoft bare. When on all fours, it appeared all hairy; when ereet, it appeared lefs hairy. The face, hands, and foles of the feet, were without hair, and moft of the forehead; down the fides of the face the hair was thick, "an inch and a half long. The palms of the hands were as long as the foles of the 
feet; the toes as long as the fingers; the middle toe longeft. The animal often ufed his hinder feet as hands; fometimes its hands inftead of feet.

In its paffage to England, thofe it knew on fhip-board, it would embrace with great tendernefs, opening their bofoms, and clafping its hands about them. Monkies of a lower fpecies it held in averfion; always avoided the place where they were kept in the fame veffel. After it was a little ufed to wear clothes, it grew very fond of them; part it would put on without help; the reft it would carry in its hands to fome of the company, for their affiftance. It would lie in a bed, place its head on the pillow, and pull the clothes upwards, as a man would do.

Mr. Buffon defcribes one, which, fays he, I have feen give its hand to fhow the company to the door, fit at table, unfold its napkin, wipe its lips, ufe the fpoon and the fork to carry the victuals to its mouth, pour out its drink into a glafs, touch glaffes when invited, take a cup and faucer and lay them on the table, put in fugar, pour out its tea, leave it to cool before drinking, and this often of its own accord.

However, many of thefe extraordinary habits were probably the refult of education. It is very fuppofable the mott perfect of this kind are generally prone like quadrupeds, for when we examine the palms of their hands, and the foles of their feet, we find both equally callous and beaten; a proof that both have been equally.ufed. It is even faid; that when they are taken, their hands are tied behind them, to teach them to walk upright; and, thus educated, an ape, or a quadruped, may be an admirable object for human curiofity, but little advanced in regard to its own. felicity; its conveniencies for its manner of life are neither improved nor augmented: all its acquifitions are ufelefs to itfelf, and calculated to caufe wonder in fpectators, not to rank their poffeffor a fingle ftep higher in the fcale of being.

Pyrard relates, that in Sierra Leona, in Africa, are a kind of apes, called Baris, ftrong and mufcular, which walk upright, pound at a mortar, go to the river to fetch-water, in a little pitcher, on their heads; but if care be not taken to receive the pitcher at their return, let it fall, and then, feeing it broken, cry for their lofs.

The gigantic races of the Ouran Outang are truly formidable; are as tall or taller than a man; active, trong; intrepid, cunning, lafcivious, cruel; found in many parts of Africa, in the Eaft-Indies, in Madagafcar, and in Borneo. In the laft, the people of quality courfe him as we do the ftag. 



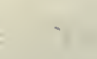




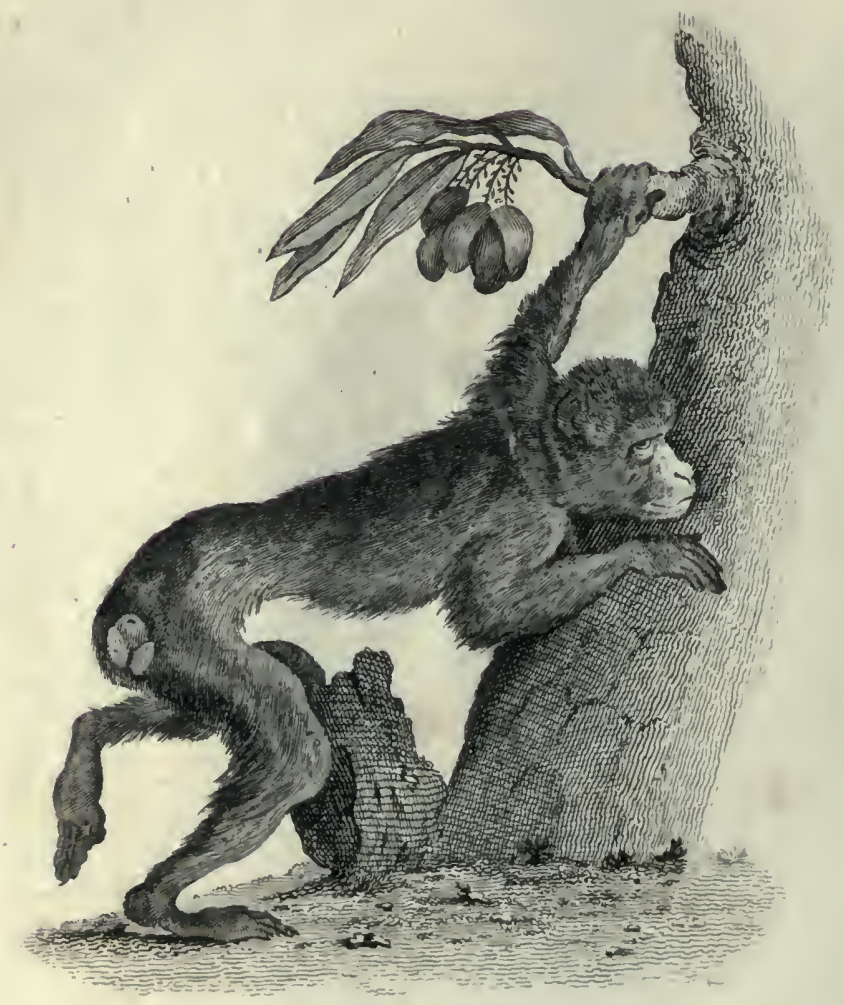

The Magot. 


\section{THE MONKEY KIN D.}

The African Pongo walks on his hinder legs, neeps under trees, builds a hut to protect him againft the fun and the rains; lives only on fruits; not carnivorous. When the negroes make a fire in the woods, this animal comes near and warms himfelf by, the blaze, but has not fkill to keep the flame alive by feeding it with fuel. They go in companies; if they meet a man, fhew him no mercy; attack the elephant with clubs, and drive him from that part of the foreft which they clain. Are fronger than ten men.

The Ape, properly fo called, or the Pithekos of the ancients, is not above a foot and a half high; walks ereet, without a tail, and is eafily tamed.

The Long-armed Ape is from two feet to four feet high, walks ereet, without a tail, face refembling man, a circle of bufhy hair round the vifage, eyes are large and funk in its head, face tanned, ears well proportioned. When it ftands ere?, its arms reach the ground; fo that it can walk on all fours, yet be ereet at the fame time. Native of the Eaft-Indies, particularly the coaft of Coromandel.

The Cynocephalus, or Magot (of Buffon) wants, a tail, but has a fmall protuberance formed by the fkin; alfo a large callous red rump; face prominent, approaching the quadruped; covered with a brownifh hair; yellow on the belly; three feet and a half or four feet high; native of Africa and the Eaft; fullen, vicious, and untractable.

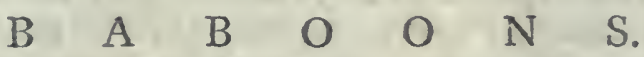

THESE animals have a fhort tail, a prominent face, canine teeth larger than thofe of men, and callofities on the rump; fierce, malicious, and untractabie.

The Baboon, properly fo called, is from three to four feet high, very ftrong built, thick body and limbs, and long canine teeth; large callofities behind, quite naked and red; tail crooked and thick, feven or eight inches long; its fnout long and thick; on each fide of its cheeks, a pouch, into which, when fatiated with eating, it puts the remainder; covered with long thick hair, reddith brown; walks commonly on all fours; hands as well as feet armed with long fharp claws, inftead of the broad round nails of the ape kind.

When 
When they rob an orchard or vineyard (for they are extremely fond of grapes, apples, and ripe fruit), they go in large companies; part enter the inclofure, but firft fet a centinel; the reft form a line from their fellows within, to their rendezvous in fome craggy mountain; thofe within the orchard throw the fruit to thofe without, or, if the wall be high, to thofe on the top, and thefe to thofe beyond them, all along the line: while this is going forward with great expedition, they obferve a. profound filence.

The natives of the Cape often take them young, and, feeding them with milk, accuftom them to guard their houfes. Inhabit alfo Siam.

The largeft of the baboon kind is the Mandril; ugly and difgufting, hort, from four to five feet high; muizzle long, of a blueifh colour, ftrongly marked with wrinkles; from the nofe iffues a fnot, which the animal at intervals licks off with its tongue; is native of the Gold Coaft; faid to walk frequently ereet, and, when difpleafed, to weep like a child.

The Wanderow is rather lefs than the former; tail from feven to eight inches long; muzzle prominent; has a large long white head of hair, with a montrous white beard, coarfe, rough, and defcending; the colour of the reft of the body brown or black; equally fierce; yet feems more tractable than mont of its kind; is chiefly feen in the woods of Ceylon and Malabar.

The Pigtail is in fize no larger than a cat; has a prominent muzzle; the tail five or fix inches long, curled up like that of a hog; native of Sumatra. Edwards kept one of them in London; another happening to be expofed in a fhew of beafts, he brought the two exiles together. The moment they came into each other's prefence, they teflified their mutual fatisfaction, and feemed quite tranfported at the interview.

\section{$\begin{array}{lllllll}M & O & \mathrm{~N} & \mathrm{~K} & \mathrm{I} & \mathrm{E} . \mathrm{S}\end{array}$}

HAVE numerous varieties: Bofman mentions above fifty forts on the Gold Coaft alone; and Condamine afferts, that it would take a volume to defcribe thofe along the river Amazons; fcarce a country in the tropical climates that does. not fwarm with them; fcarce a foreft that has not a race diftinet from all others; for the monkies of two 
cantons never mix with each other, but rigoroufly obferve a feparation, and guard their limits from the intrufion of ftrangers. Neither the tiger nor the lion will venture to difpute their dominion, fince they, from the tops of trees, continually carry on an offenfive war, and by their agility efcape purfuit. The ferpent is their chief deftroyer, and is often feen winding up the trees where they refide, and if it happen to furprife them neeping, fwallows them before the little animals have time for defence. The monkies in general inhabit the tops of trees; the ferpents, branches nearer the bottom.

To the Negroes they are their greateft plague, and do incredible damage, plundering pretty much like the baboons; are nor contented with the firt blade of corn, or the firt cane, but pull up the moft alluring, turn it round, examine, compare it with others, and if they find it to their mind, ftick it under one of their arms.

They generally keep in companies, march in order, and obey the voice of fome chieftain, remarkable for his fize and gravity. One fpecies, which Mr. Buffon calls the Ouarine, is remarkable for loudnefs and diftinstnefs of voice, fill more for their ufe of it. "s I have frequently been a witnefs," fays Margrave, "of their affemblies. Every day, morning and evening, the ouarines affemble in the woods. When all come together, one among the number takes the highef place on a tree, and makes a fignal with his hand to the reft to fit round, in order to hearken. As foon as he fees them placed, he begins his difcourfe, with fo loud a voice, and yet in a manner fo précipitate, that to hear him at a diftance, one would think the whole company were crying out at the fame time: however, during that time, one only is fpeakiny, and the reft obferve the moft profound filence. When this has done, he makes a fign with the hand for the reft to reply; and at that inftant they raife their voices together, until by another fignal of the hand they are enjoined filence. This they as readily obey; till, at laft, the whole affembly breaks up, after hearing a repetition of the fame preachment."

The chief food of the monkey-tribe is truits, buds of trees, fucculent roots and plants; are fond of fweets, particularly the plealant juice of the palm-tree and the fugar-cane. In neceffity, eat infects and worms; if near the coafts, oyfters, crabs, and thell-firh. Catch oyfters by clapping a fione between the opening thells; draw crabs from the water, by putting their tail to the crabs' hole, the crabs faftening on it, they draw them on hore with a jerk. The monkey brings one at a time, fometimes two.

No. 24 . 
Father Carli, in his hiftory of Angola, affures us, that while his health was impaired by the raging heats of the climate, his patience exhaufted by the obftinacy of the natives, and his little provifions daily plundered, without redrefs, he found more faithful fervices from monkies than from men; thefe he had taught to attend him, to guard him, while neeping, againft thieves and rats, to comb his head, to ferch his water; and he afferts, that they were more tractable than the human inhabitants.

The monkies of Africa, \&c. may be diftinguifhed from thofe of America by three marks. (1) A naked callous fubftance behind, on which they fit; which thofe of. America are without. (2) Noftrils differently formed, opening downward; whereas the American monkies open on each fide. (3) Pouches on each fide the jaw, into which they put provifion; which thofe of America are without. Alfo, no monkies of the ancient continent hang by the tail, as do many of the American.

Mr. Buffon, who has examined this race of beings with great accuracy, makes nine fpecies belonging to the ancient continent.

(1) The Macaguo, fomewhat refembling a baboon in fize, ftrength of body, and an hideous wrinkled vifage; but differs in having a very long tail, covered with tufted hair : native of Congo.

(2) The Patas is about the fame fize, has a longer body, and face lefs hideous; is remarkable for its colour, which is fo brilliant a red, that the animal looks as if it were painted: by fome called the Red African Monkey.

(3) The Malbrouk, of which he fuppofes the Bonet Chinois to be a variety: One is remarkable for a long tail and beard; the other for a cap of hair, that covers the crown of the head, from whence it takes the name : natives of the Ealt-Indies. The Bramins have hofpitals for fuch of them as happen to be fick or difabled.

(4) The Mangabey may be diftinguifhed by its eye-lids, which are naked, and of a ftriking whitenefs : native of Madagafcar.

(5) The Mona, or Cephus of the ancients, is variegated with black and red; its tail of an afh-colour, two white fpots on each fide, at its infertion : native of the northern parts of Africa.

(6) The Callitrix, or Green Monkey of St. Jago, diftinguifhed by its beautiful green colour on the back, its white breaft and belly, and its black face. 


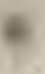




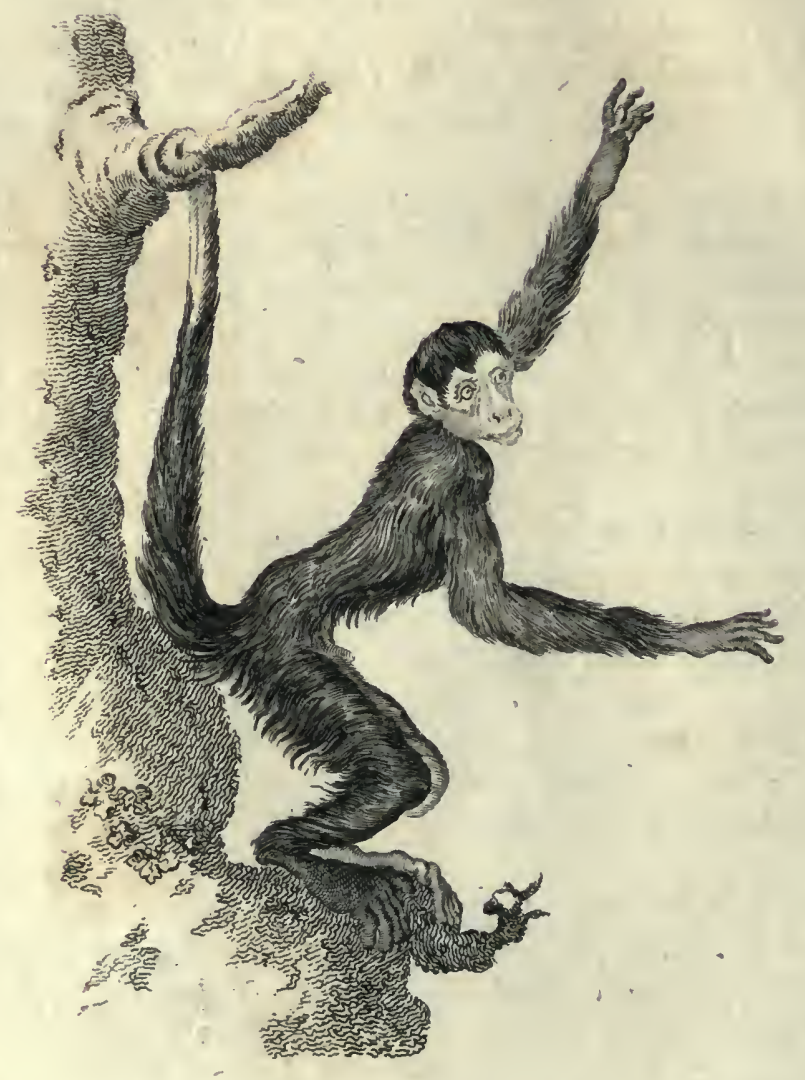

The Coaita 


\section{THE MONKEY K I N D.}

(7) The Mouftoc, or White Nofe, diftinguifhed by the whitenefs of its lips, the reft of the face being a deep blue: native of the Gold Coaft.

(8) The Talapoin, diftinguined by its variety of green, white, and yellow hair; that under the eyes being of a greater length than the reft: fuppofed to be native of Africa and the Eaft.

(9) The Douc, fo callad in Cochinchina, where it is native; with a long tail; of a fize as large as the baboon, and with a flat face like the ape; refembles the American monkies, in having no callus on its polteriors.

The monkies of the new continent, Mr. Buffon divides into thofe with mufcular holding tails, called SAPA Jous; thore with feeble, ufelefs tails, called $S_{A_{L}}$ orss. Of the fapajous are five forts; of the fagoins, fix.

\section{OF THE S A P A.J O U S.}

The firt is the Ouarine, or the Brazilian Guariba; as large as a fox, with black long hair, defcribed.p. II5; is the largeft monkey of America. This is often called the Preacber.

(2) The Coaiti is diftinguifhed by having no thumb, confequently, but four fingers on the two fore-paws. The tail, however, fupplies the defects of the hand; and with this the animal nings itfelf from one tree to another, with furprifing rapidity.

(3) The Sajou is diftinguined by its yellowin, flen-coloured face.

(4) The Sai is fomewhat larger, and has a broader muzzle; called alfo the Bewailet, from its manner of lamenting, when either threatened or beaten.

(5) The Samiri, or Aurora, is the fmalleft and mont beautiful of all; of a fine orange colour, with two circles of flefh round the eyes; a very tender, delicate animal.

\section{OF THE S A G O I N S.}

(1) The Saki, or Sagui, fo remarkable for the length of the hair on its tail, that it has been often termed the Fox-tailed Monkey; is of different Iizes. 
(2) The Tamaim is ufually black, with the feet yellow; fome brown, fpotted with yellow.

(3) The Ouifiti is remarkable for large tufts of hair on its face, and its annulated tail.

(4) The Marikina, or Lion Monkey, with a mane round the neck, and a bunch of hair at the end of the tail, like a lion.

(5) The Pinch, with the face of a beautiful black, and white hair defcending on each fide the face.

(6) The Mico. The hair on its body a beautiful filver colour, brighter than that of the mont venerable human hair; the tail, a deep brown, inclining to blacknefs; its ears, its cheeks, and lips, tinctured with bright vermillion; a very fnall kind.

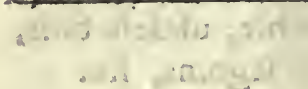

\section{T H E}

\section{MAKI, OR M O G O G O K I N D,}

7 ROM the conformation of their hands and feet, approach the 1 monkey kind; but in that refpect only. There are many kinds, varying in colour or fize, but agreeing in the human-like figure of their hands and feet, and in their long rofe.

The Mococo is about the fize of a cat; the body and limbs nenderer; a very long tail, at leaf double the length of its body; covered with fur, marked alcernately with broad rings of black and white; remarkable for the largenefs of its eyes, which are furrounded with a broad black fpace; and the length of the hinder-legs, which far exceed thofe before. When it neeps, it brings its nofe to its belly, and its tail over its head. When it plays, it ufes a fort of galloping, with its tail raifed over its back, and continually in motion. The head is covered with dark afh-coloured hair; the back and fides, with a red afh-colour, not fo dark as the head; the whole gloffy, foft, and fmooth, and ftanding almolt upright, like the pile of velvet. Native of Madigalcar; a gentle animal; moves, like all four-handed animals, in an oblique direction.

The Mongooz is lefs than the former, with a foft, glofly robe, but a little curled; nofe alfo thicker; eyes black, orange-coloured circles round the pupil; fome black, others brown: native of Madagafcar. 
$-$

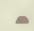




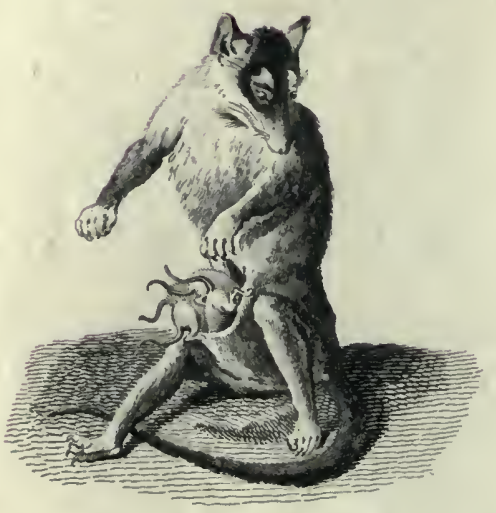

The Female Oppoffum 
The Vari is much larger than either of the former; its hair much longer; has a kind of ruff round the neck, of very long hair, by which it may be diftinguifned from the reft ; fierce and favage; its voice fomewhat refembles the roaring of the lion: native of Madagafcar.

To this tribe we may refer a little four-handed animal, of the ifland of Ceylon, which Mr. Buffon calls the Lori; of all quadrupeds the longeft, in proportion to its fize; having nine vertebra in the loins; whereas others have only feven. The body appears longer, by having no tail; refembles the maki kind in its hands, feet, fnout, and the glofs of its hair; about the fize of a fquirrel; and appears to be a tame, harmlefs little animal.

\section{O F T H E

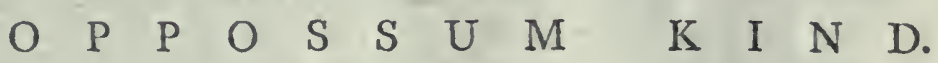

7 HESE feem to unite the monkey and the rat; are lefs than the former; have long tails, almoft bare; their fur, as well as their mape, refembling the rat kind. Some have ranked them in that clafs; but their being four-handed is fufficient diftinction.

The Oppoffum is found in N. and S. America, in Java, \&rc. the fize of a finall cat. The head refembles a fox; has fifty teeth in all, two great ones in the midnt, like thofe of a rat; eyes litule, round, clear, lively, placed upright; ears long, broad, tranfparent, like thofe of the rat lind; its tail round, long, a little hairy in the beginning, but guite naked towards the end; fore-legs fhort, about three inches long; thofe behind, four. The feet are like hands, each having five fingers, with white crooked nails, rather longer behind than before. In this animal, the thumb on the hinder-leg wants a nail, whereas the fingers, are furnithed with clawed nails as ufual. Remarkable for a falfe womb, into which the young, when brought forth, creep, and corrinue to lodge and fuckle fecurely: which is thus defribed:

Under the belly of the female is a kind of nit or opening, three inches long, compofed of a fkin, which makes a bag internaliy, covered on the infide with hair ; herein are the teats of the female, and into it the young retire. This bag is opened or thut at the will of the animal, and 
fo clofe, that in the living animal the opening can fearce be difcerned. This bag contains glands that exude a muky fubftance, which communicates to the fleth of the animal, and renders it unfit to be eaten. The young, when firt produced, are in a manner but half completed (and fome affert, not much larger than flies); on quitting. the womb, they creep into the receptacle, where they continue fixed to the teat til! they have acquired ftrength fufficient. O: their firft entrance, they feldom Alir out; when more advanced, they venture forth often in the day; at laft, feldom ufe their retreat, except in neceflity.

The Oppoffum, on the ground, is flow and helplefs; but climbs trees with great expedition; chiefly fubfifts on birds; hides among the leaves of the trees to feize them by furprife; ofren hangs by the tail, which is long and prehenfile, for hours, head downwards, watching for prey. If any animal pafs underneath, it drops upon and quickly devours it. By means of its tail, fwings from one tree to another, hunts infeets, and efcapes purfuers. Seems to live on vegetable as well as animal fub. ftances, fugar-canes, the bark, and even the leaves of trees. Is eafily tamed, but is a difagreenble domeftic.

The Marmofe, found in South-America, feems only to differ in fize, being lefs; and, inflead of a bag to receive its young, has only two longitudinal folds near the thighs. The young, when firt produced, are not above the fize of a bean; but continue Alicking to the teat, until they have arrived at greater maturity.

The Cayopolin is fomewhat Jarger, its fnout more pointed, its tail longer, and its colour different, being ath, inclining to yellow.

The Phalanger, or Surinam Rat, refembles the former, but differs by the thumb and fore-finger of its hinder-hands being joined together, except at the extremities; is about the fize of a rat.

The Tarfier relembles the former, in having four hands and a long tail; differs in the extreme length of its hinder-legs, which are longer than irs whole body. The bones of that part of the foot called the tarfus, are likewife very long; from whence the animal has received its name: the tail is naked in the midtle, and hairy at both extremities; iss hair woolly, foft, and a deep afh colaur. 


\section{AMPHIBIOUS QUADRUPEDS.}

A L quadrupeds of this kind, though covered with hair, are furA nithed with membranes between the toes. Their paws are broad, their legs thort, fitted for fwimming, for taking fhort ftrokes, and quickly repeating them. Some, like the otter, refemble quadrupeds, except as being web-footed; others, like the beaver, are not only webfooted, but have the tail covered with fcales. Others, as the feal and the morfe, have the hind-feet ftuck to the body like fins. And others, as the manati, have no hind-feet, and never come on fhore. But all get their living in the water; all continue long under water; when preft by danger, Hy to the water for fecurity; and, when upon land, are timorous and unwieldy.

The OTTER refembles quadrupeds in Thape, hair, and internal conformation; but refembles the aquatic tribes in its manner of living, and in having membranes berween the toes to affift it in fwimming. It fwims even fafter than it runs, and can overtake filhes in their uwn element. Its colour is brown; it is long, flender, and foft fkinned; is about two feet long from nofe to tail; the head and nofe are broad and Alat; the neck fhort; the body long; the tail broad at the infertion, but tapering to a point; the eyes are very finall, and placed nearer the nofe than ufual in quadrupeds; legs very hort, but remarkably ftrong, broad and mufcular. Their joints articulated to loofely; that the animal can turn them quite back, and bring them on a line with the body, fo as to perform the office of fins. Each foot is furnifhed with five toes, connected by ftrong broad webs like thofe of water-fowl.

The otter attends the fides of lakes and rivers, but particularly the former; is feldom fond of filhing in a running ftream; but in rivers always fwims againft the ftream, and meets the filnes, its prey, rather than purfues them. In lakes it deftroys much more than it devours, and often fpoils a pond in a few nights. The otter catches its prey from the bottom upward, or, purfuing it into fome little creek, feizes it there. This animal, upon taking in a quantity of air, can remain fome minutes at the bottom : there whatever fifh paffes over it is ccrtainly taken; for, as No. 24 . 
the eyes of fith are placed fo as not to fee under them, the otter feizing them by the belly, drags them on fhore, where it often leaves them untouched, to continue the purfuit for hours. In winter, when the lakes are frozen, and the rivers pour a rapid torrent, the otter is often greatly diftreffed, and obliged to live on grafs, weeds, and even bark; then courageous from neceffity, it feeds on infects, rats, and even fheep. It has the power of continuing long without food, and, though not torpid like the marmotte, yet keeps much within its retreat, which is ufually the hollow of a bank worn under by the water. There it often forms a kind of gallery, running along the edge of the water; when attacked at one end, it' flies to the other, and often evades the hunter by plunging into the water at forty or fifty paces diftance, while he expects to find it juft before him. Couples about the middle of fummer, and brings forth at the end of nine weeks, generally three or four at a time. The otter brings forth generally under hollow banks, on a bed of ruhes, flags, or weeds, on the fide of fome river or lake. The entrance of its hole is generally under water. The young are always at the water-edge; the dam teaches them to plunge fwiftly, like herfelf, and efcape among the rufhes or weeds. Though never fo young, they fwim with great rapidity, no part of them being feen above water, except the tip of the nofe.

When caught young, they are carefully fed with fmall fin and water; but, as they gather ftrength, milk is mixed among their food, their filh provifion is gradually retrenched, and at length they are fed wholly on bread. The training them to hunt for fin requires affiduity and patience; but an otter, thus taught, is a valuable animal, and will catch fin enough not only for itfelf, but for a family. Has been feen, at the word of command, to drive fin into a corner, and bring off the largeft to its mafter.

Otters inhabit moft parts of the world; different in fize and colour. In North-America and Carolina are white, inclining to yellow. The Brafilian otter is much larger than ours, with a roundifh head, almoft like a cat. The tail is but five inches long; the hair is foft, fhort, and black, except on the head, where it is of a dark brown, with a yellowin fpor under the throat. 


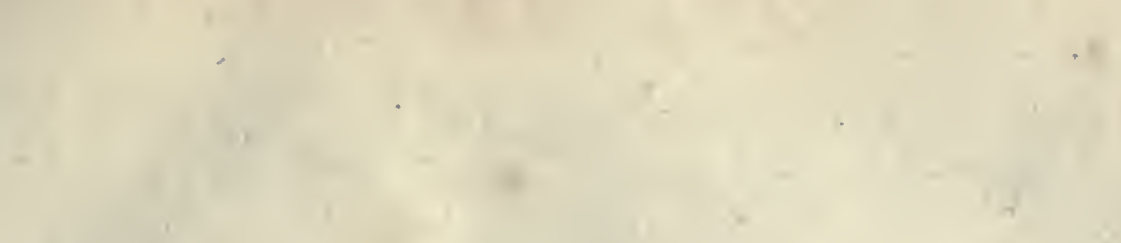




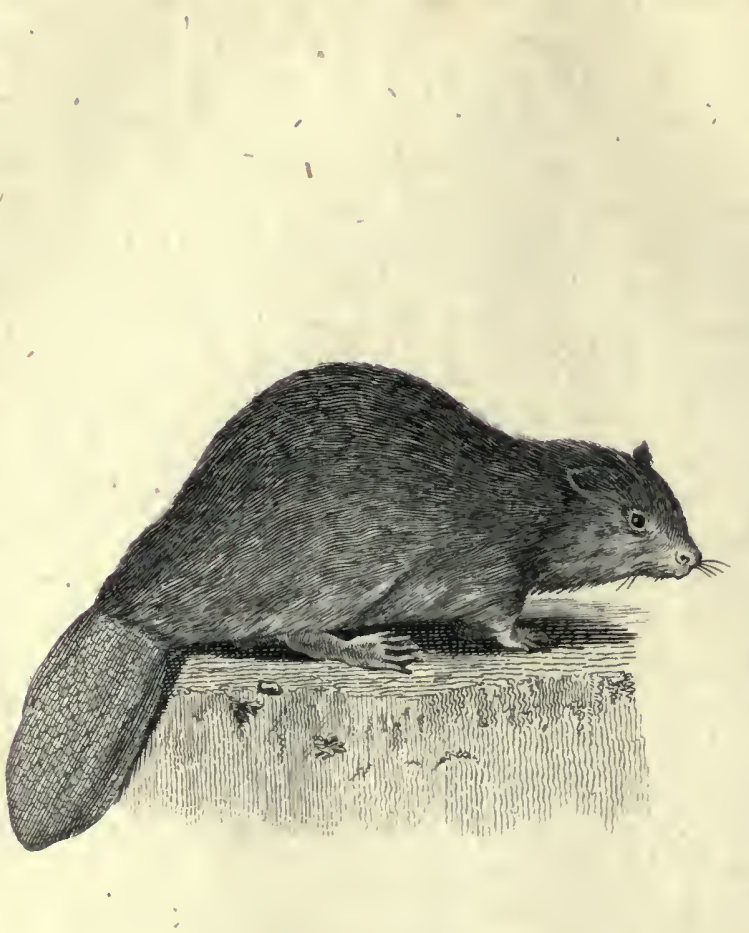

The Beaver. 


\section{$\therefore=(123)$

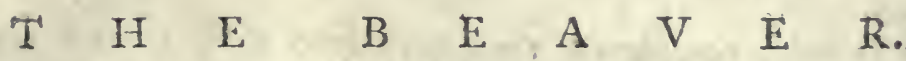

T $\mathrm{HE}$ Beaver, merely as an individual, is exceeded by many other 1 quadrupeds in cunning, and by almoft all in powers of defence. When kept in a nate of folitude or tamenefs, is grentle and familiar enough; dull, and even melancholy; of moderate pafions and appetites; calm and indifferent, without attachment or antipathy, neither feeking to offend, nor defiring to pleafe; has little induftry, few tricks, nor cunning fufficient to avoid the moft obvious fnares. The only quadruped that has a fat broad tail, covered with fcales, which, as a rudder, directs its rotions in the water. The only quadruped that has membranes betwcen the tocs on tlic hind feet only, and rione on the fore feet, which fupply the place of hands, as in the fquirrel. The only animal in its fore parts refembling a quadruped, in its hinder parts a finh; is abour two feet long, near one foot high, haped fomewhat like a rat. Its colour; a light brown; the hair of two forts; one longer and coarfer; the other foft, fine, thort, and filky. The teeth are like thofe of a rat oz a fquirrel, long, ftrong, admirably adapred to cutting timber or ftripping bark; has but one vent for the emiffion of its excrements, and its urine.

The beavers affemble in June and July from every fide, and generally form a company of above two hundred. The place of meeting is commonly where they fix their abode, and always by the fide of fome lake or river. If it be a lake in which the waters are always level, they omit building a dam; but on a running ftream, fubject to floods and falls, they build a dam or pier, that croffes the river, to form a dead water above and below; built where the river is halloweft, and where fome great tree grows by the fide, which they make a principal part in their build.ing; and fet about cutting it down. This they accomplin by their teeth, which foon lay it level, and on the fice they with it, which is always acrofs the ftream. Then cutting off the top branches, they make it lie clofe and even, as the principal beam of their fabric.

The dam is ten or twelve feet thick at the foundation, floping on that fide next the water; on the oppofite fide perpendicular; towards the top, about two feet broad, made of wood and clay. They raife the dike according to the elevation of the water. They lwim with their clay mor- 


\section{A M P B BOUS QUADRUPEDS.}

tar on their tails, and with ftakes between their teeth, to where they are wanted.

The dike being completed; they next erect their feveral apartments, which ase either round or oval, and divided into three ftories, one above the other : the firtt below the level of the caufeway, is for the moft part full of water; the other two above it, that in cafe of the water's increafe, they may move a ftory higher. If they find any little in and contiguous to their refervoir, they occupy it, and improve their dwelling. They drive piles into the earth, to fecure their habitation againft the wind as well as water. They make two apertures, at the bottom, to the ftream; one a paffage always kept neat and clean; the other for conveying foil of all forts. A third opening or door-way, much higher, prevents their being thut up when the froft and fnow have clofed the apertures of the lower floors. Sometimes they build on land; but fink trenches five or fix feet deep, to defcend into the water.

In Auguft, or September, they begin to lay in ftores. During fummer, they regale themfelves on the choiceft fruits and plants. In winter, their provifions are the wood of the birch, the plane, and fome few other trees, which they fteep in water in quantities proportioned to their numbers. They cut down branches from three to ten feet in length. According to fome curious naturalifts, the ftock of timber for ten beavers, is about thirty feet in a fquare furface, and ten in depth. They regularly take out thofe parcels only which have been duly fteeped in the water, and impartially divide it.

The hunters, knowing that green wood is more acceptable to them than what is dry, plant a quantity of fit round their lodgments; and when they come out to partake of it, catch them in fnares; or take them by furprife. When the frofts are very fevere, they fometimes break a large hole in the ice; and when the beavers refort thither for fresh air, either kill them with their hatchets, or cover the opening with a large fubftantial net. After this, they undermine the whole fabric; whereupon the beavers fly with the utmoft precipitation to the water; and plunging into the aperrure, fall into the net, and are taken. 



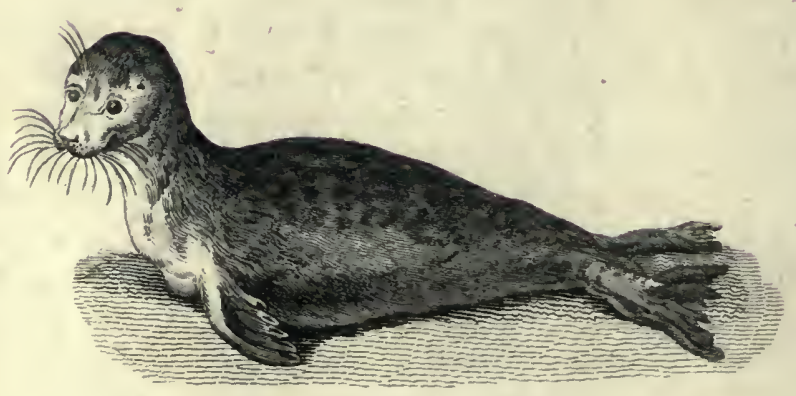

The Phoca. 


\section{( 125$)$ \\ THE SEAL, OR PHOCA.}

$7 \mathrm{HE}$ Seal refembles a quadruped in fome refpeets, and a fifh in others. The head is raund; the nofe broad; the teeth like thofe of a dog; the eyes. large and fparkling; no external ears, but holes; the neck of a moderate length; the body thickeft at the houlders; from whence the animal tapers to the tail. The body is covered with a thick briftly fhining hair, which lonks as if rubbed over with oil.' The feet of this animal, though furnihed with the, fame number of bones as quadrupeds, yet are fo tuck on the body, and covered with a membrane, that they refemble fins, excepi by their claws. The fore-feet are greatly hid under the fkin, and are covered with a thick Rin, which ferves like a fin, for fwimming; have five claws, long, black, and piercing. The hind-feet are Atretched out on each fide the Itort tail, covered alfo with a hairy $\mathrm{Rin}$, and almoft joining at the tail. Thefe being turned backwards, are ufelefs on land; fo that when the animal moves, it drags itfelf forward by its fore-feet.

This animal is found from four feet long to nine; fome black, others fpotted, white, or yellow. Were the fize of the brain to determine the quantity of underftanding, the feal would of all animals be the moft fagacious; for it has, in proportion, the largeft brain of any, but the fize of its brain furnifhes it with little increafe of wifdom. Its tongue is forked or flit at the end, for what purpofe we are ignorant. $B_{y}$ a fingularity of conformation, the foramen wale in the heart is open; fo that, though the blood of this animal commonly circulates through the lungs, yet it can circulate directly through the heart, whereby, being under no immediate neceffity of breathing, the vital motions are carried on while in the water: tut though it can continue feveral minutes under water, yet it is not able, like fifhes, to remain there for any length of time; is feldom found diftant from the fhore, but banking on the rocks; when difturbed, plunges at cnce to the bottom. Numbers are generally feen together; found in every climate, but in the north and icy leas particularly, by thoulands, bafking on the rocks, and fuckling their young. They are animals of parrage, and perhaps the only quadrupeds that emigrate. On the north coats of Greenland they retire in July, and return in September. They make a fecond ceparture in March to caft their young, and return in June, young and all together, obferving in their route a certain fixed time and track, like birds of paffage. The fernales 


\section{I26 A.MPHIBIOUS QUADRUPEDS.}

in our climate bring forth in winter, and rear their young on fome fand. bank, rock, or defolate ifland. Suckle their young, fitting up on their hinder legs. The feals follow and ceftroy the herrings when in the hoals by thoufands. They are very fwift in deep waters, dive rapidly, and, while the fpectator eyes the fpot, they emerge an hundred yards diftance. The weaker fithes, therefure, can eicape their tyranny, only by darting into the fhallows. They are extremaly watchful, fletp feldom longer than a minute, then raife their heads; if they fee no danger, lie down again. The oniy method to procure them, is to fhoot them : if they efcape, they haften to the deep, ninging ftones and dirt behind them as they framble along crying; if overtaken they vigoroung refilt with. their feet and teeth, till killed.

A variety of this animal, is the Sea-lion, defcribed in Anfon's voyage, from eleven to eighteen feet long. So fat that the biubber lies a foot thick all round the body. Differs from the feal, as it often grazes along the thore, and on the long grals that grows up the edges of brouks.

\section{T H E M O R S E.}

THE Morfe has very particular,formation of teeth, having two large tufks pendent from the upper jaw; it allo wants cutting teeth: In form refembles a feal, but is from twelve to fixteen feet long. Generally frequent the fame places, have the fame habitudes; the fame advantages, and the fame, imperfections as feals. The tufks are from two to three feet long; and the ivory of the fineft quality.

\section{T H E M A N A T I}

NEVER leaves the water, and lives only there; is not a quadruped, for it has but two legs; nor is it a fin, for it is covered with hair. It forms a link uniting the two tribes; the laft of beafts, or the firt of fifhes.

The Manati is fomewhat haped like the feal; has the fore legs pretty fimilar, with four claws only: Thorter in proportion, and placed nearer the head; its tail is that of a fifh, fpread out broad, and wanting even the rudiments of thofe bones which make the legs and feet. The largeft are twenty-fix.feet long; the fkin is blackin, very tough, and hard; having a few hairs fcattered, like brittles, of about an inch long. The eyes are very fmall, in proportion to the animal's head; and the ear- 


\section{H I P P O P O T A M U. S:}

holes fo narrow as frarce to admit a pin's head. The tongue is fo fhort, that fome have pretended it has none at all; and the teeth are compofed of two folid white bones, running the whole length of both jaws, and formed merely for chewing. The female has breafts placed forward; brings one at a time: which the holds with her paws to her bolom; where it fticks, and accompanies her wherever fhe goes.

This animal never leaves the water, but advances its head out of it, to reach the grafs on the river fides. Feeds entirely on vegetables; is never found far in the open fea, but chiefly in the large rivers of South America, and of en two thoufand miles from the ocean. Is alfo found near Kam:fchatka. Has no voice nor cry; the only noife it makes, is by ferching its breath hard.

\section{T HE H I P P O P O T A M U S}

HOULD perhaps have been placed firt in the lift of amphibious; $\$$ but that the outer being native of our own country, has fo much greater probability of being known, either by infpection or defcription, to the reader.' It ufually forms a diftinct genus, and may be fo confidered here. Is above feventeen feet long, from the fnout to the tail; above fixteen feet in circumference round the body; and above feven feet high : the head is near four feet long, and above nine feet in circumference. The jaws open about two feet wide, and the cutting teeth, of which it hath four in each jaw, are above a foot long. Its feet are divided into four parts; tail hort, flat, and pointed; the hide amazingly thick, and though not capable of turning a mufket-ball, impenetrable to the blow of a fabre. The body is covered over with a few fcattered hairs, of a whitith colour. The whole figure of the animal is fomething between that of an ox and a hog, and its cry between the bellowing of the one, and the grunting of the other.

Chiefly refides at the bottom of the great,rivers and lakes of Africa, where it leads an indolent kind of life, feldom difpofed for action, except when excited by hunger. Upon fuch occafions, three or four, at the buttom of a river, near fome cataract, form a kind of line, and feize on fuch fin as are forced down by the ftream. In water they purfue their prey with great fwiftnefs and perfeverance; fwim with much force, arid remain at the bottom thirty or forty minutes without rifing to take breath. They walk on the bottom of the ftream, as if cn land. On 
land it is awkward and unwieldy, noves but nowly; feldom forfakes the margin of the river; finks every ftep it talses. If forced, by famine, into the higher grounds, commits dreadful havock among the plantations: the natives fee their poffeftions deftroyed, withouc daring to refift their invader; by lighting fires, friking drums; and raifing a cry, they generally frighten it back to its favourite element. Never attacks boats as they go up or down the ftream; but fhould they inadvertently frike againft or difturb it, there is danger of its fending them to the bottom. "I have feen," fays a mariner, "one of thefe animals open its jaws, and "feizing a boat between his ieeth, at once bite and fink it to the bot"tom. I have feen it upon another occafion, place itfelf under one of "our boats, and rifing under it, overfet it with fix men which were in " it ; who, however, happily received no other injury."

If this animal be attacked too powerfilly at Jand, it returns to the river, where it enters head foremoft, and after a thort time rifes to the furface, loudiy bellowing. "Though the negroes will attack the thark, or the crocodile in their natural element, and deftroy them, they decline to engage the hippopotamus.

The hippopotamos lives on fin, vegetables, and probably $\mathrm{Aef}$, when he can get it. The female comes on land to bring forth, it is fuppofed one at a time. There animals are then particularly timorous, and the inftant the parent hears the flighteft noife, it dafhes into the ftream; and the young one follows with equal alacrity. The young are faid to be excellent eating.

\section{T H. E T A P I I R.}

7 HE Tapiir may be confidered as the hippopotamus of the New Continent; but degraded both as to fize and ferocity; bears fome diltant refemblance in form to a mule; has a long frout, which it lengtheris or contracts at pleafure. Ears fmall, long, and pendent; neck and tail Mort; claws ttrong and firm, four on each foot; fkin thick, covered with brown hair. The natives made thields of it, which could not be pierced by an arrow. Chielly refides in water, bur freds entirely on vegetables in the paftures by the river-fide. Is very timorous; the inftart it hears the leaft noife, plunges into the ftream. Art greatly fought after by the'natives; their fleth is confidered as a delicacy, and thought by fome not inferior to beef. 



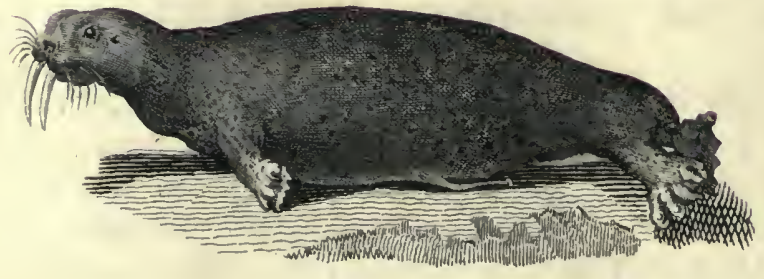

The Morse. 
- + - +2.

- $1+2$

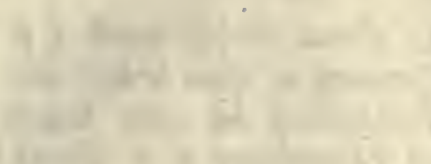

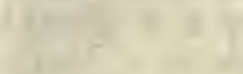

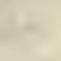

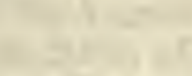

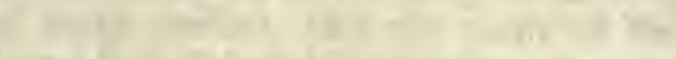

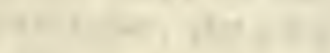

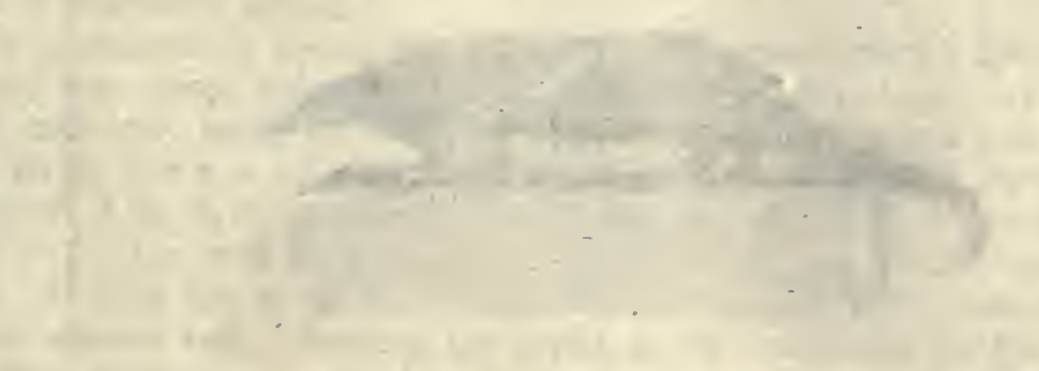

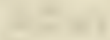

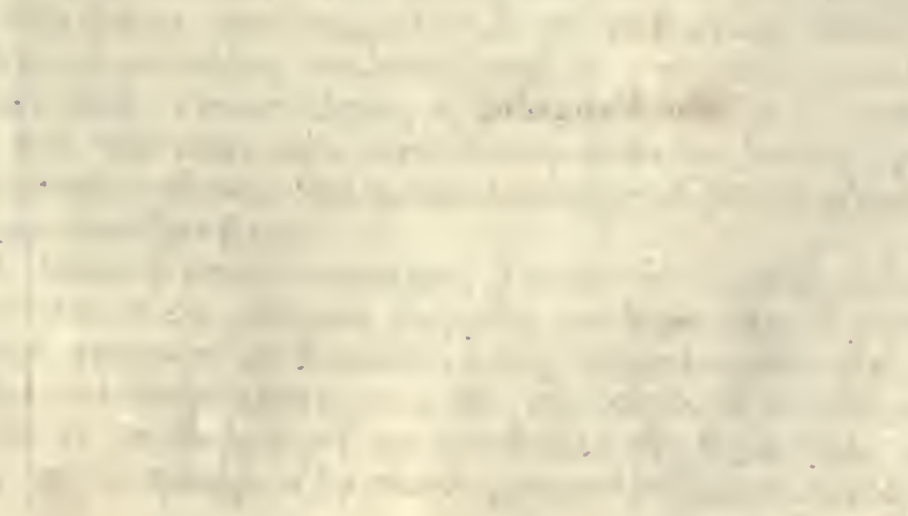




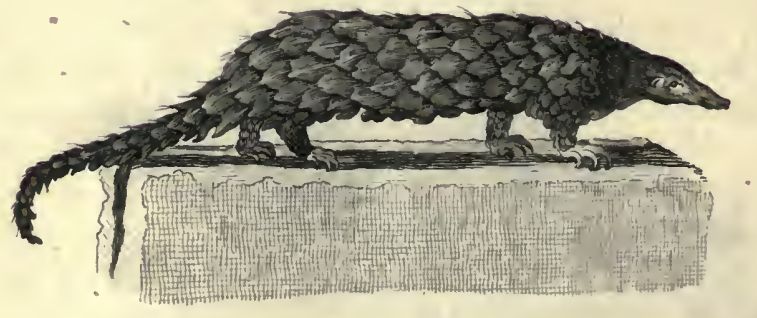

The Pangolin 


\section{SCALY AND SHELLY QUADRUPEDS. \\ T H E P A N G OLI N.}

H A S been injudiciounly called the Scaly Lizard, but it refembles the lizard only in general form, and in being covered with fcales. The lizard may be confidered as a reptile, produced from an egg; the pangolin is a quadruped brought forth alive and perfectly formed. The lizard is all over covered with the márks of fcales; the pangolin has fcales neither on the throat, the breaft, or the belly. The fcales of the Lizard feem ftuck upon the body even clofer than thofe of filhes; the fcales of the pangolin are only fixed at one end, and capable of being erected, like the quills of the porcupine, at pleafure. The lizard is a defencelefs creature; - the pangolin can roll itfelf into a ball, like the hedge-hog, and prefent the points of its fcales to the enemy, which effeetually defend it.

It is about three or four feet long, the tail as much more; has a fmall head, very long nofe, fhort thick. neck, long body, legs very thort, tail extremely long, thick at the bafe, and terminating in a point; has no teeth, five toes on each foot, with long white claws; is chiefly diftinguifhed by its fcaly covering, which defends all parts, except the under part of the head and neck, under the thoulders, the breaft, the belly, and the inner fide of the legs; all which are covered with a fmooth foft fkin, without hair. . Between the Thells, at the interftices, are hairs like briftles, brown at the extremity, and yellow toward the root. The fcales are of different fizes and forms, ftuck on the body fomewhat like the leaves of an artichoak. The largeft are, near the tail (which is alfo covered with them), three inches broad, two inches long, thick in the middle, Tharp at the edges, and terminated in a roundith point; extremely hard like horn; convex above, a little concave within; one edge fticks in the fkin, the other laps over that immediately behind it, of a durky brown colour, and when the animal has acquired its full growth, fo hard, as to turn a mufquet-ball.

The inftant it perceives danger, it rolls itfelf up like the hedge-hog; and prefents to the affailant only the cutting edges of its fcales. Its long tail encreafes its fecurity; being lapped round the body, and defended with Thells more cutting than any others. Thefe hells, fo large, fo thick, fo pointed, repel every affault: the tiger, the panther, the hyzna, vainly attempt it by treading on, or rolling it about. The Ne- 



\section{THE ARMADILLO, OR TATOU.}

back, fides, rump, and the tail to the very point; but not the throat, breaft or belly, which are covered with a white foft fkin, yet offer rudiments of thells, even in their fofteft parts. Coimplete ofification cakes place only on parts of leaft friction, and moft expofed. By means of the divifions in its thell, the animal has a motion in its back. The bands are varioús in number and fize; generally, two large pieces cover, one the fhoulders, the other the rump. Between thefe, the bands lap over each other. Befides their opening crofs-ways, they alfo open along the back. They are differently coloured in different linds, but ufually are a dircy grey. The fhell itfelf is covered with a foftifl kin, linooth and tranfparent.

The armadillo has the fame method of protecting itflf as the hedgehor. or the pangolin. When attacked, it withdraws its head under its thells, tucks its feet under its belly, while the tail ferves as a frengthening band: thus it becomes like a ball, flatifi on each fide. In this fituation it is tofiet about by other quadrupeds, and liftle refembles a cresture endowed with life. The Indians, by laying it clofe to the fire, foon oblige the poor animal to unfold itfelf.

Though native of the warmett parts of America, yet it bears our climate. Their motion feems to be a fwift walk, they can neither run, leap, nor climb trees. Their refource, when purfued, is to make toward their hole as faft as they can; or, to make a new one. For this they require but a very few moments advantage, having four claws on each foot extremely large, frong, and crooked. If caught by the tail when making their way into the earth, by sheir refiftance they leave their tail in the hand of their purfurer. The fleth of the fmaller kinds is faid to be delicate eating. If the armadillo be near a precipice, it often efcapes by rolling iffelf up, and tumbling from rock to rock. They are fometimes taken in fnares laid for them by the fides of rivers and low moift places, which they particularly frequent. Their burraws are very deep, and they feldom ftir our but at night, and pever far from their retreats.

They moftly root the ground, like a hog, in fearch of roots. - They eat alfo melons, vegetables, and flerh, when they can get it. They frequent watery places, were they eat worms, fmall finh, and water infects, and are frequendly found in the fame hole with the ratte-fnake.

The firft of this kind, has three bands between the two large pieces that cover the back, is called the Tatu Apara. The tail is morteft in this kind, being about two inches long, while the whole fhell is one 


\section{Q U A D R U P E D S.}

foot long and eight inches broad. (2) The Tatou of Ray, or the Encoubert of Buffon, has lix bands acrofs the back; is about the fize of a pig of a month old, has a fmall long head and a very long tail. (3) The Tatuette, with eight bands, much fmaller; tail longer, and legs horter. Its body about ten inches long, the tail feven. (4) The pig-headed Armadillo, with nine bands, two foot long from nofe to tail. (5) The Kabaffou, or Cataphractus, with twelve bands, ofren found above three feet long, is never eaten. (6) The weafel-headed Armadillo, with eighteen bands, a large piece before, and nothing but bands backward, above a foot long; tail five inches. The Kabaflou and the Encoubert are the largett; the reft are of a much fmaller kind.

In the large kinds, the thell is much more folid than in the others, and their flefh much harder. Thefe generally refide in dry upland grounds, but the fmall fpecies in moift places. When rolled into a ball, thofe whofe bands are feweft are leaft capable of covering themfelves up completely. The Tatu Apara, when rolled up, prefents two great interftices between its bands, by which it is eafily vulnerable.

\section{THE ELEPHANT.}

THE elephant, at firft view, prefents an enormous mafs of flefh covered with a callous hide, without hair; legs fcarcely formed for motion; little eyes, large ears and longtrunk; and an air of extreme ftupidity which fubfides when we come to examine its hiftory. "But thefe favourable appearances encreafe our furprife when we confider the various advantages it derives from fo clumfy a conformation, and the admirable fagacity connected with it.

The elephant is from feven to fifteen feet high. The forehead high and rifing, ears very large and dependant, eyes extremely fmall, the trunk long, body round and full, back rifing in an arch, the whole figure thort in proportion to its height. The feet are round at bottom; on each foot are five flat horny rifings, which feem to be the extremities of toes. The hide not hairy. At the end of the tail is a tuft of hair, a foot and a half long. The female is lefs than the male, and the teats between the fore legs. 
The ftrongeft and largeft of quadrupeds; yet, neither fierce nor formidable. Mild, peaceful, and brave, it never abufes its power, and only exerts its force for its own protection. Is a focial creature: the oldeff conduct the band; the young, the weak, and fickly, fall into the centre; the females carry their young, and keep them from falling by means of their trunks. Wherever they march, the forefls feem to fall before them; they bear down the branches upon which they feed, and, if they enter an inclofure, quickly deftroy the labours of the hufbandman.

They delight to live along the fides of rivers, in the deepeft vales, in the mot thady forefts. They cannot live far from water, and always difturb it before they drink. Often fili their trunk, either to cool lt, or to divert themfelves by fpurting it out like a fountain. Are equally diftreffed by extremes of heat and cold.

Their food is vegetable.

The elephant is remarkable for its hearing. A ppears delighted with mufic, readily learns to beat time, to move in meafure, and even to join iss voice to the found of the drum and the trumpet.

Its fenfe of fmelling is exquifite, pleafed with the fame odours that delight mankind. Gathers flowers with great pleafure, picks them up cne by one, unites them into a nofegay, and feems charmed with the perfume. The orange flower feems to be particularly grateful to it.

In the fenfe of touching, it excels all the brute creation, and perhaps even man. This fenfe lies wholly in the trunk, which is, properly fpeaking, only the fnout lengthened out, hollow, ending in two openings, or noftrils. An elephant of fourteen feet high has the trunk about eight feet long, and five and an half in circumference at the mouth, where it is thickeft: a partition runs through it. Is capable of being lengthened or fhortened, bent or ftraightened, pliant, yet ftrong. To aid its grafp, are feveral little eminences, like a caterpillar's feet, on the underfide, which probably contribute to the fenfibility of its touch. Through this trunk the animal breathes, drinks, and fmells: at the very point of it, juft above the noftrils, is an extenfion of $\mathrm{fkin}$, about five inches long, in the form of a finger. By this, the elephant can take a pin from the ground, untie the knots of a rope, unlock a door, and even write. By. fucking up its breath through the extremity of the trunk, it lifts and furtains a weight.

The neck is fo mort that it can farce turn its head. The legs bend not without difficulty. While the elephant is young, it bends the legs to lie down; when old, or fickly, this is not performed without alintance. No. 25. 
The fole of the foot is furnined with a fkin as thick and hard as horn, which completely covers the under part of the foot. Its two enormous tufks are unferviceable for chewing, and only weapons of defence. Thefe, as the animal grows old, become fo heavy, that it is fometimes obliged to make holes in the walls of its ftall to eafe itfelf of the fatigue of their fupport. They proceed from the upper $\mathrm{jaw}$, and are fometimes fix feet long.

The elephant is only native of Africa and Afia : there are none in the northern parts of Africa at prefent. In Africa, the largett do not exceed ten feet high; in Afia they are found from ten to fifteen. The ulual colour of the elephant is a dunky black, but fome are faid to be white; and thefe are ineftimable. The elephant never breeds in a ftate of fervitude.

To take them wild, a fpot of ground is fixed on, which is furrounded with a ftrong pallifade, made of the thickeft and ftrongeft trees, and ftrengthened by crofs bars. Polts are fixed at fuch diftances, that a man can eafily pafs between; only one great paffage is left open, which thuts behind when the beaft is entered. A female elephant is conducted into the heart of the foreft, where it is obliged by its keeper to cry out for the male, who readily anfwers and haftens to join her: the keeper obliges her to retreat, repeating the cry, till the leads the animal into the enclofure, which grows narrower all the way, till he finds himfelf completely thut up. After a day and a night, its indignation fubfides. In a fortnight it is completely tamed. The elephant, when tamed, becomes gentle and obedient; conceives an attachment for its attendant, careffes, obeys him, and frequently takes fuch an affection to its keeper, that it will obey no other. Receives his orders with attention, executes them with prudence, eagerly, yet without precipitation. Kneels down to receive its rider. Seems to take a pleafure in the finery of its trappings. Can carry on its back three or four thoufand weight; on its tunks alone can fupport near a thoufand. Its ordinary pace is as fatt as a horfe can eafily trot; when pufhed, it can move as fwiftly as a horfe at full gallop. Can travel with eafe fifty or-fixty miles a day. 


\section{$135)$ \\ THE R H I NOCEROS.}

THE rhinoceros is ufuaily twelve feet, from the nofe to the tail; fix to feven feet high; the circumference of its body is nearly equal to its length. Has a horn, growing from the fnout, fometimes three feet and an half long; without this, that part would refemble the head of a hog; the upper lip is much longer in proportion, ends in a point, is very pliable, ferves to collect its food, and deliver it into the mouth: ears large, erect, and pointed; eyes fmall and piercing; thin naked, rough, knotty, and lying upon the body in folds; of a dirty brown colour; fo thick as to turn the edge of a fcymiter, and to refift a mufquet ball: the belly hangs low; the legs are fhort, ftrong and thick, and the hoofs divided into three parts, each pointing forward.

Native of Afia and Africa, and found in thole extenfive forefts frequented by the elephant and the lion. Subfits entirely on veretable food; is peaceful and harmlefs: though it never provolses the combat, didains to Aly; and, every way fitted for war, refts content in fecurity. Is particularly fond of the prickly branches of trees, and feeds on fuch thorny thrubs as would be dangerous to other animals, either to gather or to fiwailow. Is fometimes taken in pit-falls, covered with green branches, laid in patis which the rhinoceros makes in going from the foreft to the river fide.

Some found in Africa have a double horn, one growing above the other. This weapon is one of the ftrongeft, and moft dangerous, that nature furnifhes to any animal: is entirely folid, formed of the harde!t bony fubftance, growing from the upper naxillary bone, by fo ftrong an apophyfe, as feemingly to make but one with it.

\section{GIRAFFE, OR CAMELOPARDALIS.}

T TS head fomewhat refembles a deer, with two round horns (which perhaps it Theds), a foot long, blunt, thick, and tufted with hair; its neck refembles a horfe; its legs and feet, a deer; fore legs much longer than the hinder. Its tail refembles a horfe, but has lels hair. 
Its hoofs are extremely black, obtufe', and fpread. A kind of mane runs all down its fpine; inclining backwards to half way of the back, then inclining forwards, and near the tail inclining backwards again. This mane is long on the neck, fhort toward the tail. Its eyes have eye-lafhes of ftiff hair; fome ftiff hairs alfo round the mouth. A bony kind of tubercle makes a fort of third horn on the forehead. Ears large. Its teeth, refembling thofe of deer, are made entirely for vegetable pafture. It is beautifully fpeckled with brown or black fpots, on a light brownifh or dirty white ground: the females lighter than the males. Timorous and harmlefs; lives entirely on the leaves of trees; always carries its head very high. Kneels down to drink. Its motion is a kind of pace, the two front or two hind legs moving together; runs awkwardly, and badly. Often lies down on its belly. Was known to the ancients, but rarely feen in Europe. Pompey exhibited, at one time, no lefs than ten. Inhabits the internal regions of Africa.

The dimenfions of a young one, brought from the Cape of Good Hope, were as follows: Length of the head, one foot eight inches; the fore leg, from the ground to the top of the fhoulder, ten feet; from thence, to the top of the head, feven, making together feventeen feet; height of the hind leg, eight feet five inches: from the top of the thoulder, to the infertion of the tail, feven feet. Sometimes are twenty-five feet from nofe to tail.

\section{THE B E A R.}

F the bear, are three different kinds; the brown bear of the Alps, the black bear of North America, which is fmaller, and the great Greenland or white bear. Of the fame habitudes, carnivorous, treacherous and cruel.

The brown bear is properly an inhabitant of the temperate climates; the black finds fubfiftence in the northern regions of Europe and Ainerica: the great white bear inhabits the moft icy climates. The brown bear, favage and folitary, takes refuge in the moft dangerous precipices of uninhabited mountains; in the gloom of the foreft, in fome cavern hollowed by time, or in the hollow of fome old enormous tree. There, alone, it paffes fome months in winter without provifions, and without ftirring abroad; 
abroad; not entircly deprived of fenfation. - Scems to fubfift on the exuberance of its former fat, and only feels the calls of appetite, when what ic hat acquired in fummer is watted. When the bear retires to its den for the winter, it is extremely fat; but at the end of forty ar fifty days, when it cones forth to feek freh nourihment, it feems to have flept away ail its fleth. Couples in autumn; cime of geftation unknown: the female takes great care to provide a proper retreat for her young, in the hollow of a rock; where fhe provides a bed of hay. Brings forth in winter; the young begin to follow her in fpring.

The voice of the bear is a kind of growi, interrupted with rage, often capricious. Capable of fome degree of inftruction: can dance in awkward meafures on its hind feet, to the voice or to the inftrument of its leader; and is often the beft performer of the two. When cone to maturity, can never be tamed. The leaft dangerous method of taking it is by intoxicating it, by throwing brandy upon honey, of which it is very fond. In Canada, they are taken by fetting fire to their retreats, which are often thisty feet from the ground. The old one generally firf iffues from her den, and is fhot by the hunters. The young ones, as they defcend, are caught in a noofe. Their hams, and efpecialiy their paws, are faid to be a great delicacy.

The white Greenland bear, though it preferves the general external form of its fouthern kindred, grows to above three times their fize. The brown bear is feldom above fix feet long; the white bear often from twelve to thirteen. The brown bear is made ftrong and fturdy; the Greenland bear, though covered with very long hair, is nender; the head, neck, and body, more inclining to the hape of the greyhound. Seems the oniy animal, that in the coldeft climate grows larger than thofe of its kind in the temperate zones. Come down to view our failors on their fhores with an awkward curiofity; approach nowly, as if undetermined. When hot at, or wounded, endeavour to ly ; finding that impracticable, make a fierce and defperate refiftance.

The number of thefe animals about the north pole, is amazing. They are rot only feen at land, but often on ice floats, feveral leagues at $\mathrm{fea}$; and are tranfported in this manner to the very hores of Iceland, where the natives are in arms to receive them. It often happens, when a Greenlander and his wife are out at fea, by coming too near an ice-foat, a white bear unexpectedly jumps into their boat, and, if he does not overfet it, fits calmly where he firft came down, and like a paffengeb fuffers himfelf to be rowed along. 
Lives chielly on fih, feals, and dead whales; feldom removes far from the hore. When forced by hunger, ventures into the deep, fwims after feals, and devours whatever it can feize; is but a bad fwinmer, and is often hunted by boats, till fatigued, and at laft deftroyed.

\section{THE R A C O O N.}

7 HE racoon, which fome have called the Jamaica rat, is about the 1 fize of a fmall badger; body fhort and bulky; fur fine, long, and thick, blackifh at the furface, grey toward the botiom; nofe rather Phorter, and more pointed than that of a fox; eyes large and yellow; teeth refembling thofe of a dog; tail thick, but tapering, marked with rings of black, at leaft as long as the body; forefeet much fhorter than the hinder; boch armed with five fharp claws, with which, and his teeth, the animal makes a vigorous refiftance. Like the fquirrel, ufes its paws to hold its food (differs from the monkey kind, which ufe but one hand, whereas the racoon and the fquirrel ufe both). Though hort and bulky, yet very active; by its pointed claws it climbs trees with great facility; runs up the trunk with the fame fwifnefs that it moves on the plain; and fports among the extreme branches with great agility; moves forward chiefly by bounding, and though it proceeds obliquely, has fpeed enough frequently to efcape its purfuers.

Native of the fouthern parts of America, found in noxious abundance, in Jamaica, on the mountains; often defcends to feed on the fugar-cane. 'The planters confider thefe animals as one of their greatent miferies; have contrived various methods of deftroying them, yet they propagate in fuch numbers, that neither traps nor fire-arms can thin them; fo. that a fwarm of thefe familhed creatures do more injury in one night, than the labours of a month can repair.

When tame, is harmlers and amufing; capable of being infructed in various tricks. Is playful and cleanly: eats of every thing given it; if left to itfelf, no cat can be-a better provider; cxamines every conner, eats fleth, boiled or raw, eggs, fruits, corn, infects, fnails, worms and beetes; has a particular fondnefs for fweets. Will cat its provifions dry, 
,
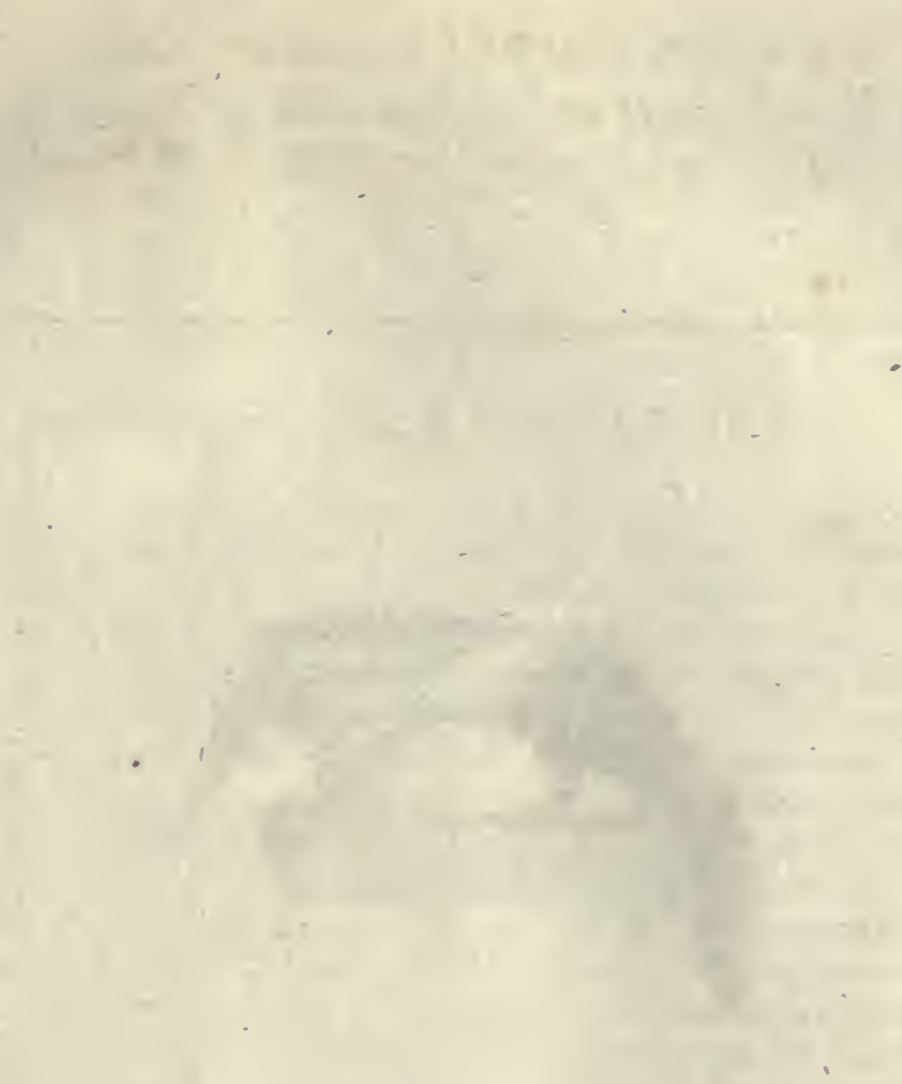


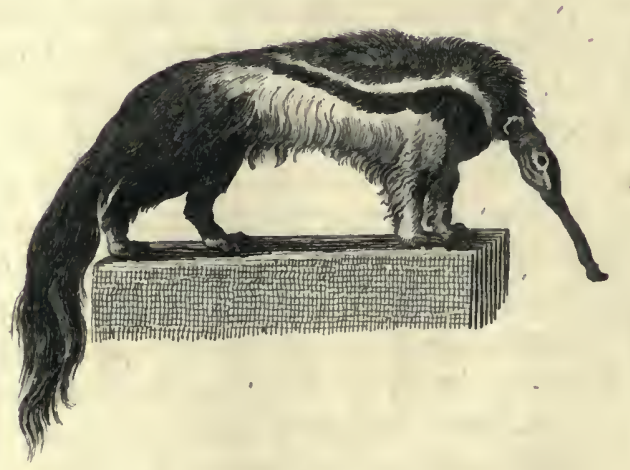

The Ant Bear, 


\section{THE C O A T I M O N D I, \&c.}

dry, but will by choice dip them in water, if it happens to be in the way. Has a peculiarity in drinking, as well by lapping like the dog, as by fucking like the horfe.

\section{T H E C O A T I M O N D I.}

T. T S fnout fomewhat refembles that of the hog, but is greatly elonI gated; the neck and the body are long, the fur thort, the eyes fmall, the upper jaw an inch longer than the lower, and the fnout, which is moveable in every divifion, turning up at the end. Sets up on the hind legs, and in this pofition, with both paws, carries the food to its mouth. Length from nofe to tail eighteen inches.

Is very apt to eat its own tail, which is fomerimes longer than its body (fome of the monkey kinds do the fame, and feem to feel no pain in wounding a part of the body fo remote from the centre of circulation). Of playful nualities, and indifcriminate appetite; at liberty will purfue poultry, and deftroy every living thing it can conquer; though playful with its keeper, yet cbllinate againlt receiving inftruction: neither threats nor careffes can induce it to practife any arts to which it is not naturally inclined. When it neeps, rolls itfelf up in a lump, and fo continues often fourteen or fifteen hours together. Inhabits Brazil.

\section{TH E A N T-E A T E R S}

T- A VE been clafied, by Mr. Buffon, into the larger tamandua-(our (1. ant-bear), the fmaller tamandua, and the ant-eater. The antbear is four feet long, from the fnout to the tail; legs Mort, armed with four ftrong claws; tail long and tufted; the animal often throws it on its back like the fquirrel. The tamandua is eighteen inches long, the tail without hair, trails on the ground as the animal moves. The ant-eater is not above feven inches from the fnout to the tail. The two former are of a brown dunky colour, this a beauciful reddih, mixed with yellow. 
Though they differ in figure, they refemble in nendernefs of fnout; and amazing length of tongue. The two laft have prehenfile tails.

The ant-bear is neither numerous, nor often feen; its retreats are in the moft barren parts of South America only; refides chiefly in woods, hides itfelf under fallen leaves; lives entirely upon ants and infeets, which are found in abundance, and often build hills, many feet high. Near an ant-hill, it creeps howiy on its belly, cautiouny concealing itfelf, till within a proper diftance; there lying clofe, it thrufts forth its round red tongue (often two feet long) acrofs the path of thele bufy infects, and lets it lie motionlefs. The ants fwarm upon it; but where they touch they ftick; held by a nimy fluid, which covers the tongue. Though without teeth, fights with its claws very obttinately againt the dog, and even. the jaguar: throws itfelf on its back, faftens on its enemy with all its claws, fticks with great perfeverance, and even, áfter killing its invader, remains faftened upon him with vindictive defperation.

\section{THE S L O- T H.}

F the foth, are two kinds, diftinguifhed by their claws; the Unan with only two claws on each foot, and without a tail; the Ai, having a tail, and three claws on each foor. The unan has the fnout longer, the ears more apparent, and the fur very different; differs alfo in the number of its ribs, having forty-fix, while the Ai has but twentyeight. Neverthelefs thefe two animals ftrongly refemble each other in their general outlines and manners.

The fur of the $\mathrm{Ai}$ is coarfe and faring, fomewhat refembling dried grafs; tail very hort, mouth large, eye dull and heavy, feet with three claws, the fect thort, but longer than its legs; proceeding from the body obliquely, fo that the fole of the foot feldom touches the ground. 'When the animal is compelled to ftep forward, it forapes the back of its nails along the furface, and wheeling its leg circularly about, ftill touching the ground, at length places its foot: limb after limb is moved with equal difficulty, not above three feet in an hour.

Lives entirely on vegetable food, the leaves, fruit, and flowers of trees. Has four ftomachs; and generally ftrips a tree of its verdure in 


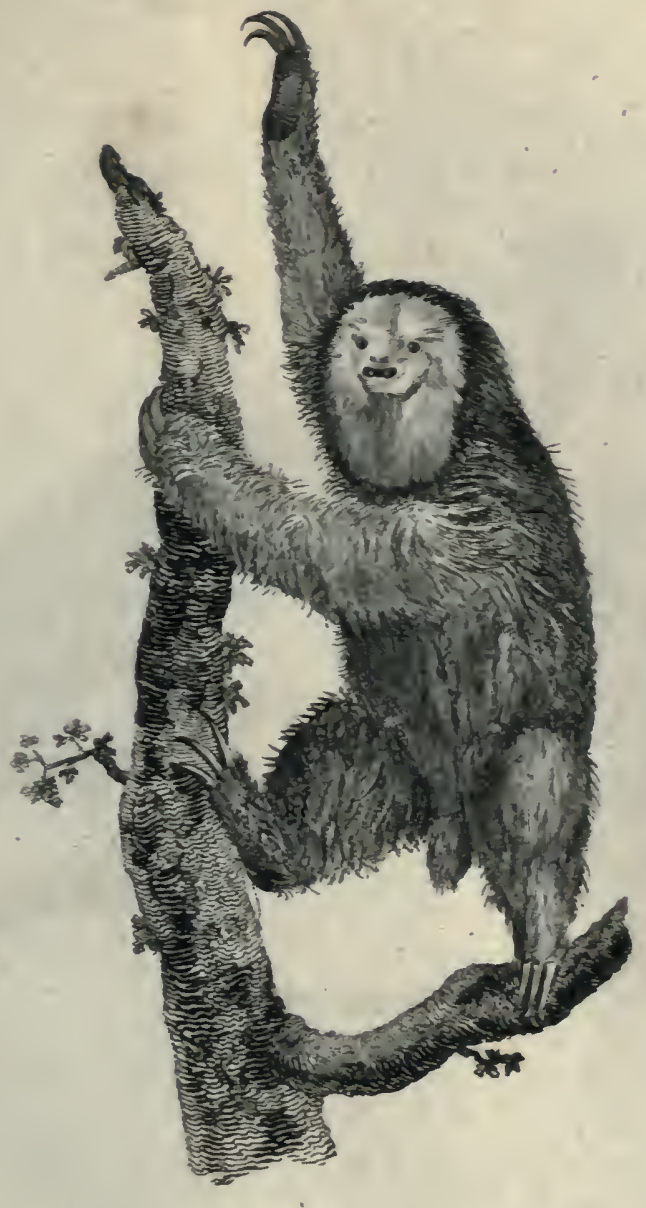

The Sloth 


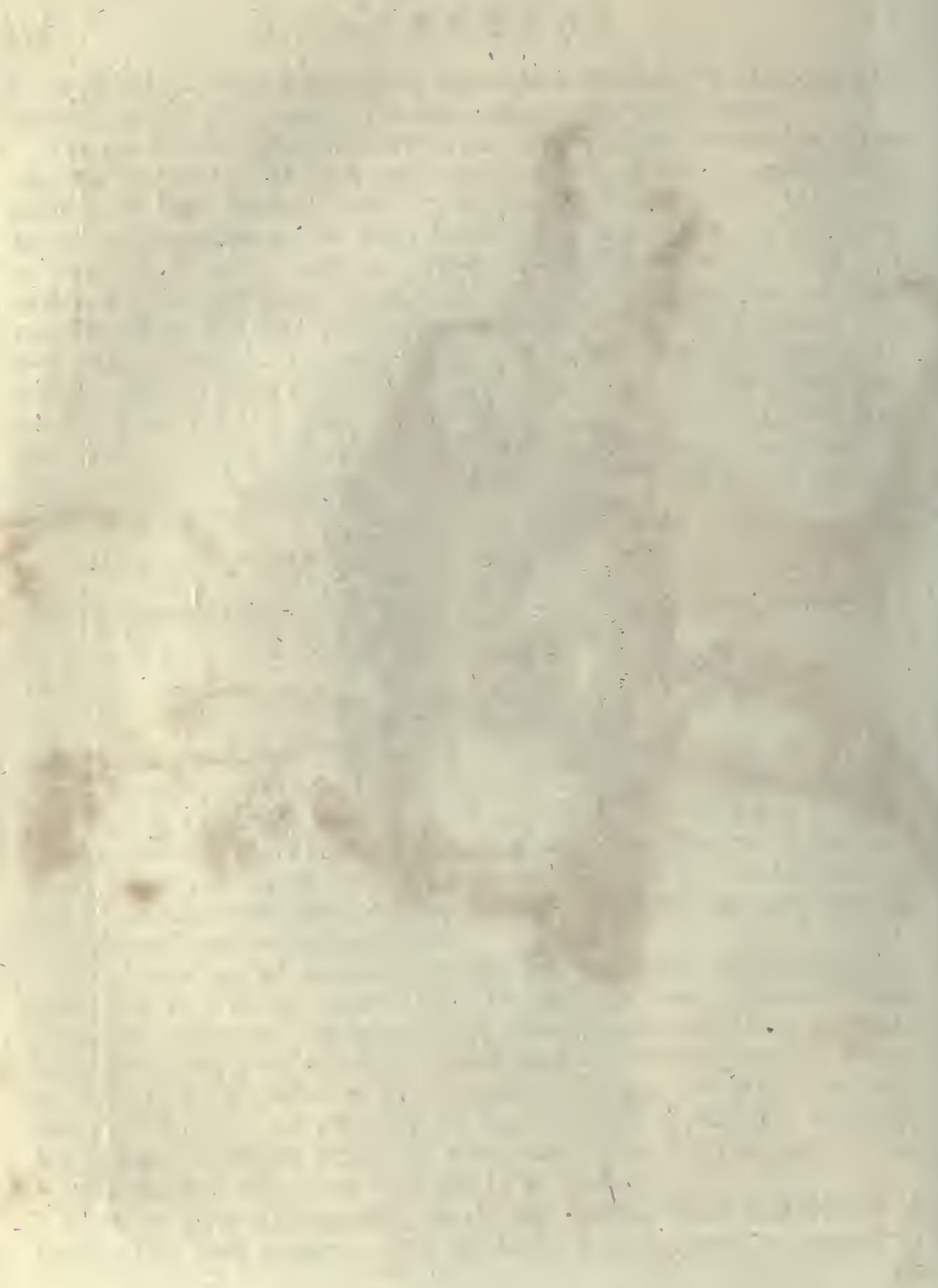




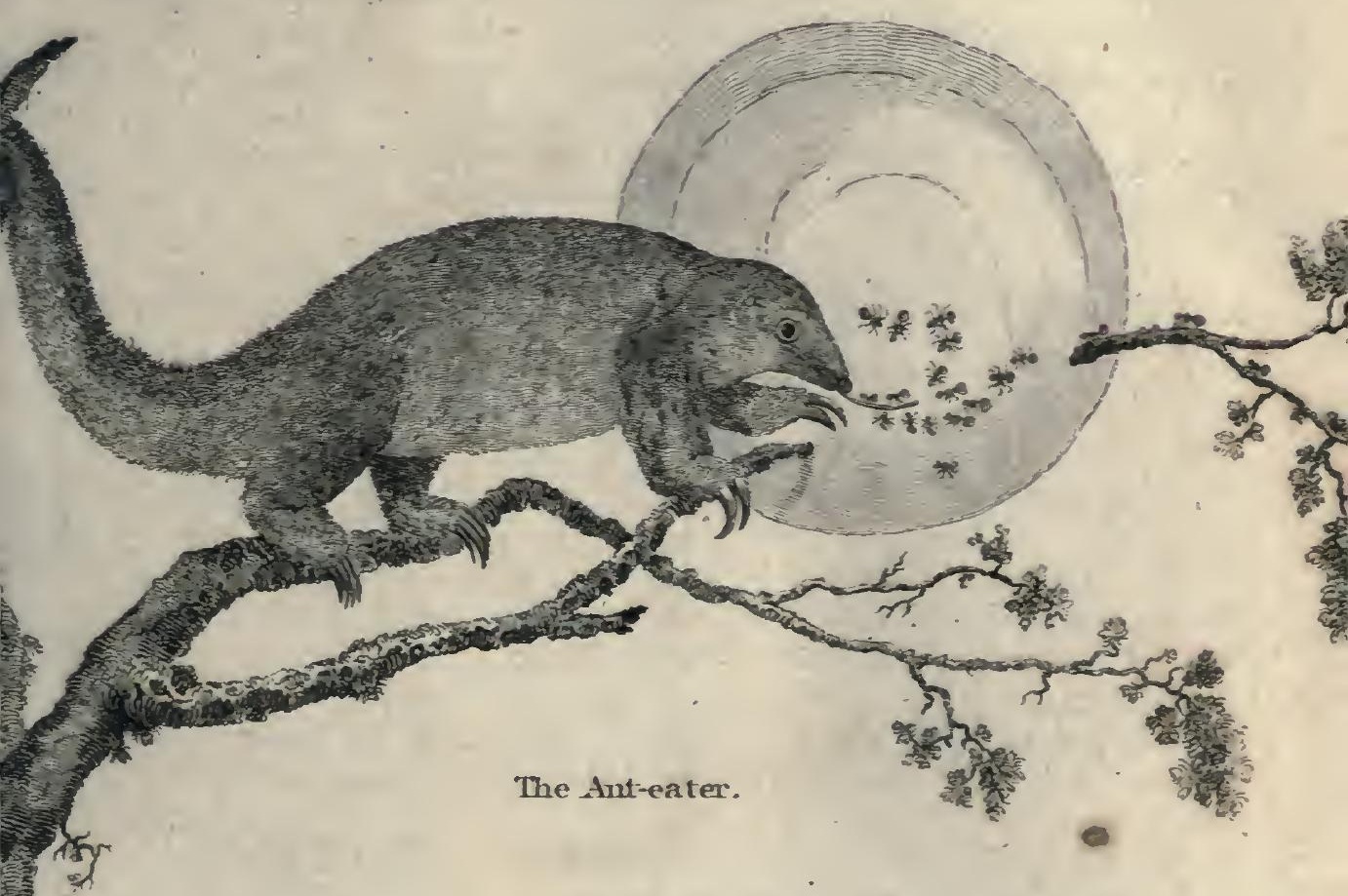



Jefs than a fortnight; but unwilling to quit, while any thing alive remains, it devours the bark, and thortly kills the tree on which it fed. Uiterly unable to defcend, it is obliged to drop to the ground like a Thapelefs heavy mafs, then journeys to fome neighbouring tree. Often takes a wetk in crawling to a tree not fifty yards diftant. Every ftep it emits a moft plaintive, melancholy cry, accompanied with tears; which excites difguft, mixed with pity. This feems its chief defence. When at length it reaches its deftined tree, mounts it with much greater eafe than when moving on the plain: devours with famifhed appetite, and, as before, not fparing the very fource of its fupplies. Has but one common vent. Lives fome time after its nobler parts are wounded, or taken away.

\section{T H E G E R B O A}

T A S four feet, "but, in running or refting, ufes only the hinder, yet 1 is one of the fwiftert crentures in the world.

is not above the fize of a large rat. Its head not totally unlike a rabbit, its teeth refemble thofe of the rat kind; two cutting teeth in each $\mathrm{j} a \mathrm{w}$; a very long tail, tufted : head, back and fides covered with large afh-coloured fofithair; breaft and belly whitih, the fore-legs not an inch long, four claws and a thumb on each; the hinder legs two inches and -a quarter, exactly refembling thofe of a bird, having but three toes, the middle longert.

Found in Egypt, Barbary, Paleftine, and the deferts; its fore-paws grafp its food, and in fome meafure perform the office of hands. Jump fix or eight feet at a bound; extremely fwift. Are lively, harmlefs, live on vegetables, burrow like rabbits. Are more expert diggers than the rabbit; when purfued, if they cannot efcape by their fwiftnefs, they try to make a hole inftantly in the ground. Is provident, and lays up for winier. Cuts grafs in heaps of a foot fquare, which, when dried, carries into its burrow for food or warmth.

The following animal has much external refemblance to the Gerboa: what is its true ftation, muft be decided by future obfervations; our lateft information is as follows. 


\section{TH E K A N G A R O O.}

\section{Extract from Captain Tench's "Account of Botany-Bay."}

" $7 \mathrm{~F}$ the natural hiftory of the kangaroo we are fill very ignorant: We may, however, venture to pronounce this animal a new fpecies of opofium, the female being furnifhed with a bag, in which the young is contained; and in which the teats are found. Thefe laft are only two in number; a frong prefumptive proof, had we no other evidence, that the kangaroo brings forth rarely more than one at a birth. But this is fettled beyond a doubt, from more than a dozen females having been killed, which had invariably but one formed in the pouch. Notwithitanding this, the animal may be looked on as prolific, from t'ie early age it begins to breed at; kangaroos with young having been taken of not more than thirty pounds weight; and there is room to believe that, when at their utmoft growth, they weigh not lefs than one hundred and fify pounds. A male of one hundred and thircy pounds weight has been killed, whofe dimenfions were as follow: Extreme length feven feet. three inches; the tail three feet four inches and a half; the hinder legs three feet two inches; the fore paws one foor feven inches and a half; the circumference of the tail at the root one foot five inches. After this, perhaps, I thall hardly be credited when I afirm, that the kangaroo, on being brought forth, is not larger than an Englin moufe. It is, however, in my power to fpeak pofitively on this. head, as I have feen more than one inftance of it.

In running, this animal confines himfelf entirely to his hinder legs; which are poffeffed with an extraordinary mufcular power. Their fpeed is very great, though not in general quite equal to that of a greyhound; but when the greyhounds are fo fortunate as to feize them, they are incapable of retaining their hold, from the amazing ftruggles of the animal. 'The bound of the kangaron, when nut hard preffed, has been meafured, and found to exceed twenty feet.

When young, the kangaroo eats tender and well-flavoured, tafting like veal; but the old ones are more tougli and ftringy than bull-beef. They are not carnivorous, and fubfit altogether on particular flowers and grass. Their bleat is mournful, and very different from that of any other ani$\mathrm{mal}$; it is, however, feldom heard but in the young ones."

The head, neck, and houlders are very finall in proportion to the body, 


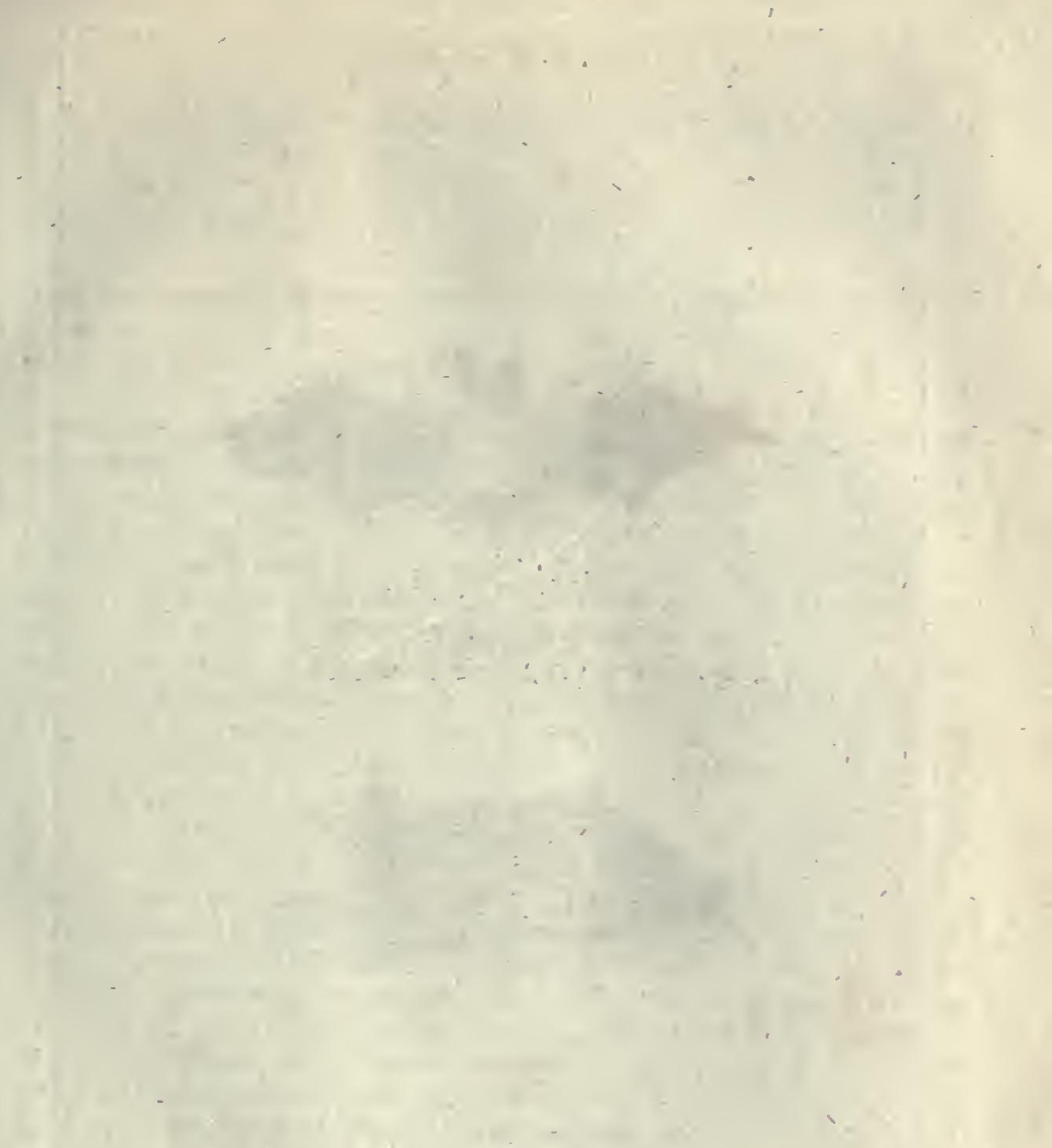


Fig. 2.

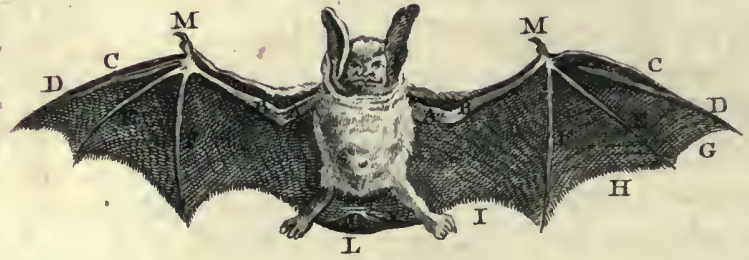

TheBat

Fig. 1.

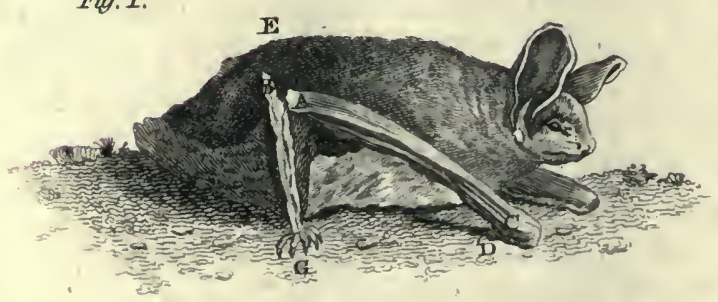


kody, which, though tapering upwards, enlarges below. Tail nearly as long as the body, tapering toward the end, covered with a fhort fur, except the head and ears, which bear a night refemblance to the hare. Probably the difference of fize in this creature, indicates different kinds.

\section{TH E B A T:}

THE bat fomewhat refembles a bird, in its power of fuftaining itfelf in the air; though iss motion is very awkward and ftruggling-but, it brings forth its young alive, fuckles them, has teeth; and its lungs, its inteftines, and its fkeleion are like thore of quadrupeds.

The bat, moft cominon in England, is about the fize of a moule; or nearly two inches and an half long. Its membranes, calied wings, are properly an extention of the fkin all round the body (not the head), which, in flying, is ftretched, by the four interior toes of the fore feet, which are enormounly long. The firt toe is loofe, and ferves as a heel when the bat walks, or as a hook, when it would adhere to any thing. The hind feet are difengaged from the furrounding $\mathrm{nkin}$, and divided into five toes, fomewhat refembling thofe of a moute. The fkin, by which it flies, is of a duky colour. The body is covered with a fhore fur, of a moufe-colour, tinged with red. The eyes are very fmall; the ears like thofe of a moufe.

It appears early in fummer, flies in the dufk of evening. Frequents the fides of woods, glades, and fhady walks; often fikims along the furface of water. Purfues gnats, moths, and nocturnal infects; and will not jefule meat. Its flight is laborious, irregular; and, if irterrupted, it cannot readily acquire a fecond elevation. Appears only in pleafant evenings; Aies in purfuit with its mouth open. At other times abides in its retreat, the chink of a ruined building, or the hoilow of a tree. Thus, even in fummer, neeps the greateft part of its time, ncver venturing out by day-light, nor in rainy weather. Its Mort life is further abridged by a torpid ftate, during winter. Often hangs by its hooked claws to the rocfs of caves, regardlefs of furrounding dimps. Such as feek not deep retreats of uniform temperature, often persh by the weather becoming fo mild in winter as to warm them prematurely into life, and to allure. them from their holes in queft of food, when they exhauft themfelves in purfuit of infects which are not to be found. 
The bat cosples and brings forth in fummer, from two to five. The female has two nipples, forward on the breaft. She makes no' neft for her young, but is content with the firtt hole fhe meets, where fticking: herfelf by her hooks, the permits her young to hang at the nipple, for the firt or fecond day. When fhe finds a necenity of fitiring abroad, the ficks her littie ones to the wall as the before hung herfelf; where they cling till her return.

The bat has ftrong pectoral mufcles to afint its fight, and weak legs, (wherein it agrees with birds). And is never feen to walk, or rather to puth itfelf forturd with its hind legs, but in extreme neceffity. The roes of the fore legs, or, if we may ufe the expreflion, its very long fingers, extend the web-like membrane between them ; which being extremely thin, ferves to lift the little body into the air: where, by uncealing perculion, the animal continues, and direets its fight; but is fatigued in lefs than an hour.

Anong its varieties, are the long-eared bat, which is very fmall; the horfe-fhoe bat; with an odd procuberance round its upper lip, in form of a horfe-thoe; the rhinoceros bat, with a horn growing from the nofe.

But the race of bats in the Eaft and Weit-Indies, are truly formidable; and in fuch numbers, that, when they fly, they obfcure the fetting fun.

The largeft we certainly know of, is the roufette, or great bat of $\mathrm{Ma-}$ lagafcar; near four feet broad, wings extended; one foot long, from the nofe to the tail. Is fox-coloured; its head and nofe alfo refemble that animal; and fome have called it the Flying-fox : it differs in the number of its teeth'; and in having a claw on the fore foot, which is wanting in ours. Inhabits Madagafear, the coafts of Africa and Malabar. When they repofe, they ftick to the tops of the tallef trees; with their heads downward. When in motion, like clouds, they darken the air, day and night, deftroying the ripe fruits of the country, and fometimes fettling on animals, or man: they devour fruits, flefh, infeets, and drink the juice of the palm tree : their horrid din is heard at night in the forefts, at two miles diftarice; at the approach of day, they retire. Some have obferved, that the ancients feem to have taken thcir harpies from thefe fierce and voracious creatures, as they agree to many parts of the defeription, being equally deformed, greedy, uncleanly, and cruel.

But ftill more mifchievous is the American Vampyre; lefs than the former; more deformed, and more numerous. Has a horn like the shinoceros bat, and extremely long ears. Thefe enter towns and cities, and, after fun-fet, cover the Atreets like a canopy. "They are," fays 
Ulloa, "the moft expert blood-letters in the world." The inhabitants of thofe warm latitudes being obliged, by the exceffive heats, to leave open the doors and windows of their chambers, the vampyres enter, and if any part of the body be expofed, they faften on it, and fuck the blood; often the perfon dies under the operation. "I have been affured," continues he, "by perfons of the ftricteft veracity, that fuch an accident has happened to them; and that, had they not providentially awaked, their neep would have been their paffage into eternity; having loft fo large a quantity of blood as hardly to find ftrength to bind up the orifice, The reafon why the puncture is not felt is, befides the great precaution with which it is made, the gentle, refrelhing agitation of the bat's wings, which contribute to encreafe fleep, and foften the pain." Ulloa fuppofes, the puncture is made by a fingle tooth. Mr. Buffon fuppofes the wound is inflicted by the tongue. Others think that, without inflicting any wound, by continual fuction, it enlarges the pores of the $\Omega i n$, till the blood paffes. But all agree as to the fact, though they difagree as to the manner.

Thefe animals are a great peft of South America; and often prevent the peopling many parts of that continent : having deftroyed at Barja, and feveral other places, the cattle brought there by the miffionaries to form a fettlement. 


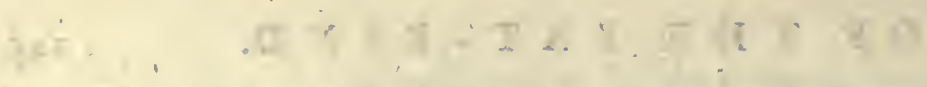

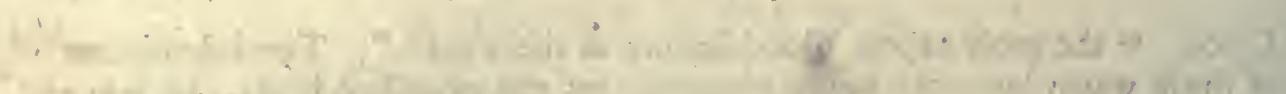

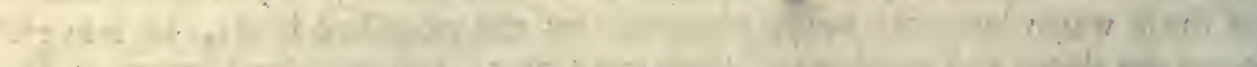

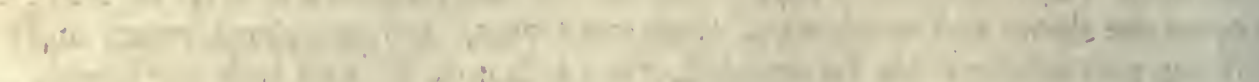

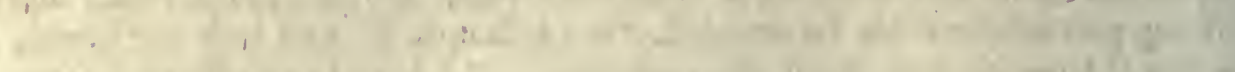

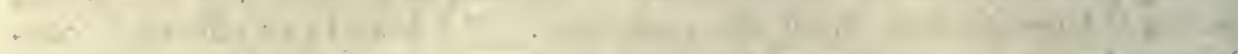
L

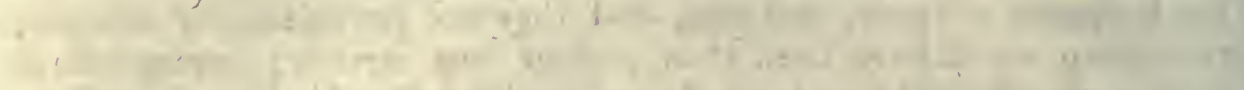
a.

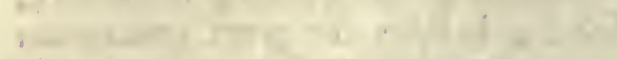

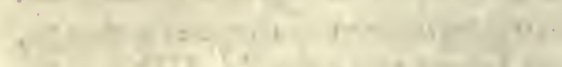

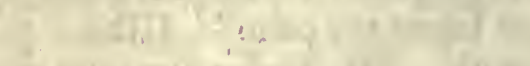

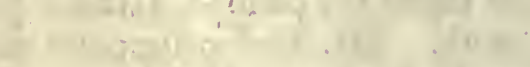

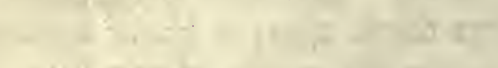

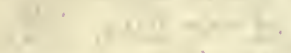

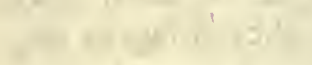

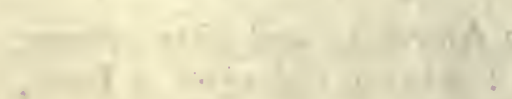

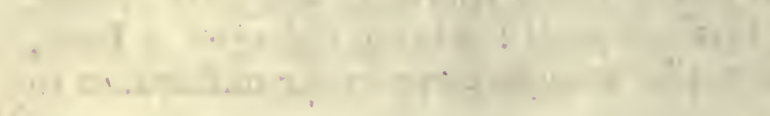




\section{SURVEYS OF NATURE.}

\section{PART THE FOURTH.}

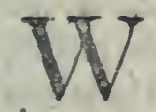

E come now to a large divifion of creatures, entirely diftinct from what have hitherto engaged our attention. It is true, we have feen quadrupeds flying, or rather leaping (as the fquirrel), and labouring a progrefive motion (as the bat), but far from being able to endure, and continue this exercife, they foon become enfecbled: ftill lefs have they power to attain great elevation, or to float on the atmolphere as if at ref. Their flight was a deviation from the general nature of quadrupeds, wherein they approached to fomewhat of a bird; as the incapacity of fome birds for flight, deviates alfo from the general nature of their kind, and fumewhat approaches a quadruped: nevertielefs, the great diftinction between thefe kinds of creatures is, the capacity of one to rife in air, while the other is confined to refidence on the earth.

To this quality of rifing contribute, (I) Their external thape; (2) Their clothing of feathers; (3). The great Atrength of their pectoral muicles; (4) Their capacity of inhaling confiderable quantities of air: moft probably conneeted with a principle whereby they accommodate themfelves to the different degrees of rarity in the air, as they afcend to confiderable heights.

PART IV. No. 24. 
The external thape of birds, is evidently adapted to pierce through a yielding medium; Sarp, at firft-gradually fwelling -its chief bulk in the middle - and its termination not fudden, but diminifhing-yet, by means of the tail, capable of expanfion: the very conftruction of a fwift failing veffel!

The capability of expanfion, or retraction, appears to great advantage in the conftruction of their clothing: is remarkable alfo in their wings and tail, whereby they occupy greater fpace in the fluid wherein they move, without augmenting their weight. A wing, when folded, is in fo clofe union with the creature's body, as to make a part of it; but when expanded, is incomparably beyond the effect of oars on a veffel: not only is it generally fpread, but all its parts, not only its joints, but its feathers affume a new direction, and as fo many radii from the centre of their infertion diverge as much as may be, to occupy a greater fpace; yet never fo much as to leave vacuities between any two.

Feathers are not merely adapted for flight, by ftrength combined with lightnefs, by elafticity, and by form; but, as defenfative, they protect their wearer from injury, and, as clothing, they anfwer every purpofe of warmth and comfort. They generally are uniform in their pofition, are laid all the fame way, one over another, regularly, neatly, fo as to make a perfectly Jmooth fuperficies, whofe external evenne/s may prevent fettlings of water, \&c. while, next the body, a cherifhing foft down forbids the penetration of cold to injure its wearer. To maintain this fmoothnets, which, by expofure to accideints, is liable to be deftroyed, the bird has a gland fituated on the rump, furnifhed with an excretory duct; this fupplies an oil, for the purpofe of dreffing the feathers, which the bird communicates to each feather as wanted, by drawing it through his bill, in which he has previoufly gathered a quantity. Water-fowl have this oil in the greateft abundance, land-fowl have lefs, and thofe domefticated very little: Thefe are rarely far from thelter; and nature beftows nothing fuperfluous or ufelefs. 


\section{SURVEYS OF NATURE.}

\section{3}

A Feather is an admirable inftance of artful appointment: its quill ftrong, but not:folid; its ftem fpungy and flexible, its vane or beard, fubdivided into many parts, each refembling a feather; having other parts rifing from them, whofe hooked terminations keep fant hold of their neighbours; and by a kind of interweaving (eafily feparable if neceffary, yet able to refift the impulfes of the air) complete the unitednefs of the whole. The combination feems thus: the hooked offspring from the vanes unite the vanes; the vanes of one feather lying over thofe of another, unite the feathers into compactnefs. In the thaft of a feather is the pith, which nourifhes the ftem, and its parts. Feathers are generally placed according to their length and ftrength, fo that their duty is proportioned to their ability.

The wing is fituated in birds according to its intent: where it is little ufed, befide being fmall, it is lefs accurately placed to poife the body, and to receive the whole force of its moving powers, and is ufually fquat; where it is the inftrument of extenfive excurfion, it is longer, lefs flefhy, and very carefully fitted. At the extremity, is a kind of finger-like appendage, ufually called a baffard-wing. The beards of wing-feathers are remarkably broad on one fide, and narrow on the other: the narrow fide of one lying over the broad fide of its fellow, contributes to the ftrength of the whole; by introducing its ftem to the fupport of its fellow, where weakeft.

The manner in which moft birds rife is thus: they quit the earth with a bound, in order to have room for flapping the wing; then they ftrike the body of air beneath the wing with its whole under furface; but, to avoid friking the air on the upper fide with equal violence, the wing is inftantly contracted; fo that the creature rifes by the impulfe of this firf blow, till it fpreads the wing for a fecond. For this reafon, birds chocie to rife againt the wind, becaufe they have a greater body of air on the under than on the upper fide of the wing. For thefe reafons alfo large fowls do not rife eafily, becaufe they have not fufficient room at firt 
for the motion of their wings, and becaufe the body of air does not lie fo directly under the wing as they rife.

The office of the pectoral mufcles being to move the wings, they are endowed with peculiar ftrength: the ftroke of a fwan's wing would break a man's leg, and fuch a blow from an eagle has deprived a man of life. Befide mere Atrength, they have occafion alfo for perfeverance: their efforts muft often be maintained long together; and this in birds of paffage is remarkable: they poffets not the power of an eagle, but polfibly they exceed many of that kind in continuance; fome birds feem always flying, and are found hundreds of leagues from flare, ever on the wing.

The toes in fome are webbed, to fit them for the waters; in others feparate for their better clafping. Thofe with long legs have alfo.long necks, or how could they gather their food? But thofe with long necks have not, always long legs; we inftance in fivans and geefe.

The bones of birds are extremely light and thin though compact, and the mufcles (except thofe moving the wings) extremely flight. The tail, which is compofed of quill-feathers, balances the head and neck; directs their flight like a rudder, and greatly affints in defcending.

We find by ourfelves, that rapid motion fpeedily induces difficulty of breathing; yet the principal mufcles ufed in fuch exercife, are not feated around the lungs: were our arms exerted with equal violence. (of which they are unable) their effeets might be greater. To prevent this impeded refpiration in birds, their lungs (commonly called the fole) adhere to the ribs and back, and very little dilate or contract. But the branches of the wind-pipe open into them, while thefe open into the cavity of the belly, and convey the air inhaled by breathing into certain receptacles like bladders, ruming the length of the whole body: to that air blown into the wind-pipe will diftend the animal's body like a bladder; confequently they have great facility of long and large infpiration. Sometimes alfo the wind-pipe makes many convolu. tions within the body of the bird, and is then called the labyrinth; but of what ufe are thefe convolutions is not known. 


\section{SUR VEYS OF NATURE.}

I fufpect alfo, that as fome birds have a vacuity between the flefh and 1kin, fo that air blown between fwells them externally (i.e. their $\mathrm{kin}$ ), while their flefh remains little affected; fo birds, which rife to great heights, may fwell and dilate themfelves when high, more than when low ; to counteract the effect of the rarer medium at thofe heights, againt which frength of wing is a feeble refource.

Birds have, properly fpeaking, but one ftomach; but different in different kinds. In the rapacious kinds that live on animal food, and in fome of the firh-feeding tribes, the gullet is replete with glandulous bodies, which dilate and moiften the food as it paffes; the ftomach is always large, and generally wrapped round with fat, to increafe its warmth.

In granivorous birds, the gullet dilates juft above the breaftbone, and forms a pouch or bag, called the crop; this contains falivary glands to moiften its contents. They are very numerous, with longitudinal openings, which emit a whitifh and vilcous fubftance. After a convenient time the food pafles into the belly, where (inftead of a foft, fat, moift ftomach, as in the rapacious kinds) it is ground between two pair of mufcles, commonly called. the gizzard, covered on the infide with a ridgy coat; almoft cartilaginous. Thefe ridgy coats, rubbing againft each other, are capable of bruifing and attenuating the hardeft fubftances, even iron or ftones.

Birds are in general very much longer-lived in proportion than quadrupeds : the age of quadrupeds is calculated at about feven times the interval between their birth and maturity; that of birds is probably ten or twelve times that interval. Their difeafes are few: the moft remarkable is their moulting. We have feen fomewhat refembling this among quadrupeds; but in birds it is mot notorious. We have feen the itag caft his horns, the camel his coat, the rabbit his fur; we have feen winter atimilate to its fnows the clothing of polar animals, and their varying colours return in fpring; but in birds, this change is to powertul, that they PART IV. No. 24.

become 
become hardly recognizable : efpecially the difference is great between a young bird, and one which has often undergone this operation.

During this feafon, thofe moft remarkable for courage become timid, and thofe of weakly conftitutions often die. All ceafe to breed; and their whole nourinment is abforbed by the nafcent plumage, whofe progrefs feems to be as follows, -

A quill or feather, when come to its full fize, grows harder as it grows older, and receives a kind of periofteum or $\mathrm{fkin}$ round its thaft. In proportion as the quill hardens, its diameter thrinks, its nourithment decreafes, and it becomes loofe in its focket, till at length it falls. In the mean time, the rudiments of an incipient quill are beginning. The fkin forms a little bag, which is fed by a fmall vein and artery, and which daily increafes till protruded. While one end vegetates into the beard or vane of the ifeather, that attached to the $\mathrm{fkin}$ is foft, and receives a conftant nourifhment, which it diffufes through the whole by the pith. When the quill is full grown, the vein and artery diminifh, and at length difappear. The quill thus deprived continues in its focket; till after its proper time it fhrinks, loofens, and quits its place to a fucceffor.

We have feen quadrupeds dwell in fubterranean habitations, in dens, in burrows, or among trees; inhabitants of the air may be expected to choofe a free communication with their peculiar element, they decline therefore depth as not to them fecure; and neftle in the grove, the foreft, or the field, on the fhore, or among rocks, in hopes of concealing their abode from the eye of hungry enmity.

Quadrupeds being viviparous, the male has little opportunity of teftifying his fatisfaction till the young appear; but among birds, the male contributes to the advancement of the future progeny; fometimes by pofitive incubation, fitting on the eggs in the abfence of the female, fometimes by his fong, cheering his confort, and anticipating his endearments, and fometimes by catering for her while confined in her important occupation. When the 


\section{SURVEYS OF NATURE.}

young rife into life, is the fummit of both their joys, both are tranfported with pleafure, and elated with pride: at this period, the moft timid become courageous, the rapacious become unufually fierce and active: They carry their prey, yet throbbing with life, to the neft, and early accuftom their young to Aaughter. While the young are unfledged, the parents provide them regular fupplies; and feed each in its turn. When the family is plumed, and capable of flight, they are led forth when the weather is fine, and taught the art of fubfiftence; where their food lies, and the method of difcovering and fecuring it : they return to the neft, for a day or two, but when able to thift for themfelves, the old ones forfake them, and totally difclaim all future connexion.

The greaten number of birds remain in their native difricts. The rook, if undifurbed, never defires to leave his native grove; the black-birc frequents his accuftomed hedge; and the red-breaft, though feemingly mild, claims a certain diftrict, from whence he feldom moves, but drives out every one of the fame fpecies. Why then do birds of pafiage yearly forfake us, and regularly return? Few fubjects are fo much involved in darknefs.

Food is probably one caufe, yet thofe which in cages have plenty of food, are equally anxious, as if they were ftarving: temperature is probably another caufe; yet thofe theltered and kept warm, are equally reftlefs. Do they fly from man in countries too well inhabited for their repofe? Whence have the young this knowledge? However it be, it feems a preconcerted undertaking: They afiociate in fome open place, feveral days before their departure, and, by an odd kind of chattering, feem to debate the fubject. They take flight together, and often in fuch numbers, that, to mariners at fea, they feem like a cloud that refts on the horizon. - By far the greatent number make good their intention; but many grow weary, and fpent by fatigue.

Of the numerous tribes of the duck kind, that frequent our Dhores-we know fcarce more than five that breed here. The reft contribute to form that amazing multitude of water-fowl which 
aninually repair to the dreary lakes and defarts of Lapland, where they perform the duties of incubation and nutrition in full fecurity, among lakes, rivers, fwamps, and mountains, covered with thick and gloomy forefts. Here the ground remains moift and penetrable during the fummer; here the woodcock, fnipe, and flender billed birds feed at eafe; while the web-footed birds find food in plenty from infinite fwarms of infeets. From hence they defcend at the approach of winter in numbers abfolutely innumerable; and which Limnaus has obferved for eight whole days and nights to cover the furface of the river Calix.

It has been often a fubject of aftonifhment, how thefe creatures fhould perform fuch long journeys, fhould know whither to fteer; and when to fet out. It is probable they rather follow the weather than the country; and that they proceed as they continue to find the atmofphere favourable, of the minuter variations of which they are probably fpeedily fenfible and early apprized.

Thus fome birds by migrating inhabit every part of the earth; in general each climate has its peculiar birds. Thofe of the temperate zone have little baauty of plumage, but the fmaller kinds have exquifite melody of voice. Thofe of the torrid zone are of bright and vivid colours, but of fcreaming voices, or are filent. The frigid zones boaft little of either melody or brilliancy, but abound with birds of the aquatic kinds, whofe clothing is warm not thewy, and fubftantial not gaudy.

The number of quadrupeds little exceeds two hundred kinds: of the fe, by grouping them together, we have obtained a tolerably diftinct conception, having given to each that portion of attention which its importance might claim: there is much greater difficulty, in endeavouring to acquire equally determinate knowledge of birds, becaufe (I) their numbers are greater, probably exceeding a thoufand, even omitting many varieties. (2) They are fpread as well over the waters as the land. (3) Their changes are greater in the courfe of their lives. (4) The difference between the fexcs is ftronger. (5) The infuence of climate is very 


\section{S U R V E Y S OF N A T U R E.}

confiderable. (6) They feem capable of uniting their varieties more than quadrupeds are. (7) With regard to fome of them, though we can defcribe their manners while with us; we know little of their procedures while abfent : in thort, birds more eafily efcape our purfuit than quadrupeds; and confequently our knotvledge is built on more diftant acquaintance. :

Thus circumftanced, muft we give up the purfuit of knowledge, or be content with what is attainable? Certainly, thefe obftacles may excite diligence in the obferver, and candour in the inftrueted; for evidently much remains obfcure, and equally evidently, what is difcovered has been the work of time, and the effect of labour, toil, trouble, expence, dexterity, genius, and remark, which though they may err, yet on the whole deferve praife; and though not complete in knowledge, may juftly affume a credit for all that is known. 


\section{(10)}

\section{OF THE}

\section{I S T I N C T I O N S OF B I R D.}

$7 \mathrm{HE}$ legs and toes diftinguih land from water fowl. Land birds have divided toes, without any membranes between them. Thofe that wade, bave legs ufually long and naked; thofe that fwim, have the toes webbed together: thefe are leading diftinctions of nature itfelf.

Land birds of the rapacious kind, have a large head, a frong crooked beak, notched at the end; ftrong fhort legs, and tharp crooked talons; bodies fibrous and mufcular; wings well feathered and expanfive. The fight of fuch as prey by day is aftonithingly quick; and fuch as ravage by night fee objects in obfcurity with extreme precifion.

Formed for war, they lead a life of folitude and rapacity. Their fiercenefs extends even to their young, which they force from the neit, at a time when they fill thould protect and fupport them.

Birds of prey are remarkable for one fingularity. The males are a third lefs, and weaker than the females. Hence the male is called by falconers, a tiercel; a tierce or third lefs than the other. The females are of greater fize, more beautiful and lovely for thape and colours, Atronger, more fierce and generous, than the males: probably it is neceflary for the female to be thus fuperior, that the may efficacioufly proted herfelf, and her young, not only. from enemies, but from the male himfelf; fince it is out of her power to fecrete them, as we have feen the females of beafts of prey. Otherwife perhaps fome accefs of fury from difpleafure or defpair might prompt him to deftroy them. 


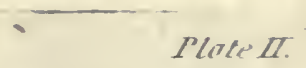

BIRISS BILLS.
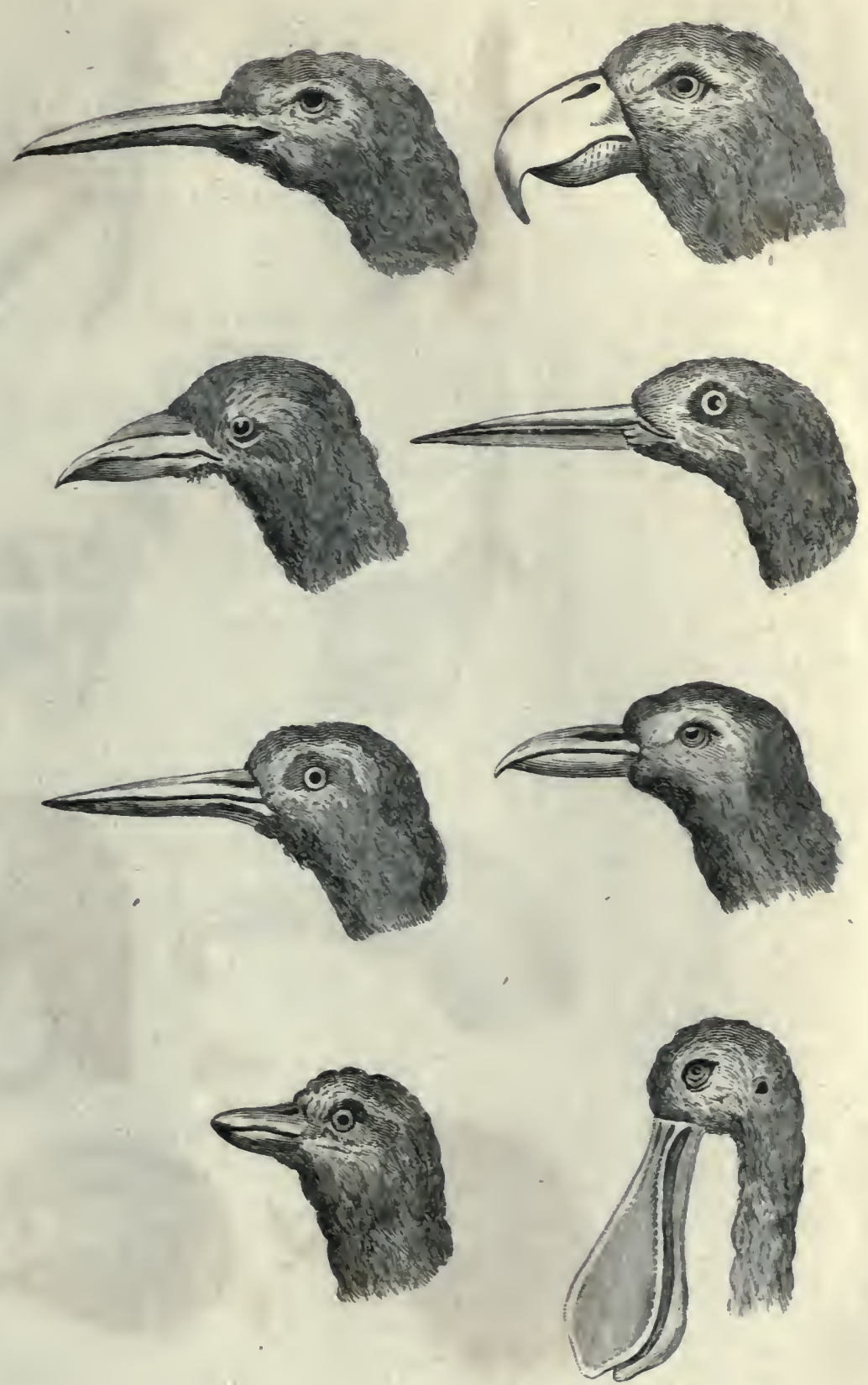


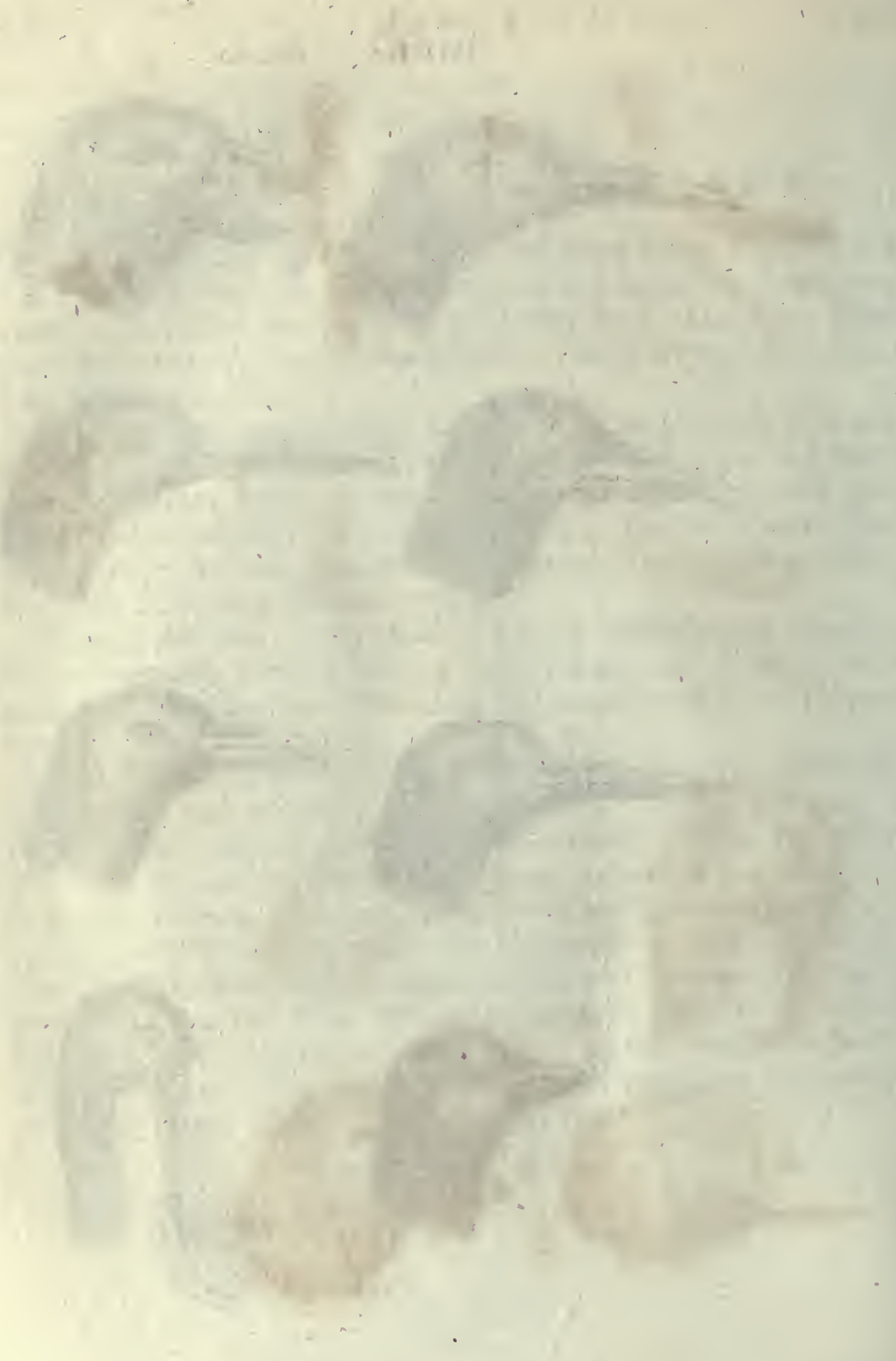



Plite 1.
BIRDS
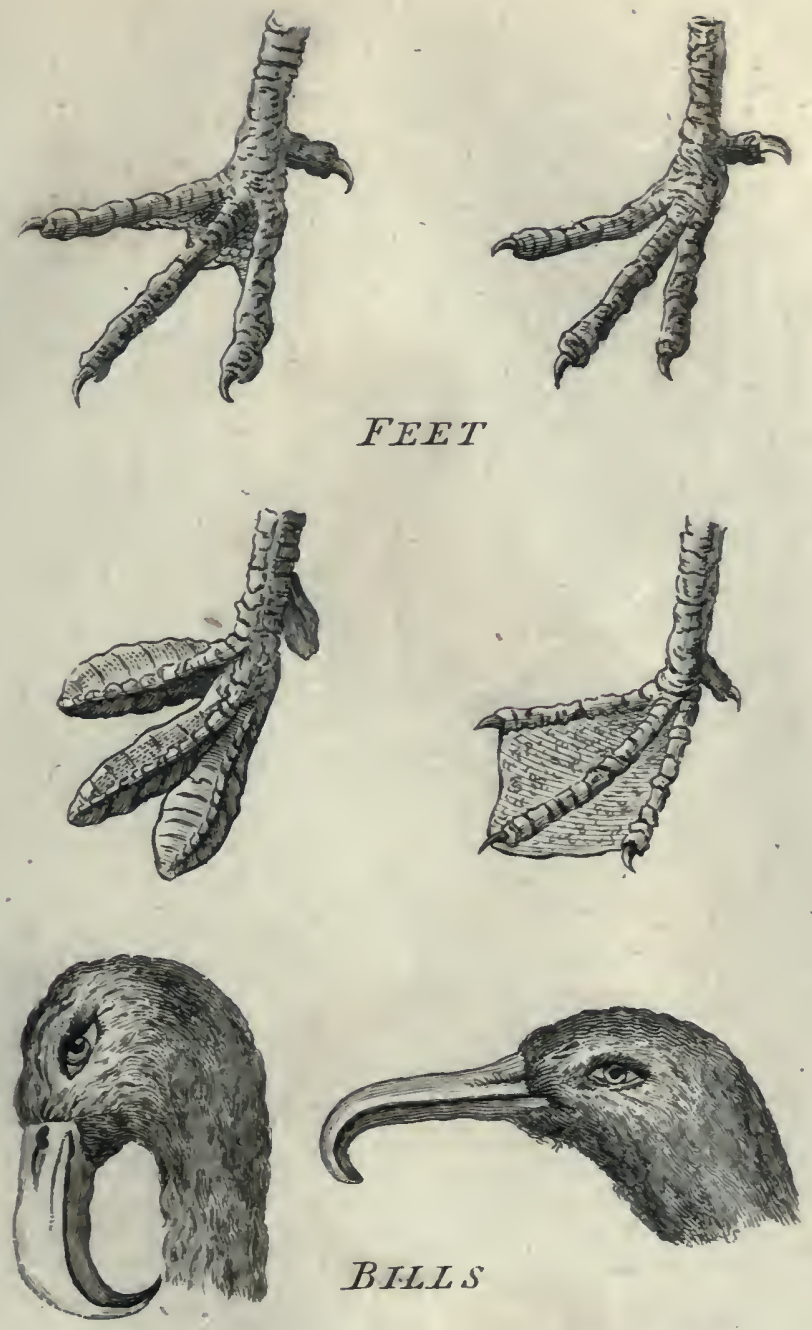

BILLS

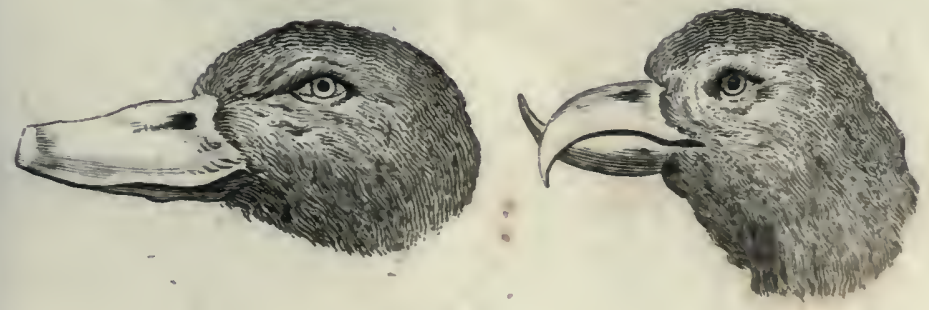




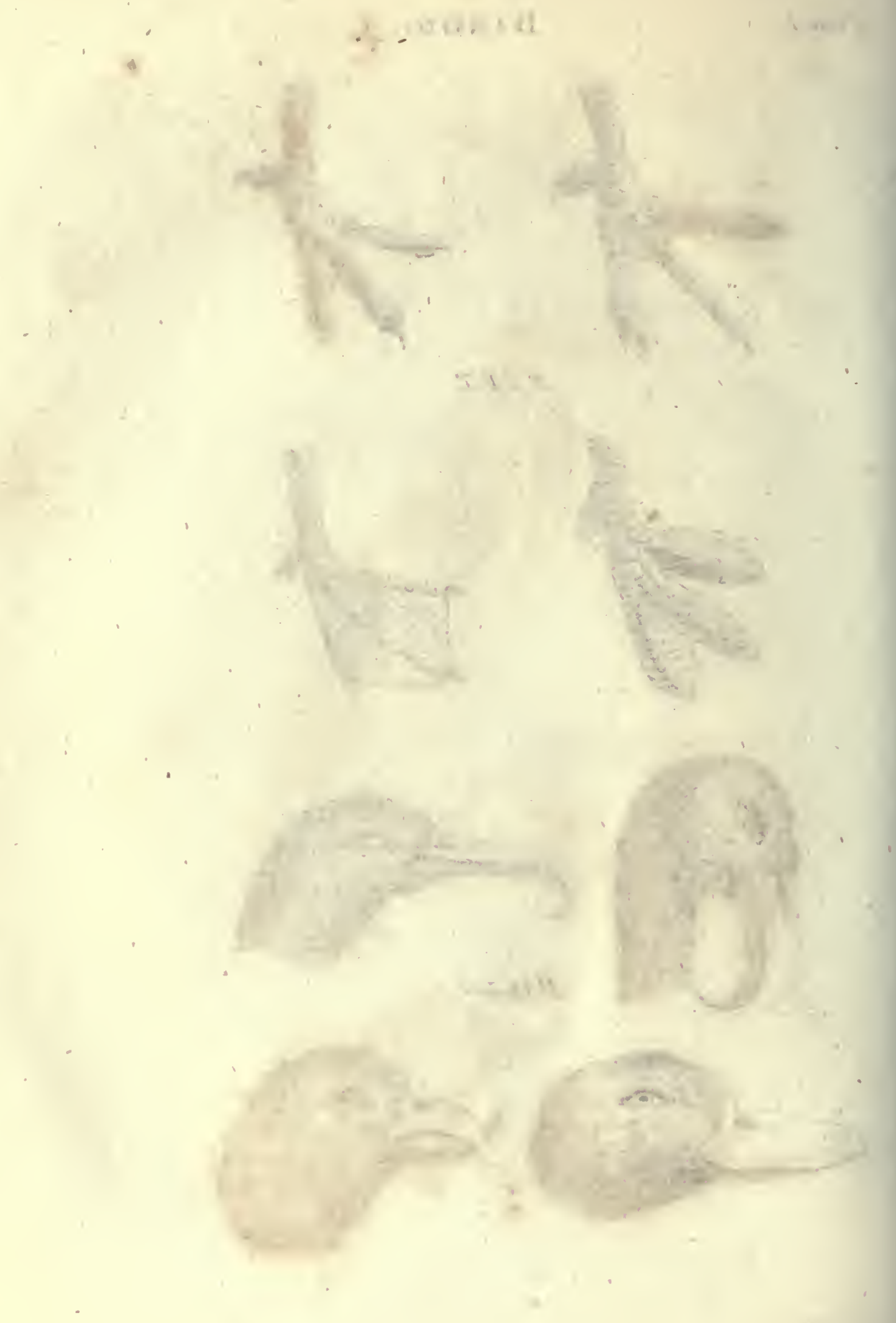




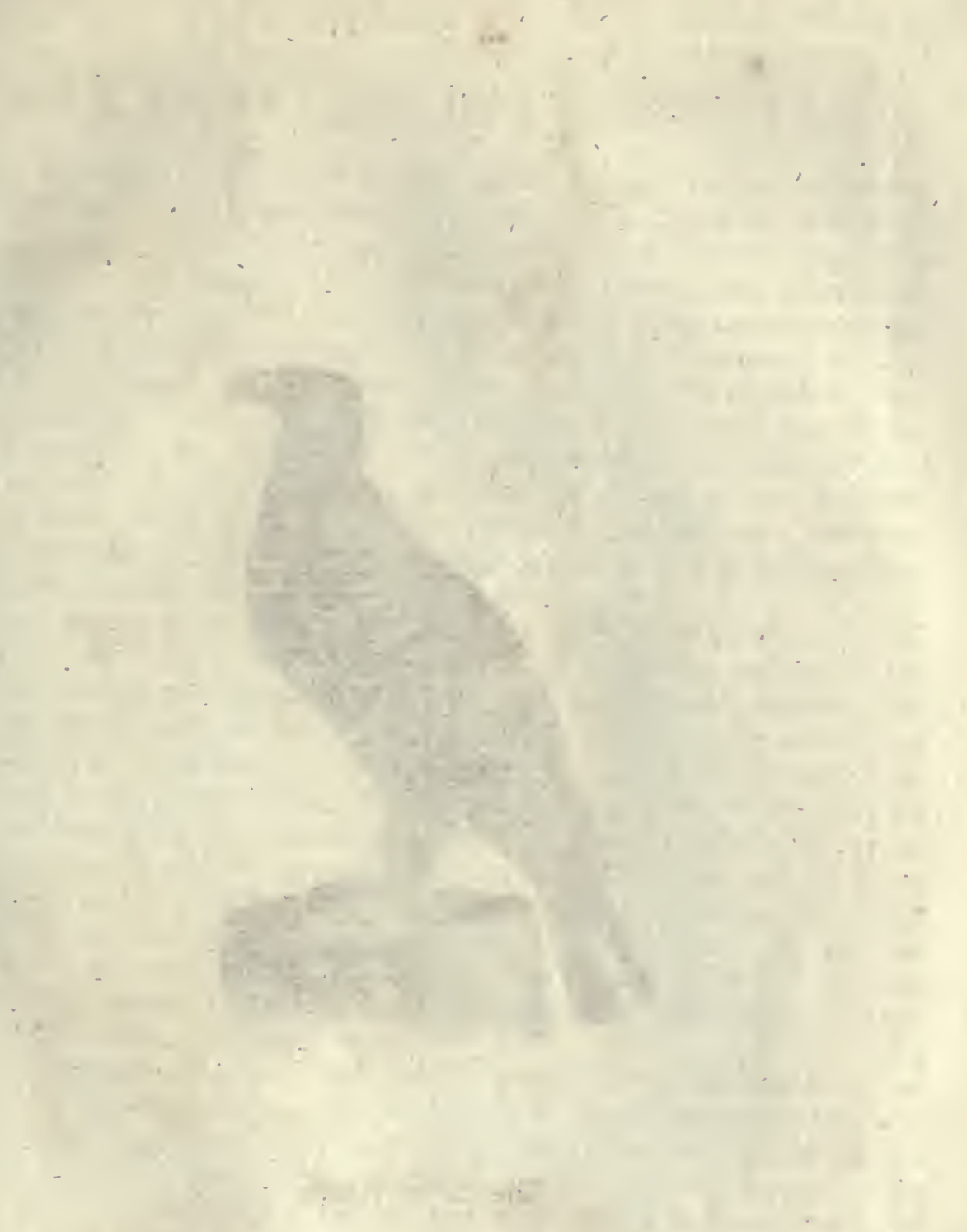




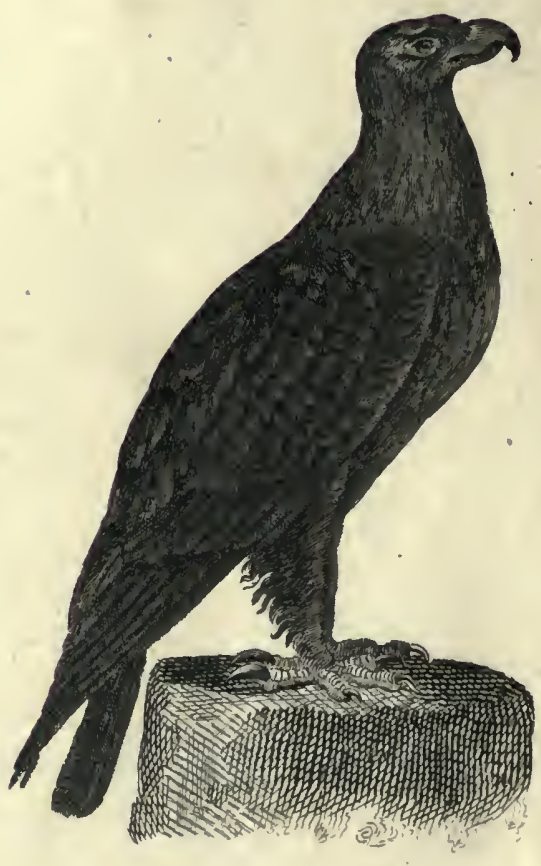

The Great Fagle. 


\section{THE EAGLE, AND ITS A F F I N I T IES.}

F thefe the Golden Eagle is the largett. Weighs twelve to eighteen pounds. His length three feet to three and a half; extent of wings, feven feet to eight and a half; bill three inches long, deep blue colour; eye hazel. His fight and fmell very acute. Head and neck clothed with narrow Tharp-pointed feathers, deep brown bordered with tawney; thofe on the crown of the head, by age, become grey. The body throughout, is dark brown; the back feathers clouded with a deeper fhade. Wings reach to the end of the tail : 'The quill feathers are chocolate colour, the Thafts white. Tail deep brown, barred and blotched with obfcure afh-colour, ufually white at the roors of the feathers. Legs yellow, fhort, very ftrong, three inches in circumference, feathered to the very feet. Toes covered with large fcales, armed with formidable claws, the middle one two inches long.

Found in mountainous and ill-peopled countries; breed among the loftieft cliffs, the fame neft ferves them for life. Powerful but magnanimous, difdains finaller plunder; nor, till after long provocation, punifh s the teazings of the rook or the magpie. Difdains to thare the plunder of another bird : never ftoops to carrion; never returns to the fame carcafs. Solitary, keeps the defert to himfelf; of fparkling eyes; ftrong breath; loud and terrifying cry; fierce, proud, not eafily tamed, even by great patience and much art: though taken young, and fubdued by long affiduity, ftill dangerous, and often to its mafter. If, when let lcofe, it firft ftoop toward the ground, then rife perpendicularly into the clouds, it quits its domelticity for ever; but if brought to an attachment for its feeder, is highly ferviceable, both for pleafure and profit: will hunt not only game, but the fox, or wolf.

Of all biro's fies higheft, and has the quickeft eye (but his finell far inferior to the vulture). Purfues by fight. When he has feized his prey, ftoops from his height, as if to poife its weight: always lays it on the ground before he carries it off. Finds it difficult to rife when down; feizes geefe, cranes, hares, lambs, and kids; often deftroys fawns and calves, drinks their blood, and carries part of their fiefh to his retreat. Infants have been deftroyed by them. Smith, in his hiftory of Kerry, relates, that a poor man in that country got a comfortable fubfiftence for his family, during a fummer of famine, out of an eagle's neft, by robbing the eaglets of food, clipping their wings, and retarding their flight. PART IV. NO. 25 . 
Her eggs feldom exceed two in the larger fpecies, and three in the fmalleft. Are hatching about thirty days; frequently one egs is addled. It is afferted, that when the young are fomewhat grown, the mother kilis the moft feeble or the moft voracious. They are firft white, then yellow; at laft light brown. Age, hunger, captivity, difeafes, make them whiter. Is faid to live above an hundred years; and to die, not of old age, but from the beak turning inward on the under mandible, and thus preventing their talking food. Drinks but feldom, perhaps, at liberty not at all, as the blood of his prey ferves to quench his thirft.

The Sea-Eagle and the Ofprey live chielly upon fifh. Build their netts on the fea-fhore, by the fides of rivers, on the ground among reeds. Often lay three or four eggs, rather lefs than thofe of a hen. They catch their prey, by darting down upon them.

The Bald-Eagle of North Carolina has peculiar habits. When the eaglets are juft covered with down, and a fort of white woolly feathers, the female eagle lays again. Thefe eggs are hatched by the warmch of the recent young, whereby the flight of one brood makes room for its juft hatched fucceffors. Thefe birds fly very heavily. They often attend a kind of firhing-hawk, which they ftrip of its prey. Generally alfo attend fowlers in the winter, and feize birds that are wounded.

M. Buffon confiders, as genuine eagles, only the golden eagle firft defcribed, the common eagle, and the little eagle; thereby feparating thofe which refide entirely on land, from thofe which prey in waters.

The common eagle is brown, head and upper part of the neck inclining to red; tail-feathers white, blackening at the enc's; outer ones, on each fide, ah-coloured; legs covered with feathers of a reddih brown.

The bald eagle, brown; head, neck and tail-feathers white; thofe of - the upper part of the leg brown.

The white eagle, the whole whitc.

The rougb-footed eagle, dirty brown; fpotted under the wings, and on the legs, with white; the tail-feathers white at the beginning and point; leg-feathers dirty brown, fpotted with white.

The robite-tailed eagle, dirty brown; head white; ftems of the feathers black; rump inclining to black; tail-feathers, firft half blacliy the end half white; legs naked.

The erne, dirty iron colour above, iron mixed with black below: head and neck afh, mixed with chefnut; points of the vings blackins; tail-feathers white; legs naked. 
The black eagle, blackin; head and upper part of the neck mixed with red; tail-feathers, the firft half white, fpeckled wich, black, the other half blackinh; leg-feathers dirty whice; thought to be only a variety of the common brown eagle.

The fea eagle, inclining to white, mixed with iron brown; belly white, with iron coloured fpots; covert feathers of the tail whitifh; tailfeathers black at the extremity; the upper part of the leg-feathers iron brown.

The ofprey, brown above; white below; back of the head white; outward tail-feathers, on the inner fide, ftreaked with white; legs naked.

The fean le blans: above, brownin grey; below, white, fpotted with tawney brown; tail-feathers on their outfide and extremity brown; infide, white, ftreaked with brown; legs naked.

The eagle of Brafil, blackinh brown; afh colour, mixed in the wings; tail-feathers white; legs naked.

The Oroonoko engle: with a topping, above, blackin brown; below; white, fpotted with black; upper neck yellow; tail-feathers brown, with white circles; leg-feathers whire, fpotted with black.

The crowned Africen eagle, with a topping; the tail of an afh colour, ftreaked on the upper fide with black.

The eagle of Pondicberry: chefnut colour; the fix outward tail-feathers black one half. Said to be the molt highly ornamented bird of the kind, in regard to mixture of colours.

\section{THE VULTURE, AND ITS AFFINITIES.}

ULTURES are diftinguinhed by the nakednefs of their heads
and necks, which are only covered with a very few fcattered hairs. Their eyes are prominent. Claws thorter, lefs hooked than the eagle's. The infide of the wing covered with thick down, different from all other birds of prey. Their attitude and their flight heavy.

The Golden Vulture feems foremoft of the kind. From the beak to the tail, is four feet and a half; to the claws forty-five inches. The upper mandible nearly feven inches long; the tail.twenty-feven. Neck, breaft 
breaft and belly red; faint on the tail, deeper near the head: the back black; wings and tail yellowih brown.

Cruel, unclean, indolent; amazingly acute of fmell, having two large noftrils without, and an extenfive olfactory membrane within. Have both a crop and a ftomach; which may be regarded as a kind of gizzard, from the extreme thicknefs of its mufcles; whereby they feem adapted to eat corn, \&zc. when neceffary for fubintence.

In Africa and Afia, are found in great abundance. The infide down of their wing is converted into a warm kind of fur, and is fold in the Afiatic markets. In Egypt are great flocks of them around the city of Grand Cairo, which are protected, and repay that protection by their fervices, in devouring the carrion and filth which might otherwife corrupt the air. In America they follow the hunters, at a little diftance: when they fee a beaft flead and abandoned, they call out to each other, pour down on the carcafs, and pick its bones bare. "At the Cape of "Good Hope," fays Kolben, "they have a wonderful method of lepa" rating the fleth from the bones, yet leaving the fkin entire. It often "s happens that an ox returning home from the plough, lies down by the "s way: then, if the vultures perceive it, they fall furiouny down, and " inevitably devour him. They fometimes attempt them grazing, and, "s to the number of a hundred, or more, make their attack together. " Their fenfe of fmelling is fo exquifite, that the inftant a car"s cafs drops, the vultures, floating from all quarters, come foufing "s on their prey." They eat lambs, \&c. ferpents are their ordinary food. They perch, feveral together, on old pine and cyprefs-trees, where they continue all the morning, with their wings unfolded: nor are they fearful, but fuffer people to approach them very near, particularly when they are eating. Their noth, filth, and voracioufnefs almoft exceed credibility. When they have liberty to feed at their eafe, they fo, gorge themfelves, that they are unable to fly; but keep hopping along when purfued (at all times are of now flight, and with difficulty rife from the ground); being utterly helplefs: But they often vomit up what they have eaten, and then they ly off with greater facility.

There is perpetual enmity between the vulture of Brazil, and the crocodile, which lays its eggs (above a hundred) in the fands, on the fide of the river. She takes every precaution to hide the place : but a number of vultures (or galinafós, as the Spaniards call them) fit, filent and unfeen, concealed in fome neighbouring foreft, and view her opefartions. 'They wait till the has laid all her eggs; has covered them care- 
7

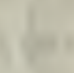

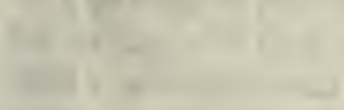

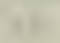
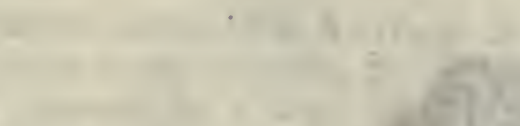

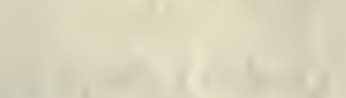

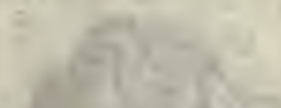

a

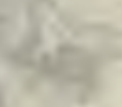

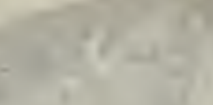

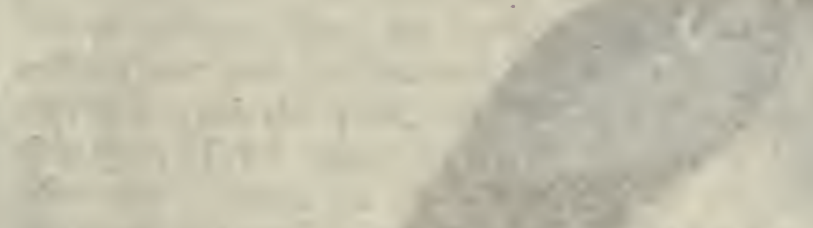

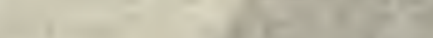

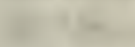

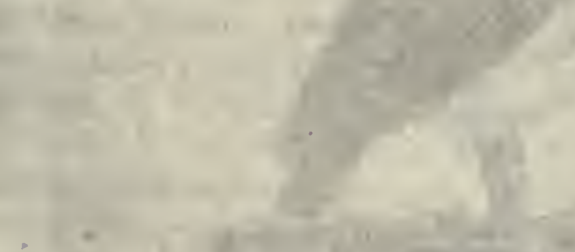

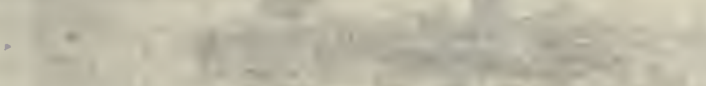
12

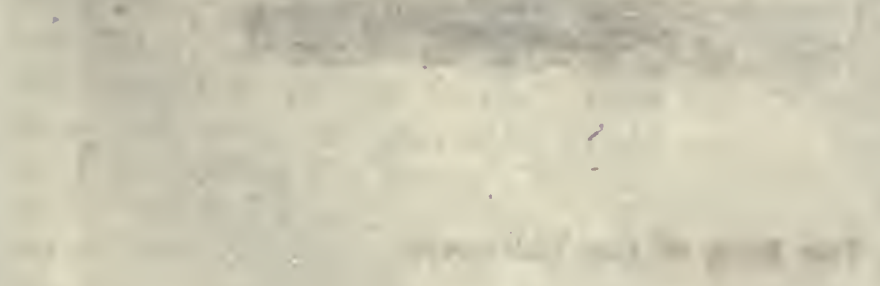




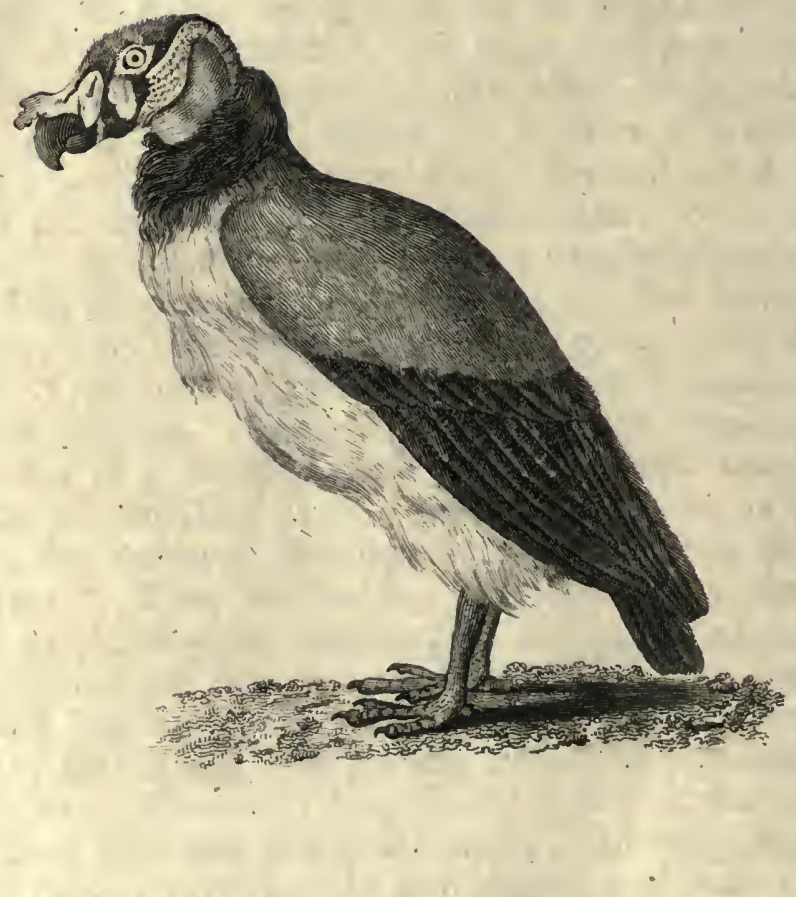

The Ifing of the Vultures. 
fully under the fand, and is retired; then, encouraging each other with cries, they pour down on the neft, lay the eggs bare, and devour the whole brood without remorfe.

Lay two eggs at a time, produce once a year. In Europe make their nefts in inacceffible cliffs, nor defcend but when forced by inclemént feafons. Among the moft remarkable birds of this clafs, is the following-

The king of the vultures is native of America, in fize equals a turkey; his wings not fo long as many vultures, his bill ftrong and thick, its bafe environned and covered with a large indented orange-coloured fkin, rifing to the head, fomewhat like the comb of a cock; in this are placed the noftrils, which are oblong; this comb falls on either fide, according to the movement of the bird's head. The eyes are furrounded by a fcarlet-coloured $\mathrm{Kkin}$, the iris has the colour and lultre of pearl, the head and neck are without feathers; covered with a fkin, which is fleh-coloured on the top of the head, bright red behind, durkier before. Below the hind part of the head rifes a littie tuft of black down, from whence iffues and extends on each fide, under the throat, a wrinkled fkin; brownifh, behind mingled with red and blue, ftreaked with little lines of black down; the cheeks or fides of the head are covered with black down; and between the bill and the eyes, behind the corner of the bill, is on each fide a fpot of brownif purple; on the upper part of the neck, is on each fide a fmall longitudinal ftreak of black down; the fpace between them dufky yellow, the fides of the neck are red gradually changing to yellow; below the naked part of the neck; is a collar formed by long foftin feathers, deep an-coloured, which furrounds the neck, and falls on the breaft. Into this collar the bird fometimes thrinks his neck, and part of his head, as into a kind of hood, whence fome have called him monk. The breaft, belly, thighs, and legs, are white; the wings and tail black. The feet are in fome yellowin, in others blackifh; the claws are thort and crooked. It is the moft beautiful of the family. Neither its habits or inftincts vary from thofe of the tribe; being now, cowardly, living on rats, lizards, ferpenis, and carrion or excrement, when it happens. The flefh is fo bad, that even favages themfelves cannot abide it. 


\section{THE F ALCON, AND ITS ÁFINITIES.}

A $\mathrm{F}$ many of the ancient falcons, formerly ufed in the chace, we know only the names. Thofe ufed at prefent, are the gyr-falcon, the falcon, the lanner, the facre, the hobby, the keftril, and the merlin. Thefe are called the long-winged-hawks, to diftinguifh them from the gofs-hawk, the fparrow-hawk, the kite, and the buzzard, that are of Morter wing; and too now, cowardly, indolent, or obftinate to furnifh amufement in the field. Of the generous tribe of hawks, the wings reach nearly as low as the tail. The firt quill of the wing longeft; which the fecond always nearly equals, and terminates in a point, which begins to diminish at about an inch from its extremity. In the bafer races, the tail is longer than the wings, the firt feather of the wing is rounded at the extremity, and the fourth feather the longeft.

The generous race is from this length of wing fwifter, from their fwiftnefs bolder, and, from native generofity, more docile than the other.

The gyr-falcon exceeds all others in fize, approaching nearly in magnitude to the tagle. The top of the head is Aat, afh-coloured; bill blue, ftrong, thick, fhort; on the back and wings marked with black fpots heart-hiaped. Courageous and fierce, he fears not the eagle himfelf; but chiefly flies at the ftork, heron, and crane. Native of the colder regions of the North, but maintains his ftrength and courage in milder climates.

The falcon-gentil and the peregrine-falcon, are much lefs than the gyr, and about the fize of a raven. The falcon-gentil moults in March, often fooner; the peregrine-falcon moults in Augurt. 'The peregrine is Atronger in the fhoulder, has a larger eye, more funk in the head, his beak ttronger, longer legs, and his toes better divided.

The lanner is now little known in Europe. The facre is diftinguifhed by legs of a bluein colour. The hobby is uled for fmaller game, for daring larks, and ftooping at quails. The keftril was trained for the fame purpofes. The courage of the merlin, though he is not much larger than a thrum, is formidable to birds ten times his fize. He has often been known to kill a partridge or a quail at a fingle pounce. In this he may be confidered as a fpecimen of the fpecies.

The hare, partridge, or quail profitably repay the trouble of taking; but the moft delightful fport is the chace of the heron, kite, or wood-lark. For thefe, when threatened by the approach of the hawk, rife into the fkies, 
almoft perpendicularly (accompanied by their ardent purfuer, who tries to rife above them), till they are loft in the clouds; they defcend ftruggling together; but after a defperate defence, the falcon proves victorious. When a lark is purfued by a couple of merlins, the amufement is, to fee one of them mounting to get the afcendant of the lark, while the other, lying low for the beft advantage, waits the fuccefs of its companion's efforts; thus, while one ftoops to ftrike its prey, the other feizes it coming down. The kite or the gofs-hawk approach their prey fide-ways : thefe falcons dart perpendicularly on their game; defcending from the clouds an amazirg herght, with inevitable fivifnefs.

The bafer races being lefs courageous are more patient; and, lefs fwift, are more cunning. The kite, ditinguithed by his forky tail, and his low floating motion, feems almont ever on the wing, and to reft on the air without effort. He lives on accidental carnarge; ever prowling, hungry and cefperate; is exquifite of fight; when to us invifible by his height, will fly round and sound to mark a clutch of chickens, and fuddenly dart like lightning on one of the brood, and carry it off in fpite of refintance.

There is a black kite, whofe tail is not forked, in fize rather lefs.

The buzzard is nuggin, inactive, and often remains perched whole days on the fame bough. Lives more on frogs, mice, and infects, than on birds; or by robbing the nefts of orher birds, and fucking their eggs. His figure expreffes ftupidity of difpolition. Some are white, fome have whirin heads, others are fpotted.

The honey-buzzard, the moor-huzzard, and the hen-harrier, all of this ftupid tribe, differ chiefiy in fize, growing lefs in the order named. The gofs-hawk and fparrow-hawk are fhort-winged, and unfit for training, however injurious they may be to the pigeon-houfe. Length of body 20 or 21 inches; extent of wings expanded, four feet and a half; tail eight inches.

This kind being greatly fpread has feveral varieties in foreign parts, differing rather by plumage than manners, and by dimenfion than conformation. 


\section{B U T T C H E R - B I R D S.}

THE great Butcher-Bird is about as large as a thruh ; is an-coloured; its bill black, an inch long, and hooked, whereby, together with its carnivorous appetite, it ranks among rapacious birds; its legs and feet flender. The leffer Butcher-Bird is little above the fize of a lark; the fmalleft not fo big as a fparrow. Live as well on flefh as on infects, and thus partake, in lome mealure, of double qualities.

The moft redoubtable birds of prey refpect them; the kite, the buzzard, and the crow, feem rather to fear than feek an engagement. Nothing in nature better difplays the refpe $\&$ paid to courage, than to fee this little bird, apparently fo contemptible, fly in company with the lanner, the falcon, and other tyrants of the air, without fearing their power, or avoiding their refentment. Small birds, which are its ufual food, it feizes by the throat, and frangles in an inftant. When it has killed a bird or infect, it is afferted that it fixes them on fome neighbour.. ing thorn, and, when thus fpitted, pulls them to pieces with its bill. It is fuppofed, that as Nature has not given this bird ftrength futficient to tear its prey to pieces with its feet (as hawks do) it has recourle to this expedient.

During fummer, fuch of them as conftantly refide here (for the finaller reci butcher-bird migrates in autumn, and returns in fpring) remain among the mountainous parts of the country; but in winter they defcend ints the plains. The larger kind neftle on the higheft trees; the lefier build in bulhes; lay about fix eggs, white, encircled at the bigger end with a ring of brownith red. The female feeds her brood with caterpillars and other infects while very young; but foon accuftoms them to teen, which the male procures with furprifing induftry. The whole brood live in one family, generally compoled of the male, female, and five or fix young. It is eafy to diftinguith thefe birds at a diftance, not only by their going in companies, but by their manner of flying, which is always up and down, feldom direct or fideways.

The woodchat is brown, and not red. There is ftill another, lefs than the former, found in the marnhes near London; a bird of prey, though 
not much bigger than a tit-moufe. Of foreign birds of this kind there are feveral varieties, whofe manners are little known. The hot climates produce moft, and among them one tufted.

\section{O F T H E

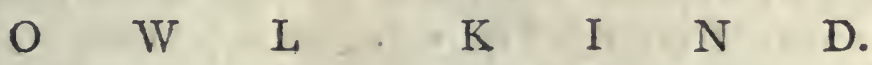

D IRDS of this kind have one common mark, by which they are 13 diflinguifhed: their eyes are formed for feeing better in the dufk than in fun-thine, whereby they are fitted for a life of noturnal-depredation. In thefe birds the pupil is capable of opening very wide, or Shutting very clofe; befide this, there is an irradiation on the back of the cye, and the iris has a faculty of reflecting the rays of light, to affift vifion in gloomy places, where thefe birds frequent: but they do not fee beft in the darkeft nights, but in the dufk of evening, or the grey of morning. When the moon thines is the time of their moft fuccefsful plunder. The faculty of nocturnal vifion is not alike in all : fome fee by night better than others; and fome are fo little dazzled by day-light, as to perceive their enemies. 'The white, or barn-owl, fees with fuch exquilite acutenefs in the dark, that though the barn has been fhut at night, and the light excluded, it perceives the fmalleft moufe that peeps from its hole; and the brown horn-owl is feen to prowl along the hedges by day, fometimes with fuccefs.

Owls may be divided into thofe with horns, and thofe without. The horns are two or three feathers that ftand up on each fide the head over the ear.

Of the horned kind is, the GREAT HORNED OWL, which appears as large as an eagle; but obferved more clofely is much lefs; his extent of wing about five feet : his horns are compofed of feathers, that rife above two inches and a half, and which heican erect or deprefs at pleafure; his eyes are large and tranfparent, encircled with an orange-coloured iris; his ears large and deep, probably he poffeffes mott exquifitely the fenfe of hearing; his plumage is reddifh brown, marked on the back with black and yellow fpots, on the belly yellow only. 
The COMMON HORNED OWL is much fmaller; his horns, about an inch long, confift of fix feathers, variegated with black and yellow; his extent of wing about three feet. A fmaller'kind of horned owl is little larger than a black-bird, whofe horns, remarkably fhort, are compofed but of one feather, not above half an inch high.

To thefe fucceeds the tribe without horns. The HOWLET is the largeft of this kind, with dufky plumes, and black eyes; the ScréchOw 1 fmaller, with blue eyes, and iron-grey plumage; the Wurte Ows, about equal in fize, with yellow eyes and whitilh plumage; the Great Brown Owh, lefs, with brown plumage and a brown beak; and the Litrie Brown Owh, with yellowifh-coloured eyes, and orange-coloured bill.

In proportion as one of thefe bears day-light beft, he begins earlier in the evening his purfuit of prey. The cavern of a rock, a hollow tree, the battlements of a ruined caftle, wherever is obfcurity, there they retreat; if they be feen out of thefe in the day-time, they may be confidered as wandering, and furrounded with danger. At the approach of evening they fally forth, and fkim along the hedges; but the barn-owl, who lives chiefly upon mice, takes his refidence upon fome flock of corn, or the point of fome old houfe; and there watches in the dark, with the utmoft perfpicacity and perfeverance. They all have an hideous note, which has fomething terrifying in it; as in the filence of midnight, it breaks the general paufe with a variation, alarming and difagreeable. The prejudices of mankind have united with their lenfations to make the cry of the owl difagreeable, and the fcreech-owl's voice was confidered among uninformed people as ominous, whereas it is his nute of tendernefs to his mate. While preying, they are filent.

When one is furprifed by day-light, he takes fhelter in the firft tree or hedge that offers concealment, but often, with all his precaution, is defcried by the birds of the place. The fmalleft, the feeblent, the moft contemptible of his enemies, are then foremoft to torment hin. They increafe their cries and turbulence round him, and flap him wich their wings. Aftonifhed and dizzy, he only replies to their mockeries by awkward and ridiculous geftures, by turning his head, and ftupidly rolling his eyes. An owl by day fets the whole grove in an uproar. Sometimes they hunt him till evening returns; but this reftoring him his fight, thofe birds, which a few minutes before came to provoke their enemy, now Bly him with tersor, as lately they teafed him with infolence. 


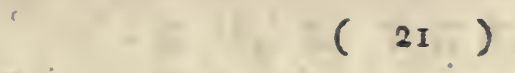

O F T H E

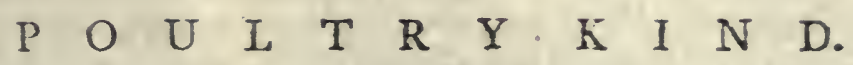

T NDER this clafs we may rank our cork, peacock, turkey, pintada or Guinea-hen, pheafant, buftard, grous, partridge, and quail. Thefe being granivorous, fiefhy, and delicate, are among birds, whar - beafts of pafture are among quadrupeds. Their thorr wings are il! formed for wandering, and their thorr bills for offence; their legs are ftrong; but their toes made for fcratching up, and not for holding or tearing; while their aptitude to fatnefs and fleth, renders them unwieldy, and almoft local, incapable of ftraving far' from each other. They are furnifhed with a very ftrong ftomach (or gizzard); their vorarioufnefs fcarce knows any bounds; even in captivity, they enjoy the pleafure of eating; and foon grow fat and unwieldy.

Among the habits peculiar to this clafs of birds is that of dufting themfelves, by lying flat in fome dufty place, and with their wings and feet fcattering the cuft over their whole body. For what reafon is not eafy to explain, wherher to deftroy infects, or to prevent adhefion of their feathers.

\section{THE BUSTARD}

S the largeft land-bird native of Britain. The increafed cultivation E of the country, and the extreme delicacy of its fleh, has grreatly thinned the fpecies; notwithftanding it inhabits only the open plain, where its food is abundant, and where every invader may be feen at a diftance.

The male weighs about twenty-five pounds (the female is about haif. the fize: a remarkable-difference). The neck is a foot long, the legs a foot and a half, covered with fmall fcales; three toes on each foot; under the foot is a callous tubercle ferving as a lieel. The wings are nine fet from tip to tip; flies with great difficulty, but can continue feveral milcs. The head and neck of the male are ant-coloured; the back: 
barred tranfverfely with black and bright ruft colour. The greater quill feathers are biack; the belly white; the tail, confinting of twenty feathers, is marked with broad red and black bars, the legs dunky. The male (only) has a tuft of feathers, about five inches long, on each fide the lower mandible. He (only) has alfo a pouch, whofe entrance lies immediately under the tongue, capable of holding near feven quarts of water. This is probably filled upon proper occafions, to fupply the hen when fitting, or the young before they can lly.

They haunt the plains, downs, heaths and uplands. Their food is corn, berries, and large earth-worms, whofe moifture enables them to live on plains which furnim but little water. They fwallow pebbles like the oftrich. They have always centinels placed at proper eminences, which warn the flock of the finalleft appearance of danger. Are feldom thot, buc often run down by greyhounds; having fed themfelves fo very fat, that they are unable to fly without great preparation, which gives an advantage to their purfuers.

They feparate in pairs about the latter end of fummer, if there be a fufficiency of females; if not, the males fight till one of them falls. The male fruts around the female, and fpreads his tail like a turkey-cock. They neftle on the ground, juft fcraping a hole in the earth, fometimes lining it with a little long grafs or ftraw. Lay two eggs, the fize of a goole-egg, pale olive brown, marked with darker fpots. They hatch in about five weeks, and the young run about as foon as they are out of the thell. They affemble in flocks in October, and keep togecher till April.

There is a fmaller buftard not half the fize of this, being only eighteen inches long, but of the fame manners. Found in France; is rare. Its fleth is brown, but excellent. Cunning to a proverb.

Mr. Pennant places the Stone-Curlew as a third of this kind.

In Arabia is a tufted buftard, called Lo-pong.

In Africa a buftard aln-coloured, and black; which has been miftakenly called a flying-oftrich.

In India, a fmail kind with longer legs, colours black, brown; and grey; inhabits Bengal. 


\section{$(-23)$ \\ THE TINAMOUS}

DARTAKES much of the buftard and partridge. But whereas thefe European birds never perch on trees, thofe which refemble them in America perch; and even many of the web-footed kinds (which is Europe is never feen): for though they frequent the water in the daytime, they return to rooft on trees at night. To this they are prompted by necefity, as weil to avoid jaguars and beafts of prey, as ferpents, and the innumerable hofts of infects which fwarm in thofe countries. The ants alone compore immenfe columns, and would quickly devour any young birds they could envelope during their neep: cerrain quails which live on the ground are often fwallowed by ferpents. Perhaps thefe quails are new-comers, and hereafter may improve in carefulnefs.

The tinamous is aften called partridge by the colonitts: but has a nender bill, long, foft at its extremity, black above, white below; notirils oblong, placed toward the middle of the bill; the nind toes fhort; nails long, large, and hollow; feet fcaly; wings (thort. They perch upon trees during night, fometimes during day ; never feek greas trees, or high branches. Are of white fleh, good to eat, feed on fruits, or coffee-berries. Scratch a hole for their neits, lay many eggs, liy heavily, but run fwiftly; the female exceeds the male in fize, which in Europe is peculiar to birds of prey. There are many varieties; one equal to a pheafant in fize. They live in woods. A fmall kind neftles in trees among the low brancies.

\section{$\begin{array}{llllllllllllllll} & T & H & E & & -T & U & R & K & E & Y & \end{array}$}

TITH us, when your:g, is the tenderent of bircls; yet wild, it is found in plenty among the forefts of Canada, where they go in troops of hundreds: much larger than in their ftate of domenticity, and more beautiful; their feathers being dark grey, bordered on the edges with bright gold colour. The Indians hunt them with a dog, which, when they firit difcover, they leave far belind: he follows, fenlible they murt foon be tired, as they cannot go fuli peed long; and at laft, forces them to take helter in a tree, where they fit quite fpent and fatigued, till the huncer comes up, and, with a long pole, knocks them down: if one is thot, the others never attempt an efcape, or take warning.

PART IV. NO. 25. 
Stupid, vain, querulous, yet without weapons. Every body knows the Atrange antipathy of the turkey-cock to red; how he fwells, and, with his pecular gobbling, flies to brave it. If the head of a turkey be fmeared with dirt, the reft run to attack it with all fpeed. Two of them, thus difguifed, will fight each other till almoft fuffocated with fatigue and anger. Weak and cowardly againft other animals; there is none, how contemptible foever, that will boldly face the turkey-cock, but he will $\mathrm{Ay}$ from: while, with the infolence of a bully, he purfues any that feems to fear him; yet fometimes they will defend themfelves againft vermin, as ferrets, \&c.

The temale feems milder. Hunts about in queft of grain and infects; is delighted with the eggs of ants and caterpillars. Lays eighteen or twenty eggs, larger than thofe of a hen, whitilh, but marked with fpots refembling frẹckles. Her young are extremely tender at firft, and often have not ftrength to pierce the fhell which includes them.

Some are white, others black and white; often white and brownith yellow.

Properly fpeaking, the turkey has two tails, one fuperior, the other inferior; the firtt compofed of eighteen great feathers, which he can erect at pleafure, the other horizontal, as ufual. The male has a fpur on his leg. Some are tufted.

When grown up, turkies are hardy birds, bearing even expofure to the rigour of winter, and feed themfelves at very little expence. Thofe of Norfolk are faid to be the largeft of this kingdom, weighing from twenty to thirty pounds. - In the Eaft Indies (where they are known only in their domeftic ftate) they grow to the weight of fixty pounds. Abundant in the Antilles, where they breed three or four times a year.

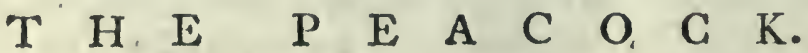

TT HEN this bird appears with its tail expanded, none of the feathered creation can vie with its beauty; but its horrid fcream abates the pleafure of viewing it, while its gluttony and depredation render it a noxious domettic. Sheds its tail annually, and then conceals tfelf, as if afhamed. Is faid to be very fufceptible of flattery, and to 
fpread his tail if careffed, but if contemned, to clofe it. Is two years coming to maturity. Has a fpur on each leg.

Peacocks were brought from the Eaft. Indies: they are ftill found in valt flocks; wild, in the inlands of Java and Ceylon.

The peacock's Alem keeps longer unputrefied than that of any other animal; even feveral years. The peacock feeds on corn, prefers barley. Is very proud and fickle; every kind of food it will at times covet and purfue; infects and tender plants often. Though it flies heavily, walls cannot eafily confine it; it ftrips the tops of houfes of their tiles or thatch, lays wafte the labours of the gardener, roots up his choiceft feeds, and nips his favourite flowers and buds.

He requires five females at lealt; and if there be not a fufficient number, he will even force the fitting hen. For this reafon, the peca-hen endeavours to hide her neft. She fits twenty or thirty days. She lays five or fix eggs in this climate before the fits. Ariftotle fays twelve; and probably, in her native climate, the may be more prolific: In India to twenty or thirty. The young do not hew their tufts till they are a month old: the cock does not acknowledge them till then, but drives them off. Being troubled with infects, they fratch each other on the head.

There are varieties of this bird, fome of which are white; yet retaining fome marks of the eyes on their tail-feathers, others crefted: that which is called the peacock of Thibet, is the molt beautiful of the feathered. creation, containing in its plumage all the moft vivid colours, red, blue, yellow, and green, difpofed in an almoft artificial order, to pleafe the eye.

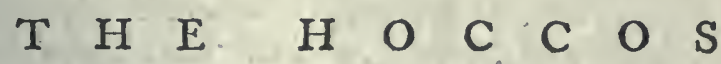

A RE ftrangers to Europe, and belong only to the hot climates of A America. Their various names, as given by various tribes of Indians, have greatly augmented their feeming numbers: their real varieties are confiderable.

The hocco is nearly the fize of a turkey; diftinguifhed by a creft, ufually black, fometimes black and white, two or three inches high, reaching from the bafe of the bill to the back of the head: this the bird 
can erect or deprefs at will : the creft is compofed of narrow feathers inclining baekward, but their points bending forward: among them are feveral inclofed in a kind of covering half their length. The reigning colour of the plumage is black velveted, fometimes fpeckled with white. Soine have a yellow fkin at the bafe of the bill, which includes the noftrils; this $\mathrm{fkin}$, extending on each fide the head, furrounds the eyes; in others, it becomes a kind of knob on the bafe of the fuperior mandible. Peaceable, and even ftupid, fociable, and domettic, eafily tamed; though one wanders far in the day -time, he returns at evening, and knocks at the door for admiffion; pulls the fervants by their clothes, when they forget him : follows his mafter every where. In his wild ftate, inhabits the mountains; feeds on fruits, perches on trees during night; flies heavily, walks boldly; his flefh is white, good eating, but rather dry.

\section{THE PHEA SA N T}

TX A S brought into Europe from the banks of the Phafis, a river of Colchis, in Afia Minor; from whence their name; and are faid to be firft brought by the Argonauts in their famous expedition. Thefe are ftill the fineft known.

Next to the peacock, are the moft beautiful of birds, as well for the vivid colour of their plumes, as for their happy mixtures and variety.

The iris is yellow, the eyes furrounded with farlet, fprinkled with Imall fpecks of black. On the fore part of the head are blackifh feathers mixed with hining purple. The top of the head and the upper part of the neck are. tinged with a hining darkin green. In fome, the top of the head is of a thining blue; the head, and upper part of the neck, appear either blue or green, as differently beheld by the fpectator. The breaft, thoulders, middle of the back, and the fides under the wings, have a blackinh ground, with reflections, black or purple, according to different lights, under which is a tranfverfe treak of gold colour. The tail, from the middle feathers to the root, is about eighteen inches; the legs, feet and toes, are dufky. On the legs are black fpurs, fhorter than thofe of a cock. A membrane larger than ufual among the poultry kind connects the toes, as if advancing to the water-bird claffes. The male is molt beautiful. Its fle $\mathrm{h}$ is confidered as the greateft dainty. 
The pheafant has multiplied in its wild ftate, and, as if difdaining the protection of man, has taken thelter in woods and forefts (not mountains), attached to its native freedom; and now wild among us ornaments our parks and plantations, where he feeds on acorns aid berries. (In Italy, \&c. frequents marhes.) This fpirit of independance feems to attend the pheafant in captivity; and is fo influential as to render him folitary. In the woods, the hen lays from eighteen to twenty eggs; in a domeftic ftate, feldom above ten. Is particular in making her own neft, in coverts; - when wild, the maintains her brood with patience, vigilance, and courage: when tame, the never fits well; and as for leading her young to their food, The is utterly ignorant where to find it, and they ftarve, if left folely to her. Sits twenty to twenty-five days.

They have no great fagacity, and are eafly taken. At night they rooft on the highelt trees of the wood, head under the wing; by day they defcend among the lower brakes and buhes. The female has farce any voice; that of the male is between the peacock and the pintado, confequently far from melodious. When taken young into keeping, they become as familiar as chicken; when they are defigned for breeding, they are put together in a yard, five hens to a cock. The young are very difficult to rear, and inuft be fupplied with ant-eggs, which is their food when wild: infects make a variety. Lives fix or feven years. From the common hen, coupled with the cock-pheafant (for the mixture is not barren), will be produced a fpecies tamer, ftronger, and more prolific. This is probably the cocquar, or baftard pheafant.

It is afferted by fome, that fuch is the carnivorous difpofition of this bird, that when feveral are in the fame yard, if one fickens, or feems to be pining, the reft will deftroy it.

There are white pheafants, black and white pheafants, crefted pheafants, fpotted pteafants; but of all others, the golden pheafant of China is the moft beautiful; his plumage red, blue, and gold. $\mathrm{He}$ is fmaller than the common. The iris, bill, and feet, yellow; his tail long, no red round his eyes. The female is at firft but dull in her colours, but in a few years acquires all the brilliancy of the male.

There is alfo a horned pheafant, having two horny: excrefcences on the head, blue, cylindrous, obtufe, inclining backwards. No red round his eyes, but black hairy-looking feathers, fomewhat of wattles under throat. His head red.

In America a bird not truly a pheafant, but reprefentative of the fpecies named KATracA. China and Thibet furnifh feveral birds allied to the pheafant, and to the peacock, without being truly either. 


\section{T H E}

\section{P.I N T A A, OR GUINEA-HE N,}

耳 $N$ fome meafure unites the characteriftics of the pheafant and the tur$1 \mathrm{key}$. Has the delicate fhape of one, and the bare head of the other; has been by Pliny called bumped, which, though it is not, it is roundbacked. Is about the fize of a common hen, but having longer legs, looks much larger. Has a round back, tail turned downwards. The head covered with a kind of cafque; the plumage black or dark grey, pretty regularly fpeckled with white fpots not unlike pearls; has wattles under the bill, which do not proceed from the lower chap (as in cocks), but from the upper, which gives it a peculiar air; while its reftlefs gait and odd chuckling found, often repeated; diftinguin it from all other birds.

By fome is called the Barbary-hen, by others, the Tamis bird, and by others, the bird of Numidia. We have named it from that part of Africa, whence probably it was firft brought to us.

In their native country, are feen in vaft flocks in queft of food. Their habits are like thofe of the poultry-kind. The male and female are fo alike, that they can hardly be diftinguifhed. The only difference lies in the wattles, which in the cock are bluinh; in the hen, more inclining tored. Their eggs are fpeckled: in our climate, they lay But five or fix in a feafon: but are far more prolific at home, where they will lay a hundred and fifty by proper treatment. They are kept among us rather for thew, as their fleth is little efteemed, and as they are troublefome to rear.

There are many varieties; fome quite white, fome with red combs, fome bluifh; fome with white bands on the breaft. Is a quarrelfome bird, of a ftrong bill, and weak head. Thofe of St. Domingo often frequent the marhes.

Mr. Buffon thinks they rather refemble upon the whole the partridge than the pheafant. Moft authors affirm that they little regard their brood. They live on grain and infects. This bird being African, hasi had many names: - formerly fome Mahometans fold them very dear to the Chriftians, under the name of the Jerufalem bird; but the fraud being difcovered, thefe refold them to other good Mufulmen at an extravagant rate, under the tirle of Mecca hens. 


\section{$29)$ \\ $\begin{array}{lllllllllllllll}\mathrm{T} & \mathrm{H} & \mathrm{E} & \mathrm{C} & \mathrm{O} & \mathrm{C} & \mathrm{K}\end{array}$}

THE cock feems the oldeft companion of mankind, and firft reclaimed from the foreft; in confequence, perhaps, he exhibits the greateft varieties; there being fcarce two birds of this fpecies completely alike. The tail, which ornaments the generality of thefe birds, is wanting in fome; and not only the tail but the rump. The toes, which are ufually four in the poultry kind, yet in a fpecies of the cock are five. The feathers, which lie fo orderly and neek in moft, in a peculiar breed are inverted, and ftand the wrong way: a fpecies from Japan, inftead of feathers feems covered with hair. Some have feathers to the feet, fome even to the claws. The cock was one of the foods forbidden among the ancient Britons.

The cock is found wild in the inland of Tinian, in others of the Indian Ocean, and in the woods on the coaft of Malabar. Here his plumage is black and yellow; his comb and wattles yellow and purple. The bones of thofe of the Indian woods, of the Philippine Inands, and of St. Jago, when boiled, are black. Probably this tincture proceeds from their food.

His wings being fhort, he rarely flies, crows indifferently night or day. Some hens crow, but feebiy. Drinks by raifing his head and fwallowing; neeps often ftanding on one leg, and hiding his head under his wing. On his head a comb, under his chin wattles, which are a double membrane. His claws, when four, are three before and one behind; when five, two behind. His feathers are remarkable, by growing in pairs from the flefl. His tail has fourteen feathers divided into two parts, uniting at the top. On his legs, fpurs. He is very watchful and fond of his hens, and jealous alfo.

No animal has greater courage than the cock when oppofed to one of his own fpecies.: In China, India, the Philippine Inands, and all over the eaft, cock-fighting is the fport of kings and princes. With us it is declining daily.

A fingle cock fuffices for ten or a dozen hens. But he foon grows old. Hens alfo, as they for the greateft part of the year daily lay eggs (in Samogitia, Malacca, and elfewhere, twice a day; in Illyria, fays Ariftotle, three times), for the moft part after three years become effete and barren: for when they have exhaufted all their feed-eggs, of which they had but a certain quantity from the beginning, they mult neceffarily ceafe to lay, there being no new ones generated within. 


\section{P O U L T R Y K I N D.}

The hen foldom clutches a brood of chicken above once a feafon. Will lay in a year above two hundred eggs, provided the be well fed and fupplied with water and liberty. Her neft is merely a hole fcratched into the yround among a few buthes.

If left to herfelf, the hen would feldom lay above twenty eggs, without attempting to hatch: but while her eggs are removed, the continues to lay: In the wild ftate, the hen feldom lays above fifteen eggs. "Nothing can exceed the perfeverance and patience of the fitting hen; the continues for fome days immoveable, forgetting even food; yet does not know her own eggs; or brood, but rears ducklings, even though they be water-fowl. She carefully turns her eggs, and removes them to different fituations; in about three weeks, the young give figns of a defire to burft their confinement. When, by the repeared efforts of their bills, they have broke the fhell, the continues fitting till all are excluded; then leads them forth to provide for themfelves: abftains from all food that they can fwallow; flies boldly at every invader, and even fometimes furprifes birds of prey into flight by unexpected refiftance; acts the commander, and by variety of notes calls her train to their food, or warns them of approaching danger.

Ten or twelve chicken are the greatent number a good hen can rear and clutch; but by the artificial method of hatching chicken in ftoves, as is practifed at Grand Cairo, they produce thoufands. In our colder climate, the little animal may equally be hatched, but few reach maturity.

A capon may eafily be taught to clutch chicken by gradually introducing them to his acquaintance.

Chymifts fay, the products of the Aefh of a cock and a capon are not alike; capons do not moult, nor crow diftinctly; but ear, neep, and fatten.

An experiment has been tried on young cocks, by grafting a fpur into their comb, which has taken root and grown to the length of two inches and a half, affuming the appearance of a horm.

The fpecies is fpread throughout the world; was introduced into America from Europe. Some are tufted, their comb is ufually fmall. The Madagafcar cock is extremely finall, the eggs very diminutive, fince the hen often hatches thirty. The Java and Bantam breeds are very fmall. Some are fo fhort-legged their wings trail on the ground. The frizzled breed, whofe feathers ttand up, are fuppofed to be natives of Afia. The Padua cock is extremely large, and has a double comb and a creft. 
tan +2

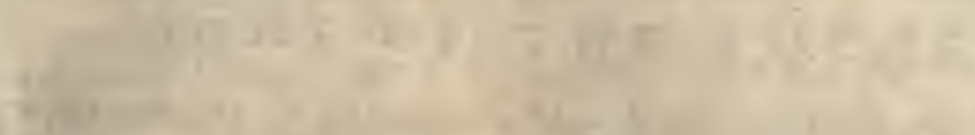

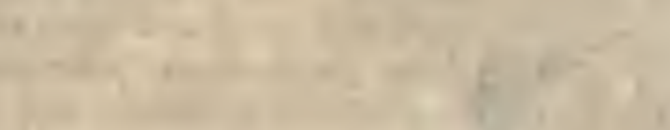

.

,

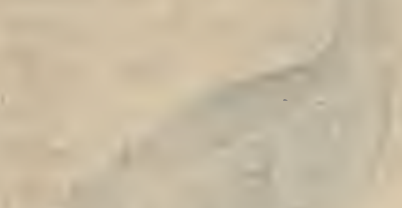

$+2$

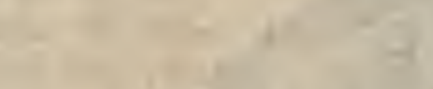

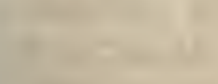
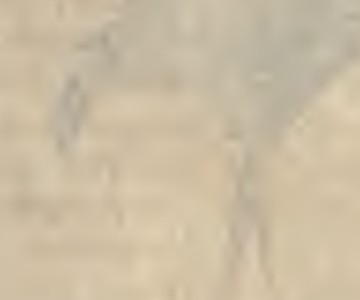

(1)

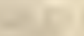

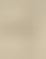

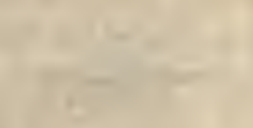

$\cdot x-1=14$

$-4$ 


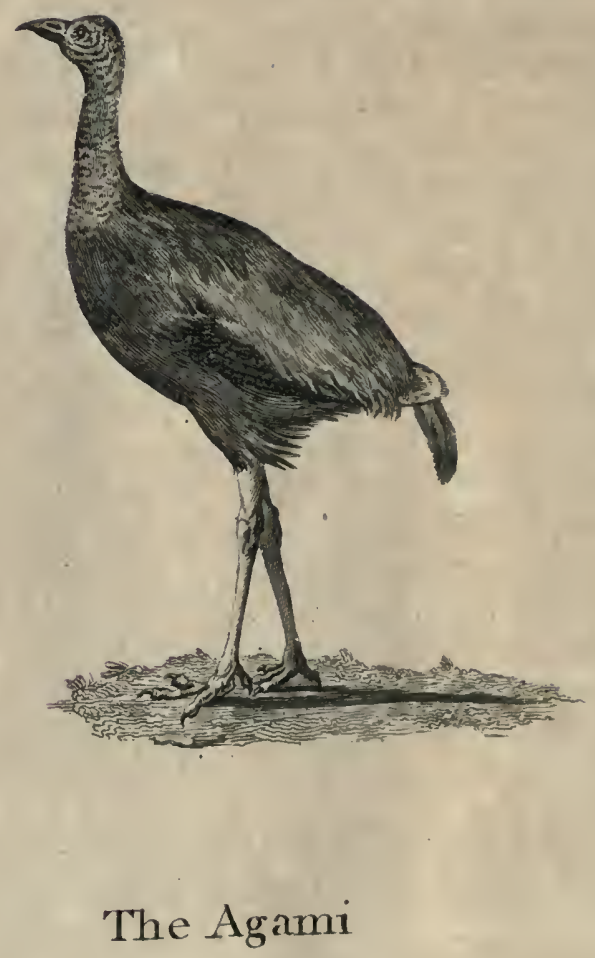




\section{( $\left.3^{\text {I }}\right)$ \\ T H E \\ C O C K O F T H E R O C K S,}

THOUGH of a uniform colour, is yet among the handfomett of America, becaufe his colour and plumage are beautiful. Eats fruits, perhaps for want of grain. He refembles the cock, but differs by the form of his toes, which are united by a membrane; the firft and fecond toes to the third articulation; the fecond toe to the third, only to the firtt joint. His bill is compreffed on the fides toward the extremity; tail thort and fquare; as alfo feveral feathers of his wings. His principal diftinction is his creft, which is placed longitudinally on his head, in the form of a femicircle. This creft is not fingle, but double, formed of two planes inclined to each other, and meeting at the fummit. The male is a beauriful red, the female brown. She has a creft, but lefs full, lefs elevated, lefs rounded, and further advancing on the bill than the male's. About the fize of a pigeon. The young male is brown, like the female; becomes red by time. Inhabits deep chafms among rocks, and dark caverns; fees and flies during day, but more and better by twilight.' They are very wild, can only be fhot; and that after great patience. Their flight rapid, but hort: they fratch the ground and beat their wings like the cock, but do not crow; their only cry refembles the fyllable ke. Wild among rocks, in a night nett, made of dry wood, lay two eggs, the fize of pigeon's. The males quit their caverns oftener than the females, which are rarely feen. May be tamed. There is a variety in Peru, which has a long tail; has black about his plumage; his creft lefs complete. Thefe might be thought the reprefentatives of our poultry in America; but that there are others, which, though lefs, refemble them clofer by the comb and tail, as well as general figure.

\section{T H E A G A M I}

TNHABITS mountains and high woods, like the partridge, and pheafant: is about two feet long; his bill refembles the cock kind; his tail thort, not beyond the wings when clofed, but overhot by the $\mathrm{F}_{2}$ back 
back feathers; legs five inches, fcaly; head, throat, and neck downy; the front of the neck fplendid; the back, and back of the neck black; the lower part of the back brownifh-red; the reft black, as alio the wings and tail; the legs greenifh.

This bird is fingular, by its power of making a noife, dull and deep, not unlike the cooing of pigeons; which has always been thought to proceed from the anus, but which rather may be fuppofed to be a particular motion of the lungs, whofe found is heard through the flefh: this tooo tooo he repeats feveral times, and often, when urged by the imitation of it by by-ftanders.

Are cleanly birds, drefs their feathers with their bills, leap and beat their wings freely. Eat grain, little filh, bread, \&c. Attach themfelves like a dog to a mafter, and diftinguifh him, leap upon, to falute him, trumpeting (as fome call it); runs to meet him when returning hoine; at home careffes him, and if he fuppofes a rival, drives him off; will peck the negro fervants on the legs, when they approach his mafter; obeys the voice of his mafter; loves to be ftroked and fcratched on his head and neck; comes to table without being called; drives off all the cats and dogs before he begins to eat; never runs away, but avoids the blows of his adverfaries by flying up, and falling on them. May be taught like a dog to guard, and to guide a flock of theep. Follows his mafter out of town, and returns with him. They often follow fomebody to whom they take a liking, will feek and find him out, and wait at a door two or three hours till he comes out; run if he runs, and ftop if he ftops. Some will attend ftrangers into the garden of a houfe, and walk with them in every turn and alley.

When wild, go in troops from ten to forty, fly little, but run much; and fwiftly. Neftle at the foot of fome great tree, where they make a hole, but no neft: lay ten to fixteen eggs: the young keep their firft down longer than chicken, \&c. till fometimes it is two inches long, and they feem like bealts covered with hair. The young are not bad caring, the old ones dry. 


\section{$\left(33^{\circ}\right)$}

THE

\section{GROUS, AND ITS A F F INITIES.}

T. HE Cock of the Wood, or larger Grous, refembles a cock in form, in bill, in the red $\mathbb{N}$ kin over his eyes, and in the fingularity of his feathers which grow two together; but has neither wattles nor fpurs. His legs are feathered, and his toes fomewhat indented. His tail is expanfible like the turkey's.

Is chiefly fond of a mountainous and wooded fituation, in temperate climates; but in Hudfon's Bay he prefers the plains. In winter he refides in the darkeft receffes of the woods; in fummer he ventures from his retreats, to make thort depredations on the farmer's corn. As he is greatly fought after, he is always on his guard, and feldom furprifed. Thofe who would take him, muft venture up to his native retreats. When in the foreft, attaches himfelf principally to the oak and the pine-trees; the cones of the latter ferving for his food, and the thick boughs for an habitation. Sometimes will ftrip one tree of its cones, before he vill deign to touch thole of another. Feeds alfo on cranberries, and ants' eggs, which feem a high delicacy to all birds of the poultry kind.

During February, March and April, this bird is feen at fun-ife and fun-fet, extremely active, on one of the largeft branches of a pine-tree. His tail railed and expanded; his wings lowered; he walks backward and forward, his neck ftretched out, his head fwollen and red, and making a thoufand ridiculous poftures : his cry, upon that occafion, is a kind of loud explofion, which is inftantly followed by a noife like the whetting of a fcythe, which ceafes and commences alternately for about an hour, and is then terminated by the fame explofion. All this time, the bird feems deaf and infenfible; even though fired at, he continues his call; and this is the opportunity fportfmen generally take to hoot him. At all other times, he is timorous and watchful; but now he feems entirely abforbed by his inftinets. This extraordinary cry, which is accompanied by a clapping of the wings, is no fooner finifhed, than the females hearing it, reply, approach, and place themielves under the tree, from whence the cock defcends. One cock will engrofs the females of a confiderable diftrict.

The female is much lefs than her mate, and entirely differs in plumage, fo that the might be mittaken for a bird of another fpecies: lays fix to 
nine eggs, white, marked with yellow; larger than a common hen's egg : the generally lays them in a dry place and a moffy ground, and hatches them without the company of the cock. When the is obliged, during the time of incubation, to leave her eggs in queft of food, the covers them up fo artfully, with mofs or dry. leaves, that, it is extremely difficult to difcover them. She often keeps to her neft, though ftrangers attempt to drag her away.

As foon as the young are hatched, they run after their mother, though fometimes not entirely difengaged from the fhell. The hen leads them into the woods. They are hardy, and their food is plentiful; but their numbers are thinned by rapacious birds and beafts of every kind; and ftill more by their own contefts. The brood follows the mother a month or two; at the end of which the young males entirely forfake her, and keep in harmony together till the beginning of fpring: then they confider each other as rivals : they fight like game-cocks; and are fo inattentive to their own fafety, that often two or three are killed at a fhot.

The BLACK COCK, is greatly fimilar to the foregoing in form and manners; but is much fmaller, not weighing above four pounds; is almoft black (the hen grey); and has a kind of forked tail, flat, and divided in the middle, the ends turning outward. They deepen in blacknefs gradually; and gradually acquire, as they become old, a number of white fipots on their tail. Sometimes eats fcarce any thing during two or three months in winter.

There is a!fo a black cock, whofe tail is not divided, but full.

Another kind, native of Courland, changes colours with the feafon. Niale and female are alike; do not perch upon trees.

Of much the fame general habits are the RED COCK of Scotland, that of the Alps, and the Ptarmigan : all may be known by the fcarletfkin above the eyes.

\section{TH E}

\section{PARTRIDGE, AND ITS VARIETIES.} $\mathrm{F}$ Partridges are two kinds; the grey and the red. The red is the
largert of the two, and often perches on trees; the grey, which is common in England, is moft prolific, and always keeps on the ground. Is found in every country, and in every climate; feems to adapt itfelf 


\section{THE CALAOS.}

horny. excrefcences equal in dimenfions: thefe birds are the fize of a turkey-hen. We thall defcribe one which may convey a good idea of the whole kind.

He was the fize of a raven, about two feet and a half long from bill to tail; his bill eight inches long, two inches wide, a little curved : a kind of fecond bill furmounted the firt, following its courfe; this reached to within two inches of the point of the bill, rifing two inches and a quarter ; the height of bill, and excrefcence together (in the middle), full four inches; this excrefcence has much the look of a fecond bill, but clofed, yet hewing a mark where it might almoft be thought to open, running down the midlt of it; this does not join the cranium, but a kind of forehead void of feathers, covered with a lkin, through which paffes the nourihment of this falfe beak. The true bill terminates in a blunt point, is of a horny fubftance, almoft offeous; the falfe bill very thin, and yielding to the fingers, is within cellulated like a honey-comb, is black at its termination, has a black line at its origin, as alfo at the root of the true bill, the reft yellowin white; the interior of the bill and palate black; at its root is a white folded fkin on each fide. The eye is red-brown; the head refembles that of the jay. In general, the appearance of this calao was a mixture of the jay, the pie, and the raven. His head and neck were black; he could elevate his tuft like the jay. His back and wings black, with feeble reflections of violet and green; on fome of his wing-feathers irregular borders of brown; the ftomach and belly dirty white; feet black, thick and fcaly; nails long, but not fharp. Leaped with both feet without walking, like the jay and pie; when repofed held his head backward. Eat flefh as well as fruits; incapable of bearing cold. The whole tribe are ignoble, and fome filthy, living on carrion; yet they are kept by the Indians to chafe rats and mice, which they fwallow whole, for they cannot tear or divide with their bill.

As the bill is the moft remarkable diftinction of this bird, as alfo of the Toucan, he may properly be followed by that bird.

\section{TH E T O U C A N}

I $S$ about the fize of, and haped like, a jack-daw, with a large head; its bill, from the angles of the mouth to its point, is fix inches and an half; its breadth, in the thickeft part, exceeds two; its thicknefs near the head is one inch and a quarter; it is a little rounded PART IV. No. 25. 
along the top of the upper chip, the under-fide being round alfo; the whole bill extremely night, and little thicker than parchment. The upper chap is of a bright yellow, except on each fide, which is a fine fcarlet; as is alfo the lower chap, except at the bafe, whch is purple. Between the head and the bill is a black line of feparation all round the bafe of the bill; in the upper part of which the noftrils are placed, and are almoft covered with feathers. Round the eyes, on each fide the head, is a fpace of bluin $\mathrm{kkin}$, void of feathers, above which the head is black, except a white fpot on each fide joining to the bafe of the upper chap. The hinder part of the neck, the back, wings, tail, belly, and thighs, are black. The under fide of the head, throat, and the beginning of the breaft, white. Between the white on the breaft, and the black on the belly, is a fpace of red feathers, in the form of a new moon, with - its horns upwards. The legs, feet and claws, are of an afh-colour; and the toes Atand like thofe of parrots, two before, and two behind.

Is harmlefs and gentle, eafily made tame, even to fit and hatch in houfes. Feeds chielly on pepper, which it devours greedily, gorging itfelf fo much, that it voids.it crude and unconcocted: and this the natives prefer. Grapes, being plucked off fingly, and thrown into the air, it will dexterouny catch before they fall to the ground. Its bill being very light, and fo thin, as eafily to bend by a night preffure with the fingers, has little ftrength, nor can it peck or ftrike fmartly therewith. Its tongue feems to affift its efforts; is long, thin and flat, and often extends tive or fix inches from the bill; of a flem colour, remarkably fringed on each fide with very fmall filaments, exactly refembling a feather; and is faid to be truly a feather.

Builds its nett in holes of trees, which have been previouny fcooped by fome ftronger bill; lays two eggs, leaving only a hole large enough to go in and out at. There it fits, with its great beak, guarding the entrance. Found in the warm climates of South America, where it is in great requeft, for the delicacy of its Alen, and the beauty of its plumage. Is erratic, go in troops of eight or ten, fly badly, frequent marfhes where the fofter fruits grow; though lively they feem heavy, and though active awkward, becaufe of the prodigious overbalance of their bill. They are fo fearful of cold, that they make a kind of warm bed of herbs, \& $c$. for the nights, in the hotteft climates. There are feveral varieties.

The A'rACARI is a toucan, fmaller, of lefs beak, and its fubftance harder. 


\section{OF THE M A GIE AND ITS AFFINITIES.}

THE MAGPIE is the chief of this kind with us, and is well known. Its black, white, green and purple, the rich and gilded combination of glofres on its tail, equal any that adorn the moft beautiful of the feathered tribe; but it is vain, reftlefs, loud, quarrelfome, intrufive, and mifchievous.

The magpie refembles the butcher-bird in its bill, which has a fharp procefs near the end of the upper chap, in Thortnefs of wing, and form of tail, each feather fhortening from the two middlemoft; ftill more in its food, living not only on worms and infects, but on fmall birds when they can be feized; a wounded lark, a young chicken feparated from the hen, and fometimes a black-bird: has been feen to attempt a crab, whofe pincers were however too fharp for it. Is capable of being trained for the chace, eafily becomes familiar, and even imperative; has been known to pars days and nights among a troop of cats, and to make its part good. Is capable of being taught to fpeak, and takes pleafure in it; ftudies its words, rejoices after the acquifition of new ones, and is vexed when they are too difficult. Often perches on the back of an ox or a heep, pecking up infects, chattering, and ftretching out its neck for combat; feeks out alfo the nelts of birds. Nothing feems amifs; it Thares with ravens in their carrion, with rooks in their grain, with the cuckoo in eggs; and when it is fatisfied for the prefent, lays up the remainder. Even when tame will hide its food when filled, and after a time return to its hoard with renewed appetite and vociferation.

Its neft is not lefs remarkable for arfful conftruction, than for fecurity of fituation. The place is always difficult of accefs. The body of the reft is compofed of hawthorn branches; the thorns fticking outward, but well united by mutual infertions. It is lined with fibrous roots, wool, and long grafs, and nicely plaiftered with mud and clay. A canopy defends it above, compofed of the Tharpent thorns wove together, and denying all entrance except at the door, which is jut large enough to permit egrefs and regrefs to the owners. The magpie lays fix or feven eggs, of a pale green colour, fpotted with brown. Watchics its neft very clofely, and defends it valiantly. If it obferves a man has handled its eggs, tranfports them elfehwere in its claws for fafety. The young are blind, and barely perfeet; the mother maintains them with much tendernefs. Lives twenty years. 
The fowlers fay, that if the obferves a man enter a hut at the foot of the tree where her nett is, fhe will not vifit her neft till he is gone. If two enter the hut, fhe watches both out; the fame for three, or four; if fix enter, and five come out, the is contented, and forgets the fixth.

To this tribe we may refer the $\mathrm{J}_{A Y}$, which is one of the moft beautiful of the Britifn birds. The forehead is white, ftreaked with black; the head is covered with very long feathers, which it can erect into a creft at pleafure; the whole neck, back, breaft, and belly, are of a faine purple, dafhed with grey; the wings are moft beautifully barred with a lovely blue, black, and white; the tail is black, and the feet of a pale brown. Feeds upon fruits, will kill fmall birds, and is extremely docile. Very petulant, lively, and quarrelfome, even to forgetting felf-fecurity; for they will fight over branches, and fometimes are ftrangled by being caught by the throat between two. In cages they beat themfelves to pieces. Neftle in woods far from habitations, preferring old oaks grown over with ivy. Often, in attempting to fteal birds caught in fnares, are themfelves caught. There is a white jay which yet retains the blue on his wings. The Rind is fpread in diftant parts.

The CHATTERER, native of Germany, may be placed in this rank; is a wandering bird; fometimes in fuch number's as to darken the fun; is fomewhat lefs than the former: is tufted, and variegated with a beautiful mixture of colours; red, afh-colour, chefnut, and yellow : but what difinguines it are horny appendages at the tips of feven, fometimes eight (or more) of the leffer quill-feathers, which ftand bare of beards, and have the colour and glofs of the bett red fealing wax. Feeds on berries and grapes; is very cleanly.

The Roller is not lefs beautiful. The breaft and belly blue; the head green; the wings variegated with blue, black, and white. Is diftinguilhed by. a fort of naked cubercles or warts near the eyes. Is a birc of paffage, fomewhat rare; inhabits Germany; dwells in thick woods; is quite wild; feeds on grain, \&c. are good eating in autumn. The Ara. bian Sbaga-rag.

The Nutcracker is a German bird, living on the mountains, and whofe manners are little known; there are two races. They do much mifchief among the trees, and lodge in them like the woodpecker Every fifteen or twenty years come in focks, or rather armies (like the Leming of Lapland), and devour much of the harveft: 


\section{(45)}

\section{O F T H E}

\section{WOODPECKER AND ITS AFFINITIES.}

I I E chiefly on infects contained' in the bodies of trees; for this purpofe have ftraight, hard, ftrong, angular, Tharp bills, fit for piercing and boring. Tongue long, round, tharp; dentated legs, fhort and ftrong; four thick, ftrong, nervous toes, ftanding two forward, and two backward; one of which is remarkably ftrong; all have very ftrong and crooked nails, which are particularly ferviceable in holding by branches of trees. They have ftiff hard tails, to lean upon when climbing; the feathers of which end more or lefs Jarply, and which contribute to fix them; for they often pafs a whole night in the attitude of ftriking, and neep while fo fituated.

Of this bird there are many kinds, and many varieties in every part of the world. They differ in fize, colour, ant appearance; the largeft equal a crow, the fmalleft a thrufh. Are moft numerous in warm climates.

The Green Woodspite, or Woodpecker, is called the Rain Fowl in fome parts of the country; becaufe, when it makes a greater noife than ordinary, it is fuppofed to foretel rain (the ancients thought it ominous). Is about the fize of a jay; the throat, breaft and belly are of a pale greenifh colour; the back, neck, and covert feathers of the wings green. The tongue is its diftinguihing characteriftic.

Feeds on infeets; particularly on thofe which lodge in hollow or rotten trees. Thefe it procures by its tongue. This is round, ending in a ntiff, Tharp, bony tip, dentated on both fides, like the beard of an arrow ; this it can dart three or four inches out from the bill, and draw in again at pleafure. Thus its prey is transfixed, and drawn into the mouth. When a wood-pecker has found a rotten hollow tree where there are worms, refting by its ftrong claws, and leaning on the thick feathers of its tail, it begins to bore with its fharp ftrong beak, till it difclofes the internal habitation; then it fends forth a loud cry, which terrifies the whole colony; while they creep hither and thither, feeking fafety, the bird feafts on the whole brood. Sometimes alights on the ground, to try iis fortune at an ant-hill, which it pecks, in order to call the inhabitants abroad; then thrufts out its long red tongue, which being like a worm, 
worm, the ants come out to fettle on in great numbers: the bird with draws'its tongue at a jerk, and devours the devourers.

The woodpecker choofes, however, for its neft, trees that are decayed, or wood that is foft. In thefe, it makes deep holes exactly round, but often makes twenty before one is found to give fatisfaction. Of thofe it deferts, other birds, not fo good borers, and lefs delicate, take poffeffion; the jay and the ftarling often, and fometimes bats. Its eggs are depofited in the hole, without any thing to keep them warm, except the heat of the parent's body. Their number is generally five or fix; white, oblong, and of a middle fize. When the young are excluded, and before they leave the'neft, they are adorned with a fcarlet plumage under the throat, which adds to their beauty.

\section{TH E C R E E P E R S}

A RE a numerous family, fpread in various parts of the world, A which creep along the trees, upwards or downwards; and along the branches, over them or under them; they alfo run very nimbly along beams, \&c. in houfes. Many of them refemble the tirlarks; others the colibris, by their beautiful plumage. They live intirely on infeets, but are unable to bore for their prey as the woodpecker does; they follow, therefore, thofe who are able to pierce the wood, and take the prey they meant for themfelves; or are content with fuch infeets as wander from their retreats, which, in the warmer climates e'pecially, are not a few.

The creeper is about the fize of a wren, extremely active and mobile; inhabits the hole of a tree, whence he iffues to ftrike the infects of the bark and mofs. Here the breeds; lays five to feven eggs.

The WALLCREEPER inhabits walls; there lodges, creeps, and lays. Inhabits rocks alfo, and church-yards; flies, ants, and efpecially fpiders, are their food.

At the Cape of Good Hope, the Dutch maintain'many of the creeper kind, by giving them fugared water: the flies, \&c. (which are the plague of the inhabitants) fupply the reft; they die if fed on any other food than infects. 


\section{$(47)$ \\ T H E H O O P O E S.}

THE Hoopoe is diftinguifhed by a double aigrette, or creft, which is almoft peculiar to himfelf (or refembled only by the Cockatoo), by his long bill, thin and curved, and his hort feet ; about equal to the thrufh in fize; belongs to the old continent. One of thefe birds, taken when full grown, became fo attached to its keeper, as to be jealous of the prefence of ftrangers, and to fet up his tuft; was always with his miftrefs, could not bear feparation, nor was he defirous of liberty. Was fo fond of mufic, as to ftand on the harpfichord fo long as his miftrefs played. Eats infeets; follows the courfe of the Nile in Egypt for this purpofe; in Europe are birds of paffage; neitle in the holes of trees, or in walls ; their nefts filthy, lay two to feven eggs.

\section{T H E P R O M E R O P S}

V RA T LY refembles the Hoopoe; has no creft, but two frizzled Tufts of feathers on each fide the body, compofed of nine leng feathers, which are capable of elevation, as are alfo fome of the fcapulary feathers, which, when raifed together, affume the form of a fan; thefe being ornamented with brilliant green, and changeable blue and violet, give a fort of garland-like appearance to the wings. From thefe frizzled feathers, originate on each fide a dozen or fifteen long feathers, which have the fame reflections. The head and belly are green, the reft chiefly black; bill and feet black; tail very long. One fpecies is orangecoloured.

\section{T H E B E E - E A T E R S}

$A$ RE fo named from their food; not that they eat only bees, for they A devour wafps, and other flying infects, which they chafe much like fwallows. The children in the ifle of Candia ufe fuch infeets for baits for them, and $f / f$ for them by lines hung in the air, on precifely the fame principles as baits are ufed for fifh; the bee-eater fivallows the infeet, and is caught by the hook. Sometimes eat grain; they perch on fruit trees, and dart on their prey; lay in holes, which, with their ftrong and fhort PART IV. No. 25. 
feet, and iron bills (as the Sicilians call them), they make fix feet deep in foft ground. About the fize of a thrufh. The kinds are numerous.

\section{T H E F L Y : C A T C H E R S}

A R among the moft ufeful birds of prey; for fuch they truly are, A qs they live only on infeets. This kind is extremely numerous in fpecies and varieties. The larger are equal in fize to the butcher-bird, the fmalleft to the black-bird. They have a ftrong bill, almoft trianguJar (furrounded with wbifkers), and little hooked, in fome kinds, at the end; in the larger kinds confiderably bent; tail long. Wild and folitary; they inhabit great trees; rarely defcend to the ground. The climates of the fouth, where the infects abound, are their true countries. Only two kinds known in Europe; but in Africa we count eight, and in America thirty; where alfo are the larger kinds.

The Európean fly-catcher is under fix inches long, plumage grey, white, and deepilh alh-colour; comés in April, goes away in September. Lives in woods; wild and ftupid; build their nelts expofed. In America fome of the kinds are but the fize of a wren; others are powerful birds.

Without the affiftance of thefe birds, diminutive as fome may feem, every endeavour would be vain to overcome and drive away the clouds of flying infects which are a perpetual annoyance; they are too numerous to be deftroyed; are conftantly ftinging men and cattle, devour the productions of the ground; infect, by their excrements or their eggs, all provifions, \&c. intended for ftores; no candle can be lighted, but their numbers extinguioh it; no neep can be obtained without the utmoft care to exclude them, which often is infufficient. To thefe birds, therefore, we are under great obligations; and nature has encreafed the devourers, where the has multiplied their prey.

\section{T H E A N T - E A T E R S}

4 O R M a remarkable class of birds: they abound in the humid and low countries of South America, where infects and reptiles, by their numbers, tyrannize over all other fpecies of creatures.

In Guyana and Brafil, the ant-hills are the fize of hay-ftacks, and at 
leaft as populous as our own ant-hills; nor are thefe hills rare, but exceed ours in number, as in bulk, perhaps an hundred to one.

To prevent the total devaftation which thefe animals might create, nature has appointed not only quadrupeds, but birds, to leffen their numbers. Thefe birds are not totally unlike our black-birds in figure, but have hort tails and wings; they perch but little, but run on the ground like partridges; go in troops; are generally found on ant-hills twenty feet high; are of a larger and fmaller fpecies, but greatly alike; keep in woods. The largeft of the kind has been named King of the Ant-eaters, becaufe there is feldom more than one of this kind among a troop of others, which he feems to avoid from dignity; is lefs lively than the others; the female (as throughout the fpecies) larger than the male.

That called the Béfroi, though in fize but fix inches, has a voice (which he exerts morning and evening) as ftrong as a bell founding the alarm, and may be heard at above a mile diftance. The ftrokes follow rapidly, for an hour together, in all feafons.

That called the Chimer (carrilloneur) generally goes in companies of four or fix : their clamour has exactly the effect of a fet of three bells chiming alternately; their voice is loud, but not equal to the foregoing : whether each has three tones, or there are different tones of voice among them, is uncertain.

\section{TH E W R Y - N E C K}

T S a bird, whofe fingular manners merit attention, and are juftly exL preffed by his name: he is diftinguilhed by a habit of turning and twifting his reck, bringing his head over his back, and half thutting his eyes; this movement is not rapid, but flow and gradual; it feems to be the effect of affright and aftonimment at the fight of an object whofe novelty furprifes him, or to be an attempt at felf-defence when he is feized; yet, as the young in the neft have the fame habit, it may rather be thought a confequence of fome natural conformation. One of thefe birds taken and caged, when vifited, looks fteadily, at the fpectatcr, then raifing himfelf on his feet, pokes himfelf nowly forward, elevating the feathers on the crown of his head, fpreading his tail; then fuddenly withdrawing himfelf, ftrikes with his bill the bottom of his cage, and depreffes his tuft; this he repeats an hundred times running. Upon 
thefe oddities, fuperftition adopted this bird in inchantments, and pre= fcribed it as the moft powerful of philtres; but where any analogy of caufes and effects could be fuggefted, is utterly inconceivable. The wry-neck is not numerous; comes over in May, returns in September; is folitary; feeds on the ground; is the fize of a lark; plumage grey, black, and tan-colour, waved and banoied; producing a rich effeet, nor unlike a fnipe's, eats ants like the woodpecker.

The ftrange motion of her neck has often protected her neft; for it refembles fo ftrongly that of a ferpent, that many a-bird-nefter has refrained from plunder, terrified by this fuppofed dangerous menace.

\section{T H E A N I S}

" $\mathrm{R}$ ' $\mathrm{E}$ birds of manners fo focial, that they not only fly in flocks, A but feveral females fit and hatch on the fame neft. They have many nick-names, as Devil's-bird, Tobacco-ftalk, \&c. in the Weft Indies.

They have two toes before, two behind, fhort bills crooked, thicker than large; the inferior mandible ftraight, the fuperior femi-circular, hooked at the end. About the fize of a thrufh; fome larger; colour, black, or deep brown-black.

The neft is made large; conftrueted of dry fticks and twigs, fo as to hold five or fix birds, and enlarged according to the number of fitters, fometimes to eighteen inches wide. They build together, breed together, fly together, perch together as clofe as poffible, whiftle together, and feed together; eat grain, alfo reptiles and infects. They fly badly, and hurricanes often deftroy numbers : if their eggs are mixed, they hatch each one the others', nor do they refufe fuftenance to their neighbours young.; cover their eggs with leaves; and often one lits while the others are building around her. Are not eatable.

\section{T H E O X - P E C K E R}

Y. $S$ a fmall-bird, about the fize of a lark; of a grey-brown colour, 1 which is very fond of the larve of certain infeets which breed under the epidermis (or upper $\mathrm{fkin}$ ) of oxen, and which live there till their change. He ftands on the back of the animal, and, by ftriking with his bill, opens the place where the infects are whereon he feeds. Inhabits hot climates. 
T $N$ the forefts of hot countries, among the firft ftrange objects that excite I curiofity, is the multitude of birds' nefts hanging at the extremity of almoft every branch. Many kinds of birds build in this manner; but as the chief of them are of the woodpecker kind, we thall here defcribe the moft remarkable. In thefe folitary forefts, man is but feldom feen; the little bird has therefore nothing to apprehend from man; but is fatisfied if its neft be out of the reach of thofe rapacious animals that live by robbery and furprife. The monkey and the fnake muft be guarded againft, the bird has no other enemies to fear.

On one of thefe immenfe trees, is feen the moft various, and the mort inimical affemblage of creatures that can be imagined. The top is inhabited by monkies of fome particular tribe, that drive off all others; lower down twine about the great trunk numbers of the largeft fnakes, patiently waiting till fome unwary animal comes within reach; and at the extremes of the branches hang nefts in great abundance.

The CAROUGE of the Weft Indies makes it of a kind of mors, called by the Englifh inhabitants of thefe countries old man's beard. It is fibrous, not unlike horfe-hair, which bears being moulded into any form, and fuffers being glued together. This, therefore, the bird firft glues by fome vifcous fubftance, to the extreme branch of a tree; then building downward, the neft depends in fecurity.

The Toucnam-courvi of the Philippine inands builds its neft of little fibres interlaced together, fo as to form a kind of bag, open on one fide ; to this opening is adapted a long funnel, or tube, compoled of the fame kind of fibres, hanging down, and opening below, fo that the true entry to the neft is not feen; thefe nefts are hung at the end of branches.

The BAGLAFECHT is an Abyfinian bird, which rolls its neft fpirally, much like the fhell of a nautilus; he hangs it at the end of a branch, almoft always over a ftanding water; the entrance is always turned from the rainy quarter, thereby guarding againft wet, as weil as enemies. To attain the fame advantages, the Gross-BEAK of Abyflinia makes his neft pyramidal, turns its opening from the rainy quarter, and alfo divides the cavity of the pyramid by a partition, forming, as it were, two chambers; the firt, where is the entry; then he defcends under his divifion into the fecond, where is the neft; fo that let the rain or wind be ever fo violent, it cannot reach the eggs.

Some birds glue their neit to the leaf of the banana-tree, which makes two fides of their little habitation; while the other two are artificially compofed by their own induftry. Thus their nefts hang before the fpoilers a temptation, but beyond their acquifition. 


\section{BIRD OF PARADISE AND ITS VARIETIES.}

THIS bird appears as large as a pigeon, though in reality the fize - 1 of a thruh. The tail is about fix inches; as is the body; the wings are large; compared with the bird's dimenfions. The head, throat, and neck are veivetted pale gold colour; eyes fmall; the bafe of the bill, and the fide of the head and throat, are furrounded by black feathers, fof as velvet, and changeable by a varied incidence of light; the hinder part of the head is fhining green, mixed with gold; the body and wings are chiefly covered with beautiful brown, purple, and gold feathers; the feet long and Atrong; the upper part of the tail feathers are pale yellow, thofe under them white, and longer than the upper, for which reafon the hinder part of the tail appears all white; but what is moft remarkable are two long naked feathers, which fpring from the upper part of the rump above the tail, and which are ufually three feet long; thefe are bearded only at the beginning and the end; the Thaft for two feet nine inches being a deep black, while the feathered extremity exhibits changeable colours, and an ornament fomething like the eyes of a peacock's tail. Black is the principal colour of fome kinds.

This bird, whofe beauty is fuperlative, is native of the Molucca Inands, but found in greateft numbers in that of Aro, in whore delightful and fpicy woods they Hy in large flocks. The inhabitants give them the name of God's birds (Manucodiata). At niglit all generally perch upon the fame tree. They are called by fome Swallows of Ternate, from their rapid flight, and from being continually on the wing in purfuit of infects. In the rainy feafon, it is faid they fly to other countries where their food is in greater abundance; they have their ftated times of return. In Auguft, they are feen in great numbers fying together.

The natives, who make a trade of killing thefe birds and felling them to the Europeans, having concealed themfelves in a bower made of the branches of the trees they frequent, fhoot the birds with arrows of reeds.

There is alfo a Manucodia which has fix long feathers iffuing from his head, like thore of others from the tail; a kind of creft from the bill; the feathers on the belly are four inches long.

N. B. The natives cut off the legs of many birds they $\{\mathrm{ell}$, and fay they haye none. 


\section{$53)$ \\ TH E \\ CUCKOO AND ITS VARIETIES.}

TH IS fingular bird is fomewhat lefs than a-pigeon, thaped like a magpie, of a greyifh colour, diftinguimed by its round prominent noftrils; the opening of its bill large; its claws two behind, two before; legs nort, tail long. It difcovers itfelf early in the fpring by its call, which is at firft very weak, and earlier or later as the feafon feems to be more or lefs inviting. The call of the cuckoo, as fummer advances, improves both in frequency and loudnefs. This invitation is ufed only by the male, who, perched upon fome dead tree, or bare bough, repeats his fong, which he lofes as foon as the genial feafon is over. His note is pleafant, though uniform; and feldom occurs to memory, without reminding us of the fweets of fummer.

The female makes no neft of her own, but fometimes lays in holes of rocks; much oftener the invades the property of fome other bird, the water-wagtail, hedge-fparrow, lark, or ftock-dove, and about twenty different birds; and often, after devouring the eggs of the owner, lays her own in their place. She ufually lays but one (rarely two in the fane place), which is fpeckled, and of the fize of a blackbird's. This the forter-parent hatches with great affiduity, and finds no difference in the great ill-looking changeling from her own, or at leaft treats it as her own. To fupply this voracious creature, the credulous nurfe toils with unufual labour, and, though forced by perpetual craving to fupply extraordinary food for an unulual length of time, yet continues the difficult employment.

Fle?h and infects are their nourifhment, meal-worm infects efpecially. The capacity of their ftomach is enormous, and reaches from the breaftbone to the vent; it is partly membranous, partly inufcular.

They are naturally weak and fearful, as appears by their lying from fmall birds which every where purfue them, and often drive the female cuckoo from her defign of laying in their neft. The young birds are brown, mixed with black; and in that ftate they have been defcribed by fome authors as old ones. A female cuckoo has been found fo like a merlin in plumage, as might deceive obfervers. It moults fo entirely as to be naked, and in this ftate may be miftaken for another animal. 
The cuckoo, when Aledged and fitted for fight, follows its fuppored parent fome time; but its appetite for infect food increafing, it quits its fuppofed dam. The little birds of the grove feem to confider the young cuckoo as an enemy; they purfue it wherever it flies, and oblige it to take thelter in the thickeft branches of fome neighbouring tree; the wry-neck, in particular, is active in the chace.

Early at the approach of winter, it difappears, and its paffage can be traced to no other country. 'Some fuppofe it lies hid in hollow trees or rocks, where it is faid to have been found naked; others, that it feeks warmer climates ; but to what country it retires, or whether it has been ever feen on its journey, is unknown.

Of this bird there are many kinds in various parts of the world, not only differing in their colours but their fize, to the amount of above thirty, of various notes, fome far from mufical, but fufficiently noify.

The Hou-bou of Egypt live principally (if not only) on grafshoppers; never perch on trees, or ftand on the ground, but fit on bufhes.

The Cuckoo of the Cape of Good-Hope, called Indicator, has the cultom of finding the nefts of wild bees; and giving notice, morning and night, to thofe who feek the honey, he even redoubles his clamour, flies before them, and leads them on if they linger. After they have taken the hive, they always leave him a portion. The fweets are encloled in a hive, whofe opening is too narrow for him by himfelf to procure them.

The Tac-bo of the Weft Indies devours not only infects, but reptiles, lizards, fnakes, frogs, rats; fwallow fnakes head foremoft, and is a bird valuable for its deftruction of hurtful anirrals; is naturally half domeftic. Its neft has never been feen. Moft of the American cuckoos build and hatch their own young.

One is entitled the Laugber, from the refemblance of his note. 


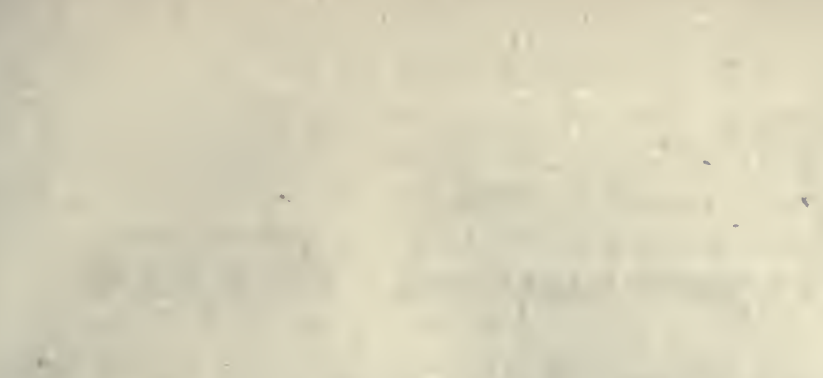




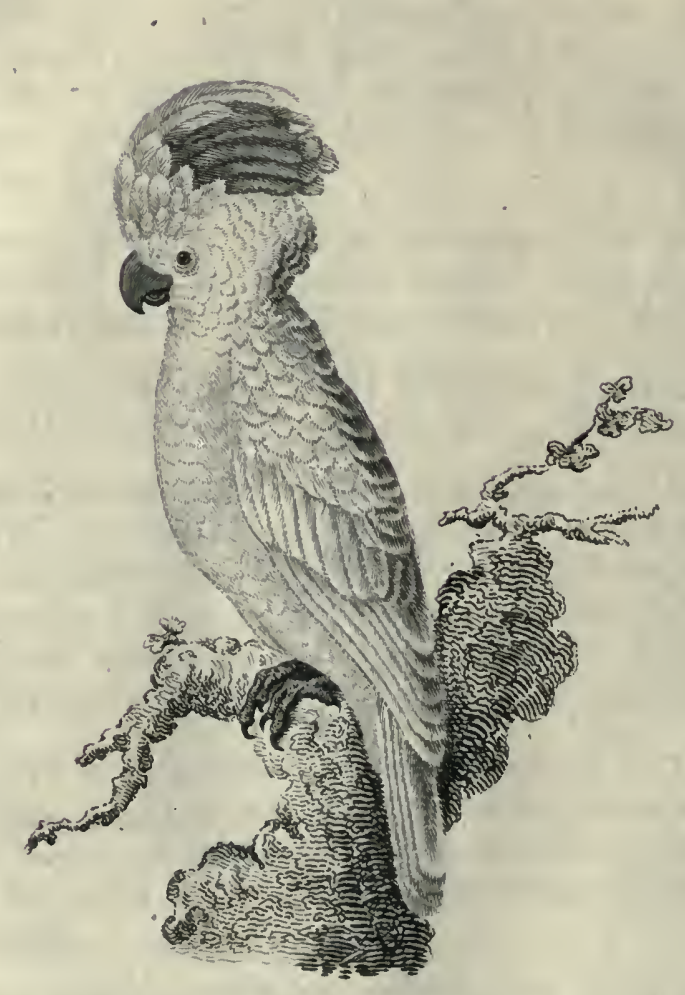

The Cockatoo. 


\section{PARROT AND ITS AFFINITIES.}

THE eafe with which this bird is taught to fpeak, and the number of words it is capable of repeating, is furprifing.

Willoughby tells a ftory " of a parrot belonging to king Henry the Seventh, who then refided at Weftminfter, in his palace by the river Thames, which had learned many words from the paffengers as they happened to take water. One day, fporting on its perch, the poor bird fell into the water, at the fame time crying out, as loud as he could, $\mathcal{A}$ boat, a boat, tiventy pound for a boat l A waterman who happened to be near, hearing the cry, made to the place where the parrot was-floating, and taking him up, reftored him to the king. As the bird was a favourite, the man infifted that he ought to have a reward rather equal to his fervices than his trouble; and as the parrot had cried twenty pounds, he faid the king was bound in honour to grant it. The king at laft agreed to leave it to the parrot's own determination, which the bird hearing, cried, Give the knave a groat."

In their native countries the forefts fwarm with them. It is afferted by fenfible travellers, that the natives of Brafil can change the colour of a parrot's plumage by art; if this be true, they can multiply fpecies at pleafure, to the evident embarraffment of nomenclators.

Their varieties exceed an hundred : to repeat their diftinctions, therefore, would be barrennefs itfelf, fince their general nature is fimilar, and afterknowledge of one or two, little novelty arifes from the reft.

Thofe of the old continent may juftly be feparated from thofe of the. new, and divided into the cockatoo, the parrot, the lories, long-tailed paroquet, and hort-tailed paroquet : thofe of the new world divide into the mackaws, the amazons, the criks, the popinjays, the long-tailed paroquet, and Thort-tailed paroquet.

\section{THE C O C K A T O O}

T $S$ the greateft parrot of the old world, and feems attached to the warmer climates of Afia, India, and the inands of the Indian Ocean; their name expreffes their cry generally. Their white plumage, and 


\section{THE PIE K I N D.}

rounded and hooked bill, diftinguifh them; but efpecially a tuft on the head, which they can elevate or deprefs at pleafure. They are not eafily taught to fpeak, fome not at all; but they are eafily tamed, and often neftle on houres. They feem the moft intelligent of their kind; liften, underftand, and obey, better than moft, and may be taught various tricks and motions; are graceful and agile. That with a white creft is about the fize of a hen; is white throughout, except a little yellow under the wings and on the tail; his bill and feet black; his creft is compofed of ten or twelve large feathers, of the nature of the wing-feathers, well bearded, placed in two lines, from back to front, and forming a double fan. In fome the creft is yellow; in fome red. Some are black.

\section{- OF PAR R T S}

THERE are feveral fpecies; fome grey, as the jacoo, which has much docility; brought from Guinea, and the interior of Africa; imitates, by preference, the voices of children; but acquires alfo the imitations of other voices; is fo fond of talking, that he talks in his neep: learns alfo to dance, but very awkwardly; loves wine, as do all parrots, and ate very merry with it. There are alfo black of this kind.

\section{T H E L O R I E S}

A $\mathrm{R}$ E fo named from a refemblance to their cry ; are diftinguined by their plumage, which is red, more or lefs deep; their bill is lefs crooked, thorter, and fharper, than in moft parrots. They are lively, agile, and the only one which can leap on their ftick if placed a foot high; are eafily tamed, and preferve their gaiety in captivity. Are found in the Molucca illands, and in New Guinea.

\section{LONG-TAILED PAROQUETS}

$A \mathrm{RE}$ of various colours; green with a red collar; with wings blue, A yellow, and orange; fome with blue heads; fone green and red; and many various mixtures. 


\section{7) \\ SHORT-TAILED PAROQUETS}

A RE very numerous in Afra and Africa; generally build their nefts at the end of branches; many of thefe are but fmall.

\section{$M A C A \quad A \quad W \quad S$}

RE of fplendid plumage; purple, gold, and azure embellifh 1 them : they are haughty, yet may be domefticated; are peaceful, gencle, and obedient; all belong to America; are found even in defert inands. They are large birds, equal to a raven; are of four kinds, the red, the blue, the green, and the black. They have long tails, a naked fkin of a dirty white, which furrounds the head on each fide, and beneath; alfo the bafe of the inferior mandible of the bill; this is their dittinguifhing mark. In the middle of this fkir are the eyes, which imparts a difagreeable appearance to thefe birds. They live in woods, in moift lands, among palm-trees, on whofe fruit they feed, and of which are vaft forefts in overfowed favannas; go in pairs, rarely in Alights; fometimes affemble in the morning, and are heard afar off; always cry while lying; fly the beft of the kind; crols open places, but never ftay; perch on the tops of trees; if they feek food at a diftance (as a league) return home at night. Neftle in old trees, enlarging fome hole in a rotten part; breed twice a year, laying two eggs, the fize of a pigton's, fpotted like thofe of a partridge. Male and female fit alternately, and jointly provide for their young, nor abandon them till well grown; they are not the beft fpeakers among parrots; their flefn is not bad eating; are very fubject to the epilepfy; their diforder is called the cramp, and is faid to follow their ftanding on iron of any kind; their cages, therefore, fnould be wholly made of wood.

\section{THE A M A Z O N S}

A RE named after their native country; they are dittinguifhed by $1 \mathrm{~N}$ red on the end of their wings. Their green plumage is brilliant, and even dazzling; the fame is the yrellow on their heads; they are lefs than the mackaws; are rare, and come only from Amazonia. They. 
fly in troops; inhabit both woods and mountains; fome have red heads, fome white, fome are yellow.

\section{TH E C R I K S}

TAVE a little sed on their wings, but never on the end; their I green plumage is flat and yellowin ; the yellow on their heads is dull, and mixed with other colours; they are much fmaller than mackaws, and are the commoneft of all parrots; they are much like the amazons in manners, and both, in many refpects, conform to the mackaws. Cotton feed makes thefe (and all) parrots drunk; as alfo do fumes of tobacco, which the Indians blow into their bills, in which ftate they are lefs wild, and more manageable. Some criks, are yellow-necked, fome powdered, fome have blue faces, fome blue heads, and lome violer heads.

\section{TH E P O P P I N J A Y S}

$\mathrm{RE}$ lefs than the amazons, and have no red in their wings; are $\mathrm{A}$ of various colours, yellow, red, and mottled.

The long and the fhort-tailed P A RO QUETS of the new world, are extremely various, beautiful, docile, and entertaining.

PARROTS are formed alike, their toes two before and two behind for climbing and holding; ftrong hooked bills for breaking nuts and hard fubftances, on which they feed; and loud harh voices, by which they fill their native woods with clamour. Their toes are remarkable, which appears when they walk or climb, and when eating. To climb, they ftretch two of their toes forward and two backward; but when they feed, they bring the food to their mouths with their foot, and dexterouny turn the greater hind toe forward, fo as firmly to gl:arp the nut or fruit, ftanding all the while on the other leg. Other animals turn their neat inwards to the mouth; whereas thefe turn their mi cat outwards, and thus hold the hardeft nuts, as if in one hand, till with their bills they break the flell, and extract the kernel. The bill has g reat peculiarities, for both chaps are moveable. In moft other birds, tike upper chap unites with the flull; 
but in thefe (and in one or two fpecies of the feathered tribe more) the upper chap is connected to the bone of the head by a ftrong membrane, placed on each fide, that lifts and depreffes it at pleafure. By this contrivance, they can open their bills the wider, to great advantage, as the upper chap is fo hooked and over-hanging, that, if the lower only had motion, they could fcarce gape-fufficiently to take their nourifhment.

Thefe birds cannot readily hop from bough to bough (their legs not being adapted), but ufe both the beak and feet; firft catching hold with the beak, then drawing up the legs and faftening them, then projecting the beak again, and then the feet, till they have completed their progrefs.

The tongue fomewhat refembles that of man; but the organs by which founds are articulated lie farther down in the throat, to which contributes the great motion which the os hyoides has in thefe birds.

The parrot, though common in Europe, rarely breeds here; and though it bears our winter when arrived at maturity, yet lofes both its fpirit and appetite during the colder part of the feafon, and feems quite changed from that buttling loquacious animal which it appeared in its native forefts.

A parrot at firft obftinately refifts inftruction; but is won by perfeverance; attempts to imitate the firft founds, and when it has got one word diftinctly, the fucceeding come with greater facility.

The parror, called Aicurous (an Amazon), the head of which is yellow, red, and violet, the body green, the end of the wings red, the tail long and yellow, is afferted by Clufius to be a prodigy of underftanding. "A Brafilian woman had a parrot of this kind, which was the wonder of the place. As we paffed by her houfe, the ufed to call us to ftop, promifing, if we gave her a comb, or a looking-glafs, the would make her parrot fing and dance to entertain us. If we agreed, as foon as the had pronounced fome words to the bird, it began not only to leap and fkip on the perch on which it ftood, but alfo to talk and to whiftle, and imitate the houtings and exclamations of the Brafilians when they prepare for battle; if the woman bid it to fing, it fang; if to dance, it danced. But if, contrary to our promife, we refufed payment, the parrot feemed to fympathize in her refentment, was filent and inmovable; neither could we, by any means, provoke it to move either foot or tongue."

As thofe birds have the greateft docility that are taken young, a neft is confidered as worth taking fome trouble to be poffeffed of; the ufual method is, by curting down the tree. The old are thot in the woods PART IV. No. 26. 
with heavy arrows, headed with cotton, which knocks down the bird without killing it: fome die, but others recover, and, by kind ufage and plentiful food, become talkative and noify.

Some of them are, particularly the fmall paroquet tribe, delicate food. In general, whatever fruit or grain they moftly feed on, their flefh partakes of the flavour. When the guava is ripe, they are fat and tender; if they feed on the feed of the acajou, their flefh contracts an agreeable Havour of garlick; if they feed on the feed of the fpicy trees, it taftes of cloves and cinnamon.

The paroquet kind in Brafil, Labat affures us, are beautiful and talkative, very tame, and appear fond of mankind; pleafed with holding parley with a man; they never have done; but while he continues to talk, anfwer him, as if refolved to have the laft word.

When a fowler in purfuit of them walks into the woods, as they are green, and exactly the colour of the leaves among which they fit, he only hears them, without feeing a fingle bird; fenfible that his game is within gun-Thot in abundance, he is mortified to the laft degree that it is invifible. Unfortunately for themfelves, they are ever on the wing; for as foon as they have ftripped the tree on which they fat of its berries, fome one of them flies to another; if fit for their purpofe, it gives a loud call, to which the reft refort. At this opportunity the fowler fires among the flock while on the wing, and feldom fails of bringing down fome.

On the coaft of Guinea, parrots are confidered by the Negroes as their greateft tormentors. The parrots perfecute them with unceafing fcreaming; and devour whatever fruits they attempt to produce in their little gardens.

The green paroquet, with a red neck, was the firt brought into Europe, and the only one known to the ancients from the time of Alexander the Great to the age of Nero. This was brought from India ; afterwards the Romans found others in Gaganda, an inand of Ethiopia.

T H E

\section{PIGEON AND ITS VARIETIES.}

THE tame pigeon, and its varieties, derive their origin from the 1 ftock-dove, the Englifh name, implying its being the flock of the other 
other domeftic kinds. This bird, in its natural ftate, is of a deep blueifh afh colour; the breaft enlivened with fine changeable green and purple; its wings marked with two black bars; the back white, the tail near the end barred with black. Thefe fimple tints have deviated into unlimited variety.

The STOCK-DOVE, in its native woods, breeds in the holes of rocks and the hollows of trees. All other of the pigeon-kind build in the topmoft branches of the foreft. But this foon takes to build in artificial cavities; and, excited by ready provifion and numerous fociety, eafily becomes domeftic. It preferves its native colour for feveral generations.

The dove-houfe PIGEON breeds every month; but muft be fupplied with food when the weather is fevere, or the fields are covered with fnow. Lays two white eggs, which ufually produce young of different fexes. The female fits fifteen days, in cold weather more, relieved at intervals by the male. The intervals are ufually regulated with great exactnefs. From three or four o'clock in the evening till nine the next day, the female fits; then the male takes his place from ten till three, while his mate is feeding abroad. If the female delays her return, the male follows, and drives her to the neft; fhould he in his turn be dilatory, hre retaliates upon him.

The young require no food the three firt days, only warmth, which the female fupplies entirely, nor ever ftirs out, except for a minute's food. The old ones gather corn or grain in the fields, and keep it in their crops, from whence they throw it up into the mouths of their young, who greedily demand it.

Of all birds, for its fize, the pigeon has the largeft crop, which has alfo peculiar properties. Air, blown into the wind-pipe, diftends the crop or gullet prodigiouny. By what apertures the air thus blown enters the crop is unknown; but fome of them (which are called croppers) can fo much diftend it, that the bird's breaft feems bigger than its bady. The ufe of the air, thus introduced, is to contribute to the ejection of the halfmacerated grain contained in the crop, with which the pigeon feeds its young. The expanfive and contractive powers of the crop enable it to hold a greater quantity than otherwife it would, and to eject it at pleafure. This the young receive open-mouthed; being thus fed three times a day. In feeding, the male ufually fupplies the young female; and the old female fupplies the young male. When well fed, the old ones do not wait the total difmiffion of their young; - but in the fame neft are found young ones almolt fic for flight, and eggs hatching. 
The fidelity of the turtle-dove is proverbial; but the pigeon of the dove-houfe is not faithful. Two males often quarrel for the fame miftrefs; if the female admit the addreffes of a new gallant, her old companion is difpleafed, abftains from her company, or approaches only. to chaftife her. There have been inftances when two males, difpleafed with their refpective mates, have exchanged them, and have lived in great harmony with their new companions.

So prolific is this bird, that near fifteen thoufand may in the fpace of four years be produced from a fingle pair. But the ftock-dove feldom breeds above twice a year; ceafing in winter. They feem to have a ftronger attachment to their young than thofe who breed fo often. From a fpecies of thefe, thofe pigeons called carriers, are produced. Thefe are eafily diftinguithed by a broad circle of naked white fkin round their eyes, and by being of a dark blue or blackifh colour. From their attachment to their young, thefe birds are employed as carriers. They are firft brought from home, the letter is tied under the bird's wing, and it is let loofe. It afcends direQty into the clouds to an amazing height; then, directing itfelf by fome furprifing inftinct towards home, fometimes at many miles diftance, brings its meffage; in the fpace of an hour and a half performing a journey of forty miles.

The varieties of the pigeon are beyond mention. Hence we have croppers, carriers, jacobines, powters, runts, turbits, and a thoufand other varieties, heightened by food, climate, and pairing, producing different fpecies.

The RING-DOvE is larger than the former; builds its neft with a few dry fticks, in the boughs of trees, and maintains its native freedom, notwith tanding attempts to render it domeftic : for, though their eggs have been hatched by the tame pigeon in a dove-houfe, yet, as foon as they could $\mathrm{fly}$, they always betook themfelves to the woods. In winter affemble in great flocks in the woods, and leave off cooing till March; neither do they coo in wet weather; is, in fome places, a bird of feafon.

The TURTLE-DOVE is fmaller, and fhyer, than the former ; is diftinguined by the iris, of a fine yellow, and by a beautiful crimfon circle that encompaffes the eye-lids. The fidelity of thefe birds is noted; and a pair being caged, if one dies, the other will not furvive it. Is a bird of paffage; few or none remain in winter; they comelate, and depart early. They lly in flocks when they come to breed here in fummer, and delight in open, mountainous, fandy countries. But they build in woods, and choofe the moft retired fituations. Feed on grain; are fond of millet.

The 
The Peacock-pigeon that (female as well as male) fpreads the tail is a curjous variety, has thirty feathers in the tail (others have but twelve); they advance theit tail when they fpread it, and throw back the head till it almoft touches the tail, trembling all the time, and agitating the head and neck. The wind often acts fo powerfully on this large tail as to dafh them to the ground.

To this lift might be added a long catalogue of foreign pigeons, of which we know little more than the plumage and the names. The CRow N-FowL, which belongs to the family of pigeons, is in fize equal to a turkey; native of the ille of Banda : in India they breed them as poultry. In America a fpecies the fize of a lark.

\section{BIRDS, OF THE SPARROW KIND.}

7 HESE chiefly live in the neighbourhood of man, and among them are thofe endowed with mulical notes. Their living near man is not the refult of affeetion but of neceffity, and becaufe inhabited grounds furnin their chief provifion; the defert yields neither grain nor tender buds, nor infects; the receffes of the foreft abound in enemies, not in advantages. All birds, even thofe of paffage, ieem content with a certain diftrict to provide food and melter in. The red-brealt or the wren feldom leaves the field to which it is accuftomed; they'mark out a territory to themfelves, on which they will permit none of their own fpecies to encroach; but guard their dominions with the utmoft vigilance. When food is in plenty they never wander. Some are called birds of paffage, becaufe obliged to take long journeys for this neceffary; but, ftrictly fpeaking, moft other kinds are birds of paffage, though their migration is lefs extenfive, either from one county to another, or from the more inland provinces toward the thore. Refpecting thefe, autumn is the principal feafon when the bird-catcher employs his art to entrap the wanderers, which is chiefly effected by the aid of his callbirds; thefe having moulted prematurely in a warm cage, call louder and better than thole that are wild: there even appears a malicious joy in thefe call-birds, to bring the wild ones into captivity. Their fight or hearing is exquifite; the inftant the wild birds are perceived, notice is given by one of the call-birds, who all unite in the fame tumultuous ectafy of pleafure, inciting the wild ones by fhort jerks. The allurement of this call is fo great, that the wild bird on hearing it is fopped in 
its moft rapid fight. It frequently happens that if half a flock only are caught, the remaining half will immediately afterwards alight between the nets, and thare the fate of their companions; or thould only one bird efcape, this unhappy furvivor will alio venture into danger till it is caught; fuch a fafcinating power have the call-birds.

It is not eafy to account for the nature of this call, whether it be a challenge to combat, an invitation to food, or to courthip; whethertheir motives be gallantry or war, the fmall birds are equally remarkable for both.

For however contemptible thefe little warriors are to larger creatures, they are often formidable to each other; and fometimes fight till one of them yields up his life with the victory. Sometimes two male birds fhall ftrive in fong till,' after a long ftruggle, the loudeft fhall entirely filence the other. During thefe contentions, the fernale fits a filent auditor, and often rewards the loudeft fongfter with her company during the feafon. Singing among birds is almoft univerfally the prerogative of the male; it ferves as a blandifhment at firt; as delight to her during the time of incubation; as fecurity, to affure her that no danger threatens; for if danger offers, the male itops fuddenly, as a fignal to his mate to provide for her fecurity.

Willoughby has divided the fmaller birds into (I.) thofe that have nender bills, and (2.) thofe that have fhort and thick bills. Thofe with flender bills chiefly live on infects; thofe with fhort, ftrong bills, live moftly on fruits and grain. Among nender-billed birds; he enumerates the thrum, the blackbird, the fieldfare, the ftarling, the lark, the titmoufe, the water-wagtail, the nightingale, the red-ftart, the robin red-breaft, the beccafigo, the ftonechatter, the whinchat, the goldinch, the whitethroar, the hedge-fparrow, the pettichaps, the golden-crowned wren, the wren, the humming-bird, and feveral others of the fparrow kind unknown in this part of the world.

Thefe feek and deftroy the eggs of infects that would otherwife propagate in numbers beyond the arts of man to extirpate : they know better than man where to feek for them; and thus at once fatisfy their own appetites, and render him the moft effential fervices. In this tribe, we have the fweeteft fongfters of the grove, the nightingale, the thrufh, the blackbird, the lark, the red-breaft, the black-cap, and the wren.

Birds of the fparrow kind, with thick and hort bills, are the grofsbeak, the crofsbill, the greenfinch, the builinch, the houfe-fparrow, the chaffinch, the brambling, the goldifinch, the linnet, the filkin, the bunting, 
the yellow-hammer, the ortolan, the wheat-ear, and feveral other foreign birds, of which we know rather the names than the hiftory. Thefe chiefiy feed on fruits, grain, and corn : the harveft often fuffers from their depredations; but they alfo have their ufes, and are frequently the diftributors of feeds into different diftricts ; and fome are thought to thrive the better, for having undergone a kind of maceration in the ftomach of thefe birds before they are voided. The fongfters of this clafs are the canary-bird, the linnet, the chaffinch, the goldfinch, the greenfinch, the bullfinch, the brambling, the fifkin, and the yellow-hammer. Their notes are not fo generally pleafing as that of the former clafs, but they ufually hold it longer; and, in a cage, thefe birds are more eafily fed, and are more hardy.

\section{O F TH E}

\section{THRUSH AND ITS AFFINITIES.}

TJ I T H the thrufh we may rank the red-wing, the fieldfare, the blackbird, the ring-ouzel, and the water-ouzel.

To this tribe may be alfo added the ftare or ftarling, which, though with a flat bill, too much refembles thefe birds to be placed any where elfe.

The Missel-thrush is diftinguifhed by its fuperior fize; it differs little from the throftle; but the fpots on its breaft are larger. It builds in burhes, or on the fide of fome tree, ten or twelve feet high (as all this kind do); lays four or five eggs, deep blue, black fpots; its fong is very fine, which it begins in pring, fitting on the fummit of a high tree; fings more than half the year; the largeft of all birds that have mulical voices; all greater birds either fcreaming, chattering, or croaking : feeds on infects, holly, and miletoe-berries; when frighted or difturbed fends forth a very difagreeable fcream; is in Burgundy a bird of paffage; pair early; breed twice a year; fexes clofely refemble; both affift in bringing up their young; live in woods; fometimes get drunk by eating ripe grapes, and are taken by thoufands.

There is a white thrum, which yet retains the brealt fpots: alfo a tufed thrufh.

PART IV. No. 26. 
The BLACKBIRD whifles early in fpring, and all fummer-time, with a note extremely pleafing at a diftance (being the deepeft toned warbling of the woods), but rather unpleafant in a cage, being too loud; lays four or five blueith eggs, in a neft ufually built at the ftump of fome old hawthorn, well plaiftered on the infide with clay, ftraw, and hair. Is more eafily tamed than thruhes; readily improves its fong, and will counterfeit the human voice; love to bathe themfelves. Birds of prey are fond of their fleth. Of the fame kind are fome black and white, fome white, and fome rofe-coloured: to avoid, therefore, the ridicule of a rofe-coloured black-bird, the clafs thould affume its old Englifh name of ouzel.

Among the ouzels muft be reckoned the BLUE-BIRD, which re. fembles a blackbird, except in colour; it lives in the higheft Alps (as al fo a rock-ouzel, which even there choofes the moft craggy rocks and the moft frightful precipices for its refidence); is rarely caught, but highly efteemed in the countries where it breeds. It not only whiftles delightfully, but fpeaks diftinctly; is docile, and, though waked at midnight by any of the family with a light, it will fpeak and whiftle. Its colour, toward winter, from blue becomes blackifh, which re-changes to its original hue early in fpring. It makes its neft in deep holes, or in folitudes inacceffible, not only by man, but alfo by the fhammoy, or other wild animals : produces ufually five young; feldom defcends into the plain; flies fwifter than a blackbird, and ufes the fame food; defends its neft by ftriking at the eyes of the aflailants.

The FIELDFARE and the RED-WING make but a fhort ftay in this country. With us they are infipid tunelefs birds, flying in flocks, and exceffively watchful to preferve the general fafety. Their feafon of mufic and pleafure is employed in the more northern climates, where they fing moft delightfully, perched, among the forefts of maples, with which thofe countries abound. They build their nefts in hedges, and lay fix blueifh-green eggs fpotted with black. Linnæus mentions a fieldfare fo tame as to drink wine our of the glafies on the table; he drank fo much as to render him bald; but being kept a whole year without wine, his feathers returned. Is a bird of pafaige, clofely allied to the thruth.

The Stare, or Starling, diftinguinable from the reft of this tribe by the glofly green of its feathers, in fome lights, and the purple in others, and its fpots, breeds in hollow trees, eaves of houfes, towers, ruins, 


\section{TH E TH R U S H, \&.}

ruins, cliffs, and often in high rocks over the fea; its young refemble thofe of the thrufh very clofely; lays four, or five eggs, pale greenifh anh-colour; makes its neft of ftraw, fmall fibres of roors, and fuch like; and often ufes the nefts of other birds. Its voice is rougher than the reft of this kind; but what it wants in the melody of its note, which it will learn, it compenfates by the facility with which it is taught to fpeak. ' It fpeaks equally French, German, Englinh, Latin, Greek, not words only, but phrafes, and pronounces diftinctly that difficult-letter $R$. So foon as their young are able, thefe birds affemble in vaft flocks, and feed upon worms and infeets; at the approach of fpring, they affemble in fields; often fly in a troop fo united, yet fo agitated, and rolling on itfelf, that they embarrafs a bird of prey, which, unable to determine on any one for prey, quits the whole. They affemble efpecially in evenings; pafs the night among reeds; chatter much while together ; are fond of cherries ; live on grain, fruit, and infeets ; drink, much like the cock, and take delight in bathing. In foreign parts fome are white, fome black and white, and fome grey.

To this tribe might be added above an hundred other birds of nearly the thrunh fize, and living like them upon fruit and berries : but as it is imporfible to defcribe the fplendid tints that adorn the foreign birds of the thruth kind, paffing thefe beautiful, but little known kinds, we advert to the American mock-bird, the favourite fongter of a region where the birds excel ratter in the beauty of their plumage than the fweetnefs of their notes.

The American Mock-BIRD is but a plain bird to the eye, about the fize of a thrufh, a grey-brown colour, has a few Might breaft fpots, and a reddifh (in fome blackifh) bill; blackifh feet. It is poffeffed not only of its own natural notes, which are mulical and folemn, but ic can affume the tone of every other animal in the wood, from the wolf to the raven. It feems even to fport itfelf in leading them aftray; will firft allure the leffer birds with the call of their mates, then terrify them with the fcreams of the eagle. There is no bird in the foreft but it can mimic ; and there is none that it has not at times deceived.

The Indians have named it cencontlatolli, which means four hundred. languages. Not only he fings well, but with energy, and accompanies his voice tith regular motions; he firft rifes on his wings, then falls head foremoft feveral times; then he begins dancing, and accompanies it with his. fong. If his fong is lively, his flight defcribes in the air a multitude of crofling circles, mounting, defcending, and frifking; $\mathrm{M}_{2}$ 


\section{T H E S P A R R O W K I N D.}

if his fong is vigorous, he beats his wings in cadence; if his fong becomes folemn, piano, and feemingly loft in filence, he finks gradually down, gently hovers over his tree with imperceptible undulation of his wings, and fettles as if motionlefs while fufpended in the air.

The French Mock-bird has breaft-fpots in common with the thrun, and is about the fame fize; inhabits Carolina and Virginia.

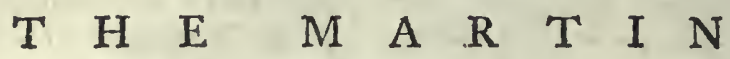

TS allied to the ouzel kind in form; inhabits the Philippine Inands; is extremely voracious; like our pies and crows feeks among the hair of horfes, cows, \&c. the infects which torment them; ten or a dozen will fometimes alight on the fame animal; but fhould it have any part of its flefh bare by a fore, the martins make free with that allo, and become a much worfe plague than the vermin of which they rid the animal: will devour fmall rats, and fwallow them; are particularly fond of grafshoppers ; fettle in fuch flocks on a tree as to cover it, fo that fcarce a leaf can be feen; brought up young among poultry, imitate their cries and motions; are of mixt colours, grey, black, and white.

\section{O F T H E \\ NIGHTINGALE, AND OTHER SOFT-BILLED S O N G - B I R D S.}

THIS mont famous of the feathered tribe vifits England only in April, and leaves us in Auguit; is unknown in Scotland, Ireland, and North Wales. They frequent thick hedges and low coppices, and generally keep in the middle of the bufh, fo that they are rarely feen. They begin their fong in the evening, and generally continue ic the whole night; for weeks together, if undifturbed, fit upon the fame rree. His note is foft, various, and interrupted; he feldom holds it without a paufe above the time that one can count twenty: this bird's mufic is more pleafing becaufe heard when all the reft are filent. Gefner 
Gefner affures us that it is not only the moft agreeable fongfter in a cage, but that it is poffelfed of a molt admirable faculty of talking.

In the beginning of May, the nightingale prepares to make its neft, which is formed of the leaves of trees, ftraw, and mofs; it is built at the bottom of hedges where the bufhes are thickeft and beft covered, yet is often deftroyed by foxes, weafels, fnakes, \&x. . While the female continues fitting (about eighteen days), the male, at a diftance, but within hearing, cheers the patient hour with his fong. She lays four or five eggs, uniform greenifh brown, of which but a part, in our cold climate, comes to maturity. The female feeds her young from her crop.

It neeps in the day-time, while it fings during night, and not only neeps but dreams, having been heard to warble, \&rc. in a very low and indittinct manner: They bathe after finging, and in an evening. A male, which efcaped from his cage, ruthed into a fire that was near; probably being dazzled by it. Lives many years; becomes grey by age. Pliny mentions a white nightingale prefented to Agrippina, wife of Claudius, which coft fixty thoufand fefterces; little fhort of two thoufand poundis. Is found in Perfia, China, and Japan.

The RED-BREAST, during the fpring, haunts the wood, the grove, and the garden; retires to the thickeft and fhadieft hedge-rows to breed; but in winter feems to become more domeftic, and often claims protection from man : the firt awake in the woods in a morning, the laft at going to repofe at night. The red-breant continues with us the year round, and endeavours to fupport the famine of winter by chirpirig round the warm habitations of mankind, by coming into frelters which moderate the rigour of the feafon, and where infeets are found (if at all) attracted by the fame caufe.

This bird breeds differently in different places: in fome countries, its neft is ufually found in the crevice of fome moffy bark, or at the foot of an hawthorn in hedge-rows; in others, it choofes the chickeft coverts, and hides its nelt with oak leaves. The eggs are from four to five, of a dull white, with reddith ftreaks; is in fome countries a bird of paffage.

There is a BLUE-BREAST, which, except in that colour, little differs from the red-breatt; lives in moift places; equally familiar; fings at night. Alfo a blue-red-brealt in America.

LARKs, whether the $1 \mathrm{ky}-\mathrm{lark}$, the wood-lark, or the tit-lark, are dittinguinable by the length of thtir heel. Their fong is loud and pleafing.

The 
The SKY-LARK builds its neft upon the ground, beneath fome turf that ferves to hide and fhelter it. The female lays four or five eggs of a duiky greyin colour, fpotted brown; fits about fifteen days; her young are foon moving from the neft: while the is fitting the male ufualiy entertains her with his finging, chiefly morning and evening; while he rifes to an imperceptible height, fill has his lovely partner in his eye, nor once lofes fight of the neft while he is afcending or defcending: never perches on trees; are often carried by ftrong winds many miles out to fea ; often taken by being attracted by larking-glafies, a kind of mirror, whofe brilliancy excites their attention. The cuckoo often lays in their nefts. There is a white lark, and alfo a black one. Of the titlark we remark that it can perch upon trees, and that the female fings.

The BLACK.CAP and the WREN, though fo very diminutive, are yet prized by fome for their finging : the former is called by fome the mocknightingale; his fong lafts longer, and he is eafily and thoroughly tamed: the latter is admired for the loudnefs of his note, compared to the little body from whence it iffues. The wren inhabits walls, ftacks of wood, barns, \&c. enlivening winter with his notes; his tail always erect; he hardly weighs a quarter of an ounce; lays eight or ten eggs, in a round neft, which looks like only a ball of mofs, and thereby efcapes notice.

The Golden-crested Wren is among the fmalleft of birds; he efcapes'eafily through the mefhes of a net, or the wires of a cage. Nature has given him a tufi, and crown; and as moft languages have called him little king, KInG let him be : he is fo fmall that if he now appears he is inftantly invifible; the fmalleft. leaf conceals him; the fmalleft infects (or their larva) are his food, and finall worms, which he devours till he is full; active and lively, weighs one hundred and twenty grains.

\section{O F T $\mathrm{THE}$}

\section{CANARY-BIRD AND FINCHES.}

FHOUGH, by its name, it appears that this bird came originally 1 from the Canary Inands, yet we now have them from Germany, where they are bred in great numbers, and fold into different parts of 


\section{THE B U L L-F I N C H.}

Europe. About a century ago they were fold at very high prices, and kept only by the great; they have fince multiplied abundantly. In Italy and Provence are fpecies of finches, nęarly allied, and capable of breeding together.

In its native ilands, the canary-bird is of a duke grey colour, and fo different from thofe ufually feen in Europe, that fome have even doubsed whether it be of the fame fpecies: by their domefticity they are become fome white, fome mottled, fome greenifh; but are nore efteemed for their note than their beauty; it is fhrill and piercing, like all of the finch tribe, continuing long in one breath without intermiffion, then rifing higher and higher by degrees, with great variety. The nightingale is the fongiter of the woods, the canary-bird the mulician of the chamber; of retentive memory and apt imitation, he exchanges his native notes for the compofitions of art.

More eafily reared than any of the foft-billed birds (but fubject to the epilepfy); his fong continues throughout the year. In choofing the canarybird, thofe are beit that appear with life and boldnefs, ftanding upright on the perch, and not apt to be frighted.

Canary-birds fometimes breed throughout the yeai, but ufually pair in April, and breed in June and Auguft; they are generally iwo or three days in building their neits; the hen commonly lays five eggs, and fits fourteen days; fometimes the female is ready to hatch a fecond brood before the firtt quits the neft; then the male breeds up the young left behind, and fits them for a ftate of independence. The female canarybird pairs with the linnet, or gold-finch, and produces a mixed breed, like the canary.bird, and refembling it in fong. The fpecies has increafed in the Weft Indies, and exilts in Abyfinia.

\section{T H E B U L L - F I N C H}

耳 remarkable for his aptnefs in acquiring, and memory in retaining, the leffons taught him; though his native notes are harh, yet he is capable of the moit melodious, and this capacity is not reftricted to the male, but belongs to both fexes: not only he jearns the airs which are taught him, but he often embellifhes them by tatte or expreffion, and feerns to fing as if prompted by fentiment. Is capable of attachment. Ore that had efcaped from its cage, after a year's liberty, returned to its Part IV. No. 26. 
owner, and recollected her voice. Others have died when feparated from their mafters. In thort; they have an excellent memory. One which had been thrown down in its cage by fome blackguards, though not feemingly injured at the time, ever after fell into convulfions at the approach-of ill-looking people, and in one of thefe fits died, eight months after its fall. The young begin to whiftle when able to eat alone : of four young ones, the three eldeft, which were able to eat, fed the fourth that was unable. They are conftant to their conforts, the year round; have the look of attention and thought, yet are eafily entrapped; their $\mathrm{kin}$ is very fine; their flem bitter or eatable, according to the fruit or grain on which they have fed; fome of them are of paffage; come in April, return in October.

The gold-finch learns a fine fong from the nightingale; the linnet as well as bull-finch may be taught, forgetting the wild notes of nature, to whifte a long and regular tune; but his own natural fong is pretry. He is a long-lived and healthy bird. The chaffinch offers, lefs of fong, and many of the fincires have none at all; indeed fome have'neither good melody nor good manners; witnefs the following.

\section{TH E G R O S S - B E A K}

S fo named from the fize, thicknefs, and ftrength of his bill : it were Defrable that his character could be vindicated from the charge of ill-nature; or elfe, it is well that his numbers are but few : filent, folitary, but courageous, and boldly defending their nefts; their ftrength of bill enables them to crack nuts and other hard fubftances, but allo to deftroy birds fmaller than themfelves; for without a quarrel, or a word peaking, they attack them by biting pieces out of them, not by ftriking with their bill. Nearly allied in figure and manners is

\section{THE C R O S S - B I L L,}

W H ICH alone is diftinguined by this conformity (fome fay deformity) of bill : the bill is croffed fometimes to the right, fometimes to the left: whether this arifes from the habit of the bird to take its food on the right or left ficle, is uncertain; the mandibles of the 

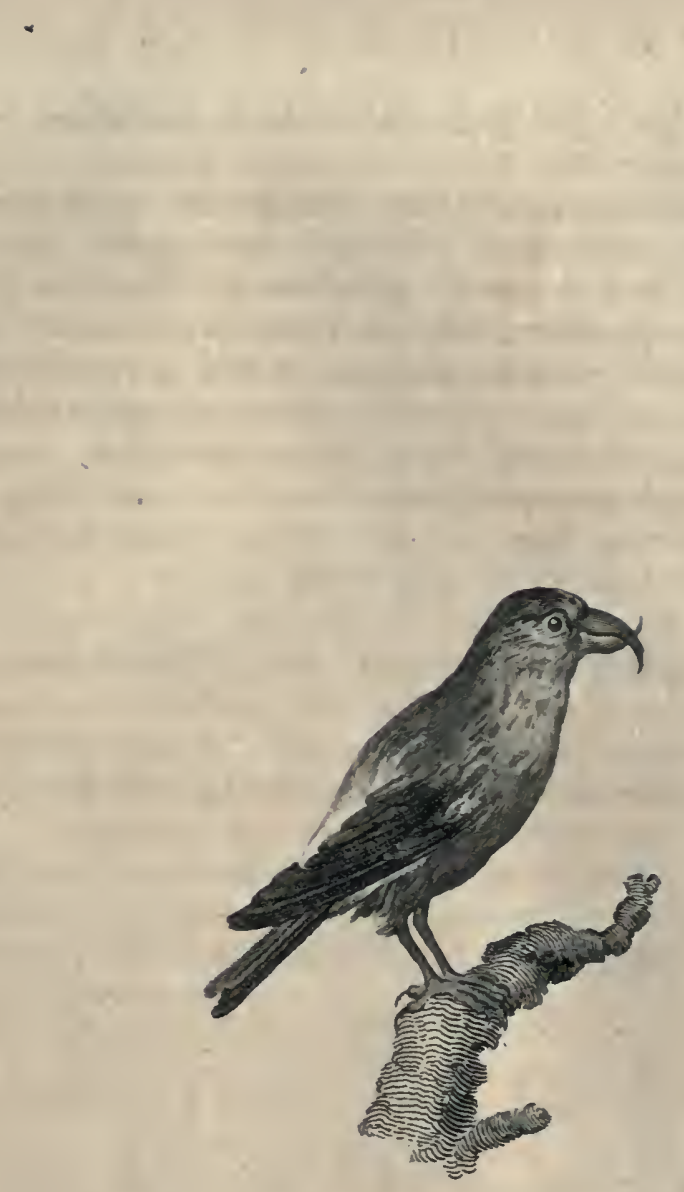

The Crofs-bill 

bill overgrowing, the points will not meet, fo that he cannot ftrike forward to any advantage. He feeds on the grains found in pine-apples, and is extremely dexterous in procuring them, by detaching the icales of the pine-apple, under which they lie. His crofs-bill alfo ferves him in. climbing, like a parrot's, and hence fome have called him the German parroquet : they are but dull birds.

\section{O F T HE}

\section{SWALLOW AND ITS AFFINITIES. \\ THE GOAT-SUCKER.}

$7 \mathrm{HERF}$ is nothing more unfortunate in natural hiftory, than when a creature has obtained a name, which expreffes falfe manners as if appropriate to it; this is inftanced in the prefent article, which, if properly named, fhould be entitled

\section{THE NIGH T-S W A L L O W,}

As coming neareft to its true character; yet it differs from the fwallow by being a bird of night, by being folitary, by its voice; by the number of its eggs, by its laying them bare on the ground, and by its time of appearing and difappearing. It agrees in exterior form, and much of its manners, its fhort feet, fmall bill and large throat, its food, and method of taking it. Lives upon infects, efpecially thore that fy by night; he chafes in the evening twilight, for light dazzles him; he has no need to thut his mouth to fecure his prey, for the infide of his bill is replete with a kind of glue, adhefive enough to retain as well moths as beetles, and to hold them by their wings. They are fpread in various parts of the world; many in America : any hole ferves for a neft; lays two or three brownim eggrs; is very jealous of her neft's being difcovered. Their open mouth caufes a found, which in fome parts of England procures them the name of wheel-bird, for their humming noife refembles that of a fpinning-wheel. 
The Night-Swallow then is the largett of this kind; but its tail not forked. To this tribe belong the Houfe-Swallow, which is too well known to need a defcription; the Martin, inferior in fize to the former, and the tail much lefs forked; its neft is covered at top, whereas that of the houfe-fwallow is open; and the Swift, rather larger than the houfefwallow, with all the toes ftanding forward, in which it differs from the reft of its kind: it comes later and-goes fooner; lays in old walls, as high as it can; makes, no neft, but lines the hole with litter : thefe refemble each other fo ftrongly, that it is not without difficulty the fmaller kinds are known afunder; they are confidered as friendly to man by their deftruction of infects; in fome places perch in multitudes on trees during night, chooling the branches fheltered from the wind, which afterwards die.

They have all very large mouths, when lying always kept open; fhort nender feet, fcarce able to fupport the weight of their bodies; and wings of immoderate length for their bulk : their plumage is gloffed with a rich purple; their note is a night twittering, which they feldom exert but upon the wing.

Their food is infeets, which they always purfue flying; during fine weather, when the infects are abroad, the fwallows are ever on the wing, purfuing their prey with amazing fwifness and agility, through their fhorteft turnings, its long tail like a rudder turning its moft rapid motions.

Early in the fpring, when the re-warming fun begins to rouze the infeet tribes, the fwallow is feen returning from its diftant migration, and making its way feebly from other hores : as the weather grows 'varmer, and its infect fupply increafes, it gathers greater ftrength and activity; but fometimes a rainy feafon, by repelling the infects, ftints the fwallow in its food; when the weather is fair, the infect tribes make bolder flights; the fwallow follows their aërial journeys, often fo high as to be imperceptible.' When the weather is likely to be foul, the infects-fly low; and from the fwallow's following, we are often foretold the approaching change; often they dip in the water, in purfuit of their prey, or aquatic infeets; and in times of fcarcity they difpute with the fpiders, and even fwallow them alfo.

The fwallow's neft is built with great induftry and art; particularly by the common fwallow, which builds on the tops of chimneys; the martin fticks it to the eaves of houfes; the night-fwallow on the bare ground, as do the bank-martins; this neft is buile with mud from fome neighbour- 


\section{THE N I G H T - S W A L LOW.}

ing brook, or fuch as has been caft up by worms, well tempered with the bill, moiftened with water for better adhefion, and farther kept firm by long grafs and fibres; within it is lined with goofe feathers.

On the coafts of China and Coromandel, fays Willoughby, are "a fort of party-coloured birds, of the fhape of fwallows; thefe at their breedingtime come (fome out of the country) to the rocks, and from the foam or froth of the fea-water dafhing againft the rocks, gather a certain glutinous matter (the fpawn of fifhes), of which they build their neits; thefe the Chinefe pluck from their ftations, and bring in great numbers to fell; they are efteemed great delicacies when diffolved in chicken or mutton broih, far before oyfters, muthrooms, or other dainty or liquorih morfels." This kind of fperm of fifhes often floats on the fea for leagues together, in thofe climates.

Ufually lays from five to fix eggs, white, fpeckled with red; fometimes breeds twice a year. The fwallow fupplies her broods very plentifully, the firft parcicularly; always keeps her neft clean.

At the latter end of September, or in Oetober, they leave us; a few days previous to their departure, vaft flocks affemble on houfe tops, as if deliberating on their fatiguing journey, which is thought to be ufually to Senegal, and along the Morocco thore : they fet out at night, to avoid birds of prey ; always choofe a favourable wind; the latter weakly broods, which are not yet in a condition to fet out, delay, and are fometimes too feeble to venture; thefe wretched little families, being compelled to itay, perifh in cold weather; while the tender parents fhare the fate of tireir offspring, and die with their new-fledged brood. They are thought to perform their fatiguing journey in about feven days; when interrupted by contrary winds, in their courfe far off at fea, they alight on whatever finip they find in their paffage, fpent with famine and fatigue, yet ftill they boldly venture, when refreined by a few hours reft, to renew their Aight, and continue their courfe. They do not breed in Senegal, nor ever bring with them into Europe young of the fame year.

Yet it remains doubtful whether all fwallows migrate, or whether there may not be fome fpecies, that, though externally alike, is fo internally diftinet as to be very differently affected by the approach of winter. Many witneffes affirm, that fwallows hide in holes under ground, or in rocks or crevices, or in caverns in mountains; fome inform us that they have feen them taken out of the water, and even from under the ice, in bunches. Reaumur, who particularly interefted himfelf in this inquiry, received feveral fuch accour.ts. 
That fome may hide in warm caverns is poffible, but that they do not hide under water has been pretty well proved, hy the noted experiment of Frifch, who tied feveral threads dyed in water-colours, round the legs of fwallows, that were preparing for departure : thefe, the enfuing fummer, brought their threads back with them, no way damiged in colour; which moft certainly they would have been, if, during winter, they had been fteeped in water.

Kolben fays, that, at the Cape of Good-Hope, they are feen all the year; but in greateft numbers in winter. There are many kincs, as, well in America as elfewhere; in general, pretry clofely related by form and manners.

\section{T H E}

\section{HUMMING-BIRD AND ITS VARIETIES.}

F all that flutter in the garden, or enliven the landfcape, the humming-bird is the moft delightful. Of this charming little fpecies there are varieties, from the fize of a fmall wren, to that of an humblebee, fporting in the fields of America, from flower to flower, and extraking their fweets with its little bill. They feem confined between the tropics; follow the fun to the folftices, and retire with him. The Indians called them rays, or hair of the fun.

The fmalleft humming-bird is about the fize of a hazel-nut; the fearhers on its wings and tail are grey-black; thofe on its body, and under its wings, golden-greenilh brown, with an inimitable red glofs; a finall creft on its head, green at bottom, gilded at top, which Iparkles in the fun; the bill is black, ftraight, nender, like a fine needle. Found in Brafil and the Windward Inands. The larger humming-bird is near half as big as the common wren, and without a creft; is covered from the throat, half way down the belly, with crimfon-coloured feachers, that, in different lights, exhibit a variety of beautiful colours; head fmall, with very litrle round eyes, as black as jet; lègs and feet very fmall, often black; ten feathers in the tail.

There are upivards of twenty kinds of humming-birds, befide the Cozigris, which differ only in having the bill a lirtle curvated, and bending 


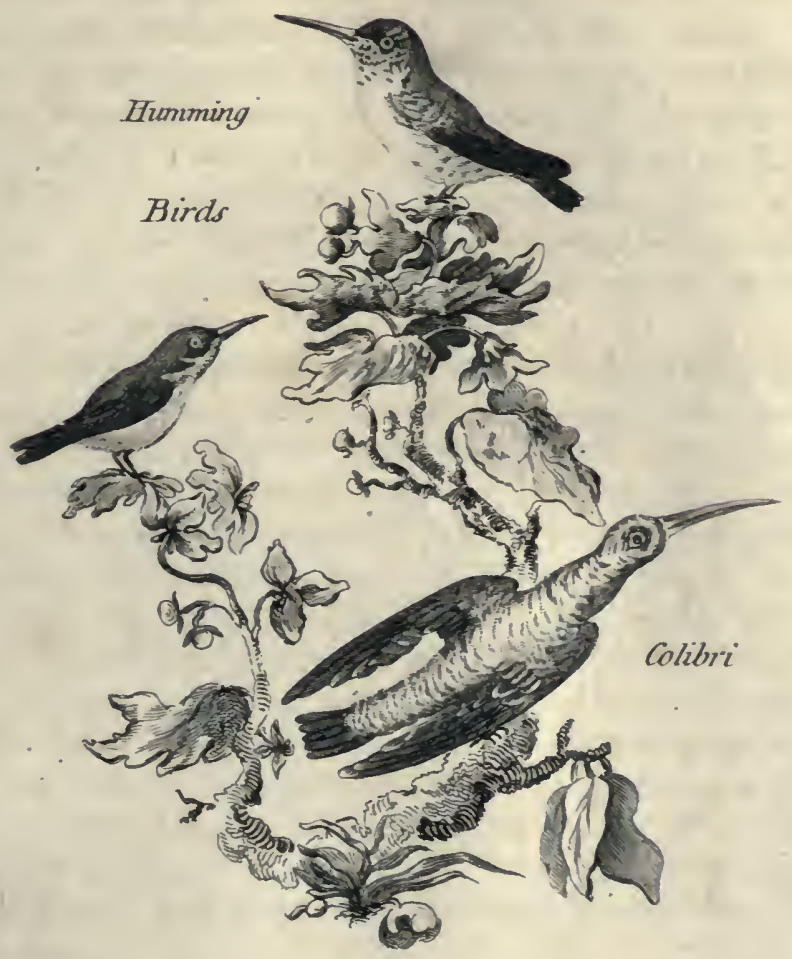



bending throughout; of thefe are above twenty forts; fome are alfo rather larger; their manners are precifely the fame; and knowing one is knowing both.

As foon as the fun is rifen, the humming-birds, of different kinds, are feen fluttering about the flowers, without ever alighting on them. Their wings vibrate fo rapidly, that it is impoffible to difcern their colours, exceps by their glittering. They feem actionlefs by force of their activity, continually in motion, vifiting flower after flower, and extracting its honey. For this purpole they poffefs a tongue, compofed of two hollow grooves, forming a little canal, divided at the end; this is thruft into the cup of the flower: upon this nectar they fubfift. The rapid motion of their wings occalions a humming found, from whence they are denominated. They chafe and drive off birds twenty times their fize. Impatience is their general character; they even tear in a pet, a llower whofe fweet is exhaufted. They are folitary.

Their nefts are fufpended at the point of a twig of an orange, a pomegranate, or a citron tree (fometimes even in houfes, if they find a fmall and convenient twig for the purpofe); the female is the architest, while the male furnithes materials, cotton, fine mors, and vegetable fibres; of thefe a neft is compofed (about the fize of an hen's egg cuc in two), warmly lined with cotton. They lay two eggs, the fize of fmall peas, white as fnow, with here and there a yellow fpeck: the male and female fit by turns, but the female moft ; the' feldom quits the nett, except a few minutes morning and evening, when the dew is upon the flowers, and their honey in perfection. During this thort interval, the male takes her place; for the egg is fo fmall, that expoling it ever fo fhort a time to the weather, might injure it: the fits twelve days, when the young appear, the fize of a fly, at firft barc; by degrees they are covered with down; and at laft with feathers; but lefs beautiful than thofe of their parents.

Father Mondidier, in the miffion to America, found the neft of a colibri in a thed, and took it in, when the young were about fifteen days old: he placed them in a cage at his chamber window, to be amufed by their fportive flutterings; but he was foon furprifed to fee the old ones, that came and fed their brood regularly every hour in the day. By thefe means they themfelves foon grew fo tame that they feldom quitted the chamber; but, without any conftraint, came to live with their young ones. All four have frequently come to perch upon their mafter's PART IV. No. 26. hand, 
hand, chirrupping as if at liberty. He fed them with a very fine clear pafte, made of wine; bifcuit, and fugar; they thruft their tongues into this pafte, till they were fatisfied, and then fluttered and chirruped about the room; ever attentive to the voice of their mafter, when he called them. In this manner they lived with him fix months, when he unfortunately forgot to tie up their cage to the ceiling at night, to preferve them from the rats, and he found they were devoured in the morning.

Thefe birds, on the continent of America, at Surinam, and at Jamaica, continue the whole year; as the honey of flowers never fails them in thofe warm latitudes : but in the Antilles; when the winter approaches, they retire, and, fome fay, continue torpid.

It is a doubt whether or not thefe birds ing : Labat afferts, that they have a moft pleafing melancholy melody in their voices, though fmall and proportioned to their organs. Some may poffers agreeable voices, though the reft may in general be filent.

The Indians formerly made great ufe of this pretty bird's plumage, in adorning their belts and head-drefs. The children take them in the fields upon rings fmeared with bird-lime : they are inftantly killed and gutted, and hung up to dry.

Not 'very diftant in nature are thofe birds, which live only on the fweets of the fugar-cane; nor very diftant in plumage, fince the Creoles often confound them. 


\section{W A T E R - B I R D S.}

TTATER-BIRDS enjoy at once the land, the air, and the waters; not indeed that they feek the land, but at a time when neceflity impels them; nor that they wing the air, but to attain fome fituation otherwife inpracticable. The water is their abode; here they feed, they reft, and often neep; and to this they train their offspring in their earlieft powers. Tempefts and ftorms are familiar to them; with the rifing and the falling billows they rife and fall; fport in the dafhing fpray, and view, without alarm, the rolling gulph. Many of them traverfe the vaft ocean, and are found hundreds of leagues from fhore; others inhabit rocks, and are attached to the furrounding feas. Some prefer temperate climates; others (and thofe the greater number) choofe frozen dwellings, floats of ice, or fhores benumbed with froft: where not the Greenland bear, nor the morle, nor the whale inhabits, thither retreat many kinds of birds; only difturbed by the apprehenfion of too long night, and only quitting the extremes of the globe, as darknefs fpreads itfelf around their dwellings. To enjoy a few hours of light, they follow the fun with reluctance, and with joy precede his annual vifits to their polar abodes.

Water-fowl are peaceable among themfelves, and have no tyrants of their own kind to dread; but often their chace proves dangerous, and, intead of taking their prey, they become victims: large firh draw them under water; whales, and cachalots, open the gulphs of their enormous throats, not only for thoals of herrings, or mackarel, but for flights of birds that follow them. Water-fowl have among them no birds of fong; for what is melody among the waves? What the modulations of Philomel herfelf among the boifterous roar of the agitated deep? Loudnefs and ftrength that may be audible from afar, though lefs brilliant, are moft ufeful.

Water-fowl are always moit plenty where fith abounds; and often two fides of an inand ihall be remarkable, one for the abundance, the other for the fcarcity, of birds, from this caufe.

Few water-fowl, in proportion to other kinds, are tamed; and thofe which man has adopted, are rather captives than domeftics; for being incapable of bearing confinement, they enjoy a partial liberty, if no more, 


\section{T H E W A T E R - F O W L.}

and by means of it retain moft of the marks which belong to their native Atate; nor do they form, by any means, the varieties and crofs breeds that land-birds do; but are capable of returning fooner to their wild ftate, as being lefs diftant from it.

Between land-birds that Thun the water, and water-fowl that inhabit it, nature has placed a numerous tribe of a middle nature, whofe divided toes indicate a refidence on land, but whofe appetites attach them to the ftreams; living among waters, yet incapable of fwimming, their long legs fit them for wading, and their long bills for groping, in fhallows.

Birds habituated to marhy places, may be known by the fcaly furface of their legs; moft alfo are bare of feathers half way up the thigh; all of them above the knee; their habits of wading continually in moilture preventing the growth of feathers on thofe parts.

The bill of this clars is, in general, long, and in fome finely fluted on every fide; its point poffeffes extreme fenfibility, being furnifhed with nerves for the better feeling their food. Sume have long legs, for wading; long necks, for ftooping; long bills, for fearching; and nervous points, for feeling. Others have long bills, but moderate legs; others long necks, but hort legs. Where a bird's legs are long, the neck is alfo long; no bird is fo defective in conformation, as to ftand upon ftilts above its food, without poffeffing an inftrument to reach it. They live on fifh, or infects, a few excepted; "even thofe called mudfuckers probably feed on worms.

Such are the general habits of amphibious birds. Quitting thefe for water birds, of manners truly aquatic, we come to thofe whofe firt great diftinction appears in the toes, which are webbed together by broad Ikins; fo that they expand two broad oars to the water; and, moving them alternately, fwim with the greateft facility; the toes, by friking backward, beat the water with their broadeft hollow furface; but when advancing for a fecond blow, their front furface contracts, and offers no refiftance againft the fluid to impede the birds progrefs.

Web-footed birds have very hort legs; were the leg long, its motions would be flow and laborious. They have a clofer, warmer plumage than birds of any other clafs; are alfo furnifhed with an animal-oil, that glazes their furface, and keeps each feather feparate. This oil contributes alfo to their warmth in the watry element. They abound with fat, fo that, by the warmth of their feathers externally, and this natural lining internally, they are better defended againtt the weather, than other claffes. 
Some water-fowl prey by fudden ftoops from above, to feize what fifk come near the furface; others, not furnifhed with wings long enough for fight, take their prey by diving.

After thefe hints, we divide aquatic birds into (I) thofe of the $C_{R A N E}$ kind, or fuch as are amphibious, and frequent banks and ftreams, rather than extenfive waters; (2) thofe of the Gul k kind, with long legs and round bills, that fly along the furface to feize their prey; (3) thofe of the PENGUIN kind, that, with round bills, fhort legs and wings, dive after their prey; (4) thofe of the Goose kind, with flat broad bills, that chiefly fubfint on infects and vegetables.

The gull kind are active and rapacious, conftantly on the wing; with tharp ftraight bills for piercing, or hooked at the end for holding, their finy prey. In this clafs we include the albatrofs, the cormorant, the gannet or folan goofe, the thag, the frigate bird, the great brown gull, and all the leffer tribe of gulls and fea-fivallows.

The penguin kind, with wings fhort, and bodies large, can neither run nor $\mathrm{Ay}$, but are formed for diving; their feet are placed fo far backward, and their legs fo hid in the abdomen, that the nighteft ftroke impels them head foremott in the water. To this clafs we may refer the penguin, the auk, the fkout, the fea-turtle, the bottle-nofe, and the loon.

The goofe kind are diftinguimable by their flat broad bills, covered with a Kin; and by cheir manner of feeding, which is moftly on vegetables. In this clafs we comprife the fwan, the goofe, the duck, the teal, the widgeon, and their numerous varieties.

\section{T}

TS a tall, nerider bird, with a long neck and long legs; the top of the head covered with black briftles, thinly fcattered, efpecially on the back, which thereby feems bald, and is red in the male; which fufficiently diftinguithes this bird from the ftork, to which it is very nearly allied in fize and figure. The plumage in general is clear ah-coloured; except the tips of the wings and the head; and there are two large tufts of feathers that fpring from the pinion of each wing. Thefe bear a refemblance to thofe in the fides of the oftrich; the quill feathers are black, 
and are finely curled at the ends; the bird has a power of erecting and depreffing them at pleafure. The crane varies in fize, from three feet high, to four and even five feet, from tip of the bill to the toes. The naked part of -the leg is about four inches, the feet are black, ten or eleven inches long; bill four inches, ftraight, pointed, compreffed on the fides; blacking green in colour.

The crane is a very focial bird, and feldom feen fingly; they affemble in flocks of fifty or fixty; while part feed, others iftand like centinels : ever wandering, and greatly fubfiting on corn and vegetables, but partly alfo on reptiles; and is known in every country of Europe (except our own); from north to fouth; and even to Ethiopia. They generally leave Europe about the latter end of autumn, and return in the beginning of fummer; crofling the inland parts of the continent in flocks of fifty or an hundred, lying chiefy in the night.

In thefe journeys they, afcend amazing heights; their note is the loudeft among birds, and is often heard in the clouds; when they are unfeen. Light for its fize, and fpreading a large expanfe of wing, it is capable of floating, where the air is lighteft, in tracts too fatiguing for other birds. Though unfeen themfelves, they have diftind vifion of objects below; they direct their flight by their cries.

The cold arctic regions feem to be this bird's favourite abode; in the fouthern parts they are rather vifitants than inhabitants.

The peculiar clangot of their voice arifes from the extraordinary length and contortion of the wintipipe; from the throat it enters through the flefh into the breaft-bone, which has a great cavity within to receive it; there being thrice reflećred, it goes out again at the fame hole, turns down to the lungs, and enters the body a fecond time.

They rife heavily, are very thy, and feldom let the fowler approach them. Their depredations are ufually made in the darkeft nights, when they enter a field of corn, and trample it down. They choofe fome folitary marsh, where to range themfelves by day, as if in deliberation; and not having grain, warte the marhes, for infects and other food.

In general is a peaceful bird, both at home and abroad; is eafily tamed, and taught poltures and dances.

The female is diftinguifhed from the male, by not being bald behind; lays two, eggs at a time, like thofe of a goofe, but blueinh. The young ones are foon fit to fly, and then their parents forfake them; previoufly leading them to wher their food is moft eafily found. Though unfledged, shey 
they run fo fwiftly that a man cannot eafily overtake them. As they grow old, their plumage becomes darker : they are very long lived; that of Leonicus Thomeus lived with him forty years.

Their various manners of flying indicate changes in the weather; always fet a centinel when on the earth during night; vigilant, even to a fymbol; all (except the centinel) fleep, the head under the wing.

White cranes are fometimes found, but rarely.

South of the tropics are cranes, as in thefe northern parts, of the fame appearance, and probably of the fame manners.

In America a white crane (a conftant race), but its great quill feathers of the wings black, is ftronger made, larger headed, and longer billed, than the European cranes.

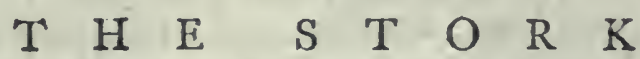

ESEMBLES the crane in bill, neck, legs, and body, but is Tomething fmaller, and fomething more corpulent; in colour the ftork is gliftering white and brown, or black on its wings; the nails of its toes are peculiar, not clawed like thofe of other birds, but flat like the human. Feet and bill red; its long neck bent; arcund the eyes a naked wrinkled $\mathbb{R}$ kin, blackifh red. Rudiments of a membrane between its toes.

The ftork is filent, except a noife caufed by clacking its under chap againft the upper : its windpipe has no convolution through the breaftbone, but is formed as ufual : preys entirely on frogs, fines, birds, and ferpents. When flying, holds forward its head ftiff; while its legs, extended backward, are alfo ftiff, as if ferving for a rudder. When refting, ftands on one leg, its neck bent backward, and its head refting on its houlder; is eafily familiarized, is cleanly, has a dejected afpect, yet is often lively, and frolics with children, leaping and playing; is long lived, lives always in or near towns: lays generally four eggs, dirty white and yellow.

Are birds of paffage; quit Europe in Augult; travel to Egypt, Belon fays, in troops of four or five thoufand. Kempfer fays they are ftationary in Japan. All affemble on a particular day, and leave none of their company behind. Take their light generally in the night : generally return in the middle of March; neftle on the tops of chimneys and houfes, as well as of high trees: always return to the fame nefts; if the neft is dePART IV. No. 26.

$\mathrm{P}$ Atroyed, 
ftroyed, build another in the fame place. Male and fernale fit upon their eggs by turns; are a month in hatching; are particularly folicitous for the fafety of their young : thefe, unable to ftand on their thin and feeble fupports, draw themfelves along in the neft on their knees. Belon afferts that they breed alfo while in Egypt.

The Dutch are very folicitous for the prefervation of the ftork in their republic. This bird builds on the tops of their houfes without moleftation, and is familiar in theirftreets. There are few towns on the continent, in low marfhy fituations, but have the ftork among them.

Is faid to maintain its parents, when infirm by accident or age; and to give a kind of token at parting, and at returning to its neft.

The BLACK STORK is rather brown, than black; changing by reflection to violet and golden green; a lively red fkin round the eyes; red bill; wild and folitary ; flies from habitations, and frequents marfhes and deferts, or the deep receffes of the woods. Neftles on old trees, high pines, by the fides of lakes; befides finh, feeds on infects; found in the Alps, and Germany; is fuppofed to migrate: the fpecies is rare; feems to avoid where the white ftork prefers.

The MAGUARI inhabits the hot climates of America; and feems to be reprefentative of the fpecies in the new world.

The Couricaca, ill denoted by the title wood-pelican (fince it has little in common with the pelican), inhabits Guyana, Brafil, and South America. In fize equals the ftork, higher mounted on its legs, and having a longer neck; has a hard, ftrong, thick, and large bill : plumage brown, black, and white: his throat capable of extenfion, but nothing like the bag of the pelican. Is a bird of paffage; frequents Carolina at the clofe of fummer; haunts marthes.

\section{T H}

$7 \mathrm{HE}$ ancient Egyptians worhipped the IвIs, a bird in appearance between the crane and curlew; the moderns referring it to the latter kind, the ancients to the former. Thar man hould at any time, or on any occafion, workhip brutes, is only to be accounted for on principles heretofore hinted; and by remarking that, while fecond caufes were elevated to the ftation of the great Firft Caule, there werc no limits whereby the infuence of fo difhonourable and detrimental a principle could be confined. 


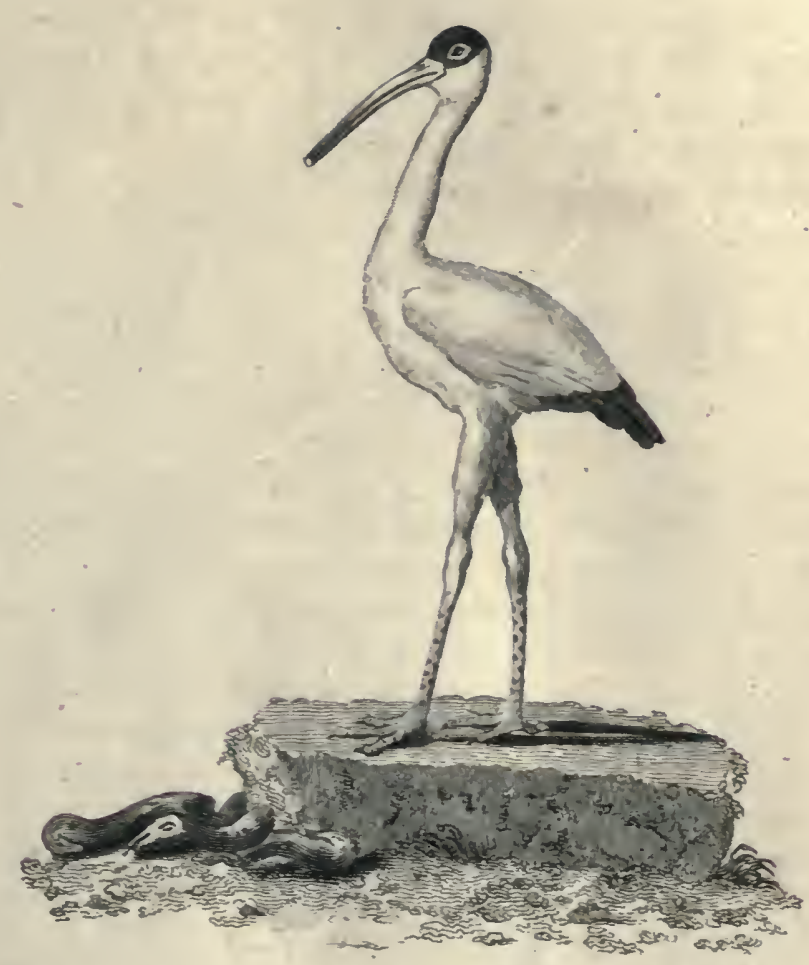

The white Tbis 



The Ibis was. ferviceable to the Egyptians, by ridding their country of ferpents; and ftill continues the fervice, having particular delight in killing reptiles of all forts, even when fatiated with food. There are two kinds; the black, which is very fcarce; and the white; which is common. The whire is rather lefs than the ftork, about three feet and a balf in length, legs long and naked, face and forehead without feathers, bill arched, the tips of the wings and tail black; the reft of the plumage white; the bill is yellowin, roundifh, and terminates bluntly; the head, eyes, and throat are covered with a wrinkled nkin; the fides of the bill are fiarp, cutting, and hard enough to cue ferpents; which probably is the manner in which the bird deftroys them. The legs are red, fcaly; the nails pointed, narrow, blackinh; rudiments of membranes; tongue very fhort; globe of the eye fmall.

Known to be the ancient Ibis by the bills remaining in fome pots of mummies, and by the bones of the leg. Being held in efteem in Egypt, frequents towns, and lives freely, wandering at pleafure in the ftreets. Neftles on palm trees, and among tufts of prickly leaves; to prevent the attack of cats: lays four eggs; fits four weeks : this rellation to the four phafes of the moon, and the black and white plumage of the bird, occafioned it to be confecrated to Ifis (i. e. the inoon). Is long lived: the Egyptian prielts Thewed to Herodotus one which was $\int_{0}$ old, as they faid, it could rot die.

The Black Ibis is fmaller than the white, and not fo long legged; in the reft refembling the former.

In Egypt, \&c. are cranes, ftorks, hawks, kites, and falcons, all equal enemies to ferpents, and that devour a vaft number. The modern ibis is not peculiar to Egypt; and fome perfons have even thought that the true ibis is a bird of the vulture kind, called the capon of Pharaoh, which not only is a devourer of ferpents, but will follow the caravans that go to Mecca, to feed upon the offal of the animals that are killed on the journey; of fomewhat like which we have a hint in JosEPHus, though much difguifed, relating to the ibis : but thefe birds have not the fame relation to Ifis, as the true ibis has, and which feems to fix it to the bird we have defcribed.

\section{$\begin{array}{llllllllll}T & H & E & J & A & B & I & R & U\end{array}$}

THE JABIRU is the largeft bird of the crane kind; much higher than 1 the crane itfelf, and double its fize; in body exceeding the fwan. 
Inhabits the borders of the rivers Amazons and Oroonoko, where reptiles abound in prodigious numbers. Here the ftrength of the jabiru is but proportionate to the fize of the ferpents which it has to deftroy; and its height to/ the depth in which it has occalion to wade. Its bill is thirteen: inches long; three broad at the bafe, black, tharp, cutting, flat on the fides, hard as horn, flightily incurvared upward; the neck ftrong, thick as a man's arm; the head, and two thirds of the neck, covered with a naked black fkin; on the fummit a few grey hairs. The fkin at the bottom of the neck, four or five inches high, is of a bright red, and forms a large and handfome collar to the bird, whofe plumage is white. Legs ftrong, covered with black fcales, and partly without feathers; a fmall membrane between the toes: the tail is large, extends not beyond the wings when clofed; inhabits marthes and lakes; its flefh dry, but not bad;: is very fat in the rainy feafor.

The NANDAPOA is a fmaller jabiru; refembling the former in its: head and neck, but differing by its bill being arched downward, and being only feven inches long. The bird is about equal to the ftork in fize: fummit of its head, grey and bare, even bony : eyes black; ears. lárge, and very open; wings and tail black; plumage white; flefh good eating, after, taking off the fkin. Called the jabiru guacu, or large jabiru, where the former is not known.

\section{T $\mathrm{H}$ E $\dot{\mathrm{K}}$ A $\mathrm{M}$ I $\mathrm{C} \quad \mathrm{H}$ I.}

THE KAMICHT; fo called in Guyana; in Brazil, the Anbima; in Amazonia, Cabuitabu, from his cry, (which is fo loud as to cerrify into filence all birds and reptiles, its neighbours, as it echoes along the waters); others exprefs it vyboo vyboo; is a water-fowl, feeding on ferpents and reptiles; bigger than a fwan. The head, which is fimall for the fize of the body, bears a black bill, which is not above two inches long; the upper mandible; longent, and a little pointed; a horn growing from the forehead, three or four inches long; ending in a tharp point, bending forward, Theathed at its bale, thicker than a crow-quill, as round as if it were turned in a lathe, and of an ivory colour : the head and neck frizled, with very little feathers. At the fore parc of each wing, and at the lecond joint, fpring two ftraight triangular fpurs, about as thick as one's little finger : the uppermoft of thefe fpurs is the largeft, two inches long, a little bent at the end, and is theathed at its bafe; the hinder is. Morter, flieathed alfo; and both of a duky colour. The claws alfo are long and harp; general 


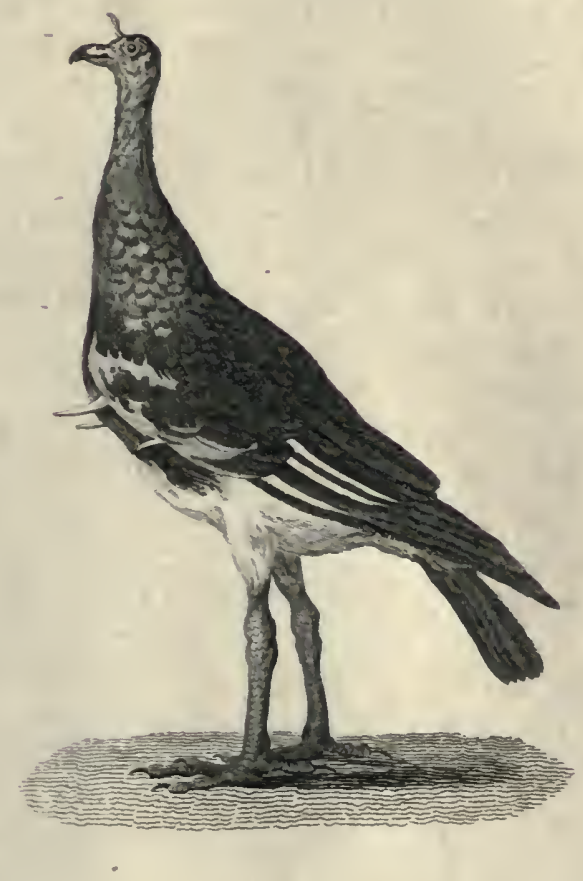

The Kanichi. 



general colour brown, black, and white. Notwithftanding thefe arms, never attacks birds, but reptiles only. Wings and tail very long; the feet covered with very ftrong fcales; toes yery long; the middle toe, including the nail, five inches; the nail hooked, hollow beneath; toe behind refembling that of a lark: he walks with his head high, and his neck erect. They are never found alone, but in pairs, prowling together; and their fidelity.is faid to be fuch, that, when one dies, the other never departs far from the carcafe, but wanders groaning around the place, and dies with its companion. It makes its neft of clay, at the foot of trees, on the ground, in thape like an oven : haunts the forefts, but efpecially marthes and favannas, where the reptiles grow to enormous fizes.

\section{THE SECRETARY, oR MESSENGER,}

$\mathrm{T}$ among the mott remarkable of birds, as well in form as manners; 1 has long legs, like waders in general, yet a hooked bill like birds of prey. He feems to exhibit an eagle's head, on the figure of a crane. Full the height of a crane, and the fize of a turkey-cock. On the head, neck, back, and covert of the wings, grey, inclining to brown, becoming lighter in front; wings and tail black, black waved with grey on the legs; a pacquet of long feathers, like wing feathers, hang behind his neck; moft of them fixinches long, black, fome fhorter, and fomegrey; all are nender near the quill, broad at their ends. The leg is almolt bare of feathers; the toes fhort and thick, that behind very ftrong; nails crooked; the neck is thick, bill ftrong, and divided beyond the eyes; the upper mandible hooked like the eagle, pointed and cutting; the eyes are placed in a naked orange-coloured $\mathrm{kin}$, extending beyond the exterior angle of the eye, and originating from the bafe of the bill : has alfo eye-lafhes, of one row of black hairs, three quarters of an inch long, which, being a peculiarity of an extraordinary kind, contributes much to the fingularity of the bird itfelf. Though armed by a bill proper to birds of prey, yet he is timid; and often, to elude the attacks of even a weak enemy, leaps eight or nine feet high : gentle and lively, he becomes eafily familiar, and, when brought up young from the neft, is domefticated; and actually at the Cape of Good-Hope is ferviceable in deftroying rats, lizards, ferpents, \&c. When the bird finds a ferpent, he artacks him by blows with his wings, to weaken him; then feizes him by his

เ2il, 
tail, raifes him a great height in the air, and by repeated falls beats him to death. When running he fpreads his wings, and is often feen thus running ard flying at once. Neftles in bufhes, fome feet from the ground; lays two white eggs, with rufty fpots; when difturbed, croaks; is not dangerous, but mild. He eats meat greedily, does not refufe fifh. When repoling or fleeping, crouches on his belly: fome of his cries refemble fome of thofe of the eagle, His ordinary exercife is to walk fwiftly, backward and forward, a long time without ftopping; whence his name of Meffenger: as that of secretary, from his feathers, as it were, ntuck like a clerk's pen behind his ears. Diverts himfelf by throwing up a ftraw frequently: when approached, he is fearful; but foon recovers his gaiety, and becomes curious. While the defigner was drawing him, he came feverąl times to infpect the portrait, ftretching out his neck, and erecting his neck feathers; often alfo fpreading his wings : when prompted by great curiofity, erects his neck feathers very high; was never feen to drink; to eat at his eafe, he half lies down; his greateft ftrength feems to be in his feet, by a blow of which he will kill a chicken, or a rat, for which he will watch affiduounly before its hole; prefers living animals to dead, and flem to firh. Is but lately known at the Cape of Good-Hope ; inhabits the interior of Africa : alfo the Philippine Iflands. In fome, the neck feathers are frizled; fome have two long feathers in the tail, probably the male.

\section{T H E C A R I A M A}

CURPASSES the heron in fize; lives on the banks of waters, and $\$$ marhes; has long feet, and nalked legs, but a bill thort and hooked like birds of prey : carries his head high; his neck is long: at the bafe of his bill, which is yellowifh, is a feather refembling an aigrette; his plumage refembles that of a hawk, being greyin, waved with brown. His eyes are bright gold.colour, having long black eye-lantes; his feet "yellowith; toes united at their origin by a partial membrane; the middle toe longeft (nail fhort and rounded); the hind toe placed fo high, as not to reach the ground; heel thick and round, like that of the of rich. The voice of this bird refembles that of the turkey-cock, is loud and audible from afar; his fleh is tender and delicate; is thought not incapable of domeftication. Inhabits South America. 


\title{
( 89$)$
}

\author{
T H E
}

\section{GROWNED AFRICAN CRANE} S pretty nearly the thape and fize of the ordinary crane, with long
legs and neck, but the bill horter; colnur of the plumage dark greenilh grey; the bill, feet, and legs black. The head and throat form the moft ftriking part of this bird's figure. On the head ftands up a compaEt round creft of filken brifties, flat, and fpiraled, fpreading every way like diverging rays, the longeit ray about three inches and a half ; on each grow, ttanding up, very fmall hairy feathers, black, pointed, and topped with a kind of tlack taffels, which give them a beautiful appearance. A large wattle of a membranous $\mathrm{kkin}$, white on the temples, bright fcarlet on the cheeks, furrounds his face, and defcends under his bill; on his head a tine down; the eyes large and ftaring; the iris white, the pupil black and big, furrounded with a goldcoloured iris that completes the bird's very fingular appearance. Beautiful feathers of a deep leaden black colour hang down his neck, and fpread on the fhoulders and back; the firft feathers of the wing are black, the others reddith brown; its voice refembles the crane.

When running, ftretches out its wings, and goes very fivifrly, but its ufual motion is fow : when domefticated, walks very deliberately among poultry, and is gentle and peaceful. At Cape Verd is half-domefticated, and comes freely to eat grain among the poultry; is even difpleafed when folitary too long; loves to be vifited and fpoken to. They feldom rooft in houfes; but, when difpofed to go to reft, perch on fome high wall in the manner of a peacock, which bird they fo much refemble in lome of its manners and difpofition, that feveral authors have called them the fea-peacock. Has been fuppofed, erroneounly, to be the Balearic crane of Pliny: neither correfponds to his hint, nor is found in the Palearic Inands, but inhabits the Gold Coaft, Cape Verd, \&c. Its habits and food refemble the crane kind: loves to bathe itfelf; loves fifin, infects, \&c. 


\section{THE NUMIDIAN CR A NE}

TS vulgarly called by our failors the Buffoon Bird; by the French, the 1. Demoifelle; very clofely refembles the crane in figure and colours. When performing its gefticulations, after making fundry reverences, rifes, lifts one wing, then another, turns round, fails forward, then back again; walks with a good air 'and oftentation, oftén bounds and leaps gaily, as if it would dance : has been called the actor, the mimic; has great vanity; loves to Thew its feats; prefers applaufe to its food, and follows fpectators in hopes of further infpection. Has two tufts of fine white feathers, confifting of long, delicate, almolt hairy fibres, which fall from the fides of the head, forming a kind of head-drefs, about four inches long; the fummit of the head covered with long and fof black feathers, reclining, while the fore part of the neck is adorned with black feathers, compofed of very fine long and filky fibres, that hang down upon the ftomach, and give the bird a very gracefuli appearance: under the wings alfo depend long and flexible tufts of feathers. Might perhaps be naturalized in Europe, as it has lived and bred here, though a native of the Tropics.

\section{THE SPATULA OR SPOONBILL.}

$7 \mathrm{HE}$ Spoonbill differs much from the crane, yet approaches this 1 clafs more than any other. The European fpoonbill is about the bulk of a heron; but thorter in the legs. Neck furnined with fmall feathers; thofe of the back of the head fall down the neck; its eyes are furrounded with a naked $\mathrm{kin}$; the feet, and naked part of the legs, are covered with a black $1 \mathrm{kin}$; a partial membrane unites the toes.

Its common colour is a dirty white; thofe of America are of a beauriful rofe colour, or crimfon, and larger than the European; its bill, which is very particular, is about feven inches long, and fpreading at the end, to three times the width of the bill, terminating in a hooked point, as its name denotes; it is there upwards of two inches wide; the upper mandible feems to comprize the whole forehead, it is fo large. This inftrument in fome is black, in others of a light grey, or yellowin, barred black; in thofe of America, is red, like the body. Round the upper chap runs a kind of rim; with which it covers that beneath; within it has a long gutter, in the upper mandible; the fubftance of this bill is nor hard, but flexible like leather; its tongue is not half an inch long, is triangular: the windpipe has a double intection. 


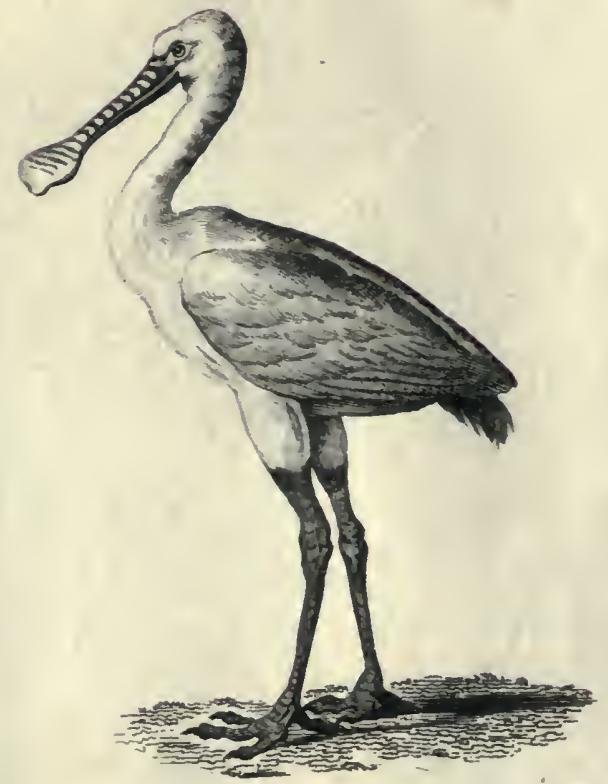

The Spatula or Spoon-bill. 



Inhabits the fides of the fea, lakes, and marhes; feeds on frogs, toads, filh, Thell fifh; aquatic infeets, and worms, and throws up the fhells after digefting the flefh; allo on ferpents, of which, particularly at the Cape of Good-Hope, they deftroy great numbers. The inhabitants efteem them as formerly the ancient Egyptians did their Ibis : he runs tamely about their houfes; a ufeful, if not a beautiful companion.

This bird breeds in Europe, in company with the heron, in high trees; and in a neft formed of fimilar materials. Willoughby mentions a certain "grove, at a village called Seven Huys, near Leyden, where they build and breed yearly in great numbers. Here, alfo, the heron, the bittern, the cormorant, and the fhag refide, and annually bring forth together. Here the crane kind feem to have formed their general rendezvous; and, as the inhabitants fay, every fort of bird has its feveral quarter, where none but their own tribe are permitted to refide. Of this grove the peafants make good profit." It is now deftroyed.

The fpoonbill is very noify in hatching-time; lays three to five eggs, white, powdered with a few pale fpots. The fpecies is fpread throughout the world, but is no where numerous.

\section{T H E F I A M I N G O.}

$7 \mathrm{HE}$ Flamingo is the moft remarkable of all birds refembling the crane, the talleft, flendereft, and moft beautiful. The body fcarce equals that of a fwan; but its legs and neck are fo long, that when ereet it exceeds fix feet high. Its wings, extended, are five feet fix inches from tip to tip ; and it is four feet eight inches from tip to tail.

Its plumage is bright fcarlet, or flame-coloured (whence its name), fome fpots deeper, fome lighter; the tips of the wings conftantly black, their upper parts remarkably vivid fcarlet; this colour gradually extends to the back, the rump, the breaft, and on to the neck; the upper part of the neck, and the head, are covered with down; only the top of the head is bare of feathers.

Its bill is of a very extraordinary form, feven inches long, flat, and very ftrongly turned downwards at half its length; his head and throat feem fwelled to fupport this bill, efpecially the inferior mandible; the fuperior mandible is rather longer than the inferior, to include it; the edges of both are furnithed with a row of tharp fmall teeth, turning back-

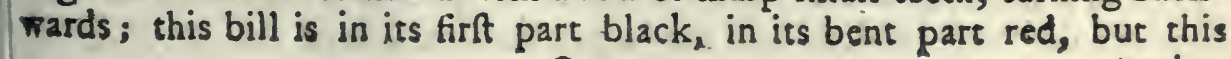


varies; its upper chap is fuppofed to be moveable. The legs and thighs are not much thicker than a man's finger; about two feet eight inches ligh; its neck near three feet long. The feet are not furnimed with Tharp claws, but feeble, and partly united by femi-membranes; the bird is never feen fwimming; its legs and thighs being fufficient for bearing it into thofe depths where it feeks for prey.

This extraordinary bird is found in Italy, Spain, all over Africa, and in America; wanders, but confines its wanderings to warm climates. In America, or where molefted, they chiefly keep near deferted fhores, near falt-water lakes and fwampy inands. They come down to the banks of rivers by day, and often retire to the mountainous parts at night; in the day they appear drawn up in a long clofe line of two or three hundred together; and, as Dampier tells us, prefent, at the diftance of half a mile, the exact reprefentation of a regiment of foldiers, or a long brick wall. Their rank is broken when they feek for food; but they appoint a centinel, whofe duty is to give notice of danger, while the reft feed. As foon as this trufty centinel perceives the remoteft appearance of danger, he fcreams, with a voice loud and Thrill as a trumpet, and inftantly the whole cohort are on the wing : they feed in filence; but now all the flock are in chorus, and fill the air with intolerable fcreamings.

In Africa they affemble by thoufands, perch on the trees within and about villages and dwellings, and are very clamorous; the found is heard at near a mile diftance. The Negroes confider their fociety as a gift of Heaven. In fome places they are hot by mariners; their young, which run exceffively faft, are often taken with nets. When their long legs are entangled in the methes, they cannot efcape; but they continue to combat; and the old ones, though feized by the head, will fcratch with their claws, and often do mifchief. Of all delicacies the flamingo's tongue is the mont celebrated; a feaft, fays Dampier, for an emperor! In fact, the Roman emperors thus confidered it; and we have an account of one, who procured fix hundred flamingos' tongues to compofe a fingle dirh. This tongue is larger than that of other birds, is black and grifty; a lump of fat at its root is much admired.

Their cry founds like the word Tococo, from whence the Canadian Indians have named them. In their flight they appear of as bright 3 red, as a burning coal. Their manner of feeding is fingular : the bird thrufts down its head, fo that the upper convex fide of the bill fhall only 


\section{T H E F'L A M I N G O.}

touch the ground; in this pofition he appears, as it were, ftanding on its head. In this manner it paddles its feet, to attract the water, mud, \&c. and their inhabitants; and moves the bill about, and feizes whatever firh or infect happens to offer. They eat fmall fifhes, thell-fifh, fifh-fpawn, and water iniects, where there are plenty. . When tame, eat bread, \&c. which they foak in water ; fear cold, and come fo clofe to a fire as to fcorch their legs; neep ftanding on one leg, the other drawn up under the belly, the head turned back under the oppofite wing.

Their time of breeding is according to the climate; in North America they breed in our fummer; on the other fide the line they take the molt favourable feafon of the year. They build their nefts in extenfive marfhes, and where fecure from furprize. The neft is raifed from the furface of the pool about a foot and a half, formed of mud fcraped up together, and hardened by the fun, or the heat of the bird's body : it refembles a truncated cone, or one of the pots which we fee placed on chimneys; on the top it is hollowed out; in this cavity the female lays her eggs, without any lining but the well-cemented mud that forms the fides of the building. She lays two eggs; and as her legs are immoderately long, the ftraddles on the neft, while her legs hang down, one on each fide, into the water; her body, properly fpeaking, does not enter the neft, but rather her sump, while her tail covers it.

The young ase long before they $\mathrm{A} y$, but they run with amazing fwiftnefs : they fuffer themfelves to be carried home, and are tamed very eafily; in five or fix days they become familiar, eat out of the hand, and drink a furprifing quantity of fea-water, which is indifpenfable to them; but are not reared without great difficulty; generally pine away for want of their ratural fupplies, and die in a fhort time. While young, their colours are very different from the lively tints of their kind. In the firft year their plumage is white, mixed with grey; in the fecond year the whole body is white, with here and there a night cint of fcarlet; and the great covert feathers of the wings are black : the third year the bird acquires all its beauty. 


\section{( 94$)$}

T H E

\section{HERON, AND ITS VARIETIES.}

$5 \mathrm{HE}$ Heron may be diftinguined from the crane and ftork, as well by being much lefs, as by its bill, which is much longer in proportion; but efpecially by the middle claw on each foot being toothed like a faw.

Brifon has enumerated not lefs then forty-feven forts, differing in fize, figure, or plumage. In fact, the kind is numerous, but of uniform manners; cowardly and rapacious, indolent, hungry, exceffively deftructive and voracious, yet ever of lean and carrion bodies.

The common heron is remarkably light in proportion to its bulk, farce weighing four pounds; yet, wings expanded, is five feet from tip to tip. Its bill is very long, being five inches from the point to the bafe; its claws long, tharp, and the middlemoft toothed: thus armed, yet indolent and cowardly, it fies at the approach of a fparrow-hawk. Is very melancholy when taken old, and even refufes food; but, if taken young, may be domefticated.

Of all birds, commits the greateft devaftation in frefh-waters; fcarce a fifh, though ever fo large, that he will not ftrike at and wound, if unable to carry it away. But the fmaller fry are his chief fubfiftence; thefe, purfued by the larger fifhes, take refuge in thallow waters, where they find the heron a ftill more formidable enemy. He wades as far as he can into the water, and there patiently waits the approach of his prey. "I have feen a heron," fays Willoughby, "Mhot, that had feventeen carps in his belly; thefe he will digeft in fix or feven hours, and then to fifhing again. I have feen a carp taken out of a heron's belly nine inches and a half long." Several gentlemen who liept tame herons, to try what quantity one of them would eat in a day, liave put feveral fmall roach and dace in a tub, and they have found him eat fifty in a day, one day with another. In this manner a fingle heron will deftroy fifteen thoufand carp in a fingle half year.

In general, he is feen through a telefcope, for he fuffers no approach, but is very fhy; fixed in his gloomy folitary ftand by the lake-fide motionlefs; his long neck ufually funk between his houlders, his head turned on one fide, as if eying the pool intently. Thus he ftands early and late, and often fo fteady, that it feems doubtul whether it is an ani- 


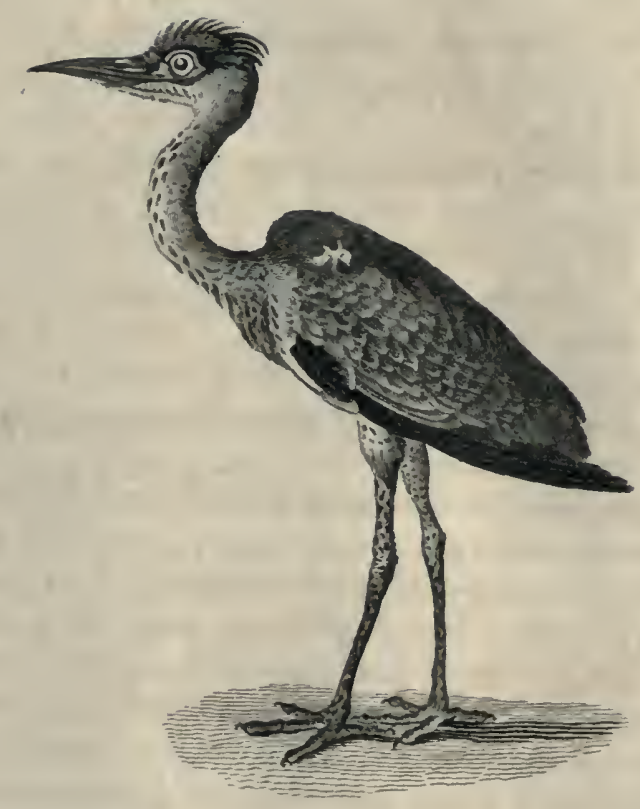

The Heron 

mated being; though fometimes half frozen and covered with icicles, flies in the night, and is heard at all feafons. When flying ftiffens his legs, lays his neck on his back, folded fo that below the bill feems to grow out of the breaft; rifes very high, and flies flat. In cold or ftormy feafons, his prey is no longer within reach: the filh now keep in the deep, as the warmeft fituation; frogs and lizards alfo, of which he devours many, abide clofely in their lurking-places; and the heron is obliged to have recourfe to patience, and to take up with water-weeds.

Often he hovers over thalluw places, where he darts on his prey with certainty; for though the fifh at fight of its enemy inftantly defcends, yet the heron, with his long bill and legs, pins it fecurely to the bottom, then rifes on the wing, with a trout or an eel ftruggling in his bill : the greedy bird, however, flies to the fhore, fcarce give it time to expire, but fwallows it whole, and then returns to filhing as before.

Neftles on the tops of the highett trees in the foreft or the grove, fometimes on cliffs hanging over the fea; where they love each other's fociety, and build in company. The female lays four large eggs of a pale green : their nefts are made of fticks, and lined with wool: often feize one from the rook, the crow, or the owl, which they enlarge. Heronries are not unfrequent in France, where the flefh of the young is in eftimation. It was formerly much efteemed in England, and a favourite dith at great tables. It was even faid the fleth of a heron was a difh for a king; at prefent, nothing about the houfe will touch it but a cat.

The young are numerous, voracious, and importunate; the old ones ever on the wing to provide for them. Is very long-lived, exceeding fixty years, but by how much is not known.

There is a white heron, the fize of the former, his bill yellow, feet. black. Alfo a black heron, a blue heron, and feveral of other colours.

The Aigrette is of the heron family, and diftinguithed by long filky feathers on his back, ufed to form ornaments for the head-drefles of ladies, knights, and fultans. They rife from each houlder in a tuft, which extends beyond the tail; are fnow-white; bill and feet black; the bird about two feet high. Is found alfo in America; alfo another of double the fize; as are feveral varieties of the heron kind, very large and very fmall. 


\section{$(96$, \\ T H E O P E N - B I L L.}

THERE is a ftrange bird of the heron family (in thape at leaft); whofe peculiarity is denoted by his name; his bill is, in fact, open and giping during two-thirds of 'its length; the upper and lower mandible equally bending outwards, leave between them a large vacancy, and only join at the tip of the bill : the bird inhabits India; has the leg and feet of a heron; his wing feathérs black; the reft of his plumage clear afh-colour; his bill blackifh at the root, the reft white or yellowifh, thicker and larger than the heron's; fize of the bird fourteen or fifteen inches. His manners unknown.

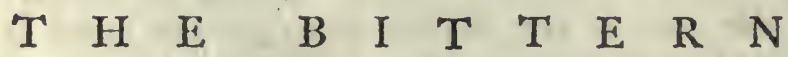

$S$ famous for its fonorous voice, which refembles the bellowing of a bull, but hollower and louder, as if iffuing from a cavern, or from fome formidable enemy being refident at the bottom of the waters; the females run to this cry, fometimes a dozen; he ftruts round them, and drives off intruders.

Is not fo big as a heron, with a weaker bill of the fame form; very deeply divided beyond the eyes; four inches long; Thorter legs; its neck clofely fet with feathers, thereby feeming thicker; throat capable of great extenfion; bill and feet greenifh; toes long: differs alfo in colour, which is generally palin yellow, fpotted and barred with black. To produce the found for which it is remarkable, the lower part of its wind-pipe, at dividing into the lungs, is fupplied with a thin loofe membrane, capable of holding a large quantity of air, and exploding it at pleafure. Thefe explofions are heard from fpring to the end of autumn.

It hides in the fedges by day, and calls in the evening, booming fix or eight times, $b$-rboud, then difcontinuing for ten or twenty minutes, then renewing this peculiar found, audible at above a mile diftant; but only when undifturbed and at liberty. When its retreats are invaded, it is filent : in domeftic captivity, under the control of man, it is mute, and nevcr utters this call; is incapable of attachment or inftruction. It - fcreams generally upon feizing its prey, and fometimes through fear. When attacked, defends himfelf by ftriking at the eyes; conquers birds 


$$
\text { a) }
$$


is thought to be a bird of paffage; is rare. Lives on infeets, as well as frogs and filhes; hides itfelf during day, flies at night, croaking kare kaw; has long toes; feet and legs yellowith green; bill black, flightly arched; ey'es bright; the iris forms a red or orange-coloured circle round the pupil.

\section{T H E S. A. V A C O U}

- NHABITS Guiana and Brafil; has much the frape and fize of the Inight-raven; refembles him alfo in manner of life, which is the fame as the heron family; , but is fingular by his bill, which refembles two fpoons meeting each other by their concave parts: the upper mandible has on its convex part two groovings, which reparate the noftrils; thefe are prolonged to the middle, and form a rifing, which terminate by a crooked point. The inferior mandible receives the fuperior, and, as it were, frames it, being covered with the fkin of the neck : both mandibles are cutting at their edges, of a very hard horny fubftance; the bill four inches long: the bird never ufes this powerful weapon to moleft others, but in watery favannas: perched on projecting branches, he waits the paffing of firh, on which he darts, and inftantly rifes : he walks in a ftrained attitude, his neck bent, and his back humped : is wild, and keeps aloof from habitations. His eyes being near the root of his bill gives him a favage air. When taken, he clatters his bill, either in anger or fear, and ereets the long feathers on the top of his head. Some are grey, fome brown; both have naked nécks; whofe fkin feems capable of extenfion: yellowinh toes, thin and long; tail fhort, and does not exceed the wings when folded.

\section{THE AVOCETTA OR SCOOPER.}

$7 \mathrm{HE}$ avocetta is chiefly found in Italy, but paffes into the north, and moft parts of Europe, and now and then comes over into England. It is about the fize of a pigeon, is a pretty upright bird, and has extremely long legs for its fize, feven or eight inches long, which are the more remarkable, as web-footed birds have Short legs. But its fingularity of figure is the bill, which turns upward. This extraordinary 


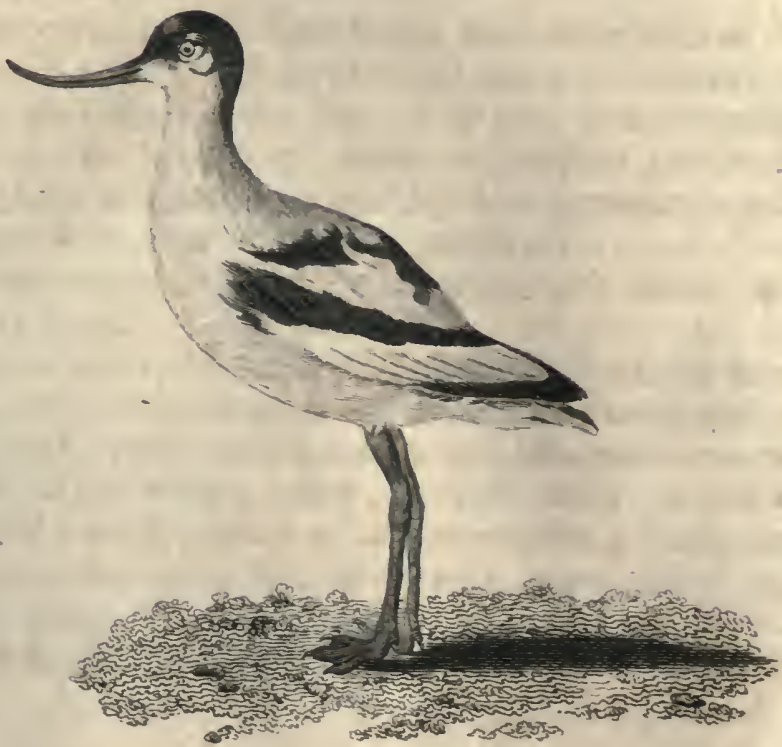

The Arocetta 

bill is thin, weak, black, flat, Tharp, and flexible, tender and almoft memsranous at the end, and about three inches and a half long; incapable of defence or effort.

From its being bare a long way above the knee, it appears that it lives and wades in waters of a few inches depth, in deeper it fwims; is very lively and alert; is very wandering, often paffing but one day in a place: when ftarted from its neft, fhams remarkably lame; is very difficult to take; is fpread over Europe, yet is rare. It has a chirping, pert note, we are told; it is web-footed.

It is difficult to conceive how this bird lives, with fo feeble and feemingly fo ill-adapted a bill; the fofteft mud feems too troublefome, if not too hard, for fo weak an inftrument to ftir. It is fuppofed, therefore, to feed on worms, and on the fpawns of fifhes which float on the water. Its ftomach contains only a gelatinous matter, and fometimes parts of infects, always mingled with fmall cryftalline pebbles.

Its plumage is fnow white in front, chequered with black on the back; tail white, feet blue.

The Corrira or Runner, of Aldrovandus, has the longeft legs of all web-footed fowl, except the flamingo and avocetta ; the bill is ftraight, yellow, black at the end; pupils of the eyes furrounded with two circles, one bay-coloured, the other white; below, near the belly, it is whitifh; the tail, with two white feathers, black at the extremities; the upper part of the body ruft colour; runs very faft, whence-its name; inhabits Italy. 'Thus we fee the flamingo', the avocetta, and the runner, have the long legs of the crane kind, yet in their almoft-webbed feet, approach the direct water-claffes.

\section{O F}

\section{SMALL BIRDS OF THE CRANE KIND.}

THIS lift comprifes the CURLEW, about the fize of a capon, with a bill uniformly bending downwards, five or fix inches long : the Wooncock, under the fize of a pigeon; bill three inches long: the GODWIT, of the fame fize; bill four inches: the GREEN-SHANK, longer legged; bill two inches and an half: the RED-SHANK, differing in COour of its feet from the former : the SNIPE, lefs by half; bill three inches.

With 
With fhorter bills-The RuF , a collar of feathers round the neck of the male; the KNot, the SAND-PIPER, the SAnderling, the DunLIN, the PURRE, and the STINT.

With bills very fhort-The Lapwing, the Green Plover, the Grey Plover, the Dottrel, the Turnstone, and the Sea-lark. Thefe, with their affinities, are natives or vifitants of this country, its hores, rivers, and marhes. The foreign birds of this kind would extend the lift to above an hundred.

All thefe birds are bare of feathers above the knee; and fome half way up the thigh. This is partly natural, and partly produced by habitually wading in water. The older the bird, the barer its thighs; yet even the downy covering of the young ones does not reach fo low as in birds of other claffes. They run with great fwiftnefs for their fize, and the léngth of their legs affifts their velocity: they are equally fwift of wing, and traverfe immenfe tracts of country without much fatigue.

All birds of this clafs live on animals of one kind or another. The long-billed birds fuck up worms and infects from the bottom; thofe furnithed with thorter bills, pick up fuch infeets as lie nearer the furface of the meadow, or among the fands on the fea-fhore.

The CuRlew, the Woodcock, the SNIPE, are ever feen in plathy brakes, under covered hedges, feeking infeets in their worm ftate. Their bills are long for fearching, but are further endowed with exquifite fenfibility at the point, for feeling their provifion. They are furnifhed with three pair of nerves, equal almoft to the optic nerves in thicknefs; which pafs from the roof of the mouth, and run along the upper chap to the point.

The LAPwing, the SAND-PIPER, and the RED-SHANK, run with furprifing rapidity along the furface of the marh, or the fea-fhore, quarter their ground with great dexterity, and leave nothing of the infect kind that happens to lie on the furface.

Thefe birds feem ever employed, feldom reft by day; and, during night, every meadow and marh refounds with their calls to courthip or to food. They feem provided by nature, with a warmth of conftitution to fit them for the cold element. They refide, by choice, in the coldeft climates; and, as other birds migrate here in fummer, their migrations 'hither are moftly in winter. Thofe that refide among us the whole feafon, retire in fummer to the tops of our bleakeft mountains; where they breed, and bring down their young, when the cold weather fets in. . 


\section{T HEV W O O D C O K K:}

The CURiew, the WoodCock, the Siŕp, the Godwit, the GreY Plover, the Green and the Long-legged Plover, the KNot, and the TURnstone, are rather the guefts than the natives of this inland. They vifit us in the beginning of winter, and forfake us in the fpring. They then retire to the mountains of the north. Their weak and delicately pointed bills are unfit to dig into a relifting foil; and their prey is departed, were they able to reach its retreats. The coldeft mountains of the north are then a preferable habitation; the marlhes there are never totally dried up; and the infects are in abundance, both above ground and underneath.

The LApwing, the RUfF, the ReDshank, the SAND-PIPER, the SeAP1e, the Norfolk Plover, and the SeA-lark, breed in this country: yet wander on fome occafions to the northern climates; efpecially when our fummers are peculiarly dry.

In neftling and bringing up their young, one method takes place univerfally. As all run and feed on the ground, all nettle there; their number of eggs is from two to four; the neft is made without art; the eggs are laid in fome little depreffion of the earth, or on a few bents and long grafs that fcarcely preferve them from the moifture below. Yet fuch is the heat of the body of thefe birds, that their time of incubation is thorter than with any others of the fame fize.

Such are the general habits of this clafs of birds; as feveral of them have however peculiar and remarkable manners, we thall notice fome more particularly.

\section{THE W O O D C O C K}

T famous as excellent game: is rather a fupid bird, and caught 1 with no great difficulty: comes over in the beginning of winter; if it does not forfake a country, retires to the mountains, where it refides and breeds during fummer; returns to the moift plains in winter. The firft fevere frofts or fnow oblige it to defcend: commonly arrive in the night, or in a foggy day, few together; never in troops: alight on thick hedges, and prefer where many leaves have fallen; here they hide by day; in twilight quit their retreat, to feek humid fpots. When followed by the fportfman, flies brikly, but not far; plunges behind buthes, and drops as fuddenly as lead; inftantly runs a little way; but ftops, holds up his Part IV. No. 27. 
head, and looks around him, to fee that all is fafe, before he thrufts his bill into the earth. It is fufpected, that though this bird's eyes be large, he fees beft by twilight, his movements being by much the brinkeft morning and evening; even thofe kept in a room, though quiet during the day and night, yet regularly took flights morning and evening. At full moon is very vigilant; feeds on worms; does not fcratch the earth with its feet, but turns leaves, earth, \&c. with its bill, brifkly to right and left; is thought to feek its food by fmelling. In fize, equals the partridge. 'Dogs never eat woodcocks; probably diniking their fcent. The young run very foon: the old ones have been feen to carry a young one when purfued: the male never quits the female, while the young are with her; is filent except.in breeding-time. Sits with the female, and both feem to enjoy laying their bills on each other's back. The fpecies is greatly fpread. There is a white woodcock.

\section{THE S NII P E}

CREATLY refembles the woodcock in appearance; and indeed J. might almoft, without impropriety, be called the Litile Woodcock: but the inipe does not frequent woods; but is confined to marhes, and watery plafhes: flies fo high as to be invifible, yet is heard; having a little cry like a kid, mee, mee, mee: never refides on mountains : is of paffage; comes in winter, goes away in fpring. The fnipe is continually piercing the earth, yet nothing is found in his ftomach but earthy refidum and liquid; probably the fubftance of the worms it eats is thus melted. The tip of its tongue is tharp, to pierce fuch prey. Hides itfelf carefully among reeds by day. The fpecies greatly fpread throughout the world.

The JACK-SNIPE is but half the fize of the former: is called by fome deaf; for it hides clofely among reeds, and never ftirs till almoft trod upon, as if it heard nothing of its purfuer. Is lefs of paffage than the former.

The Duxlan differs a little in plumage, but nothing in manners. 


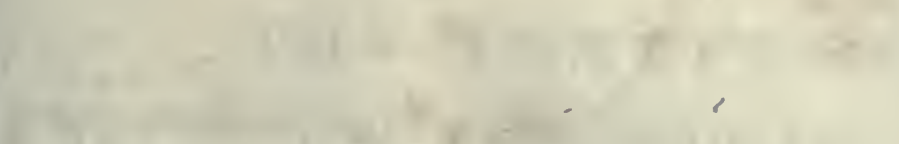

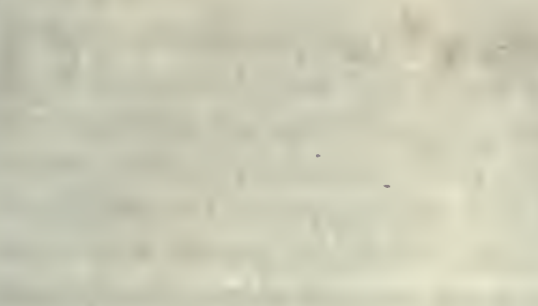




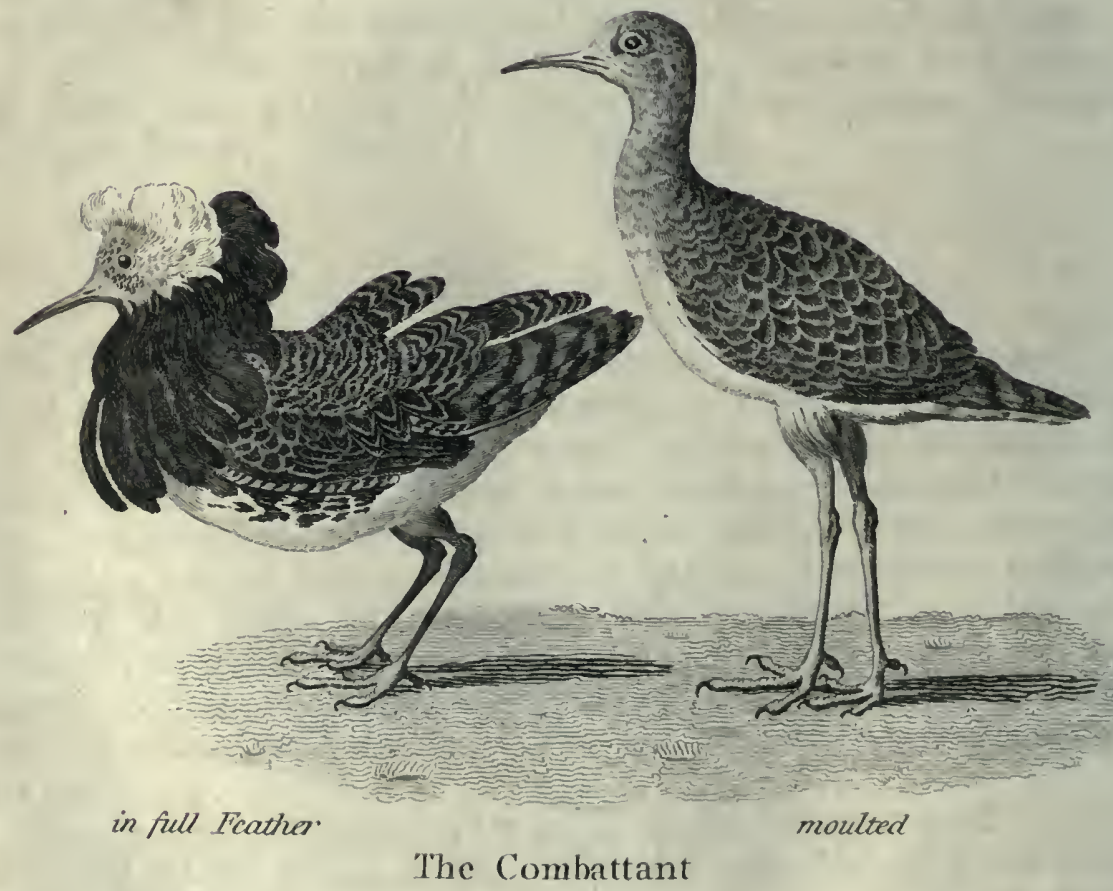




\section{$103)$ \\ THE COM BATAN T,}

R Fighter, called alfo (the male) the Ruff, and (the female) the Reeve. In the beginning of fpring, when thefe birds arrive among our marhes, the males engage each other with defperate fury; not only fingly, but alfo in troops, regulated and orderly, marching one againt the other. The males are faid to be more numerous than the females: thefe fpirit up the warriors, await at hand the iffue of the war, and reward the victors with their company ; and the conquered, if they hear the cry of frefh females, again enter the lifts, if oppofed. They are thought to come from the north.

This bird furnifhes a remarkable inftance of variation at different periods. Their ruff begins to thew itfelf foon in fpring, and fubfilts only during the feafon of courthip : the fame is obferved of the eruption of a multitude of little flefhy pimples, full of blood, which rife on the forepart of the head, and round the eyes; the whole together forming a total difimilarity in the fame bird. This ruff moults off at the end of June, the pimples flatten and difappear, and their places become covered with feathers; then both fexes are alike.

In Lincolnfhire they are taken in great numbers, and are fattened for fale with bread and milk. To keep them quiet they muft be thut up in darknefs; for if light, though but little, be admitted, they fight. Among other birds in an aviary, they challenge all round: if there be a green turf in a corner, they fight for its poffeftion; and, as if they were ardent for glory, they fight with efpecial fury in the prefence of fpectators. Their ruff ferves for defence, they erect it when fighting; it is of various colours in various birds; rarely white, often dark coloured.

\section{T H E LA P W I N G}

CEEMS to have taken his name from the found of his wings, which $\checkmark$ fomewhat refembles the noife of falling wheat, in fanning. Has a tufr, confifting of five or fix thin, long, black fhafts, falling behind on his neck. Is very lively; perpetually in motion, and frinking as well in the air, as when on the ground. Comes in the fpring; vifits the fields of green 


\section{THE C R A N E K I N D:}

corn, and marthes. Having cleared away from the hole where a worm is lodged, the little rolls of earth which the worm ejects, and thus opened the hole, he ftrikes. with feet, and ftands ftock ftill, accurately, watching: this night commotion alarms the worm, and prompts him to quit his retreat; but the moment he appears, the Lapwing feizes him. When the worms come out in the evening, to enjoy the frefh dew, the Lapwing running in the grafs, feels them with his feet, and thus fecures them.

When they firft arrive they are in locks; but they foon feparate, and pair, after at few battles among the males. The young females expofe their nefts more than the older. The arts of the Lapwing to divert men or dogs from her neft, are perfectly amufing: if the perceives the enemy approaching, the boldly runs to meet them; when as near them as fhe dare venture, the rifes with a loud fcreaming before them, feeming as if just flufhed from hatching; while she is probably a hundred yards from the neft. Thus the flies, with great clamour and anxiety, whining and fcreaming, round the invaders, and fluttering as if wounded. To add to the deceit, the appears more clamorous, as more remote from the neft. If there be dogs, he flies heavily at a little diftance before them, as if maimed; vociferous and bold, but, never offering to move toward the quarter where her treafure is. The dog purfues, in hopes every moment of feizing the parent, and by this means actually lofes the young; for the cunning bird, when the has thus drawn him off to a proper diftance, then puts forth her powers, and leaves her aftonifhed purfuer to gaze in vain.

\section{THE OYSTER-CA TCHER}

4 REQUENTS the fea-fide, feeds on fea-worms, oyfters, limpets, and other Thell-fifh, which he gathers on the fands. He is always. found on the beach, or on reefs of rocks, dry at low water ; there he carefully watches the flux and reflux of the tide, never ftraying far from thic fhore : he has alfo been called the S $\mathrm{AA}$ P I E, as well becaufe his plumage is black and white, as becaure, like the Pie, he is in continual clamour, efpecially when in a troop; but the name feems mifapplied: the fpecies is greatly fpread throughout the world; is the fize of a crow; his bill four inches long, is narrowed, and as it were compreffed, above the noftrils, and, flat on the fides, having fome refemblance to an old-fafhioned hatchet; 


\section{THE TURNSTONE, \&C.}

hatchet; which ftructure adapts his bill to detach from the rocks, or to raife from the fands, thofe fhell-fin which compofe the food of this bird. He has only three toes, little or no membranes; yet fometimes fwims, following the courfe of the water, refting on it, or quitting it, at his pleafure; probably eats worms, like others of this clafs ; yet in his ftomach are ufually found oyfters or their parts. She lays her eggs on the fands, above high water mark, without any preparation; lays five or fix eggs: quits them during the middle of the day. Of this bird the bill and feet are coral red; feet and toes fcaly and hard; eye-lids red, iris yellow; tail fhort.

\section{THE TURNSTONE.}

TIS manners are well expreffed by his name; for his cuftom is to 1 turn all the ftones lie fees on the water edge, in hopes to find under them worms and infects on which he feeds; he turns them by the force of the upper part of his bill, very quickly, even though they weigh two or three pounds, which, in a bird the fize of a thrufh, expreffes great ftrength, and great dexterity; his bill is of a very hard fubftance, is very thick at the bafe, though fharp at the point ; its upper part is a little compreffed, and nightly turned upwards; is black; about an inch long; feet orangecoloured; plumage black and white. The fpecies is pretty much fpread.

\section{THE WA TER-O.U Z E L}

CHOULD with juftice be detached from among the Ouzels; for $\checkmark$ though his fize be nearly like theirs, his plumage dark, and his breaft white (as are fome ouzels), yet he is filent, now in his movements, neither bounding nor hopping; he frequents the clear ftreams of high mountains, preferring thofe whofe defcent is rapid, and whofe beds are rocky and ftony; he is found near torrents, cafcades, and limpid ftreams, which run over gravelly ftrata; he enters the water, wholly, gradually, without plunging, walking in it at the bottom, and following the inclinations of its bed; ftrolling at his eafe, as if on land; letring his wings drop, and fhaking them; here he feeds, on little fin and water infects. His , 


\section{THE CR A N E K I N D.}

feet refemble thofe of the ouzel kind; his nails are fhort and hooked; bill thort and thin; his plumage is thick, oily, downy, and impenetrable by the water; tail fhort: neftles by the fide of a ftream; makes his ne?t of mofs, covered at top like an oven.

\section{TH E R A I L S}

A E a numerous family, inhabiting the marhy fides of lakes and rivers, efpecially if covered with water-weeds. This is the conItant difpofition of Water Rails; the Land Rail inhabits meadows : all have the body thin, compreffed on the fides, litt!e or no tail; fmall head; bill almoft like a cock, but longer.

The WATER RAIL runs along the fides of ftanding waters as quick as the Land Rail does among grafs; he is always hid among ruihes, and only quits his retreat to crofs the lake, fwimming or running, for often he runs lightly over the large leaves of the water-plants; he makes paths among fuch herbage, and by thefe goes and returns; he keeps very clofely in his hidings, and is not without great difficulty made to quit his rufhes; and flies, as the laft refource: about the fize of the Land Rail; bill longer; reddifh near the head; feet obfcure red, fometimes yellow; belly and fides ftriped tranfverfely white upon black; under parts grey flate colour; upper parts browninh red, approaching to olive.

The PEARLED RaIL is but the fize of a lark; his plumage brown olive, fpotted and clouded with white; hides and neftles in the runhes: its $n \in f$ in form refembles a gondola; is compofed of reeds interwoven, and firmly attached to fome tuft of rufhes, fo as to rife and fall with the ftream; the young, the moment they are difclofed, run; fwim, and dive; and foon feparate, for this bird is folitary at all times; is, like all Rails, fo hard to ftart, that the fportfman may fometimes take it with his hand, or ftrike it with a ftick. The kind is fpread generally, and in the marhes of America txceeds the European. 


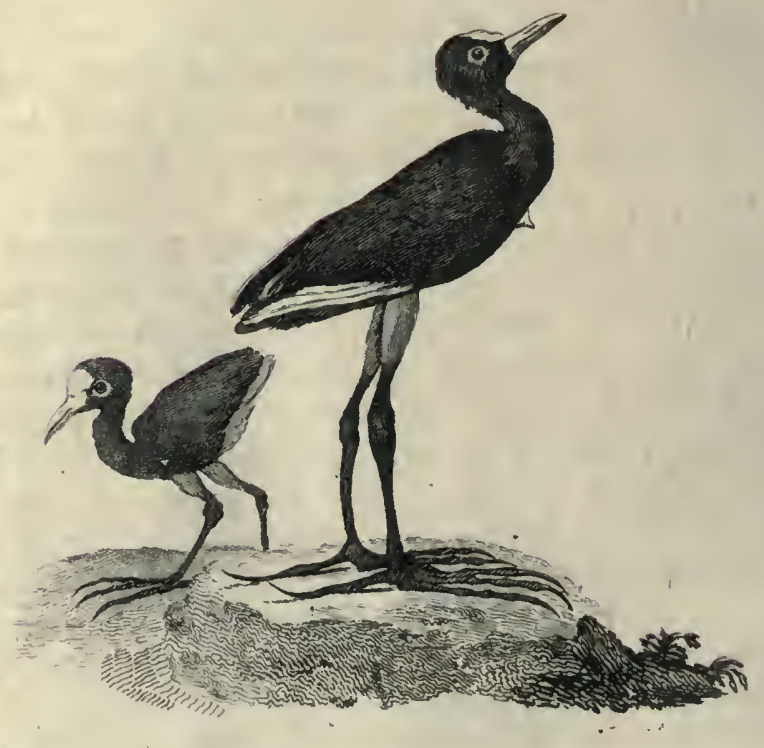

The Jacana 


\section{( 107$)$

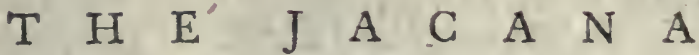

TT A S been by fome referred to the kind of Water-hens, but though refembling in manners, yet in figure, and other particulars, is very diftinct, having fpurs to each wing, and a membranous kind of comb on his head. The toes and nails exceffively long; that behind as long as the middle one before; all the nails round, fharp, and piercing; whence forne have called him Surgeon! Inhabits the marhes of Brazil and Guyana, feeding on water-infects, \&cc. There are three or four fpecies of this bird, which differ in colours, not in fize.

In one fpecies, the head, neck, and front are black, with a tint of violet ; the great wing-feathers green; the reft of his upper part cheftnut, verging on purple; each wing is armed with a harp fpur iffuing from the fhoulder: from the bafe of the bill rifes a membrane, which falls over the forehead, divides into three parts, and falls on each fide of the bill; the bill is ftrait; a little fwelled at the end, of a bright yellow, as are his fpurs; the tail fhort; his legs half way bare of feathers. In fize lefs than a pigeon; but his long legs and neck make him feem larger. Go ordinarily in pairs, and, when accidentally feparated, clamour after each other; are very wild, and only to be approached by art. Vifit St. Domingo, not only after the great rains in May and November, but fome are feen after any heavy rain, whence it is concluded, that their refidence is not diftant. Their flight is low, but rapid; their cry is audible from afar, and has fume affinity to an owl's; fo that poultry in the yard's are frightened by it: yet is not known to be of prey. Some are greenifh black; fome have the green reflections of the Pigeon.

\section{THE PORPHYRION, OR SULTANA HEN,}

W AS well known to the antients, but, till lately, loft to the modetns. The firft of the kind fubmitted to examination came from sacid gafcar, but it has fince been found to breed in Sicily, in the lake Lemitr? This bird is gentle, innocent, timid, fond, freking folitude and places, hiding itfelf when eating, when approached has a frarp ending internally. Prefers filh, but eats fruits and rooss; can liv grain; often foaks his food, repeatedly; if the piece be fometrat harg. he grafps it in one foot, and, holding it hallf way to his mouth, eats

PART IV. No. 27. 
morfels; for his legs are longer in proportion than his neck is, according to the general make of birds. His plumage is blue, foft, and hining, with fplendid reflections; his feet long, and a kind of flat piece on his head, bare of feathers, as it were a large fcale; the bafe of his bill is of a beautiful red; a tuft of white feathers at the tail fets off his blue plumage. The female refembles the male, but is rather lefs; not quite equal to a Hen in fize. This beautiful bird has all the qualities requifite to domeftication, and was domefticated among the Romans, but for fhew, only. Lays fix white eggs, round; dufts itfelf like the Cock; its toes are very long; no membranes. Male and female affit in making the neft.

\section{THE. KIN G-F I S H E R}

H XHIBITS the beautiful plumage of the peacock, the hadings of 14 the humming bird, the bill of the crane, and the fhort legs of the fwallow.

Not much larger than a fwallow; Mape clumfy; legs difproportionabiy fmall; bill difproportionably long; two inches from the bafe to the tip; the upper chap black, and the lower yellow; the crown of the head and the coverts of the wings are of a deep blackin green, fpotted with bright azure; the back and tail are of the moft refplendent azure; the whole under-fide of the body is orange-coloured; a broad mark of the fame paffes from the bill beyond the eyes; beyond that a large white fpot; the tail is Thort, and confifts of twelve feathers of a rich deep blue; the feet are of a reddin yellow, and the three joints of the outmoft toe adhere to the iniddle toe, while the inner toe adheres only by one; which is a fingular conformation.

Is for ever on the wing, and feeds on fith; frequents the banks of rivers ; and takes its prey, in winter efpecially, by balancing at a certain diftance above the water for a confiderable time, then falling like lead into the water, and feizing the firh with inevitable certainty. While fufpended in the air, in a bright day, the plumage exhibits a beautiful variety of the moft dazzling and brilliant colours; but he often fits on a projecting branch or ftone, watching the water.

The King-fifher with which we are acquainted at prefent, though moft likely the ancient Alcyone, lias none of thofe powers of allaying the ftorm, or building upon the waves, with which fable furnifhed it anciently; 


\section{$T H E$ W A T E R-H E N}

but is contented to make its neft on the banks of rivers, in fuch fituations as not to be affected by the rifing of the ftream. When it has found a place for its purpofe, it hollows out with its bill a hole about a yard deep; or if it finds the deferted hole of a rat, or one cauled by. the root of a tree decaying, it takes quiet poffeffion. This hole it enlarges at the bottom to a good fize, lining it with the down of the willow, and partly clofing the opening. Here are found great quantities of bones and fcales of filhes, the remains of the bird's food. The king-fifher, as Belon fays, feeds upon fifh, but is incapable of digefting the bones and fcales, which he throws up again, as eagles and owls are feen to do a part of their prey; but this is not confirmed by fome late obfervers, though its feems probable. In thefe holes, which from fuch remains are very fœtid, the king-fifher is often found with five eggs to nine. There the female continues to hatch, even though difturbed; and though the neit be robbed, the will again return and lay there. She begins to lay early in the feafon, and excludes her firt brood about the beginning of April. The male brings her large provifions of filh while thus employed; and, contrary to molt other birds, the is found plump and fat at that feafon. The male, that ufed to twitter before this; now enters the neft as quietly and as privately as poffible. The young ones are hatched at the expiration of twenty'days; but are feen to differ as well in theirfize as beauty. Thefe birds are not numerous; there are twenty fpecies in the tropical climates of the old world, and feven or eight in the new.

\section{T H E W A T E R-H E N.}

THE Water-hen is rather compreffed on the fides of her body; the bill-fomewhat approaches the cock kind, but fhorter; the forehead bare of feathers, and covered with a thick brick-coloured membrane, (as are fome fpecies of rails): flies with her feet hanging; hás long toes, with a membranous border round them; legs long; thighs partly bare; wings hort.

Refides entirely where her food lies; and never leaves the pond or river in which the feeds, along the grafly banks, and often along the furface of the water; does not fwim far or much; but hides among the water weeds, and roots of aquatic trees, and only quits them in the evening, firft covering her eggs, when hatching, with rumes and grafs; the hides her neft very fuccefsfully, as alfo her young, which are rarely taken. She builds her neft on low trees and fhrubs, of fticks and fibres, by the 
water edge. Her eggs are tharp at one end, white, with a tinçture of green, fpotted with red. She lays twice or thrice in a fummer; her young fwim the moment they leave the egg, purfue their parent, and imitate all her manners. She rears, frequently, two or three broods in a feafon; and when the young are grown up, the drives them off to hift for themfelves.

According to the feafon, forfakes or return to neighbouring mountains, defcending in hard weather; the fpecies is greatly fpread. There are three races, diftinguinable by their difference in fize. Plumage irongrey and white.

\section{T H E $\quad$ G $O \quad O \quad T$,}

T.HOUGH not entirely web-footed, is as good a fwimmer as any bird whatever; and perhaps paffes as much of its time on the water as any, except the Divers : is rarely feen on the land, or, if feen there, is fo out of its element that it may be taken with the hand; fies and feeks its food at night; and, like many water birds, fees diftinctly in obfcurity; keeps in rivers, and among ruhy margined lakes. It there makes a neft of fuch weeds as the ftream fupplies, and lays them one on another, without order, among the reeds, floating on the furface, and rifing and falling with the water. The reeds keep it faft; fo that it is feldom walhed into the ftream; but if this happens, the bird fits in her neft, like a mariner in his boat, and with her legs fteers her cargo into the neareft harbour : there the continues to fit in great tranquillity, regardlefs of the impetuofity of the current; and though the water penetrates her net, : The hatches her eggs in that wet condition.

When difturbed in her retreat, hides among the rufhes, and even in the mud, rather than take to flight; the young are playful, and not fo circumfpect, which expofes them to the deftructive pounces of the buzzard; they often dive fo inftantly as to efcape the fhot fired at them. In early winter they affemble in lakes, and, though chafed by boats, only fly from fide to fide of the lake, by which obftinacy many hundreds are killed: lays eighteen or nineteen eggs, hatches in twenty-two or twentythree days; the young directly leap into the water, and never re-enter the neft; are then black and downy; the white creft-like furface on the head fcarcely difcernible. This fubftance is a prolongation of the upper layer, which compofes the upper mandible; this is foft and almoft flefhy at the bafe. Plumage black, in fize equals a hen; its feet have a large membranous border, fcolloped; lives on water-infeets, fmall fifh, \&r. fometimes eats grain : their flefh is black. 


\section{(112) \\ T $\mathrm{E}$ E $G R E$ B E}

TS dittinguißhed by a tippet, and a plumage which unites to the foftnefs, clofenets, and thicknefs of down, the fpringinefs of feathers, and the Juftre of filk; efpecially the plumage of the breaft is 2 compact, fmooth, regular layer, forming one uniform furface, impenetrable both to cold and wet; by this fubftantial clothing, the bird is enabled to fuftain the moft rigorous winters, though conftantly on the waters. The feet of this bird have a membrane, which is divided, and cut into fcollops round each toe; his legs are placed very much backward, and he takes his flight with very great labour, to which he is with difficulty excited; and endeavours to avoid it, fwimming always againft the wind. On land is eafily caught, yet defends himfelf well with his bill; in the water is as active and alert, as heavy on land; fivims; dives, and foats admirably; purfues filh to great depths; and is often taken in nets; frequents equally falt water, and frefh rivers, and lakes. The fize of a Coot; about one foot fix inches from bill to tail : nearly two feet from bill to toes; plumage deep thining brown on the back ; the front of moft filvery white; head fmall ; bill ftrait, Iharp; a little red Ikin round the eye, wings thort, voice ftrong; foot fpread, and flatted, covered with fcales; nails large and flat; no tail but a rump; is generally very fat; eats weeds as well as fifh; neftles on rocks, near the fea; but around lakes makes a neft of rufhes and reeds, floating on the water, and faftened to fome fecure ftation.

The tufted Grebe is ornamented by a plume from the back of his head, falling behind, capable of elevation and depreffion; is larger than the common Grebe. The little tufted Grebe differs, in that his tuft divides, as does that of the borned Grebe; he has alfo a kind of mane, or ftaring hair, red at the root, black at the point, furrounding his neck, which gives him a ftrange wildnefs of air : he is larger than the common. There is a lefs of this kind.

The chefmut-coloured Grebe, is not only diftinguifhed by his colour, but by being among the fmalleft birds that navigate the ocean; he frequents alfo rivers, efpecially in winter, when he is very fat; eats fmall fint, and frall thell-fint.

The name of this family, in many partsjof England, is DoB-cHrck: the fpecies inhabits moft parts of the world. 


\section{T H E A H I N G A}

TS among the moft remarkable of birds by its form, which fuggeits the idea of a reptile mounted on the body of a bird: its neck exceffively long and thin; its fmall cylindric head, fharpened into a long pointed bill, refembles the figure and alfo the motions of a ferpent, as well in the manner of the bird's fuddenly thrufting forward his neck when quitting a tree, as in his manner of ftriking at filh, when in the water; the head and neck are covered with down, clofe fet, and foft as velvet; the eyes are brilliant black, the iris golden, a naked 1kin furrounds them; the point of the bill is furnifined with fmall jagged points turning backward; the body is about feven inches long; the neck alone is double that length; the tail is large, formed of twelve fpreading feathers, unlike moft water-birds; yet the anhinga fwims and dives; holding its head above water; but this it withdraws on the leaft appearance of danger ; is very wild; never taken on the hore; is always on the water, or perched on the tops of the higheft trees along the fides of rivers, or drowned favannas, where he neftles; is among the number of birds perfect palmipeds, or having toes completely united by a membrane; the nail of the middle toe dentelated internally like a faw. Its fkin is very thick; its fleth not eatable, but very at; its plumage mingled with grey; its wings are long, the colours of fome reddifh. Found principally in America, but fome in Africa.

\section{TH E PEL I C A N.}

7 H Pelican is among the largett of water-birds; much larger in the l. body than a fwan, and fomewhat of the fame fhape. Its four toes are all completely webbed together, are red or yellow; and its neck in fome meafure refembles that of a fwan: its fingularity is its bill, and the great pouch underneath. This enormous bill is fifteen inclies from the point to the opening, which is behind the eyes; at the bafe is fomewhat greenifh, but varies towarc's the middle and end, being reddifh. It is flat at top, very thick in the beginning, but tapers off to the end, where it hooks downwards. The under-chap is ftill more extraordinary; it confifts of two fexible branches, which divide to accommodate the fize of the pouch which hangs to it, reaching the whole length of the bill to the neck, and faid to be capable of containing fifteen or twenty quarts of wa- 


$$
3
$$




$$
1
$$



ter; is large enough to contain a man's arm or head. 'This bag the bird has a power of wrinkling up into the hollow of the under chap; but by opening the bill, and putting one's hand down into the bag, it may be dif tended at pleafure. The fkin of which it is formed is a blueifh afh-colour, with many fibres and veins running over its furface. Is not covered.with feathers, but with a Thort downy fubftance, as fmooth" and as foft, as fattin. When this bag is empty it is not feen; but when the bird has filhed with fuccefs, it is often incredibly dilated. The firt thing the pelican does in fifhing is to fill up this bag; and then it returns to digeft its burthen at leifure. It is compoled of two kins, one the outfide Rkin of the neck, the internal that of the gullet. When the bird fwallows his prey, this bag is clofed by two mufcles, to prevent the water paffing into the gullet; alfo, to prevent fuffocation, the wind-pipe quits its ufual place, and is projected. The noftrils are very fmall, placed at the root of the bill.

Its legs are fhort, but its wings extend eleven or twelve feet, and are capable of raifing it great heights; at thefe elevations he balances nicely, and falls plump on his prey, friking the water with his whole extent of wing, making it foam, and dafhing fo as to confound the filh : thus one proceeds when fingle; when in troops they range in a line, or fwim in a circle, clojing on the filh. They fifr morning and evening. It is pleafant to fee them rife feveral feet above the water, their pouches half full, then dart again for more. To digeft their food they fly to fome rock, where they fit with their heads laid on their fhoulders: at night perch upon trees. Arevery unclean and filthy; their fleth fmells infufferably. Preys in frefh water as well as at fea; yet avoids marthes, but frequents dry countries, as Arabia and Perfia, where it is called water-carrier, for the carries to her neft her pouch full of water. The Egyptians call it River-camel, from the fame circumitance.

The bird preys upon fifh of feven or eight pounds weight, and hides them by dozens in its pouch. Du Tertre affrms, that it will hide as many filh as will ferve fixty hungry men for a meal. It is faid it will eat rats, \&x.

This bird weighs twenty-four or twenty-five pounds, yet its Rkeleton not one pound and a half; his bones are fo thin they are tranfparent : the air which enters this bird, is conveyed manifeftly and evidently even into the quills of his feathers, filling a cellular membrane, which furrounds the whole body under the membrane whence the feathers grow, infomuch that, by preffure of the parts, the efcape of the air is remarkPART IV. No. 27. 
able. Probably other birds have the fame powers in various degrees, but not fo traceable.

Its amazing pouch may be confidered as analogous to the crop in other birds, with this difference, that as theirs lies at the bottom and within the gullet, fo this is placed on the outfide, and under the bill; it has no digeftive heat. She brings the fifh frefs to her young; to difcharge its contents, preffes the pouch on her breaft. At the bottom of its bag is a tongue, but fo fmall that many have faid it had none. When tame is very thievin in fifh-markets. Eats fideways, and catches what is thrown to it.

The pelican, fays Labat, has ftrong wings, furnifhed with thick plumage of an afh-colour, as are the reft of the feathers over the whole body; on the neck a hort down; on the nape of the neck longer, forming a fmall tuft. Its eyes are very fmall, when compared to the fize of its head, which is flattin on the fides; its cheeks naked; its countenance and its air melancholy. Torpid, inactive and gluttonous.

The female drops her eggs on the bare ground to the number of five or fix, and there continues to hatch them. She feeds her young with filh from her bag; and, when they cry, flies off for a new fupply.

The Americans kill vaft numbers, to convert their large bags into purfes and tobacco-pouches, dreffing the $\mathbb{R}$ in with falt and athes, rubbing it well with oil. It thus becomes fo foft and pliant, that the Spanifh women fometimes adorn it with gold and embroidery to make work-bags of.

Father Raymond affures us, he has feen one that would go off in the morning at the word of command, and return before night to its mafter, with its great paunch diftended with plunder; part of which it was made difgorge, and part it referved.

"The pelican," as Faber relates, "is not deftitute of other qualifications. One of thofe which was brought alive to the Duke of Bavaria's court, where it lived forty years, feemed to be poffeffed of very uncommon fenfations. It was much delighted in the company and converfation of men, and in mufic, both vocal and inftrumental; for it would willingly ftand," fays he, "by thofe that fung or founded the trumpet; and ftretching out its head, and turning his ear to the mufic, liften very attentively to its harmony, though its own voice was little pleafanter than the braying of an afs," whence the Greeks named it onocrotalos. Gefner tells us, that the emperor Maximilian had a tame pelican which lived for above eighty years, and that it always attended his army on their 
march. It was one of the largett of the kind, and had a daily allowance by the emperor's orders.

\section{THE COR MORA N T.}

THE Cormorant in fize nearly equals a goofe, but is rather nender; its four toes are completely united by membranes together: the middle toe being toothed or notched like a faw, to affift it in holding its fifhy prey. The bill is ftraight, till near the end, where the upper chap bends into a hook; plumage black, or variegated with deep brown; two white fpots outfide of the legs; front of the neck white; tufts of long feathers on the head and the upper part of the neck; front and fides of the head bald; a naked fkin accompanies the bill beneath.

This unclean bird combines, with the groffeft appetites, the moft rank and difagreeable fmell. More fœetid than carrion; its form difagreeable; its voice hoarfe and croaking; all its qualities obfcene :-No wonder Milton fhould make Satan perfonate this bird, when furveying the beauties of paradife, on the bafeft of purpoles.

It is feen as well by land as by fea; fifhes in frefh-water lakes, as in the ocean; builds in the cliffs of the rocks, as well as on trees; and preys not only in the day-time, but by night.

The cormorant is trained up in China for the purpofe of fining, as it was formerly in England. The finher carries them out into the lake, perched on the gunnel of his boat; at the firt fignal given, each ties a different way, to fulfil the talk afligned. It is very pleafant, on this occafion, to behold with what fagacity they portion out the lake or the canal. They hunt about, they plunge, they rife an hundred times to the furface, until they have at laft found their prey. They then feize it with their beak by the middle, and carry it without fail to their mafter. When the firh is too large, they give each other mutual affiftance: one feizes it by the head, the other by the tail, and in this manner carry it to the boat together. There the boatman ftretches out one of his long oars, on which they perch, and being delivered of their burthen, they fly off to purfue their fport. When they are wearied, he lers them reft for a while; but they are never fed till their work is over. They have always, while they fith, a fring faftened round their throats, to prevent them from 
devouring their prey, as otherwife they would at once fatiate themfelves, and difcontinue their purfuit the moment they had filled their bellies."

The cormorant is the beft filher of all birds; and though fat and heavy, is generally on the wing. The great activity with which it purfues, and from a vaft height drops down to dive after its prey, offers one of the moft amufing fpectacles; it is often feen rifing heavily, with a fifh larger than it can readily devour. It fometimes alfo happens, that the cormorant has caught the fin by the tail; and confequently the fins prevent its being eafily fwallowed in that pofition. In this cafe, the bird is feen to tofs its prey above its head, and very dexterouny to catch it, when defcending, by the proper end, and fo fwallow it with eafe.

\section{TH E A L B A T R O S S.}

THIS bird is thus defcribed by Edwards: "The body rather larger than that of a pelican, and its wings ten feet from tip to tip; bill fix inches long, yellowifh, terminates in a crooked point. Top of the head bright brown; back dirty deep fpotted brown; the belly, and under the wings white; the toes, which are webbed, fleth colour.

Inhabits the tropical climates, and the Streights of Magellan in the South Seas. Is one of the moft fierce and formidable of the aquatic tribes, not only living upon fifh, but alfo fuch fmall water-fowl as it can take by furprize. It preys, as all the gull kind do, on the wing; and chiefly purfues the flying-filh, that are forced from the fea by the dolphins; purfues the gulls, and obliges them to relinquilh their prey.

Few birds float upon the air with more eafe than the albatrofs, or fupport themfelves longer in that element. They, night and day on the wing, are always prowling, yet always emaciated and hungry. Seem to have a peculiar affection for the penguin, and a pleafure in its fociety. Choofe the fame places of breeding; fome diftant uninhabited inand, where the ground nants to the fea, as the penguin is not formed either for flying or climbing. At Falkland Inands they build with amazing uniformity; their nefts covering fields by thoufands, and refembling a regular plantation. In the middle, on high, the albatrofs raifes its neft on heath fticks and long grafs, about two feet above the furface : round this the penguins make their lower fettlements, rather in holes in the ground; and moft ufually eight penguins to one albatrors. 
t 


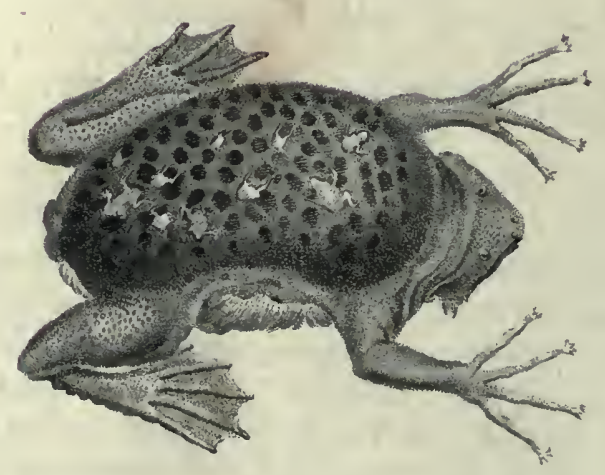

The Pipal. 


\section{SMALLER GULLS AND PETRELS.}

F the Gull, properly fo called, there are above twenty kinds; of the Petrel three; and of the Sea-fwallow feveral. The gulls may be diftinguifhed by an angular knob on the lower chap; the petrels by their wanting this knob; and the fea-fwallow by their bills, which are ftraight, nender, and harp-pointed. They all, however, agree in their appetites and their places of abode.

The gull is well known in this kingdom. Is fometimes feen flowfailing, hovering over rivers to prey on firh; fometimes following the plowman in fallow fields to pick up infeets; and, when living animal food was ablent, has been known to eat carrion, and whatever elfe offered, as if it were the vulture of the aquatic tribes. Round our boldeft rockieft fhores they appear in the greateft abundance; there the gull breeds and brings up its young; and there millions are heard fcreaming with difcordant notes for months together. The rocks offer them a retreat for their young, the fea a fupply of food, and renders the place inacceffible from below. Thefe are the fituations to which fea-fowl chiefly refort, and bring up their young. Thefe birds, like all of the rapacious kind, lay but few eggs; and hence, in many places, their number is daily feen to diminifh : lay from one egg to three, in a neft formed of long grafs and fea-weed. Moft are finy-tafted, with black. ftringy fleth; yet the young ones are better food: and thefe, with feveral other birds of the penguin kind, the poor inhabitants of our northern inands make their food.

\section{THE F R I G A T E-B I R D,}

DCEIVES his name from the fwiftnefs and manner of his fight. 1. In fact, of all fea-birds, he has the mott powerful and durable flight, and extends his courfe to greater diftances than any other bird. His wings are prodigiouny long, and his mation fmooth; he feems to fwim in the air, till the inftant his prey appears, then he darts like lightning upon it. When the $\mathrm{ky}$ is tempeltuous, he rifes above the clourds, 
clouds, and feeks ferener fkies, at elevations where he is beyond our fight. Ever on the wing, he flies night and day. Thofe fifh that go in thoals (as the flying-fifh, \&c.) are purfued by dolphins, bonitos, \&c. thefe he difcerns from amazing heights, and notices the track of a column with the greateft accuracy: often the Thoal is fo large as to agitate the water, and fo clofed together as to whiten it; then the frigate-bird, fkimming along the furface, feizes with his bill, or his claws, or both, thofe fifh which offer. Is principally found between the tropics in both hemifpheres: tyrannizes over the Boobies, and makes them yield their, prey; is a very bold bird; has tharp claws; long hooked fharp bill; thort, ftrong feet, covered with feathers, like a bird of prey; rarely is feen to fwim, yet his feet are membraned; like the boobies has no apparent noftrils, but has futures on his bill. About the fize of a hen in body; but his wings eight, ten or fourteen feet, from tip to tip. This exceffive length of wing embarraffes the bird when about to rife from the ground, and obliges him to feek fome fmall elevation, for on level ground he may be killed ere he can fly. Neftle on rocks, numbers together; fometimes on trees; lay one or two eggs, white ftained with Alefh colour; with dots of crimion. The young have a grey white down; their feet and bills white, but, when adult, their colours change, becoming reddifh or black, and bluein in the middle. The head is fmall, and flat at top, the male has under his throat a membrane of a lively red, of the nature of wattles. Tail extremely forked. This, and their long wings, diftinguifh them. Plumage ordinarily black, with blueifh reflections; belly white, efpecially the females. Relembles the boobies in the naked fkin around the eyes, and the dentated nail of the middle toe.

\section{THE BOO BIES.}

7 HESE birds feem to have received from nature but a partial thare of that inftinit, by which creatures in general are prompted to felf-prefervation : large and ftrong, armed with a bill fufficiently powerful, with long wings, and well-membraned feèt; they have all the neceffary abilities to exercife their faculties, as well in air, as in water, yet they feem.ignorant of what fhould be done, or fhould not be done, for felf-defence. Spread generally in moft climates; yet in none have they 


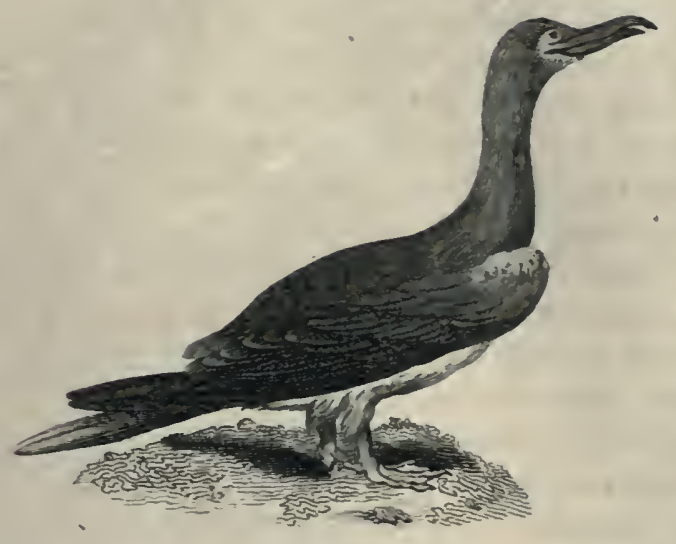

The Booby 

learned to know their chief enemy; but fuffer themfelves to be taken, not only when at fea, refting on parts of hips, but on land, where they are killed in great numbers by blows with a ftick; no one taking warning by obfervation of what happens to others, nor turning away from thofe who thus naughter their companions. To what caufe this muft be attributed is unknown: the difficulty of putting in motion their wings, in order to rife, which fome fuggeft, feems inadequate to this purpofe. Not only man is their enemy; they are fcarcely lefs perfecuted by the frigate bird, who, darting upon them when fying, purfuing them without remiffion, and beating them with bill and wings, forces them to yield their prey, which is fwallowed by their conqueror; for whom, perhaps, they labour a fecond time for other prey, in like manner taken from them.

The booby fifhes by flying fteadily over the water; and falling on the firn the moment he perceives it near the furface. They inhabit inands even the moft diftant from other land. "In form they pretty much refemble the cormorant; their bill is remarkable, in that the fuperior mandible is, as it were, articulated, and compofed of three pieces, joined by two futures; that next the point giving fomewhat the appearance of a nail to the tip of the bill; that next the head is fo loofe as to permit the former part of the bill to open two inches, without any motion in the under chap. Their cry is ftrong, between the crow and the goofe; it is generally excited by fear. When flying, they ftretch out the neck; and - pread the tail : muft have fome little rifing, from whence to take light: they perch on trees. Dampier even fays, they, neftle on trees in the ine of Aves; elfewhere they neitle on the ground, multitudes together; lay one or two eggs; the young are long covered with a very foft white down.

The booby. of the Antilles is lefs than a goofe; about two feet five inches long, bill four inches and a half, the naked ikin round the eye yellow; as alfo the bafe of the bill, its point brown; the feet pale yellow; the belly white; the reft of the plumage afh-coloured brown. One kind is white. The greater booby in fize equals a goofe; is fix feet from tip to tip of its wings; plumage deep brown, fprinkled with white fpots on the head; larger fpots on the breaft and back. Inhabits the coaft of Florida. Dives deeply, and is thought to be often attacked and devoured by tharks and other voracious fifhes. 


\section{THE GANNET, OR SOLAN GOOSE,}

TS reckoned among the boobies; and is the fize of a goofe, but its wings fix feet over; bill fix inches long, ftraight almoft to the point; the fides irregularly jagged, the better to hold its prey. Its colour is chiefly white; inftead of noftrils, it has a long furrow, reaching almoft to the end of the bill. From the corner of the mouth a narrow nip of black bare fkin extends to the hind part of the head; beneath is another that is dilatable, and of fize fufficient to contain five or fix entire herrings, which, in the breeding feafon, it carries at once to its mates or its young; is fometimes choaked in fwallowing too large a firh.

The fkin of thefe birds is not clofely adhering to the flefh, but is connected to it by little bunches of fibres, placed at unequal diftances, as from one to two inches, and capable of extenfion, fo that by blowing air into the fkin it fwells like a bladder; no communication between this interval and the thorax is difcoverable ; yet, doubtlefs, the air has paffage, probably through the cellulary membrane.

The inands to the north of Scotland, the Skelig inands off the coafts of Kerry, in Ireland, and thofe in the north fea off Norway, abound with them. But on the Bafs inland, in the Frith of Edinburgh, they are feen in the greateft abundance. In St.Kilda, Martin affures us, the inhabitants confume annually twenty three thoufand young birds, befides amazing quantities of their eggs. On thefe they principally fubfift.

The gannet is a bird of paffage. In winter it feeks the more fouthern coafts. of Cornwall, hovering over the hoals of herrings and pilchards that then come down from the northern feas: its firft appearance in the northern inlands is in the beginning of fpring; and it continues to breed till the end of fummer. But, in general, its motions are determined by 'the migrations of the fhoals of herrings, which it affiduouny attends in their paffage, and keeps with them their whole circuit round our inland.

Is poffeffed of a tranfparent membrane under the eye-lid, with which it covers the whole eye at pleafure, without obfcuring the fight in the finalleft degree. This feems neceffary to fecure the eyes of fo weighty a creature, whore method of prey is by darting headlong from an height of an hundred feet into the water. Breed yearly, and lay but one egg, 
which being taken away, they lay another; if that is alfo taken, then a third; but never more for that feafon. The young birds, during the firft year, are of a dufky hue, fpeckled with numerous triangular white fpots.

\section{TH E NO D D Y}

TS in manners clofely related to the boobies; but in fize refembles the greater fea-fwallow, to which clafs his bill is conformable; but he has the feet of the fea-mew. All his plumage is deep brown, except a kind of white cap on his head; like the boobies he alights on veffels, and even on the fift, if held out to him. Is found near the tropics, and between them. Are very numerous; during hatching time they prey together in great flocks; when that is paft, each becomes folitary, and wanders at large over the valt ocean. Their eggs are good food; but muft be fought in rocks at no little rifk.

\section{TIE SEA-S WALLOWS, OR TER N S,}

YOMPOSE a fmall family of birds, which, in many refpects, refemble the land birds of the fame name. Their plumage is black and white; their wings very long and thin; their, tails forked; their flight alfo is fimilar; agile, fwift, and, as it were, wanton. They fkim the furface of the water for their prey, and feize llying fuch little fifh as they there catch. In other refpects they differ; their feet have fmall membranes attached to the toes, and their bills are very diftinct. Though feemingly capable of fwimming, they are not fond of it, but dart down on the water, and inftantly dart up from it. They live ordinarily on the banks of the fea, or rivers, or lakes. They are always chattering or fcreaming, and are extremely noify in nefting-time. They frequent our coafts in fpring, return in autumn. Some of them partly feed on infects : are bold birds; not frightened at fire-arms. Their legs are fhort, little adapted for walking, bare of feathers partly up the thigh; bill ftraight, narrow, pointed, fmooth, and flatted on the fides. The kind is very greatly fpread. 
The great fea-fwallow is thirteen inches from the bill to the toes; fixteen to the end of the tail, wings extended two feet, his fhape elegant; his head black; his upper parts grey; his front white. They digeft their food almolt as foon as taken, for it melts in their gullet; the lower part next the ftomach firt, even while perhaps the tail fticks out of the mouth. The female lays two or three eggs on the bare fands; and it is remarked, that when the weather is warm, the egg firtt laid comes to maturity one day fooner than that laid fecond, as the fecond does one day fooner than the third : fuch effect has the warmth of the fand on thofe firt laid : but if the weather be gloomy and chilly, no fuch effect occurs, but all three are hatched together. The young are covered with a thick down, and are perpetually crying for food, which the parents hower on them from on high; are fix weeks before they fly.

The little fea-fwallow is but the fize of a lark; which is its conftant, and almoft only diftinction from the former. There are feveral other kinds in foreign parts; but clofely allied in plumage and manners.

\section{T H E T R O P I G B I R D S}

A $\mathrm{RE}$ of natures very different from thofe which inhabit the exA tremes of the globe, and to which eternal fnows are not only familiar, but friendly; thefe, on the contrary, inhabit only the central divifion of the earth, nor ever quit the torrid zone, where the orb of day thines in full fplendor : hence their appearance is to navigators a certain indication of their approach to the line, and the name of Tropic birds is impofed on them by general confent. They are found on the fea at vaft diftances from land, and on inands, remote from either continent, as well in the Atlantic Ocean as in the South Seas.

Befides a powerful and rapid flight, thefe birds have the faculty of repofing on the water; and perhaps of neeping on it. Their feet are entirely united by a membrane; they can perch on trees; they refemble fea-fwallows in their length of wings, which crols each other over the tail when folded. Are about the fize of a pigeon; plumage ftrikingly white; but are at once diftinguifhable by a long double thaft of feathers, as if a ftraw was ftuck in its tail; and from this fome have given them the name of fraw-tails. This double thaft is compofed of two thin ftems, 
each almoft bare of feathers, and.only having fome fhort feathery beards. They are prolongations of the two middle feathers of the tail, which is, except thele, very thort, and fcarce perceptible. Thefe thafts are fometimes two feet long; they are monlted; and the inhabitants of Otaheite, \&rc. form ornaments of them for the cafques of their warriors; while the Caribbees pals them through the Jeptum of the nofe, either to increafe their beauty, or their terror.

This bird farce can move on larid. There are various fizes; fome lefs than a pigeon, fpotted with black on the wing-feathers next the body; a kind of horfe-fhoe mark over the eye. Some have red fhafts, fome have little ftreaks of black acrofs the back.

\section{THE PEN G U I N.KI N D}

A RE ill fitted for llight, and worfe for walking. Their wings are A1 thort, fcantily furnifhed with quills, and the pinion placed too forward, to be ufefully employed. For this rearon, the largeft of the penguin kind, with thick, heavy bodies, cannot ly at all. Their wings ferve them rather as paddles, when they attempt to move fwiftly; and in a manner walk along the furface of the water. Even the fmaller kinds feldom fly by choice. Their legs are ftill more aukwardly adapted for walking, all above the knee being hid within the belly; and nothing appears but two fhort legs ftuck under the rump, upon which the animal is very aukwardly fupported. Thei: fhort legs drive the body in progrefion from fide to fide; and were they not affifted by their wings, they could fcarcely move fafter than a tortoife; but this pofition of the legs adapts them admirably for a refidence in water; and thefe birds, like Indian eanoes, are the fwifteft in the vater, by having their paddles in the rear. Nor are they lefs qualified for diving; for by ever fo little inclining their bodies forward, they lofe their center of gravity, and every ftroke from their feet tends to fink them the fafter. In this manner they dive at once to the bottom, or fwim between two waters, where they continue fifhing for fome minutes, and then afcending, catch an inftantaneous breath to defcend again to their operations: If they perceive themfelves purfued, they inftantly fink, and thew nothing more than their bills. Their lungs are fitted with numerous vacuities, by which they can take in a very large infpiration; and this probably ierves them for a length of time. 
Of, this tribe, the Magellanic penguin is the largeft, and the moft remarkable. In fize it is near a goofe. It never flies, its wings being very thore, covered with ftiff hard feathers, and always hanging ufelefsly down by the bird's fides. The upper part of the head, back and rump, are covered with ftiff black feathers; while the belly and breaft are of a fnowy whitenefs, except a line of black croffing the crop. The bill, which from the bafe to about half-way, is covered with wrinkles, is black, but marked croffwife with a ftripe of yellow. They walk esect, their. heads high, their fin-like wings hanging down like arms; fo that to fee them at a diftance, they look like fo many children with white aprons. From hence they are are faid to unite in themfelves the qualities of men, fowls, and fifhes. Like men, they are upright; like fowls, they are feathered; and; like fillies, they have fin-like inftruments, that beat the water before, and ferve for all the purpofes of fwimming rather than flying. They feed upon filh; and feldom come alhore, except in the breeding feafon. In fome the flefh is fo tough, and the feathers fo thick, that they ftand the blow of a fcymitar without injury. A fmall depreffion in the earth; without any other neft, ferves for their laying: By the warmth of their feathers, and the heat of their bodies, incubation is carried on very rapidly. But in fome places, the penguin burrows two or three yards deep; in others it clambers up the ledge of a rock, probably in confequence of dear-bought experience. The egg of the penguin is very large for the fize of the bird; being generally bigger than that of a goofe. 'There are many varieties of the penguin, differing in fize from that of a Mufcovy duck to a fwan; the eggs differ in the fame proportion.

\section{O F T H E}

\section{AUK, PUFFIN, AND OTHER Birds OF THE PENGUIN KIND.}

$\mathrm{O}$ F a fize far inferior, but of nearly the fame form, and exactly the fame appetites and manners, there is a very numerous tribe.

The great Northern Diver, is nearly the fize of a goofe: beautifully variegated all over with many ftripes, and differs from she pencruin, in being much nenderer and more elegantly formed. The grey fipeckled Diver does not exceed the fize of a Mufcovy duck; and, except in lize, 


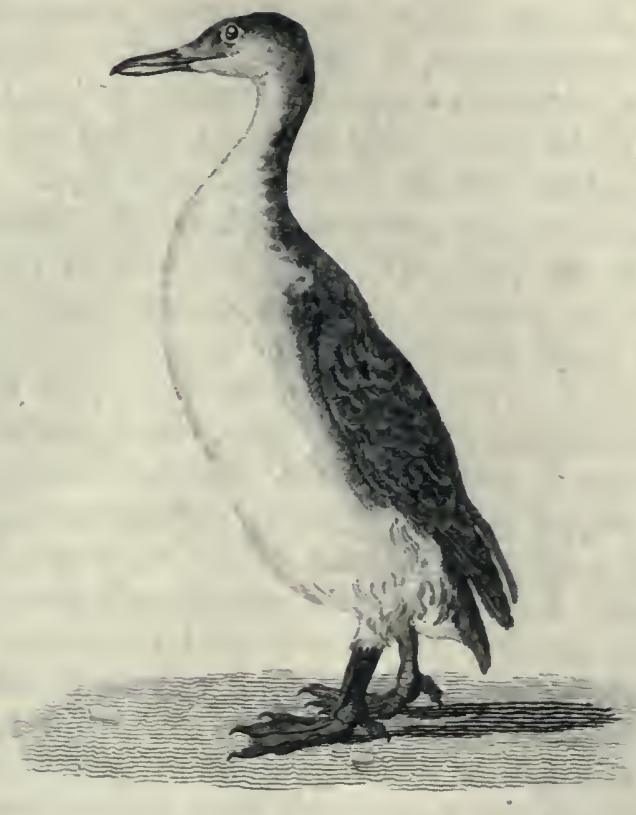

The Diver. 

greatly refembles the former. The Auk, which breeds on the inlands of S. Kilda, chiefly differs from the penguin in fize and colour. It is fmaller than a duck; and the whole of the breaft and belly, as far as the middle of the throat, is white. The Guillemot is about the fame fize; it differs from the auk, in having a longer, a nenderer, and a ftraighter bill. The Scarlet-throated Diver may be diftinguifhed by its name; and the Puffin or Coulterneb, which is, by its bill, one of the moft remarkable birds we know. The bill is flat; its edge upwards; of a tri-, angular figure, ending in a harp point; the upper chap bent a little downward, where joined to the head; a certain callous fubftance encompaffes its bafe, as in parrots. It is of two colours; an-coloured near the bafe, and red towards the point. It has three furrows, or groves, impreffed in it; one in the livid part, two in the red. The eyes are fenced with a protuberant $\mathrm{fkin}$, of a livid colour; and they are grey or afh-coloured. It is a fmall bird, not much bigger than a pigeon; when it once rifes, it can continue its flight with great celerity.

The auk and guillemot, when they have once laid their fingle egg, which is extremely large for their fize, feldom forfake it until excluded. The male, who is beft furnined for flight, feeds the female during this interval; and fo bare is the place where the fits, that the egg would often roll down from the rock, did not the body of the bird fupport it. The puffin, relying on its courage, and the ftrength of its bill, with which it bites moft terribly, either makes or finds a hole in the ground, where to lay and bring forth its young.

At the latter end of March, or the beginning of April, come over a trcop of their fpies or harbingers, that ftay two or three days, as it.were to view and fearch out for their former fituations, and fee whether all be well. This done, they depart; and about the beginning of May, return again with the whole army of their companions. But if the feafon be tempeftuous, they undergo increaible hardhips; and are found, by hundreds, caft away upon the fhores, lean and perifhed with famine.?

The puffin, when it prepares for breeding, which always happens a few days after its arrival, begins to fcrape up an hole in the ground, not far from the Thore; and when it has fome way penetrated the earth, it then throws itfelf upon its back, and with bill and claws thus burrows inward, till it has dug a hole with feveral windings and turnings, from eight to ten feet deep. It particularly faeks, to dig under a ftone, where it expects the greateft fecurity. In fome places, where rabbits breed, the puffin difpoffeffes the rabbits, and not unlikely deftroys their young. Here young PART IV. No. 27 . 
puffins are found in great numbers, and become a very valuable acquiftions to the natives. The old ones, at break of day, leave their nefts, nor do they return till night-fall. Whatever filh, or other food; they have procured in the day, by night-begins to fuffer a kind of half digeftion, and is re. duced to an oily matter, which is ejected from the ftomach of the old ones into the mouth of the young. By this they are nourifhed, and become fat to an amazing degree. When they are arrived to their full growth, they are dug out, or drawn out, from their burrows, with an hooked ftick. They bite extremely hard, and keep faft hold of whatever they feize upon.

The Goofander is a bird, with the body and wing thaped like thofe of the penguin kind, but with legs not hid in the belly. It may be difringuifhed from all others by its bill, which is round, hooked at the point, and toothed, both upper and under chap, like a faw. Its colours are various and beautiful: its manners and appetites entirely refemble thofe of the Diver. It feeds upon fin, for which it dives; and is faid to build its neft upon trees, like the heron and the cormorant.

\section{OF BIRDS OF the GOOSE KIND, PROPERLy So CALlED.}

FHE Swan, the Goofe, and the Duck, leaders of a numerous, ureful, and beautiful tribe, we have reclaimed from a ftate of nature, and taught to live in dependance about us. The duck-kind approach the goofe fo nearly, that it may be proper to mark the diftinctions.

The marks of the goofe are, a bigger body, large wings, a longer neck, a white ring about the rump, a bill thicker at the bafe, flenderer towards: the tip, with fhorter legs, placed more forward on the body; both have a waddling walk; but the duck, from the pofition of its legis, is moft waddling. The duck fometimes equals a goofe in fize, yet there are fill other fufficient diftinctions. Their having been tamed has produced alterations in each, by which they differ as much from the wild ones of their refpective kinds as they do among themfelves. In all the goofe kind the bill is flat and broad, for the purpofe of nimming ponds or lakes of the mantling weeds that ftand on the furface; alfo they are fheathed with a Skin which covers them all over. Eat infeets, grais, corn, \&xc. Thefe birds do not reject animal food when offered, yet fubfint on vegetables, and feldom feek any other. They breed in abundance, and lead their 


\section{T H E S W A N.}

young to the pool the inftant they are excluded. The fwan was confidered as a high delicacy among the ancients, while the goofe was abftained from; bu: the goofe is now the favourite; and the fivan feldom brought to table, but for oftentation. At all times the duck was highly eftermed. There have been many changes wrought in their colours, their figures, and even their internal parts, by human cultivation. Thefe birds, in a wild ftate, are fimple in their colourings; but in the tame, no two are exactly alike.

\section{OF TIE SWAN, TAME AND WILD.}

THE, Swan has long been rendered domeftic; and now we doubs 1 whether there be any of the tame kind in a ftate of nature: The wild fwan, though ftrongly refembling in colour and form, is yet different; for it is very differently formed within. The wild fwan is lefs than the rame almoft a fourth; this weighs twenty pounds, the other only fixteen; the tame fwan is all white; the wild bird is, alongr the back and the tips of the wings, afh-coloured. In the taine fwan, the wind-pipe finks down into the lungs in the ordinary manner; but in the wild, after a contortion, like what we have feen in the crane, it enters a hole in the breaftbone; being reflected therein, returns by the fame aperture; and, being contrakted into a rarrow compars by a broad and bony cartilage, is divided into two branches, which, before they enter the lungs, are dilated into two cavities. It is not eafy to account for this difference of conformation; but it is more difficult to reconcile the accounts of the ancients with the experience of the moderns, concerning the vocal powers of this bird. The tame fwan is very filent, the wild one has a note extremely loud and difagreeable; and fuch is its harhnefs, that the bird from thence has been called the Hooper. It is probable the ancients had fone mythological meaning in afcribing melody to the fwan.

Its chieffood is corn, bread, herbs growing in the water, and roots and feeds which are found near the nargin. It prepares a neft in fome retired part of the bank, and chicfly where there is an intet in the ftream. It is compofed of water-plants, long grafs and fticks; and the male and female afift in forming it with great affiduity. The fwan lays feven or eight eggs, white, much larger than thofe of a goofe, with a hard, and fometimes a tiberous finell. It fits near two months; its young are afh$\mathrm{Y} 2$

coloured 
coloured when they firt leave the Thell, and for fome months after. It is not a little dangerous to approach the old ones, when their little fumily are feeding round them. "After a twelve-month, which it takes to come to maturity, the young fwans change their colour with their plumage. Some fay it lives three hundred years; Willoughby feems to believe it. A goofe, as he juftly obferves, has been known to live an hundred; and the fwan, from is fuperior fize, and from its harder, firmer Hefh, may naturally be fuppofed to live ftill longer. We fee multitudes on the Thames and Trent; but no where greater numbers than on the falt water-inlet of the fea near Abbotfbury, in Dorfethire.

\section{OF THE GOOSE AND ITS VARIETIES.}

FHE Goofe, in its domeftic ftate, exhibits a variety of colours. The wild goofe always retains the fame marks: the whole upper part is afh-coloured; the breaft and belly dirty white; the bill narrow at the bafe, at the tip black; the legs of a faffron colour; the claws black. Thefe marks are feldom found in the tame, whofe bill is entirely red, and whofe legs are entirely brown. The wild goofe is rather lefs than the tame; but both invariably retain a white ring round their tail, which thews that they are both defcended from the fame original.

The wild goofe is fuppofed to breed in the northern parts of Europe; and, in the beginning of winter, to defcend into more temperate regions. They fly at very great heights, in flocks from fifty to an hundred, feldom refting by day. Their cry is frequently heard when they are imperceptible above us; and this feems repeated among them, as among hounds in purfuit; but this they feldom exert, when they alight. On coming to the ground by day, they range themfelves ii a line, like cranes. When they have thus fat an hour or two, one of them, with a loud long note, founds a kind of charge, to which the reft attend, and they purfue their journey with renewed alacrity. Their fight is very regular: they either go in a line a-breaft, or in two lines, joining in an angle in the middle. It is thought their light is thus arranged to cut the air with greater eafe.

The Barnacle differs from both thefe; being lefs than eicher, with a black bill, much Shorter than the preceding. 
The Brent Goofe is ftill lefs. The head, neck, and upper part of the breaft black; about the middle of the neck, on each fide, are two fmall fpois or lines of white, which together appear like a ring.

Thefe, and many other varieties, are found in this kind. The tame goofe is the mott prolific, having lefs to fear, leading a fecurer and more plentiful life: the wild goofe feldom lays above eight eggs, the tame often above twenty. The female hatches with great affiduity; the gander vifits her twice or thrice a day, and fometimes drives her cff to take her place, where he fits with great ftate and compcfure. But beyond that of all animals is his pride when the young are excluded: he feems then to confider himfelf as a champion, not only obliged to defend his young, but alfo to keep off the fufpicion of danger; he purfues dogs and men that never attempt to moleft him; and, though the moft harmlefs thing alive, is then the moft petulant and provoking.

Of goofe-feathers molt of our beds in Europe are compoled. Great numbers of geefe are kept tame in the fens in Lincolnhire, and are plucked once or twice a year. The down of the fwan is brought from Dantzic. The fame place alfo fends us great quantities of the feathers of the cock and hen; but Greenland, Iceland, and Norway, furnith the beft feathers of all; and in this number we may reckon the Eider down.

\section{OF THE DUCK AND ITS VARIETIES.}

TH E tame Duck is the moft eafily reared of all our domeftic ani. 1 mals. The inftincts of the young direet them to their favourite element; and though conducted by a hen, they defpile her clamorous admonitions. The duck feems to be an heedlefs, inattentive mother; the frequently leaves her eggs till they fpoil; is equally regardlefs of her young; the leads them to the pond, and thinks the has fufficiensly provided for her offspring when the has thewn them the water.

The wild duck differs, in many refpects, from the tame; and in them there is nill greater variety than among the domeftic kinds. Of the tame duck there are not lefs than ten different forts; and of the wild, Briffon reckons 
reckons above twenty. The moft obvious diftinction berween wild and tame ducks is in the colour of their feet; thofe of the tame duck being black, thofe of the wild duck yellow.

Sea-ducks, which feed in the falt-water, and dive much, have a broad bill, bending upwards, a large hind toe, and a long blunt tail." Pondducks, which feed in plafnes, have a ftraight and narrow bill, a fmall hind toe, and a thort pointed train.

In this tribe, we inay rank, as natives of our own European dominions, the EIDER DUCK, which is double the fize of a common duck, with a black bill; , the VELVET DUCK, not fo large, with a yellow bill; the Scoter, with a knob at the bale of a yellow bill; the Turted Duck, adorned with a thick creft; the ScAup Duck, lefs than the common duck, bill greyifh blue; the GOLDEN ExE, a large white fpot at the corners of the inouth, refembling an eye; the SHELDRAKE, the bill a bright red, fwelling into a knob; the MaLLARD, which is the ftock from whence our tame breed has probably been produced; the PinTail, the two middle feathers of the tail three inches longer than the reft; the POCHARD, the head and neck bright bay; the WIDGEON, bill lead-coloured, plumage on the back marked with narrow black and white undulated lines, but beft knuwn by its whiftling found; the $T_{E A L}$, the fmalleft of this kind; bill black, head and upper part of the neck bright bay.

The moft noted foreigners of the tribe are, the Mufcovy, or, more properly, the Musk DUck, fo called from a fuppofed muiky fmell; with naked $f$ in round the eyes; native of Africa. The Brasilian DUCK, the fize of a goofe, all black except the tips of the wings. The American WOod Duck, with a variety of beautiful colours, and a plume of feathers that falls from the back of the head like a friar's cowl. To thefe might be added many others.

All thefe live in the manner of our domeftic ducks, keeping in flocks in the winter, and flying in pairs in fummer, bringing up their young by the water-fide, and leading them to their food as foon as out of the fhell. Their nefts are ufually built among heath or rulhes, not far from the water; and they lay twelve, fourteen, or more eggs before they fit. Their nelts are fometimes on the tops of trees; generally compofed of the longeft grafs, mixed with heath, and lined with the birds' own feathers. In proportion as the climate is colder, the neft is more artificially made, and more warmly lined with a layer of long grals and clay; within that another of 



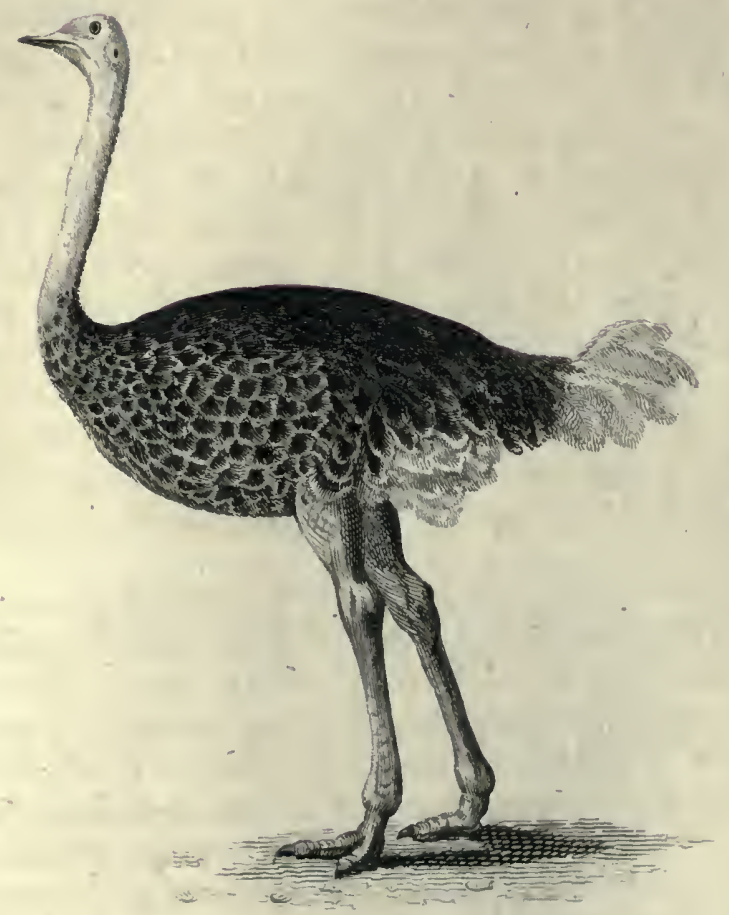

The Oftrich. 
mofs, and, laftly, a warm coat of feathers or down. The eider duck is particularly remarkable for the warmth of its neft. The infide lining, on which the eggs are depofited, is the fofteft, warmeft, and lighteft fubftance with which we are acquainted. This is the infide down which covers the brealt of the bird in the breeding-feafon. This the female plucks off with her bill. The natives watch the place where the begins to build, and, fuffering her to lay, take away both eggs and neft. Not difcouraged by this difappointment, fne builds and lays in the fame place a fecond time; and this they allo take away: the third time the builds, bus the drake muft fupply the down from his breaft to line the neft with; and, if this be robbed, they forfake the place, and breed there no more. They are in general birds of paffage, and moft probably perform their journeys acrols the ocean, as well on the water as in the air.

Ducks flying in the air are often lured down by the loud voice of the mallard below. Nature feems to have furnifhed this bird with very. par. ticular faculties for calling. The wind-pipe, where it begins to enter the lungs, opens into a kind of bony cavity, where the found is reflected as in a mufical inftrument, and is heard a great way off. To this call all the itragglers refort. Though a timorous bird, yet they are eafily deceived. Above thirty thoufand have been fent up, in one feafon, from tén decoys in the neighbourhood of Wainfleet,

\section{T H E O S T R I C H.}

THE OAtrich is the largeft of birds; fome brought into England were 1 feven feet high. The head and bill fomewhat refemble tho'e of a duck; and the neck that of a fwan; but is much lunger; the legs and thighs refemble thofe of an hen; from its fize and appearance the Arabians call it the Camel-bird. From the back to the ground four feet; the head and neck three. From the rop of the head to the rump, when the neck is ftretched our, fix feet; the tail about a foot; a wing, withor:t the feathers, a foot and a half; with the feathers, three feet. The plumage generally black and white; fome grey. The greateft feathers are at the extremities of the wings and tail, generally white. The next row is black and white; the fmall feathers, on the back and belly, are fome white, others black; no feathers on the fides, on the thighs, nor under the wings. The lower part of the neck, about half way, is covered with ftill PART IY. No. 27.

rmaller 
fmaller feathers than thofe on the belly and back; and of different colotirs All thefe feathers are of the fame kind, peculiar to the oftrich; as foft as down, utterly unfit for Aying or defence. The feathers of other birds have the webs broader on one fide than the other, but thofe of the oftrich have their thaft exactly in the middle. The upper part of the head and neck are covered with very fine clear white hair, that thines like the briftles of a hog; and in fome places there are fmall tufts of it, confifting of about twelve hairs, which grow from a fingle fhaft, about the thicknels of a pin. At the end of each wing, there is a $\mathrm{k}$ ind of fpur almoft like the quill of a porcupine; an inch long, hollow and horny. There are two of thefe on each wing; the largeft at the extremity of the bone of the wing, the other a foot lower. The neck feems more nender by being void of feathers. The flkin is of a livid fleth colour ; the orifice of the ears bare, but a little hair within it. The bill is hort and pointed, and two inches and an half at the beginning. In form, the eye is fomewhat like the human, the up: per eye-lid immovable, having eye-lathes; the tongue is fmall, very thort; in 'forne about an inch long, and very thick at the buttom. In others half an inch, and a litcle forked at the end. The thighs are very flefhy and large, covered with a white fkin, inclining to rednefs, and wrinkled, in the manner of a net, whofe mefhes will admit the end of a finger. Some have very fmall featiners here and there on the thighs: and others neither fearhers nor wrinkles. The legs are covered in front with large fcales; the foot has two very large toes, covered with fcales. The largett, on the infide, is feven inches long, including the claw, which is near three-fourths of an inch in length, and almoft as broad. The other toe, four inches long, has no claw.

The internal parts are no lefs furprifingly peculiar. On the breaft; under the $\mathrm{fkin}$, the fat is two inches thick; on the fore-part of the belly, thicker, and as hard as fuet in fome places. It has two ftomachs: The firft, which is lowermoft, fomewhat refembles the crop in other birds; is confiderably larger than the other, and furnined with ftrong mnicular fibres, as well circular as longitudinal. The fecond ftomach, or gizzard, is always filled with a variety of difcordant fubftances; hay, grafs, barley, beans, bones, ftones. The kidneys are not, as in other birds, divided into lobes. The heart and lungs are feparated by a midriff, as in quadrupeds; and other parts bear ftrong refemblance.

Native of the torrid regions of Africa, never known to breed out of that country, formed to live in fands and deferts, where few vegetables clothe the earth, and where rain is unk , wn. Here oftriches are 
feen in large focks, which, to the diftant fpectator, appear like a regiment of cavalry.

The oftrich is, of all animals; the moft voracious; devours any thing that is given; and digefts all that is digeftible; what the ftomach cannot foften, paffes whole. In their native deferts they live chiefly on vegetables, inoffenfive and focial, the male, as Thevenot affures us, afforting with the female with connubial fidelity. Lay very large eggs, fome above five inches in diameter, and weighing five pounds, having a very hard hell. In the northern parts of Africa, about the beginning of July; in the fouth, about the latter end of December. Are very prolific; lay thirty to forty eggs at once: In thofe hot climates, there is no neceffity for continual incubation; and the female frequently leaves her eggs by day, but broods over them by night; yet probably this varies with the temperature of the air; \&c: In temperare climates the young are unable to walk for feveral. days after they are hatched. During this time, the old ones are very affiduous in fupplying and defending them; when brought forth, they are afh-coloured the firft year, and covered with feathers all over.

Some favage nations of Africa hunt them for their fle $\mathrm{h}$, or breed them tame to eat the young ones, hence called Struthophagi, or Oftricheaters. The eggs are faid to be well-tafted, and extremely nourifhing; and a fingle egg fufficient for eight men.

Of all knuwn animals that ufe their legs in rusning, the oftrich is by far the fwifteft: when purfued at a diftance, he begins to run at firf but gently; his wings, like two arms, working with a motion correfpondent to that of his legs; his fpeed would very foon fnatch him from the view of his purfuers; but, inftead of going off in a direct line, he takes his courfe in circles; the hunters making a fmall courfe within, relieve each other, and keep him thus employed, two or three days together, till fpent with fatigue and famine. Sometimes he defends himfelf with his beak, his wings, and his feet: Such is the force of his motion, that a man would be utterly unable to withftand him in the fhock.

\section{T H E T.O U Y Y O U}

TS chiefly found in Guiana, along the banks of the Oroonoko, in the 1 inland provinces of israfil and Chili, and the vaft forefts that border on the mouth of the river lata; though not fo large as the oftrich, is only 
fecond to it in magnitude; by much the largeft bird in the New Continent: at full growth fix feet high; its legs are three feet long; its thigh is near as thick: as that of a man. The toes differ from thofe of the oftrich, as there are three in the American bird, and but two in the former. Its neck is long, its head fmall, and bill flatted like the oftrich; but, in other re: fpects, it more refembles a laffowary. The form of the body appears round; the wings are short, and unfit for flying; has no tail, but is covered on the back and rump with long feathers, which fall backward, and cover the anus: "thefe feathers are grey on the back, and white on the belly. It is very fwift, and feems afifted in its motion by a kind of tubercle behind, like an heel, upon which, on plain ground, it treads very fecurely, but not on a defcent; in its courfe it ufes a very odd kind of action, lifting up one wing, which it keeps elevated for a time," till, letting it drop, it lifts up the other; whether as a fail to catch the wind, or as a rudder to turn its courfe, to avoid the arrows of the Indians, remains to be afcertained: however this be, the emu runs with fuch fwiftners, that the Aeeteft dogs are thrown out in the purfuit. One of them, finding itfelf furrounded by the hunters, darted among the dogs with fuch fury, that they made way to avoid its rage; and it efcaped, by its amazing velocity, in fafety to the mountains.

When the young ones are hatched, they are familiar, and follow the firt perfon they meet. I have been followed myfelf, fays Wafer, by many of thefe young oftriches, which at firt are extremely harmlefs and fimple, but as" they grow older, they become more cunning and diftruftul; and run fo fwift, that a greyhound car fcarcely overtake them. Their Alefh, in general, is good to be eaten; efpecially when young. Their maintenance could nor be expenfive, if as Narborrough fays, they live entirely upon gra!s.

The lateft account we have of this bird is by Captain Tench, in his account of Botany Bay, which we thall give in his own words.

" "The bird which principally claims attention is a fpecies of oftrich, approaching nearer to the Emu of South America than any other we know of. One of them was thot, at a confiderable diftarice, with a fingle ball, by a convict employed for that purpofe by the governor; its weight, when complete, was feventy pounds, and its' length from the end of the toe to the tip of the beak, feven feet two inches, though there was reafon to believe it had not attained its full growth. On diffection many anatomical fingularities were obferved: the gall-bladder was remarkably Jarge, the liver not bigger than that of a barn-door fowl, and after the ftriktent 
ftricteft fearch no gizzard could be found; the legs, which were of a vaft length, were covered with thick, ftrong fcales, plainly indicating the animal to be formed for living amidt defarts; and the foot differed from an oftrich's by forming a triangle, inftead of being cloven." Goldfmith, whofe account of the Emu is the only one I can refer to, fays, "that it is covered from the back and rump with long feathers, which fall back ward; and cover the anus; there feathers are grey on the back, and white-on the belly.' "The wings are fo fmall as hardly to deferve that name, and are unfurnifhed with thole beautiful ornaments which adorn the wings of the oftrich: all the feathers are extremely coarfe, but the conftruction of them deferves notice; they grow in pairs from a fingle thaft, a fingularity which the author I have quoted has omitted to remark. It may be prefumed, that thefe birds are not very fcarce, as feveral have been feen, fome of them immenfely large; but they are fo wild, as to make fhooting them a matter of great difficulty. Though incapable of fying, they run with fuch fwiftnel's, that our fleeteft greyhounds are left far behind in every attempt to catch them. The fle was eaten, and tatted like beef."

This gentleman confounds the names. Touyou and Emu, as others have before him; whereas the Emu is properly the Caffowary of Java.

\section{THE CASSOWARY}

T A firt brought into Europe by the. Dutch, in 1597 , from Java, in the Eaft In!lic's, in which patt of the world it is only found; the natives call it Ene or Emu. Next to the preceding, the largeft and heavieft of the feathered ipecies: the Caffowary, though not fo large as the former, appears more bulky; its body being nearly equal, and its neck and legs much thickér and ftronger in proportion.

It is five feet and an halflong, from the point of the bill to the extremity of the claws. The legs are two feet and an half high, from the belly to the end of the claws. The head and neck together are a foot and an half; and the largeft toe, including the claw, is five inches long. The claw alone of the leaft toe, is three inches and a half in length. The wing is fo fmall, that it does not appear, being hid under the feathers of the back. All the feathers are of the fame kind, and outwardly of the fame colour. They are generally double, having two long thafts, which grow out of a thort one, which is fixed in the fkin. Thofe that are double are always of unequal lengths; fome fourteen inches long, particularly on the rumps 
while others are not above three. The beards that adorn the ftem or fhate are, from about half way to the end, very long, and as thick as an horfehair, withour being fubdivided. The ftem or haft is flar, Mining, black, and knotted below, and from each knot proceeds a beard; likewife, the beards at the end of the large feathers are perfectly black, and towards the ront of a grey. tawny colour; fhorter, more foft, and throwing out fine fibres, like down; fo that nothing appears except the ends, which are hard and biack; becaufe the other part, compofed of down, is quite covered. There are feathers on the head and neck; but they are fo Phort, and thinly fown, that the bird's fkin appears naked, except toward the hinder part of the head, where they are a little longer. The wings, when deprived of their feathers, are but three inches long; their feathers are like thofe on the body. The ends of the wings have five or more prickles, of different lengths and thicknefs, which bend like a bow : hollow throughout, having only that night fubftance within which all quills have. 'The longeft' of thefe prickles is eleven inches; a quarter of an inch in diameter at the root, being thicker there than towards the extremity; the point feems broken off.

The part moft remarkable is the head; it is bare, and in a manner armed with an helmet of horny fubtance, that covers it from the root of the bill to near half the head backwards. This helmet is black before, and yellow behind. Its fubtance is very hard, being formed by the elevation of the bone of the $\mathrm{kull}$; and it confifts of feveral plates, one over another, like the horn of an ox. The eye is a bright yellow, and the globe, being above an inch and an half in diameter, gives it an air fierce and extraordinary. At the bottom of the upper eye-lid is a row of fmall hairs, over which is another row of black hair, which looks pretty much like an eye-brow. "The lower eye-lid, which is the largeft, is furnithed alfo with plenty of black hair. The hole of the ear is large, open, and uncovered, furrounded with fmall black hairs: The fides of the head, about the eye and ear, having only a few hairs of covering, are blue, except the middle of the lower eye-lid, which is white. The part of the bill which anfwers to the upper jaw in other animals, is very hard at the edges above, and the extremity of it like that of a turkey-cock. The end of the lower mandible is nightly notched, and the whole is of a greyin brown, except a green fpor on each fide: As the beak admits a very wide opening, this contributes not a little to, the bird's menacing appearance; the tongue an inch long, The neck is of a violet colour, inclining to that of llate; is red behind in everal 


\section{THE CASSOWAR Y.}

places, but chiefly in the middle. About the middle of the neck before, at the rife of the large feathers, there are two proceffes; round at the bottom, formed by the $\mathrm{kin}$, which refemble fomewhat the gills of a cock, but are blue as well as red. The $\mathrm{kin}$, which covers the fore-part of the breaft, on which this bird leans and refts, is hard, callous, and bare. The thighs and legs are covered with feathers, and are extremely thick, ftrong, ftraight, and covered with feales of feveral fhapes; but the legs are thicker a little above the foot than in any other place. The toes are likewife covered with fcales, and are three in number: the claws are of a hard folid fubftance, black without, and white within,

The internal parts are equally remarkable. The caffowary unites, with the double ftomach of animals that live upon vegetables, the fliort inteftines of thofe that live upon fleh. The heart is very fmall, being but an inch and an half long, and an inch broad at the bafe.

It never attacks others; and inftead of the bill, when attacked, it rather makes ufe of its legs, and kicks like an horfe, or runś againfr its purfuer, beats him down, and treads him to the ground. The manker of going of this animal is not lefs extraordinary than its appearance, Inftead of going directly forward, it feems to kick up behind with one leg, and then, making a bound onward with the other, it goes with fuch prodigious velocity, that the fwifteft racer would be left far behind. Swallows every thing that comes within the capacity of its gullet. It is faid, that the pafrage of the food is performed fo fpeedily, that fometimes the eggs it has fwallowed whole pafs unbroken: the alimentary canal of this animal, as was obferved above, is extremely hort; and it may happen that many kinds of food are indigeftible in its ftomach, as wheat or currants are to man, when fwallowed whole.

The caffowary's eggs are of a grey afh colour, inclining to green; not fo large nor fo round as thofe of the oftrich. They are marked with a number of little tubercles of a deep green, and the thell is not very thic The largett of thefe is found to be fifteen inches round one way, and about twelve the other. The fouthern parts of the Indies feeir to be the natural climate of the caffowary. His domain, if we may fo call it, be. gins where that of the oftrich terminates. The latter has never been found beyond the Ganges; while the caffowary is never feen nearer than the iflands of Banda, Sumatra, Java, the Molucca Inands, and the core sefponding parts of the continent. Yet even there is rare. 


\section{$138)$ \\ T H E D O D O.}

T TS body is maffive, almoft round, covered with grey feathers; juft 1 barely fupported on two thort thick legs like pillars, while its head and neck rife from it in a manner truly grotefque. The neck, thick and purfy $y_{2}$ is joined to the head, which confifts of two great chaps, that open far behind the eyes, which are large, black and prominent; fo that the animal, when it gapes, feems to be all mouth. The bill is of an extraordinary length, not flat and broad, but thick, and of a bluinh white, harp at the end, and each chap crooked in oppofite directions. They refemble two pointed fpoons laid together by the backs. From all this refults a ftupid and voracious phyfiognomy; which is ftill more increafed by a bordering of feathers round the root of the beak, and which gives the appearance of an hood or cowl, and finifhes this picture of ftupid deformity. Bulk, which in other animals implies ftrength, in this only indicates inactivity. The dodo feems weighed down by its own heavinefs, and has fcarce ftrength to urge itfelf forward. It is furnifhed with wings, covered withe foft anh-coloured feathers, but they are too thort to affift it in flying. It is furnifhed with a tail, with a few fmall curled feathers; but this tail is difproportioned and difplaced. Its legs are too Short for running, and its body too fat to be ftrong.

This bird is native of the ine of France; and the Dutch, who firt difcovered it there, called it in their language the naufeous bird, as well from its difgulting figure, as from the bad tafte of its flem: however fucceeding obfervers contradict this firft report, and affert that its flefh is good and wholefome eating. It is a filly, fimple bird, as may be very well fuppofed from its figure, and is very eafily taken. Three or four dodos are enough to dine an hundred men.

Whether the dodo be the fame bird with that which fome travellers have defcribed under the bird of the Ine of Nazareth, remains uncertain. The country is the fame; their incapacity of flying is the fame; the form of the wings and body is fimilar; the chief difference is in the colour of the feathers, which, in the female of the bird of Nazareth, are faid to be extremely beautiful; and in the length of their legs, which in the dodo are fhort, in the other are defcribed as long. 


\section{SURVEYS OF NATURE.}

\section{P A R T THE F I F T H.}

VIPAROUS QUADRUPEDS may jufly claim a fation after the fuperior orders of viviparous quadrupeds, and birds : endowed with lefs powers in certain refpects, yet exhibiting much diverfified contrivance, adaptation, and manners: Many perfons have given the general name of REPTILE to this whole divifion; but that feems more properly applied to ferpents, or fuch as ufe their belly to affift their motion.

This clafs of creatures thave neither bzeafts, nor hair; but are clothed with a bony covering, hard or fharp fcales, and tubercles more or lefs prominent, or with a naked fkin, bedewed with, a vifcous liquid. They have hort legs; and, inftead of fpreading their feet when walking, they fold them.

The moft confiderable are natives of the torrid zone; yet their blood is lefs endued with heat, than that of moft other animals: they have alfo a lefs quantity of blood; it circulates flowly, and but little depends on the lungs. Many of them have no ribs; many have only four vertebre in the neck, confequently little motion. Their heart has only one ventricle; their breathing is with intervals, and irregular, often fufpended for a long time; they are fond of warmth and of humidity; and though inhabitants of various foils, rocky and dry, or fandy, or of the woods, yet all are amphibious; but cannot continue altogether deprived of air, or remain long under water, like firhes. In general furvive confiderable wounds, and even feparation of rome members, which, in certain cafes, are reproduced. They are alfo extremely patient of hunger, and fome live months without food: Their particles tranfpire but flowly, and confequently require only now renovation. They never fweat. The major part of them are 


\section{(110)}

torpid, when the atmofphere is cool, and fleep during winter though often, if the feafon be mild, and the cold abated, they revive, and are found aetive and vigorous, even in winter. $\mathrm{Ex}$ treme cold converts their torpidity into death. They lofe farce any of their weight during their torpid tate; on their recovery; their external covering ufually changes, and till their new attire is fufficiently hardened, they are greatly concealed, and folicitous of: avoiding the rifque of accidents. They are often found in troops; but their affembling is not the refult of focial, but of individual intereft. They are in general very prolific, and often the largeft kinds, efpecially; in which they contradict the rule adopted in refpect to viviparous quadrupeds. Their eggs are never hatched by the parent; but, though not left open to accidents (being hidden, \&c.) yet neglected; and confequently the pofterity never knows its parent, nor experiences the tender cares neceffary to avert or to foften the accidents of life. Mont of them may be tamed, crocodiles not excepted. In general, they have more or lefs of a mufky fcent. They may be confidered as ufually very long-lived. Few of them are venomous. 


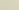


The Tortoife.
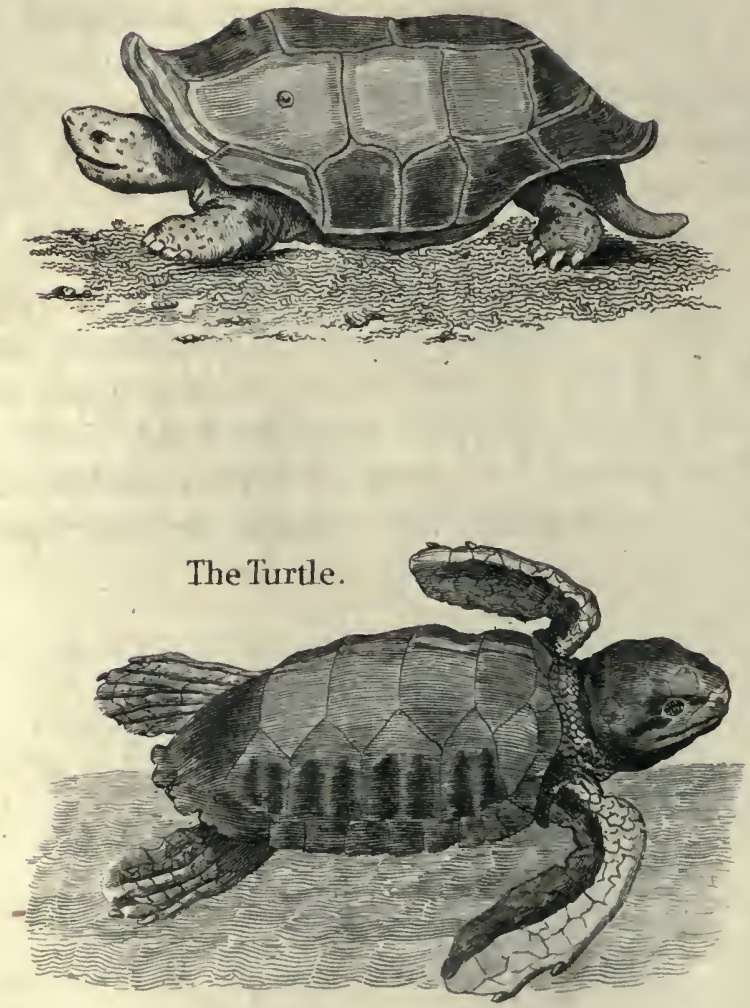


\section{THE TOR TOIS E. ?}

MORTOISES may be divided into thofe that live upon land, thofe of frefh waters, and thofe of the fea; the former being called Tortoifes, the laft Turtles, but all are amphibious; the land-tortoife will live in water, and water-tortoifes on land; they, are therefore rather named from the refidence they prefer, than from being reftricted to either.

Tortoifes, in external form, pretty much refemble each other; their covering is compofed of two great fhells, a fuperior and inferior, only touching at the fides: the ribs, and the fpine of the back, form part of the upper; the lower unites to the fternum. The lower is the leaft, the fofteft, and often almoft flat. Thefe thells are compofed of feveral pieces, bound together at the edges by very ftrong and hard ligaments, with a fmall thare of motion in fome kinds. At each end of thefe united fhells is an aperture, one for a fmall head, Moulders and forelegs, to pafs through; the other for the hind feet and the tail. Thefe Thells the animal never quits; but they ferve for his defence, and are a very fubftantial and adequate defence. The upper fhell has commonly thirteen or fifteen centre-pieces, and a border round them of twenty-two or twenty-five fmaller. The under fhell has, in tome kinds, twelve or fourteen pieces, in others twenty-two or twenty-four. Thefe coverings often weigh four hundred pound, in the marine kinds.

The tortoife has a fmall head, a little rounded at the muzzle, where are the noftrils; the mouth is beneath, opens to beyond the ears; the place of which is fcarcely ditinguifhable; no teeth, but two bony ferrated ridges in their place: thefe gather and grind its food. Such is the amazing ftrength of the jaws, it is impoffible to open them where they once have faftened; even, when the head is cut off, the jaws ftill keep their hold; and the mufcles, in death, preferve a tenacious rigidity. The legs, though fhort, are inconceivably ftrong; and it has been known to carry five men ftanding on its back with apparent eafe.

The blood circulates in this animal, as in fome cartilaginous fifhes, by a very thort pafrage through the circulation; and the lungs feem to lend only occafional afiftance. From this conformation the animal can fubfint fome time without breathing.

The land-tortoife, from the ufe of its feet in walking, is much more nimble on land than the fea-turtle: if thrown on its back, by rocking 
and balancing its body, at laft it turns itfelf on its face again; which the turtle, when once turned; is unable to do: The nails on the toes of thofe long ufed to fratch for fubfiftence, or to burrow on land, are blunt and worn; while thofe employed in fwimming only, are tharp and long. The brain of the Land-tortoife is but fmall; yet three times as large as that of the turtle. They differ in the fhape of their eggs, and in the paffage by which they are excluded; in the land-tortoife, the paffage is fo narrow, that the egg conforms to its fhape; and, though round when in the body, yet becomes oblong when excluded. "This paffage is wider in the turtle, and therefore its eggs are round. Turtles may readily be diftinguifhed from tortoifes, by their very long feet, often two feet long; their toes unequal in length, and united by a membrane, being rather fins than feet. The tortoife hardly exceeds three feet long, by two feet broad; fome kinds not many inches; the turtle is fometimes'from five to feven feet long. Size, however, is a fallacious diftinction; fince land tortoifes, in fome parts of India, grow to a very great magnitude, five or more feet long; though probably not, as the ancients affirm, big enough for a fingle thell to ferve for the covering of an houfe.

Moft tortoifes can put out, or withdraw at pleafure, their head, feet, and tail under the great penthoufe of the Thell; there, fecure from all attacks, defended on every fide, it fatigues the patience, and defies "the claws or beak of the moft formidable animal of the foreft. This the turtle cannot do fo completely. As thefe creatures live wholly on vegetable food, they never feek encounters; yet, if any of the fmaller animals attempt to invade their repofe, they are fure to fuffer: for impregnably defended, furnithed alfo with prodigious ftrength of jaw, wherever the tortoife faftens; it infallibly keeps its hold, till it has raken out the piece.

Is extremely tenacious of life; the lofs of a member is but a night injury; it will live long, though deprived of its brain, or its head. REDI cut off the head of a tortoife, and the animal lived twenty-three days after its feparation from the body: The head alfo continued to rattle the jaws, jike a pair of caftanets, for above a quarter of an hour. Tortoifes commonly exceed eighty years: there was one kept in the Archbihop of Canterbury's garden, at Lambeth, that was above an hundred and twenty. It was at laft killed by the feverity of a froft, from which it had not fufficiently defended itfelf in its winter retreat, which was a heap of fand at the bottom of the garden.. 
The tortoife lives on vegetables fometimes, fnails, or worms; is fond of fruits; and, when the foreft affords them, is generally found not far from where they grow. As it moves but nowly, is not very delicate in the choice of food. Thore kept in domelticity will eat any thing; leaves, fruits, corn, bran, or grafs.

Tortoifes are torpid like the bat, the ferpent, the mole, and the lizard; and when food is no longer in plenty, happily become infenfible to the want: is fometimes buried two or three feet in the ground, its hole furnithed with mofs, grafs, and other fubftances, as well to keep the retreat warm, as to ferve for food, in cale it hould prematurely awake. From this dormant ftate the tortoife is liberated by the genial return of lpring; not much wanted by its long confinement.

The eggs of tortoifes are furnithed with a yolk and a white; but the Thell is fomewhat like thofe foft eggs that hens exclude before their time;: yet much thicker and ftronger. The tortoife lays but few ; the turtle dezofits from an hundred and fifty, to two hundred, in a feafon. When it prepares to lay, the female fcratches a hole in the earth, generally in a warm fituation, where the beams of the fun have their full effect; there depofiting her eggs, and covering them with grafs and leaves, the forfakes them, to be hatched by the heat of the feafon. The young are generally excluded in about twenty-fix days; but this varies, as heat is more or lefs abundant. The little animals no fooner leave the egg, than they leek for provifion; their fhell, with which they are covered from the beginning, expands, and grows larger with age.

\section{A N D T O R T O I S E S.}

THE moft common is that called the GRECIAN: dwells in woods, and elevated lands. Is among the floweft of oviparous quadrupeds; refembles, in many refpects, the frefh-water tortoifes. Thofe on the mountains larger than thofe on the plains: about fourteen inches long, ten broad. A nittitating membrane to the eye; the under eye-lid only moveable; tail fhort; membraned feet; puts its feet very nowly to the ground, one toe (or rather nail) only at a time, till the whole PART V. No. 28. $\mathrm{B} \mathrm{b}$ touch 
touch the ground. Thirteen fcales compofe the centre of the upper ffell; the border has twenty-four, larger in proportion than ufual among tortoifes. The thell is greatly globated in form. Is more or lefs torpid, according to the feafon. Quit their retreats in fpring, when the fexes feek each other. Lay in June four or five eggs, white, like thofe of the pigeon, in a hole; the heat of the fun hatches them in September. Never frequent the water. Is found in mort temperate countries. Is good eating. In South-America dogs are trained to hunt tortoifes, and to bay them till the hunters arrive.

That whofe upper thell is very convex, and its fales alfo, each of its fcales being in a manner ftellated by yellow rays from its centre, where is a fix-fided fpot, yellow alfo, is a curious kind. There are feveral other kinds, of much the fame manners. One has its upper fhell, as it were, fagreened in the middle; fome are reddin; fome blackin; fome have a protuberance on the head, vermilion colour and yellow. Of the fmall kinds the eagles take advaniage, by carrying them great heights in the air; then letring them fall on the hard rocks, whereby their hells are broken, and the bird can feed on them.

\section{FRESH-WATER TORTOISES}

IFFE R from fea-turtles in having. fmaller feet; toes more apLarent, but membraned; five before, four behind; a tail half as
long as the body, and always extended when the creature is walking. Are found in' moft temperate countries in Europe, alfo in Afia, India, Japan, \&c. Cannot fupport rigorous cold; neeps even in temperate expofures; in a hole in the earth, which is often a month's work to make. Early in fpring changes this divelling for the water, where it is fond of fun-thine; in fummer is moftly on land, where the lays, placing her eggs in a hole, covered with fand. The young fcarcely exceed half an inch in length; at maturity, are eight or nine inches long; breadth three or four; they are long ere they reach this length. Feed on fnails, and infects without wings : are very deftructive of the fmaller fry of filh, and even bite the larger, till, weakened with lofs of blood, they become their prey. Often rejects the air-bladder of fin:; where many of thefe are feen fwimming, a tortoife may be fufpected of having taken up his abode. 
There are feveral kinds; among them, one whofe tail has a hooked kind of nail, refembling the fting of a fcorpion, which has given him his name.

Among the moft remarkable is the foft-fiselled tortoife; much the largeft of thofe inhabiting freth water. Inhabits Carolina; the upper thell brown, the middle of it hard, ftrong, and bony; but the fides, efpecially the hind part, cartilaginous, foft, pliant like tanned leather, eafily yielding to any form, yet thick and ftrong enough to protect the wearer : little rifings fcattered over the thell. The under fhell is projected, in front, two or three inches before the upper, fo that the animal might lay his head on it; foft and pliant here, but hard and bony behind. Head fmall; a nitlitating membrane to the eye; the noftrils placed in a kind of projecting fnout, foft, tenter, and fomewhat tranfparent. The feet ftrong and thick; five toes before; the three firt ftrong, fhort, and having hooked nails : beyond the fifth, two falfe toes; ferving to extend a large membrane, which unites them all. The fame conformation in the hind feet, but only one falle toe. This creature is Atrong, wild, and, when attacked, rifes on its hind-feet, and throws itfelf furioully on its enemy, biting violently. Is good eating.

\section{SEA TORTOISES, OR TURTLE.}

F all animals of the kind, the GREEN TURTLE is the moft noted, and the mon valuable. The delicacy, the falubrity, the nutritive qualities of its ferh, and its eafy digettion, were long known to our feamen, and to the inhabitants of the coafts where they are native. And this aliment is the more acceptable, as being found beneath the burning zone. Dampier, that rough feaman, who has added more to natural hiftory than talf the philofophers before him, appears to be the firf who informed us of their diftinctions; and that the green turtle was chielly. prized for its Aleph.

This animal is called green, from the colour of its fhell, and in fome the fleth. It is generally fix or leven feet long, three or four broad, three or four thick in the middle, weighing two or three hundred weight; though fome are from five to eight hundred, and others not above fifty. Do not acquire their entire dimenfions under twenty years. Its upper fhell is oval, furrounded by a border of feparate pieces; the largeft furtheft from the head; roundifh in part. The middle of the thell is com$\mathrm{B}$ b 2

pored 
pofed of fifteen pieces; of which fome or other are often falling off by accidents of various kinds; the number and form of thefe vary. The under Thell is horter than the upper, and fofter; compofed commonly of twenty-three or twenty-four pieces. Its feet are very long; the toes united by a membrane, and much more ufed for fwimming than for walking. In the hind feet, the firft toe only has a fharp and vifible nail: that of the fecond is lefs, and round; the three others very night. In the front feet, the two interior toes have tharp nails, and the three others night ones; the head, feet, and tail have fimall ficales like a filh; the mouth opens behind the ears; has no teeth, but jaws very hard and ftrong; and inftead of teeth, bony afperities : thefe are powerful enough to craunch fhell-itifh of any kind; which they eat frequently.

We are told by Laet, that on the Ine of Cuba they grow fo large, that five men can ftand on the back of one of them; and, what is more furprifing, that the animal will go off with them upon its back, with a flow fteady motion, towards the fea." They are found in great numbers on the Inand of Afcenfion.

Its chief food is the alga, a fubmarine plant, that covers the bottom of feveral parts of the fea not far from the fhore. There they are feen; when the weather is fair, feeding in great numbers, like flocks of theep, feveral fathoms deep upon the verdant carpet below. At other times they go to the mouths of rivers, and they feem to find gratification in frem-water and fiefl air. When done feeding, they generally float with their heads, above water, unlefs alarmed, when they fuddenly plunge to the bottom. They often feek provifion among the rocks, eating mofs and fea-weed; and probably infects and fmall animals, as they are very fond of Alefh when taken and fed for the table.

They couple in March; are during nine days almoft incapable of feparation. At breeding time, which varies on each fide the line, they take fometimes a voyage of eight or nine hundred miles to depofit their eggs on fome favourite thore. The coafts they always refort to are low flat, and fandy; for being heavy animals, they cannot climb a bold thore; nor is any bed fo proper as land to lay their eggs on. Here the female is feen toward fun-fet drawing near the fhore, and looking earneftly about her. If the perceives danger, feeks another place: if not the lands at dark, and furveys the fand, where the defigns to lay; then retires without laying; but the next night returns to depofit part of her burthen. She begins by working and digging in the fand with her fore-feet, till the has made fometimes feveral round holes, a foot broad, and two feet deep, juft 
juit above high-water-mark. She lays ninety or an hundred eggs at a me, as big as an hen's egg, and round as a ball. The white of thefe eggs is faid not to harden by heat, though the yolk does. She continues laying about an hour; during which time, nothing can difturb her. The eggs are covered with a tough white fkin, like wetted parch inent. When the has done laying, the covers the hole very lightly; but fo dexterounly that it is not an eafy matter to difcover it, and leaves her eggs to be hatched by the heat of the fun. At the end of fifteen days, in fome places; in others, three weeks, the lays about the fame number of eggs again; and again, at the end of another fifteen days, ufing the fame precautions every time. In about twenty-four or twenty-five days, the young turtles, being about two or three inches long, burft from the fand, as if earth-born, and crawl directly to the fea, inttinctively : but often, their ftrength being fmall, the furges beat them back on the thore; expofed a prey to thourands of birds, crocodiles, tigers, \&c. that then haunt the coafts. Fihermen alfo feize as many young as they can, to breed up in inclofed places free to falt water. Of the whole brood fcarce one in thirty lives to any fize. When the turtles have done laying, they return to their accuftomed places, weak, lean, and unfit to be eaten.

In thefe uninhabited inands, to which the green turtle chiefly reforts, the men that go to take them land about night-fall, and filently (for thefe animals, though without any external opening of the ear, hear very diftinctly, there being an auditory conduit that opens into the mouth), lie clofe while they fee the female turtle coming on fhore. They let her proceed to her greateft diftance from the fea; and, when the is bufily employed in fcratching a hole, they fally out and furprife her. Their manner is to turn her upon her back, which utterly incapacitates her from moving; and yet, as the creature is very ftrong, clafps the ground very faft, and ftruggles very hard, two men or more find it no eafy matter; then they go to the next; and thus, in lefs than three hours, they have been known to turn forty or fifty turtles, each weighing an hundred and fifty, or two hundred pounds. There are feveral other ways of taking them; one is, to feize them when coupled together; another is ftriking them by the harpoon, when on the furface of the water; or at the bottom; another is, by diving, coming up beneath, and feizing it by the tail; the animal awaking, ftruggles to get free, and by this both are kept afloat till the boat arrives to take them in. 
The TrunK TURTLE is commonly larger than the reft, and its back higher and rounder. The flefh of this is rank, and not wholefome.

The LOGGERHEAD is fo called from the fize of its head, which is much bigger in proportion than that of the other kinds. The fiefn of this is alfo very rank, oily, hard, and not eaten but in cafe of neceffity. Yields an oil ufeful to preferve thips from worms; its hind feet, as well as its front feet, have two harp nails among the toes; is bold, and even woracious; is faid to feize young crocodiles by the tail, when in narrow paffages, and bite it off. Eats filh, and cracks, the largeft thell-fifh; fights hard when attacked.

'The HawksBich is the leaft, and has a long and fmall mouth. 'The' fleth of this is often dangerous eating; but the fhell fupplies the tortoifethell, of which fuch variety of beautiful trinkets are made. The thells of other turtles are porous; but this is firm, and, when polined, is beautifully marbled. "They generally weigh three or four pounds; famerimes fix or eight pounds. The thell confifts commonly of thirceen leaves, or plates, placed like lates on the roofs of houfes, of which eight are flat, and five hollow; the border has twenty-five. They are raifed and taken off by means of fire made under the thell, after the flefh is taken out. As foon as the heat affects the leaves, they, ftart from the ribs, and are eafily raifed with the point of a knife. Being fcraped and por lithed on both fides, they become beautifully tranfparent; or eafily take any form, by making them foft and pliant in warm water, and then fcrewing them in a mould, like a medal: however, the fhell is moft beautiful before it undergoes this laft operation.

- Is found in Afia as well las. America; lays its eggs rather in gravel than fand; when turned on its back, can recoyer its feet.

The Great Mediterranean Turtee, which hiould rather be called the leather-coated turtle. from its covering, is from five to eight feet long, and from fix to nine hundred pounds weight; but is unfit for food, and fometimes poifonous. The fhell, which is a tough ftrong integument, refembling an hide, is unfitfor fervice. One of thefe, taken in 1729 , at the mouth of the Loire, was of enormous ftrength, and by its ftruggles involved in the nets; it appeared at firft terrible to the fifhermen; but finding it impotent, they dragged it on hore, where it made a molt: horrible bellowing; and, when they began to kill it with their gaffs, was to be heard at half a mile's diftance. They were ftill furthẹr intimidated by its naufeous and peftilential breath, which fo powerfully affected them, that they were'near fainting. This turtle wanted but four inches of eight 
feet long, two feet broad: its fhell refembles.leather, and it is faid it had teeth in each jaw, one rank behind another, like thofe of a Phark; its feet alfo wanted claws; the tail was quite difengaged from the fhell, fifteen inches long, more refembling that of a quadruped than a tortoife. $T$ wo or three have been taken on the coafts of Cornwall, in the year $175^{6}$, the largeft of which weighed eight hundred pounds.

One, molt probably of this kind, was caught about thirty years ago near Scarborough, and a good deal of company was invited to feaft upon it ; a gentleman, who was one of the guefts, told the company that it was a Mediterranean turtle, and not wholefome; but a perfon who was willing to fatisfy his appetite at the rifque of his life, eat of it : he was feized with 2 violent vomiting and purging; but his conftitution overpowered the malignity of the poifon.

\section{O F $\quad$ L I I Z A R D S.}

THIS tribe is the molt numerous of thofe which form the order of oviparous quadrupeds, exceeding fifty fpecies. They may eafily be diftinguifhed from others, by not having a fhell as tortoifes; yet having a tail, which frogs and toads have not: they are clothed with fcales, more or lefs ftrong, or tubercles, more or lefs prominent. "The forms and dimenfions of their tail vary greatly; in fome round, in others flat; in fome extremely long, in others very fhort. With refpeet to fize, no clafs has its ranks fo oppofite from the fmall Cameleon, an inch lorig, to the Alligator of the river Amazons, above twenty-feven feet. They are found of a hundred different hues, green, blue, red, chefnut, yellow, spotted, ftreaked, and marbled. The lizard would often pleafe by its colours; but there is fomething in the animal's figure, counteracting the brilliancy of its fcales, or the variety of its fpors, giving an air of exquifite venom, or great malignity., The figure of thefe animals is not lefs various: fometimes fwollen in the belly; fometimes at the throat; fometimes with a fet of fpines on the back; fometimes with teeth; fomerimes without; fome venomous, others harmlefs; or philanthropic: fome are viviparous, fome oviparous. Some bring forth fmall fpawn, like firhes. The larger kinds bring forth eggs, which are hatched by the heat of the fun. The falamanders come forth alive, perfeet and active; but thofe bred in water, and, as we fuppofe, from fpawn, fuffer PART V. No. 28. 
a very confiderable change in their form. They are produced with an external fkin or covering, that fometimes inclofes their feet, and gives them a ferpentine appearance: to this falfe $\mathrm{Akin}$ fins are added, above and below the tail, that ferve the animal for fwimming; but when the falfe fkin drops off, thefe drop alfo; and then the lizard, with its four feer, is completely formed, and forfakes the water.

They may be diftinguifhed into the larger ' $k$ ind, or crocodiles, \&c. with flatted tails; the GUANOs, which have fpines on their backs; the green or common lizard kind, whofe tails are round, and their bellies fcaly; then thofe which have fcaly feet; thofe which have only three fingers; and thofe with wings; after which, thofe properly known by the name of Salamanders.

All have many points of fimilitude, in figure and colour; the whole tribe is eafily diftinguifhed, and ftrongly marked. All have four Thort legs; tails almont as thick as the body at the beginning, and generally tapering. All are amphibious; and formed internally like the tortoife, \&c.

\section{THE C R O C O D I L E.}

TRUEE crocodiles have five fingers to their front feet, four to the hind foot, which is membraned, and nails only to the three interior toes of each foot. They have four glands, which furnith a ftrong murky fmell. To view this animal in all its terrors, of an enormous fize, in furprifing numbers, and committing unceafing devaftations, we muft explore the uninhabited regions of Africa and America, the banks of thofe immenfe rivers that roll through extenfive waftes, the midft of marfhy lakes, and drowned favannas, and among the banian trees of their fides; where arts have never penetrated, where force only makes diftinction, and the moft powerful exert their ftrength with moft confidence and fecurity. In the river Amazons, or the river Niger, they are found in hundreds, from eighteen to twenty-feven feet long, lying as clofe as a raft of timber upen one of our ftreams. They are here covered with mud, they indolently bafk on the furface, undifturbed at the approach of an enemy, fince, from repeated trials of their ftrength, they find none beyond their power to fubdue. 


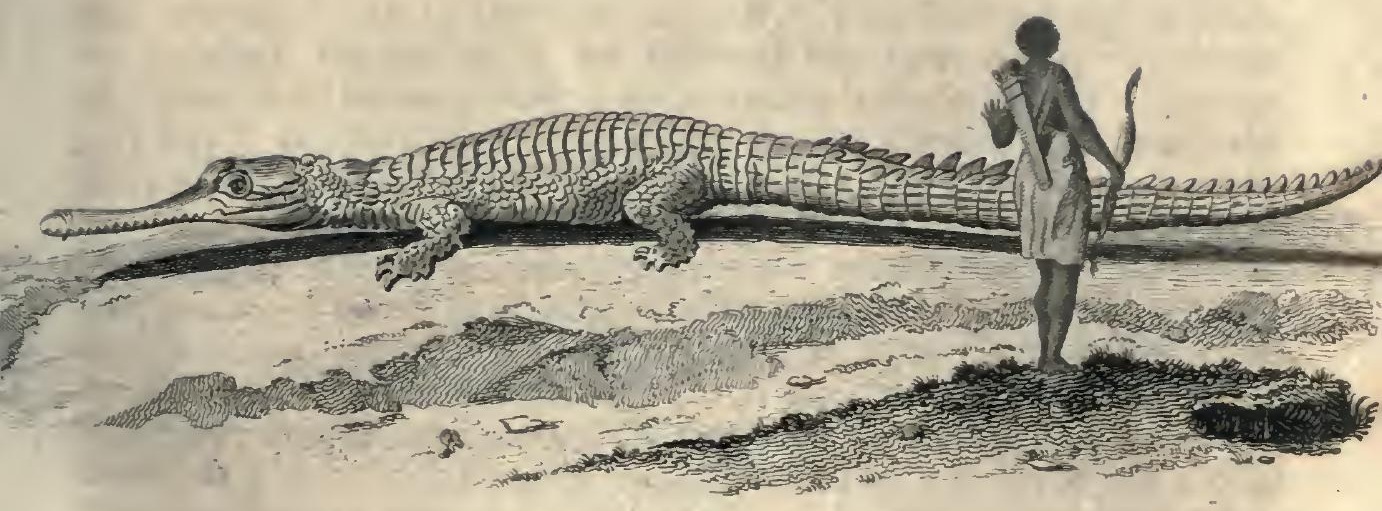

The Crocodile 


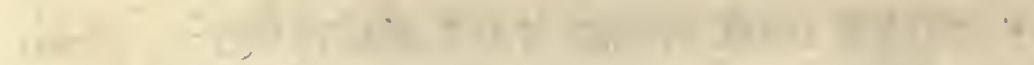

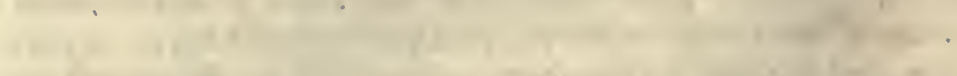

.

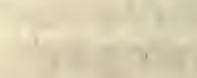

$+$

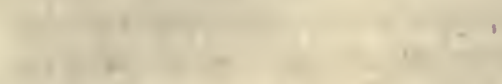

(

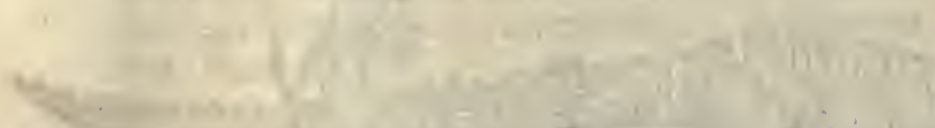

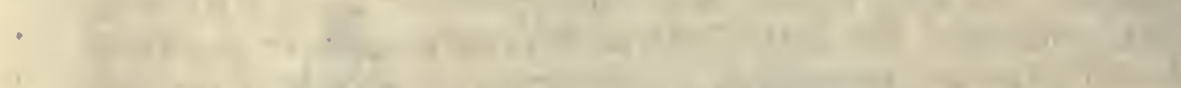

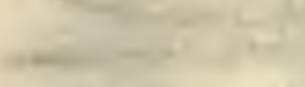

$+1$

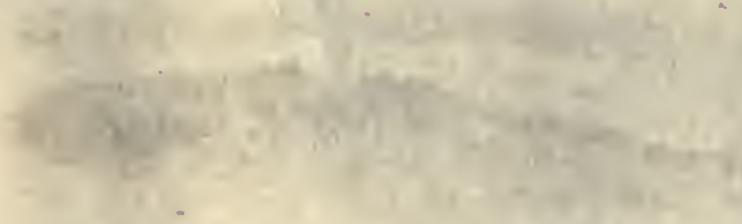

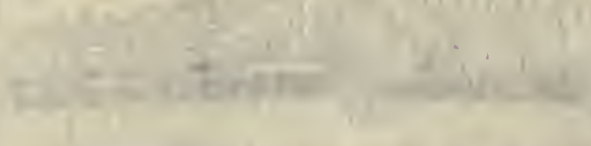

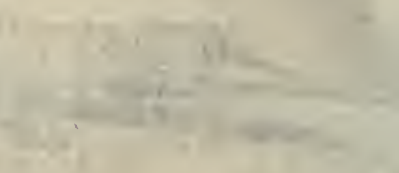

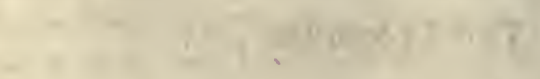

+ 
Of this terrible animal there are three kinds; the Green Crocodile, Cayman, or Alligator; for in figure and nature thefe are the fame: the Black Crocodile; and that of the Ganges.

This animal is fometimes found thirty feet long; its moft ufual length is eighteen or twenty. In one of this length, the tail exceeds five feet; the head and neck near three feet; the circumference five feet. The fore legs refemble the arms of a man, both within and without; have five fingers of a conical figure. The hinder.legs, including the thigh and paw, two feet two inches; the paws, from the joint to the extremity of the longeft claws, ten inches; of the four toes, three have large claws, the Iongeft two inches; thefe toes are united by a membrane, like thofe of a duck, but much thicker. The head is long, at the top a little rifing, the reft flat, efpecially towards the extremity of the jaws, covered by a fkin adhering firmly to the fkull and jaws. The fkull is rough and unequal; about the middle of the forehead two bony crefts, two inches high: the fkull between thefe is proof againt a mufquet ball. The eye very fmall, and fo placed in its orbit, that the outward part, when the lid is clofed, is only an inch long, running parallel to the opening of the jaws: has a double lid, one within and one without: that within, like the nictitating membrane of birds, folds in the great corner. of the eye, is tranfparent. The iris large in proportion to the eyes; yellowifh grey; the eyes fparkling, and near each other, placed obliquely. Above the eye is the ear, not unlike in form to a brow. The note is in the middle of the upper jaw, near its extremity, perfectly round and flat, two inchés in diameter, of a black, foft, fpongy fubftance, not unlike the nofe of a dog. The jaws feem to thut one within another; the under jaw only moves, and only with a ftraight down motion; twenty-feven cutting teeth in the upper jaw, fometimes thirty-fix; fifteen in the lower, fometimes thirty, with feveral void -fpaces between them: thick at the bottom, Sharp at the point, of different fizes, except ten large hooked ones, fix of which in the lower jaw, and four in the upper; the mouth fifteen inches long, nine in breadth, opens beyond the ears; could eafily take in the body of a man. The body a dark brown on the upper part, a whitih citron below, with large fpots of both colours on the fides. From the fhoulders to the tail a covering of large fcales, fquare, fifty-two in number; thofe near the tail not fo thick as the reft. The creature has all over it a coat of armuur; not every where proof againft a mufquet ball, efpecially under the belly. The gullet large. The tongue a thick, fpongy, foft flefh, Atrongly connected to the lower 


\section{2

jaw by a membrane which covers it, and which is pierced in feveral places. Sixty-two joints in the back-bone, which, though very clofely united, have fufficient play to enable the animal to bend like a bow to the right and the left.

The Atrength of every part of the crocodile is very great; the fpine is jointed in the firmelt manner; the mufcles of the legs are vigorous and ftrong; its teeth are fharp, numerous, and formidable; its claws long and tenacious; but its principal inftrument of deftruction is the tail : with a fingle blow of this it has often overturned a canoe, and feized on the poor favage, its conductor.

Such is this formidable animal, the terror of the moft navigable rivers, in fome places lying hours, and days, ftrerched in the fun, motionlefs; fo that one not ufed to them might miltake them for trunks of trees, covered with a rough and dry bark; but the miftake would foon be fatal, if not prevented; for the torpid animal, at the approach of any living thing, darts on it with inftant fwiftnefs, and drags it to the bottom. During inundations, they fometimes enter cottages, and feize the firt animal they meet with. There have been examples of their taking a man out of a canoe, in the fight of his companions, without the poffibility of affiftance.

The crocodile feldom, except when preffed by hunger, or intent on depofiting its eggs, leaves the water. Its ufual method is to float on the furface, its nofe above water, and feize whatever comes within its reach; if this method fails, it goes clofer to the bank, and there waits, covered among the fedges, in expectation of fome animal that comes to drink; it feizes the victim with a fpring, and bounds very faft for fo unwieldy an animal; then drags its prey into the water, and finks with it to the bottom. If the creature the crocodile has furprifed efcapes, the tyrant purfues with all its force, and often feizes it a fecond time, efpecially if the road be ftraight and level. Often the crocodile feizes a creature as formidable as itfelf, and meets with a molt defperate refitance. We are told of frequent combats between the crocodile and tigers; the inftant they are feized, they turn with the greateft agility, and force their claws into the crocodile's eyes, while he plunges with his fierce antagonitt into the river, There they continue to fruggle for fome time, till at laft the tiger is drowned.

We are affured by Labat, that a negro, with no other weapon than a knife in his right hand, and his left arm wrapped round with a cowhide, ventures boldly to attack this animal in its own element. As 
foon as he approaches the crocodile, he prefents his left arm, which the animal fwallows moft greedily; but fticking in its throat, the negro has time to give it feveral ftabs under the neck; the water alfo getting in at the mouth, which is held involuntarily open, the creature is foon bloared and expires. In Siam it is taken by throwing three or four ftrong nets acrofs a river. When firft taken, it employs the tail, which is the grand inftrument of ftrength, with great force; but after many unfuccefsful ftruggles, is at laft exhaufted; then the natives approach in boats, and pierce him in the tender parts till he is weakened with lofs of blood; then they tie up his mouth, faften his head to his tail, bending it like a bow, and tie his feet to the top of his back. Thus brought into fubjection, or bred up young, is ufed to entertain the great men of the Eatt; often managed like an horfe; a curb is put into its mouth, and the rider directs it at pleafure.

In Egypt, and other countries, where the inhabitants are civilized, and the rivers frequented, this animal is folitary and fearful. Far from attacking a man, it finks at his approach with precipitation. In fome places, inftead of being formidable, is not only inoffenfive, but cherifhed. In the river San Domingo, the crocodiles are quiet and gentle; the children play with them, and ride about on their backs; fometimes even heat them without receiving injury. The inhabitants are very careful of this breed, and confider them as harmlefs domeftics.

Crocodile's fleth is at beft very bad, tough eating; but unlefs the mufkbags be feparated, it is infupportable. The negroes themfelves cannot well digeft the flein: but a crocodile's egg is a moft delicate morfel to them.

Breeds near frefh waters. To depofit her brood, the female always pitches on an extenfive fandy thore, helving to the water, for the greater convenience of accefs, and near the edge of the ftream, that the young may have a thorter way to the water. The prefence of a man, a bealt, or a bird, deters her at that time; and the infallibly returns. If all is fafe, the begins by fcratching up the fand with her fore-paws, and making a hole pretty deep. There the depofits her eggs, of the fize of a tennis-ball, covered with a tough whice fkin like parchment. Lays twice or thrice, at fome days interval, from twenty to twenty-four eggs at each laying. Begins in April. She covers them clofe up in the fand, and they are vivified by the heat of the fun in about thirty days. The young crocodile is folded on itfelf in the egg; about fix or feven inches long. They quickly a vail themfelves of their liberty; and run to 
the water; where the whole brood is fcattered into different parts. By far the greateft number are deftroyed, not only by voracious fithes, but by old crocodiles preffed with hunger; the reft find fafety in their agility or minutenefs.

The eggs of this animal are eagerly fought by every beaft and bird of prey; including monkies, and feveral kinds of water-birds. The ichneumon was deified by the ancients for its fuccefs in deftroying thefe eggs. At prefent the vulture, called Gallinazo, is their moft prevailing enemy. Hiding in the thick branches of the trees, that thade the banks of the river, they watch the female in filence, and permit her to lay all her eggs without interruption: When the has retired, flocking all together on the hidden treafure, they tear up the eggs, and devour them in much lefs time than they were depofited.

Thofe between the tropics are lively the whole year; thofe diftant from them are more or lefs torpid in winter. The crocodile lives probably much above an hundred years, as it does not attain its full growth under thirty:

The Black Crocodile is found in the river of Senegal; its fnout is longer than the former; its manners and ferocity yet more favage.

The crocodile of the Ganges refembles the firft in colour; its jaws are very long and narrow, its teeth more numerous; its manners much the fame.

\section{T H E W H I P-T A I L}

T fo named, not from the refemblance of its tail to a whip in form, 1 but in motion; vibrating yery rapidly. This lizard inhabits the hot climates in America, particularly Peru : is often feveral feet in length; his tail is fomewhat dentelated on the fides, is flatted; its feet membraned, like the crocodile, but he has five toes to each foot. One of the ifland of Ceylon drives off invaders, by beating them violently with his tail, which he Thakes like a whip. 


\section{$1=$}




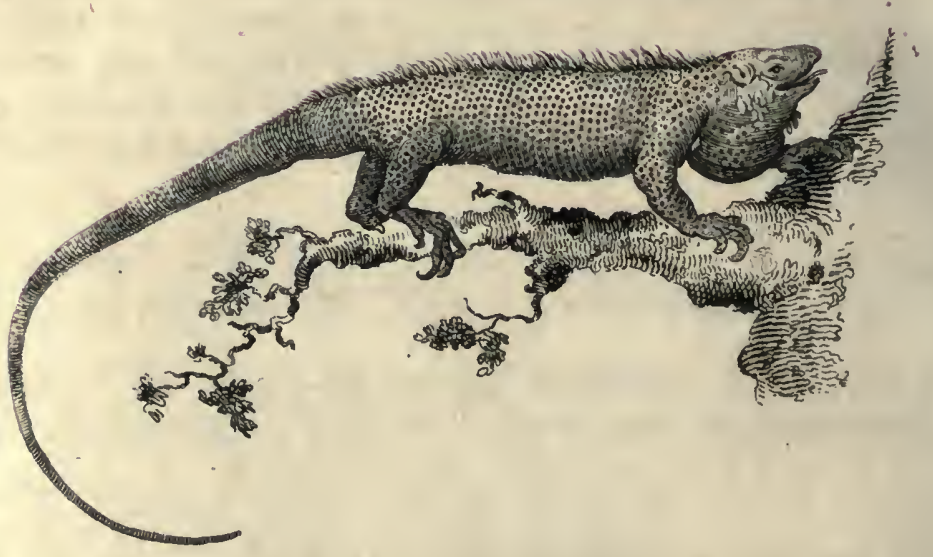

The Guano. 


\section{THE FORKED-TONGUED LIZARD}

TTA S often been miftaken for a young crocodile, or cayman, which 1 he greatly refembles in general, from having a large throat, tubercles on the back, and a fatted tail; colour deep rufty yellow, mingled with greenih; but he has five toes to each foot, and they are not membraned, but very much feparated from each other; each having allo a nail, tharp and crooked. His tongue being divided, and extremely mobile, gives him a refemblance to ferpents; in the rapid motions of his tail he refembles the whip-tail, by which name he has fometimes been called. Inhabits South-America. Is capable of climbing trees, by its toes being feparated; is fond of water, but frequents the woods, and there preys. Its Refh good to eat; and its eggs fought after.

\section{TH E I G U A N A.}

THE Iguana may be known at once by : a large protuberant tkin beneath his throat, and by a range of elevated fpines which runs down his back, and part of his throat, formed of very long and Tharp fcales, placed vertically; higheft on the back, and gradually diminifhing to the tail, which is round. The iguana is from five to feven feet long; the body about as thick as one's thigh : the Nin of the body, tail, and feet is covered with fmall fcales; thofe of the head extremely polithed and luftrous. The eyes are large, feem but half opened, except when the ani$\mathrm{mal}$ is angry; then they appear large and fparkling; the opening for the ear is large : both jaws are full of very tharp teeth; the bite is dangerous, though not venomous, for it never lets loofe till killed, or violently ftruck on the nofe. The male has a nkin hanging under his throat, which reaches down to his breaft; when difpleafed, he puffs it up like a bladder: he is one-third larger and ftronger than the female. The males are afhcoloured, or yellow, mingled with green, and the females are often a very beautiful green. The toes are feparated; five to each foot; nails Atrong and hooked. In the front feet, the interior toe has but one joint, the PART V. NO. 28. $\mathrm{D} d$ fecond 


\section{6-OVIPAROUS QUUADRUEEDS.}

fecond two; the third three, the fourth four, the fifth two: the fame in the hind foot; but the fifth toe has three.

The flem, efpecially of the females, is the greateft delicacy of Africa, America, or India; the fportfmen of thefe fultry climates go out to hunt the iguana, as we do the pheafant or hare, in the beginning of the feafon, when the great floods of the tropical climates are paft, and vegetation ftarts into univerfal verdure. - This animal is the moft' harmlefs creature of all the foreft, except when defending its female. About two months after the clofe of winter, the female quits the woods to lay her eggs on the fands of the fea-Phore, always an odd one, from thirteen to twenty-five; the Phell fupple, like thofe of the turtle; the contents whitifn, no glair; they are thought of exquifte relifh. It lives on vegetables and infects among the trees, or fports in the water, without offering to offend: there, having fed upon the flowers of the mabot, and the leaves of the mapou, that grow along the banks.of the ftream, it repofes on the branches that hâng over the water. Swims badly; its feet folded clofe to its body; its tail only moving, and driving it forward: But on land is fwift. When in polfeffion of a tree, feems confcious of fecurity, and never offers to fir. . There the fportfman finds it, and faftens his noofe round its neck; if the head be placed fo that the noofe cannot readily be faftened, by hitting the animal a blow on the nofe with a ftick, it lifts the head, and offers it in fome meafure to the noofe; or its attention is caught by whiftling, and it lifts up its head; as it will, if tickled by the noofe. May be domefticated; lives in the garden; is active during night; fees well in obfcurity, and eafily catches nocturnal infeets. In walking he often darts out his tongue; he lives eafy, and becomes familiar. Colours vary according to climate, age, and fex.

\section{THE B A S I L I S K}

T S very far removed from that imaginary creature, whofe fight was morI tal, and whofe fubitituary reprefentations are made by awkward and extraordinary contorfions of the. Spiny Ray; a fin which is no monfter, till made fuch by art. This lizard inhabits South America; has a very high 


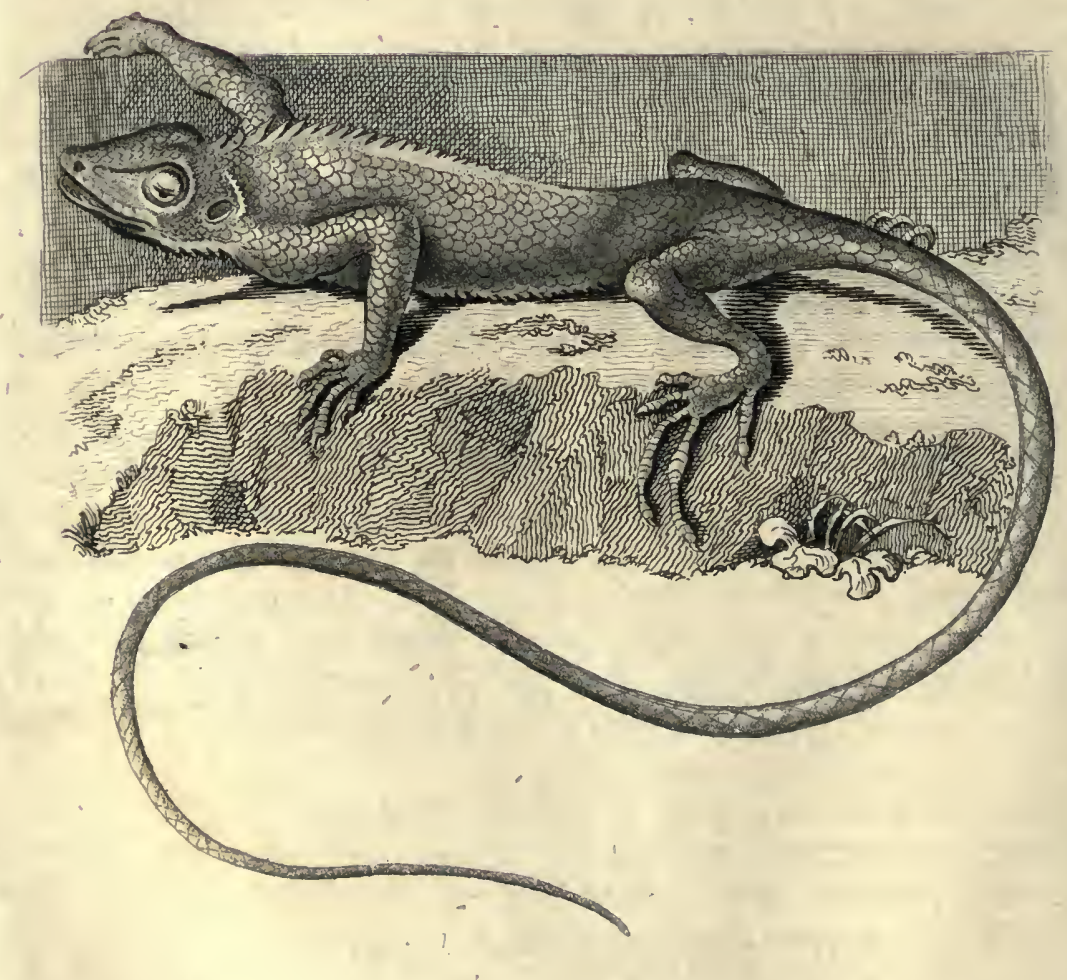

The Galeote. 


\section{THE G A.E E O T E, \&}

Yow of creft-like fcales down his back, in the form of rays, a little feparated from each other; he has alfo a kind of hood on his head; he lives among trees, climbing eafily; alfo by fwelling his hood with air, and puffing up his whole dimenfions, he becomes much lighter than before; leaps, and as it were flies from branch to branch; the fame extenfion of his parts he ufes when fwimming. When repoled, tempering his natural vivacity, he feems pleafed with being infpected; and gently agitates his creft 2 raifing and falling it; which, by the different reflections of his fcales, has a pretty effect. Often exceeds three feet long.

\section{T H E G A L E O T E}

T AS a creft from his head to the middle of his back, formed of 1 fcales, feparate, large, thin, and pointed: his head is flat, very broad behind; eyes large; opening for the ears'large; the throat a little fwelled; feet long, and toes alfo, which are widely feparated from each other. The tail is tapering, and three times as long as the body. Is but fmall. Some are azure on the back; whitifh on the belly. Found in Afra, the Ine of Ceylon, Arabia, and Spain. Lives in the houfes, on the roots; feeds on fpiders, and fome fay on young rats; and fights with finall ferpents, as do many other lizards.

\section{THE GREY LIZAR D}

T $S$ the gentlent, moft innocent, and moft ufeful of its kind; is the com1 moneft alfo. Its motions are lively, and its courfe rapid. Is fond of the heat of the fun; is not afraid of man, nor huns him, but looks at him: yet at the leaft noife is frighted, and difappears. Has five toes to each foot; his back is grey, with whitih fpots, and has three long Atreaks, of almoft black, running down it; his belly is greenifh changing to blue: his throat has a kind of collar, of feven gold-coloured fcales: belly is covered wih fcales, larger than thofe on the upper parts, forming crofs $\mathrm{Dd} 2$ bands, 
bands, five or fix inches long. Does not bite when taken, but foon becomes'familiar: was called by the ancients the Friend of Man. Its tail is very fragile; rearly twice as long as the body ; fpotted black and white; fometimes re-fboots a part mutilated. Feeds on infects, efpecially thofe which infert the garden or the field; to feize them, darts its tongue; which is large, forked, and has little afperities, fcarce fenfible, yet enough to hold its winged prey. Can live long without food; is torpid in cold weather. The female lays her eggs in the warmeft expofure; they are round, fcarce half an inch in diameter, are hatched by the warmth of the atmofphere. This lizard quits his $\mathrm{kin}$, after, his awaking from neep; and alfo before he enters on his torpid ftate.

\section{THE GREN LIZAR D}

- T $\mathrm{S}$ confidered by LinNeus as a variety of the grey, but is much larger, and more thewy in its colours, which appear in perfection when it has acquired its new covering in fpring. In the hot countries is fometimes thirty inches long; is of the fame gentle manners as the former.

\section{THE C A M E L E N}

S a very extraordinary animal; is from eleven to fourteen inches long: delights to fit on trees, being afraid of ferpents, from which it is unable to efcape on the ground; is very gentle and inoffenfive, but faid to, be always fearful or angry. This report is probably unfounded.

The head is flat at top; and on the fides: two rifings originate from the nofe, pafs immediately over the eyes, and unite behind the head; where they meet a third coming from its fummit, and two others coming from the chaps, The neck is fhort; the nottrils are at the end of the muzzle; the mouth is often fo clofely thut, that the feparation of the lips is fcarce difcernible. No opening is found for the ears; its hearing therefore very imperfect; has no teeth, but bony ridges; the lips divide beyond the jaws; the tongue refembles an earth-worm, five or 


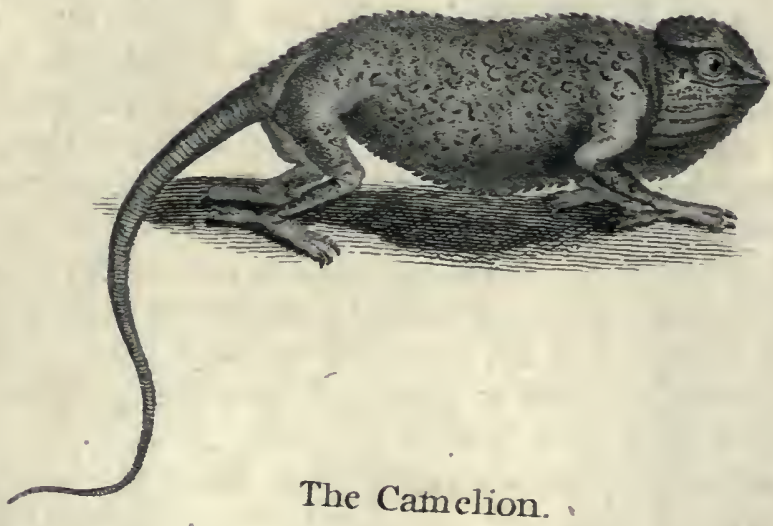



hix inches long, ending in a kind of a thick knot, hollow, attached to a kind of Spike, which enters. into its cavity, and which it flueatbs, when drawn on to it; it has a vifcous liquid on it, which holds flies and other infects, on which the cameleon feeds; this he darts rapidly. Can live long (almoft a year fay fome) without eating; he has no voice, but a kind of hifs when furprifed. The eyes ftand out of the head : they have a fingle eye-lid, fhagreened like the reft, attached to the eye, and following its motion, through a crevice in which the fight of the eye appears, which is of a fhining brown; and round it is a little circle of a gold colour ; the animal often moves one eye, when the other is at reft; fometimes one will look direclly forward, the other,backward; one upward, the other downward. Has five very long toes on each foot; nails ftrong and hooked; the fkin of the legs extends to the ends of the toes, and unites them together, yet fo that they are divided into two parcels, one of three toes: the other two in the front foot the exterior parcel has the two toes; in the hind foot the interior has the two toes. $\mathrm{He}$ is not fond of water; but by this conformation of his feet he eafily gripes fmall branches of trees; for his further fecurity, his tail is prehenfile, and ferves as a fifth hand. When he changes place, and attempts to defcend from an eminence, he moves with the utmoft precaution, advancing one leg very deliberately before the other, ftill fecuring himfelf, by holding whatever he can grafp with his tail.

The head of a large cameleon is' two inches long; from thence, to the beginning of the tail, four or five: the tail five inches, the feet two and a half : the body differs in thicknefs, at different times; fometimes, from the back to the belly, it is two inches, fometimes but one, for it can expand or contract itfelf at pleafure, not only throughout the back and belly, but alfo the legs and tail. The cameleon is often thus blown up for two hours together; then it becomes lefs and lefs, infenfibly; for the dilatation is aiways more quick and vifible than the contraction. In its contracted ftate, the animal appears extremely lean; the fpine of the back.feems frarp, and all the ribs may be counted; the tendons of thie legs and arms may be feen very diftinctly. This method of puffing itfelf up is fimilar to that in pigeons, whofe crops are fometimes greatly diftended with air. The cameleon has a power of driving the air it breathes from its lungs over every part of the body, tail and legs, between the $1 \mathrm{kin}$ and mufcles; the mufcles themielves are never fwoln. The $\mathrm{fkin}$ is very cold to the touch; and though the animal feems fo lean, there 
there is no feeling the beating of the heart. The $\mathrm{kin}$ is ftrewed with litule rifings, and has a grain not unlike thagreen, but very foft, bécaufe each eminence is as fmooth as if it were polifhed. Some of thefe little protuberances are as large as a pin's head, on the arris, legs, belly, and tail; but on the Thoulders and head they are of an oval tigure, and a little larger; thofe under the throat are ranged in the form of a chaplet, from the lower lip to the breaft. The colour of all thefe eminences, when the cameleon is at reft in a thady place, is of a bluein grey, and the fpace between is of a pale red and yellow.

But when the animal is removed into the fun, the whole furface of the $\mathrm{fkin}$ foon feems to imbibe the rays of light; and its fimple colouring changes into a variety of beautiful hues. Wherever the light comes on the body it is of a tawny brown; but that part of the lkin on which the fun does not thine changes into feveral brighter colours, pale yellow, or vivid crimfon, which form fpots of the fize of half one's finger: fome of thefe defcend from the fpine half way down the back; and others appear on the fides, arms and tail. When the fun is withdrawn, or in the fhade, the original grey colour returns by degrees, and covers all the body. Sometimes the animal becomes all over fpotted with brown fpots of a greenilh caft. When it is wrapped up in a white linen cloth for two or three minutes, the natural colour becomes much lighter; but not quite white, as fome authors have pretended. The caufe of thefe fpots is by fome thought to befear, or heat, agitating its humours; for in the cold they are lefs vivid, and when dead very pale : others think the animal fubject to a kind of jaundice, and thefe are effected by its bile.

Le Bruyn, during his Aay at Smyrna, bought feveral, and kept four in a cage, permitting them at times to run abour the houfe. The freth fea: breeze feemed to give them moft fpirits and vivacity; they opened their mouths to take it in; he never perceived that they eat any thing, except now'and then a ly, which they took half an hour to fwallow; he obferved their colour often to change, three or four times fuccellively, without being able to find out any caufe for fuch alterations; their common colour he'found to be grey, or rather a pale moufe-colour; but its inn?t: frequent changes were into a beautiful green, fpotted wilh yellow: fometimes the animal was marked over with dark brown; and this often changed into a lighter brown. Some colours, however, it never affunes; but moftly affects thofe neceffary to its prefervation; fuch as the 

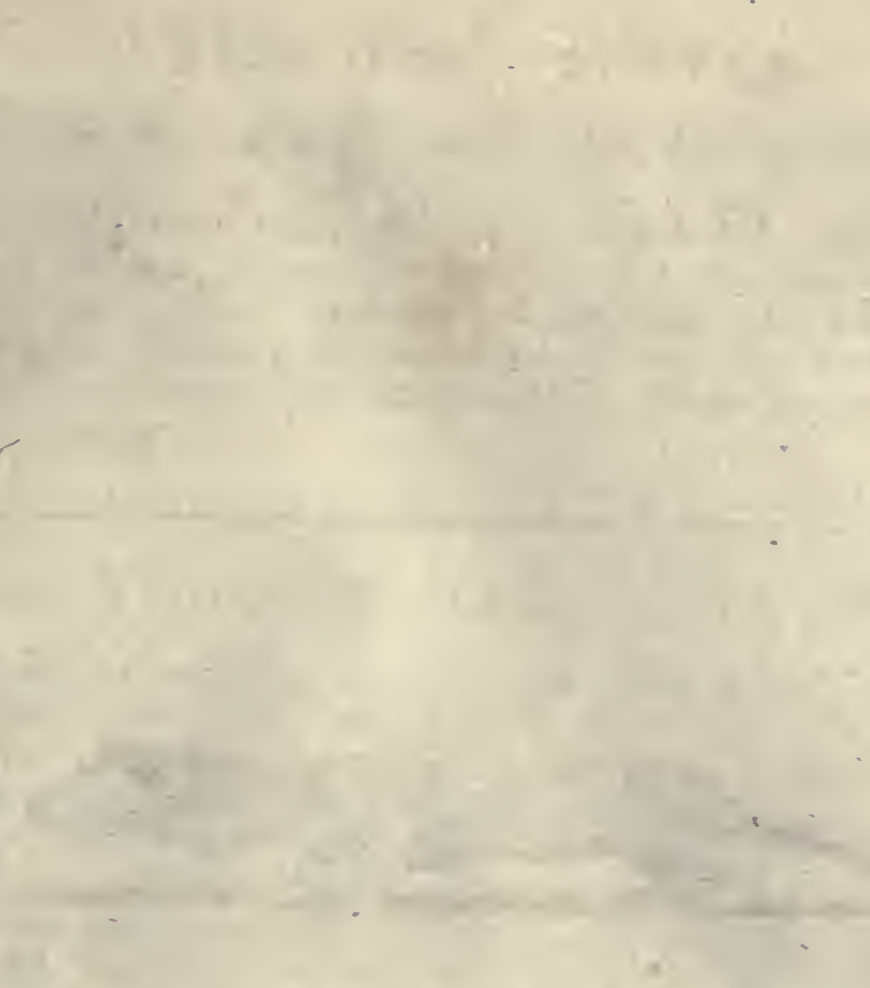

\section{$+2+3 \quad$ nit}
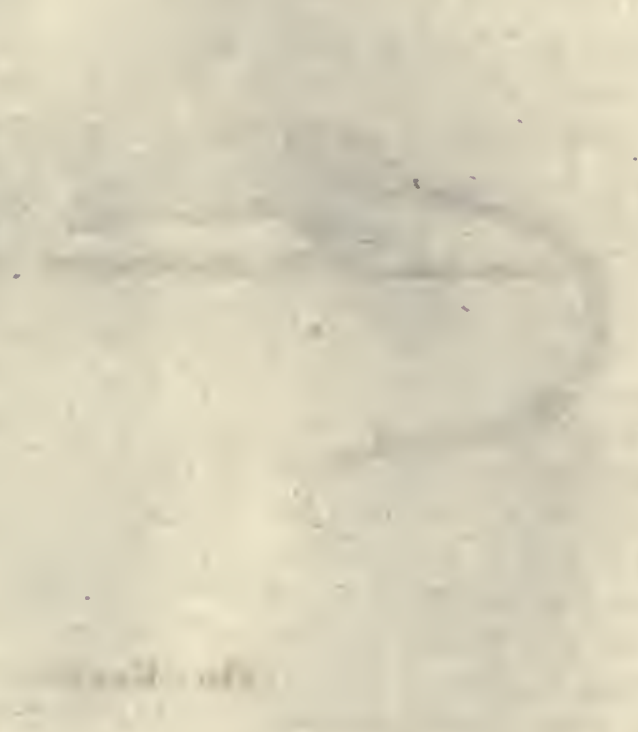

, 


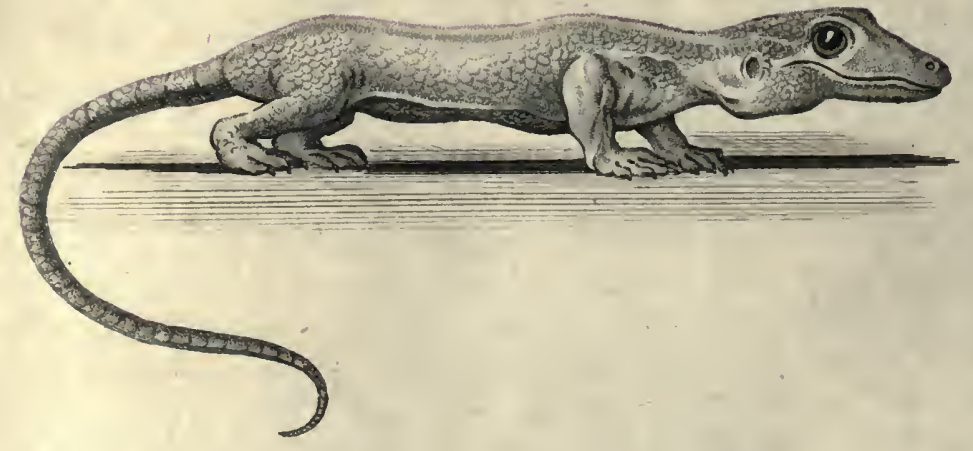

The Gecko. 
green of trees, their bark, \&c. where it lies concealed by its clofe fimilarity.

Lays nine to twelve eggs, oval and of fupple Thell. Inhabits all hot countries, Mexico, Africa, Ceylon, \&c. On the banks of the Se. negal, and the Gambia, is the object of veneration: the Negroes do not kill them; but when they are dead they eat them. There are foine fmall variations (principally on the head) among them; but in general the race is pretty uniforin:

\section{THE WOOD SLAVER, OR SPUTATOR,}

TS a lizard of two inches long, of which the tail is half; whitifh under the belly, grey on the body : Atriped croffwife with deep brown; four bands of this deep colour crofs the thead and back; another fmaller borders the upper $\mathrm{j}$ xw; fix others form fo many rings round the tail. There is no apparent opening for the ears: the tongue is broad, flat, and a little divided at the extremity: 'black fpots on the fummit of the head, and the muzzle; the feet are varied with grey, black, and white; five toes to each foot; Tcaly beneath, terminating in a kind of ball or fcaly onell, without any fentible nail. Inhabits the hot countries of America, in houfes, and carpenters'yards; hurts nobody, if not difturbed; bur muft be infpected with caution, as he is eafily irritated. He runs along the walls, and if frightened he gets as near as he can to his eneiny, and ejects againt him a kind of black fpittle, fo venomous, that a drop of it fwells the part on which it falls; the fwelling is cured by camphorated fpirit of wine or brandy, which is ured in America againt the ftirg of fcorpions; this fpittle may be feen gathering in the corners of the creature's mouth fometirnes, when he is angry. Seldom quits his hole but by day.

\section{$\mathrm{T} H \mathrm{E} \quad \mathrm{G}, \mathrm{E} C \mathrm{~K}$ O}

T $S$ among the moft extraordinary animals, by the general diffurion of its 1. venom. In form, has anight refemblance to the cameleon; his head PART V. NO. 28: E 
almoft triangular; is large in proportion to his body; his eyes large, tongue Hat, covered with fmall fcales, and the top indented; teeth fharp, and fo ftrong, fays Bontius, that they make imprefions on the hardeft fubftances, even fteel. This animal is entirely covered with little warts, more or lefs rifing; beneath the thighs is a row of tubercles, elevated and hollow : the feet are remarkable by oval fcales, 'more or lefs indented in the middle, as large as the furface of the toes, regularly difpofed one over another, like the 'nates upon houfes': has nails to all' its toes except the firft. The tail longer than the body, covered with rows of "fcaly rings. General colour clear green, fpotted with fcarlet; his name imitiates his cry, efpecially when rain is expected. Found in Egypt, $\mathrm{In}$ dia, Amboyna, the Molucca Ines. Hides in half rotten trees, and humid places; fometimes vifits houres, where he fpreads general confternation, and is quickly deftroyed. Bontius afferts, his bite is fo venomous, that unlels the part wounded be cut off, or burnt, it is mortal in a few hours. The touch of his feet is very dangerous, and is faid by fome to poifon provifions on which he walks. Some think this proceeds from his urine, which is very corrofive; others, that it is a fweat proceeding from the bollow tubercles beneath his thighs; his blood, and a kind of foam which ftarts from his mouth, when angry, are confidered as mortal venoms, and furnifh the inhabitants of Java a poifon for their arrows. HASSELCUIST affirms, that the feet dépofit a poifon; that the creature is fond of fubftances impregnated with falt, and, by walking over them, leaves behind him a dangerous poifon. He faw at Cairo three women nearly killed, by having eaten cheefe lately falted, on which the Gecko, had depofited his poifon. He faw alfo one of thefe lizards run over the hands of a man who endeavoured to take him: where he had trodden, was covered with little puttules, rednefs, heat, and fome pain, like nettleftings: It may be that this quality varies according to climate, feafon, \&c. In the night this lizard croaks fomewhat like a frog, which difcovers his approach. After rain, lie comes out of his retreat; walks nowly; eats ants and worms. The female lays oval eggs; covers them fomewhat with earth, and the fun hatches them. - Is fuppofed to be the Tockaie of Siam. Exceeds a foot in length.

There are one or two other lizards not unlike this in form; but whether in manners alfo, accounts have not determined. 


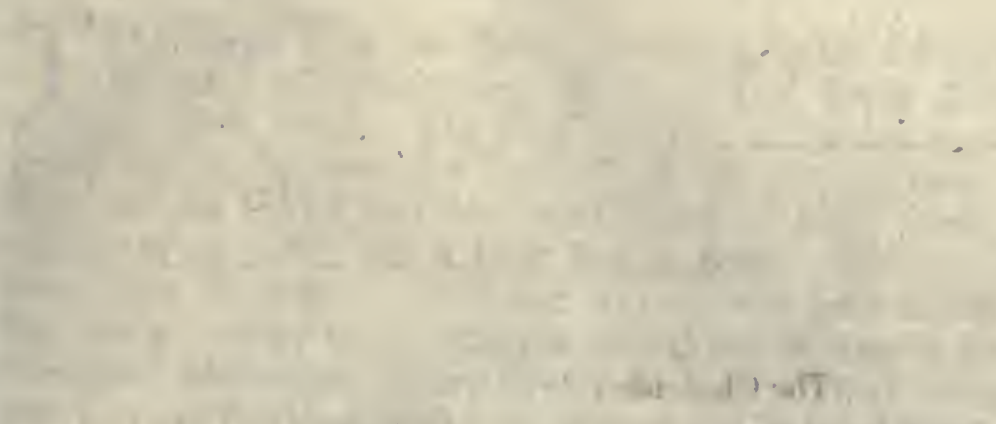

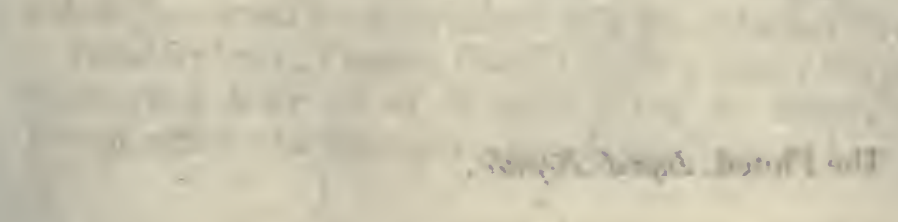

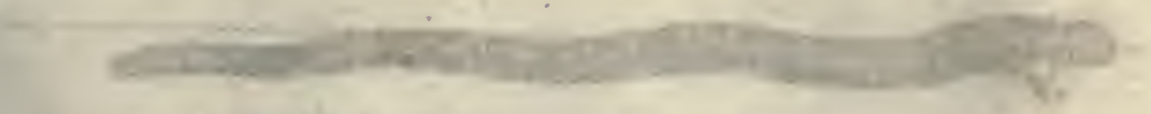

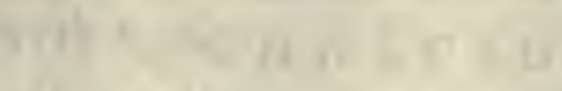

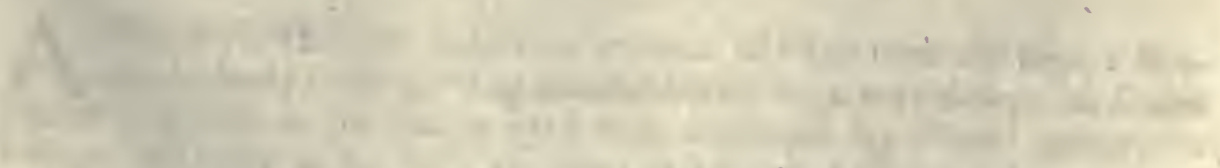
14

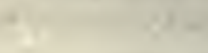

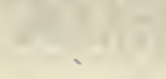

$$
\text { Fin }
$$


The Chalcide.

\author{
The Fluted. Biped-Reptile.
}




\section{$(163)$}

\section{$\therefore \mathrm{T} H \mathrm{E} \sim \mathrm{S} \mathrm{E} \mathrm{P}$.}

THE Seps mut be clofely examined, to be diftinguifhed from a ferpent; as the opening for its ears is fcarce diffoverable, nor its legs. Eyes finall. The Seps feems to make one in that particular group which feparates the lizard from the ferpent race. It has four legs, like the lizard, but very fhort, under an inch, fometimes fcarce a quarter of an inch; and a long nender body, which it rolls round on itfelf, like the ferpent. The fore legs are very near the head; the hind legs are placed far backward; the animal moves them brikly, and perhaps with advantage. They have three toes. Thefe animals are found two or three feet long, with a large head and pointed fnout. The whole body is covered with quadrangular fcales; and the belly is white mixed with blue. It has four crooked teeth; alfo a very tharp pointed tail, which, however, inflicts no wound. On the back, two ftreaks of a lighter colour, bordered on each fide with a thin blacker ftreak.

Inhabits Italy, France, \&cc. It is viviparous; fifteen young ones having been taken alive out of its belly. On the whole, it appears to bear a ftrong affinity to the viper; and fome think its bite may be dangerous.

\section{TH E C H A L C I D}

A PPROACHES yet nearer to ferpents in form than the Seps: lonA ger in body; no opening for the ears; legs very thort; its fcales placed ring-wife on its body; each ring feparated by a little gutter, as well on the body as the tail; the head refembles the Seps; three toes to each foot; inhabits hot countries; might have been thought the imme-; diate link that unites the lizard to the ferpent clafs, had nor fomo biped reptiles been difcovered, whofe peculiar forms arc yet more ferpentine, from that circumitance. 


\section{$\left(\begin{array}{l}564 \\ 6_{4}\end{array}\right.$}

\section{$T H E \subset D A G O N$.}

TTHE Dragon of imagination is a moft terrible animal, but not that; of nature; like what we have feen of the Bafilink, fancy has been equally remoie from fact as from probability.

The Dragon or Flying Lizard lives on fruit-trees, and feeds on flies, ants, butterflies, and other fmall infects. Is a very harmlefs creature, and does no mifchief in any refpect. Its wings are compofed" of fix cartilaginous rays, placed horizontally on each fide the back, and near the fore legs; 'thefé bend backward, and fuftain a membrane, which furrounds the firft ray, and extends to the hind legs; each wing reprefents, a triangle, irs bafe attached to the back of the creature; this membrane, as alfo the body, is covered with fcales, hardly perceptible, except under the wings; thefe wings refemble thofe of the fiving fifh, or thofe of flying fquirrels. Alsowt the neck are three bags, which he can inflate at pleafure; his thruat is wite; he has many and harp teeth; on the back three rows of tubercles, ranging lengthways; legs long; five toes to each foot; long, leparate, and having hooked nails; tail very thin; twice as long as the body, and fcaly; whole length a foot. When he fkims from one tree to another, he ftrikes the air audibly, with his wings, and fometimes leaps thirty fert.

- Inhabits Afra, Africa, and America; has an agreeable mixture of colours, black, brown, and blue, in fpots or Atreaks, varying with climate, \&zc. He fwims well; his wings and inflated watcles rendering him very buoyant,

\section{T H E SALA M N D ER.}

T.HE ancients have defcribed a lizard bred from heat, living in flames, and feeding on fire. Marvellous imagination has here furpaffed itfelf; or certain ill-obferved circumftances have been magnified and multiplied, till, the bounds of truth being paffed, no limits were fet to roving fuggettion. 


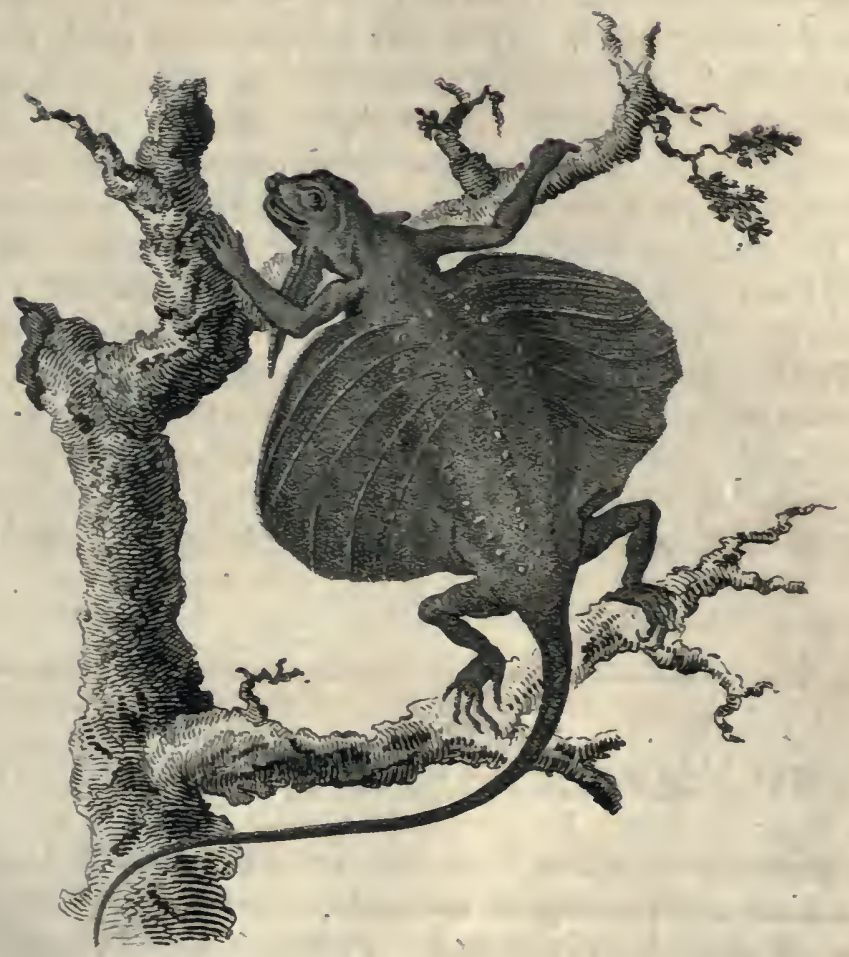

The Dragon 


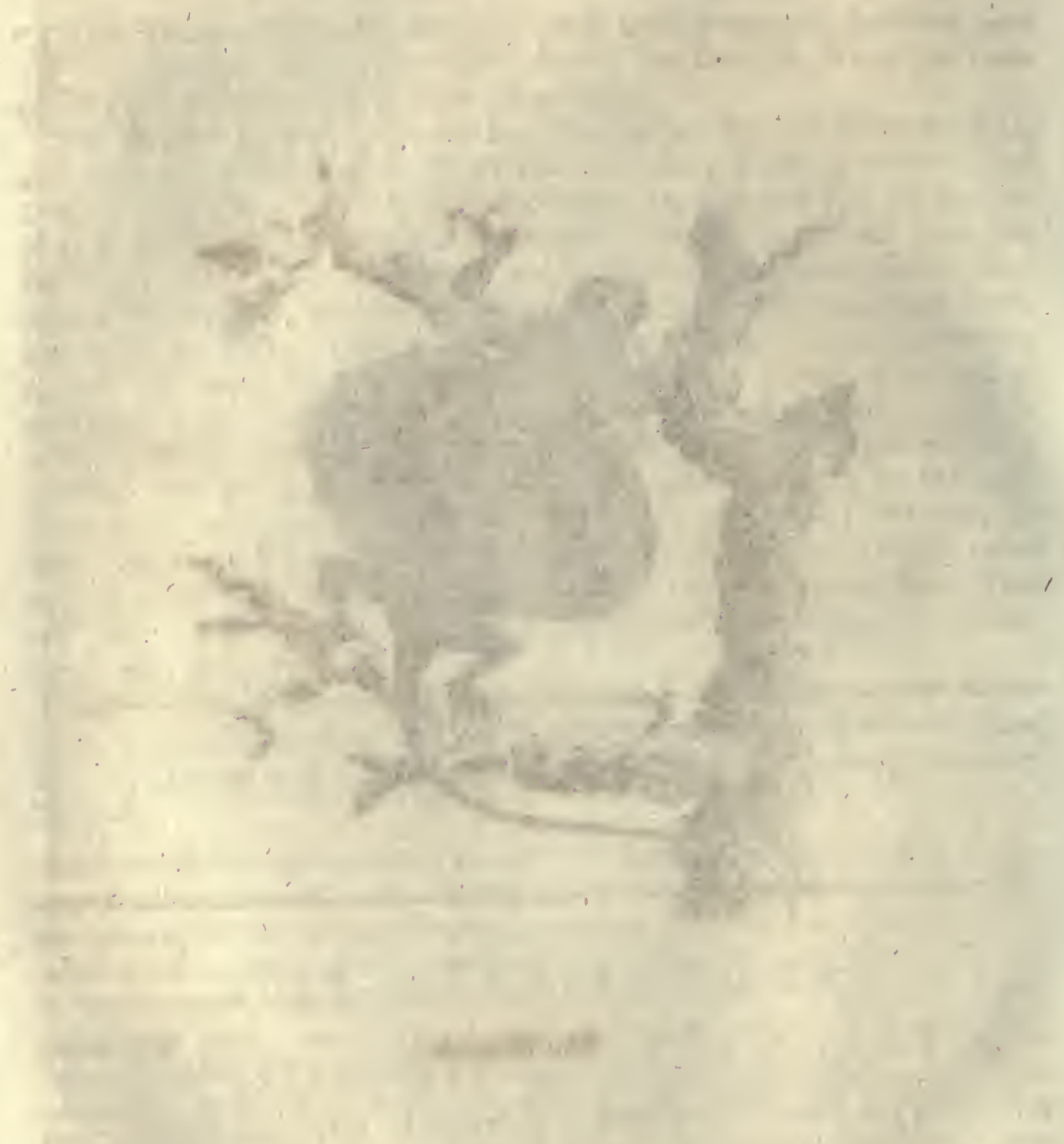




\section{FLAT-TAILED SALAMANDER.}

The terreftrial Salamander is of the lizard kind. This name comprehends a large tribe. This lizard has been but imperfectly known, becaufe he is rarely feen out of his hole: has four toes before, five behind; length feven inches or upwards. No fcales on his fkin, but a great number of little orifices, which difcharge a vifcous liquid that fpreads over the $\mathrm{kin}$, and varnißes the whole animal. The head is fomewhat flat ; the eyes on its upper part prominent, as alfo interiorly in the palate, where they are furrounded by a row of very fmall teeth, like thofe of the jaws. Colour deep; blueinh on the belly; broad yellow fpots on the body, feet, and evelids. In the woods of Germany, fome black above, yellow below. Has no ribs (like frogs). When touched, inftantly bedews itfelf with the unctuous liquor mentioned, and can as rapidly become dry. This liquor is very acrid. Loves humid and cool fpots, thick thades and woods, or hollow trees : paffes winter, many together, in holes under ground. Walks very flowly on the ground; does not climb trees: is very retired; fears the heat of the fun, and quits its afylum only in rainy weather. Lives on flies, beetles, and other infects. Is offen folded on itfelf like ferpents; can remain fome time in water, where it quits its kin; always endeavours to keep its nofe above water. Has no apparent orifices for the ears; is filent. Defends itfelf only by its covering liquid, and feems infenfible of danger. Is viviparous, brings forty to fifty young.

\section{THE FLAT-TAILED. SAI AMANDER}

TS capable of living on land as well as in water; but prefers the latter element for his refidence. Has no fenfible fcales on his body, or nails on his toes; four toes before. Length fix or feven inches. Head flat; tongue broad and fhort; Rkin hard, and Theds a kind of milk, when wounded: fmall whitifh warts on the body. General colour more or lefs brown, lightening under the belly to a yellow. Is? fpotted, often round, deep-coloured brown in the male; fometimes bluein. The male has a kind of creft running down his back, membranous, and jagged : the tail has a membrane vertically, which makes the tail feem flat: the fame nearly occurs in the female; but the has no creft on the back. 
Loves gravelly water, where it hides under the ftones, in ditches, and marhes, or ponds; rarely in running ftreams. In winter, retires commonly into fubterranean humid places; walks very nowly on land; fometimes, when it comes to breathe at the water edge, has a little kind of whiltle; is very tenacious of life; has been found in the midit of ice, fometimes frozen up, and recovered when the ice was thawed, which in ice-houfes has been a long time after its congelation. Eats flies, water-inlects, frog fpawn, \&c. alfo water-beans, which float on the ponds. Is not viviparous; but in April or May lays eggs, often twenty, which form two flings, and are united by vifcous matter, which alfo envelopes them fingly. When laid, they fall to the bottom of the water ; as they enlarge, through the vifcous jelly, and the tranfparent membrane which it inclofes, is feen the young falamander folded in the liquor which this membrane contains. This embryo enlarges infenfibly, and quickly moves with great agility: after eight or ten days he tears the membrane, and gains his liberty. In this tate he has fome conformity to fines; while his legs are very thort, he has on each fide, and a little above his fore legs, little fringed tufts, which refemble fins, or a feather : they are analogous to the gills of filh, and perhaps ferve for the fame purpofe, to filtrate the air contained in the vater; thefe gradually diminifh, and difappear, adhering to the fkin.

In fummer the aquatic Salamander quits his Rin every four or five days; in more temperate weather after a longer interval. A day or two before this change, the animal is more liftlefs than ordinary, nor regards worms or infects, his favourite prey. His $\mathrm{kin}$ is detached from his body in feveral places; and its colour fades: he ufes his front feet to loofen and open his tkin about his jaws, this he pufhes over his head, till his fore leys are free; he continues to purn this loofened fkin off from him, as far as his fore-legs can reach; but he is obliged to rub againt the ftones, gravel, \&cy. to further his endeavours. After a while, the front part of the fkin is turned on his back and tail; when feizing it with his mouth, and difengaging one hind 'foot after the other, he gets free from his late covering. Thus the old fkin is turned inflde outwards; but is not torn in any place: the fpace for the eyes is left void and open. After this operation, which engages an hour and a half, the animal appears in his full vigour, and his new fkin is fmooth and brilliart. The caft $\mathrm{R}$ in is found floating on ponds, \&c. Even in winter, this animal often forms more than one new fkin; for in temperate winters he is not torpid. 



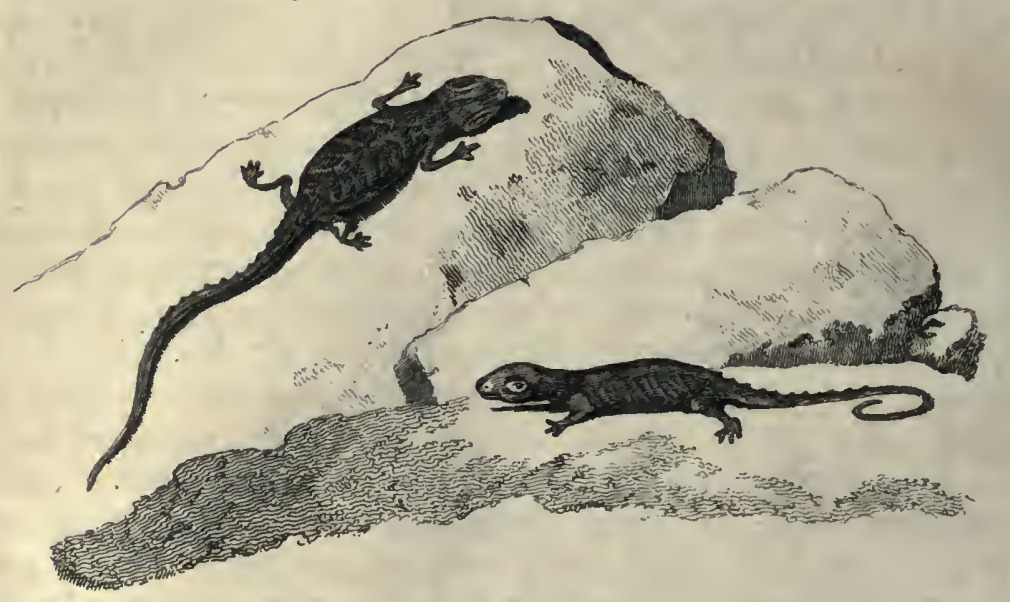

The three-fingered Salamander. 
Sometimes the back part of this nin adheres too clofely to yield to the creature's efforts; then it corrupts, and corrupts alfo the leg adjacent, which drops off; but this lofs does not kill the animal. Salt is fatal to falamanders. Are not venomous. Inhabit moft parts of the world.

\section{THE THREE-FINGERED SALAMANDER}

T $S$ an inftance, that, though imagination may have greatly augmented and difguifed fome obfervations and facts of Natural Hiftory, yet at the bottom may be truth; and could we ftrip off fallacy, or could we diftinguifh addition from fact, many relations, which are now ridiculous and falfe, might be admitted, under certain limitations. That the falamander is the creature of fire, is falie; yet, the only one known of this fpecies was found on the crater of Vefuvius, furrounded by the burning lava of that volcano. What further authority does poetic licence require to regard this lizard as incombuttible?

This falamander has ribs; three toes before, four behind; head flat, rounded in front; tail thin, longer than the body. Colour deep brown, mingled with reddith on the head and belly. Nothing of its natural habits known, this being a folitary fpecimen: perhaps as many lizards, \&c. are fond of the heat in the torrid zone, this might have ftrayed to where it was found, without fuffering a heat greater than many others of its fpecies elfewhere enjoyed.

\section{OVIPAROUS QUADRUPEDS WITHOUT TAILS,}

$7 \mathrm{HE}$ abfence of the tail is in thefe a ftriking and permanent 1 diftinction; they are alfo but fmall in fize, eight or ten inches being the largeft. They have no fcales on their body; their $\mathrm{kin}$ is full of warts, or tubercles, and bedewed with a vifcous.liquid. Moft have only four toes before; fome, inftead of five behind, have fix, more or PART V. No, 28 . 
lefs marked; in fome diftinct, in others membraned. The hind legs much longer than the front; whence they do not walk, but leap: the tarjus almoft always as long as the legs. They have no ribs, nor vertebræ in the neck, or at mont one or two; their head being attached immediately to the body, like that of a filh. The young appear long under the tadpole form.

They may be divided into three kinds: I. Thofe with long bodies and heads, thin bellies, and very long legs. 2. Thofe whofe toes have a fmall vifcous ball, by means of which they fix themfelves even on the under furface of the molt polined bodies. 3. Thofe with round bodies and heads, very fhort fore legs, hind legs not long; leap with difficulty; fear the light, and appear only in an evening; their eyes being formed fimilar to thofe of owls, \&c.

\section{T H E $\mathrm{H}$ R $\mathrm{O}$ G.}

THE figure of the Frog is well known. Its power of taking large leaps is remarkably great. It is the beft fwimmer of all four-footed animals; Nature hath finely adapted its parts for thofe ends, the arms being light and active, the legs and thighs long, and furnifhed with very ftrong mufcles : muzzle ends in a point; large eyes, lively, encircled with gold colour; ears behind the eyes, covered with a membrane: noftrils near the end of the muzzle: large mouth; no teeth; tubercles, and afperities on the back. Colour, more or lefs bordering on green, in fome kinds. Four toes before; five behind, thefe membraned. The inner toe in all the feet feparated from the others, and largeft. A vifcous humour fweats through the pores of its fkin. Very little brain for its fize; a very wide fwallow; a ftomach feemingly fmall, but capable of great diftention. The heart has but one ventricle; fo that the blood circulates without affiftance from the lungs, while under water. The blood. moves very nowly, and unequaliy, drop by drop. While young, they open and fhut their mouth and eyes, every time the heart beats. The lungs refemble a number of fmall bladders joined together, like the cells of a honey-comb: are connected to the back by mufcles, and can be diftended or exhaufted at the animal's pleafure. 


\section{$\begin{array}{lllllll}T & H & E & F & R & O & G .\end{array}$}

The common Brown Frog couples early,-generally about the middle of March. The male is ufually greyinh brown; the female inclining to yellow, fpeckled with brown. At this time their colours are nearly alike on the back; but as they change their fkins almoft every eighth day (the old one, after falling off, affuming the form of mucus), the male grows yellower, and the female browner. In the males the arms and legs are much the ftrongett; at this tirne they have on their thumbs a kind of flefhy excrefcence, which they fix firmly to the breatt of the female. Couple once a year: continue uniced days together. Their bellies greatly fwollen; the female with eggs, the male with a limpid water. He throws his fore legs round her breaft, and clafps his fingers between each other; the thumbs preffing with their thickeft fides againft her breaft: nothing can induce him to let go his hold: the grafp feems involuntary and convulfive; they fwim and creep together till the female has fhed her eggs : thefe form a kind of cord, united by a glutinous matter which covers them: thefe the male impregnates as they are ejected.

A fingle female produces from fix to eleven hundred eggs; in general by a fingle effort, though fometimes the is an hour in this tank. While thus engaged, the male promotes their expulfion by working with his thumbs, and compreffing her body clolely. The eggs, when excluded, expand into a round form, and drop to the bottom of the water.

The egg, or little globe, black on one fide, whitifh on the other, which produces a tadpole, is furrounced with two different kinds of liquor, each inclofed in its proper membrane. That which immediately furrounds the globe is clear and tranfparent; that which furrounds the whole is muddy and mucous. The tranfparent liquor ferves for nourifhment to the tadpole from time to time, anfwering the fame purpofes as the white of the egg to birds. The tadpoles, when this membrane is broken, are found to adhere to it by their umbilical cord, which is attached to the head.

At the bottom of the water the white quickly and fenfibly increafes. After four hours the eggs begin to enlarge; and, growing lighter, moune to the furface of the water. After eight hours the whice grows thicker, the eggs lofe their blacknefs, and, as they increafe in fize, fomewhat of their fpherical form. After fifteen days the eyes appear (fometimes finut), and the lineaments of the hind legs. As the fotus increafes in fizé, the fkin lengthens: where the toes will be, is marked by little knobs; and F f 2

though 
though no bone is yet formed, the thape of the foot is difcoverable. The front legs remain hidden by the covering $\mathrm{kin}$. The mouth of the tadpole is under the head; fo that, like the fhark, it muft turn on its back to catch any thing above it: this motion they execute with almoft imperceprible rapidity. The twenty-firft day the egg opens a little on one fide, and the tail peeps out, becoming more and more dittinet every day. The thirty-ninth day the little animal begins its motion, moving at intervals its tail; and the liquior in which it is circumfufed perceptibly ferves it for nourifhment. "In two days more, fome fall to the bottom; while others remain fwimming in the fluid around them, increafing in vivacity and motion. Thofe at the bottom remain there the whole day; but having lengthened themfelves a little (for hitherto they are doubled up) they mount at intervals to tine mucus they had quitted, and are feen to feed upon it. 'The next day they acquire their tadpole form. In three days mo:e they are perceived to have two little fringes, that ferve as fins, beneath the head; and thefe in four days after affume a more perfect form. Now they feed greedily on the pond-weed; and, leaving their former 'food, continue to fubfift on this till they arrive at maturity. When ninety-two days old, two fmall feet begin to burgeon. near the tail; and the head appears feparate from the body: The next day, the legs are confiderably enlarged; four days after, they refufe all vegetable food; their mouth appears furnifhed with teeth, and their hinder legis are completely formed. In two days more the arms are completely produced; the fkin divides on the back near the head, which paffes through the divifion: the membrane, which ferved for a mouth to the tadpole, is 'drawn backward; the arms are projected; and the enveloping $\mathbb{A k i n}$, perpetually driven backwards, at length quits the body : and now the frog is every way perfeet, except that it fill continues to carry a tail. In this odd fituation the animal, refembling at once both a frog and a lizard, is feen frequently rifing to the furface to breathe. Thus it continues about fix or eight hours, till the tail diminithing by degrees, the animal appears in its moft perfect form.

So extraordinary is this transformation, that the food it fed on greedily a few days before, is now rejected; it would even ftarve if fupplied with no other: from having fed on vegetables, it becomes carnivorous, and lives entirely on worms and infects; quitting its native element, thefe it feeks on land. At firft, being feeble, and unable to bear the warmth of the fun, it hides among buthes and under ftones; but if a thower refre?h the earth, then multitudes quit their retreats, to enjoy the grateful humidity : 


\section{$\begin{array}{llllllll}T & F & E & F & R & O & G .\end{array}$}

midity : often the ground is feen perfectly blackened with their numbers, fome feeking for prey, and fome for fecure lurking places. From the myriads that appear on fuch occafions, fome have thought they were generated in the clouds, and howered down on the earth.

The Frog lives moftly out of water; but, when the cold nights begin, returns to ftagnant waters, where it can lie concealed at the bottom. Here it continues torpid, or with very little motion, att the winter; but fome refide in holes in the earth.

The difference of fexes is not perceivable in thefe animals till their fourth year, when they begin to propagate. It is faid they live about twelve or fifteen years : but probably much more.

Frogs eat infeets of all kinds; alfo young fnails, young mice, and ducklings; but never, unlers they have motion. They continue fixed and immovable till their prey appears; when it comes fufficiently near, they jump up or forward, fometimes a foot or two, with great agility, dart out their tongues, and feize it with certainty. The tongue is extremely long (and this length of tongue is drawn out, like a fword from its fcabbard, to affail its prey). It is furnifhed with a glutinous fubftance; and whatever infect it touches infallibly adheres, till drawn into the mouth.

The Frog is very vivacious, and can bear hunger long. It will live and jump about feveral hours after lofing its head; will continue active, though embowelled: nor does the lors of its heart imply the lofs. of motion.

The croaking of frogs is well known; and from thence, in fome countries, they are diftinguifhed by the ludicrous title of Dutch Nightingales. The large water frogs have a note like the bellowing of a bull, and puff up their cheeks to a furprifing magnitude. The male only croaks; the female rather growls. The male has' a lefs difagreeable voice, as the call to courthip. When they couple, their croaking is in fome places very troublefome, for the whole lake feems vocal, and a thoufand diffonant notes perfectly ftun the neighbourhood; alfo, before wet weather, their voices, in full exertion, with unceafing affiduity welcome the approaches of their favourite moifture. Dry weather is hurtful to their health, and prevents them from getting their prey : they alfo want that grateful humidity which moiitens their $\mathbb{R}$ kin, and renders them alert and active.

CATESBY thinks that in Carolina the Frogs prefer thofe infects that hine in the dark; whether as better pleafing their palate, or as being more 


\section{72}

\section{OVIPAROUS QUADRUPEDS.}

more readily difcernible, is uncertain. Being out in the air one very hot evening, he chanced to let fall fome burning tobacco from his pipe, which was inftantly fwallowed by a frog; as was a fmall burning coal of wood, and many other fhining (though heated) bodies.

\section{THE B U L L F R O G}

T very large; has large oval eyes, brilliant and prominent; iris red, bordered with yellow; upper part of his body deep brown, fpotted deeper, with a tinge of yellowilh green, particularly on the front of the head: belly dirty yellow, clouded with yellow, and, lightly fpotted. Commonly five toes to each foot, with a tubercle under each joint. Is lefs frequent than moft other frogs; lives in fprings, which are often on the fides of hills in Virginia; commonly two to each fpring or pond. They fit at the entry of the hole which furnifhes the water, and when furprifed leap into the water. The Virginians think they purify the water, which perhaps they do, by deftroying infects that might otherwife pollute it; but they alfo deftroy young ducklings, if not goflings; which, having a very wide gullet, they can eafily do. This conforma- tion, and their fize, aided by the echoes of the furrounding banks and cavities, renders their croaking fomewhat formidable, and like that of a bull bellowing at a diftance. A traveller, unufed to them, is greatly at a lofs to account for the noife they make, as they are themfelves invifible, being entirely under water, except juft their muzzles, whence iffues their furprifing croaking. Some have fix toes on the hind feet.

\section{THE TRE E F R O G S}

GORM a peculiar fpecies, diftinguiliable by. a kind of fmall knob or button at the extremity of each toe. Thefe knobs are unctuous, or vifcid; and by this property the creature can eafily fupport itfelf on the branches or leaves of trees. 


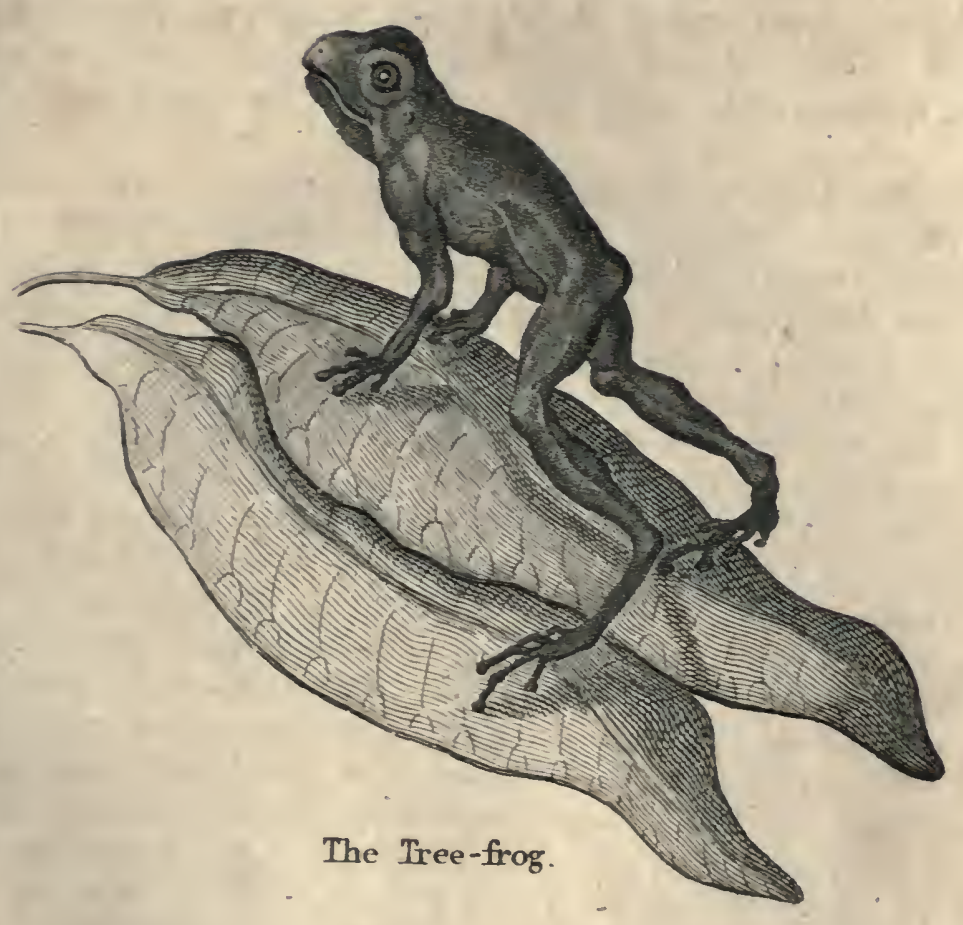





\section{THE TREE FROGS.}

Whatever has been faid of the inftinet or agility of frogs, applies with greater force to the Green or Common Tree Frog, which, in fize, is lefs than the frog. Colour, on the upper parts, a beautiful green; beneath, where it has Imall tubercles, whitifh. A yellow ftreak, nightly bordered with violet, extends on each fide the head and back, from the nofe to the hind feet; and another, anfwering it, from the upper jaw to the front feet. The head is fhort, as large as the body, but a little fnubbed in front. The jaws are rounded; the eyes elevated. The body is fhort, almoft triangular; very broad near the head, convex above, flat beneath. The front feet, which have but four toes, are fhort and thick; thofe behind have five toes; are very long and thin. The nails are flat and rounded.

The Green Tree Frog leaps with fuperior agility to the common Frog, becaufe its hind legs are fo much longer than the front. It paffes all the fine weather in the midlt of the woods, or branches of trees : its $\mathrm{nkin}$ is fo fticky, and its toes fo adhefive, that it has but to place itfelf any where on a leaf, above or below, and it fears not falling. CATESBy fays, they have the faculty of rendering their little knobs concave, which occafioning a vacuity, attaches them more ftrongly to the furface on which they faften. He fays alfo that they fometimes leap twelve feet. In tine weather they are feen darting on the infects that come within their reach ; thefe they ftrke with their tongues like frogs, leaping from branich to branch. Like frogs, they continue long in their tadpole ftate; nor attain complete maturity till after three or four years, when they couple : till then they are nearly filent, even the males. They feek each other in the waters as frogs; and; in winter, hide in marnhy places, but always thofe furrounded with trees, as if they ftill paid attention to what is their favourite refidence. In April or May they are found in the lakes, and with fonorous croakings, perpetually repeated, and multiplied by every neighbour's note in addition, like a pack of hounds in full cry, they compofe a moft noify chorus, which, in the filence of night, when rain is expected, may be heard at a league diftance. The young are often two months before they attain their moft perfeet ftate; but, fo foon-as. they are perfect, they forfake the waters for the woods. May be kept in houfes without much trouble. Is found in Europe (the fouthern parts): in Africa, and America.

One American fpecies is milk white, with faded jpots.

That which our plate reprefents is the American kind, uied by the Indians to colour the feathers of young parrots red or yellow. By PABT V. NO. 28. 
plucking the natural feathers of the parrot, and rubbing the place with the blood of this creature, the following feathers, inftead of being green, as they otherwife would be, are red or yellow. Its colour is reddifh.

\section{$\begin{array}{lllllll}T & H & E & T & O & A & D .\end{array}$}

TS colours vary with the feafon; fometimes inclining to red, then to black, or to olive. Why thould the figure of the Toad difgult more than that of the Frog? Its form and proportions are not unlike; it chiefly differs in colour, being blacker, and by its low and heavy motion, which exhibits nothing of the agility of the frog. Its body is rounded and broad; its back covered with a dukky, pimpled hide; its belly large and fwagging; its pace laboured and crawling; its retreat gloomy and filthy; and by thefe ideas its appearance excites difguft. Its pimples are often greenifh black. The auditory canal is clofed by a membrane. Its front feet are hort, and have four toes; thofe behind have fix toes, united by a membrane. Its head is as large as its body, its jaws have no teeth; its eyes are fwelled; its motion, when feized, is a Jroelling; it leaps badly; it ejects a liquor (thought to be its urine) when feized; and this, in fome kinds and climates, has the repute of being venomous, or at leaft hurtful. The humour which fweats from its body, and its naver, have the fame character; but much feems to have been faid beyond what our European Toads verify.

Lives in ditches, drains, dunghills, and caverns, in forefts, and beneath great ftones; here remaining all day hidden, unlefs a fhower call it out. Préfers night to feek its prey. Is amphibious; lives on worms and infeets, fnails and beetles, which it feizes by darting out its length of tongue; crawls in moift weather; couple as frogs, early in fpring, fometimes on land, but ufually in the water; are united fome hours. The obitetrical affiftance which the male lends the female, is a peculiarity in this fpecies. In a fummer's evening, a French gentleman perceived, in the king's gardens at Paris, two toads coupled. Two facts equally new furprifed him : the firt was the extreme difficulty the female had in laying her eggs; the fecond was the affiftance lent her by the male for this purpofe. The eggs of the female lie in her body, like beads on a ftring; after the firt, by great effort, was excluded, the male caught it with his 


\section{$T H E=T O A$ D.}

hinder paws, and kept working it till he had extracted the whole chain, which is often forty feet long, impregnating every egg as it iffued from the body. It is probable this difficulty occurs only on land. The number of males is found to furpafs that of the other tex thirty to one.

The account given of the progrefs of the frog in and after its tadpole ftate, is defcriptive of the fame events in the life of a toad, and need not be repeated. When they have undergone all the variations of that ftate, they forfake the water, and are often feen, in a moift fummer's evening, crawling up, by myriads, from fenny places into drier fituations. There, having found out a retreat, or having dug themlelves one with their mouth and hands, they lead a patient, folitary life, feldom venturing out, except when the moiture of a fummer's evening invites them abroad. We have the authority of Linnæus for faying, that they fometimes continue immoveable, with the mouth open, at the bottom of Thrubs, where butterflies, in fome meafure falcinated, are feen to ly down their throats.

In a letter from Mr. Arfcott are fome curious particulars relating to this animal. "I knew it myfelf above thirty-fix years;-and by conftantly feeding it, brought it to be fo tame, that it always came to the candle and looked up, as if expecting to be taken up and brought upon the table, where I always fed it with infeets of all forts. It was fondeft of fiefh maggots, which I kept in bran; it would follow them, and when within a proper diftance, would fix his eyes, and remain motionlefs for near a quarter of a minute, as if preparing for the ftroke, which was an inftantaneous throwing its tongue at a great diftance upon the infect, which ftuck to the tip by a glutinous matter. The motion is quicker than the eye can follow. I cannot fay how long my facher had been acquainted with the toad befor I knew it; but when I was firl acquainted with it, he ufed to mention it as the old toad I have known fo many years. This oid toad made its appearance as foon as the warm weather came. Spiders, millepedes, and flen maggots, feem to be this animal's favourite food. In the heat of the day they will come to the niouth of their hole, I believe for air. I once, from my parlour window, obferved a large toad I had in the bank of a bowling-green, about twelve at noon, a very hot day, very bufy and attive upon the grafs. So uncommon an appearance made me. go out to fee what it was; when I found an innumerable fwarm of winged ants had dropped round his hole; which temptation was as irrefiftible as a turtle would be to a luxurious alderman. A tame raven one day feeing it. at the mouth of its hole, pulled it out, and, although I refcued it, pulled out one eye, and hurt it fo, that notwithtanding its living a $\mathrm{G} \$ 2$ ewelye 
twelvemonth, it never enjoyed itfelf, and had a difficulty of taking its tood, miffing the mark for want of its eye."

The Toad is torpid in winter ; often many in the fame hole; and re. treats to the hollow root of a tree, the cleft of a rock, or the bottom of a pond, where it is in a ftate of feeming infenfibility. As it is very longlived, it is very difficult to be killed; its $\Omega$ kin is tough, and cannot be eafily pierced; and, though covered with wounds, the animal continues to fhew figns of life. But what thall we fay to its living lodged in the bofom of ftone, or cafed within the body of an oak? BAcon afferts that Toads have been fo found: Dr. Plot afferts the fame. There is to this day a marble chimney-piece at Chatfworth, with the print of the toad upon it, and a tradition of the manner in which it was found. In the Memoirs of the Academy of Sciences there is an account of a toad found alive and healthy in the heart of a very thick elm. In the year 173 i there was another found near Nantz, in the heart of an old oak without the fmalleft iffue to its cell, and the difcoverer was of opinion, from the fize of the tree, that the animal could not have been confined there lefs than eighty or a hundred years. To thefe we can only oppofe the ftrangenefs of the facts; the necefity this animal appears under of receiving air; and its dying like all others in the air pump, when deprived of this all-fuftaining fluid. Certain it is that, if kept in a damp place, the toad will live for eighteen months without any food whatfoever; and though kept in boxes fealed carefully with wax. It is proba. ble that thofe in trees were not abfolutely without air; fince fome might be tranfmitted by the pores or air veffels of the wood. That fome, thus found, were rather preferved from putrefaction, than really living, feems alfo fuppofable; and if fo, there being no evaporation through flone, they might have;retained their moifture many centuries, and yet have furnithed fomewhat thought to be blood.

Of this animal there are feveral varieties; fuch as the Water and the Land Toad, which probably differ only in the ground colour of their Nkin. In the firft, it is more inclining to ant-colour, with brown fpots ; in the other, the colour is brown, approaching to black. The water toad is not fo large as the other; but both equally breed in that element. The fize of the toad with us is generally from two to four inches long; but, in the fenny countries of Europe, much larger. But this is nothing to their fize in fome of the tropical climates, where travellers often, at the firft time, iniftake a toad for a tortoife. Their ufual fize is from fix to feven inches, and fome larger. In Carthagena and Porto-bello their bite 


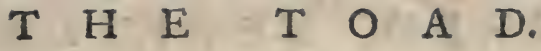

bite is faid to be very dangerous. All thefe are found in the tropical climates in great abundance, and particularly after a fhower of rain; then the ftreets, courts, and gardens feem entirely covered with them; they then crawl from their retreats, and go into all places to enjoy their favourite moifture. With us, the opinion of its raining toads and frogs is juftly exploded; is ftill entertained in the tropical countries, and that not by the natives only.

The BROWN TOAD is mooth-fkinned, having no warts, but large brown fpots which touch each other; largeft on the back. The crevice for the eyes, when contracted, is vertical, inftead of horizontal. Is found in marnes: when enraged, exhales a fœtid fmell, fomewhat like gunpowder, ftrong enough to caufe weeping. Some have thought it mortally.venomous; this is too much; but that it may be hurtful feems likely.

The CALAMITE has two falfe nails on the foles of his feet, which, with horny fubftance at the extremity of his toes, enable him to clamber up walls, \&c. feveral feet.

The FIRE-COLOURED TOAD carries his agility yet farther; can bear day-light, and his eye then takes a triangular form, whofe outline is golden. Croaks withour fwelling his throat. Seems to form a link between the frog and the toad kinds.

The PIPAL or SURINAM TOAD. The male and female are fo different, that they may eafily be miftaken for two diftinct fpecies. The male has four toes, feparate, on the front feet; and five, membraned, on the hind feet. Each toe on the front foot is divided into four fmall parts at its extremity. The head is fcarce diftinguimable from the body; the opening of the gullet very large; the eyes very finall, and diftant from each other, placed on the upper part of the head; head and body very nat. General colour olive, more or lefs clear, and fprinkled with very minute fpecks, red or reddiff.'

The female is much larger than the male; her head is triangular; at its bafe much larger than th: anterior part of the body. The body is commonly full throughout of very finall warts; is five or fix inches long; in other refpects agrees with the male.

It was once thought that the eggs, when formed in lie ovary, were fent, by fome internal canals, to lie and come to maturity under the bony fubftance of the back, and, in this ftate, were impregnated by the nale, the fkin continuing ftill apparently entire, forming a very thick covering over the whole brood; but the fact is, that after the eggs are impregnated 
impregnated in the ufual way, the male gathers them up, and places them on the back of the female, where they adhere: the Rin of her back fwells and forms around them little cells, where they are hatched. At firft, they have a tail like tadpoles, which foon quits them.

The HORNED TOAD is frightful; his head half the fize of his body; his jaws open enormouny ; his eye-lids have the form of a pointed cone, which makes them feem armed with horns, wherein are his eyes. His feet have fomething the air of hands.

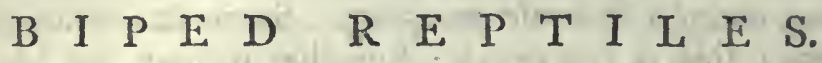

T $\mathrm{E}$ have feen that the Seps and the Chalcide approach very nearly in form to the order of Serpents, by their length of body, and by their extreme thortnefs of feet. The prefent clafs of reptiles is yet more ferpentiform, and unites more clofely the Lizard kind to the Serpent. They follow; with propriety, the Oviparous Quadrupeds, as in many refpects allied, yet differing, by having two feet only; and they precede the Serpents, as feet are entirely wanting to thofe creatures: in other refpects they mighe eafily be confounded with them, by their length of body, proportion of the head; and form of the fcales.

On this clafs of creatures little has hitherto been determinate and authentic: that many imperfeet quadrupeds of the feps, \&c. kinds, have been fuppofed bipeds is certain; on the other hand, the immature ftate of fome falamanclers, and others, refembles that of the feveral fuppofed bipeds; but whether there be any creature which in its larva ftate equals thirty-one inches in fize, as fome of thefe have been found, remains in obfcurity.

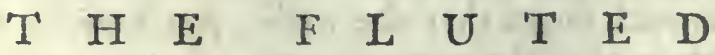

T. AS found in Mexico by M. Velaseuez; has no hind feet; is clothed with fcales, difpoled in rings; has a very fort tail. Its icales are almoft fquare, ranged in half rings on the back, and alfo on the belly, correfponding to each other where they meet; and here is a kind of fluting, or groove, running down the animal on each fide. The tail has its fcaly rings entirely round. Total length of this individual nine inches. The head of this creature is rounded; the upper part covered 


\section{THE SHELTOPUSICK.}

with one great fcale; the muzzle has three fcales; the two exterior perforated, for the noftrils. Teeth very minute; eyes fcarce vifible; no eye-lids. The feet covered with little fcales in rings; four toes to each foot, with nails long and hooked. This remarkable creature's manners are unknown: probably they refemble thofe of the Seps, and the Chalcide.

\section{THE SHELITOPUSICK}

W

A S firlt difcovered by Dr. Pallas: is found near the Volga, in the fandy deferts of Naryn, and near the Cuman. Prefers long grafs, and thady vegetation: hides among fhrubs, and fies when approached. Preys on frall lizards. His head thicker than his body; fnout rounded; fmall teeth; large nottrils : two moveable eye-lids; and openings for the ears, like lizards. On each fide the body a kind of groove; at the ends of thefe grooves, near the vent, two very fmall feet, covered with four fcales, dividing into two kinds of toes, llrarpifh. The tail much longer than the body. Total length exceeding three feat. Colour nearly uniform, pale yellow. 


\section{$(18 a)$ \\ e F S S R ENTS.}

THERE is fcarce a country in the world that does not maintain forre of this poifonous brood; for though mankind have driven off the lion, the tiger, and the wolf, the fnake and the yiper defy their power; and frequently punih their temerity. In Europe; however; not only their numbers are thinned, but their powers are diminithed: if we have not extirpated them, we have prevented, their multiplication; and the temperature of our climate refuifes to furnifh the qualities neceffary highly to exalt their venom. The malignity afcribed to European ferpents of old, is now unknown. A burning pain in the part, removeable by timely applications, is the worft effect now-generally experienced from their bite. In the ardent countries of "the tropic, "thole regions of both hemifpheres where the fields are unpeopled and fertile, where the climate fupplies warmth and humidity, where the fun is hot, the forefts thick, and men few, there ferpents cling among the branches of the trees in infinite numbers, encompaffing them like a wreath, and rifing and defcending at pleafure. Many are common to both continents: efpecially the largeft kinds. In thofe burning countries, what had the appearance of a great river in the rainy featon, becomes in fummer one dreary bed of land; here a lake that is conftant, or a brook that is perennial, is to all animals the greateft enjoynent; parched by the heat; they traverfe whole deferts to find out water, nor can danger deter them from attempting to flake their thirft. On its banks thoulands of animals attend to drink or to prey. The lion and tiger, but chiefly the larger ferpents, are upon the watch. Not an hour paffes without fome dreadful combat; but the ferpent, defended by its fcales, 'and naturally capable of fuftaining a multitude of wounds, and even of renovating its tail, is of all others the moft formidable; it is the mort alert, efpecially before a ftorm; it is the molt wakeful alfo; for the whole tribe neep with their eyes open.

It is probable, in early times, that ferpents, continuing undifurbed poffeffors of the forett, grew to amazing magnitudes; and might reign the tyrants of a diftrict for centuries. Time and rapacity might lengthen them to an hundred or an hundred and fifty feer. It is polfible too they might fometimes venture from their retreats, and carry confternation among mankind, as they laad before fpread defolation among the lower 
anks of nature. We are told that, while Regulus led his army along re banks of the'river Bagrada in Africa, an enormous ferpent difputed is paffage over. We are affured by Pliny, who fays that he himfelf iw the 1 kin, that it was an hundred and twenty feet long, and that it had eftroyed many of the army. At laft, however, the battering engines ere brought out againft it, and by thefe it was foon deftroyed. Its poils were carried to Rome, and the general was decreed an ovation or his fuccefs. The fkin was kept feveral years in the Capitol.

Serpents even now are the longeft of animals, exceeding even crocoliles, and yielding only to whales, \&c. They are alfo the fmalleft, nany being but two or three inches long, and the fize of a quill. -Thofe if the large kinds are rare, and diftant from each other; thofe of the niddle fizes often are heaped on each other in fubterranean retreats.

Serpents, in general, are evidently diftinguifhed from the reft of aninated nature. They have the length and the fupplenefs of the eel, but no ins; they have the fcaly covering and pointed tail of the lizard, but no egs; they have the crawling motion of the worm, but alfo lungs to reathe with: upon the whole, their external fhape is the fimpleft among inimals poffeffing blood.

The colours of ferpents are extremely various and brilliant, efpecially n fun-lhine; from the moft lively white and red, to the deepert black. Some thew one thade only; others exhibit manycolours-con. trafted, interwoven in mefhes, diftributed in lines, prolonged in ftreaks, difpofed in bands, fpread in fpots, or fcattered in ftars; fometimes in regular forms, fometimes in irregular: an infinite diffmilarity.

Their head is generally protected throughout by a bony helmet : but the back of the fkull is rather Ahort, by which formation the origin of the pinal marrow is expofed; and here they are eafily and mortally vulnerable. All ferpents have very wide mouths in proportion to the fize of the head, and can fivallow the head of another animal three times as big as their own. Their jaws do not open as ours, one way only, but are held rogether at the roots by a ftretching mufcular fkin; by which they open widely, like ftretching leathẹ, extending to admit the morfel, which the ftomach re. ceives in part, while the reft remains in the gullet till diffolved; often part remains in the mouth, and fills it, their windpipe being placed fo as to fuffer no injury.

Their hearing is probably dull : the fonorous rays pafing through a covering of fcales to the audicory proceffes. Their fmell is alfo thought to be feeble; as their noftrils are but fimall, and furrounded with fcales. 
The eyes of ferpents are fmall, compared to their length of body ; differently coloured in different kinds; yet in all malign, brilliant, and lively; very mobile and projecting, and fo placed as to receive images from the greateft fpace their pofition admits. Their fight, therefore, may juftly be efteemed hiarp and piercing. In fome, the upper eye-lid is wanting, and the ferpert winks only with that below ; in others, the animal has a nictitating membrane, refembling that of birds, which keeps the eye clean, and preferves the fight. The fubftance of the eye in all is hard and horny; the cryftalline humour, occupying great part of the globe.

The tongue is thin, long, and forky; compoled of two long flethy fubftances, which terminate in points, and are very pliable. At the root it is connected very ftrongly to the neck by two tendons, that give it a variety of play. Some of the viper kind have tongues a fifth part of the length of, their bodies, which are continually darting out; but their poifon is not in thefe.

The guller is wide, capable of being diftended greatiy; at the bottom of this lies the ftomach, which is not equally capacious.

Serpents are furnithed with very large lungs, in fome extending three qualters of their bodies : thefe they fill with. air at once, but let it nowly. efcape.

The heart, as in the tortoife, frog, and lizard, has but one ventricle; and the communication between the blood which comes to, and that which quits the heart, is independent of the lungs and of breathing. Hence they are amphibious; but though all are amphibious, fome love the water more than others; and probably the largeft kinds. Their blood flows extremely nowly, poffeffes little warmth; and hence they are in certain degrees of temperature torpid. Thefe are the leffer kinds; the larger inhabiting climates where no fuch temperature is known. They awake early in fpring, and, what is remarkable (as of all neeping animals), when the air is not equally warm as when they forfook it in autumn.

The vent in thefe animals ferves for the emifion of the urine and the faces, and they contain the neceffary parts for perpetuating the fpecies. Thefe are double; but there are no external marks whereby to diftinguifh the fexes.

The body of ferpents is long, nender, and capable of bending in all direetions, and even folds feveral times on itfelf: the joints in the backbone are numerous; in fome amounting to an hundred and forty-five from the head to the vent, and twenty-five more from that to the tait. 


\section{$O F: S E R P, E N T$ S.}

Thefe bones play one within another, like ball and focket, fo that they have complete motion upon each other in every direction. From the head to the vent are two ribs to every joint, ufually longeft in the middle of the body, and capable of motion in various directions: towards the end of the tail thefe ribs ceafe. They are furnifhed with mufcles, four in number, which being inferted into the head, run along to the end of the tait. The vertebra and ribs compole the whole folid parts of ferpents; fo that their internal parts are defended below only by the fcales on which they move, and by a kind of fatty matter, which lines the nin of their belly, often in confiderable quantities. This fat alfo contributes to their warmeh.

Some time after the animal awakes in fpring, he acquires a new fkin, and hides till it be hardened.

Almolt all their icales, but particularly thole under the belly, which contribute to motion, are moveable, independent of each ocher, by a mufcle which belongs to each. As the edge of the foremoft lies over the end of the following, when the fcale is erected, it catches in the ground, and furnifhes a point of refiftance to promote the animal's progreflive motion. It is evident that thefe fcales, lying all one way, impede, or at leaft do not afist; motion the other way; and very few ferpents move equally well backward as forward, though fome do. In fome of the ferpent kind there is the exacteft fymmetry in thefe fcales; in others they are difpofed more irregularly. In fome there are larger fcales on the belly; and often anfwering to the number of ribs; in others, the animal is without them. But ferpents have another more powerful principle of motion, by bending into an arch more or lefs of their body; the two extremes of this arch being drawn together, one of them ferves for a point of refintance to the other, when the arch is ftraightened. At each repetition of this action, they may be faid to make aleap of fuch a diftance; and this is proportionate to the fize, \&c. of the creature. During this motion they carry their heads as high as they can. In comparing this to vernicular motion, we obferve, that the earth-worm has no backbone; but its body is compoled of rings, which it can lengthen or fliorten as recerfary : therefore, to move forward, it lengthens the body, and by the fore part clings to the point it has reached; then contracts, and brings up its rear; then, the body being thortened, the fore part is lengthened astain for another progreffion, and fo on: while the ferpent, initead of fhortining the body, bends it into an arch; and this is the principal difference between ferpentine and vermiculas progreffion. 
When certain ferpents propore to dart fuddenly on their prey, they roll themfelves into a fpiral, raifing only their head; and fpringing at once, uniting the elafticity of each part into one whole, they bound with the rapidity of a dart. The motions of ferpents, when climbing trees, proceeds on the fame principles as on the ground; but fometimes they hang by the tail, and fwinging themfelves backward and forward, at length reach the bough they afpire to. . There are many ferpents that dart with fuch amazing fwiftnefs, they appear rather to leap than crawl; and we are told by fome that they will dart to a very great diftance. The manner of progreffion in the fwifteft ferpent we know (the Jaculus), is by inftantly coiling itfelf upon its tail, and darting from thence to its full extent; then carrying the tail as quick as lightning to the head, coiling and darting again; and by this means proceeding, with extreme rapidity, without ever quitting the ground. CARLI defcribes the Long Serpent of Congo, making its track through the tall grafs, like mowers in a fummer's day. He could not without terror behold whole lines of grafs lying levelled under the fweep of its tail. In this manner it moved forward with great rapidity, till it found a proper fituation frequented by its prey.

Among ferpents fome are filent; but hifing is their common found, either as a call to their kind, or as a threat to their enemies. In the countries where they abound, they are generally filent in the middle of the day, when they are obliged to retire from the heat of the climate; but as evening approaches, they are then heard iffuing from their cells, with continued hiffings. Their hiffing is generally the prelude to their combats; never is the language of pleafure or of love, but always befpeaks anger and fury, or pain and vexation; is never heard from far, as it would betray their retreats or approaches. The ferpent preys indifcriminately; the buffalo, the tiger, the gazelle, the ftag, the porcupine, birds alfo, of which it generally ejects the feathers; nay, they frequently are feen to devour each other; yet they are capable of protracted hunger, and fuffer little by it. Vipers are often kept in boxes fix or eight months without food : and fome affert, certain ferpents may be kept years. In a letter by ANDREW CLEYERUS, printed in the German Ephemerides, we have an account of a combat between an enormous ferpent and a buffalu, by a perfon who affures us that he was himfelf a fpectator. The ferpent had for fome time been waiting near the brink of a pool, in expectation of its prey; when a buffalo was the firft that offered. Having darted upon the affrighted animal, it inftantly began to wrap it round 
with its voluminous twiftings; and at every twift the bones of the buffalo were heard to crack. It was in yain that the poor animal ftruggled and bellawed; its enormous enemy entwined it too clofely to get free ; till at length, all its bones being mahhed to pieces, and the whole body reduced to one uniform mals, the ferpent untwined its folds, to fwallow its prey at leifure. To prepare for this, and in order to make the body nip down the throat more glibly, it was feen to lick the whole body over, and thus cover it with its mucus. It then began to fwallow it at that end that offered leaft refiftance; while its length of body was dilated to receive its prey, and thus took in at once a morfel that was three times, its own thicknefs. Similar accounts have confirmed this. Whenever they feize and fwallow their prey, they feem, like furfeited gluttons, unwieldy, ftupid, helplefs, and neepy; they feek fome retreat, where they may lurk for feveral days together, and digeft their meal in fafety: the Imalleft effort at that time is capable of deftroying them; they can fcarce make any refiftance, and are equally unqualified for flight or oppofition: this is the happy opportunity of attacking them with fuccefs.

Serpents have a moft horrible fætor : this proceeds from the putrefaction of their food, which corrupts ere their ftomach digefts it. Some perfons who have opened ferpents have been almoft fuffocated with the ftench. To this alfo contribute two glands near the vent, like thofe in the weafel or polecat; and, like thofe animals, in proportion as they are excited by rage or by fear, the fcent grows ftronger. The rattlefnake and viper have no finell whatever; nay, we are told that at $\mathrm{Calecut}$ and Cranganon, in the Eaft Indies, there are fome very noxious ferpents whofe excrements are fought after, and kept as the moft pleafing perfume. The Efculapian ferpent is alfo of this number.

All ferpents come from an egg; but in fome the egg burfts in the womb, being come to maturity : and thefe bring forth their young alive, as the viper: while others bring forth eggs, which are afterwards hatched by the heat of their fituation; as the common Black Snake, and the majority of the ferpent tribe. The number of their eggs is uncertain, as is the time of their coming to maturity. The eggs are not always laid at once, but one by one, at intervals; and of en, it is thought, with pain. If either kind is opened, the eggs will be found in the womb, covered with their membranous thell, and adhering to each orher like large beads on a ftring. In the eggs of both, the young ones will be found, though at different ftages of maturity: thofe of the viper will crawl and bite in the moment the fhell that inclofes them is broke open; thore of PART V. No. 29:

I i

the 
the fnake are not yet perfect. After they have acquired life, they receive no leffons or cares from their parent, but are left folely to inftinet; and perhaps a fmall proportion reaches maturity. Their length of life is unknown, but probably very long. Father Labat took a viper nine feet long, and ordered it to be opened. In this creature were fix eggs, each equal to a goofe egg, but longer, more pointed, and covered with a membranous fkin, by which alfo they were united to each other. Each egg contained from thirteen to fifteen young ones, about fix inches long, and as thick as a goofe quill. Though the female from whence they were taken was fpotted, the young feemed to have a variety of colours very different from the parent; and this led the traveller to fuppofe that the colour was no characteriftic mark among ferpents. Thefe animals were no fooner let loofe from the fhell, than they crept about, and put themfelves into a threatening pofture, coiling themfelvès up, and biting the ftick. with which he was deftroying them. In this manner he killed feventy-four young ones. Thofe that were contained in one of the eggs efcaped at the place where the female was killed, by the burfting of the egg, and their getting among the burhes.

Though the generality of mankind regard this formidable race with horror, yet there have been countries, and there are fome at this day, that confider them with veneration. Their worlhip by the ancient Egyptians is well known; and many of the nations along the weftern coaft of Africa retain the fame unaccountable veneration. On the gold and nave coalts; a ftranger, on entering the cottages of the natives, is furprifed to fee the roof fwarming with ferpents, that cling there, unmolefting and unmolefted by the natives. But his furprize increafes, farther fouth ward in the kingdom of Widah, when he finds that a ferpent is the god of the country, has its habitation, its temple, and its priefts : and numbers are daily feen to offer not only their prayers, their goods, and their provifions, at the fhrine of their hideous deity, but alfo their wives and daughters.

Serpents may be diftinguifhed not only by their colours, but by the number, form, fize, and arrangement of their fcales.

I. The ADDERS, which have a fingle row of great fales under the belly, and two rows of leffer under the tail. This clafs includes the viper, the afpic, and adders of various marks.

II. Thofe which have a fingle row of great fcales under the belly, and alfo under the tail. This fpecies includes the largett kinds. 


\section{$O F S E R P E N T S$ :}

III. Thofe which have large fcales under the belly and tail; but their extremity is terminated by a moveable and articulated rattle.

IV. Thofe whofe fcales under the belly and tail are like thofe of the back.

V. Thofe encircled by faly_rings, ufually called ampbifena.

VI. Thore whofe fides have folds, not ribs, named cacilia.

VII. Thofe whofe body, next the head, thews great fcales; then the body thews fcaly rings: the tail alfo thews thefe rings at its origin, and fimple fcales at its extremity.

VIII. Thofe whofe $\mathrm{fkin}$ is replete with little tubercles.

In the fe thould be formed a divifion of thofe viviparcus, properly called vipers; and thofe oviparous. This diftinetion is not eafy to afcertain : but it is fuggefted that all vipers are venomous; confequently may be diftinguirhed by their fangs, which are always diftinet from their teeth. It has been fuggefted, alfo, that thofe which had-fangs were generally, yet with exceptions, on the fummit of the head covered with fmall fcales, nearly like thofe of the back : all others having in that part larger fcales, of a very different form, always nine in number, and placed in three rows; the firft and fecond (counting from the nofe) compofed of two fcales, the third of three, and the fourth of two. Not only the colours of ferpents vary, between the young and the old; but alfo the number of fcales on their bodies, the oldeft having the moft. It is vain to attempt their arrangement by colours, as fometimes young of feveral-different colours thall iffue from one parent.

\section{OF VENOMOUS SERPENTS IN GENERAL.}

TCHE poifon of ferpents has ever been one of the greateft objects of human confideration. The glands that ferve to fabricate this venomous fluid, are fituated on each fide the head, behind the eyes, and have canals leading from thence to the bottom of the fangs in the upper jaw, where they empty into a kind of bladder, from whence grow the fangs on each fide.

When the ferpent is irritated to give a venomous wound, it opens its formidable jaws to their wideft extent: the moveable bones of the upper jaw nide forward; the fangs, that lay before inclining, are thus ereted; they are ftruck with force into the fleth of the object bitten; by meeting refiftance 
refiftance at the points, they prefs upon the bladders of venom from whence they grow; the venom iffues up through the hollow of the tooth, and is preffed out through its nit into the wound which by this time the tooth has made in the, ikin. Thus, from a night puncture, and the infufion of a drop of venom fcarce larger than the head of a pin, the part is quickly inflamed; and, without a proper antidote, the whole frame contaminated.

If a viper inflict the wound, it caufes an acute pain in the place affected, attended with a fwelling, firt red, afterwards livid. This, by degrees, fpreads to the neighbouring parts; great faintnefs, and a quick though low and interrupted puife, enfues; great ficknefs at the ftomach, bilious and convulfive vomitings, cold fweats, pains about the navel, and death. Thefe fymptoms are much more violent, and more rapid, after the bite of a rattle-fnake; but when the perfon is bit by the cobra di capello, or naja, he dies in an hour, his whole frame diffolving into a putrid mafs of corruption.

A ferpent, having once bitten, exhaufts for that time the greateft part of its poifon; and, though the wound cauled by its biting a fecond time is attended with malignant fymptoms, yet they are much milder than before. A ferpent biting upon a fponge, or a piece of foft bread, and then biting immediately after, inflicts a wound not much more dangerous than the prick of a needle., A needle dipped in the venom produces as painful effects as the rooth of the animal itfelf.

As none of this malignant tribe grow to a great fize, they feldom feek the combat with larger animals, or offend others till they are firt offended. They lurk in the clefts of rocks; or among itony places; they twine round the branches of trees, or fun themfelves in the long grafs at the bottom; only feeking repofe and fafety. If fome unwary traveller invades their retreats, their firft effort is to fly; but when purfued, or accidentally'trod upon, they then make a fierce and fatal refiftance. They raife themfelyes according to their ftrength upon their tail, ereet their head, feize the limb that preffes them; the wound is given, and the head withdrawn in a moment. The viper is the only animal in Great Britain from whofe bite we have any thing to fear. 


\section{$(189)$}

\section{$T H E$ V I P E R}

TS the beft known among this noxious tribe, and is moft frequert throughout Europe; infefting our woods, and often our dwellings. Apparently fmall, feeble, and innocent, but really dangerous. Without elegance of proportion, or colours : commonly two feet long; tail three or four inches: colour, afh-grey : from his head, down his back, to his tail, a kind of chain of black fpots, zigzag; on each fide, a range of leffer fpots, of which each correfponds to the angle of the zigzag. The belly is fteel-colour; the head narrows near the nofe; the fcales on the jaws large: number of teeth often eighteen in the upper jaw, twentyfour in the under. On each fide, in the upper jaw, one, two, three, or four fangs, white, tranfparent, hooked, and very harp; one thitd or more of an inch long: thele are capable of confiderable motion, and may be erected or declined at the pleafure of the animal: commonly they are laid down along the $\mathrm{j}: \mathrm{w}$, and then their points are not feen; but, to bite, they are erected. Near their bafe, and connected' to their roots, are feveral refémbling them, but fmaller, and feemingly defigned to replace them if torn away. Thefe fangs are hollow, having two cavities; one on the convex, the other on the concave part of the fang: the firft of thefe opens on the bafe of the tooth, and at its point; the fecond at the bafe, where it receives veffels and nerves: thefe fangs are alfo inclofed in a kind of covering during two thirds of their length. The poifon of the viper is contained in a bag placed on each fide the head, below the murcle of the upper jaw; which mufcle, when in action, preffes this bag, and fqueezes out the venom, which, paffing through the cavities in the fangs, reaches the points, and penetrates into the wound. No other venom is in the viper, though fome have thought its faver to be noxious. This poifonous juice is yellow : neither alkali, acid, nor cauftic: when dry, fplits and divides, to a refemblance of a fpider's web : has no effect on animals void of blood, nor on vipers themfelves: in warm-blooded animals, its effects are quickeft in the fmaller fpecies, and in proportion to the quantity injected into the wound, probably alfo according to the heat of the feafon, climate, \&xc. Is dangerous taken internally in fufficient quantity. It acts probably by acrimonious coagulation of fome kind; fpreads by mingling with the blood: if wounds do not penerrate to the blood, they are lafe. The fright attending wounds is often a caufe of danger. 
The eyes of the viper are lively; have eye-lafhes: when irritated it opens its jaw's, projects its tongue (which is fplit two thirds of its length), and Thakes it with great vivacity; this member is enveloped in a kind of theath. The jaws of this creature may not only be widely feparated from each other, but alfo the two fides of each jaw are capable of motion independent of each other : this contributes to the eafier fwallowing of his prey, which, while tightly held by the teeth on one fide, is drawn by thofe of the other fide. Feeds on infects, fcorpions, lizards, frogs, toads, rats, moles, \&c. Suftains hunger long; when captive, will kill, but not eat, even mice, its favourite prey. In cold weather many affemble for mutual warmth. Are often taken clothed with a double fkin, the old and the new one; change in fpring: come to full growth in fix or feven years, but in two or three are capable of reproduction: couple in May; female goes three or four months; fometimes produces twice a year. The eggs: in the viper are the fize of blackbirds eggs; in two parcels; in number, from one dozen to two : the young ones are rolled round in the egg before their "birth. "The fpecies is greatly fpread, from India to Siberia, and throughout Europe; is always fow of motion; does not bite large animals unlefs provoked. When held up by the tail, he cannot bite the hand that holds him. The heart of a viper beats long after taken from the body; the mouth opens after the head has been cut off fome time, and its wounds are equally dangerous as before. The venom retains its quality after feveral years keeping. Tobacco, and its effential oil, is fatal to them, as is the oil of cherry laurel.

The black viper differs principally in colour, but is much fmaller : is the kind beft known in England. Vipers are found in many parts of this inand; but the dry, ftony, and in particular the chalky counties, abound with them. Is chiefly diftinguifhed from the common black fnake by the colour, which in the latter is more beautifully mottled; by the head, which is thicker than the body; but particularly by the tail, which in the viper, though it ends in a point, does not run tapering to fo great a length as in the other. The viper is nower than moft other ferpents.

The young continue in the womb till in fuch perfection as to be able to burtt from the fhell; and are faid by their own efforts to creep from their confinement into the open air, where they continue for feveral days withour taking any food whatever. "We have been often affured," fays Mr. Pennant, "by intelligent people, of the truth of a fact, that the young of the viper, when terrified, will sun down the throat of the parent, and feek thelter in its belly, in the fame manner as the young of the op.- 


$$
\{0
$$



poffum retire into the ventral pouch of the old one. From this," continues he, "fome have imagined that the viper is fo unnatural as to devour its own young; but this deferves no credit, as thefe animals live upon frogs, toads, lizards, and young birds, which they fwallow whole, though the morfel is often three times as thick as their own body:" Of this 1 have received repeated information; but have never been fo fortunate as to meet with a perfon who had diffeeted a viper while thus concealing her young; or who had ever feen the young iffue from their concealment. Certainly many kinds of ferpents devour each other.

Though, when at liberty, they remain torpid throughout the winter; yet, when confined, have never been obferved to take their annual repofe. Their poifon decreales in proportion to the length of their confinement ; and it is thought the virtues of their flefh alfo, which has been efteemed a very powerful reftorative medicine in battered conftitutions. They are ufually taken with wooden tongs, by the end of the tail; but in York?hire the viper catchers wear double leather gloves, and worfted ones over them, which they efteem ample fecurity. By the application of olive-oil their bite is faid to be effectually cured.

The Viper of Egypt, or the Aspic of ancient authors, is faid to poffers a poifon which kills without pain; but induces a gentle repofe, and then a found neep, terminating in death. This is faid to have been therefore chofen by Cleopatra.

The Ammodytes hides in the fand; its venom often kills in three hours time. This kind, in Africa, after having eaten their prey, fall into fo found a neep, that they are not waked without difficulty, but lie in the paths and are trod on.

. The CERAstes is fingular by its horns: was well known to the ancient Egyptians, and inferted among their hieroglyphics. Its horns are moveable at the will of the animal; are placed exactly over the eyes; are a little bent. The head of the Ceraftes is flat; nofe thick and fhort; general colour yellow ; deeper-coloured blotches, in the form of bands, on the body; deepeft on the back. About two feet long; tail Mort; is very greedy, and devours much : then neeps, and is eafily killed. Many devoured by eagles, and other birds of prey; yet they have reputation for cunning, and for hiding themfelves to feize their prey at advantage.

$$
\text { PART V. No. 29:- }
$$


The Naja, or Speezacled Serpent, is among the mort beautiful by his colours, and the moft fatal by his poifon. Far from fuppofing him noxious, he may be viewed with pleafure and admiration. On the back of his neck is placed a curved ftripe, which rifing in the middle; and turning up at the ends, has fome refemblance to eyes, or to thofe. kind of fpectacles which are mounted on the nofe : in reality, however, the eyes and nofe of this ferpent are at his fnout. General colour'yellow; a broad band of brown on the junction of the neck and body; whitifh under the belly; the fpectacles are a white ftripe, bordered by deepcoloured ftripes. The upper part of his head has nine large fcales, difpoled in four rows; two in the firft, two in the fecond, three in the third, and two in the fourth; yet this ferpent is an exception to a rule given, and among the moft venomous. Eyes lively and fiery; fcales oval, flat, and lengthened; attached to the fkin only at one part, and capable of confiderable erection; are not fo clofe as to touch each other on the inflated part of the neck, but form rows, and hew the fkin between them. Thefe fcales in the fun- Thine glitter like burnifhed gold. The inflation of the neck is formed by the ribs, which here are longer than elfewhere, and are covered by a loofe membrane, which the ferpent can dilate at will: this he does efpecially when angry; at which time he is erect, and holds h's head horizontally : this has the appearance of a hood, or coronet; whence he has been called the booded ferpent. The female has this extenfion, but not the fpectacles. Generally three or four feet long, or more, fome feven or eight. Ferocious and fatal; his poifon produces convulfions or gangrene, which are fpeedy death.

Greatly feared by the Indians; yet their mountebanks educate him to dance, and as a thow : going from city to city, and pretending to be preferved by virtue of a certain root. They take their ferpent out of the vafe in which he is kept; then prefenting a ftick, or often the fift only, he raifes himfelf on his tail, fwelling his bood, opening his chaps, and thrufting our his forked tongue, hifling; his eyes fparkling, and his actions lively; he begins a kind of combat againft his mafter, who prefenting his fift now to the right, now to the left, produces correfponding motions in the ferpent; and to this he gives the idea of a dance, by finging and moving himfelf. The Naja endures this exercife for feveral minutes; but when his mafter perceives that his anger becomes ferious, he withdraws his hand, ceafes to fing, the ferpent lies down, and the fhow is over. The ferpent is brought to this by having been long accuftomed to fimilar provocation; and, when ftriking at the fift, his vafe is 


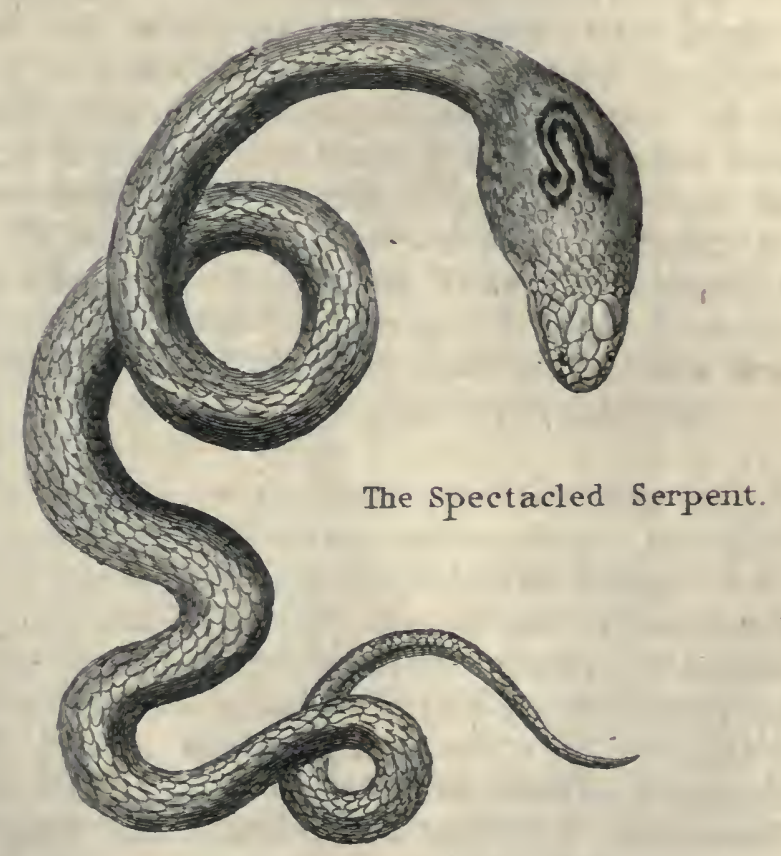





\section{T H E V I P E R.}

prefented quickly inftead of it, againft which he bruifes his noftrils, and hence becomes wary. Befide this, his keeper makes him frequently bite a piece of rag, or other foft matter that may imbibe his venom; and they retard the frefh growth of this venom, by keeping him from moift food. Is worhipped on the coaft of Malabar. Called by the Portuguefe Cobra di capello.

There is a fpeckled ferpent in Peru. One in Brazil, whofe mark is rather heart-fhaped, than like fpectacles.

The Yelzow SeRPENT of Martinico is remarkable for two orifices between his eyes and nofe, which are thought to lead to the organ of hearing: if this be true, he is herein fingular. $H$ is venom is deadly; limpid as water, but yellowin, like olive oil beginning to change. He is neepy, efpecially if the air be cool ; hides under parcels of leaves, in old trees and holes; is very fetid, and generally followed by certain birds who give the alarm. When a perfon is furprifed by this ferpent, to prefent him a branch of a tree, a parcel of leaves, or any fuch object, takes off his attention, and gives time for felf-defence. Often a fingle blow kills him. After the head is cut off, the body preferves for fome time a vermiculated motion. Six feet long; three inches in diameter.

The Wbip Snake is native of the Eaft, about five feet long, yet not much thicker than the thong of a coachman's whip. It is exceedingly venomous; and its bite is faid to kill in about fix hours. To this formidable clafs might be added the Afp ; the Jaculus of Jamaica alfo, one of the fwifteft of the ferpent kind; the Hæmorrhois; the Coral Serpent, which is red, and whofe bite is faid to be fatal ; and a number of ochers, fome very partially known, many fcarce at all. To remedy the bite of thefe animals, the Indians ufe a compofition called in Europe Pietro de Cobra, or the Serpent Stone; and which, applied to the wound, is faid to draw out the venom. The compolition of this ftone, for it is an artificial fubftance, is kept a fecret; and perhaps its effects in extracting the venom may be imaginary: neverthelefs, it is certain that it has a.power of fticking to the fkin, and fucking a part of the blood from the wound. Some maintain it has great virtues, others doubt them altogether. 


\section{OF SERPENTS WITHOUT VENOM.}

CERPENTS without poifon may be diftinguifhed from thofe that are veriomous, by their wanting the fang teeth : their heads alfo are not fo thick in proportion to their bodies; and in general they taper off to the tail more gradually in a point. Their teeth are fhort, numerous, and in the fmaller kinds perfectly inoffenfive; they lie in either jaw, as in frogs and firhes, their points bending backwards, the better to fecure their. prey. As inftruments of difence, they never attempt to ufe them. Even among the largeft, the teeth are never employed in defperate engagements. When a hare or a bird is caught, they may ferve to prevent luch fmall game from efcaping; but when a buffalo or a tiger is to be encountered, it is by ftrong folds of the body, by fierce verberations of the tail, by twining round, and drawing the knot with convulfive energy.

\section{T H E S N A K E.}

TI THER TO this kind of creatures has furnithed only mifchievous 11 reptiles, whofe mortal poifons, thóugh hidden, were dreadful; minifters of death,' counteracting the principles of life. But we muft not thus confider all that belong to it; on the contrary, the green and yellow jnake of France is faid to be mild, gentle, and even familiar; his colours are iplendid and beautiful; and it is not uncommon to fee children tie two by the tails, and drive them, in imitation of coach-horfes, where they pleafe, not only without refiftance from the creatures, but with feeming pleafure. They even acquire an affection for thofe who keep them: we are told of one who knew its miftrefs ${ }^{\circ}$ voice and manner of laughing; came when called; followed by her fide when walking, as if waiting orders; glided around her arms, as if careffing her: at length he was thrown into a river to fwim, while his miftrefs followed in a boat; to this he kept clofe for fome time, ever attentive to the voice of his miftrefs; till the turn of the tide proved too powerful, and he was drowned. Is three or four feet long. Oviparous. 


\section{THE LADIES' SNAKE.}

The Common Snake in England is of the fame nature; remarkably fond of milk, and is faid to fuck cows when lying down.

The Black Snake is the largeft of Englifh ferpents, fometimes exceeding four feet in length. The neck is nender; the middle of the body thick; the back and fides covered with fmall fcales; the belly with oblong, narrow, tranfverfe plates : the colour of the back and fides is a dufky brown; the middle of the back marked with two rows of fmall black fpots, running from the head to the tail ; the plates on the belly are dufky; the fcales on the fides are of a blueifh white; the teeth are finall and ferrated, lying on each fide of the jaw in two rows. The whole fpecies is perfectly inoffenfive; taking thelter in dunghills, and among buthes in moift places; from whence they feldon remove, unlefs in the midit of the day, in fummer, when they are called out by the heat to baik themfelves in the fun. If difturbed or attacked, they move away among the brambles with great fwiftnefs; but, if too clofely purfued, they hifs and threaten, and thus render themfelves formidable, though incapable of offending.

Preys upon frogs, infeets, worns, mice, and young birds; and, confidering the fmallne fs of the reck, it is amazing how large an animal it will fwallow. The black fnake of Virginia, which is larges than ours, and generally grows to fix feet long, takes a prey proportionable to its fize; partridges, chicken, and young ducks. It is generally found in the neighbourhood of the hen rooft, and will devour the eggs even while the hen is fitting upon them: thefe it fwallows whole; and often, after it has done the mifchief, will coil itfelf round in the neft.

: Are oviparous, excluding eighty or an hundred eggs at a time, which are laid in dunghills or hot-beds; the heat of which, aided by that of the fun, brings them to maturity. During winter they lie torpid, in banks or hedges, and under old trees.

\section{THE L A D I E S' S N A K E}

GEEMS to enjoy a name which unites contrary ideas; few of the fair $\checkmark$ fex, in thefe climates, being fond of this genus of animals: but, on the coaft of Malabar, the ladies carefs this fnake, warm him in their bofoms, keep him there without fear, and the little creature feems fenfible of their good-will, and returns carefs for carefs : this is during the 
rainy feafon, when the fnake is apt to be chilled by the too great fiefhnefs of the air: During the heats, they receive from him-a contrary fervice, and his coolnefs is then to them refrehing; his polifhed fcales being always cooler than the atmofphere. Is beautiful black and white, highly luftrous; he is not fearful, nor flies when approached. 'Is but fmall.

This is not the only ferpent familiar with the human race. In fome countries, where fuch reptiles are common, while they deftroy ferpents of one kind with great animofity, they take others into their houfes and bofoms with affection. The Efculapion Serpent of Italy is among this number. It is fuffered to crawl about the chambers, and often into the beds. It is a yellow ferpent, about an ell long; familiar and innocent, yet will bite when exafperated. They are faid to be great deftroyers of mice; and this may be one reafon why they are taken under human protection. The Boiga of Ceylon (it inhabits both continents alfo) is equally a favourite among the natives; and they, confider the meeting it as a fign of good luck. They confider themfelves as extremely happy if this animal comes into their huts. The colours of this ferpent are fo many and beautiful, that they furpafs defcription; and thefe perhaps are the chief inducements to the favages to confider its vifits as fo very fortunate. An equal favourite is the Japanefe Prince of Serpents. The fcales on the back are reddifh; finely thaded, and marbled with large fpots of irregular figures mixed with black. The fore part of the head is covered with large beautiful fales, the jaws bordered with yellow, the forehead marked with a black marbled ftreak, and the eyes handfome and lively.

\section{T H E T A B O I E,}

THOU.GH not hurtful by its poifon or its fangs, is yet among thofe moft injurious to mankind, as it is the object of idolatry among the inhabitants of Whida, on the coatt of Africa, where he has his temples, his altars, his priefts, his donations; and his devotees; including a felection of beauty enjoyed in his name, but not by himfelf.

He is whitifh on'this upper parts; with great oval fpors, reddifh, bordered black or brown, which lie in three rows from head to tail, the fcales on his head refembling thofe on his back; yet he is not venomous. 


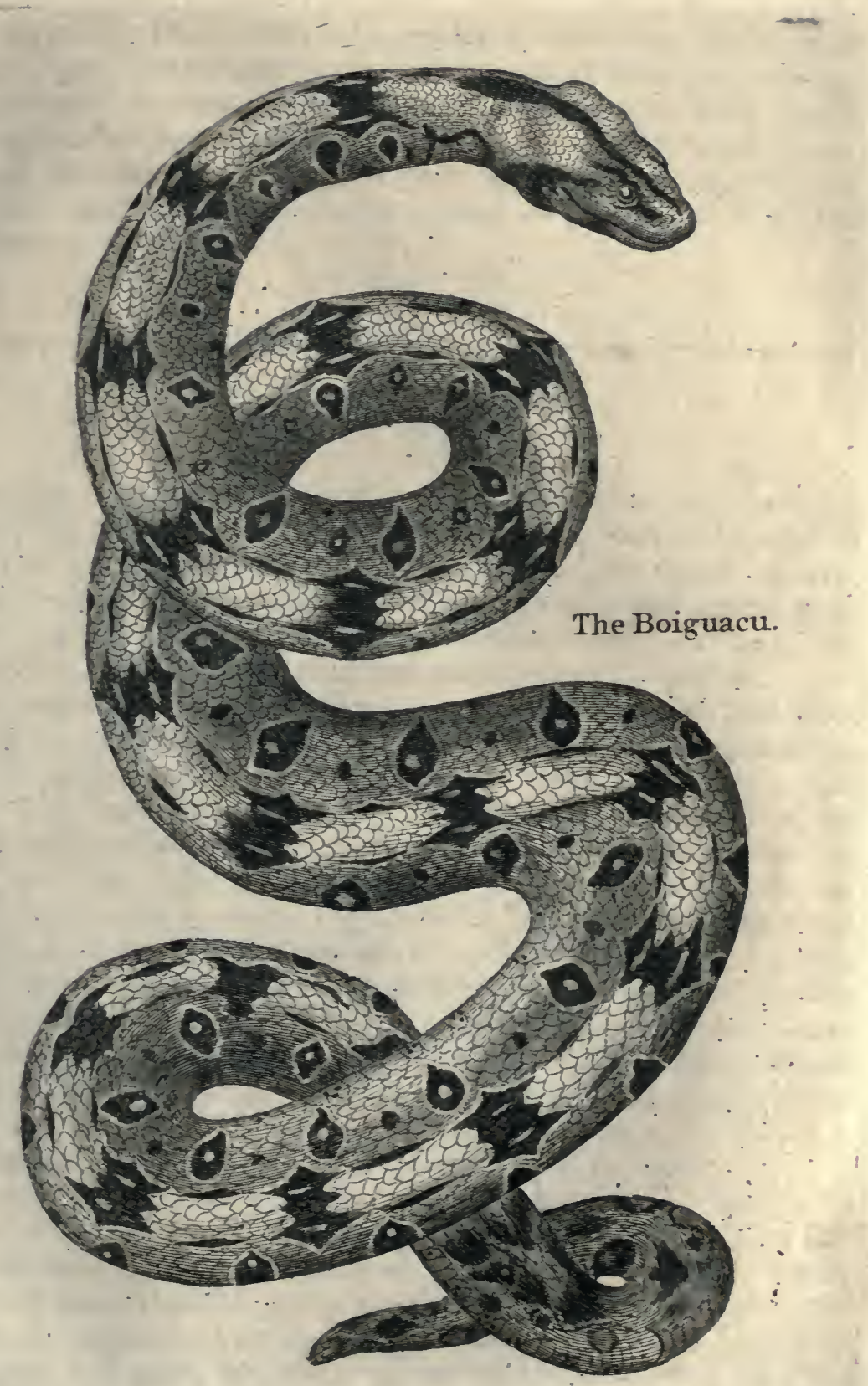




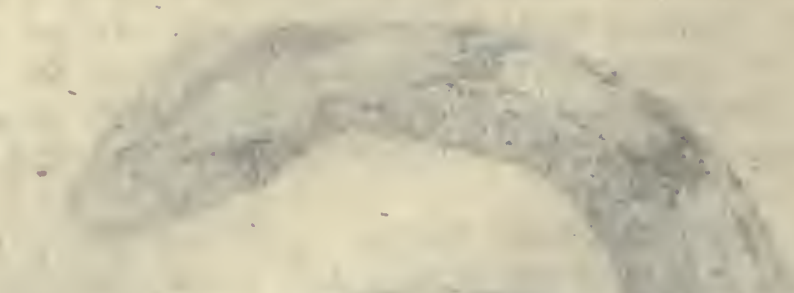

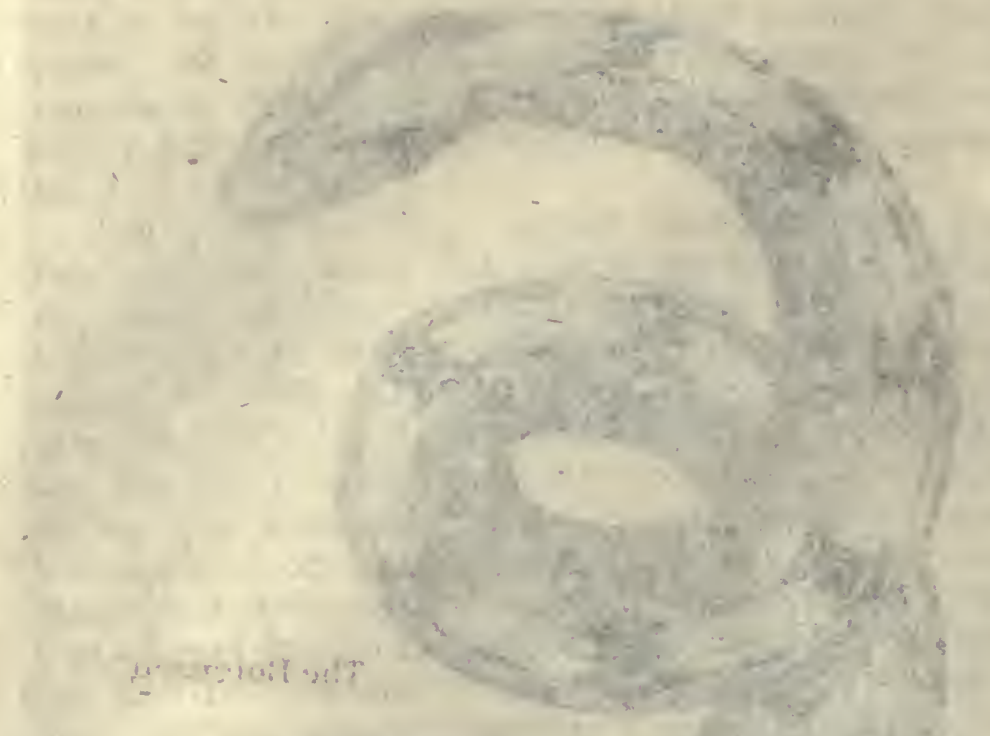

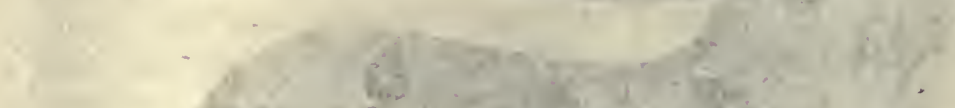

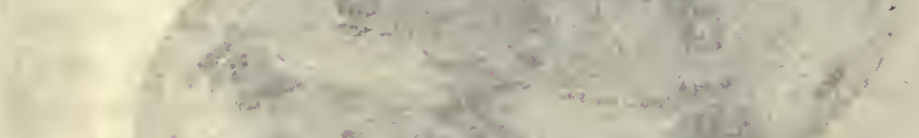

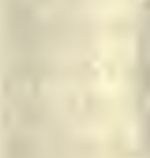

- .

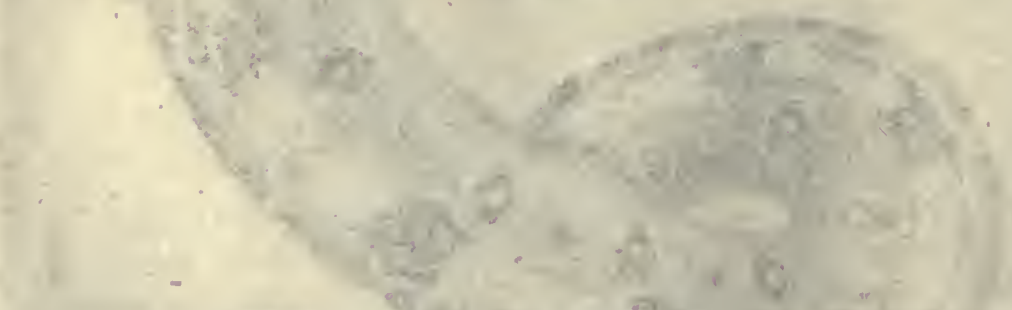

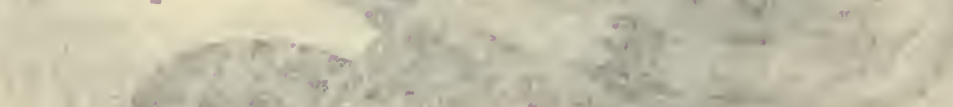

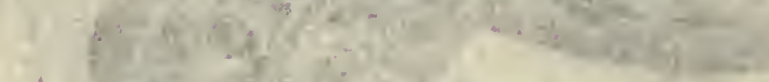

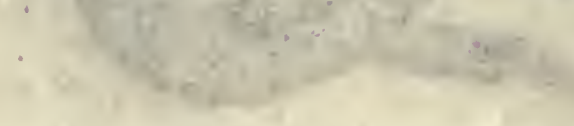


Length three to four, feet. Where he refides, animals that might injure him are forbidden; particularly the hog, though fo ufeful a quadruped in devouring noxious ferpents, leaft he thould devour their GOD. He is familiar to man; but has the reputation of attacking venomous ferpents, infects, and worms, which overrun that country: nor is he lefs efteemed for miraculou's affiftance in battle, in arts, commerce, and good fortune.

\section{T-H E B O I G U A C U}

T $S$ the largeft ferpent in the world; of that kind which has the fcales on its tail and belly fimilar; has no venom, but ample ftrength to counterbalance its abfence. Nature has beftowed on this reptile, beauty, fize, agility, ftrength, and induftry. As the elephant among quadrupeds, he furpaffes the reft of his order. Is commonly twenty feet long, but fometimes forty or fifty, where food and quiet permit his growth.

His head refembles that of a fetting dog; the fummit is wide; the forehead raifed, and divided by a longitudinal hollow; his eyes are large, their orbits projecting; his mouth opens very wide; his teeth are long. This enormous reptile is diftinguifhed by the beauty of his fcales, and the vivacity of their colours, which vary according to climate, age, and fex. On the head he has a great deep-coloured or black fpor; orhers are regularly ranged down him : belly afh-coloured yellow, fpotted black. His hiffings are long, tharp, and frightful : thefe are thought to be molt frequent before ftorms and temspefts, perhaps before peftilential diftempers which arife from the atmofphere; and therefore thefe have terrified into fuperftition the natives of Mexico, who confider this reptile as a meffenger of divine wrath; and floods of human gore have been offered to his image. In Africa alfo he is no lefs territically worhipped, on the coaft of Mofambique, and in Japan.

Inhabits all countries hot enough to maintain him, fertile enough to furnifh him with prey, and fpacious enough to prevent his being frequently molefted; formerly was known more northerly, when woods were more abundant on this fide the Mediterranean. In Africa, the only mean of deftroying him is by fire: fteel avails little : but often fire is fet to. the long grals, \&c. already fcorched by the burning fun; this PArt V. No. 29. 
foon fpreads, and interpofes a barrier which ftops his purfuit. He fwims readily, even in agitated waves, in rivers, or arms of the fea; he mounts the higheft trees. with rapidity; and, ftationed at various heights, often waits in ambufh the approach of prey, leaping from tree to tree. Some eat firh, and all, devour whatever they can conquer. A ftroke of his tail will knock down a man. He devours tigers and cougars. His manner of feeding, and condition after it, we have already noted : his inactivity is fo fixed, that travellers have walked over him (covered as he is with leaves, \&c.), or repofed upon him, without his moving; nor has he-given figns of life till the heat of their fire has reached him. Often large animals are placed as baits for him, and he is knocked on the head after his meal. The negroes eat his fleh, which they highly relim. In other countries they wear his fkin for clothing or ornament, as did the heroes of antiquity. Sheds his fkin after the rainy feafon; and then the fexes feek each other. The egg from whence iffues this monfter, is but two or three inches long, hatched by the fun's heat. "Its length of life unknown, probably very great; fince to reach his ordinary dimenfions, muft require many years.

There are others of this kind (for indeed it includes the largeft of the ferpent tribe); but none equal, or nearly equal, in fize or voracity.

\section{T H E R A T T L E-S N A K E:}

$7 \mathrm{HE}$ lion, by his roar, is not more terrific to the furprifed traveller, 1 than this fnake by his rattles and his fetid fmell ; his poifon is not lefs deftructive than that of the Naja.

Is peculiar to America, which it inhabits from north to fouth. Some are as thick as a man's leg, and fix feet in length; but their moft ufual fize is from four to five feet long: tail four inches. In many particulars it refembles the viper; having a flatted head, covered near the nofe with fix fales, larger than their neighbours, difpofed in three rows croffwife, two in each row. The throat is large; the tongue black, thin, forked; partly covered, and very mobile and agitable. The two bones of the fides of the jaws are not united in front, but admit of feparation: its teeth turn backward, are largeft next the nofe; their fangs refemble thofe of the viper. The eye fparkles and fhines, in the dark; is furnifhed with a nictitating membrane, that preferves it from duft. Its 


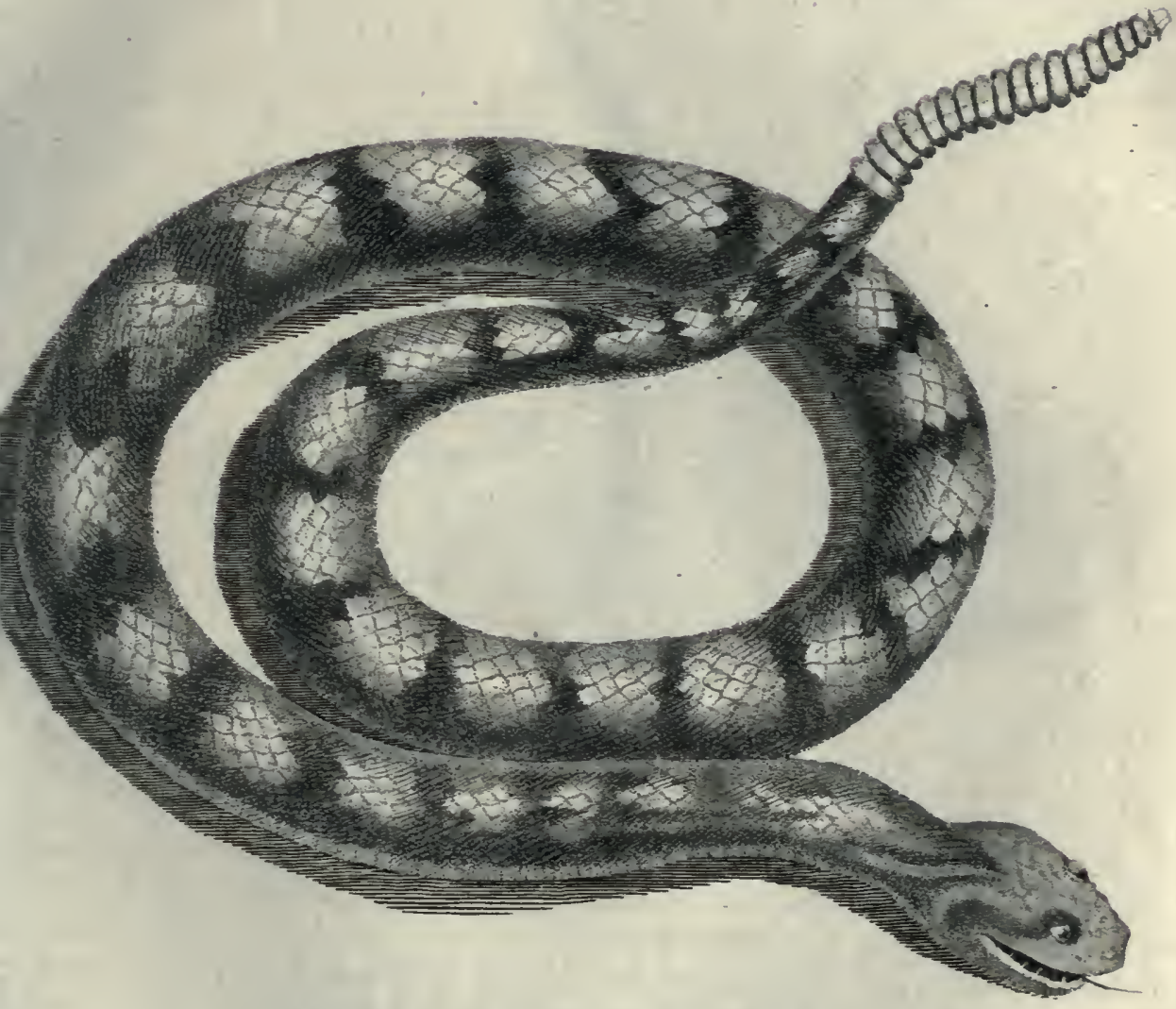

Rattle-Snake

Plate 1. 

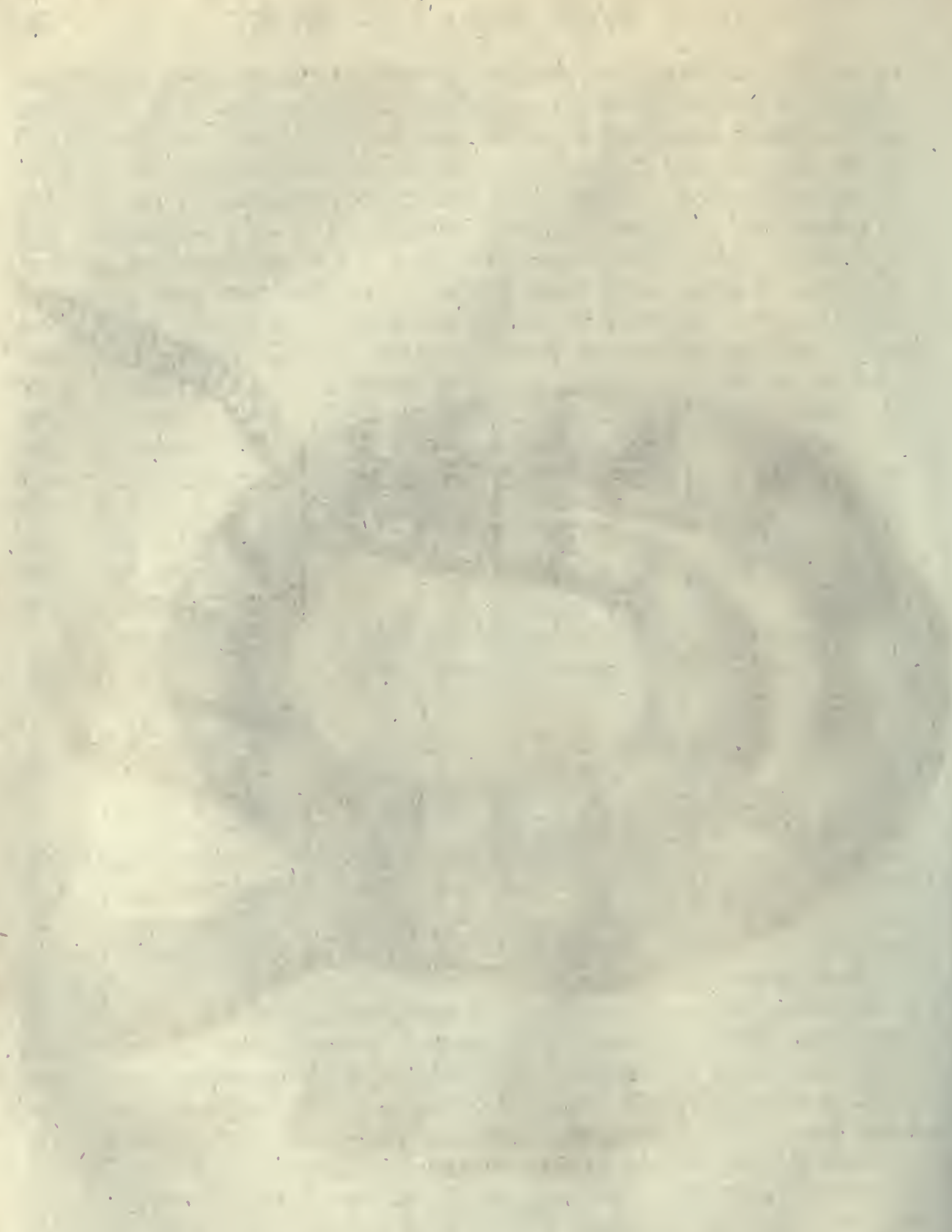

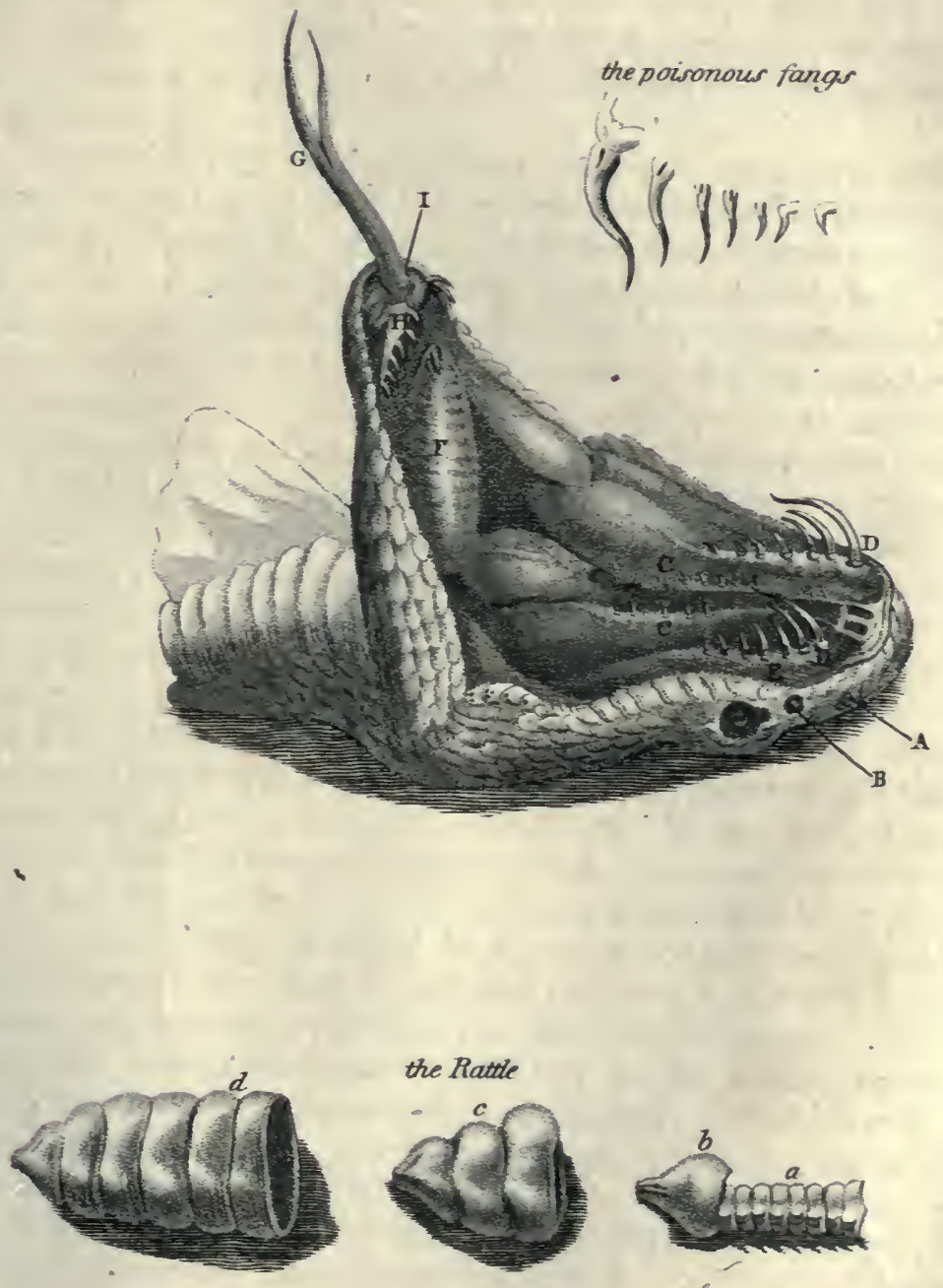

Rattle-Snake.

Plate II. 

icales are of a confiderable degree of hardnefs, oval, and rifing in the middle. A fingle row of fcales under both tail and belly. They are orange-tawny, and blackifn-coloured on the back; and of an afh-colour on the belly, inclining to lead, with black fpots. The male may be readily diftinguifhed from the female, by a black velvet fpot on the head, and by the head being fmaller and longer. But that which is peculiar to them is the rattle at the end of their tail, by which they make a loud rattling noife when they move.

This rattle is compofed of feveral pieces, from one to thirty, alike in form, and often in fize; brittle, elaftic, femi-tranfparent, and of the fame nature as the fcales; pyramidal, having four fides, two oppofite larger than two others; that next the body inclofes the latter vertebra of the tail; is formed upon them, and feparated from them by a very thin membrane, fo as to fit them exactly. Are hollow; each piece locks into another, being inclofed two thirds of its length in its fucceffor, yet fo as to play freely in it. Neither nerve nor mufcle attaches any of thefe rattles (except that next the tail) to the ferpent's body, but an exterior covering includes them : the furtheft is formed firft, the internals afterwards, punhing that off gradually; the whole are very dry and brittle, and rattle by ftriking each other : their noife refembles the crackling of parchment; may be heard fifty or fixty feet difance : it were defirable that the diftance were greater.

It is fuppofed by fome that the fnake acquires an additional bone every year; and that from hence its age may be precifely known : but this is very uncertain, efpecially as they eafily break off. However this be, fnakes of a year or two old have no rattles; while many old ones have been killed that had from eleven to thirteen; and tradition fays, formerly fome had thirty or more. They fhake thefe rattles with prodigious quicknefs when difturbed; yet the peccary and the vulture, no way terrified, haften at the fignal to feize the fnake, as their favourite prey.

It moves along with the moft majeftic rapidity ; neither feeking to offend, nor fearing infult. Unprovoked, it meddles only with its natural prey; but when accidentally trod upon, or purfued, it makes a dreadful and defperate defence. It folds itfelf into a circle, erects itfelf on its tail, throws back its head, and inflicts its wound in a moment; then parts, and inticts a fecond wound. The inftant the wound is inticted, though fmall, it appears more painful than the fing of a bee. This pain, which is fo fuddenly felt, far from abating, grows every moment more excruciating and dangerous : the whole body fwells; the venom reaches the $\mathrm{Ll}_{2}$ head, 
head, which is foon of a monftrous fize; the mouth is too fmall to contain the fwelling tongue; the eyes are red and fiery; the heart beats quick, with frequent interruptions; the pain becomes infupportable; devouring thirft torments the patient, and water or drink makes it worfe; the fpittle becomes bloody: and fome expire under it in five or fix hour's; but others, who are of Atronger conftitutions, furvive the agony for a few hours longer, only to fink under a general mortification which enfues, and cor: rupts the whole body. Sometimes ten minutes time is fatal. One that was teized and irritated' to bite himfelf, died in twelve minutes.

Several remedies have been tried to alleviate this calamity. A decoc. tion of the Virginian feneka, or fnake-root, is confidered as the mott effectual. The Indians dip their arrows in the poifon under the rattlefnake's fangs, when they defire to take a fignal revenge on their enemies. The Indians eat them, feizing them by the head, in cool weather. They do not quit their retreats till after all the fnow is melted; at this time they are purfued with little or no danger. In fummer they prefer hilly countries, and warm expofures on the fouth afpect of a hill : hide fometimes under fallen trees, fo that the Americans do not crofs them if they can help it; if they muft, they leap off from them as fár as poffible.

Eats worms, frogs, hares, fquirrels, birds, \&c. Climbs trees with facility; leaps from branch to branch, or from rock to rock; on level ground moves with heavier motion. With regard to his charming his prey, when out of reach; opinions are divided; fome referring it to the fire and vivacity of his eyes, fome to their being overcome by his fotor; fome think there is no fuch thing, but that they have been previouny bitten, and efcaped; yet, being poifoned, he awaits the effect. During rain and thunder he is moft dreadful (not that he fears water, for he fwims well), efpecially as then his rattles do not found. Has a formidable enemy in a fnake as large as itfelf, which is very ftrong, and twifts itfelf round him with fuch contractile force as to fqueeze him to death; hence this fnake is called confriztor: it is not venomous, therefore its breed is encouraged. Who can tell but that in time, by the exertion of fo many enemies, men, hogs, vultures, and fellow fnakes, a rattle-fnake might be confidered as an animal merely ideal, or found only in cabinets.

There are other ferpents having rattles in their tails. Such are the Millet, whofe head has nine fcales on it; general colour, grey: a fmall kind. The Dryinas, whitifh, fpotted, and yellow. The Durifus. And the Pifcivorous, which has properly no rattle (i. e. of many bones), 'but prhore tail terminates in a boney or cornified point, not an inch in length : 


\section{THE BLIN D WOR M.}

length: five or fix feet long: he hangs on branches of trees that are fufpended over ftreams, and dartsd own on fifh that are pafing : purfues and feizes them in the water, and brings them to land to devour: fometimes falls in the fame manner on men.

\section{THE BLIN D W O R M.}

THE Blind Worm is a harmlefs reptile, with a formidable appearance. Has nine large fcales on his head; firft one, then two; a third and fourch row, three each : his fcales are very imall : his tail is longer than his body : the bones of his under jaw are not feparated, as in moft ferpents. The ufual length of this fpecies is eleven inches, but in fome countries three feet. The eyes are red; the head fmall; the neck nender; from that part the body grows fuddenly, and continues equal, to the tail, which ends quite blunt: the colour of the back is cinereous, marked with very fmall lines, compofed of minute black fpecks; the fides are of a reddin calt; the belly dufky, and marked like the back. The motion of this ferpent is now : from which, and from the fmallnefs of the eyes, are derived its names; fome calling it the Slow, and fome the Blind Worm. Like all the reft of the kind, in our climates, they lie torpid during winter; and are fometimes found, in vaft numbers, twifted together. The moft remarkable property of this ferpent is, that when irritated it becomes as ftiff as a board; and, if fmartly ftruck in this ftate, is eafily broken; its mufcles being compofed of fibres that readily feparate. Hence it is called by fome the Glajs Snake, and by Lin waus Anguis fragilis.

\section{TH E A M P H I S B N 度}

A R E eafily diftinguifhed from all other ferpents, as they have, proA perly fpeaking, no fcales, but rings round their bodies: their upper and under fides are fo fimilar, that, were their head and vent hidden, their 
their back or belly could not be diftinguifhed. This peculiarity of rings gives them great facility in many motions of which other ferpents are incapable; and by offering no impediment either way, but almait equal affitance, they can move forward or backward at pleafure. Their tail is as round as their head; fo that, when moving backward, no wonder they have been fuppofed to have a head at each end. That beft known is the SMoxy : almoft black, mingled with white : a foot or two in length, but fcarce two inches of tail; his eyes very fmall, covered by a membrane. Inhabits Ceylon and America. Eats worms, infects, beetles, \& \& $c_{\text {. }}$ is fond of ants. His fkin is very hard, and his mufcles ftrong; has no fangs, confequently is not venomous,

Another of this kind is wHITE, and often fpotlefs.

Of ferpents with tubercles only one kind is known: native of Java.

The Langaba of Madagafcar is divided, in its length, into three different parts', by fo many different kinds of fcales : has alfo a horned kind of fnout projecting; Is very venomous. 


\section{(203) \\ O $\quad$ F $\quad$ F. I S H E S.}

Y $T$ ' has been thought that all fin are naturally of the ocean; and that fome have mounted into freth water by accidental migration; yet, as many cannot live in falt water, this is at leaft doubtful. A few, indeed, fwim up rivers to depofit their fpawn; but the great body of fifhes keep to the fea, and would quickly expire in frefh water.

The number of fifh which we have named, and whofe figure we know, according to Linnæus, is above four hundred. But of the greatelt part of thefe we know very little befides their figure. Thofe qualities, fingularities, or advantages, that render animals worth our attention, are undifcovered. The hiftory of fifhes, therefore, has little in it entertaining: and will detain us proportionably lefs than any fubject yet introduced.

Moft fin offer the fame external form, fharp at either end, and fwelling in the middle, by which they are enabled to traverfe the fluid which they inhabit, with greater celerity and eafe. Every part feems exerted in this difpatch; the fins, the tail, and the activity of the whole back-bone; and to this flexibility fifhes owe their great velocity. The fins affitt not only in progreffion, but in rifing, finking, turning, or even leaping out of the water. The pectoral fins, like oars, pufh the animal forward; they are placed behind the opening of the gills; generally large and ftrong; and are to fin in the water what wings are to birds in the air. They alfo balance the firh's head, when large, and keep it from tumbling prone to the bottom; as is feen in large-headed fifhes, when the pectoral fins are cut off. Next thefe are the ventral fins, toward the lower part of the body, under the belly: thefe always lie flat on the water; and ferve to raife or deprefs the fin. The dorfal fin is fituated along the ridge of the back; keeps it in equilibrio, and alfo affifts progreffive motion: In many this is wanting; but in all flat filhes it is very large, as the pectoral fins are proportionably fmall. The anal fin lies between the anus and the tail; and ferves to keep the fin upright. But the tail, which in fome is flat, in others upright, feems the grand inftrument of motion: the fins are fubfervient to it, and direet its impetus.

To explain this by experiment-A carp put into a large veffel, in a ftate of repofe, fpreads all its fins, and feems to reft on its pectoral and ventral fins near the bottom, If the filn folds up either of its pectoral fins, it inclines to PART V. No. 22. 
that fide : folding the right pectoral fin, the fifh inclines to the right fide; folding the left fin, it inclines to the left fide. If the firh defires a retrograde motion, friking with the pectoral fins, in a contrary direction, produces it. If the firh defires to turn, a blow from the tail turns it; but if the tail ftrike both ways, the motion is progreffive. In purfuance of thefe obfervations, if the dorfal and ventral fins be cut off, the fifh reels to right and left, and endeavours to fupply the lofs by keeping the reft of its fins in conitant employment. If the right pectoral fin be cut off, the filh leans to that fide; if the ventral fin on the fame fide be cut avay, then it lofes its equilibrium entirely. When the tail is cut off, the firh lofes all motion, and gives itfelf up to where the water impels it. Each of thefe fins has its peculiar ufe; but all confpire to affift each others motions. Some firh are pofferfed of all, whofe motions are yet not the fwifteft. Their number, fize, and fituation, feem calculated rather to correfpond with the animal's figure, than folely to anfwer the purpofes of fpeed. Where the head is large and heavy', the pectoral fins are large and forward. Where the head is fmall or long, the pectoral fins are fmall, and the ventral fins wanting.

Inhabitants of the water are covered with a nimy glutinous matter (a fecretion from the animal's body), that defends their bodies from the immediate contact of the furrounding fluid, and contributes to their eafy progrefs through the water. Beneath this, in many kinds, is a ftrong covering of fcales, a ftill more powerful defence; and under that, before we come to the mufcular parts of the body, an oily fubftance, which fupplies, or rather which includes, the requifite warmth.

Nature feems to have beftowed on thefe animals appetites and powers if inferior kinds. Formed for paffive exiftence in their obfcure and heavy element, to preferve this exiftence, and to tranfmit it, is their whole purfuit and enjoyment. Impelled rather by neceffity than choice, and mechanically excited to every fruition, they chafe without diftinction whatever they can fwalloẅ, conquer, or enjoy.

A ceafelefs defire of food feems their ruling impulfe, and prompts them to encounter every danger. Their rapacity feems infatiable. Even when taken out of the water, and almoft expiring, they greedily fwallow the very bait by which they were allured to deftruction.

The maw is, in general, placed near the mouth; and, though poffeffed of no fenfible heat, is however endued with a furprifing faculty of digeftion, feeming in foine meafure to increafe with the quantity of food, It digents not only fin, but prawns, crabs, and lobfters, nells and all; though thefe thells are fo much harder than the fides of the ftomach 


\section{F I S E S I N GEN ERAL:}

which contains them. This amazing faculty has juftly excited curiofity; and feems to fuggeft fome principle in the ftomach, yet unknown, which acts in a different manner from all kinds of artificial maceration; and which is lodged in firhes in a greater degree than in other creatures. Ever hungry, and ever prowling, yet no animals can fuffer abftinence fo long. The gold and filver fin we keep in vafes feem never to want nourifhment : whether they feed on water-infeets too minute for our obfervation, or whether water alone is a fufficient fupply, is not evident; but they are often feen for months without apparent fultenance. Whatever living thing firhes are able to fwallow, becomes their food. Some, that have very fmall mouths, feed upon worms and fpawn of other fifh: others, whofe mouths are larger, feek larger prey. Thofe with the largeft mouths purfue almoft every thing that has life; and often meet each other in fierce oppofition; when the filh with the largeft fwallow enjoys the victory, and devours its antagonift.

Thus the life of a fifh is one fcene of hoftility, violence, and evafion. The fmaller fry efcape, by fwimming into thofe thallows where the greater are unable to purfue. Yet, even in the Rallows, the muffel, the oyfter, and the fcallop, lie in ambufh at the bottom, with their fhells open; and whatever little fifh inadvertently approaches into contact, they clofe their fhells upon, and devour. The purfuit of filhes is not confined to a fingle region, or to one effort: hoals of one fpecies follow thofe of another through valt traets of ocean, from the vicinity of the pole down to the equator. The cod, from the banks of Newfoundland, purfues the whiting even to the fhores of Spain. The cachalot purfues herrings, and fwallows thoufands at a gulp.

This may be one caule of the annual migration of fifhes; but fithes may be induced to change their place of refidence for one more fuited to their conftitutions, or more adapted to depofiting their fpawn. No fifh are fond of very cold water, but frequent places where it is warmeft. In fummer, they affemble in the thallows where the fun has power to warm the water to the bottom; in winter, they are found deeper.

All fifh require air for their fupport. The whale kind breathe, and come to the furface every two or three minutes for frefh infpiration: but thofe which continue entirely under water, if totally deprived of air, will expire in a very few minutes. Thus all the fin of a pond die, when the ice every where covers the furface, and keeps off the air. If a hole be made in the ice, the fin will be feen to come all to that part, for the $\mathrm{Mm}_{2}$ benefi: 
benefit of a frelh fupply : yet nothing is more difficult to be accounted for than the manner in which they obtain this fupply. Fin in the water have a motion of their lips and gills, - or at leaft of the bones on each fide that cover them. This motion is, without doubt, analogous to our breathing; yet it' is not air, but water, that the fifh actually fucks in. Their manner of breathing is probably thus: The fin firft takes a quantity of water at the mouth, which is driven to the gills; thefe clore, and keep the water fo fwallowed from-returning by the mouth; while the bony covering of the gills prevents it from going through them, until the animal has drawn the proper quantity of air from the water thus imprifoned: then the bony covers open, and difcharge it; the gills alfo admit a frefh quantity of water. Should the fin be prevented from the free play of its gills, or Should the bony covers be kept from moving, by a ftring tied round them, the animal would fall into convulfions, and die.

The air-bladder may ferve to contain this air for vital purpofes; as well as contribute to enabling the fin to rife and fink in the water at pleafure, as it is dilated or compreffed. The air-bladder is a bag filled with air, fometimes compofed of one, fometimes of two, and fometimes three divifions, fituated towards the back of the fifh, and opening into the maw or the gullet. Some fifh have an air-bladder that continually crawl at the bottom, fuch as the flounder; and fome are without it that fwim at eafe in every depth; fuch as the anchovy and gudgeon. Its neceffity then is not always equally ftrong.

"Moft of the diforders incident to mankind," fays Bacon, "arife from the changes and alterations of the atmofphere: but firhes refide in an element little fubject to change; theirs is an uniform exiftence; their movements are without effort, and their life without labour. Their bones alfo, which are united by cartilages, admit of indefinite extenfion; and the different fizes of animals of the fame kind among filhes is very various. 'They ftill keep growing; their bodies, inftead of fuffering the rigidity of age, which is the caufe of natural decay in land animals, ftill continue increafing with frelh fupplies; and, as the body grows, the conduits of life furnifh their ftores in greater abundance. How long a fifh, that feems to have fcarce any bounds put to its growth, continues to live, is not afcertained; perhaps the life of a man would not be long enough to meafure that of the fmalleft."

When a fifh's fcale is examined through a microfcope, it will be found to confift of a number of circles, one circle within another, in fome meafure refembling thofe which appear upon the tranfverfe fection of a tree, 
tree, and fuppored to offer the fame information: for; as in trees we can tell their age by the number of their circles, fo in filhes we can tell theirs by the number of circles in every fcale, reckoning one ring for every year of the animal's exittence. By this method M. Buffon found a carp, whofe fcales he examined, to be not lefs than an hundred years old. Gefner brings us an inftance of one of the fame age; and Albertus of one more than double that period. The age of the fate and the ray, that want fcales, may be known by feparating the joints of the back-bone, and then minutely obferving the number of rings which the furface, where it was joined, exhibits. But thefe methads may be, and probably are, very imperfect.

But their longevity is nothing, compared to their fecundity. few of the larger excepted) multiply by hundreds, and fome by millions. Some bring forth their young alive; fome produce eggs: the former are the leaft fruitful, yet even thefe produce two or three hundred at a time. Thofe that produce eggs, which they leave at the bottom of the water, or floating on the furface, are much more prolific: of thefe eggs few rife to life; they are devoured by the leffer fry, by aquatic birds, and by the larger fifh. Still, however, there are enough for fupplying the deep with inhabitants. The cod fpawns in one fealon, as Lewenhoeck affures us, above nine million of eggs, or peas, contained in one fingle roe. The flounder is commonly known to produce above one million; and the mackarel above five hundred thoufand. Such an amazing increafe, if permitted to come to maturity, would overftock nature, and the ocean itfelf would not be able to contain the half of its inhabitants. But two wife purpofes are anfwered by this amazing increafe; it preferves the fpecies in the midft of numberlefs enemies, and ferves to furnin the reft with a fuftenance adapted to their nature.

Fin have different feafons for depoliting their fpawn: fome that live in the depths of the ocean, are faid to choofe the winter; but in general they choofe fummer. They leave the ocean, and hoal round the coafts, or fwim up the freh-water rivers, which are warm as they are comparatively thallow. When they have depofited their burthens, they then return to their old ftations, and leave their nafcent progeny to fhift for themfelves.

The fpawn continues in its egg-ftate in fome firh longer than in others, and this in proportion to the animal's fize. In the falmon, the young continue in the egg from the beginning of December till the beginning of April; the carp continues in the egg not above three weeks; the little 
gold fifh from China is ftill quicker. Thefe at firft efcape by their mirutenefs and agility. They rife, fink, and turn; much readier than grown fin ; and they can efcape into very fhallow waters when purfued.

But there are fome that have all the tendernefs of birds or quadrupedes for their young; that nurfe them with conftant care, and protect them from every injury : of this difpolition are the cetaceous or whale kind; they bring them alive into the world, and defend them with courage and activity: alfo, in part, the cartilaginous kinds, which have griftles inftead of bones. But the tribe we have been defcribing, that leave their fpawn without protection, are called the fpinous or bony kind, from their bones refembling the Tharpnefs of thorns.

The cetaceous, the cartilaginous, and the spinous, differ from each other in conformation, appetites, bringing forth, and in the education of theiryoung. Thefe three great diftinctions are ftrongly and firmly marked in nature.

\section{O F. G E TACE O US F I S H E S.}

7 HIS tribe comprifes the Whale, the Cachalot, the Dolphin, the Grampus, and the Porpeffe. All thefe refemble quadrupedes in their internal ftructure, and in fome of their appetites and affections. They have lungs, a midriff, a ftomach, inteftines, liver, fpleen, bladder, \&c. Their heart alfo refembles that of quadrupedes, with its partitions clofed up, as in them, and driving red and warm bluod in circulation through the body. Every internal part bears a moft ftriking fimilitude; and, to keep thefe parts warm, the whole kind are covered, between the $f$ kin and the mufcles, with a thick coat of fat or blubber, like the bacon-fat of a hog. As thefe animals breathe, they are conftrained, every two or three minutes, to come up to the furface to take breath, as well as to fpout out through their noftril what water they have fucked in. This conduit is placed in the head, a little before the brain. Though externally the hole is fingle, it is internally divided by a bony particion, which is clofed by a fphineter mufcle on the infide, that huts it up at the pleature of the animal. Another-mufcle or valve prevents the water from going down the gullet. When therefore a quantity of water is neceflary to be difcharged, it thuts 


\section{OF T H E W-H A LE.}

the mouth, clofes the valve of the ftomach, opens the fphineter at the noftril, and then breathing ftrongly, drives out the water.

Their eyes have eyelids, as in man; it is moft likely that they can hear, as they certainly utter founds, and bellow to each other. This vocal power would be needlefs to animals haturally deaf. The female fuckles in the manner of quadrupedes, her breafts being placed above the navel.

The number of their fins never exceeds three; i.e. two pectoral fins, and one back fin; but in fome forts the laft is wanting. Thefe fins are made up of bones and mufcles; and their nkeleton refembles that of a man's hand. Their tails alfo are placed fo as to lie flat on the furface of the water; not upright or edgeways. This flat poficion of the tail enables them to force themfelves fuddenly to the furface.

Some are without teeth, properly called whales; others have teeth only in the lower jaw, and are called by the French cacbalots: the narwhal has teeth only in the upper jaw; the dolphin, porpeffe, and grampus have teeth both above and below.

\section{OF TH E W H L E.}

TJ E now no longer hear of whales two hundred, and two hundred N and fifty feet long, which were often feen two centuries ago. They have been deftroyed by mankind, and the fpecies is dwindled into a race of diminutive animals, from thirty feet to eighty. Taking the whale at his ordinary fize of eighty feet long and twenty feet high, what an enormous animated mals it appears! Yet this great creature gambols in the deep, with the eafe and agility of the fmalleft animal, and makes its way with incredible fwiftnefs! Though this be wonderful, perhaps greater wonders are concealed in the deep. Who knows the fize of thofe that remain conftantly under water, and that have been increafing in magnitude for centuries? to receive all that has been faid of the fea-ferpent, or the Kraken, would be credulity; to reject all, or to deny the poffibility of their exiftence, would be prefumption.

The whale is the largeft animal of which we have any certain informa. tion; there are feven different kinds; the Great Greenland Whale, without a back fin, and black on the back; the Iceland Whale, without a back fin, and whitin on the back; the New England Whale, with a hump on the back; the Whale with fix humps on the back; the Fin-filh, PART V. No. 29: 
with a fin on the back near the tail; the Pike-headed Whale, and the Round-lipped Whale. The fin-fith having a larger fwallow than the reft, is more active, nender, and fierce, living chiefly upon herrings. However they are none of them very voracious.

The Great Greenland Whale is the fin the taking which is fuch an object in different-parts of Europe. It is a large heavy animal, and the head alone makes a third of its bulk. The fins on each fide are from five to eight feet, compofed of bones and mufcles. The tail about twentyfour feet broad; and when the fin lies on one fide, its blow is tremendous. The fkin is fmooth and black, and, in fome places, marbled with white and yellow; which, running over the furface, has a very beautiful effect. This marbling is particularly obfervable in the fins and the tail.

The whale ures only the tail to advance in the water, and it is furprifing to fee with what force and celerity its enormous bulk divides the ocean. The fins are only ufed for turning, and directing the velocity impreffed by the tail. The female alfo ufes them, when purfued, to bear off her young, clapping them on her back, and fupporting them by the fins on each fide from falling.

The outward or farf $\mathrm{fkin}$ of the whale is no thicker than parchment; but, this removed, the real fkin appears, an inch thick, and covering fat or blubber from eight to twelve inches in thicknefs; of a beautiful yellow. The mufcles lie beneath; and thefe, like the flefh of quadrupedes, are very red and tough.

The mouth is above twenty feet long, the upper jaw furnifhed with barbs, the greateft in the middle, the fmalleft toward the fides. Thefe are the whale-bone; the longeft fpars of which are eighteen feet. The tongue is almoft immoveably fixed to the lower jaw, feeming one great lump of fat; and, in fact, it fills feveral hogheads with blubber. The eyes are not larger than thofe of an ox; and when the cryftalline humour is dried, it does not exceed a pea. They are placed towards the back of the head, being the moft convenient fituation for enabling them to fee, both before and behind; as alfo to fee over them, where their food is principally found. They are guarded by eye-lids and eye-lantes, and they feem to be very fharp-fighted. As foon as the thin fcarf-fkin above mentioned is remoyed, a black fpot is difcovered behind the eye; under that is the auditory canal, leading to a regular apparatus for hearing. In Short, the animal hears the fmalleft founds at very great diftances, and 
at all times, except when it is fpouting water; which is the time that the filhers approach to ftrike it.

The fpout-holes or noftrils in this whale are two; one on each fide the head, before the eyes, and crooked, fomewhat like the holes on the belly of a violin. From thefe holes this animal blows the water very ficrcely, and with fuch a noife that it roars like a hollow wind, and may be heard at three miles diftance. When wounded, it then blows more fiercely than ever, fo that it founds like the roaring of the fea in a great ftorm.

The real bones are hard, like thofe of great land animals, very porous, and filled with marrow. Two great ftrong bones fuftain the under lip, lying againt each other in the thape of a half-moon: fome of thefe are twenty feet long.

The whale goes with young nine or ten months, and is then fatter than ufual, particularly when near the time of bringing forth. The cub, when excluded, is black, and about ten feet long. When fhe fuckles her young, the throws herfelf on one fide, on the furface of the fea, and the young one attaches itfelf to the teat. The breafts are two, generally hid within the belly; but the can produce them at pleafure, fo as to ftand forward a foot and a half, or two feet; and the teats are like thofe of a cow. In fome, the breafts are white; in others fpeckled; in all, filled with a large quantity of milk, refembling that of land animals. The young continue at the breaft for a year; during which time they are called by the failors fort-beads. They are then extremely fat, and yield above fifty barrels of blubber. The mother, at the fame time, is equally lean and emaciated. At the age of two years they are called ftunts, as they do not thrive much immediately after quitting the breaft; they then yield fcarce above twenty or twenty-four barrels of blubber: from that time forward they are called kull$_{\text {-fifh, }}$, and their age is wholly unknown.

Every fpecies of whale propagates only with thofe of its own kind, and does not at all mingle with the reft: however, they are generally feen in thoals of different kinds together, and make their migrations in large companies from one ocean to another. They are a gregarious animal, which implies their want of mutual defence againft the invalions of fmaller, but more powerful fithes.

They cannot fwallow large fiches, as their throat is fo narrow that an animal larger than a herring could not enter. How then do they fubfint and grow fo fat? A fmall infect which is feen floating in thofe feas, and which Linnæus terms the Medufa, is fufficient for this fupply. Thefe 
infects are black, and of the fize of a fmall bean, and are fometimes feen floating in clufters on the furface of the water. They are round, like fnails in a box; but they have wings, which are fo tender that it is farce poffible to touch them without breaking. Thefe ferve rather for fwimming than flying; and the little animal is called by the Icelanders the Walfifchoas, which fignifies the whale's provender. They have the tafte of raw muffels, and have the fmell of burnt fugar. Thefe are the food of the whale, - which it is feen to draw up in great numbers with its huge jaws, and to bruife between its barbs, which are always found with feveral of thefe fticking among them.

As the whale is an inoffenfive animal, it is not to be wondered that it has many enemies, willing to take advantage of its difpofition, and inaptitude for combat. There is a fmall animal, of the fhell-fifh kind, called the Whale-loufe, that fticks to its body, and infinuates itfelf chiefy under the fins; and whatever efforts the great animal makes, it ftill keeps its hold, and lives upon the fat. The faw-fifh, however, is the whale's moft terrible enemy. At the fight of this animal, fays Anderfon, the whale feems agitated in an extraordinary manner; leaping from the water as if with affright: wherever it appears, the whale perceives it at a diftance, and flies from it. "I have been myfelf," continues he, "a fpectator of their terrible encounter. The whale has ro inttrument of defence except the tail; with that it endeavours to itrike the enemy; and a fingle blow taking place, would effectually deftroy its adverfary: but the faw-filh is as active as the other is ftrong, and eafily avoids the ftroke; then bounding into the air, it falls upon its great fubjacent enemy, and endeavours, not to pierce with its pointed beak, but to cut with its toothed edges. The fea all about is foon dyed with blood, proceeding from the wounds of the whale; while the enormous animal vainly endeavours to reach its invader, and ftrikes with its tail againft the furface of the water, making a report at each blow louder than the noife of a cannon."

There is ftill another and more powerful enemy, called, by the fifhermen of New England, the Killer. 'This is itfelf a cetaceous animal, armed with ftrong and powerful teeth. A number of thefe are faid to furround the whale, in the fame manner as dogs get round a bull. Some attack it with their teeth behind; others attempt it before; until, at laft, the. great animal is torn down, and its tongue is faid to be the only part they devour when they have made it their prey. They are faid to be of fuch. great ftrength, that one of them alone was known to ftop a dead whale that 


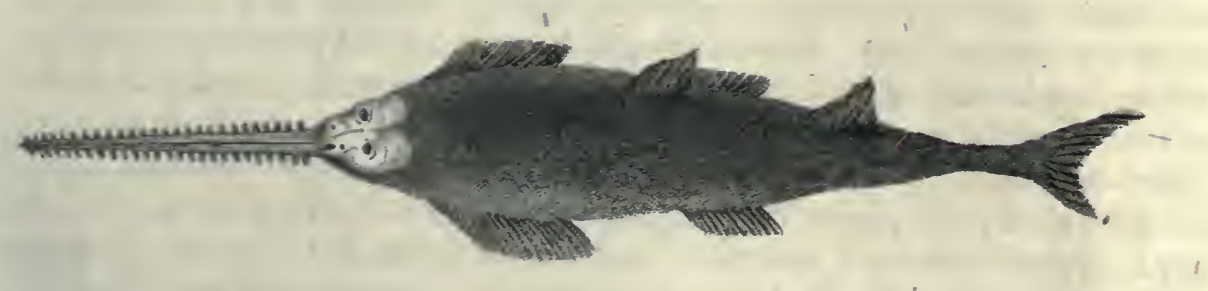

The Saw-fifh 


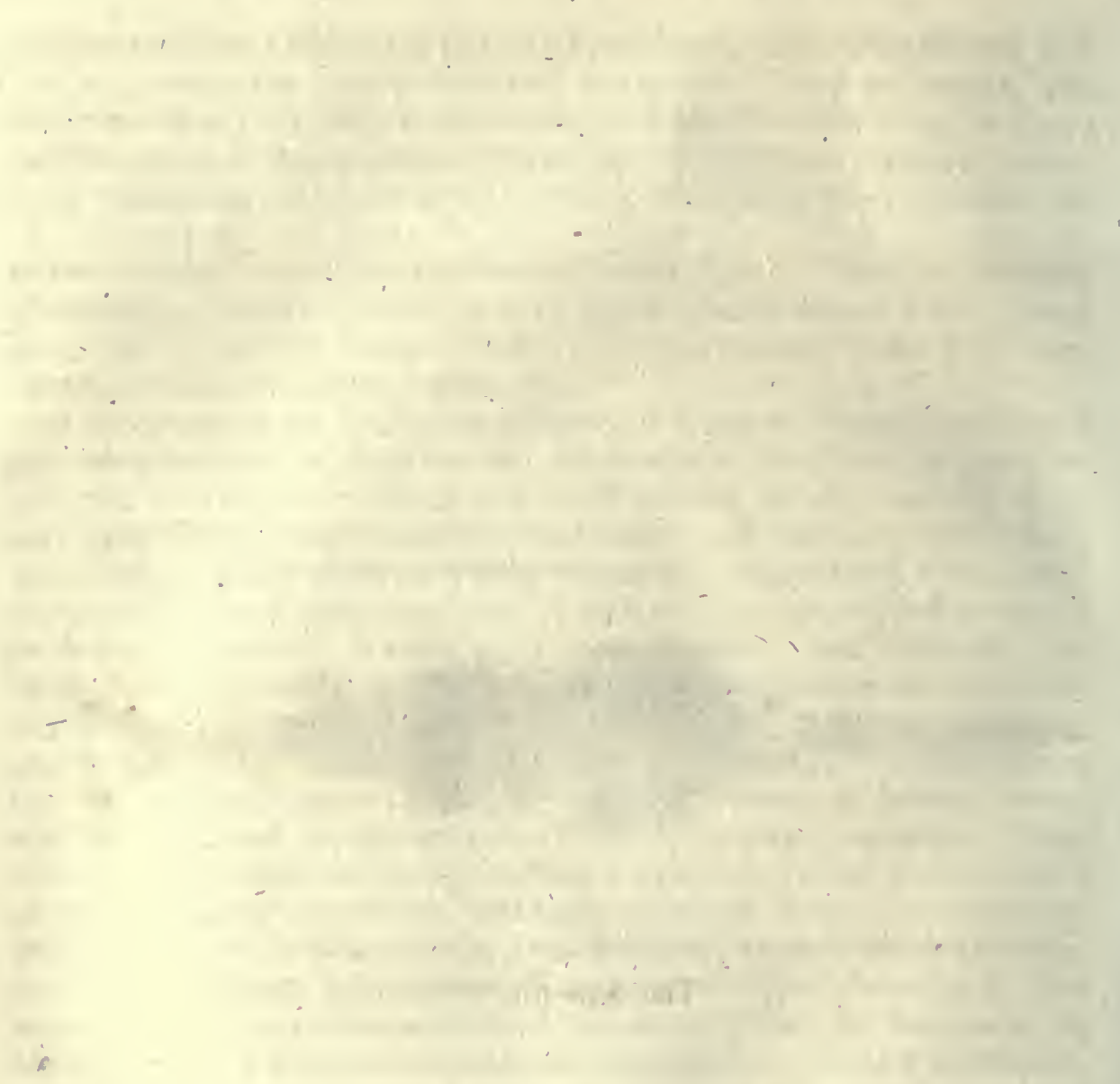


that feveral boats were towing along, and drag it from among them to the bottom.

But of all the enemies of thefe enormous filhes; man is the greateft: he alore deftroys more in a year than the reft in an age, and actually has thinned their numbers in that part of the world where they are chielly fought. The European thips, foon afier the improvement of navigation, found the way into thofe féas; and as early as the beginning of the fourteenth century, the Bifcayners were in poffeffion of a very confiderable trade to the coaft of Greenland. The Dutch and the Englin followed them thither, and foon took that branch of commerce out of their hands. At prefent, the quantity of fin are fo greatly reduced, by conftant capture for fuch 2 valt length of time, that we crofs the line, and voyage to the South Pole, for what we ufed to find in the North.

When arrived at the part where the whales are expeeted, the fhips always keep their fails fet; and a failor is placed at the maft-head, to give information when he fpies a whale. As foon as he difcovers one, the whole crew are inftantly in employment : they fit out their boats, and row to where the whale was feen. The harpooner, who is to ftrike the fin, ftands at the prow of the boat, with an harpoon or javelin in his hand, five or fix feet long, pointed with fteel like the barb of an arrow, of a triangular thape. As this perfon's place is that of the greateft dexterity, fo alfo it is of the greateft danger: the whale fometimes overturns the boat with a blow of its tail, and fometimes drives againft it with fury. In general, however, the animal feems to neep on the furface of the water; while the boat approaching, the harpooner ftands aloft, and, with his harpoon tied to a cord of feveral hundred fathom length, darts it into the animal, and then rows as faft as poffible away. It is tome time before the whale feems to feel the blow; the inftrument has ufually pierced no deeper than the fat ; and, that being infenfible, the animal continues for a while motionlefs: but foon roufed from its feeming lethargy, as the fhaft continues to pierce deeper and deeper into the mufcular flefh, it lies off with amazing rapidity. In the mean time, the harpoon fticks in its fide; while the rope, which is coiled up in the boat, and runs upon a fwivel, lengthens as the whale recedes, but ftill thews the part of the deep to which it has retreated. This cord is coiled with great care : for fuch is the rapidity with which it runs off, that if it was but the leaft checked, as it follows the animal's retreat, it would infallibly overfet the boat, and the crew would go to the bottom. It fometimes happens alfo; that the rapidity with which it runs over the fwivel at the edge of the boat, heats it, and it would 
would certainly take fire, did not a man ftand continually with a wet mop in his hand, to cool the fwivel as the cord runs. The whale having dived to a confiderable depth, remains at the bottom, fometimes for near half an hour, with the harpoon in its belly; and then rifes to take breath, fuppofing the danger over : but the inftant it appears, they are all with their boats ready to receive it, and fling their harpoons into its body: the animal again dives and again rifes, while they repeat their blows. The fhip follows in full fail, like all the reft, never lofing fight of the boats, and reacy to lend them affifance; the whole ocean feems dyed in blood. Thus they renew their attack, till the whale begins to be quite enfeebled and fpent ; when they plunge their longer: fpears into various parts of it's body, and the enormous animal expires. When it is dead, to prevent it from finking, they tie? it with a ftrong iron chain to the fide of the boat; and either cut it up in pieces, and carry it home in that manner ; or extract the oil from the blubber on thip:board.

\section{T H E N A R W H A L.}

7 ROM whales that entirely want teeth, we come to one that has 1 them in the upper jaw only; the Narwhal or Sea-unicorn. Not 10 large as the whale, about fixty, feet long. Slenderer than the whale, and not fo fat. : Diftinguifhed, by its tooth or teeth, which itand pointing directly forward from the upper jaw, from nine to fourteen feet long. This terrible weapon is generally fingle; but there, is the $\mathrm{fkull}$ of a Narwhal at the Stadthoufe at Amiterdam with two. It is as ftraight as an arrow, about the thicknefs of the fmall of a man's leg, wreathed, tapering to a harp point; and is whiter, heavier; and harder than ivory. Its root enters into the focket above a foot and a hate. When the animal poffeffed of thefe formidable weapons is urged to employ them, it drives directly forward againt the enemy: with its teeth, that, like protended fpears, pierce whatever ftands before them. Both fexes are found armed in this manner; the horn is fometimes wreathed, and fometimes fmooth; fometimes a little bent, and fometimes ftraight; but always ftrong, deeply fixed, and tharp-pointed. Yet the narwhal is one of the moft harmlefs and peaceful inhabitants of the ocean. Conftantly and inoffenfively 
$+1+2=$
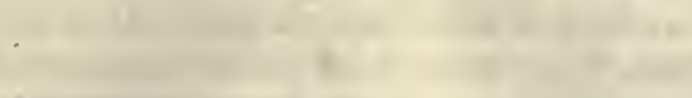

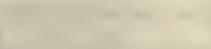

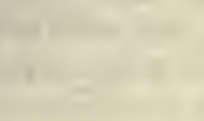$$
-
$$

1

I

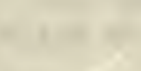

1 


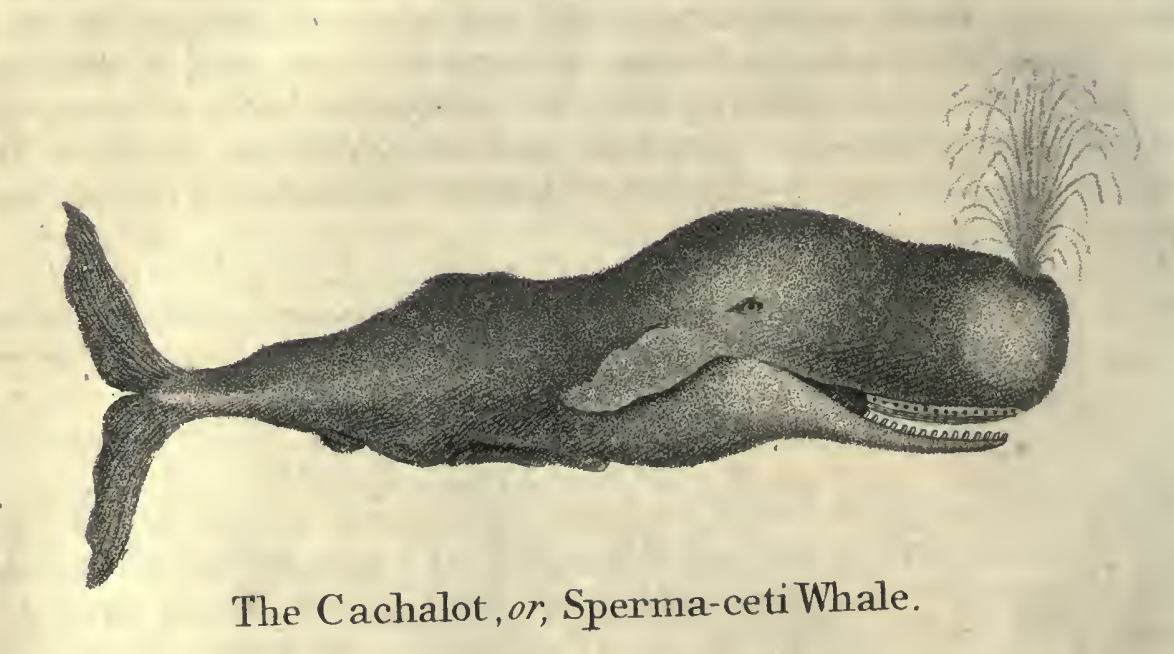




\section{TH E C A C H A L O T.}

fporting among the other great monfters of the deep, no way attempting to injure them, but pleafed in their company. Wherever it is feen, the whale is thortly after fure to follow. This may arife as well from the natural paffion for fociety. in thefe animals, as from both living upon the fame food, the infects above defcribed.

The Narwhal has a much narrower gape than the Great Whale; and therefore does not want the ufe of barbs to keep in its food when once fucked into the mouth. It is alfo much fwifter, and would never be taken but for thofe very tufks, which at firt appear to be its principal defence. Thefe animals, as was faid, being fond of living together, are always feen in herds of feveral at a time; and whenever they are attacked, they crowd together in fuch a manner, that they are mutually embarraffed by their tufks. By thefe they are often locked together, and are prevented from finking to the bottom. It feldom happens, therefore, but the filhermen make fure of one or two of the hindmont, which very well zeward their trouble.

\section{THE CACHALOT.}

TCHE Cachalot, often called the Spermaceti Whale, has feveral teeth in the under jaw, but none in the upper. There are feven diftinktions in this tribe. The Cachalot with two fins and a black back; that with two fins, and a whitin back; that with a fpout in the neck; that with a fpout in the fnout; that with three fins and Tharp-pointed teeth; that with three fins and tharp-edged teeth; and, laitly, the Cachalot with three fins and flatted teeth.

This tribe is not above fixty feet long, and fixteen feet high; more flender, and much more aetive, than the Whale; they remain - longer time at the bottom; and afford a fmaller quantity of oil. The head is folarge as to make one half of the whole. The tongue is finall: but the throat very formidable; and with very great eafe it could fwallow an ox. In its ftomach are found loads of fifh of different kinds; fome whole, fome half digefted, fome eight or ni 5 ta.. long; for the Cachalot can at one gulp fwallow a fhoal of firhes

PART V. No. 29.

east. 
enormous gullet. Linnæus tells us that this fifh purfues and terrifies. dolphins and porpeffes fo much, as often to drive them on fhore.

It furnifhes two very precious drugs; fpermaceti, and, fome fay, ambergrife. The capture of this animal, that alone fupplies them, therefore turns out yery advantageous, particularly fince the art has been found out of converting all the oil of this animal, as well as the brain, into that fubftance called fpermaceti. This fubitance is found in the head of the animal, and is the brain. The outward fkin of the head being taken off, a covering of fat offers, about three inches thick; and under that, inftead of a bony $\mathrm{fkull}$, the animal has only another thick $\mathrm{Nkin}$, that ferves for a covering and defence of the brain. The firft cavity, or chamber, of the brain, is filled with that fpermaceti which is fuppofed of the greateft purity and higheft value. From this cavity there are generally drawn about feven barrels of the cleareft fpermaceti; that thrown upon water coagulates like cheefe. Below this there is another chamber juft over the gullet, which is about feven feet high ; and this alfo contains the drug, but of leîs value. It is diftributed in this cavity like honey in a hive, in fmall cells, feparated from each other by a membrane like the inner fkin of an egg. In proportion as the oily fubftance is drawn away from this part, it fills anew from every part of the body: and from: this is generally obtained about nine barrels of oil. Befides this, the fpinal marrow, which is about as thick as a man's thigh, and reaches all along the back-bone to the tail, where it is not thicker than one's finger, affords no inconfiderable quantity.

Ambergrife, which is faid to be fometimes found in this whale, was long confidered as a fubftance found floating on the furface of the fea; but time has difcovered that it chiefly belongs to this animal; is found in the place where the feminal veffels are ufually fituated in other animals, in a bag of three or four feet long, in round lumps, from one to twenty pounds weight, floating in a luid rather thinner than oil, and of a yeblowifh colour. There are never feen more than four at a time in one of thefe bags; and that which weighed twenty pounds, and which was the largeft ever feen, was found fingle. Thefe balls are not found in all firhes of this kind, but chielly in the oldeft and frongert. 


\section{$[217]$}

\section{THE DOLPHIN, GRAMPÚS, AND PORPESSE.}

A IL thefe fin have teeth both in the upper and the lower jaw, and are much lefs than the whale:

The GRAMPUS exceeds twenty feet; is diftinguined by the flatnefs of its head, which refembles a boat turned upfide down.

The PORPF.SSE refembles the Grampus, except in being only half its length; its fnout alfo more refembles that of an hog.

The DOLPHIN has a ftrong refemblance to the porpefle, but its fnout is longer and more pointed.

They have all fins on the back; heads very large, like the reft of the whale kind; and refemble each other in appetites, manners, and conformation; equally voracious, active, and roving. All this tribe, and the dolphin in particular, are not lefs fwift than deftructive. No fifh could elcape them, but from the aukward pofition of the mouth, which is placed in a manner under the head; yet, even with thefe difadvantages, their depredations are fo great, that they have been juftly ftyled the plunderers of the deep. What could inciuce the ancients to a predilection in favour of the Dolphin, it is not eafy to account for. The ancient painters and fculptors have univerfally drawn them wrong. A Dolphin is fcarce ever exhibited by them ftraight, but curved, in the pofition which they fometimes appear in, when exerting their force out of their natural clement.

They are found, the porpeffe efpecially, in fuch vaft numbers, in all parts of the fea that furrounds this kingdom, that they are fometimes noxious to feamen, when they fail in fmall veffels. In fome places they almolt darken the water as they rife to take breath; and particularly before bad weather are much agitated, fwimming againft the wind, and tumbling about with unufual violence. It is probable they dread thofe fealons of turbulence, when the leffer filhes hrink to the bottom, and their prey no longer offers in fufficient abundance. In fairer weather they herd together, purfuing fnoals of various fin with great impetuofity. Their method of huning their game, if it may be fo called, is to follow in a pack, and give each other mutual affiftance. At that feafon when the mackarel, the herring, the falmon, and other fin of paffage, begin to make their appearance, the cetaceous tribes are feen fierce. in the purfuit ; urging their prey from one creek or bay to another, deterring them from the hallows, drivifg them towards each other's amD 22 burh, 
bufh, and ufing a greater variety of arts than hounds are feen to exert in purfuing the hare. However, the porpeffe not only feeks for prey near the furface, but often defcends to the bottom in fearch of fand-eels and fea-worms, which it roots out of the fand with its nofe, in the manner hogs harrow up the fields for food. For this purpofe, the nofe projeets a little, is fhorter and ftronger than that of the dolphin; and the neck is furnithed with very ftrong'mufcles, which enable it the readier to turn up the fand.

They are often taken in the Thames at London, both above the bridges and below them. It is curious to obferve with what activity they avoid their purfuers, and what little time they require to fetch breath above the water. The Porpeffe yields a very large quantity of oil; and the lean of fome, particularly if the animal be young, is faid to be as well tafted as veal.

Go with young ten months; feldom bring above one at a time, and in the midft of fummer : they live to a confiderable age (though fome fay not above twenty-five or thirty years); and neep with the fnout above water. They feem to poffers, in a degree proportioned to their bulk, the manners of whales.

\section{OF GARTILAGINOUS FISHES.}

THEJR firft great diftinction is, in having cartilages or griftles inftead of bones. Age, that hardens the bones of other animals, rather contributes to foften theirs. The fize of all filhes increafes with age; but, from the pliancy of the bones in this tribe, they feem to have no bounds to their dimenfions : and it is fuppofed that they grow larger till they die. Cartilaginous fifhes, like the cetaceous tribes, have organs of hearing, and lungs; like the fpinous kinds, they have gills, and a heart without a partition; thus poffefling a two-fold power of breathing. This double capacity of breathing, is one of the moft remarlsable circumftances in the hiftory of nature. The apertures by which they breathe, are placed about the head; either beneath, as in lat fifh; on the fides, as in flarks; or on the top of the head, as in pipe-fifh. To thefe apertures are the gills affixed, but without any bone to open and fhut them, as in fpinous filhes, from which they may be eafily diftinguifhed by this mark. From thefe are bending cylindrical ducts, that run to the lungs, and are fuppofed to convey the air that gives the organs their proper play.

From this ftructure, they are enabled to live longer out of water than shofe 

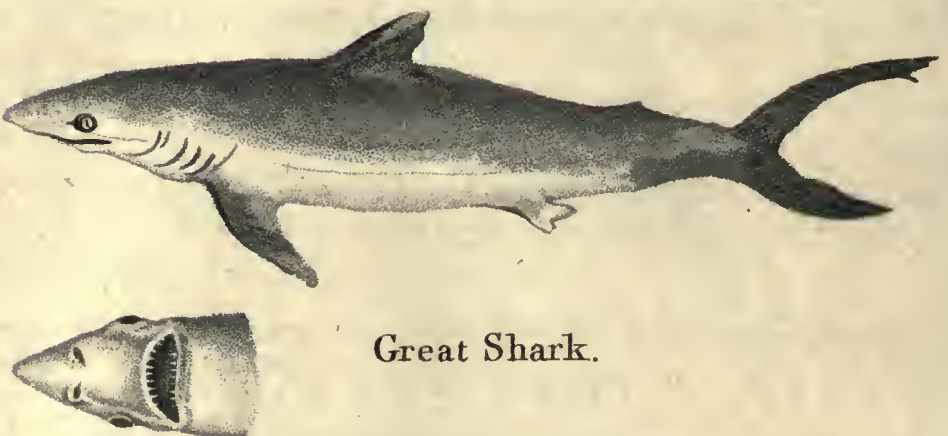

Great Shark. 
thofe whofe gills are more fimple, often feveral hours; or they can remain continually under water, without taking bfeath. Some bring forth their young alive; and fome bring forth eggs. The young; while in the body, continue in the egg till a very little time before they are excluded: fo that thefe eggs they may properly be faid to hatch within the body. The eggs confift of a white and a yolk; and have a fubftance, inftead of Thell, that may be compared to foftened horn.

Cartilaginous filhes may be divided, firft into thofe of the Thark kind, with a body growing lefs towards the tail, a rough Rkin, the mouth placed far beneath the end of the nofe, five apertures on the fides of the neck for breathing, and the upper part of the tail longer than the lower.

The next divifion is that of flat fifh; whofe broad, flat, thin thape furficiently diftinguimes them. They may be eafily known from fpinous flat filh, by the holes through which they breathe, which are uncovered by $a$ bone; and which, in this kind, are five on each fide. In this tribe we may place the Torpedo; the Skate, the Sharp-nofed Ray, the Rough Ray, the Thornback, and the Fire Flare.

The third divifion is that of the nender fnake-Thaped kind; fuch as tis Lamprey, the Pride, and the Pipe Fin.

The fourth divifion is of the Sturgeon and its variety, the Ifing-glafs Fin.

The laft divifion may comprife fin of different figures and natures, that do not rank under the former divifions. Thefe are the Sun Finh, the Tetrodon, the Luinp Fin, the Sea Snail, the Chimera, and the Fifhing Frog.

\section{THE S H A K K I N D,} $\mathrm{F}$ all the inhabitants of the deep, the fierceft and the moft voracious.
The fmalleft of this tribe is dreaded even by great fin : but the Great White Shark, which is the largelt, joins to the moit amazing rapidity, the ftrongeft appetites for mifchief: he approsches nearly in fize to the Whale, far furpaffes him in ftrength and celerity, in the: formidable arrangement of his teeth, and his infatiable voracity. 
Is found from twenty to thirty feet long; fome affert, to four thoufand pound weight; and we are told of one, that had a human corpfe entire in his belly. The head is large, fomewhat flatted; fnout long; eyes large: mouth enormouny wide; the throat capable of fwallowing a man with eafe. Has fometimes fix rows of teeth, extremely hard, flarppointed; and triangular, and finely ferrated: fome fay feventy-two in each jaw, making one hundred and forty-four in all; others think that, as the arin:al grows older, they increafe. With thefe both the jaws appear planted: the animal can ereet or deprefs them at pleafure. When the Shark is at reft, they lie Alat in bis mouth; but when he prepares to feize his prey, he erects them, by a fet of mufcles that join them to the jaw. His fins are large; his great goggle eyes he turns with eafe on every fide, to feé his prey behind as well as before : his fkin. is rough, hard, and prickly. His colour light afh. Providentially the upper jaw projects fo far above the lower, that he is obliged to turn on one fide (not quite on his back, as is generally fuppofed) to feize his prey: As this takes fome fmall time to perform, the animal purfued feizes that opportunity of efcaping. It breathes with gills and lungs; its bones are griftly; and it is viviparous: Belon aftures us, he once faw a female produce eleven young.

No fin can fwim fo fait; none is fo conftantly employed in fwim. ming; he outfrips the fwifteft hips, plays round them, darts out before them, and returns, feeming to gaze at the paffengers, without any apparent effort. The dread of failors in all hot climates; where he attends the thips, in expectation of what may drop over-board. A man who unfortunately falls into the fea at fuch a time, is fure to perin; for, when once it has tafted human flem, it never defilts from haunting thofe places where it expects fuch prey.

The ufual method of our failors to take him, is by baiting a great hook with a piece of beef or pork, which is thrown out into the fea by 2 ftrong cord, ftrengthened near the hook with an iron chain. Without this precaution, the hark would quickly bite the cord in two, and thus fet himfelf free. It is no unpleafant amufement to obferve this voracious animal coming up to furvey the bait, particularly when not preffed by hunger. He approaches it, examines it, fwims round it, feems for a time to neglect it, perhaps apprehenfive of the cord and the chain; he quits it for a little; but his appetite preffing, he returns again; appears freparing to devour it, but quits it once more. When the failors have lufficiently diverted themfelves, with his evolutions, they make a pretence, 
by drawing the rope, as if intending to take it away : then his hunger excites him; he darts at the bait, and fwallows it, hook and all. Sometimes, however, he does not fo entirely gorge the whole, but that he once more gets free; yet even then, though wounded and bleeding with the hook, he will again purfue the bait unil he is taken. When he finds the hook lodged in his maw, his utmoft efforts are excited, but in vain, to get free: he tries with his teeth to cut the chain; he pulls with all his force to break the line; he almoft feems to turn his ftomach infide out to difgorge. the hook; in this manner he continues his.formidable, though fruitlefs efforts; till quite fpent, he fuffers his head to be drawn'above water, and the failors, confining his tail by a nooze, in this manner draw him on thip board, and difpatch him. This is done by beating him on the head till he dies; yet even that is not efferted, without difficulty and danger; the enormous creature, terrible even in the agonies of death, ftill itruggles with his deftroyers; nor is there an animal. in the world that is harder to be killed. Even when cut in pieces, the mufcles ftill preferve their motion, and vibrate for fome minutes after being feparated from the body. Inftantly as he is taken up, to prevent his souncing, they cut off the tail with an axe.

Some of the negroes on the African, cont, take a bolder and more dangerous method to combat their terrible enemy. Armed with only a knife, the negro plunges into the water, where he fees the Shark watching, and fwims forward to meet him; though the great animal does not come to provoke the combat, he does not avoid it, and fuffers the man to approach him; but juft as he turns upon his fide to feize the aggreffor, the negro watches the opportunity, plunges his knife in the finh's belly, and purfues his blows with fuch fuccefs that he liys the ravenous tyrane dead: he foon however returns, fixes the fin's head in a nooze, and drags him to More, where he makes a noble feaft for the adjacent villages.

The flel is hardly digeftible by any but the negroes, who are fond of it; the liver affords three or four quarts of oil; fome imaginary virrues have been afcribed to the brain; and its thin is, by great labour, polined into that fubftance called Mhagreen. Mr. Pennant is of opinion, that the female is larger than the male in all this tribe; which would, if confirmed by experience, make a triking agreement between them and birds ofprey.

There are many kinds: as the Blue Shark; Angel Shark, which approaches in form to a Ray ; Baking shark which is fond of warm and funny waters, and is faid not to be voracious, but to feed on plants, \&c. ; the Long-tailed Shark, or Sea Fox; the Spotted Shark; and many orhers. PART Y. No, 29. 
Among the moft remarkable by its form, is the Hammer-beaded Shark; whofe head extends fideways into two great flaps, at the extremities of which-are the eyes, large; round, and projecting; its mouth under its head; its teeth ftrong, fharp, and three or four rows; breathing holes on the fides. By this peculiarity of head, it is dittinguifned from all other fin.

The Remora, or Sucking Fin, is faid to follow the Shark every where. This fifh has a power of adhering to whatever it fticks againft, as a cupping-glass fticks to the human body. Thus this animal fticks to the Shark, and drains away its moifture.

\section{T H E R Y K I N D.}

A LL fifh of the Ray kind are broad, cartilaginous, fwimming flat on Al the water, and having fpines on their body, or tail. Their eyes and mouth are placed quite under the body, with apertures for breathing either about or near them." All have teeth, or a rough bone which anfwers the fame purpore. Their bowels are very wide towards the mouth; diminihing to the tail. The tail is narrow, ending either in a bunch or a point. But they are chielly diftinguifhed by their fpines or prickles, on different parts of their body. "Some liave fpines above and below-i others on the upper part only; fome at the tail; fome have three rows, others but one: in fome they are comparatively foft and feeble; in others, ftrong and piercing. The fmalleft of thefe fpines ufually incline toward the tail, the larger toward the head.

The SKATE has the middle of the back rough, and a fingle row of fpines on the tail, on the edges a few others. The Sharp-nofed Ray has ten fpines fituated toward the middle of the back. The Rough Ray has fpines over the whole back. The Tbornback has three rows on the back, and more on the tail. The Fire-flare has but one fpine, but that a dangerous weapon, placed on the tail, about four inches from the body, five inches long; of a finty hardnefs, the fides thin, fharp-pointed, clofely and Tharply bearded its whole length. The Torpedo has no fpines that wound; but is poffeffed of one of the moft potent and extraordinary faculties in nature, viz. that of electrifying whatever it touches.

Of the larger fin thefe are the moft numerous. Except the white thark and cachalot no firh can fwallow them, and their fpines make them dangerous; the fize of fome is fuch, that even the thark himfelf is unable to 


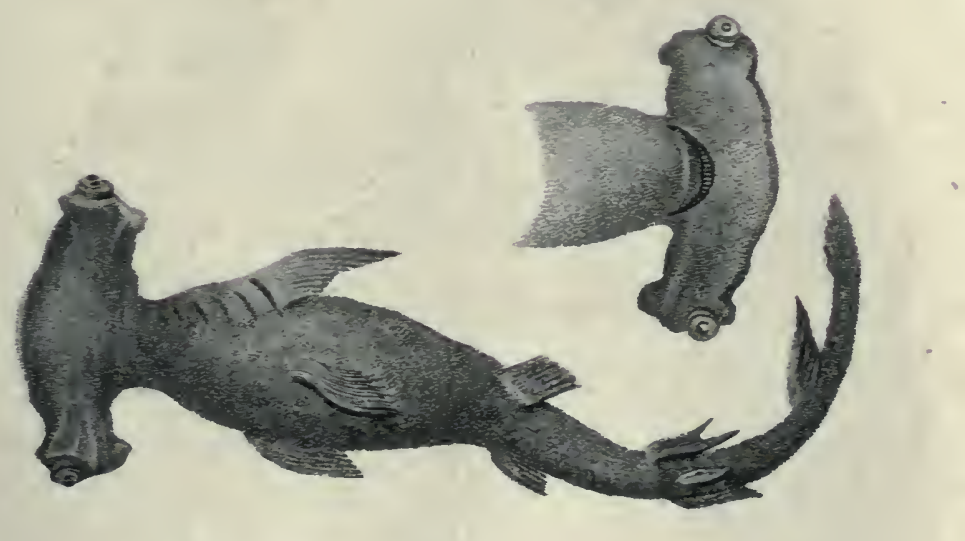

Hammer-headed Shark. 



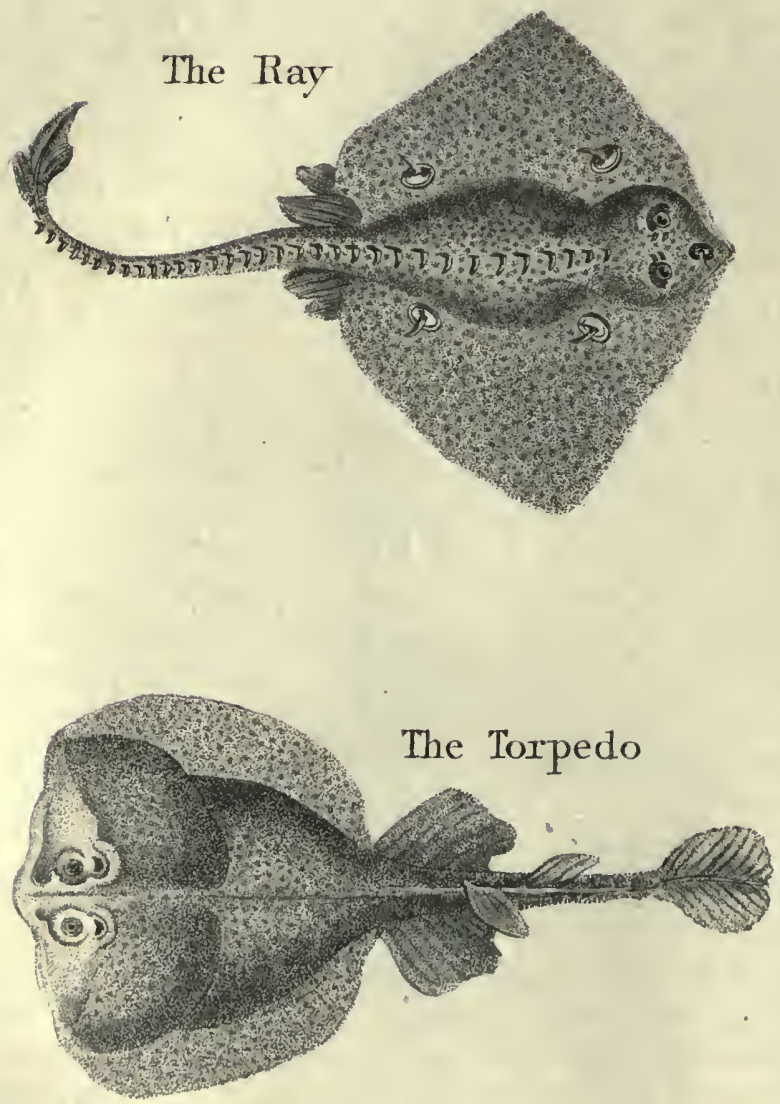
devour them: fome have been feen in England weighing two hundred pounds; but that is nothing to their enormous bulk in other parts of the world. Labat tells us of a prodigious Ray fpeared by the negroes at Gaudaloupe, thirteen feet eight inches broad, ten feet from the fnout to the infertion of the tail. The tail itfelf fifteen feet long; twenty inches broad at its infertion, and tapering to a point. The body two feet in depth; the fkin as thick as leather, and fpotted; which fpots, in all of this kind, are only glands, that fupply a mucus to lubricate and foften the fkin. This enormous fifh was utterly unfit to be eaten by the Europeans; but the negroes chofe out fome of the niceft bits, and carefully falted them up as a moft favourite provifion. Ulloa gives the fame account of a fin in the South Seas, called the Manta or Quilt, from its wrapping the divers to death in its fins; for fear of which they always carry a knife with them when they go down. Yet, large as this may feem, it is probable that, as the largeft generally keep at the bottom, they are feldom or never feen. It is generally luppofed that of this kind are the largett inhabitants of the deep.

The Ray generally chufes a black muddy bottom; the large ones keep at great depths; the fmaller approach the Shores, and feed on whatever they can meet with. As they are ravenous, they eafily take the bait, yet will not touch it if it be taken up and kept a day or two out of water. Generate in March and April ; at which time only they are feen fwimming near the furface. They adhere falt together: the females are very prolific, three hundred eggs having been taken out of the body of a fingle Ray. Thefe are covered with a tough horny fubftance, which they acquire in the womb. When come to proper maturity, they are excluded, but never above one or two at a time, and often at intervals of three or four hours; they begin in May. In October, when they ceafe, they are exceedingly thin; in November they begin to improve, and grow gradually better till May, when they are in the higheft perfection.

The Skate and the Thornback are very good food; and their fize, which is from ten pounds to two hundred weight, very well rewards the trouble of fifhing for them. But it fometimes happens that the lines are vifited by very unwelcome intruders; by the rough ray, the firefiare, or the torpedo. To thefe the fifhermen have mort mortal antipathy; and Thudder at the fight ; for they fometimes feel the refentments of this angry tribe; and, inftead of a prize, find they have caught an enemy.

The Rough ray irflicts but night wounds with its prickles. The ignorant would at firft fight take it in his hand, without apprehenfion; P p 2 
but he foon finds that there is no part of its body without fpines; and no way of feizing the animal; but by the little fin at the end of the tail.

The Fireflare is dreaded by the boldeft and moft experienced fither. men; inflietıng a terrible wound, attended with dangerous fymptoms; but it cannot be poifonous, as the fpine has no theath to preferve the fuppofed venom on its furface; nor has the animal a gland to feparate-the noxious fluid; the fpine is fixed to the tail, as a quill to the tail of a fowl, and is annually fhed in the fame manner.

The body of the Torpedo is almoft circular, and thicker than others of the ray kind; the $\mathrm{k}$ in is foft, fmooth, yellowinh, marked, as all the kind, with large annular fpots; the eyes very fmall; the tail tapering to a point; weighs from feven to fifteen pounds. Redi found one of twentyfour pounds.

The hock of this fifh proceeds from an animal electricicy, which ic has a power of ftoring up, and difcharging. The fhocks, and duration of the pain, are like the electric: but how the animal contrives to renew the charge, how it is prevented from evaporating ic on contiguous objects, how it is originally procured, are difficulties. As its itrength ceafes, the force of its fhock diminifhes, and when dead is deftroyed; it may be handled or eaten with perfeet fecurity : when immediately taken out of the fea, its force is very great, and not only affects the hand, bur, if even touched with a ftick, the perfon finds himfelf fometimes affected. It appears that the Torpedo has an apparatus under the $\mathrm{fkin}$, entirely for this purpofe ; which, like the electric battery, is an affemblage of ftrength, formed from various fmaller powers : thefe, difcharged at once, give an exceeding fmart hock: while earth and water, as well as air, are replete with the electric fluid, we may confider them as furnifhing thofe ftores which this creature, by its extraordinary qualities, has the power of conduling. The ufes of this power feem to be, firf, the numbing its enemies when they attempt to feize it; ' אecondly, numbing its prey, as it paffes over. It is frequent in Torbay. Brings forth its young in September. Seems to be capable of fuperfoetation. The Crab and Sea-Leech annoy them. Sume weigh eighty pounds. Godignus, in his Hiftory of Abyffinia, carries this quality to a moft ridiculous excefs: he tells us of one of thefe that was put into a banket among a number of dead filhes and that the next morning the people, to their utter aftonifhment, perceived that the Torpedo had actually numbed the dead filhes into life again.

There are other filh poffeffed of this numbing quality, which has acquired them the name of the Torpedo. Thefe are defcribed by Atkins and Moore, as found in great abundance along the coaft of Africa. They 
are finaped like a mackarel; except that the head is much larger ; the effects of thefe feem alfo to differ in fome refpeets. Condamine alfo informs us of a fin poffeffing thefe powers, refembling the Lamprey (the Gymotus Electricus). This, if touched by the hand, or with a Atick, inftantly benumbs the hand and arm to the very Thoulder; and fometimes the man falls down under the blow. Inhabits America.

\section{T H E L.A M P R E Y.}

THEE Lamprey is efteemed according to the feafon, or the place where it has fed. Thofe that leave the fea to depolit their fpawn in frefl waters, are the beft; thofe entirely bred in our rivers, are much inferior. In March, April, or May, jutt after leaving the fea, they are very good; thofe caught after they have caft their fpawn, are flabby and of litrle value. Thofe caught in feveral of the rivers in Ireland, the people will not venture to touch; thofe of the Englin Severn are confidered as the moft delicate of fifh.

The Lamprey refembles an eel in general appearance, but is of a lighter colour, and clumfier make. Its mouth is round, placed rather obliquely below the end of the nofe, more refembling the mouth of a leech than of an eel : on the top of the head a hole through which it fpouts water, as in the cetaceous kind; feven holes on each fide for refpiration; the fins are formed rather by a lengthening out the $\mathrm{kin}$, than by a fet of bones or fpines for that purpofe. The mouth has a property of fticking clofe to, and fucking, any body it is applied to. We are told of one that weighed but three pounds; yet ftuck fo firmly to a ftone of twelve pounds, that it remained furpended at its mouth, from which it was feparated with no fmall difficulty. This power of fuction is fuppofed to arife from the animal's exhauting the air within its body by the hole over the nofe, while the mouth is clofely fixed to the object, and permits no air to enter; has twenty rows of fmall teeth in its nouth. Its adhefive quality may be in fome meafure increafed by that nimy fubftance with which its body is all over fmeared.

From fome peculiarity of formation, this animal fwims generally with its body as near as poffible to the furface; and it might eafily be drowned 
by being kept by force for any time under water; it feems to have but one great bowel, runining from the mouth to the vent, narrow at both ends, and wide in the middle. The Lamprey's food is either nime and water, or fuch fmall water-infects as are fcarce perceivable. Perhaps its appetite may be more active at fea, of which it is properly a native.

It quits the fea in the beginning of fpring, in order to fpawn, and after a ftay of a few months it returns again to the fea. Their preparation for fpawning is by making holes in the gravelly bottom of rivers; and on this occalion their fucking power is particularly ferviceable; for if they meet with a ftone of a confiderable fize, they will remove it, and throw it out. Their young are produced from eggs; the female remains near the place where they are excluded, and continues with them till they come forth. She is fometimes feen with her 'whole family playing about her; and after fome time the conducts them in triumph to the ocean. But fome have not fufficient ftrength to return; and there continue in the frefh water till they die. This fifh, according to Rondeletius, is very. Thort-lived, and two years is generally the limit of its exiftence.

They are ufually taken in nets with falmon, and fometimes in bafkets at the bottom of the river. It has been an old cuftom for the city of Gloucefter annually to prefent the king with a lamprey-pie; and as the gift is made at Chriftmas, it is not without great difficulty the corporation can procure the proper quantity, though they give a guinea apiece for taking them. There are two or three fizes, rather than forts : that salled the Pride of the Ifis, is not peculiar to that river,

\section{THE STUR G E O N.}

$7 \mathrm{HE}$ Sturgeon in its general form refembles a frefh-water pike. The nofe is long; the mouth is fituated beneath, fmall, and without jaw-bones; allways open in the dead fifh. The body is long, pentago. nal, flat below, and covered with five rows of large bony knobs, one row un the back, and two on each fide; on the back a fingle fin near the tail; which is bifurcated. Five other fins below.

Of this fifh there are three kinds; the Common Sturgeon, the Caviar Sturgeon, and the Hufo or Ifinglals Fin. The firft has eleven knobs or 


\section{THE STURGEON.}

feales on the back; the fecond fifteen; the latter thirteen on the back and forty-three on the tail. The firft is the Sturgeon; the flefh of which is fent pickled into all parts of Europe. The fecond is the fifh from the roe of which that noted delicacy called caviar is made: and the third, befides fupplying the caviar, furnithes alfo the valuable commodity of ifinglafs. They all grow to a very great fize; and fome of them have been found above eighteen feet long.

There is not a country in Europe but what this filh vifits at different feafons; it annually afcends the largeft rivers to $\int p a w n$, and propagates in amazing numbers. The inhabitants along the banks of the $\mathrm{Po}$, the Danube, and the Wolga, make great profit of its incurfions up the ftream, and have their nets prepared for its reception. The fturgeon alfo is brought daily to the markets of Rome and Venice, and abounds in the Mediterranean; thofe that keep entirely either in falt or frefh wa: ter are comparatively fmall. When the fturgeon enjoys the viciffitude of frefh and falt water, it grows to an enormous fize. It is often accidentally taken in our rivers in falmon-nets : a figh taken in the Eike weighed four hundred and fixty pounds. North-America alfo furnines the fturgeon; their rivers, in May, June, and July, fupply them in very great abundance. At that time they are feen fporting in the water, and leaping from its furface feveral yards into the air. When they fall again on their fides, the concufion is fo violent, that the noife is heard in ftill weather at fome miles diftance.

It is never caught by a bait in the ordinary manner of fifhing, but always in nets; it never attempts to feize any of the finny tribe, but lives by rooting at the bottom of the fea for infects and fea-plants. Nothing is found in its ftomach bue a kind of nimy fubftance, which has induced fome to think it lives only upon water and air. From hence there is a German proverb, which is applied to a man extremely temperate; when they fay he is as moderate as a fturgeon.

The fmalleft filt is alone fufficient to terrify a hoal of fturgeons; for; being unfurnithed with any weapon of defence; they are obliged to truft to fwiftnels and caution for fecurity. Sturgeons live in fociety among themfelves; Gefier afferts, that he has feen them thoal together, at the notes of a trumpet.

The nets in which the fturgeon is caught are made of fmall cord, and placed acrols the mouth of the river; bur in fuch a manner that, whether the tide ebbs or.flows, the pouch cif the net goes with the ftream. The flurgeon thus caught, while in the water; is one of the ftrongeft filtes that PART Y. No. 29. 
fwims, and often breaks the net to pieces that enclofes it ; but the infant it is raifed with its head above.water, all its activity ceafes: it is then a lifelefs, fpiritlefs lump, and fuffers itfelf to be tamely dragged on thore; yet it has been found to break a fifherman's leg with a blow of its tail.

Caviar is made from the roe of all kinds of fturgeon, but particularly the fecond. It is a confiderable merchandize among the Turks, Greeks, and Venetians. Caviar fomewhat refembles foft foap in confiftence; but it is of a brown, uniform colour, and is eaten as cheefe with bread. It is made of the fpawn from the body of the fturgeon; for the Aturgeon differs from other cartilaginous firh, having fpawn like a cod, not eggs like a ray.

The Hufo, or Ifinglafs Fin, is caught in great quantities in the Danube, from the months of Oetober to January : feldom under fifty pounds weight, often above four hundred : its flem is foft, glutinous and flabby; but it is fometimes falted, which makes it better tafted, and then it turns red like falmon. It is for the commodity it furnifhes that it is chiefly taken. Ifinglars is of a whitifh fubftance, inclining to yellow, done up into rolls, made of the fkin, the entrails, the fins and the tail of this fin, cut into fmall pieces, macerated and boiled to a jelly; which hardens when dry.

\section{OF ANOMALOUS CARTILAGINOUS FISHES.}

$\mathrm{N}$ this clafs we have the Pipe Finh, that almoft tapers to a thread; the Mole, or Sun Fin, that has the appearance of a bulky head, but the body cut off in the middle; the Hippocampus, with an head fomewhat like that of an horfe; and the Water Bar, whore head can fcarcely. be diftinguinhed from the body; the Finhing Frog, from its deformity, called the Sea Devil, the Chimæra, the Lump Finh, the Sea Porcupine, and the Sea Snail. Of thefe the hiftory is but little known.

The Mole, or Sun Firh, fometimes grows very large; one taken near Plymouth was five hundred weight. In form it refembles a bream, or fome deep fin cut off in the middle : the mouth is very fmall, and contains in each jaw two broad teeth, with Tharp edges : the colour of the back is durky and dappled, the belly a filvery white. When boiled, it has been obferved to turn to a glutinous jelly, and would molt probably 

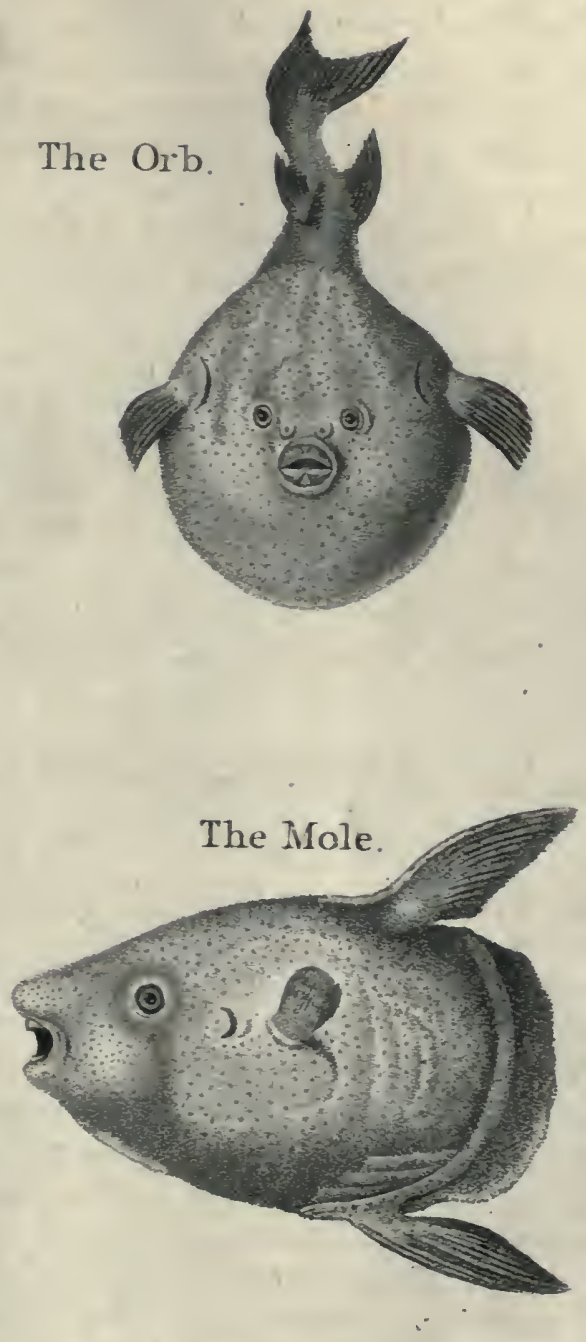




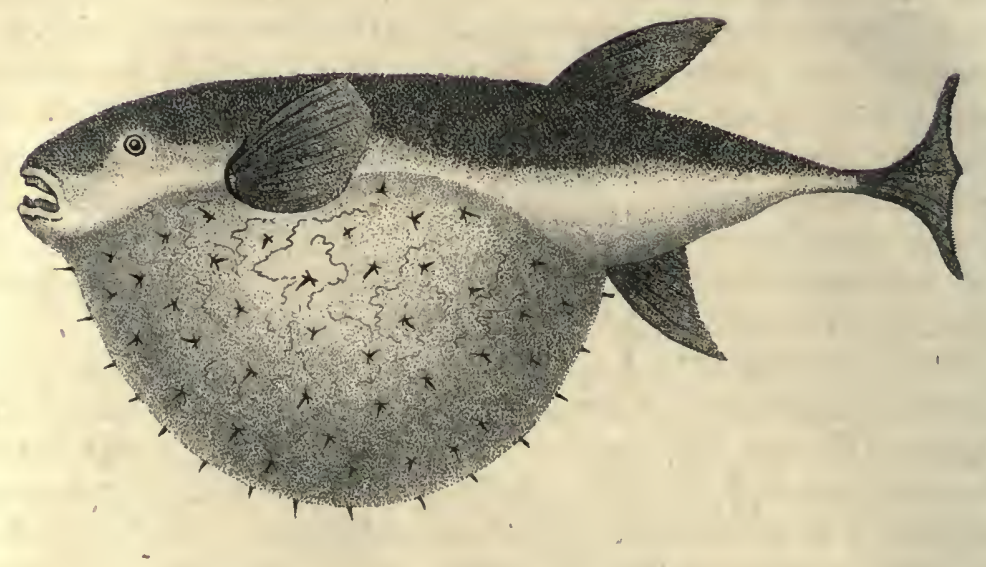

The Globe Mole, or Diodon 
ferve for all the purpofes of ifinglafs, were it found in fufficient plenty. Of this there is a Morter and a longer. The Globe Mole, or Diodon, is remarkable for, the power of inflating its belly, which is ufually oblong, to a very great fize and globular thape, thereby erecting the fpines with which that part is covered fo as to render it lefs feizable, and more terrific to fifh of prey. Circumference of one in this $c$ sndition, two feet fix, length of the belly one foot, whole length one foot feven inches, belly and fides white, wrinkled: Common to Europe and Carolina.

The Fifing Frog in thape generally refembles a tadpole; but it grows to above five feet long, and its.mouth is fometimes a yard wide. The head is much bigger than the body; the under jaw projects before the upper; both are armed with rows of flender, harp teeth : the palate and tongue have alfo teeth; the eves are on the top of the head, encompaffed with prickles: immediately above the nofe are two long beards or filaments, fmall in the beginning, but thicker at the end; and round. There is another fpecies that has no beards. Rondeletius informs us; that, when embowelled, the body has a kind of tranfparence; and, if a lighted candle be placed within it, as in a lanthorn, has a very formidable appearance. It is an enemy to the dog-finh, the bodies of thofe fierce and voracious animals being often found in its ftomact.

The Lump Fin is in length fixteen or twenty inches, weighs about four pounds; Thape deep; it fwims edgeways; the back is Tharp and elevated, and the belly flat; the lips, mouth and tongue a deep red; the whole fkin is rough, with bony knobs; the largeft row is along the ridge of the back; the belly a bright crimfon: but what makes the chief fingularity in this firh, is an oval aperture in the belly, furrounded with a flenthy foft fubftance, that feems bearded all round; by means of this part, it adheres with valt force to any thing it pleafes. If flung into a pail of water, it will ftick fo clofe to the bottom, that, on taking the firh by the tail, one may lift up pail and all, though it hold feveral gallons of water.

The Sea Snail takes its name from the foft and unctuous texture of its body, refembling a land fnail. It is almoft tranfparent, and foon diffolves and melts away. It is five inches long; colour, when frefh taken, pale brown; thape round, but flatted near the tail; the back-fin reaches all the way from the head to the tail. Beneath the throat is a round depreffion, of a whitifn colour, furrounded by twelve brown rifings, placed in' a circle, by which it is thought to be alfo a fucker. It is taken in England, at the mouths of 'rivers, four or five miles diftant from the fea. There are other fuckers of much fmaller dimenfions. 
The Pipe Fin, in the thickeft part, is not thicker than a fwan-quilf, yet is above fixteen inches long: hexangular in part, the tail quadrangular. General colour ol ive brown, marked with numbers of blueith lines, pointing from the back to the belly. Is viviparous; for, on cruning one that was juft taken, hundreds of very minute young ones were obferved to crawl about. There are others lefs, and not viviparous.

The Hippocampus, which, from the form of its head, fome call the Sea Horfe, never exceeds nine inches in length. It is about as thick as. a man's thumb; and the body is faid, while alive, to have hair on the fore part, which falls of when it is dead. The fnout is a fort of tube, with a hole at the bottom, to which there is a cover, which the animal can open and thut at pleafure. Behind the eyes are two fins, which look like ears; and above them are two holes, which ferve for refpiration'. The whole body feems to be compofed of cartilaginous rings; on the intermediate membranes of which feveral fmall prickles are placed. It is found in the Mediterranean, and alfo in the Weftern Ocean ; and, upon the whole, more refembles a great caterpillar than a fifh. The ancients confidered it as extremely venomous.

Among foreign animals of this kind, chiefly Indian and American, we may place the Sea Orb, which is almoft round, has a mouch like a frog, and is: from feven inches to two feet long. Like the porcupine, from whence it fometimes takes its name, being alfo called the Sea Porcupine, çovered over with long thorns or prickles, which point on every fide; and, when the animal is enraged, it can blow up its body as round as. a bladder. Of this extraordinary creature there are many kinds; fome threatening only with fpines, as the SealHedge-hog; others defended with a hony helmet, that covers the head, as the Ontracion; others with a coat of mail from the head to the tail, where it terminates in a point, as the Centrifcus; and others ftill armed offenfively and defenfively. with bones and fpines, as the Shield Orb. Of thefe fearce one is without its peculiar weapon of offence. The centrifcus wounds with its fpine; the oftracion poifons with its venom; the orb is impregnable, and is abfolutely poifonous, if eaten.

They are of different-lizes; fome not bigger than a foot-ball, and others as large as a burhel. They almoft all flatten and erect their fipines. at pleafure, and increafe the terrors of the the approach of dariger. At firft they feem inoffenfive; their body oblong, with all their weapons pointing towards the tail; but upon 


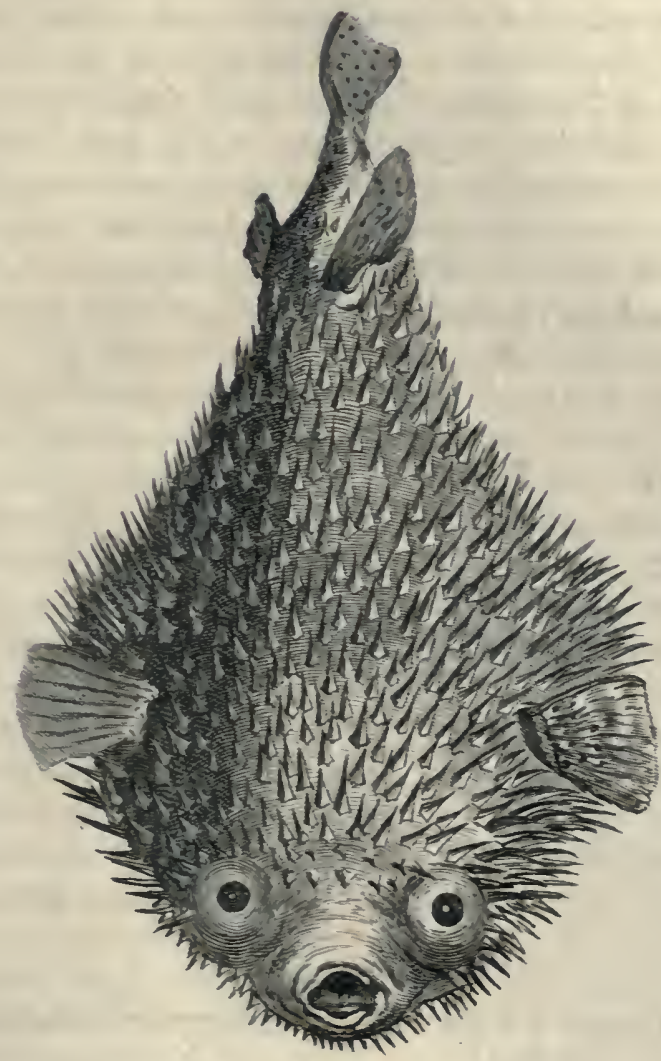

The Sea Hedghog: 

being provoked or alarmed, the body that before feemed fmall fivells rounder and larger, all its prickles ftand upright, and threaten the invader on every fide. In the middle of the belly is a fort of bag or bladder filled with air, by inflation of which the animal fivells itfelf.

The Galley (which Linnæus degrades among infects, under the title Medufa), to the eye of an unmindful fpectator, feems a tranfparent bubble fwimming on the fea, variouny and beautifully painted with vivid colours, where red and violet predominate, as differently oppofed to the fun's rays. It is however a fifh; its body compofed of cartilages, and a very thin Rin filled with air, which keeps it floating. Sometimes it is thrown afhore by one wave, and wathed back by another. Perfons walking along the fhore often tread on thefe animals; and the burfting of their body has a report like that of the air bladder of a fifh. It has eight broad feet; it faftens itfelf to whatever it meets by its legs, which have an adhefive quality. Whether they move when on fhore Labat could never perceive, though he did every thing to make them ftir; he only faw 'that it ftrongly adhered to whatever fubftances he applied it. It is common in America, the fize of a goofe-egg, or fomewhat more. Perpetually floats, and no efforts can fink it. Beneath, in the water, are four feet ferving as oars, the other four are expanded above to fail with. But what is remarkable is the violent pungency of the nimy fubftance with which its legs are fineared. If the fmalleft quantity but touch the fkin, it burns it like hot oil dropped on the part. The pain is wort in the heat of the day, but ceafes in the cool of the evening. From feeding on thefe he thinks the poifonous quality of fome Weit-Indian filh-may be accounted for. They are extremely common along all the coafts in the Gulf of Mexico; and whenever the fhore is covered with them in an unufual manner, it is confidered as a cerrain forerunner of a ftorm.

\section{OF SPINOUS FISHES.}

THESE are difinguihed by having a complete bony covering to their gills; by breathing with gills only; by thet bones being fharp and thorny; and their tails being placed perpendicular to the body. The foregoing claffes bear no proportion to them in number. 
3. Of the real hiftory of thefe filhes, very little is known; our information relates only to their external form.

Fith that have bony prickly fins, are calied Prickly-finned Fin ; thofe that have foft or cartilaginous fins, are called Soft-finned Filh. Spinous fifh therefore are formed into thefe two divifions.

Linnaus has alfo arranged them by remarking the fituation of their fins: the ventral or belly fins (which are thofe particularly to be remarked) are (1) eicher wholly wanting, as in the eel; then the fith is called Apodal (a Greek word. fignifying without feet); or (2) the ventral fins are placed forworder than the pectoral fins, as in the haddock; then the animal is called a Fugular filh; or $(3)$ the ventral fins are placed directly under the pectoral fins, as in the father-lafher; then it is called a Tiboracic fith; or (4) the ventral fins are placed nearer the tail than the pectoral fins, as in the minow; then it is an Abdominal fifh.

Prickly-finned filh making one general divilion, and the foft-finned fith another, there are prickly-finned apodal fifhes, prickly finned jugular fithes, prickly-finned thoracic filhes, and prickly-finned abdominal fihes : alfo, on the other hand, there are foft-finned apodal fifhes, foft-finned jugular firhes, foft-finned thoracic filhes, and foft-finned abdominal fifhes.

\section{OF SPINOUSS FISHES IN GENERAL.}

FHE hiftory of any one of this clafs very much refembles that of the reft : they breathe air and water through the gills; they live by rapine; each devouring fuch animals as it can fwallow; and they propagate, not by bringing forth their young alive, as in the cetaceous tribe; nor by diftinet eggs, as in the generality of the cartilaginous tribe; bue by fpawn, which contains hundreds of thoufands. Their bones when nightly infpected appear entirely folid; yet, viewed clofely, are hollow, filled with a fubftance les tancid and oily than marrow. They are'very numerous, and pointed. The fkeleton of a fin has its members very regularly difpofed ; and every bone its fixed place, with perfect precifion. Their number of bones is according to their number of fins; and the number in each fin is in proportion to the number and fize of the fins: for every fith has a regular apparatus of bones and mufcles, by which the is 
fins are moved; thofe fifh which are large, fat, and have few fins, are the leaft bony: thofe which are fmall, lean, and have many fins, are the moft bony.

Spinous fifh can live out of their own element but a very fhort time. In general, when taken out of the water, they pant violently and at clofe intervals, the thin air not maintaining their gills in proper play; and in a few minutes they expire. But fome are more vivacious than others; the eel lives Several hours out of water ; and the carp has been fattened in a damp cellar; being placed in a net well wrapped up in wet mofs, the mouth only out, and hung up in a vault; fed with white bread and milk; and the net now and then plunged into the water. Thus managed, it has been known not only to live a fortnight, but to growi exceeding fat, and of fuperior favour. - To fome fifhes, bred in the fea, frefh water is immediate deftruetion : on the other hand, fome fithes, that live in our lakes and ponds, cannot bear falt water. Probably this arifes from the fuperior weight of the fea water, and its greater force on the organs of refpiration; fo that fifn ufed only to frefh water, cannot bear the weight of 'the marine fluid. No firhes imbibe any of the fea's faltnefs with their food, or in refpiration. The flefh of all fithes is equally frefh, both in the river, and at the falteft depths of the ocean; yet there are fome whofe organs are equally adapted to either element: the falmon, the thad, the fmelt, and the flounder, annually quit their native ocean, and come up our rivers to depofite their fpawn. There is no danger they will not encounter, even to the furmounting precipices, to find a proper place for depofiting their future offspring. The SALMON afcend rivers five hundred miles from the fea; braving not only the danger of enemies, but alfo the afcent of cataracts as high as a houfe. When they come to the bottom of fuch a torrent, they feem difappointed at the obftruction, and fwim fome paces back : then view the danger before them, furvey it motionlefs for fome minutes, advance, and again retreat; at laft fummoning all their force, they leap from below, their body itraight, and ftrongly in motion; and thus moft frequently clear every obftruction. But fometimes they want Itrength to make the leap; and then, in our fitheries, they are taken in their defcent, alfo by the hook, by nets, bafkets, \&cc. Their capture makes, in feveral countries, a great article of commerce; being cured in feveral different manners, by falting, pickling, or drying:

Others, particularly the EEL, defcend from frefh water, as Redi affures us, to bring forth in li.e fea. About Augutt, annually, in the moft obfcure nights, and when the rivers are flooded by rains, they feek the ocean.' PART T. No. 29.

$\mathrm{R} r$

Having 
Having reached the fea, and produced their young (for thefe are viviparous), they again afcend, as opportunity offers, 'from January to May, when they are taken in the river Arno by millions, and fo fmall that 2 thoufand of them goes to a pound. It is certain they defcend in our own rivers after floods, in abundance, and are caught in nets, to great advantage. They poffefs alfo a power of climbing over obftacles; for, by applying their glutinous and nimy bodies, they can creep up locks, weirs, and every thing that would prevent their afcending the ftream.

There are firh that take a courfe of three or four thoufand miles in a feafon; yet preyed on by whales, Tharks, and water-fowl, that regularly wait their progrefs. Thefe filh of paffage bear ftrong analogy to birds of paffage, both from their focial difpofition, and their immenfe numbers. Such are the cod, the haddock, the whiting, the mackarel, the tunny, the herring, and the pilchard. Other fifh live in our vicinity, and refide on our coafts; or keep in the depths of ocean, feldom feen: but thefe, at ftated feafons, vifit their accuftomed haunts with regular certainty, generally returning the fame week in the fucceeding year, and often the fame day.

This is one of the mott extraordinary circumftances in the hiftory of nature. What impels them to fuch voyages; what direets their paffage ; what fupports them by the way; and what fometimes prompts them to quit, for feveral feafons, one hore for another, and then return to their accultomed harbour; are queftions philofophy can hardly refolve.

The COD feems foremolt of this wandering tribe; is only found in our northern part of the world. Its chief refort is on the banks of Newfoundland, and the other fand-banks off Cape-Breton. That extenfive flat feems to be the broad top of a fea-mountain, extending above five hundred miles, and furrounded with a deeper fea. Hither the cod annually repair in numbers beyond calculation, to feed on the worms found in that fandy bottom. Here they are taken in quantities, to fupply all Europe. Yet this immenfe capture makes but a very fmall diminution of their numbers. When their provifion there is exhaufted, or the feafon for propagation returns, they go off to the polar feas, where they depofit their roes in fecurity. From thence want of food forces them, as foon as the circumjacent feas are open, to repair fouthward.

The HADDOCK, the WHITING, and the MACKAREL, are thought, by fome, to be driven on our coafts by the purfuit of larger filhes: rather, they feek that food which is in greater plenty near the thore than out at fea. Their migrations feem remarkably regularly 
condueted, even to a day. A hoal of haddocks often extends from the Phore three miles in breadth, and in length forty. Its limits are precifely known; for if the fifhermen put down their lines more than three miles from thore, they catch nothing but dog-fith; a proof the haddock is not there.

HERRINGS and PILCHARDS are in greatert abundance in the highelt northern.feas, covered with ice great part of the year, whither neither man, the fin-fifh, or the cachalot, dares purfue them. The quantity of infect food thofe feas fupply, is very great; fo that, defended by the rigid climate, they live at eafe, and multiply beyond expreffion. Anderion fuppofes they would never depart, but that their numbers render migration neceffary; and, as bees in a hive, they are compelled to feek other retreats.

They quit the icy fea about the middle of winter, in fuch numbers, that were all the men in the world loaded with herrings, they would not carry a thoufandth part away: but they barely leave their retreats, ere millions of enemies thin their fquadrons. The fin-fith and the cachalot fwallow thoufands at a yawn; the porpeffe, the grampus, the Thark, the whole tribe of dog-filh, find them an eafy prey : the unnumbered flocks of fea-fowl that chiefly inhabit near the Pole, watch their outfet, and fpread extenfive ruin. Thus furrounded, they feek fafety by, crowding together, leaving to the outmot the danger of being firt devoured, like theep when frighted: they feparate into fhoals, one of which moves weft, along the coafts of America, as far as Carolina. In Chefapeak bay, the annual inundation of thefe fifh is fo great, that they become a nuifance. Thofe that hold to the Eaft, come down the coaft of Iceland in the beginning of March; their phalanx, though after confiderable diminutions, of amazing extent, depth, and clofenefs, covering an exient as large as the inland itfelf. The whole water feems alive, and is black with them to a great diftance. A fhovel, or hollow veffel, put into the water, takes them up without farther trouble. That body which vifits our coafts, appears off the Shetland ines in April. This is the forerunner of the grand hoal in June, whofe arrival is announced by the number of gannets, gulls, fharks, and porpeffes. The main body, of fuch breadth and depth as to alter the appearance of the ocean, is divided into columns, five or fix miles long, three or four broad; the water before them curls up as if forced from its bed. Somerimes they fink for ten or fifteen minutes, then rife again to the furface; and, in bright weather, rellect a variety of fplendid colours, purple, gold, and azure. 
The fifhermen take fometimes two thoufand barrels at a fingle draught of their nets. At the Shetland ines this great army divides, part to the weftern coafts of Ireland, where a fecond time they divide to the Atlantic Ocean and to the Irih Sea. They feek thole bays and thores where they can beft find food and defence. 'The quantity that attempts to return is but fmall; and Anderfon doubts whether they ever return.

Many doubts arife on every part of this migration. Though fuch numbers perin, yet, in comparion to thofe that furvive, the account is trifling: it is fuppofed that thofe taken by man, are not one to a million. Their leaving the fhore at a ftated time, feems not the impulfe of neceffity; neither is their fixing on fome thores for ages, then capricioufly forfaking them, never to return. Thisifeems to indicate as if food had its fhare of attraction, and was not always in equal plenty. Before the year 1584 , the number of thips that refurted to Norway was fome thoufands.' The quantity of herrings was fuch, that a man who fhould put a fpear in the water, as Olaus Magnus afferts, would fee it ftand on end. But foon after they deferted thefe fhores for the German coaft, where the Hanle-towns drove a very great trade by their capture and fale; but, for above a century, they have greatly forfaken them, and preferred the Britith Channel and the Irifh fhores.

The PILCHARD, which differs little from the herring, makes the coaft of Cornwall its principal refort. The natives fometimes inclofe a bay of feveral miles extent with their nets, called feines. The fhoals are perceived by the colour of the water, which affumes a tincture from the filnes beneath. Sometimes twelve or fifteen hundred barrels are taken at a draught; often the quantity caught exceeds the falt or the utenfils for curing them; and then they are carried off for manure.

Whence thele infinite numbers are derived, remains obfcure; but it is notorious that the STICKLEBACK, of two inches long, that might be thought eafily fupported in any water, is obliged to colonize, and leave its native fens. Every feventh or eighth year, amazing hoals' of thefe appear in the river Welland, near Spalding, and come up the ftream. - They are fuppofed to be detached from fome of the fens, overcharged with numbers. A man, employed by a farmer to take them for manure, got for a confiderable time four Rillings a day, by felling them at a halfpenny per buinel!

Such is the amazing propagation of filhes in our own climate; but this bears no proportion to the vaft quantities in the Indian ocean, where it is but going down to the More, and fifh are found in great 
numbers, in plafhes that continue to have water; and where the quantity is fo great, that they are left in fhoals on fwamps, dried by the fun, and their putrefaction contributes to render the country unhealthful.

A fingle herring, multiplying unmolefted and undiminihed for twenty years, would furnilh a progeny greater in bulk than ten times our globe; fo that the porpeffe, the fhark, the cod-filh, are benefactors, withour whofe affiftance the fea would foon become overcharged with the burthen of its own productions.

Their fpawn is depofited where the fun-beams may reach it, either at the boitom of thallow fhores, or on the furface in deeper waters. A fmall degree of heat anfwers the purpofes of incubation, and the animal iffues from the egg in perfect formation.

Annually, in July, there appear near Greenwich thoals of fmall fithes, called by the Londoners White Bait. It is univerfally agreed that they are the young of fome fin : they are never feen but at this time, and never have any roe. The quantity is amazing; and the firh that produces them in fuch numbers muft be in plenty, though it is not yet known what that filh is, as they correfpond with no other fpecies whatever. Some think thein the young of fome animal not yet come to perfect form.

The manner in which the eggs of firhes are impregnated, is wholly unknown; but fuppofed to be by the male fhedding his milt on them, when he meets them. Spinous fifhes produce by fpawn; yet fome, as the eel and the blenny, bring forth their young alive.

With refpeet to the growth of fithes, it is obferved that CARPS, the firft year, grow to about the fize of a willow leaf; at two years, are about four inches long; the third feafon, five inches; at four years old, fix inches; the fifth, feven; afterwards from eight to twelve inches. Seafin, the fifhermen afure us, mult be fix years old before it is fit for table. They affure us, MACKAREL, a year old, are as large as one's finger; thofe of two years, twice that length; at three and four years, they are that fmall kind of mackarel, without melts or roes; between five and fix, they are full-grown filh. With regard to Rat fines, they tell us the turbot and barbel, at one year, are about the fize of a crown piece; the fecond year, as large as the palm of one's hand; nor till the fifth and fixth year, large enough for table. So that fin are a confiderable time in coming to their full growth, and are along time deftroyed, before they become deftroyers. 
Of the fpinous kind, the DORADO is moft voracious; chiefly found in the tropical climates; the mott active and moft beautiful of its tribe. The back enamelled with fpots, blueifh-green and filver; tail and fins gold colour, of extreme brilliancy : the eyes are on each fide the head, large and beautiful, furrounded with circles of thi.ing gold. Thefe fifh are always in motion, and play round hips in full fail, with eafe and fecurity. Ever purfuing or purfued, they are continually in warfare; defending themfelves againt the thark, or darting after fmaller firhes. The FLYING-FISH abounds in thefe feas; and being finall, feldom larger than a herring, is chiefly fought by the dorado, which being fix feet long, not thicker than a falmon, and furnifhed with a full complement of fins, divides the water with amazing rapidity. 'The flying-fifh has two pair of fins longer than the body, and moved by a ftronger fet of mufcles than any other. The efforts to feize on one fide, and the arts of efcaping on the other, are perfectly amufing. The dorado is feen in full chace, darting after its prey, which will noc leave the water, while it has the advantage of fwimming, in the beginning; but, tired at laft, and its long fins growing ufelefs in the, water, they are now exerted in flight, in a different manner and direction: by this means he rifes from the water, flutters over its furface two or three hundred yards, till enfeebled by this exercife; but they have now acquired a power of frefh efforts in the water, and of fwimming with fome velocity : ftill the active enemy keeps it in view, and drives it again from the deep, till it drops at laft into the mouth of its fierce purfuer. Should it elcape from its enemies of the deep, yet the tropic bird and the albatrofs are ever upon the wing to feize it, and often whole fnoals of them fall on fhip-board.

It would feem that there is fomething more favourable to the fecundity of firhes in the ocean than in freth water. In frefh water allo fifhes feem to abate much of their courage and rapacity; purfue each other with lefs violence, and feem to be lefs powerfully actuated. The cod on the banks of Newfoundland, the inftant the hook, which is only baited with the guts of the animal laft taken, is dropped into the water, darts to it at once, and the firhermen have to pull up as faft as they throw down: whereas thofe who fifh in frefh waters mutt wait whole hours in fruitlefs expectation; and the palience of an angler is proverbial.

The PIKE is the moft active and voracious of freth water firhes, and will attack every fith lefs than itfelf; fometimes is choaked, by attempting to fwallow fuch as are too large : fith of all kinds, even its own, it indifcriminatcly 


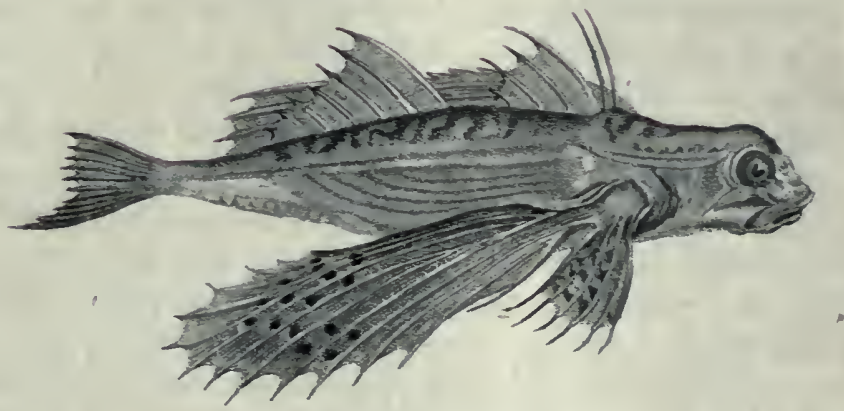

The Flying Fifh. 


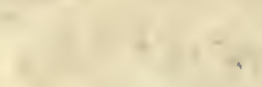

wa

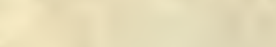

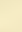

$\therefore \quad$ 
difcriminately devours, fo that every fifh owes its fafety to its minutenels, celerity, or courage. The pike will draw down the water-rat and young ducks while fwimming about. Gefner mentions a mule that ftooped to drink, when a faminhed pike that was near feized it by the nofe, nor was it difengaged till the beaft flung it on fhore. They will contend with the otter for his prey, and endeavour to force it from him. For this reafon it is dreaded by all other fifh; and fmall ones thew the fame uneafinefs and deteftation at the prefence of their tyrant, as little birds do at the fight of an hawk or an owl. When the pike lies aneep near the furface, as is frequent, the leffer fifh are often obferved to fwim around it in vaft numbers, with a mixture of caution and terror.

Other tribes of frein water fifh chiefly fubfift on worms and infects, purfuing them at the bottom, or jumping after them to the furface. In winter their appetite feems to forfake them, at leaft they continue fo torpid, that few baits will tempt them. They continue in deep holes for days together, without appearing to move. The cold feems to affect them, they lie clofe to the bottom, and feldom venture out except the day be fine, and the Thallows tepified by the rays of the fun. Some fifhes may be rendered fo torpid by the cold, in the northern rivers, as to be frozen up in their great maffes of ice, in which they continue for feveral months, the prifoners of congelation, waiting the approach of a warmer fun, to reftore life and liberty.

Each fpecies of fifh is infefted with worms of kinds peculiar to itfelf. Thefe lodge either in the jaws, and the inteftines internally, or near the fins externally. When healthy and fat, fifh are not much annoyed by them; but in winter, when lean or fickly, they fuffer very much. In fome feafons they fuffer epidemic diforders, and are feen dead by the water-fide, without apparent caufe; yet they are animals of all others moft vivacious, and often live on fubftances poifonou's to the more perfect claffes of animated nature. Whether the poifonous qualities of fome may not arife from this caufe is uncertain. That they inflict poifonous wounds is the opinion of many. Their being poifonous, when eaten, is equally notorious; and the caufe equally infcrutable. Others have afcribed the poifon of thefe filhes to their feeding upon copperas beds. With us, if fifhes, fuch as carp or tench, acquire any difagreeable flavour from the lakes in which they have been bred, this can be removed, by their being kept fome time in niner and better water. 


\section{O F S H E L L F I S H,}

THESE are divided by naturalifts into Cruftaceous and Teftaceous: both totally unlike fifhes in appearance, without bones on the infide, but having a thell ás an external covering. Cruftaceous fifh have a Thell not quite of a ftony hardnefs, but in fome meafure capable of yielding. Teftaceous firhes have a fhell of a ftony hardnefs, brittle, and incapable of yielding. Of the cruftaceous kinds are the lobfter and the crab : of the teftaceous, oyfters, mufcles, cockles, and fea fnails, in infinite variety.

The cruftaceous tribe feems placed between fifhes, properly fo called, and the fnail-like or teftaceous tribes. They have motion, and hunt for food with great avidity, like the former; but are incapable of fwimming, and creep along the bottom, like the latter. The chief of the kind is the Lobfter; under which we rank the Prawn, Cray-Fin, Shrimp, Sea-Crab, Land-Crab, and their varieties.

\section{TH E L O B S TER K I N D.}

TTHE Lobfter and the Crab are in manners and conformation nearly the fame. Voracious like filhes, they lead an infect life at the bottom of the water; and are often obliged to wait till accident brings their prey. They have neither red blood nor warmth in their bodies. Whatever they feize on is fure to perih; though never fo well defended; they even devour each other : and may, in fome meafure, be faid to eat themfelves; as they change their thell and their ftomach every year, and their old ftomach generally ferves to glut the new.

Thofe who firft fee the Lobfter, are apt to miftake the head for the tail. The animal moves with its claws foremoft. Thefe are his inftruments of provifion and defence; thefe open like a pair of nippers, have great ftrength, take firm hold, and are ufually notched, which increafes their tenacity. The Lobfter has eight legs, four on each fide; thefe, with the tail, give the animal its progreffive and fideling motion. Between the two claws is the head, finall; its eyes feem like two black 


\section{THE LOBSTER K I N D.}

horny fpecks on each fide; thefe it can advance out of the focket, or withdraw, at pleafure. The mouth opens the long way of the body; has two teeth for the comminution of its food; three more are in the ftomach, one on each fide, the other below. Between the two teeth is aflefhy fubftance, in the thape of a tongue. The inteftines are one long bowel, from the mouth to the vent; but this animal is fingular in having the fpinal marrow in the breatt bone. Two long feelers or horns iffue on each fide the head, as if to apprize the animal of danger, or prey. The tail is the grand intrument of motion; and with this it can raife itfelf in the water. Under this is lodged the fpawn in great abundance: every pea adhering to the next by a very fine filament. Lobfters are fuppofed to be felf-impregnated! The ovary, or place where the fpawn is firft produced, is toward the tail, where a red fubftance is found, which is a clufter of peas, too fmall for exclufion. Froin this receptacle go two canals, that open on each fide at the jointures of the Anell, at the belly; through thefe paffages the peas defcend to be excluded, and placed under the tail, where the animal preferves them from danger for fome time, till they come to maturity; when, being furnithed with limbs and motion, they drop off into the water.

When the young Lobfters leave the parent, they feek refuge in the fmalleft clefts of rocks, and crevices at the bottom of the fea. They grow larger in a few weeks, from the accidental fubftances which the water wafhes to their retreats. They alfo acquire a hard, firm thell, or armour. They then quit their fortreffes, and creep along the bottom, in hopes of plunder. Filh fpawn, fmaller of their own kind, but chielly worms at the bottom of the fea, fupply them with plenty.

But the body of the Lobfter increafing, while the fhell remains the fame, it becomes imprifoned within its thell. Young Lobfters change their thell oftener than the old, who renain in the fame thell fometimes two years together; but ufually all change their fiell year!y, generally at the beginning of fummer, when food is in plenty, and their vigour in perfection: foon their activity ceafes; they forfake the open parts of the deep, feeking retired fituations among the rocks or outlets, where they may remain in fafety. Some days before the change, the animal difcontinues its ufual voracioufnefs; is no longer feen harrowing up the fand at the bottom, or fighting, or hunting, but torpid and motionlefs. Juft before calting its Thell, it throws itfelf on its back, ftrikes its claws againft each other, and every limb feems to tremble; its feelers are agitated, and the whole body in violent motion: it then fwells in an unufual nuanaer; at 
laft the fhell begins to divide at its junctures; particularly at thofe of the belly, before but feemingly united. It alfo feems turned infide out; and its ftomach comes away with its fhell.' After this, it difengages the claws, which burft at the joints, with a tremulous motion-cafting them off. Now, weak and enfeebled, it continues feveral hours motionlefs; many die; all are in fuch a weakly ftate, that they neither take food, nor venture from their retreats; they have not only the foftnefs, but the timidity of a worm. The dog-filh, the cod, and the ray, devour them by hundreds. This defencelers ftate continues but a fhort time: in lefs than two days the $\mathrm{kin}$ is grown almoft as hard as before; its appetite increafes, and the firft ubject of its gluttony is faid to be its lace ftomach. This it devours eagerly, and alfo its former fhell. In about forty-eight hours the new thell is perfected, and hard as the former which was but juft thrown afide. By its new. Thell is feen that it has grown in a very few days above a third in fize.

At certain feafons of the year, thefe animals never meet without engagement. The lofs of a leg, or a claw, is no great calamity; the victor carries off the fpoil to feaft on, while the vanquined retires from the defeat, to wait for a thorough repair. Where the joint of the claw was cur away, is feen in a moft furprifing manner to burgeon out, the beginning of a new claw; at firft fmall and tender, but in three weeks time almoit as large and powerful as the old one: but it never arrives to the full fize.

Of this extraordinary yet well-known creature, are many varieties. Some three feet long, and (if the fhrimp and the prawn be of the clafs, though unfurnilhed with claws) others not above an inch. All live in the water, and can bear its abfence for a few hours. The fhell is black when. frefh, but turns red by boiling.

The Lobfters creep into a bafket of wicker-work, let into eight or ten. fathom water, for the bait, but cannot get out again. The river Crayfilh differs little from the Lobiter, but that it lives only in frefh water; the other only in the fea.

The CRAB is found equally in frem and falt water; upon land as well. as in the ocean; its Thape differs much from the Lobfter, which it refembles' in habits and conformation. The tail is the broad flap that covers. part of the belly, and when lifted difcovers the Spawn in great abundance. Its claws are two; its legs eight, four on either fide. It is bold, and voracious, and quarrelfome. It refembles the Lobfter, except in its amaz- 
ing bulk of body compared to its head, and the length of its inteftines, which have many convolutions.

The LAND CRAB is found in fome of the warmer regions of Europe, and abundantly in the tropical climates of Africa and America. Various kinds, endued with various properties; fome healthful, delicious, and nourifhing; others very poifoncus and malignant; fome half an inch, others a foot broad; fome are of a dirty brown; others beautifully mottled.

That called the VIOLET CRAB, of the Caribbee. Inands, is the moft noted for its thape, its delicacy, and its manners. . It fomewhat refembles two hands cut through the middle and joined together; for each fide looks like four fingers, and the two claws the thumbs. The body is covered with a thell as large as a man's hand, bunched in the middle, on the fore-part of which are two long eyes, the fize of a grain of barley, tranfparent as cryftal, and hard as horn. A little below there is the mouth, covered with a furt of barbs, under which are two broad tharp teeth, white as fnow; not placed crofs-ways, but rather like the blades of a pair of fciffars. With thefe teeth they cut leaves, fruits, and rotten wood, which is their ufual food. But their principal inftrument for feizing is their nippers, which hold fo tight, that the animal lofes the limb fooner than its grafp; and is often feen fcampering off, having left its claw ftill holding falt the enemy, which keeps for above a minute faftened on the finger after the crab is making off. In fact, it lofes no great matter by leaving a leg or an arm, for they foon grow again. They live in a kind of fociety in the mountains; but regularly once a year march down to the fea-fide, in a body of fome millions. They chufe April or May for their expedition; fallying out by thoufands from hollow trees, the clefts of rocks, and holes which they dig under the earth. The proceffion fets forward from the mountains, with the regularity of an army under the guidance of an experienced commander. The firft divifion confifts of the ftrongelt and boldeft males. Thefe are often obliged to halt for want of rain. The main body is compofed of females (which never leave the mountains till the rain is fet in) forming columns of fifty paces broad, and three miles deep, almoft covering the ground. Three or four days after this the rear guard follows; a ftraggling tribe of males and females, neither fo robuft nor fo numerous as the former, The night is their chief time of proceeding; but if it rains by day, they profic by ir, and move forward in their now uniforn? manner. When the fun hines hor, they hait, and wait till the cool of the evening. When terrified, 
terrified, they march back in confufion, holding up their nippers, which they of ten clatter together, as if threatening their difturbers. If any one is maimed, and incapable of proceert st the reft devour it on the fpot, and purfue their journey. After a thuifand dangers (fometimes during three months) they arrive at their deftined port, and prepare to caft their fpawn. The peas are within their bodies, not under the tail; for the creature waits the benefit of the fea-water to help delivery. The Crab having reached the fhore; eagerly goes to the water's edge, and lets the waves wafh over its body, then' withdraws to land. In a little time the fpawn grows larger, is excluded, and fticks under the tail, as big as a hen's egg, and exactly refembling the rowes of herrings. In this tate they once more feek the thore, and thaking off their fpawn, into the water, leave accident to bring it to maturity. At this time thoals of fin attend, in expectation of this annual fupply; and two thirds, perhaps, of the crabs eggs are immediately deroured by them. Thofe that efcape are hatched under the fand; and foon after millions of little crabs are feen quitting the fhore, and nowly travelling up to the mountains. The old ones have become fo feeble and lean, they can hardly creep, and their flefh changes its colour. Moft of them continue in the flat parts of the country till they recover, in holes in the earth: there throwing off their old fheils, as it were whole, the place where they opened on the belly being unfeen': they become naked, and almoft motionlefs for a week together. They have under their Itomachs four large white ftones, which gradually decreafe as the fhell hardens, at which time the animal is feen nowly making its way back; all this is commonly performed in fix weeks. This Crab, when in the mountains, is impregnable; fubfifting on vegetables, it feldom ventures out; and its habitation is inacceffible. It is only when compelled to defcend into the flat country that it is taken. The natives wait its defcent, and deftroy thoufands; but only feek that fmall fpawn which lies on each fide the ftomach within the fhell, about the thicknefs of a man's thumb. On their return, being covered with a new fkin, refembling foft parchment, almoft every part except the ftomach may be eaten. They are taken in their holes by feeling for them in the ground with an inftrument; or fought after by night with fambeaux. The inftant it perceives itfelf attacked, it falls backward, and with its claws pinches moft terribly. But the dexterous crab-catcher takes them by the hinder legs in fuch a manner, that its pippers cannot toueh him, and throws it into his bag.

Many are found poifonous, hasing fed, as it is thought, on the manchine! 


\section{THE LOB S T E R K I N D.}

chinel apple; and whenever they are found under that noxious plant, they are always rejected.

The SOLDIER CRAB has fome fimilitude to the Lobfter, without its thell. Ufually four inches long, no fhell behind, but covered to the tail with a rough $\mathrm{kin}$, terminating in a point : ftrong hard nippers before, like the Lobfter; one of them is as thick as a man's thumb, and pinches moft powerfully. Thefe have no thell, but take poffefion of one. deferted by fome other animal; it there refides till too large for its habitation: like the former, defcending yearly from the mountains to the fea-fhore, to depolit its fpawn, and to procure a new fhell. It is very probable that its firft care is to provide for its offspring; and it is thought, from the number of little fhells which it is feen examining, that it depofits its fpawn in them. After many trials and combats for a new fhell, the foldier is equipped. There is often a conteft between two for fome well-looking favourite habitation; both endeavouring to take poffeffion; they ftrike with their claws; and bite till the weakeft is obliged to yield.

When this animal is taken, it fends forth a feeble cry, endeavouring to feize the enemy with its nippers; with which, if it faftens, it will fooner die than quit the grafp. The wound is very painful, and not eafily cured. For this reafon, and as it is not much efteemed for its flefh, it is generally permitted to return fafely to its old retreat in the mountains.

\section{TESTA GEO US FISH E S.}

THE manners of this clafs of creatures, that for the moft part creep 1 along the bottom, or are driven by the waves, is almoft entirely unknown. The wreathing of their hells, or their fpots, have been defcribed; but of their appetites, combats, efcapes, and arts of fubfiftence, we are ignorant.

A thell is a natural habitation; hara and ftony; often partly derived by the animal from furrounding objects.; the fluids of the animal furnifhing the cement. Thefe unite into that firm covering which thell-fifh generally refide in.

PARTV. No.30. : T t 


\section{$246, T E S T A C E O U S$ FISHE'S.}

As we cannot defcribe the modes of the deep, and its peculiarities, to give exact ideas of the manner in which fea-fhells are formed, we murt advert to an animal within our infpection; with the formation of whofe fhell we are beft acquainted : fuch is the Garden-Snail, with whofe hiftory Swammerdam has taken endlefs pains. The fame manner of formation extends to all animals having thells, whether on land or in the water. The young fnail, at leaving the egg, carries its fhell on its back, being arrived at a certain growth, and its little habitation fufficiently hardened. This beginning of the fhell only equals a pin's head; but grows rapidly, having at firft but two circumvolutions. As the animal increafes in fize, thefe circumvolutions increafe alfo, until they be five in number, which is never exceeded in land fnails, but. fea fnails fometimes have ten. The animal enlarges its fhell at the mouth, with its little teeth biting and clearing away the fcaly 1 kin from the edges, and then adds another rim to its thell. Its whole body is furnifhed with glands, from which flows out a kind of nimy fluid, like fmall fpiders threads, which unite in one common furface, and by time condenfe into a ftony hardnefs. It is that gliftening fubftance which it leaves after its track. This fluid paffes through an infinite number of little glands till it arrives at the pores of the fkin, but is there ftopped by the fhell below; and therefore rifes to the mouth of the hell, where enlargement is wanted. There the firft layer of nime foon hardens; then another is added, which hardens alfo, till the thell becomes as thick as is requifite. Thus every thell may be confidered as compofed of a number of layers of nime, which have entirely proceeded from the animal's own body. If the external coat be fcaled off, the inner fubftance will be found of one fimple colouring; which hints that the animal's own juices give only one colour; whereas we fee fome fhells ftained with an hundred: fometimes perhaps borrowed from furrounding objects. Others think, that as in the body of every one of thefe animals feveral treaks are difcerned of a different colour, the juices flowing from thofe parts will be alfo of a different hue, and will conformably tinge that part of the Shell which their nime compofes.

Shells have generally a white ground, tinctured with red, yellow, brown, green, and other thades and mixtures; but never blue; for blue is a colour which fea-water clianges.

Convolutions, prominences, and general form depend on the animal, and ufually bear fome refemblance to the body on which they are moulded. 


\section{TES TACEOUS FIS HES:}

moulded. If the animal has any tumour or excrefcence, it creates a fwelling in that part of the incruftation to which it correfponds. When it makes additions to its apartments, the fame protuberance which had raifed the Thell before, fwells it again at fome little diftance, by which the fame inequality runs fpirally all round the fhell. Sometimes thefe tumours are fo large, or pointed, that their counterparts in the incruftation appear like horns : thefe quitted, and others made, increafes their. number. If the body be channelled, the fhell that covers it will be channelled likewife. Their diverfity is fo great, their figures and colours. fo-very ftriking, that feveral perfons have made their arrangement the bufinefs of their lives. Some fhells, fuch as the Stairs Shell, or the Admiral Shell, are equally precious, by their fcarcenefs, as pearls. Shells exhibit great difference of figure; flat, concave, long, lunated, drawn round in a circle, the orbit cut in two; fome rifing on the back, fome fmooth, fome wrinkled, toothed, ftreaked, the point variouly intorted, the mouth pointing like a dagger, folded back, bent inwards : all thefé variations, and many more, furnin at once novelty, elegance, and fpeculation.

Ariftotle has divided them into three kinds : firft, the Univalve, or Turbinated, which confift of one piece, like the box of a fnail ; fecondly, the Bivalve, confifting of two pieces, united by a hinge, like an oyfter; thirdly, the Multivalve, confifting of more than two pieces, as the Acorn Shell, which has not lefs than twelve. Thofe fined up from the deep, are called by the Latin name pelagii; thofe caft on hore, are called litiorales. Many of the pelagii are never feen on. More; they continue in their native depths, and we owe their capture to accident.

Sea-hells exceed both land and forfil thells in beauty, in high polifh, and in brilliant and various colouring. Frefh-waters have but two kinds of fhells; the bivalved and the turbinated. Land fhells are but of one kind, the turbinated; but in that are four or five very beautiful varieties. Foffil, or extraneous thells, are in great numbers, and of as many kinds as in the fea itfelf, and which our moft exact and induftrious thellcollectors have not been able to fin up from the deep, and probably thoufands of different forms ftill remain at the bottom unknown. 


\section{$248-1$ \\ OF TURBINATED SHELL-FISH.}

7 o conceive the manner in which certain animals fubfift at the bot1 tom of the deep, we muft again have recourfe to one of a fimilar nature and formation that we know.

The Snail is fuprifingly fitted for the life it is to lead. Its organs of life are almoft as compléte as the largeft animal; tongue, brain, falival ducts, glands, nerves, ftomach, inteftines; liver, heart, and bloodveffels : befides this, it has a purple bag that furnifhes a red matter to different parts of the body, together with ftrong mufcles that hold it to the Thell, and which are hardened, like tendons, at their infertion.

Its firft ftriking peculiarity is its eyes on the points of its largeft horns. When the Snail is in motion, four horns appear; the two uppermoft and longeft deferve peculiar confideration, having the eyes fixed at their extreme ends, appearing like two blackinh points. When takén out of the body, they are of a bulbous figure; they have but one coat; and the three humours, the vitreous, the aqueous, and the cryftalline, are indiftinct. The eyes are directed to different objects at pleafure, by a regular motion out of the body; or hidden, by a very fwift contraction into the body. Under the fmall horns is the mouth, furnifhed with eight ridges or reeth.

Every fnail is at once male and female; and while it impregnates ano. ther, is itfelf impregnated; veffels fupplying the fluid are placed chielly in the fore part of the neck, and extend over the body; but the organs of both fexes are always found united, and growing together. A large opening on the right fide of the neck, gives a paffage to excrements, ferves as an opening for refpiration, and alfo as an organ of generation; within which each has other neceffary parts, and from which apertures, they being greatly dilated, two organs, refembling inteftines, are feen iffuing: from the fame aperture they lance a kind of dart, which is pretty hard, bárbed, and ending in a very tharp point, fome minutes after, the fnail which received the weapon, darts one of its own at its antagonift, which is received in like manner; then foftly approaching nearer, they clofe with each other. This is generally thrice repeated, at intervals of fifteen days; and, at every time, a new dart is mutually emitted. 


\section{OF TURBINATED SHELL-FISH?}

After eighteen days they produce their eggs, at the opening of the neck, and hide them in the earth with the greatert folicitude. Thefe eggs are in great numbers, round, white, and covered with a foft fhell; fticking to each other by an imperceptible nime: about the fize of a fmall pea.

Sometimes thefe animals are cruthed feemingly to pieces and utterly deftroyed; yet, in a few days, they mend their numerous breaches by the fame fubftance of which the thell is originally made. They are fometimes feen with eight or ten of thefe patches; but though poffeffing power to mend its thell, it cannot, when at full growth, make a new one.

The Snail is very voracious; fubfifts on the leaves of plants and trees; but is very delicate in its choice. The animal moves forward by means of that broad mufcular ikin which fometimes is feen projecting round the mouth of the thell; this is expanded before, and then contracted with a kind of undulating motion; alfo by its nimy fubitance, with which it is copiouny furnifhed, and which it emits wherever it moves, as on a kind of carpet, it proceeds nowly along, without danger of wounding its tender body againft afperities; by this it afcends to its food on trees, and by this defcends, without danger of falling, and breaking its fhell.

At the approach of winter, the Snail buries itfelf in the earth, or retires to fome hole, to continue torpid during the feverity of the feafon: fometimes alone; but more frequently feveral are found together, apparently deprived of life and fenfation. For warmth and fecurity, the Snail forms a cover or lid to the mouth of its thell with its nime, which ftops it up entirely, and thus protects it from every external danger : this is whitifh, pretty hard and folid, yet porous and thin to admit air, withour which the animal cannor live. The Snail awakes one of the firlt fine days of April, breaks open its cell, and fallies forth for nourifhment : being very voracious, at firf almoft any vegetable that is green feems welcome; but the fucculent plants of the garden, and the various kinds of pulfe, are at fome fealons almoft wholly deftroyed by their numbers. So great is the multiplication of fnails at fome years, that garcieners imagine they burft from the earth. A wee feafon is generally favourable to their production; for very dry feafons, or dry places, caufe too great a confumption of its nime, without plenty of which it cannot fublitt in healtl: and vigour.

Of the Sea-Snail naturalifts have mentioned fifteen kinds; of the Frentwater-Snail eight kinds; and of the Land-Snail five. Thefe ftrongly refemble 


\section{OF TURBINATED SHELL-FISH.}

refemble the garden fnail, in the formation of their thell, in their hermaphrodite natures, in the nimy fubftance with which they are covered, in the formation of their inteftines, and in the difpofition and ufes of the hole on the right fide of the neck; yet there are one or two remarkable diftinctions: the FRESH-WATER SNAIL, and probably all fnails that live in water, have a contrivance for rifing to the furface, or finking to the bottom. This is by opening and thutting the orifice on the right fide of the neck, which is furnifhed, with mufcles for that purpofe, in order to draw in or expel the air, as it finds occafion. By dilating this it rifes; by comprefling it, it finks. It is alfo viviparous, and brings forth its young not only alive, but with their thells, in fome degree of perfection.

"March I 2," fays Swammerdam; "I began my obfervations on this fnail, and collected a great number, which I put into a large bafon filled with ran-water, and fed for a long time with potter's earth diffolved in it. Iopened one of thefe fnails, when I found nine living fnails in its womb: the largett were placed foremoft; as the firit candidates for exclufion. I put them into frefh-water, and they lived to the eighteenth of the fame month, moving and fwimming g like frails full grown."

"Of the fea kinds alro, fone are viviparous, while other lay eggs. Such are ore or two of the Buccinums; within which living.young have been frequently found upom diffection. In general the reft of this numerous clafs bring forth eggs; from whence the animal burfts at maturity; completely equipped with an houfe, which the element where it refides does not prevent from enlarging.

Among fome of the fea kinds one impregnates the other; but is incapable of impregnation by the fame, and receives it from a third, which is itfelf impregnated by a fourth. In this manner Mr. Adanfon has feen vaft numbers of fea fnails united together in a chain. In the bulin and the coret the orifices are feparate from each other: that which performs the office of the male being at the origin of the horns; the other farther down on the neck... In general all that have this orifice on the right fide, have their mells turned from right to left; on the contrary, thofe which have it on the left fide, have their thells turned from left to right.

Many , fea fnails want horns, and none have above two. Eyes are unneceffary to creatures whofe food is ufually concealed in the darkeft places; and who, poffeffed of very little motion, are obliged to grope for what they fubfitt on.-Sea fuails are larger than land fnails.

The mouth, in the garden and the frefh-water lnails, is placed croff- 


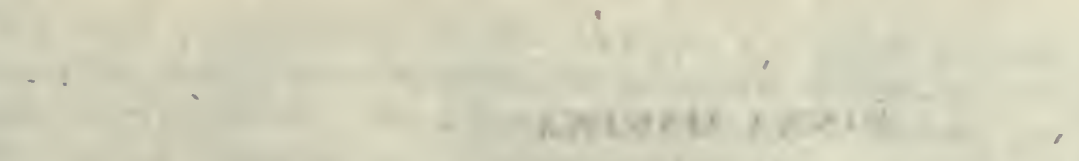

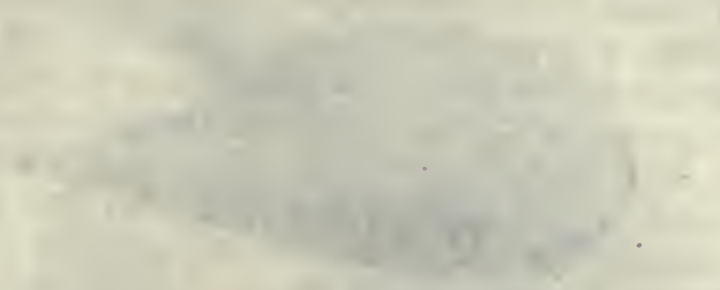

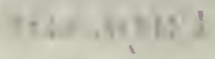

$$
\text { 18x+10y }
$$

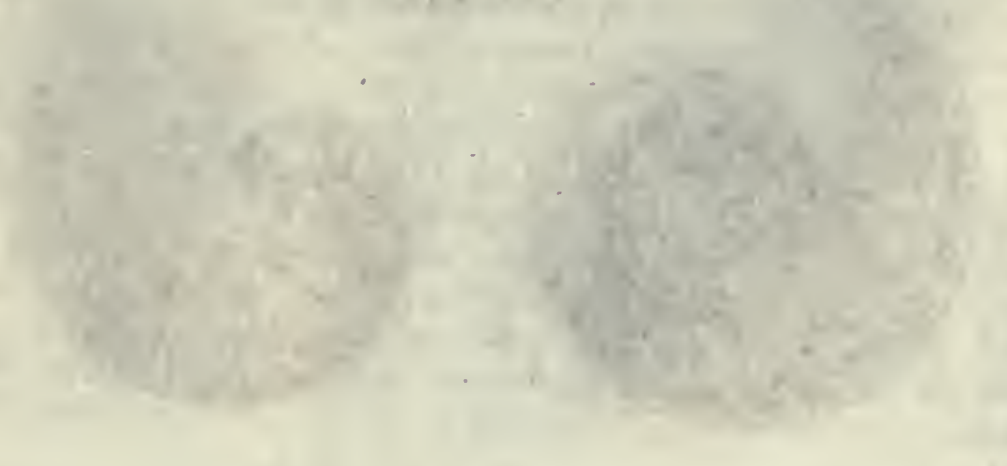


PINNA MARINA

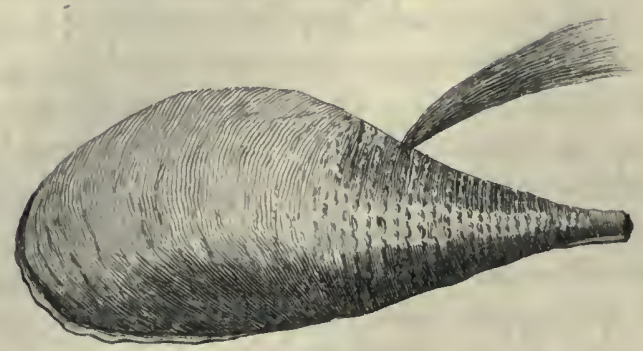

PhOLADE

F
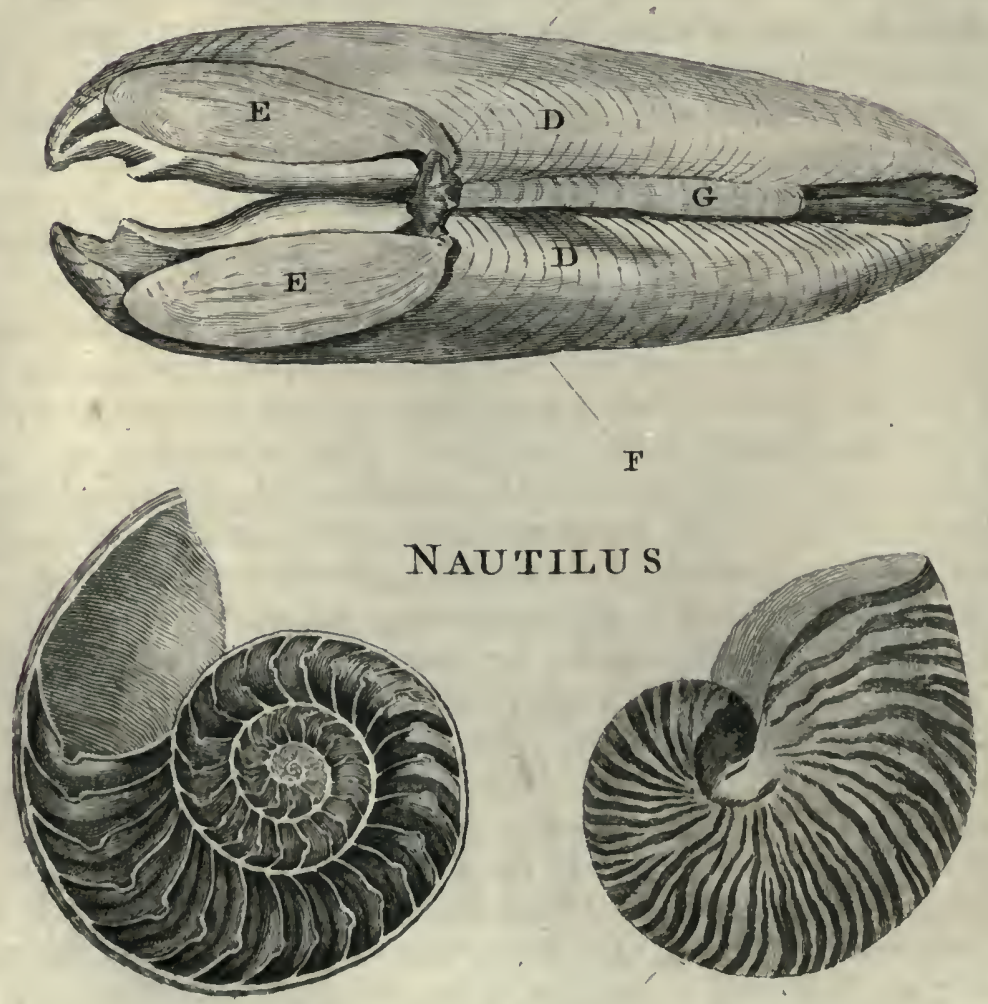
wife, as in quadrupedes. In moft fea fnails, the mouth is placed longitudinally, but in fome obliquely, or on one fide. Others, of the Trochus kind have no mouth; but a trunk, very long in fome kinds, and thorter in others. This trunk is flefhy, mufcular, fupple, and hollow. Its extremity is bordered with a cartilage, and toothed like a faw. Thefe are, among fnails, what the tiger, the eagle, or the thark is among beafts, birds, or fifhes. The whole race of fhelled animals avoid their approach; though of a thick clumfy Shell themfelves, they move with greater fwiftnefs at the bottom than moft fhell filh; and feize their prey with greater facility. No thell fo large but they will boldly venture to attack it; and, with their piercing auger-like trunk, will quickly bore it through. No efforts the invaded animal makes avail : if it expand itfelf, and rife to the furface, the enemy rifes with it ; if it fink to the bottom; its deftroyer clofely adheres. Thus this carnivorous thell-fifh ficks for feveral days, or weeks, to its prey, until with its trunk it has fucked out all fubftance, or until it drops off when the other begins to putrefy.

Befide a thick fhell, many fnails are furnished with a lid, which opens and fhuts at pleafure. When hunting for food, it opens its box, gropes or fwims about; when fatisfied, drops its lid, and finks to the bottom; where it might be fuppoled in perfect fecurity, but that the trochus breaks into its inclofure. Scarce a thell is met with entire and found to the end of its convolutions; but the thinnelt thells are moft fubject to this invafion.

Of all fea fnails, that mort frequently feen fwimming, and whofe thell is thinneft, is the NAUTILUS. Whether it is thus employed in efcaping its enemies at the bottom, or in feeking food at the furface, may be doubted. Its ftomach contains chiefly food found at the bottom. Its induftry, therefore, may be owing to its fears; and its arts of failing may have been originally the product of necefisty.

There are feveral fpecies of the nautilus, yet all may be refolved into two: one with a white fhell, thin as paper, which it often quits, and refumes; the other with a thicker fhell, fometimes of a beauriful mo:herof-pearl colour, and that quits its thell but rarely. This thell outwardly refembles that of a large fnail, but is generally fix or eight inches acrofs: within, it is divided into forty partitions, that communicate with each other by orifices through which one could fcarce thruft a goofe-quill : almoft the whole interior is filled by the animal; whofe body is divided into as many parts as its thell has chambers: thefe parts communicate with each other, though the openings, by a long blood-veffel, which runs PART V. NO. 30 . 


\section{OF BIVALVED SHELL-FISH.}

from the head to the tail : thus the body of the animal, when out of the fhell, refembles a number of foft bits of flefh, threaded on a ftring. How it contrives to difengage its body from fo intricate an habitation; how it makes a fubftance, to appearance almoft as thick as one's wrift, pafs through forty openings, each fcarcely admitting a goofe quill, is not difcovered: but the fact is certain; for the animal is often found without its Thell; and the thell more frequently without the animal. This animal, particularly that of the white light kind, is chielly found in the Mediterranean. When the fea is calm, they are obferved floating on the furface; fome fpreading their little fail ; fome rowing with their feet, as if for life and death; others foating on their mouths, like a thip keel upwards. If taken while thus employed, the extraordinary mechanifm of their limbs for failing appears manifeft. The nautilus is furnifhed with eight feet, which iffue near the mouth, and may as properly be called barbs: thefe are connected to each other by a thin membrane, like that between the toes of a duck; but much thinner and more tranfparent. Of thefe eight feet thus "connected, fix are fhort : thefe are held up as fails to catch the wind; the two others, being longer; are kept in the water; ferving, like paddles, to fteer its courfe. When the weather is quite calm, and the animal is purfued from below, it expands only part of its fail, rowing with the reft: when interrupted, or alarmed from above, it inftantly furls the fail, catches in all its oars, turns its hell mouth downward, and frnks to the bottom. Sometimes it is feen pumping the water from its leaking hulk; and, when unfit for failing, deferts its Thell entirely. The forfaken hulk is feen floating along, till it dánes, by a kind of fhipwreck, on the rocks or the fhore.

\section{OF BIVALVED SHELL-FISH, OR SHELLS OF THE OYSTER KIND.}

TJ E mall find thefe in every refpect inferior to fnails we have been defcribing; in their fentations ; in their powers of motion; in their generation. All the bivalve tribe are hermaphrodite, but require no affiftance from each other towards impregnation; and a fingle muffel or oyfter, were there no other in the world, would quickly replenifh the ocean. 
As the land fnail, being beft known, took the lead' in the former clars, for the farie reafon the fref-water muffel may take the lead in this.

The muffel of freth or falt water has two equal fhells, joined. at the back by a ftrong mufcular ligament that ferves as a hinge. The animal can open its fhells, at pleafure, about a quarter of an inch. It is fixed to each fhell by fourtendons, which hut them clofe, and keep its body firm from being crufhed by any hock againft its own habitation. Its vital organs are fituated in a very extraordinary manner. It has a mouth furnifhed with two flelhy lips; its inteftine begins at the bottom of the mouth, paffes through the brain, and makes a number of circumvolutions through the liver; then goes on ftraight into the heart, which it penetrates, and ends in the anus; near which the lungs are placed, and through which it breathes, like thofe of the fnail kind; and in this manner its languid circulation is thought to be carried on. Each muffel has two ovaries, by which it is female; and two feminal veffels, as a male. Each has its own proper canal : by the ovary canal the eggs defcend to the anus; where the feminal canals fend their fluids to impregnate them. Thus one fingle animal fuffices for generation; and the eggs are impregnated and exciuded by itfelf alone. The ovaries ufually empty themfelves of eggs in fpring, and are replenifhed in autumn. The fecundity of the fnail kind is trifling in comparifon to the fertility of thefe. Their quick multiplication alone infures the continuation of their fpecies.

The multitude of thele animals in fome places is very great; but the numbers of their deftroyers are in equal proportion. The crab, the cray-fin, and many other animals, devour them; and the trochus is their moft formidable enemy. But it feems ftill more fearful of the agitations of the element in which it refides; for if dafhed againft rocks, or thrown far on the beach, it is inevitably deftroyed. To guard againft this, the moft fatal of accidents, it is furnithed with a capacity of binding itfel f by a number of threads to whateverobject it approaches: thefe Reaumur fuppofed it fpun artificially, as fpiders their webs; but the extreme length of this beard in fome, which far exceeds that of the body, feems impoffible to be manufactured by thrufting out and drawing in the tongue, with the glutinous matter of which the French philofopher fuppofed thofe threads were formed. It alfo increafes with the animal; and, as the muffel becomes larger and older, the beard becomes longer, and its filaments ftronger. By thefe threads they adhere to fixed objects; and fometimes, when fuch are wanting, to each other; and though thrown into a lake feparately, they are taken out in bunches of many together. 
Its inftrument of motion, from place to place, is that mufcular fubftance refembling a tongue, which is in fome two inches long, in others not one. This, being thruft out of its fhell, is capable of making a night furrow in the fand. By means of this furrow the muffel can erect itfelf on the edge of its thell; and prolonging this furrow as it advances, it projects its tongue, that anfwers the purpofe of an arm, and thus carries its fhell edge-ways, as in a groove. Where it determines to refide, it fixes the ends of its beard; and thus, like a fhip at anchor, braves all the agitations of the water. Sometimes the animal is attached by a large number of threads; fometimes but by three or four, that feem fcarce able to retain it. It lives on little earthy particles that the water tranfports to its fhells, and perhaps the flefh of the moft diminutive animals. However, fome of this kind have been found a foot long. Of the beard the natives of Palermo fometimes make gloves and ftockings.

Thefe hell-fifh are found in lakes, rivers, and the fea. Thofe of lakes often grow very large; but they feem folitary, and are found generally feparate. Thofe of rivers are not fo large, but more numerous : the fea muffel is the moft abundant. Thefe are often bred artificially in faltwater marhes overflowed by the tide : being thrown in at proper feafons, undifturbed by the agitations of the fea, and not preyed on by their powerful enemies, they caft their eggs, which foon become mature', and are génerally found in clufters of feveral dozen together. It requires a year for the peopling a muffel-bed; fo that, if the number confitts of forty thoufand, a tenth part may annually be left for peopling the bed anew.

The OYSTER differs little from the muffel, except in its thicknefs of thell, and greater imbecillity. Has organs of life and refpiration, very voluminous inteftines, a liver, lungs, and heart. Is felf-impregnated; opens its Thells to receive the influx of water, and is ftrongly attached to its fhell both above and below. Thefe thells are not equal, one being cupped, the other flat; it always refts on the cupped Ihell, for if it lay on the flat fice it would lofe all its water. Its hells are, fo ttrongly lined and defended, that no animal will attempt to pierce them. But it often ferves as an object to which pipe-worms, corallines, and other little animals, fix their habitation, and live in fecurity. Among the number of thefe is a little red worm, often found on the fhell; which fome erroneouny fuppofed to impregnate their fpawn. The oyiter is utterly unable to change its fituation; but is attached very firmly to objects. Rocks, ftones, timber, fea weeds, all feem proper to give it a fixture, and to fecure it againft the agitation of the waves. Nothing 


\section{OF BIVALVED SHELL-FISH.}

fo common in the rivers of the tropical climates, as to fee oyfters hanging amidit the branches of the foreft. Many trees which grow along the banks bend their branches into the water, particularly the mangrove. To thefe the oyfters hang in clufters, like apples on a tree; and as the weight of the filh finks the branch into the water, where it ftill continues growing, the number of oyfters increafe, and hang upon it. They are often found to ftick to each other. This is effected by means of a glue proper to themfelves, which, when cemented, is as hard as the fhell, and is as difficultly broken. The joining fubftance, however, is not always glue; but the animal grows to the rocks, fomewhat like the muffel, by threads which take root in the Phell, and not from the body of the filh.

Oyfters ufually caft their fpawn in May, which at firft appear like drops of candle-greafe, and ftick to any hard fubftance : thefe are covered with a thell in two or three days. In three years the animal is large enough to be brought to market. Oyfters prepared in beds are not fo large as rock-oyfters, which are fometimes as broad as a plate, and admired by fome as excellent. In the Eaft Indies, fome oyfter hells are two feet over, and the filh capable of furnifhing a plentiful meal to eight or ten men; but no way comparable to ours for flavour.

Other bivalved fhell-fifh, the cockle, the fcallop, and the razor-fhell, have other fmall differences in form or manners; but their power of changing place is their greateft difference. The SCALLOP is remarkable for its method of moving on land, or fwimming on the furface of the water. When deferted by the tide, it makes remarkable efforts to regain the water. Firft gaping widely its fhells, often an inch, then fhutting them with a jerk, it rifes five or fix inches from the ground. It thus tumbles any how forward repeatedly, till it has attained its journey's end. When in the water it is capable of fupporting itfelf on the furface; there opening and thutting its thells, it tumbles over and over, and makes its way with fome celerity.

The PIVOT or RAZOR-SHELL, has a very different kind of motion; having only a power of finking point downward. Its thells refemble the haft of a razor; and by this form it is better enabled to dive into the foft fand at the bottom. All its motions are confined to finking or rifing, a foot downwards or upwards, in the fand; for it never leaves the fpot where firtt it was planted. From time to time it is feen to rife about half way out of its hole; but, if difturbed, it finks perpendicularly down again. Juft over the place where the razor is buried, is a fmall hole like 
a chimney, through which the animal breathes, or imbibes the fea-water. At low water, thefe holes are eafily diftinguifhed by the fifhermen, whofe method of enticing the razor up from the depth of its retreat is by fprinkling a little fea-falt on the hole. This melting, no fooner reaches the razor below than it rifes inftantly ftraight upwards, and fhews about half its length above the furface. This is inftantaneous; and if the fifher does not feize the opportunity, the razor buries itfelf with great eafe to its former depth. There it continues fecure; no falt can allure it a fecond time; but it remains unmolefted, unlefs the fifher will be at the trouble of digging it out fometimes two feet below the furface.

In this clafs of thell-firh Pearls are found ufually generated, in the internal parts of thells that are of a thining filvery colour, as well in the muffel or the fcallop as in the oyfter, and in all bivalved fhells whofe infides refemble mother-of-pearl. The oyfter that breeds a large pearl al ways breeds a large fhell, and the hell itfelf indents to receive its impreflion. The pearl is probably accidentally produced by the fame matter as forms the thell. It is foft at firft, but quickly hardens; and by fucceflive coats, layer over layer; acquires its dimenfions. Sometimes a fmall fpeck is feen in the middle, on which the coats were originally formed. The pearl oyfter has a large ftrong whitin thell, wrinkled and rough without, within fmooth and filver-coloured. From thefe mother-ofpearl is taken, which is the internal coats of the thell. The pearl is chiefly prized; being found but in few, generally adhering, fometimes making a print in the body of the Thell, fometimes at large within the fubftance of the filh.

There are many pearl fifheries in America and Afia; but thofe of America are greatly difcontinued. The moft famous of the Afiatic firheries is in the Perfian Gulph, and the moft valuable pearls are brought from thence. Their value increafes in proportion to their fize, their figure, and colour; fome are white, others yellowifh, others a lead colour, and fome black as jet. What occafions thefe different tinctures is unknown. All pearls in time become yellow; they may be confidered as an animal fubftance, converted into a ftony hardnefs, and like ivory taking a tincture from the air. They alfo decay if kept in damp or vaulted places, and moulder into a fubftance fcarce harder than chalk. 


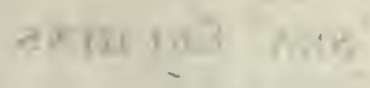

$=$

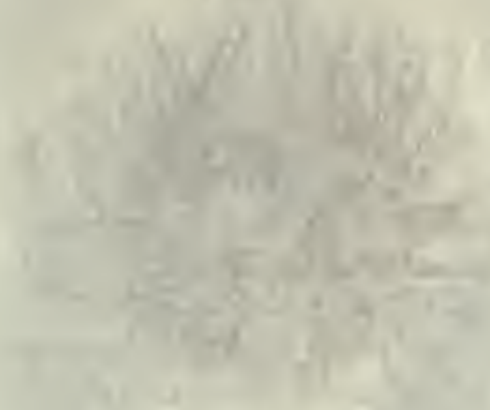

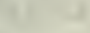

- 


\section{SEA ERCHINS}
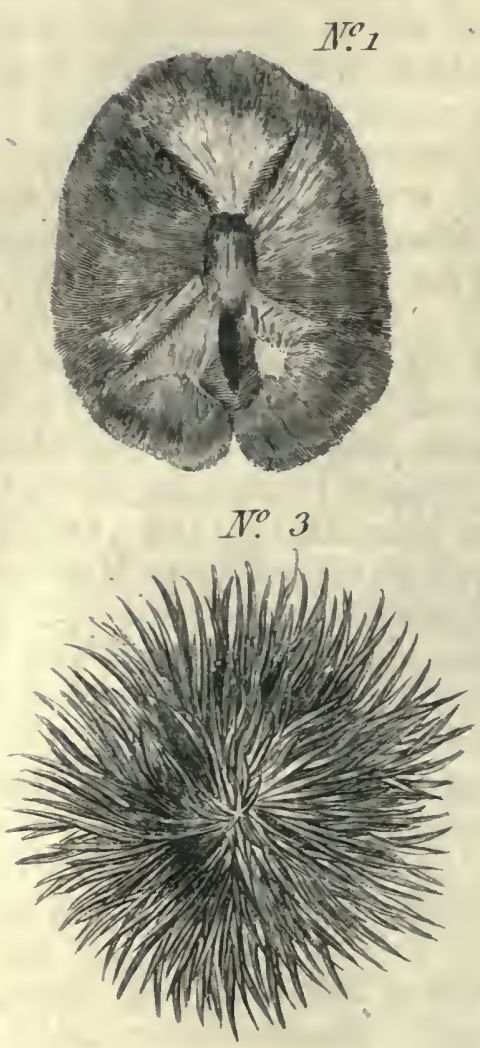

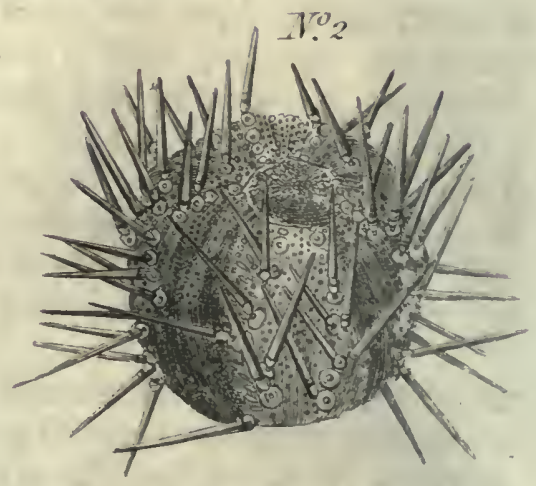

$N^{0} 4$
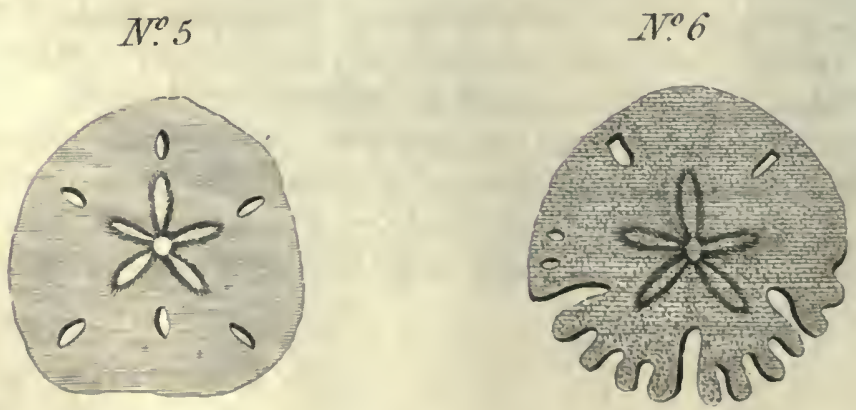


\section{7 ) \\ OF MULTIVALVE SHELL-FISH.}

F thefe are principally two kinds; fuch as move, and fuch as are ftationary : the firft are often known by the name of jea-eggs; by naturalifts, Echini, or Urchins : the latter are called Pholades or FileFinh. Of both there are feveral forts.

The SEA-URCHIN may be compared to the hurk of a cheftnut, being round, and with bony prickles on every fide. The mouth is below, the vent above; the thell is a hollow vafe, refembling a fcooped apple, filled with a foft, mufcular fubftance, through which the inteftines wind from the bottom to the top. The mouth is large and red, furnithed with five Tharp teeth, which are eafily difcerned. The jaws are ftrengthened by five fimall bones, in the centre of which is a fmall flefhy tongue; from this the intertines make a winding of five fpires, round the internal fides of the Rell, ending at the vent at top. Its horns are moveable, like the horns of a fnail, and point from every, part of the body, ferving at once as legs to move on, as arms to feel with, and as inftruments of capture and defence. Between thefe horns it has fpines not endued with fuch a thare of motion. The fpines are hard and prickly; the horns foft, longer than the fpines, and hid at the bafes of the fpines. This apparatus is only feen when the animal is hunting its prey at the bottom of the water; for, a few minutes after it is taken, all the horns are withdrawn into the body, and moft of the fpines drop off. Furnithed with two thoufand fpines, and twelve hundred horns, all ferving for legs, and from their number feeming to impede each other's motion, yet it runs not without fwiftnefs at the bottom, and it is fometimes not eafy to overtake it. It is often taken on the ebb, by following it in Thallow water, either in an ozier bafket, or fimply with the hand. Both the fpines and the horns affift its motion; and the animal is ufually feen running with the mouth downward.

Some kinds are as good eating as the lobfter; their eggs, which are of a deep red, are confidered as a very great delicacy. Of others the tafte is but indifferent; and in all places,except the Meditersanean, they are little fought for, except as objects of curiofity.

The Acorn Shell-fifh, the Thumb-footed Shell-fifh, and the Barnacle, are fixed to one fpot, and appear to vegetate from a ftalk like a kind of fungus, growing in the deep, deftitute of animal life as well as motion:

$$
\text { ParT V. No. } 30 \text {. X X }
$$




\section{$25^{8}$ OF MULTIVALVE SHELL-FISH.}

but the animal refiding within the Thell has not only life, but fome degree of voracioufnefs; it has a cover to open and thut its thell at pleafure, and twelve long crooked arms, furnifhed with hair, which it thrufts forth for its prey, and eight Imaller, which are generally kept in the fhell. They are found adhering to every fubftance in the ocean; rocks, roo:s of trees, hips' bottoms, whales, lobfters, and even crabs, like bunches of grapes clung to each other. It is amufing enough to behold their operations: when the fea is calm, they are feen opening the lid, and peeping about them; they then thruft out their long neck, look round them for fome time, and then abruptly retreat back into their box, thut their lid, and lurk in darknefs and fecurity. Some people eat them.

Of all the Shelly tribe, the PHOLADEs are the moft wonderful. They are found in different places; fometimes in their proper thell, at the bottom of the water; fometimes concealed in lumps of marly earth; fometimes lodged, thell and all, in the body of the hardeft marble. In their proper thell they affume different figures; but, in general, they fomewhat refemble a muffel, except that their fhell is compofed of five or more pieces, the fmaller ferving to clofe the openings left by the irregular meeting of the two principal:

This animal, when divefted of its thell, is roundin and foft, with two teeth, but placed fo as to be incapable of touching the hollow furface of its ftony dwelling. It has two covers to its thell, that open and fhut at either end; but the inftrument with which it performs its operations, and buries itfelf in the hardeft rocks, is a broad flefhy fubftance, fomewhat refembling a tongue, iffuing from the bottom of its thell. With this foft yielding inftrument, it perforates the moft folid marbles : and having, while yet little and young, made its way by a very narrow entrance into the fubftance of the ftone, when it begins to grow bigger, it enlarges the apartment. By now fuccefive applications, it effects what other animals are incapable of performing by force; fuch is the power of perfevering patience. While yet naked and very fmall, it has effected an entrance, and buried its body in the ftone: it there continues for life at its eafe. The fea-water that enters the aperture fupplying it with plenty, it quickly grows larger, and finds a neceffity of enlarging its habitation and its thell; in proportion as it becomes larger, it makes its way farther into the rock: when it has got a certain way in, it hollows downward, till its habitation, when completed, refembles the bowl of a tobacco-pipe; the hole in the thank being that by which the animal entered. Thus immured, the Pholas lives in darknefs, indolence, and plenty, 
plenty, never removing from its narrow manfion; the fea-water that enters by its little gallery fatisfies its wants, and, without any other food, it grows from feven to eight inches long, and thick in proportion. Their thell grows on them in the body of the rock. Thefe thells take different forms, and are compoled of a different number of valves, from three to twelve; fometimes the fhell refembles a tube, with a tole at each end, one for the mouth, and the other for voiding the excrements. Many often meet in the heart of the rock, and frequently break in on each other's retreats. Whether by accident, or of choice, cannot be determined; they are moft commonly found in numbers in the fame rock; and fometimes above twenty within a few inches of each other. 



\section{SURVEYS OF NATURE.}

\section{P.ART THE SIXTH.}

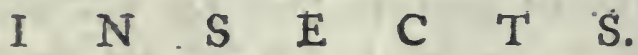

T NSECTS are a fubject almoft inexhauftible from numbers and vafiety. "After an attentive examination," fays Swammerdam, "of the nature and anatomy of the fmalleft as well as the largeft animals, I cannot help allowing the leaft an equal, or perhaps a fuperior, degree of dignity. If, while we diffect with care the larger animals, we are filled with wonder at the elegant difpofition of their parts, to what an height is our aftonifhment raifed, when we difcover all thefe parts arranged in the leaft in the fame regular manner !" Yet the infect tribe deferve but the laft and loweft rank in animated nature; they feem all the mort imperfectly formed; many of them can live a long time, though deprived of organs neceffary to life in higher ranks of nature. They are too often, among ourfelves, unwelcome intruders on the fruits of human induftry; but in lefs cultivated regions, their annoyance and devaftations are terrible. Witnefs Lapland and America, where, if a candle be lighted, the infect fwarm inftantly extinguifhes it with their numbers; where the inhabitants are obliged to fmear their bodies and faces with tar, or greafe, to protect them from the puncture of their minute enemies; where, though millions are deftroyed, famifhed millions ftill fucceed to make the torture endlefs!

Through all nature, nobler animals are flowly produced, while meaner. births are lavifhed in profufion. Of all produckions in nature, infects are the mott numerous. On minute infpection, we shall find every plant fupporting 
fupporting a number of fcarce perceptible creatures, that fill up the va rous ftages of youth, vigour, and age, in the compals of a few days exiftence. Infects have but one invariable method of operating; no arts can turn their inftinets; and generally their life is too fhort for inftruc$\mathrm{tion}_{2}$ as a fingle feafon often terminates it. Many are attached to one vegetable, or a fingle leaf; they increafe with the flourining plant, and die as it decays; a few days fill up the meafure of their lives: the ends of their production, or its pleafures, are utterly unknown to us.

Infects are little animals without red blood, bones or cartilages, furnifhed with a trunk, or elfe a mouth, opening lengthwife, with eyes which they are incapable of covering, and with lungs which have their openings on the fides. Almoft every fpecies has its diftinet hiftory, and exhibits manners and appetites peculiarly its own; generally prolific beyond computation, and multiplied beyond defcription.

To enumerate every fpecies of flies, or moths, would be fruitlefs; to give an hiftory, utterly impracticable. Mr. Ray thought there could not be lefs than twenty thoufand kinds; and one gentleman of my acquaintance, himfelf, caught eight hundred in one feafon in England; yet poffeffed very far from a majority of our natural ttibes. When roufed from their Atate of annual torpidity, and beginning to feel the genial influence of fpring, they exhibit new life in every part of nature.

By felecting fome fimilitudes in propagation, manners, or form, we derive a hint for grouping feveral in one defcription, and thus fhorten the labour of their hiftory. The firft that offer. are thofe without wings, crawling on every plant and fpot of earth. Of thefe, fome never obtain wings; others only wait their growing wings, to arrive at perfection.

The former may be confidered as the firft clafs of infects. All thefe, the flea and the wood-loufe excepted, are produced from an egg, and fuffer no further change of form, but continue to grow larger till they die.

The fecond order, when produced from the egg, have their wings cafed up fo as not to appear. This, however, does not prevent the animal's running, leaping, and moving with celerity; but when the cafe burfts, and the wings expand, all its motions become more extenfive and perfect.

The third order of infects is the moth and butterfly kind. Thefe have four wings, covered with a mealy fubftance of various colours, which when handled comes off on the fingers; and, if examined by the microfcope; appears like fcales or feathers, with which the wing is nicely embroidered. They are firt hatched from an egg, in the form of a cater- 


\section{W I N GLESS INSE C T S.}

pillar that eats, and often cafts its $\mathrm{kin}$, of which when divefted for the laft time, it affumes a new covering, called a chryfalis (or the cone in the filk-worm), in which it continues hidden till it comes forth a perfect moth or butterfly.

The fourth order is thofe winged infeets which come from a worm, not a caterpillar, yet go through changes fimilar to thofe of moths and butterflies. They quit the egg as a worm, then become a chryfalis; in fome, their wings and legs are feen; in others, the animal is detached from the cone which conceals it; but all break their prifon, and come out perfect winged animals; fome with two wings, fome with four. The wings of thefe differ from thofe of the butterly and moth kind, by not having mealy fcales. In this clafs we may place the numerous tribes of gnats, beetles, bees, and flies.

After Infects follow a numerous tribe, that may be propagated by diffection. Some, though cut into an hundred parts, retain fuch life in each, that every part fhortly becomes a perfeet animal. They feem placed between animals and vegetables, and to conneet animated and infenfible nature. To this clafs belong the earth-worm, the fea-nettle, and the polypus. Thefe are not properly infeets; but feem with propriety to follow them, in the general order of nature.

\section{W I N G I E S S I N S E C T S.}

TN general, all animals refembling the flea, the loufe, the fpider, the 1 bug, the wood-loufe, the water-loufe, and the fcorpion, never acquire wings, but are produced from the egg in that form which they never change.

This clafs is, in general, longer lived than others, often continuing their term beyond one feafon, which is the ordinary period of infect exiftence. They feem alfo lefs fubject to the influence of the weather, and often endure winter without torpidity. Sometimes the young burt the thell within the parent's body, and are brought forth alive. This is not unfrequent with the wood-loufe, and others, whicl fometimes produce eggs, fometimes young perfectly formed.

Thefe creatures often, during their exiftence, change their Nkin, in common with many animals. Their $\mathbb{R}$ ins, if compared.to their ftrength

PART VI. No. 30. Y Y and 
and fize, refemble the Thell of a lobfter, and adequately defend then from injuries, particularly from the attacks of each other. Within this they grow, till their fize exceeds that of their covering, then it burfts, and they acquire one more proportionate. Their ftrength is, for their fize, almoft beyond credibility. A flea will draw a chain an hundred times heavier than itfelf, as it will alfo eat ten times its own fize of provifion in a day.

\section{T $\mathrm{H}$ H}

HORMED for rapacity, and living only on infect food, all its habits 1 are calculated to deceive and furprife; it fpreads toils to entangle its prey; is endued with patience to await its coming; and has arms and Atrength to deftroy it when enfnared.

The houfe-fpider, which weaves its web in neglected rooms; the garden-fpider, that fpreads its toils from tree to tree, and refts in the centre; the wandering-fpider, that has no fettled abode; and the fieldfpider, that is fometimes feen mounting, web and all, into the clouds, are the chief of our native fpiders, and, though reputed venomous, are inoffenfive. But in Africa and America, in regions where all infects acquire their greateft growth, where the butterfly expands a wing like our fparrow's, and the ant builds habitations as tall as a man, their fpiders bear a proportionable magnitude. The Martinico 'fpider's body equals a hen's egg, and is covered with hair. Its web is ftrong, and its bite dangerous.

Spiders have two divifions in the body. The fore part, containing the head and breaft, feparated from the hinder part or belly by a nender thread, through which is a communication from one part to the other. The fore part is covered with a hard Shell, as alfo the legs, which unite to the breaft. The hinder part has a fupple $\mathrm{nkin}$, befet with hair. They have feveral eyes round the head, brilliant and acute, fometimes eight, fometimes fix; two behind, two before, the reft on each fide. Their eyes are immoveable, and want eye-lids. They have two pincers on the fore part of the head, rough, with ftrong points, toothed like a faw, and terminating in claws; near the point of the claw, a fmall hole emits a poifon, 
poifon, harmleis to us, yet capable of inftantly deftroying its prey. This is their moft powerful weapon; they can open thele pincers as occafion requires; when undifturbed, they lie one upon the other. They have eight legs, jointed like thofe of lobfters : if a leg be torn away, or a joint cut off, a new one will quickly grow in its place. At the end of each leg are three crooked moveable claiws; a fmall one, placed high up like a cock's fpur, by which it adheres to the threads of its web; and two others, larger, which meet like a lobfter's claw, with which they can hold by the fmalleft depreffions of very polifhed furfaces imperceptible to us. But when they walk on bodies perfectly fmooth, as looking-glafs or polithed marble, they fqueeze a little fponge, placed near the extremity of their claws, and diffufing a glutinous fubftance, adhere to the furface. They. have two other legs, or rather arms, ufed in holding and managing their prey.

The fpider's web is generally laid where flies are moft apt to come and fhelter; in the corners of rooms, round the edges of windows, in the open air among the branches of trees : here the fpider remains days or weeks together, in parient expectation, feldom changing its fituation, though never fo unfuccefsful. To make the web, nature has given this animal a large quantity of glutinous matter within its body; and five dugs or teats for fpinning it into thread. This fubftance is contained in a little bag, and at firft fight refembles foft glue; examined more accurately, it appears twifted into many coils of an agate colour; on breaking it, the contents may be eafily drawn out into threads, from the tena: city of the fubnance, not from threads being already formed. The threads which we fee, and appear fo fine, are compoled of five joined together, and thefe many times doubled to form the web.

When a HousE-SPIDER begiris a web, having chofen fome commo: dious fpot, it diftils one little drop of its glutinous liquor, which is very tenacious; then creeping up the wall, and joining its thread as it proceeds, it darts itfelf in a very furprifing manner to an oppofite point, where the other end of the web is to be faftened; this thread drawn tight and fixed, the fpider runs on it backward and forward, affiduounly doubling and ftrengthening it. The fpider makes a number of threads parallel to the firft; and croffes them with others; the clammy fubitance of which they are formed binding them, when newly made, to each other. The infect after this doubles and trebles the tbread that borders its web, and fecures the edges. The retreat is next attencied to; this is formed like a funnel, at the bottom of the web, for concealment, having two palfiages, $Y y_{2}$

or 
or outlets, one above, the other below; contrived to permit excurfions, at proper feafons, for prying into every corner, and cleaning parts which are clogged or encumbered. Ever attentive to its web, the fpider, from time to time, cleans away duft that gathers round it, giving the whole a Thake with its paws; but not to endanger the fabric. Whenever this web is touched, the fpider prepares for attack or defence. If the infect impinging be a fly, it fprings forward with great agility; if it be an enemy Atronger than itfelf, it keeps within its fortrefs till the danger be over. This retreat alfo ferves for a place.where the creature can feaft upon its game in fafety. Often the labours of an age are deftroyed in a minute, and the fpider is obliged to remain fpectator of univerfal ruin. Of the glutinous fubftance of which the web is made, in this calamity, it either makes a new web, or patches up the old one. There is originally but a certain quantity of this matter, which, when exhaufted, nothing can renew. When this refervoir is dried up, the animal is left to the chances of neceffity. An oid fpider is thus frequenily reduced to the greateft extremity; it hunts about for the web of another, younger and weaker, which is driven out to make a new web, and the old one remains in porfeffion of its labours. If unable to acquire a web, it endeavours for a while to fubfift on accidental depredation; but in two or three months inevitably dies of hunger.

The GARDEN-SPIDER fpins a great quantity of thread, which floating in the air in various direetions, from its glutinous quality, at laft fticks to fome object, a lofty plant or the branch of a tree. The fpider draws the line thus fixed, and paffing and repaffing on it, ftrengthens the thread. From the firft cord the fpider faftens another, dropping from thence to fome folid body below, then climbs up again and begins a third, which it faftens by the fame contrivance, and fo on. When the young fpider begins fpinning, its web is buoyant, and not only the thread floats in the air, but the little fpinfter is fupported by its buoyancy.

A fpider fometimes remains weeks or months' watching without catching a fingle $\mathrm{Ay}$, and is furprifingly patient of hunger. The butterfly, or the hornet, when they touch the web, fly off again, and the fpider feems not difpleafed at their retreat. The large blue-bottle-fly, the ichneumonfly, and the common meat-fly, feem to be its favourite game. When one of thefe ftrikes into the toils, the fpider is inftantly feen alert and watchful at the mouth of its hole, obferving whether the fly be completely immefhed. If he be, the fpider walks leifurely forward, feizes its prey, and inftantly kills it by inftilling a venomous juice into the wound. 


\section{T H E S P I D E R.}

If the fly be not entirely immefhed, the fpider waits, without appearing, till its prey has fatigued itfelf by its ftruggles. If the fpider has fafted long, it drags the fly to its hole and devours it; but if not preffed by hunger, it gives the fly two or three turns in its web, completely to immeen it, and there leaves it for a future fealt.

The males are much lefs than the females; having parts of generation placed in the fore arms, as if burfting out from the points of his fore feet. Their receptacle is beneath the body of the female. She generally lays from nine hundred to a thoufand eggs in a feafon; blueinh, fpeckled with black, feparated from each other by a glutinous ifubltance; not unlike frog-fpawn water. Some are as large as a grain of muftardfeed; others fcarcely vifible. She never lays till two years old. When her eggs have remained an hour or two to dry, fhe prepares them a bag by fpinning a web four or five times ftronger than that for catching flies, and lined within by a down from her breatt. This bag is as thick as paper, fmooth within, rough without. Within this they depolit their eggs. They ftick it by the glutinous fluid to the end of their body; fo that the animal appears as if the had one body behind another. If this bag be feparated from her, he employs all her affiduity to ftick it again in its former fituation, and feldom abandons her treafure but with her life. When the young are exciuded from their thells, within the bag, they remain fome time in their confinement, till the female, inftinctively knowing their maturity, bites open their prifon, and fers them free. She receives them on her back for fome time, until they have ftrength to provide for thenifelves. They begin to fpin when fcarce difcernible, and to prepare for a life of plunder. They are able to deftroy animals ten times bigger than themifelves, and they quickly recover of wounds.

Spiders are enemies of each orher; they are of fuch a malignant nature, they cannot live in fociety, but, inftead of their food, devour each other.

Of this animal are feveral kinds, nightly differing from each other, either in habits or conformation. The WATER-SPIDER is the moft remarkable. This infeet refembles the common fpider, except that its hinder part is rather the thape of a nine-pin than a ball. They differ, by living both by land and water, and fpinning in both elements. Their appearance under water is remarkable; they inhabit the bottom, yet are never touched by the element in which they refide, but are enclofed in a bubble of air that furrounds them. This bubble has the bright appearance of quickfilver; within this they continue eating, fpinning, and 
Meeping, without its burfting, or difturbing their operations : fometimes the bubble is divided into three apartments, and in the fpring the male enters one of thofe to the female; the bubble in which he was contained unites with the other, like two drops of water, when clofely approached. They fpin their webs as well in the water as on land; and mott probably they feed on the fmall infects of both elements.

The celebrated TÁrantula deferves notice as the larget of the fpider kind known in Europe. Is native of Apuleia in Italy; its body three quarters of an inch long, about as thick as one's little finger; colour generally olive-brown, variegated duky; has eight legs and eight eyes; nippers, tharp and ferrated ; between thefe and the fore legs are two little horns, or feelers, which it moves very brikly when approaching its prey. It is covered all over the body with a foft down; and propagates by laying eggs. In the fummer months, particularly in the dog-days, the tarantula creeping among the corn, bites the mowers and paffengers; but in winter it lurks in holes, and is feldom feen. Though the bite is attended with no dagnerous fymptoms, and will eafily cure of itfelf, wonderful ftories are reported concerning its virulence, which has been faid to yield only to the influence of mulic and dancing. Some have thought fuch exercife might promote perfpiration, and fo the cure; while others infift the difeafe requires no curing, being in reality nothing more than a craving for the contributions ufually levied on paffengers or bye-ftanders who happen to be prefent.

\section{T H E F L, E A.}

7 HIS infeet, the enemy of mankind, alfo of the dog, cat, and feveral other animals, is found in every part of the world, but bites with greater feverity in fome countries than in others, Its numbers in Italy and France are much greater than in England.

It has a fmall head, Jarge eyes, and a roundin body. It has two feelers, or horns, thort, compofed of four joints; between thefe lies its trunk, which it buries in the fkin, and through which it fucks blood. The body is covered with a fuit of poined armour neatly jointed, befet with many tharp prickles. It has fix legs, whofs joints are fo adapted, that it can, 


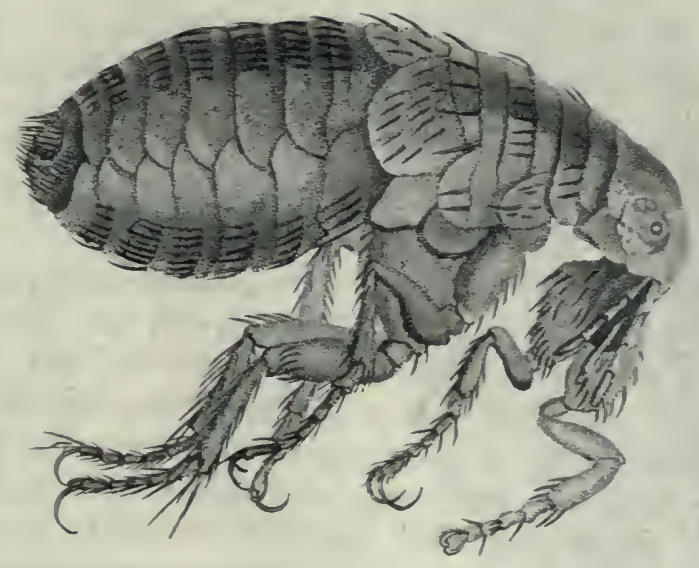

The Flea.

magnified 



\section{T H. E L O U S E.}

as it were, fold them up one within another; in leaping, they all fpring at once, whereby its whole ftrength is exerted, and the body raifed above two hundred times it own diameter.

Fleas are at firft a fort of nits or eggs, round and fmooth; from thefe proceed white worms, of a thining pearl colour : in a fortnight they are a tolerable fize, very lively and active. If touched, they roll themfelves up in a ball; foon after they begin to creep, and feek a place to lie hid in, where they fpin a filken thread from their mouth, and with this inclofe themfelves in a fmall round bag or cafe, white within, but dirty without: here they continue a fortnight, and burft from this confinement perfectly formed.

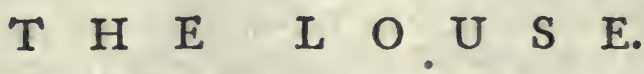

$\mathrm{N}$ examining the human loufe with the microfcope, its deformity ftrikes us with difgurt: the fore-part of the head is oblong, the hind-part fomewhat round; the $\mathrm{kin}$ hard, and, being ftretched, tranfparent, with here and there feveral briftly hairs; in the fore-part is a probofcis or fucker; on each fide the head are antennæ, or horns, each divided into five joints, covered with briftly hair ; and feveral white veffels are feen through thefe horns; behind thefe are the eyes, which feem to want thofe divifions obfervable in other infects, and appear encompaffed with fome few hairs; the neck is very hort, the breaft divided into three parts; on each fide are fix legs, confifting of fix joints, covered with briftly hairs; the ends of the legs are armed with two finaller and larger ruddy claws, ferving thofe infects as a finger and thumb, by which they catch hold of objects; the end of the body terminates in a cloven tail; the fides are all over hairy; the whole refembling clear parchment, and, when roughly preffed, cracking with a noife. On a clofer view, its white veins, and other internal parts, appear; as likewife a moft wonderful motion in its inteftines, from the tranfparency of its external covering. When the loufe feeds, the blood is feen to rufh, like a torrent, into the ftomach ; and its greedinefs is fo great, that the excrements contained in the inteftines are ejected at the fame time, to make room for this new fupply. The loufe has neither beak, teeth, nor mouth, as Dr. Hooke PART VI. No. 30. defcribed 
defcribed it, but a probofcis or trunk; or pointed hollow fucker, with which it pierces the 1 kin, and fucks the blood only: The ftomach is lodged partly in the breaft and back; but moft of it in the abdomen. When fwollen with blood, it appears dark brown; vifible through the fkin; and is either a faint red, or a full or bright brown, as the contents of the ftomach are more or lefs changed. When it is emptyे, it is colourlefs; but when filled it is plainly difcernible, and its; motion very extraordinary, working with very ftrong agitations, the old aliment mixing with the new. If kept fafting two or three days, and placed on the back of the hand, it will immediately feek for food; the more readily, if the hand be rubbed till it grows red. The animal then turns its head to the fkin, and diligently fearches for forme pore; when found, it fixes the trunk therein, and foon the microfcope difcovers the blood afcending through the head, in a very rapid, and even frightful ftream. The loufe has at that time fufficient appetite to feed in any pofture; it is then feen fucking with its head downward, and its tail elevated. If, during this operation, the 1 kin be drawn tight, the trunk is bound faft, and the animal is incapable of difengaging itfelf; but it more frequently fuffers from its gluttony, fince it gorges to fuch a degree, that it is cruthed to pieces by the nighteft impreffion.

Swammerdam is inclined to think them hermaphrodites, having found an ovary in not lefs than forty-two. In one were found ten large.eggs, and forty-four fmaller. Scarce any animal multiplies fo faft as this unwelcome intruder. The moment the nit gets rid of its fuperfluous moifture, and throws off its fhell, it begins to breed in turn. Nothing fo much prevents their increafe as cold drynefs : the nits mutt be laid warm and moderately moift to produce any thing. Linnæus is of opinion, that the head and the body loufe differ in no refpect from each other. : They feldom attack any in our climate, but fuch as from noth or famine invite their company.

It would be endlefs to defcribe the various tribes, under this name, that fwarm on every part of nature; fcarce an animal, or vegetable, that does not fuffer from its own peculiar loufe. The fheep, the horfe, the hog, and the elephant; the whale, the hark, the falmon, and the lobfter; every hot-houfe and every garden is infefted with fome. Linnæus once found a vegetable loufe on fome plants newly arrived from America: willing to trace the little animal through its various ftages, he brought it with him from London to Leyden, where it became the parent of fo numerous a progeny, that it foon over-run all the phyfic-garden of that beautiful city. 
That which fome have called the LeAF-Louse, is the fize of a fea; bright green, or blueith green colour; the body nearly oval, largeft and moft convex on the hinder part; the breaft very fmall, the head blunt and green; the eyes are prominent on the fore-part of the head, of a thining black; near thefe, is a black line on each fide; the legs are very nender. Thefe are ufually found on the leaves of the orache, and other plants; and the weaker the leaves and buds, thefe infects fwarm in greater abundance. Some plants are covered over with them. They do not caufe the plant's weaknels, but by wounding and fucking the leaf they increafe the difeafe. They generally affume their colour from the plant on which they refide. Thofe on pot-herbs and plum-trees, are afh-coloured, but greenim when young; thofe of the alder and cherry tree, are black, alfo thofe on beans and fome orher plants; thofe on the leares of apples and rofe-trees, are white: as thefe leap like grafshoppers, fome place them in the number of the flea kind. The moft uncommon colour is reddin, and this fort is found on the leaves of tanfey ; and their juice, when rubbed on the hands, tinges them red. All theie live on their refpective plant, and are often engendered within the very fubftance of the leaf.

Thefe bring forth their young alive; their fore-parts being excluded firt. Its provifion lying beneath it, during fummer it eats and creeps with great agility : for winter it endeavours to fecure a retreat near trees or plants that nourih it in fpring. They never hide in the earth, becaufe they have no part fitted to remove earch; nor can they creep into every chink, as their legs are long, and their bodies fo tender, the leatt rough particle of earth would hurt then; ; but they get into the deep chinks of the bark, and the cavities of ftronger ftalks. As neither the temperature of autumn nor fpring hurts them, they feldom feek hidingplaces before the fall of the leaf, and take the earlieft advantage of recurning warmth. They caft their fkins four times; the males have four wings, the females none. They have long legs, to creep over the long hairs of plants and leaves, or to travel from tree to tree when diftant. Their trunk or fnout lies under the breaft; this they thruft into the pores of the plant, and fuck out the juice; but fo hure the leaves by 'fucking, that they become ipotted and fcabbed, their edges always turning up. The leaf-loufe is more than a match for the ant at fingle combat. When they perceivé the ant approaching behind them, they kick back with their hinder feet, and drive off the invader, as a horfe would a lion.

The three principal and conftant enemies to thefe infects are, firft, the 


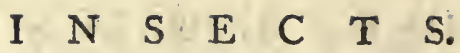

fire-fly, which lays its eggs where thefe infects are in greateft number, which produce worms, that feize and devour all the leaf-lice that come near : another enemy is the worm of a peculiar kind of beetle, which deftroys them in great numbers; but the mot formidable is the ichneumon fly, that feizes one of the largeft females, and lays its egg on her; this is hatched into a worm, which foon devours and deftroys the animal from whofe body it fprung.

\section{T H E $\mathrm{H} \quad \mathrm{B} \quad \mathrm{U} \quad \mathrm{G}$}

CONTRIVES its habitation with much art, feems to avoid the light with great cunning, and if candles be kept burning will not iffue from its hiding place; but when darknefs promifes fecurity, it iffues from every corner, drops from the teiter, crawls from behind the arras, and travels with great afiduity to the unhappy patient, who vainly wifhes for reft and refrefhment. Not lefs difagreeable from their naufeous ftench, than their unceafing appetites: when they crawl, the whole bed is infected; but, if accidentally killed, it is infupportable. In GreatBritain they multiply lefs than on the Continent. In France and Italy the beds, particularly in their inns, fwarm with them, as doth every piece of furniture. They grow larger alfo, and bite more cruelly.

This animal confifts of three principal parts; the head, the corfelet, and the belly; has two brown eyes, very fmall, and a little prominent; and two feelers, with three joints: underneath thefe is a crooked trunk, which lies clofe on the breaft. The breaft is a kind of ring, in which are the two firft pair of legs.' The belly confifts of nine rings, under which are two pair of legs more. Each leg has three joints, forming the thigh, leg, and foot, which is armed with a crooked claw, like a hook. The body is fmooth, except a few Phort hairs about the vent, and on the two laft rings. Its motion is now and unwieldy; but its fight exquifite. This infect internally has the great artery, which as in all infects performs the functions of the heart; apertures of the lungs on the right fide and left, through which it breathes; a ftomach and inteftines.

The male and female are plainly diftinguifhable. The female bas an ovary filled with eggs, joined together like a bunch of grapes; each egg being 


\section{THE WOOD - LOUSE. -}

being oblong, almoft cylindrical, inclining to white, and pretty tranfparent. In about two days after impregnation, the depofits about an hundred and fifty eggs; they continue fome months; during which time, neither cold nor heat, moifture nor fumigation, can in the leaft retard their exclufion. It is this hardinefs in the fhell that feems to contirue the breed; as the old ones die every winter, or are eafily deftroyed by fumigation. Cleanlinefs is the beft antidote to thefe naufeous infects. They are fometimes found in fuch numbers among old furniture, and neglected chambers, expofed to the fouth, that, wanting other fuftenance, they devour each other. They are alfo enemies to other vermin, and deftroy fleas very effectually.

Of the bug kind Linnæus reckons forty.

\section{THE WOO D - L O U S E}

$\mathrm{S}$ feldom above half an inch long, and a quarter of an inch broad; co1 lour livid black, when found about dunghills and on the ground; but thofe under tiles, and in drier places, are of a dun colour. It has fourteen feet, feven on each fide; only one joint each, which is fcarcely perceivable. It has two hort feelers; the body is oval. When touched, it rolls itfelf into a fort of ball; the fides, near the feet, are dentated; found among rotten timber and decayed trees: in winter, lies hid in crevices of walls and buildings. The male is diftinguifhable from the female, being lefs, and more nender; her eggs are white and fhining like feed pearls, and very numerous : properly fpeaking, although the young when excluded have the appearance of an egg, yet they are alive, and, without throwing off any thell, fir and move about; fo that this animal may properly be faid to be viviparous. The little worms at firft feem fcarce able to ftir; but foon feed, and become very brifk. Thefe animals are of great ufe in medicine; being impregnated with a faline quality, which is diuretic and ftimulating.

Of this infeet Linnaus makes three fpecies. 


\section{THE MONOCULUS, OR ARBORESCENT WATER-FLEA,}

TS the fize of a flea; appears to the fight to have but one eye; for, by the fmallnefs of the head, the eyes feem joined to each other : they are fituated in the trunk, and appear, by the microfcope, to be reticulated, or net-like; the trunk is not only fmall and harp, but tranfparent. The infeets are blood-red; fometimes in fuch multitudes on the furface of ttanding water, as to make it appear red; whence fanciful people have thought the water to be turned into blood.

This animal's branching arms, and their motion in the water, deferve. attention. By thefe it can move in a ftraight line ; waving them, as a bird its wings, fometimes upward, fometimes downward, fometimes to the right, fometimes to the left. By ftriking the water with thefe, it af-. cends with greas velocity; by ftriking in a contrary direction, it dives with equal eafe. As thefe motions are very rapid, the little animal appears to jump in the water, its head always tending to the furface, and its tail ftretched downward. This infect is produced from an egg, which, when exclued, is carried on the back of the female, and foon is feen floating in the water round her. Its appearance at firft is that of a very fmall whitifh infect, endued with a very nimble motion. Except in colour, it fuffers no change, only continuing to grow larger and redder, as it grows old. They fometimes remain feveral days on the furface of the water; and fometimes are feen at the bottom only; but never at reft. They change their fkin, like moft other infects; and the caft 1 kin refembles the infect itfelf fo exactly, that one might miftake the mank for the animal.

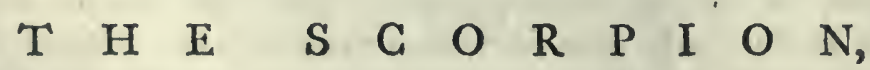

THOSE thape is hideous, whofe fize enormous, and whofe fting fatal, is entirely a ftranger among us. In feveral parts of the Continent of Europe it is but too well known, though feldom above four inches long: in the tropical climates, it is feen a foot in length, and in fize equals a lobfter. It is alfo more eminently poifonous and fatal. 
The Scorpion

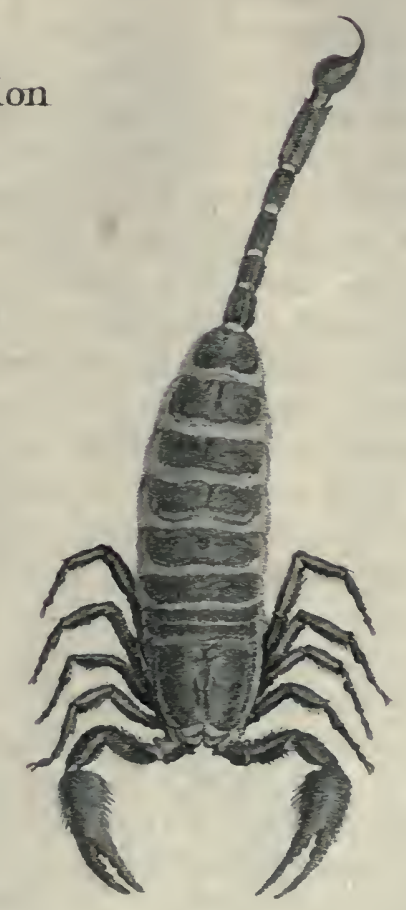



Not lefs terrible from its fize than its malignity. It refembles a lobfter fomewhat in thape. There are counted nine kinds of this dangerous infect, chietly diftinguifhed by their colour; yellow, brown, and alh-coloured, ruft-coloured, green, pale yellow, black, claret-colour, white, and grey.

There are four principal parts diftinguifhable in this animal; the head, the breaft, the belly, and the tail. The fcorpion's head feems, jointed to the breaft; in the middle of which are two eyes; and a little forwarder two more, placed in the fore part of the head, fo fmall, they are fcarcely perceivable. The mouth has two jaws; the undermoft divided, and the parts notched into each other, which ferve as teeth: thefe can, at pleafure, be withdrawn into its mouth, fo that no part can be feen. On each fide the head are two arms, each compofed of four joints; the laft large, with ftrong mufcles, and like a lobfter's claw. Bulow the breaft are eight articulated legs, each divided into fix joints, having two crooked claws, and here and there covered with hair. The belly is divided into feven litele rings; from the loweft of which is coñtinued a tail, compofed of fix joints, briftly; the laft armed with a crooked fting, long, pointed, hard, and hollow; pierçed near the bafe by two fmall holes, through which the animal ejects a drop of poifon, white, cauftic, and fatal. The refervoir of this poifon is a fmall bladder near the tail, into which the venom is diftilled by a peculiar apparatus. If this bladder be gently preffed, the venom will be feen iffuing out through the two holes above-mentioned.

Few animals are more formidable, or more truly mifchievous. As it takes refuge in fmall places, and generally in houfes; it muft almolt inevitably fting fome among whom it refides. In fome parts of Italy and France, in the province of Languedoc, it is one of the greateft pefts; but its malignity in Europe is trifling, when compared to thofe of Africa and the Eaft. In Batavia they grow twelve inches long; there is no removing any furniture without the utmot danger. Along the Gold Coalt they are equally large, and their fting fatal.

No animal in the creation feems endued with fuch an irafcible nature. When taken, they exert their rage againft the fides of the glafs veffel containing them. They will attempt to fting a ftick when put near them; and attack a moure or a frog, while thufe animals were far from offering any injury. Maupertuis put three fcorpions and a moufe into the fame veffel together, and they foon ftung the litcle animal in different places. The moufe ftood for fome time on the defenfive, and at laft PART YI, No. 30. 
killed them all, one after another. He tried this experiment in order to fee whether the moufe, after it had killed, would eat the fcorpions; but the little quadrupede feemed entirely fatisfied with the victory, and even furvived the feverity of its wounds. Wolkamer tried the courage of the fcorpion againft the large fpider, which at firft ufed all its efforts to immen the fcorpion in its web, which it immediately began fpinning; but the fcorpion refcued itfelf from the danger, by ftinging its adverfary to death: it foon after cut off, with its claws, all the legs of the fpider, and then fucked all the internal parts at its leifure.

The fierce fpirit of this animal is equally dangerous to its own fpecies. Maupertuis put an hundred of them together in the fame glafs; and they fcarce came into contact, when they began to exert all their rage in mutual deftruction : there was nothing to be feen but one univerfal carnage, without diftinction of age or fex; fo that, in a few days, there remained only fourteen, which had killed and devoured all the reft. When driven to extremity, the fcorpion will deftroy itfelf. If placed amidn a circle of burning charcoal, and thus an egrefs prevented on every fide, the fcorpion runs round the circle in hopes of efcaping; but finding that impoffible, Atings itfelf on the back of the head, and inftantly expires.

The male and female are eafily diftinguinable; the male being fmaller and lefs hairy. The female brings forth her young alive and perfeet, thirty or forty at a time. How long they live we are not told; but probably feven or eight years; and the larger kind double that duration. They caft their fhell, or fkin, which is fofter by far than the lobfter's, and fet with hairs in abundance, particularly at the joinings. The young lie in the parent, each covered up in its own membrane, and united to each other by an oblong thread, in the form of a chaplet.

There is an American fcorpion, produced from eggs no larger than pins points, and depofited in a web, which they fpin from their bodies, and carry about with them till they are hatched. As foon as the young are excluded from the Ahell, they get on the back of the parent, who turns her tail over them, and defends them with her fting. 


\section{$(277) 1$}

\section{THE SCOLOPENDRA AND GALLY-WORM。}

ThHE ScolopeNdRA, or CeNTIPEs, having many feet, is very common in many parts of the world, efpecially between the tropics. In the Eaft-Indies they grow to fix inches long (ours are but one inch), of a ruddy colour, as thick as a man's finger : they confift of many joints, and from each joint a leg on each fide : they are hairy, and feem to have no eyes, but two feelers on the head, by which they find out their way. The head is very round, with two fmall tharp teeth, with which they inflict wounds that are very painful and dangerous. Of this animal there are different kinds; fome living, like worms, in holes in the earth; others under ftones and among rotten wood; fo that nothing is more dangerous than removing thofe fubltances, in places where they breed.

The GALLY-Worm differs from the Scolopendra in having double the number of feet, there being two on each fide to every joint of the body. Some are fmooth, and others hairy; fome yellow, fome black, and fome brown. Are found among decayed trees, between the wood and the bark; alfo among ftones covered with mols. When touched, contract themfelves, rolling themfelves up like a ball. Whatever be their qualities in the tropisal parts of the world, in Europe they are perfeetly harmlefs. Thefe are fuppofed to be produced perfect from the parent or the egg. They are feen of all fizes; and this is fufficient inducement to fuppofe that they preferve their firft appearance. It is probable, however, that, like moft of this clafs, they often change their Ikins; but of this we have no certain information. 


\section{$(278)$}

T H E

\section{SECOND ORDER OF INSECTS.}

$7 \mathrm{O}$ this we refer the Libella, or Dragon-Fly ; the Formica-Leo, or Lion-Ant ; the Grafshopper; the Locuft ; the Cricket; the WoodCricket; the Mole-Cricket; the Flea-Locuft; the Flying-Bug; the Tipula; the Water-Scorpion; the Notonecta, or Water-Fly; and many others, produced by eggs, but without wings, which they afterwards acquire.

\section{THE LIBELLA, OR DRAGON-FLY,}

TS, of all the Aies which diverfify Nature, the moft various and moft 1 beautiful; of all colours; green, blue, crimfon, fcarlet, white; fome unite variety of moft vivid tints, in different hades. They are called, in different parts, by different names. They are diftinguinhed' from all other flies by the length of their bodies, the largenefs of their eyes, and the beautiful tranfparency of their wings, which are four. In fummer they lly rapidly near every hedge, and by every running brook; they fometimes fettle on the leaves of plants, and fometimes keep hours together on the wing.

Though there are three or four different kinds, yet they agree in the moft ftriking parts of their hiftory. The largeft are from two to four inches long; their tail forked; their body divided into eleven rings; their eyes large, horny, tranfparent, net-like; their wings, that always jie flat when at reft, of a beautiful gloffy tranfparency, fometimes thining like filver or gold. Within the mouth are two teeth, covered with a beautiful lip: with thefe the creatures bite fierçely when taken; but their bite is harmlels.

They are produced from eggs, depolited in the water, where they remain fome time without life or motion. They are ejected by the female into the water in clufters, like a bunch of grapes, where they fink to the bottom, 
bottom, and continue till the young find ftrength enough to break the thell, and to feparate from each other. They, firft thew life as a worm, with fix legs, bearing a ftrong refemblance to the dragon-fly in its winged ftate, except that the wings are yet concealed within a fheath. Their rudiments appear in bunches on the back, within which the wings are folded up into each other, while all the colours and varieties of painting appear through the $\mathrm{kin}$. On quitting the egg, they ftill continue in the water, where they creep and fwim, but not fiviftly. They have a tharp figlit, and fink to the bottom whenever they perceive unufual objects. Their food is foft mud, and the glutinous earthy fubftances at the bottom.

When they prepare to change from their reptile to their fying ftate, they quit the water for a dry place, as grafs, pieces of wood, ftone, or any thing elle they meet with. They there firmly fix their acute claws; and for a hort time continue immoveable. The fkin firft opens on the head and back; out of this opening they exhibit their real head and eyes, and at length their fix legs; whilft the empty finin, or flough of their legs, remains firmly fixed in its place. After this, the inclufed creature creeps forward by degrees; drawing firt its wings, then its body, out of the Ikin; and proceeding a little farther, refts for fome tima, as if immoveable. During this time the wings, which were moift and folded, by degrees expand, and fmoothen their plaits, which were laid againft each other, like a clofed fan. The body is likewife infenfibly extended, until the limbs have cbrained their proper dimenfions. All thefe furprifing and difficult operations are accomplithed by the force of the blood and the circulating humours. The creature cannot at firft ufe its new wings, but is forced to ftay in the fame place till its limbs are dried by the circumambient air. It foon, however, wings the air, and felects the variety of its provifions. Nature has provided it with two large eyes, which make almoft the whole head, and which refemble'gli:tering mother of pearl. It has four expanfive filver-coloured wings, with which, as with oars, it can turn itfelf fwiftly; and a very long body, which, like a rudder, directs its motions. As the wings are long, and the legs fhort, they feldom walk, but are ever feen either refting or Aying. They always chufe dry branches of trees or thrubs to fettle on; and, when refrefhed a little, renew their light.

They are tyrants of the infect tribe; and, like the hawk, only hovering to feize their prey. They are the ftrongeft and moft couragecus of winged infects. The blue fly, the bee, the wafp, the hornet, and 
the butterfly, are their prey. They fpend the whole day in purfuit, and have been feen to devour three times their own fize in a fingle hour. They feize their prey llying, with their fix claws, and eafily tear it to pieces with their teeth.

The males feek the females with great ardour; their part is placed not at the end of the tail, but under the brealt; that of the female lies in the tail. When he finds himfelf fufficiently near the female, he feizes the back of her head; and faftening his claws upon her, turns his forky tail, which he faftens round her neck, and fixes himfelf clofely and firmly, often for three or four hours. When he flies, the is obliged to fly with him; he ftill directs the way, and the feems entirely guided by his motion. At laft, turning up the end of her tail to his breaft, her eggs receive the neceffary fecundation. An hour or two after, the flies to fome neighbouring pool to depolit her eggs. They continue in a reptile ftate for a year, and then are changed into a beautiful $\mathrm{Ay}$, refembling the parent,

\section{THE FORMICA-LEO, OR LION-ANT,}

THEN it becomes an inhabitant of air, refembles that already defcribed; its glofly wings, its voracious appetites, its manner of oeneration, are the fame. In its reptiles ftate it differs.

Tie Lion-ANr, in its reptile ftate, is the fize of a common woodloule, but fomewhat broader; has a lopg head, and a roundifh body, narrow towards the tail; colour, dirty-grey, fpeckled with black; the body compofed of feveral flat rings, which lip one upon another. It has fix feet, four fixed to the breaft, and two to the neck. The head is fmall and flat, and has two little fmooth horns and feelers, hard, about a quarter of an inch long, crooked at the ends: at their bafis are two fmall black lively eyes, by which it can fee the fmalleft object, as is eafily difcovered by its ftarting from every thing that approaches.

This animal poffeffes the moft ravenous appetites in nature. Its legs only enable it to run backward; fo that, be it never fo familhed and rapacious (as it ever feems) its prey muft come to it, or rather into its fnares, It chufes a dry fandy place, at the foot of a wall, or under fome helter, 
to preferve its labours from rain. A heavy clogged earth would defear its labour. When it commences the hole for its trap, it bends the hinder part of its body, which is pointed, and works backward, making a circular furrow; within this firft it digs a fecond, a third, and others always lefs than the preceding. Then it begins to deepen its hole, fink ing it lower and lower in the fand, which it throws with its horns, or feelers, toward the edges. This hole is always a circle, and refembles an inverted funnel. When this infect is quite young, its firtt pit is very finall; as it grows, it makes a larger. It is generally two inches deep, and as much in diameter. The infidious infect places itfelf in amburh, hiding in the bottom under the fand, fo that its two horns encircle the bottom of the pit. The fides of this pit. fall are made of the moft loofe and crumbling materials; fo that fcarce any infect can climb up, that has once got down to the bottom. If then an ant, a wood-loufe, or fmall caterpillar walk too near the edge of this precipice, the fand gives way beneath them, and they fall to the bottom to inevitable deftruction. The fall of a fingle grain of fand gives notice at the bottorn, and the murderer never fails to fally forth to feize its prey. If the ant or wood-loufe is too nimble, and runs up the fides of the pit-fall, the lion-ant, by means of its broad head and feelers, throws up a hower of fand, which falling on the ftruggling captive with tremendous weight, once more cruphes it down to the bottom; then no efforts can releafe it : the lion-ant feizes it with its feelers, which are hollow, and darting them both into its body, fucks out all the little animal's juices with the utmoft rapacity. The prey thus reduced to a hurk, his next care is to remove the body from its cell, left its appearance might warn others of danger; he takes up the wafted trunk with his feelers, and throws it, with wonderful ftrength, at leaft fix inches from the edge of his hole; and fets about mending the breaches his fortifications had received in the laft engagement. Nothing can abate its induftry, its vigilance, its patience, or its rapacity. It will work for a week at its pit-fall; it will continue on the watch a month, expecting the approach of prey; and, if it comes in plenty, will quit the infect it has newly killed, to kill another : yet is furprifingly patient of hunger, fome having been kept in a box with fand fix months withour feeding.

When it is to change its form, it quits its ufual rapacious habits, but keeps its induntry. It furrows up the fand all round irregularly; teftifying thofe workings and violent agitations which moft infeets exhibit previous to their transformation. Thefe animals are produced in autumn, PART VI. No. 30 . 
generally live a year, perhaps two, before they affume a winged form. After furrowing up the fand, it hides itfelf under it, horns and all. It there fpins a thread, which being glutinous and humid, fticks to the little particles of fand among which it is fpun; and the infect rolls up its web, fand and all, into a ball, about half an inch in diameter, of which itfelf is the center, and its apartment fufficiently fpacious for its motions, compofed of filk only, of a fine pearl colour, extremely delicate and beautiful. It feems externally a lump of fand; and thus efcapes the fearch of birds, \&cc. The infect continues thut up fix weeks or two months; and gradually parts with its eyes, its feelers, its feet, and its $\mathrm{fkin}$; all which are thruft into a corner of the inner apartment, like a rag. It then appears almoft in its winged ftate, except that a thin fkin enwraps the wings, that. appears to be a liquor dried on their outfide. When its members have acquired the neceffary confiftence and vigour, it breaks through its enclofure. For this purpofe it has two teeth, like thofe of grafshoppers, with which it eats through till it gets out. Its body, which is turned like a fcrew, is but a quarter of an inch; but; when unfolded, becomes half an inch in length; its wings, that feemed to occupy the fmalleft fpace, in two minutes time become longer than the body: It becomes a large and beautiful fly of the libellula kind; with a long, flender, brown body; fmall head, large bright eyes, long nender legs, and four large tranfparent reticulated wings. The reft of its habits refemble that infect whofe form it bears; except that, inftead of dropping its eggs in the water, it depofits them in the fand.

\section{THE GRASSHOPPER, LOCUST, CICADA, CRICKET. AND MOLE-CRICKET.}

THE GRASSHOPPER, that breeds in every meadow, and chirps through the fummer, is well known to us; its hiftory relates that of the reft. This animal is the colour of green leaves, except a line of brown which ftreaks the back, and two pale lines under the belly and behind the legs. It may be divided into the head, the cornet, and the belly. The head is oblong, regarding the earth, and bearing fome refemblance to that of a horfe. Its mouth is covered by a kind of round buckler 


\section{TH E G R A S HOP P E R.}

buckler jutting over it, and armed with brown teeth; hooked at the points; within the mouth is a large reddifh tongue, fixed to the lower jaw: The feelers or horns are very long, tapering off to a point; and the eyes are like two black fpecks, a little prominent. The cornet is elevated, narrow, armed above and below by two ferrated fpines. The back is armed with a ftrong buckler, to which the mufcles of the legs are firmly bound; and round thefe mufcles are feen the veffels by which the animal breathes, as white as fnow. The laft pair of legs are much longer and ftronger than the firft two pair, fortified by thick mufcles; and formed for leaping. It has four wings; the anterior fpringing from the fecond pair of legs, the polterior from the third pair. The hinder wings are much finer and more expanfive than the foremoft, and are the principal inftruments of its flight. The belly is large, compofed of eight rings, terminated by a forky tail, covered with down. When examined internally, befide the gullet, we difcover a fmall ftomach; behind that a very large one, wrinkled and furrowed withinfide; lower down is a third; fo that it is not without probability animals of this order are faid to chew the cud, as they fo much refemble ruminant animals in their internal conformation.

Shortly after the grafshopper affumes its wings, it fills the meadow with its note, which is a call to courthip. The male only is vocal; at the bale of the wings is a little hole in its body, covered with a fine tranfparent membrane. This Linnæus thought to be the inftrument it employs in finging; others think the found is produced by rubbing its hinder legs againft each other. The note of one male is feldom heard; but it is anfwered; and the two little animals, after many mutual infults of this kind, meet and fight defperately. The female is generally the reward of victory; for, after the combar, the male feizes her with his teeth behind the neck, and thus keeps her feveral hours ftrongly united:

Towwards the end of autumn the female prepares to depofit her burthen; the is greatly diftended with eggs, to the number of an hundred and fifty. Nature has furnifhed her with an initrument at her tail, fomewhat refembling a two-edged fword, which the can theathe and unTheathe : with this the pierces the earth as deep as the is able, and in the hole it has made the depofits her eggs, one after the other. She does not long furvive; but, as the winter approaches, dries up and dies. Some affert the is killed by the cold; others, that the is eaten by worms. Neither the male nor female ever furvive the winter. The eggs are oval, white, and horny; their fize nearly equals annifeed; they 
are enveloped by a covering, and crack on being preffed between the fingers: their fubftance within is a whitifh, vifcous, and tranfparent fluid; they remain depofited beneath the earth during winter, till fpring. begins to hatch them. In May, every egg produces an infect the fize of a flea; at firft, whitilh; after two or three days they turn black; foon after, a reddin brown. They appear from the beginning like grafshop= pers wanting wings, and hop among the grafs, with great agility. The wings are concealed within four little bunches, that feem to deform the fides of the animal, rolled, up molt curiounly in the fmalleft fpace. Above twenty days after its exclufion, it prepares for emancipation, ceafes from its graffy food, and feeks a convenient place beneath fome thorn or thiftle, that may protect it from a fhower ; fuffering the fame laborious writhings and workings, heavings and palpitations, as other infects. At length, the fkin covering the head and breaft divides above the neck; the head iffues out firft from the burfting $1 \mathrm{kin}$, the other parts follow. Thus difengaged, it appears perfeet, but feeble, foft and tender : it may be molded like wax. It is now a greenilh white, which becomes more vivid as the moifture on the furface is dried away. Spent and fatigued with its labour for more than an hour together, it thews no fign of life; but the body is drying; and the wings, fold after, fold, opening to the fun, at laft become longer than the hind legs; the body alfo is lengthened, and becomes much more beautiful.

Thefe infects are generally vocal in fummer, and at fun-fetting louder than ciuring the heat of the day. They feed on grafs. Unwilling to fly, and now in fight, particularly when the weather is moift or cool, yet they fometimes fly to confiderable diftances. If caught by one of the hinder legs, they leave the leg behind them : this does not grow again, but prevents their flying; for, being unable to lift themrelves in the air, they have not room on the ground for proper expanfion of their wings. If handled roughly, they bite fiercely; and when they tly, make a noife with their wings. They generally keep in the plain, where the grafs is luxuriant, and the ground rich and fertile: there they depofit their eggs, particularly in thofe cracks which are formed by the heat of the fun.

The larger kinds only differ in fize, in rapidity of fight, and their powers of injury, by fwarming on the productions of the earth. When a fwarre of 1 locusts, two or three miles long, and feveral yards deep, fettle on a field, the confequences are terrible. Though they feldom vifit Europe in fuch dangerous fwarms as formerly, yet in fome of the fouthern countries they, are ftill formidable. 


\section{T H E L O C U S T.}

The Great Brown Locust was feen in feveral parts of England in 1748 , and many dreadful confequences were apprehended from its appearance. This infect is three inches long, and has two feelers an inch in length. The head and horns are brownifh; about the mouth blue, as alfo the infide of the larger legs; the fhield on the back greenith; the upper fide of the body brown, fpotted with black, the under fide purple; the upper wings brown, with Imall dufky fpots, a larger at the tips; the under wings tranfparent, light brown, tinctured with green, a dark cloud of fpots near the tips. This infect has threatened us often with its vifitations; and is truly terrible where it is bred. No animal in the creation multiplies fo faft, if the fun be warm, and the foil in which their eggs are depofited dry.

When locufts, take the field, we are affured they have a leader whofe flight they obferve, and pay a frict attention to. They appear, at a diftance, like a black cloud, which, as it approaches, gathers on the horizon, and almoft hides the light of the day. Often the hubandman fees this imminent calamity pafs away, and the whole fwarm proceed onward to fome lefs fortunate country : but wretched is the diftriet on which they fettle; they ravage the meadow and the arable ground; ftrip the trees of their leaves, and the garden of its beauty: a few minutes deftroy the expectations of a year, and induce famine. In the tropical climates they are not fo dreadful as in the fouthern parts of Europe; for there the power of vegetation is fo great, that a fmall interval repairs the calamity : but our verdure muft wait the enfuing fpring to repair the damage; befides, in their long flights to thefe parts, they are famined, and therefore more voracious where they fettle. But what they devour is not equal in damage to what they deftroy. Their bite is thought to contaminate the plant, and prevent its vegetation. To ufe the expreffion of the hubandman, they burn whatever they touch, and leave the marks of their devaftation for two or three years enfuing. But, if noxious while living, they are worfe when dead; wherever they fall, they infect the air, and the fmell is infupportable.

In the year 1690 , a cloud of locufts entered Rufra in three places, and fpread themfelves over Poland and Lithuania, in fuch aftonihing multitudes, that the air was darkened, and the earth covered with their numbers. In fome places they were feen lying dead, heaped on each other four feet deep; in others; they covered the furface like a black cloth; the trees bent beneath their weight; and the damage which the 
country fuftained exceeded computation. In 1724 , Doctor Shatw was a witnefs in Barbary of their devaftations. They firft appeared at the end of March, when the wind had been foutherly for fome time. In April, their numbers were fo vaftly increafed, that in the heat of the day they formed themfelves into large fwarms, which appeared like clouds, and darkened the fun. In May they difappeared, retiring into the plains to depofit their eggs. 'In June the young made their appearance, forming many compaet bodies of feveral hundred yards fquare; which afterwards marching forward, climbed trees, walls, and houles, eating every thing green in their way. The inhabitants, to ftop their progrefs, laid trenches all over their fields and gardens, filling them with water. Some placed large quantities of heath, ftubble, and combutible matter, in rows, and fet them on fire on the approach of the locufts: but the trenches were quickly filled up, and the fires put our, by the vaft number of fwarms that fucceeded each other. A day or two after one of thefe was in motion, others juft hatched came gleaning after them, gnawing off the young branches, and the very bark of the trees. Having lived near a month in this manner, they arrived at their full growth, and threw off their worm-like ftate, by cafting their fkins. To prepare for this change, they fixed their hinder feet to fome bufh or twig, or corner of a ftone; when, by an undulating motion, their heads would firft appear, and foon after their bodies. The whole transformation was performed in feven or eight minutes; after which, they were a little while languifhing; buc when the fun and air had hardened their wings, and dried up their moifture, they returned to their iormer greedinefs, with additional 1trength and agility. After laying their eggs, they directed their courfe northward, and probably perifhed in the'fea. It is faid that the holes thefe animals make, to depolit tthir eggs, are four feet deep in the ground; the eggs are about fourfcore in number, of the fize of caraway comfits, and bundled up together in clufters.

It feems probable that, by means of a very dry feafon in the heart of Africa, they are propagated in fuch numbers, that the vegetables are not fufficient to fuftain them ; but, being obliged to find out other countries, they traverfe fandy'deferts, where finding nothing to allure them from their height, they proceed forward, and thus come into Europe, where they alight on the firft green paftures.

Locufts are eaten in many kingdoms of the Eart, and are caught in fmall nets; they parch them ove? the fire in an earthen pan; and when 


\section{T H E L O C U S $\quad$ T.}

their wings and legs are fallen off, they turn reddih like boiled fhrimps: The natives of Barbary eat them fried with falt; they are faid to tafte like crayfifh.

There is a locuft in Tonquin about the bignels of the top of a finger, and as long as the firft joint. It breeds in the earth, in low grounds. In January or February they iffue from the earth in vaft fwarms; at firft they can hardly $\mathrm{Aly}$, fo that they, often fall into the rivers in great numbers; and the natives, in thefe months, watch the rivers, to take them up in multitudes in Imall nets. They either eat them frefh, broiled on the coals, or pickle them for keeping. They are confidered as a great delicacy in that part of the world, as well by the rich as the poor. They are regularly brought to markẹt.

The GREAT WEST-INDIAN Locust, individually confidered; is the moft formidable; about the thickne1s of 2 goofe-quill; the body divided into nine or ten joints, in all fix or feven inches long. It has two fmall eyes, ftanding out of the head like thofe of crabs, and two feelers like long hair; the whole body is ftudded with fmall excrefcences, which are not much bigger than the points of pins; the thape is roundiin, and. the body diminifhes in circumference to the. tail, which is forked into two horns; between thefe there is a fort of a theath, containing a fmall dangerous fting. If any perfon happens to touch this infect, he is fure to be ftung, and is immediately taken with a fhivering and trembling, which may foon be checked by rubbing the place affeeted with a little palm-oil.

Though there be a fpecies of CRICKET that lives in the woods. and fields, yer we are beft acquainted with the Houfe-Cricket, whofe voice is fo well known behind a country fire in a winter's evening. The cricket very much refembiles the grafshopper in Thape, manner of ruminating, voice, leaping, and method of nropagation. It differs in colour, which is uniformly a rufty brown; its food is various, and its place refidence moft uiually the warmet chinks of a country hearth; where they once make their abode, they are, fure to propagate. They are of a moft chilly nature, feldom leaving the fire-fide; and, if undifturbed, are feen to hop from their retreats to chirrup at the blaze. The wood. cricket is extremely timorous; but the chimney-cricket, being ufed to noifes, difregards them, and people near it. Whether the voice of this animal is formed by a fine membrane at the bafe of the wings, is not af. certained; nor do we know the ufe of this voice, fince anatomical in-, fpection has not been able to difcover the fmallelt organs of hearing: PART VI. No. 30. doubtler 
doubtlefs they can diftinguifn founds, though probably not like the more perfect ranks of nature : certainly their call is often regularly anfwered: none but males are vocal. As the cricket lives chietly in the dark, its eyes feem formed for obfcurity; to furprife it, requires only to light a candle unexpectedly, by which being dazzled, it cannot find the way back to its retreat. It is very voracious; eats bread, flour, meat; is fond of fugar : never drinks. Except in the very coldeft weather, never ceafes chirping.

Of all the kinds the MoLE-CRICKET. is moft extraordinary; is a large infect, two inches and a half in length, and three quarters of an inch in breadth. At the extremity of the tail are two hairy excrefcences, refembling in fome fenfe the tail of a moufe. The body has eight fcaly joints or feparate folds; brown above, deeper tinged belów; wings long, narrow, terminate in a point; each has a blackinh line running down it; when extended, they feem much broader than could be fuppofed. The thield of the breaft is firm; blackifh, and hairy ; the fore-feet, which are this animal's principal inftruments of burrowing, are ftrong, webbed, and hairy; it generally runs backward; lives under ground, where it burrows: fafter than a mole. Is thought to be amphibious. Is detefted by gardeners; for in a fingle night it will run along a furrow newly fown, and rob it of all its contents. Its legs are fo formed that it can penetrate the earth in every direction; before, behind, and above. At night it ventures from its under-ground habitation, and has its chirping call. The female makes a cell of clamrny earth, large enough to hold two hazle nuts, and in this the lays her eggs. "The whole neft equals a hen's egg, is clofed up, and well defended from the air and enemies. The eggs are generally a hundred and fifty, white, the fize of a carraway. The black beetle, being an under-ground inhabitant, would devour or deftroy the eggs; to prevent this, the female mole-cricket is often polted as a centinel near the neft; and when the black invader plunges in to feize its prey, the guardian infect feizes him behind, and inftantly bites him in two. Wherever the neft is, there feems a fortification, avenues, and entrenchments drawn round it; numberlefs winding ways lead to it, and a ditch is drawn about it, which few of its infect enemies are able to pafs; alfo, at the approach of winter, they carry their neft away, and fink it deeper in the ground, that the froft may have no influence in retarding the young brood. As the wenther grows milder, they raife their magazine till near the furface, to receive the genial influence of the fun, without expofing it. Should the froft unexpectedly return, they fink it again.wut 


\section{THE EAR WIG, THE FROTH INSECT, AND SOME PTHERS.}

F all this clars of infects, the EAR wi undergoes the fmalleft change. This animal is fo common it farce needs a defcription : its fwiftne's in the reptile ftate is not lefs remarkable than its indefatigable velo. city when on the wing. That it is very prolific appears from its numbers; it is harmlefs. It is provided with fix feet, and two feelers : the tail is forked, and with this it often attempts to defend itfelf againt alfailants; but its attempts no way ferve to âfend it. The deformity of its nender figure has fubjected it to an imputation which has more than once proved its deftruction. Theie reproaches are groundlefs. It lives amorg flowers, and deftroys theim. When fruit has been wounded by fies, the earwig generally comes in for a fecond feaft, and fucks thofe juices they began to broach.

The earwig is hatched from an egg. There are various kinds of this animal, which chure differerst places to breed in; in general, under the bark of plants, or in the clefts of trees beginning to decay. They proceed from the egg in that reptile ftate in which they are moft cominonly feen; as they grow larger, the wings under the $\mathrm{K}$ in begin to burgeon. It is amazing how very little room four large wings take up before they are protruded : their theath folds and covers them fo neatly, that the animal feems without wings; and, when burft from confinement, they can be clofely folded into a very narrow compars. When the earwig has become winged, it flies in purfuit of the female, which is its whole bufinefs. It lives, in its winged ftate, but a few days; and having provided pofterity, dries up and dies.

To this order of infects we may refer the CuCKow-SPIT or FrothWoRM, that is often found hid in a frothy matter on the furface of plants. It has an oblong, obtufe body; a large head, with fmall eyes; four wings, the external durky brown, marked with two white fpots; the head black. The fpume in which it wallows is its own formation, and refembles frothy fpittie. It proceeds from the vent and other parts of the animal; if wiped away, a new quantity will quickly fucceed. Within this fpume it acquires four tubercles on its back, wherein are the wings; thefe burfting, it becomes winged, fies to meet its mate, and prolong. its kind.

$$
3 \mathrm{C}_{2}
$$

The 
The Water Tipula has an oblong nender body, four feet fixed on the breaft, four feelers near the mouth; four weak wings, apparently not proper for Hying, but leaping only. It runs with wonderful lightnefs on the furface of the water, fo as fcarcely to put it in motion. It is fornetimes feeh in rivers, and on their banks, efpecially under fhady trees; and generally in fwarms.

The Common Water-FLy alfo breeds in this fame manner. This is by fome called the Notonecta, becaufe it does not fwim on its belly; but on its back : nor can we help admiring that fitnefs in this infeet for its fituation, as it feeds on the under fide of plants which grow on the furface of the water; therefore, being formed mouth upwards, it feeds with greater convenience.

The WATER-SCORPION is near an inch in length, and about half an inch in breadth. Its body nearly oval, very flat and thin; its tail long and pointed. The head fmall ; the feelers appear like legs, refembling the claws of a fcorpion, but without points. This infect is generally found in ponds, and is very tyrannical and rapacious. It deftroys twenty times as many as its hunger requires. I have feen one of thefe, put into a bafon of water, in which were thirty or forty worms of the libellula kind, each as large as itfelf, deftroy them all in few minutes, getting on their backs, and piercing with its trunk through their body. Thefe animals however, though fo formidable to others, are neverthelefs themfelves greately, overrun with a little kind of loufe, about the fize of a nit, which very probably repays the injury which the water-fcorpion inflicts upon others.

Water fcorpions live in the water by day; out of which they rife in the dufk of the evening, and flying from place to place, betake themfelves, in queft of food, to other waters. The infect, before its wings are grown, remains in the place where it was produced; but, when perfect, fallies forth in fearch of a companion, to continue its pofterity.

\section{TH E E P H E M R A.}

THAT there fhould be 2 tribe of flies whofe duration extends but to A. day, feems furprifing; but the furprife increafes, when we are 


\section{THE E P E M E R A.}

told that fome of this kind feem limited to an hour. The reptile from which they are bred is not fhort-lived; but formetimes lives two years, and many times three.

Ephemeras, of which are various kinds, are produced from eggs, in the form of worms; from whence they change to aurelias, a kind of middle ftate between a worm and a fly; from whence they take their laft mutation into a beautiful fy, of longer or thorter duration, aecording to its kind.

The ephemera fly is a beautiful winged infect, of ftrong fimilitude to the butterly, bo.in in fhape, wings, and fize; but ita wings are not covered with painted feashers, but are very tranfparent and thin; has four wings; the uppermolt much the largeft: when at reft, generally lays its wings one over the other, on the back. The body is long; has fix rings, larger at the origin than the extremity; from this proceeds a tail longer then all the reft of the fly, confiting fometimes of three threads of equal length, fometimes of two long and one fhort. To acquire this beautiful form, the infect has undergone feveral tranfmutations : but the hour of its perfretion is the hour of its death; the reptile of this fly inhabits the waier, and refembles firhes in many particulars; having gills by which it breathes at the bottom, and the tapering form of aquatic animals. Thefe infects bave fix fcaly legs, fixed on their corfelet. Their head is triangular: the eyes placed forward, diftinguifhed by their largenefs and colour. The mouth has teeth; the body confifts of fix rings; that next the cortelet largeft, growing lefs and lefs to the end; the laft ring is the thorteft, from which the three threads proceed, which are as long as the whole body. Thus the reptile refembles the fly; and only requires wings to be near perfection. :

There are feveral kinds of this animal, and their aurelias are of different colcurs; yellow, brown, or cream-coloured. Some bore themfelves cells at the bottom of the water, from which they never ftir out, but feed on the mud compofing the walls of their habitation; others range about in the water, or quit that element to feed on plants by the river fide, and then return to it for fafety and protection.

The reptile, though it lives long, offers little to excite curiofity; hid at the bottom of the water, it feeds almoft wholly within its narrow habitaiion. Into its fly ftate it crowds its moft various tranfactions. The fign whereby to know that thefe reptiles will change into flies fhortly, is a protuberance of wings on the back; fo that the wings are in fome degree vifible through 
their external Meath. Along the banks of the Rhine, or the Seine near Paris, about three days in the midtt of fummer, their numbers and affiduity are aftonilhing: the whole air feems alive with the new-born race, and the earth is covered with their remains. The aurelias beneath the water wait only for evening to begin their transformation. The moft early thake off their old garments about eight o'clock; the later before nine. They are fcarce lifted above the water, ere their old theathing fkin burfts; and through it a fly iffues, whofe wings, the lame inftant, are unfolded, and lift it into the air. Millions thus rife to the furface; and fill every quarter with their flutierings. But the whole foon fall to the ground, and cover the earth, like a deep fnow; every object they touch becomes fatal; and they inftantly die, if they hit even againit each other:

The males feem only born to die: they follow not the oppofite fex; but after fluttering an hour or two, they drop. But the females are fcarce rifen from the water, and have dried their wings, ere they haften to drop their eggs back again. If they happen to futter on land, they depofite their burthen where they drop. We know not how thefe eggs are fecundated. The females are in fuch hafte to depofite their eggs, that multitudes fall to the ground; but the greateft part are laid in the water. As they flutter on the furface, two clufters are feen iffuing from the extremity of their body, each containing about three hundred and fify eggs.

It would feem there was a neceflity for fuch fertility, as in its reptile ftate it is the favorite food of every kind of frefh-water finh. In vain thefe litcle animals form galleries at the bottom of the river; many kinds of fifh break' in on their retreats, and thin their numbers. Thefe infeEts are the mont grateful bnit for fifh. The ufual date of thefe flies is two or three hours; yet foine live feveral days ; and one kind, after quitting the water, has to quit another cafe or $\mathbb{k}$ in. . Thefe are often feen in fields and woods, but frequently in the vicinity of water. They are often found fticking on walls and trees, with the head downwards, without changing place, or fenfible motion ; waiting for the moment when they thall be divefted of theirlaft garment, which fometimes does not happen for two or three day's. 


\section{(293) \\ C A T E R P I L L A R S.}

A TER PILLARS alone, with their butterlies and moths, make a third part of infects. In their butterfly ftate, they are prodigiouny beautiful and fplendid. The fly may therefore well excite our curiofity to examine the reptile.

Caterpillars may be diftinguihed from worms or maggors by their feet; they are the earlieft feen in fpring on almoft every vegetable and tree, eating its leaves. They have feet before and behind, and move forward by arch-like fteps made by their fore and hinder parts: they climb vegetables, and ftretch themfelves out from their boughs and ftalks, to reach food at a diftance; have from eight feet ito fixteen. A butterfly or a moth is diftinguifhed by its wings covered with a painted duft, of various beauty.

Their tranfmutations are more numerous than thofe of infects yet mentioned; they are placed in the third order of changes by Swammerdam. When excluded from the egg, they affume the form of a fmall caterpillar, which feecis and grows larger every dzy, often changing its $1 \mathrm{kin}$, but preferving its form. When come to a certain magnitude, it difconcinues eating, makes itfelf a covering or hurk, in which it remains wrapped up, feemingly without life or motion; and after fome time fpent in this ftate, it burfts confinement, and comes forth a beautiful butterfly.

Experience proves that $\mathrm{Caterpillars}$ are hatched from the eggs of butterflies; and the fiy is very careful in depofiting its eggs where they are likely to be hatched with greateft fafety and fuccefs. During winter, they are in an egg ftate; and brave the rigours and humidity of climate: often expofed to its changes, ftill they preferve the latent principle of life which is to be exerted at the approach of fpring.

But all caterpillars rife not from eggs in fpring; for many have fubfifted in their aurelia ftate during the rigours of winter; fome inclofed in a kind of thell, which they fpun for themfelves at the end of autumn; fome concealed under the bark of trees; others in the chinks of old walls; and many buried under ground. From thefe iffue a variety of butterlies, and adorn the early part of the year with flutterings. Some caterpillars continue in their reptile ftate through the fevere feafon, in fome fecure retreat, where they remain motionlefs and infenfible, as if Part VI. No. 30. actually 
actually dead. Of this kind are found great numbers together, inclofed in one common web, to proted them from the injuries of the air. Some butterflies live all the winter : thefe are found lifelefs and notionlefs in the hollows of trees, or the clefts of timber; but, being approached to a fire, they recover life and aetivity, and feem to anticipate the defires of fpring. Many are hatched from their egg at the foot of a tree, and climb to its leaves for fubfiftence : the eggs of others have, been glued by the parent butterly to the leaves; and they are no fooner excluded from the fhell, but they find themfelves in the midft of plenty.

The caterpillar recent from the egg is fmall and feeble, and feems to make no great confumption; but as it increafes in magnitude it improves in appetite; and when adult is ravenous. A fingle caterpillar will eat double its own weight of leaves in a day:

The body of a caterpillar is compofed of rings, pretty near circular or oval; generally twelve; membranaceous. The head is connected to the firft ring by the neck, which is generally fo thort it is fcarce vifible: the head is covered by a fhell; the jaws are placed rather vertically, each armed with a large thick tooth, with which fome defend themfelves againft their enemies. Though the mouth be fhut, the teeth are uncovered, and feldom without employment. Many, while young, eat only the fucculent part of the leaf, and leave the fibres; others eat the whole leaf clean away. Some eat all day long, others have their hours of repaft, and fome chufe the night : to attack a leaf, it places the edge of the leaf between its feet, which keep it fteady, while the teeth are cutting it : thefe act fomewhat like a'gardener's fheers; and every morfel is twallowed as foon as cut. Some feed on very narrow leaves, not broader than their mouths; thefe it devours from the point.

Of their feet the fix foremoft have a fhining grifty covering; and are called fhelly legs. The hindmort, whatever be their number, are foft and flexible, and are called membranaceous. With regard to their external figure, they are either finooth or hairy : the firft kind is foft to the touch, or hard like fhagreen; the latter hairy; and as it were thorny; and generally, if handled, ftings like nettles.

Caterpillars, in general, have fix fmall black fpots on the fore ring, a little to the fide of the head: three larger than the others, convex and tranfparent : thefe-Reaumur takes to be eyes.

The ftigmata, or holes on its fides, through which it is fuppofed to breathe, are eafily difcoverable: nine on a fide, rather nearer the belly than the back; a hole for every ring of the body, except the fecond, the third, 


\section{THE C A TER P I L L A R.}

third, and the laft. Thefe oval openings may be confidered as fo many mouths, through which the infect breathes into its lungs, which are confequently eighteen. They appear at firft view to be hollow cartilaginous tubes, mother-of-pearl colour. They often unite with each other; fome open into the inteftines, and fome go to different parts of the furface of the body. That thefe convey air, appears from the experiment of Malpighi; who by ftopping up the mouths of thefe ftigmata with oil, quickly fuffocated the animal. Oil on other parts of the body, leaving the ftigmata free, feemed innocent; the infect continued to move and eat as ufual: he rubbed on the ftigmata of one fide, and it underwent a partial convulfion, but recovered foon after. Caterpillars will live in an exhaufted receiver feveral days.

The inteftines run ftraight from the mouth to the anus. They refemble a number of fmall bags opening into each other; ftrengthened on both fides by a ferhy cord, by which they are united. Caterpillars often caft the internal eoat of their inteftines with their food, in their frequent changes. But the inteftines take up a fmall part of the body, compared to the fatty fubftance in which they are involved. This fubftance changes its colour when the infect's metamorphofis approaches, and from white ufually becomes yeliow. All caterpillars fpin at one time or other, like the filk-worm.

Many caterpillars change their fkins five or fix times in a feafon; and this caft-off covering feems fo complete, that it might be miltaken for the real infect. A mong hairy caterpillars, the caft $\mathrm{fkin}$ is covered with hair; the feet, as well griftly as membranous; remaining; even the parts which nothing but a microfcope can difcover, are vifible in it; all the parts of the head; not only the fluli, but the teeth. As the time approaches for the caterpillar to caft its ${ }^{\circ}$ 依in, its colours become more feeble, and the kin feems to wither and dry like a leaf no bonger fupplied with moilture. A day or two before the critical hour, the infect ceafes to eat, lofes its ufual activity, and feems immoveable : it feeks fecurity ; and, no longer timorous, feems regardlefs of the touch. It often bends itfelf, elevates its back, ftretches itfelf to its utmoft extent : lifts up its head, and lets it fall, waves it three or four times from fide to fide, and then remains quiet. At length, fome of the rings of its body, particularly the firft and lecond, fwell confiderably, the old kin diftends and-burfts; till, by repeated fwellings and contraetions in every ring, the animal difengages itfelf, and creeps from its inconvenient covering, in the fpace of a minute; and feems to enjoy new vigour, as well as colouring and beaucy. The hairy preferve their hair ; for every hair appears to have been drawn. 
A new crop of hair grows between the old $\mathrm{fkin}$ and the new, and probably helps to throw off the external covering.

The caterpillar begins at laft to prepare for its change into a chryfalis. It is probable all parts of the butterfly lay hid in the infect, in its reptile ftate; and, when perfected, its firft great and principal change is into an aurelia, or chryfalis. Preparatory to this, it attaches itfelf to the ftalk or ftem of the plant, often voids even the internal membrane which lined its inteftines. Thofe which fpin a web, fet about that operation; thofe which have already fpun, await the change in patience. When it has done fpinning, it ftrikes in the claws of the two feet under the tail, and afterwards forces in the tail itfelf. If taken from the web they appear in great languor; and, incapable of walking, thus they remain one or two days, preparing to change; their bodies bent into a bow, which they occafionally Atraighten. As their change approaches, their body becomes more and more bent; their extenfions and convulfive contractions more frequent. The animal quits the hinder part of its $\mathrm{k}$ in to drive itfelf up into the fore part, ftill continuing to heave and work as before; the rkull burfts into three pieces; and an opening is made in the three firft rings, through which the infect thrufts forth its naked body, with ftrong efforts, and gets free from its caterpillar nkin. Now the parts of the future butterfly are vifible; but fo foft, that the fimalleft touch difcompofes them. The animal is now become helplefs and motionlefs; waiting for the air to dry up its fuperficial moifture, and fupply it with a cruft for refitting injuries: it is now green. In ten or twelve hours its parts harden, its external covering becomes firm; and in about four-andtwenty hours the chryfalis may be handled without dariger. Such is the little pod or cone fo common by every pathway, fticking to nettles, and fometimes fhining like polifhed gold; whence its name, Chryfalis.

Some mix fand with their gummy and moift webs, to ftrengthen the incruftation; others bury themfelves in the ground. Thofe that are to remain in this ftate but a few days, choofe fome tender leaf, which they render more pliant by diffufing a kind of glue on it : the leaf gradually curls up, and withering as it enfolds, the infect wraps itfelf within it. Others faften their tails to a tree, or to the firft worm-hole they meet in a beam, and there wait. Such as are to lie feveral months in this ftate, act with greater circumfpection : either mix their web with fand, or build deeper in wood. Such as prefer the leaves of willows, break their tender twigs into fmall pieces, then pound them to powder; 2nd, by 


\section{THE. C A T E R P I L L A R.}

their glutinous filk make a kind of pafte, in which they enwrap themfelves. Many are the forms they affume in this helplefs ftate; and often the molt deformed butterflies iffue from the molt beautiful aurelias. Some continue in this ftate ten days, fome a month, fome a year. The fame fpecies of infect does not at all times affume the fame hue as an aurelia. In fome the beautiful gold colour is found; in others it is wanting. It is formed by a beautiful tranfparent brown varnifh, laid on a white ground; the white gleaming through. In this ftate, the life of the infect may be retarded or quickened, without injury: the firft, by preventing the evaporation of its humidity; but, by evaporating its moifture, in a warm fituation, the animal affumes its winged ftate before its ufual time.

If hut up within a cone, the butterfly always gets rid of the natural internal kin of the chryfalis before it eats its way through the cone. To attain this, there feems a violent agitation in the humours of the body. Its fluids feem driven rapidly through the veffels; it labours violently with its legs, and ftruggles to get free. Thefe motions concurring with the growth of the wings and body, the brittle fkin which covers it at length gives way, by burfting in four diftinct and regular pieces. The nkin of the head and legs.firt; then the fkin at the back difengages the back and wings. The butterfly, as if fatigued, remains quiet for fome time, its wings pointed downward, its legs fixed in the fkin it had juft thrown off. Its wings take up fuch little room, one would wonder where they were hidden : but foon after they expand fo rapidly, the eye can fcarce attend their unfolding; they become five times larger than before, growing thinner as they become broader; all the fpots and paintings, before fcarce difcernible, are proportionably extended; fo that what feemed only confufed, unmeaning points, now become diftinct and beautiful ornaments. The wings, fo fuddenly extended, appear like wet paper, foft, and wrinkled. In half an hour they dry, and their wrinkles difappear. The butterfly difcharges three or four drops of a blood-coloured liquid, as the laft remains of its fuperfluous moifture. The exit of aurelias inclofed within a cone, is more difficult, as they have the cone to break through: but this they quickly perform by butts with the head violently againft it, and probably with their eyes, that are rough and like a file, rubbing the internal furface away.

The butterly needs no other food than the dervs of Heaven, and the 
the honeyed juices diftilled from every flower. Thofe of the warm climates are the largeft and moft beauriful.

Butterflies have four wings; and, though two of them be cut off, can fly with the two remaining. They are tranfparent, but rendered opake by the feathery duit with which they are covered; of different dimenfions and forms, generally fupported on a footftalk, regularly laid on the whole furface, and of a perfeetly beautiful arrangement, like the tiles of an houfe; thofe of one rank a little covered by thofe that follow : on cine part may be feen oval ftuds; on another, clufters of ftuds heartformed, or long, or triangular; interfperfed with taller ftuds. The wing is compofed of feveral thick nerves, very ftrong, though light. The animal fupports itfelf long in air, although its flight be not graceful. When the butterfly defigns to vifit a confiderable diftance, it afcends and defcends; going fometimes to the right, fometimes to the left; it flies thus irregularly in purfuit of its mate, which it can difcover at a mile's diftance.

The animal may be divided into three parts; the head, the corfelet, and the body. The body is the hinder part compored of rings, generally concealed under long hair, with which that part is clothed. The corfelet is more folid than the reft of the body, becaufe the fore wings, and the legs, are fixed therein. The legs are fix; four only are ufed by the animal; the two fore legs being often concealed in the long hair of the body. Thefe parts internally have the fame fet of veffels in the butterfly as in the caterpillar; but the blood or humours which in the caterpillar circulated from the tail to the head, in the butterfly circulate from the head to the tail.

The eyes of butterties have not all the fame form; fome are large, others fmall; fome are the larger portion of a fphere, others but juft appearing from the head. In the outward coat of all is a luftre, offering the colours of the rainbow; it refembles a multiplying glafs; having 2 great number of fides, or facets, like moft other infects.

Leuwenhoek afferts there are above fix thoufand facets on the cornea of a flea. Puget adapted the cornea of a fly to fee objects through it by means of a microfcope; and nothing could exceed the ftrangenefs of its reprefentations : a foldier, feen through it, appeared an army of pigmies; for it multiplied and diminifhed objects : the arch of a bridge exhibited a moft magnificent fpectacle; and the flame of a candle feemed a beautiful illumination.

Butterflies, like moft flying infects, have on their heads two feelers, 
moveable at their bafe; and having a great number of joints, to turn them in every direction. Thofe of butterflies are placed at the top of the head, pretty near the external edge of each eye.

The trunk, few infects of the butterlly kind are without. This is placed exaetly between the eyes; and, when not employed in fecking nourifhment, is rolled up, like a curl. A butterfly, when feeding, fettles on fome flower; the trunk is then uncurled, thruft out, and is employed in fearching the flower to its very bottom, be it ever fo deep. This trunk confifts of two equal hollow tubes, nicely joined to each other, like the pipes of an organ.

But the greateft number lly by night; thefe are Morms. Butterflies fly by day, moths by night. They are dittinguilhed by their antenne or feelers: thofe of the burterly being clubbed, or knobbed at the end; thofe of the moth pointed.

The general rule among infeets is, that the female is larger than the male: the male fmaller and nenderer; the female more thick and oval. If they be difturbed while united, the female flies off with the male on her back, who feems entirely paffive. The females of many moths and butterflies feem to have affumed their form merely to fecundate their eggs, and lay them. After a junction with the male of about half an hour, they depolite their eggs, and die : they are impregnated by the male at one aperture, and lay their eggs by another. Their eggs are difpofed in the body like a bed of chaplets; when excluded, are whitin: fome oval, fome round, fome flatted. The fhell of the egg, though folid, is thin and tranfparent; each egg contains but one caterpillar. The butterfly is careful to place her brood only on plants that afford good nourifhment to its pofterity; not the plant molt grateful to itielf in its winged ftate, but fuch as it has fed on, in its reptile form. Thefe eggs are attached to the leaves of the favourite plant, by a fort of glue; fometimes round the tender fhoots of plants, in the form of a bracelet, or a ring, two hundred in each. Some fecure their eggs, by covering them with hair, plucked from their own bodies, for warmth, and concealment.

All female moths lay their eggs fhortly after they leave the chryfalis; but many butterflies flutter the whole fummer without laying, till towards winter: fome continue the winter in hollows of trees, nor provide for pofterity till the beginning of April, when they leave their retreats, depofite their eggs and die.

The caterpillar has of all animals the greateft number of enemies; and exifts by its furprifing fecundity. Some animals devour them by Part VI. No. 3 I. $3 \mathrm{E}$

hundreds; 
hundreds; others, more minute, deftroy them in various ways : a fparrow and its mate, that have young, deftroy three thoufand caterpillars in a week. Some of the caterpillar kind, that feem fitted only to eat leaves; will however eat each other; the ftrongeft devouring the weak, in preference to their vegetable food. That which lives on the oak, feizes its. companions, when it can, by the firft rings, and inflicts a deadly wound; then feafts in tranquillity on its prey.

Many fies lay their eggs either on or within their bodies; and as thefe turn into worms, the caterpillar nourines a brood of inteftine enemies, that muft fhortly be its deftruction. "Towards the end of Auguft," fays Reaumur, "I perceived a little fly, of a beautiful gold colour, bufily employed on the body of a large caterpillar, of that kind which feeds upon cabbage. I gently feparated that part of the leaf on which thefe infects were placed; from the reft of the plant, and placed it where I might obferve them more at my eafe. The fly, wholly taken up by the bufinefs in which it was employed, walked along the caterpillar's body, now and then remaining fixed to a particular fpot. Upon this occafion, I perceived it every now and then dart a fting; which it carried at the end of its tail, into the caterpillar's body, and then drew it out again, to repeat the fame operation in another place. It was not difficult for me to conjecture the bufinefs which engaged this animal fo earneftly; its whole aim was to depofite its eggs in the caterpillar's body; which was to ferve as a proper retreat for bringing them to perfection. The reptile, thus rudely treated, feemed to bear all very patiently, only moving a little when ftung too deeply; which, however, the fly feemed entirely to difregard. I took particular care to feed this caterpillar; which feemed to me to continue as voracious and vigorous as any of the reft of its kind. In about ten or twelve days, it changed into an aurelia, which feemed gradually to decline, and died. Upon examining its internal parts, the animal was entirely devoured by worms; which, however, did not come to perfection, as it is probable they had not enough to fuftain them within."

The large cabbage caterpillar is fo fubject to this injury, that, at certain feafons, it is much eafier to find them with than withour them. The icbneumon-fiy particularly infefts thefe reptiles, and is of all others moft formidable to infents of various kinds. The fpider himfelf often falls a prey to the ichneumon, who purfues him to his retreat, defpifes his nets, and tears him in pieces, in his own labyrinth. This infect, redoubtable as the little quadruped that deftroys the crocodile, has received the fame name; it depofits its eggs in the caterpillar's body; ten, fifteen, or twenty. 
As they. are laid in parts not mortal, the reptile ftill lives and feeds, changes its $\mathrm{fkin}$; and fometimes into an aurelia: ftill the fatal intruders within fecretly devour its fubftance : foon after they burft through its Ikin, and quit it to fpin themfelves a covering, previous to their own transformation. It is aftonifhing fometimes to fee the number of worms, the thus iffue from the body of a fingle caterpillar, but more that they fhould devour its entrails, without deftroying its life : but they feed only on the fatty fubltance within the caterpillar's body; and not on its vitals.

\section{T H 'E S I I L K W O}

$T$ is fuppofed that filkworms were not brought into Europe till the beginning of the twelfth century; when Roger of Sicily brought tome from Afia Minor, after his return from the Holy Land, and fettled them in Sicily and Calabria.

The filkworm is a large caterpillar, whitith, with twelve feet, and producing a moth. Its cone is formed for its covering while in the aurelia ftate; the threads of feveral of thefe, wound off, and united, form ftrong and beautiful filken threads. 'Feeding thefe worms, gathering, winding, twifting, and weaving the filk, is a principal manufacture of Europe.

There are two merhods of breeding filkivorms : they may be left at liberty on the trees where they are hatched; or they may be kept in a place built for that purpofe, and fed every day. with frelh leaves. The firft method is ufed in China, Tonquin, and other hot countries; the other in places where the animal has been artificially propagated, and continues a ftranger. In the warm climates, the filkworm proceeds from an egg, which has been glued by the parent moth on the mulberry-tree, and which remains there during winter. 'Unaffected by the weather, frolts that kill the tree, injure not the filkworm. The infects never quit the egg till nature has provided a fupply in the budding leaves for their fupport; then burfting from their eggs, they crawl on the leaves, and feed voraciouly. After fome months feeding, they depofit on every leaf finall cones of filk.

But in European climates, the frequent changes of weather, and the hea$3 \mathrm{E}_{2}$ 


\section{$\begin{array}{lllllll}I & N & S & E & C & T & S .\end{array}$}

vy dews forbid this method. A room is preferred with a fouth afpect; the windows well glazed, the walls well built, the floor exceeding clofe, fo as to admit neither air nor infects. In the middle are four pillars forming a pretty large fquare. Between thefe are different ftories made with ozier hurdles; and under each hurdle a floor, with an upright border round, hung on pulleys, placed or taken down at pleafure. When the worms are hatched, fome tender mulberry leaves are placed in the paper box in which the eggs were, and which is large enough to hold a number. When they have acquired ftrength, they mut be diftributed on beds of mulberry leaves in the different ftories. They have a thread by which they can fufpend themfelves, to prevent any fhock by a fall. Frefh leaves muft be brought every morning, and ftrewed very. gently and equally over them; the filkworms will forfake the old leaves. The leaves muft be gathered when the weather is dry, and kept dry, if a ftore be neceffary. To give them air, open their chamber windows, when the fun thines warmett.

The worm, when it burfts the Thell, is extremely fmall, and black; but the head more fhining black than the body: fome days after, they begin to turn whitifh, or grey. The infect throws off its $\mathrm{kin}$, and appears clothed anew feveral times. When ready to affume the aurelia form, the animal forfakes, for the laft time, all food and fociety, and prepares its cone, or ball of filk, which is fpun from two little longinh kinds of bags that lie above the inteftines, and are filled with a gummy fluid, of a marigold colour. The little animal is furnifhed with a furprifing apparatus for fpinning it to every degree of finenefs, fomewhat like a wire-drawer's machine. The threads proceed from two gum bags, each fupplying its own. The thread is flatted on one fide, and grooved along its length ; feeming as if doubled juft on leaving the body, and that the two threads ftick to each other by their gummy quality. Previous to fpinning, the filkworm feeks a convenient place to erect its cell. When it has found a leaf or chink to its purpole, it wreathes its head in every direction, and faftens its thread on every fide. Though its firft effays feem confufed, yet they are not without defign : the firft threads being thrown at random, to ferve as a fhelter againft rain; for nature having appointed the animal to work on trees in the open air, its habits remain, though it is brought up in a warm apartment. It is compofed externally of a kind of rough cotton-like fubftance, called flofs; within the thread is more dittinct and even; -and next the aurelia, the apartment feems lined with a paper-like fubftance, but of flronger confiftence The thread lies very irregularly, and winds off now from one fide 


\section{THE S I L K W O R M.}

of the cone, then from the other. This whole thread, if meafured, is about three hundred yards long; and fo very fine, that eight or ten are generally rolled into one by manufacturers. The cone is in form like a pigeon's egg, mott pointed at one end, where the head of the aurelia generally is; and here the infect, when a moth, burfts through. After a fortnight or three weeks the aurelia becomes a moth; when free from its confinement, it appears exhaufted with fatigue, and feems produced only to tranfmit a future brood. It neither flies nor eats; the male only feeking the female : their union continues for four days; the male dies immediately after feparation; and the furvives him only till the has laid her eggs, which are not hatched into worms till the enfuing fpring.

As their burfting through the cone deftroys the filk, the manufacturers kill the aurelia, by expofing it to the fun, before the moth comes to perfection, and throw the cones into warm water, till the firft thread offers them a clue for wirding all off. They generally take eight of the filken threads together; the cones ftill kept under water, till a proper quantity of the filk is wound off : they do not take all; for the latter parts grow weak and bad. The paper-like fubftance which remains, fome ftain with a variety of colours, to make artificial flowers; others let it lie in the water, till the glutinous matter which cements it is diffolved: then carded like wool, and fpun with a wheel, it is converted into filk ftuffs of an inferior kind. 


\section{FOURTH ORDER OF INSECTS.}

$\mathrm{N}$ this clafs of infects we place a various tribe, firt laid as eggs, then excluded as maggots or grubs, then changed into aurelias, with their legs and wings not wrapped up, but appearing; and, laftly, affuming wings, in which ftate they propagate. Some of thefe have four tranfparent wings, as bees; fome two membranous cafes to their wings, as beetles; fome but two wings, which are tranfparent, as ants. We in-. clude the bee, the wafp, the humble bee, the ichneumon-fly, the gnat, the tipula or longlegs, the beetle, the may-bug, the glow-worm, and the ant.

\section{, T H E B E E.}

$7 \mathrm{O}$ give a complete hiftory of this infect, whofe nature and properties 1 Atill continue in difpute, is impoffible. The account given by Reaumur is fufficiently minute, and wonderful; but many of the facts he relates, are doubted, fome denied, though it is not eafy to difprove them, nor effectively to contradict the affertions of a man whofe life was fpent in this ftudy. That he might err is poffible, that he erred wilfully none affert; and fince his time, none have offered as guides, in whom we, may place greater confidence.

There are, fays Reaumur, three different kinds of bees: firft, the labouring bees, which are the greateft number, and neither male or female : fecondly, drones : of a darker colour, longer, and thicker by one third than the former: they are the males; and there is not above a hundred of them, in a hive of feven or eight thoufand bees : thirdly, a larger ftill, and in number fewer; being but one in every fwarm: but later obfervers mention there being fometimes five or fix in the fame hive. Thefe are called queen-bees, and are faid to lay all the eggs from which the fwarm is hatched.

In the common working bee, the firft remarkable part is the trunk, 4 which 
which extracts the honey from flowers. It is formed like a befom, to fweep, or a tongue, to lick it away. The teeth ferve in making wax. This is gathered from flowers, like honey; and is that duft or farina which fecundates plants : it is molded into, wax by the little animal at leifure. A bee enters the cup of a flower, particularly if charged with this yellow farina. Being covered with hair, it rolls itfelf in the flower, till quite covered with duft, which it brufhes off with its two hind legs, and kneads into two little balls. In the thighs of the hind legs are two cavities, edged with hair ; into thele the animal fticks its pellets. Thus employed, the bee flies from flower to flower, increafing its ftore, and adding to its ftock of wax; until the ball upon each thigh becomes as big as a grain of pepper ; when baving got a fufficient load, it returns to the hive.

The belly of the bee is divided into fix rings, which fometimes thorten the body, by nipping one over the other. It contains, befide the inteflines, the honey-bag, the venom-bag, and the fting. The honeybag is tranfparent, receives the honey the bee has collected, of which the greater part is carried to the honey-comb; the remainder ferves for. nourifhment: for, during fummer, it never touches what has been laid up for winter. The fting is compofed of three parts; the theath, and two darts, extremely fmall and penetrating, having feveral tharp points or barbs, which render the fting more painful. The theath, which has a thatp point, makes the firt wound; this is followed by the darts, and then the venom is poured in. The theath fometimes fticks fo faft in the wound, that it is left behind; by which the bee foon after dies, and the wound is conflderably enflamed. Without a fting this little animal would have too many plunderers, and lazy animals, fond of honey, would intrude on the fweets of the hive.

All its provifions are laid up for the community; all its arts in building are for pofterity. Bees build their cells with wax, falhioned into convenient apartments. When they begin to work, they divide themfelves into four companies : one roves the fields in fearch of materials; another lays out the bottom and partitions of their celts; a third fmoothens the infides from corners and angles; the fourth bring food, or relieve thore who return with their burthens. They often change tans; thofe at "work,' go abroad; and thofe from the fields take their places. When any one wants food, it bends down its trunk to tlie bee from whom it is expected, which then opens its honey-bag, and lets fome drops fall PART VI. NO. 3 I. 
into the other's mouth, which is opened to receive it. In a day's time, they make cells, upon each other, to contain three thoufand bees.

The cells are perfect hexagons: double, opening on either fide, and clofed at the bottom. There lodgings have fpaces, like ftreets, between them, large enough to give the bees free paffage; yet narrow enough to preferve the neceffary, heat. The mouth of every cell is ftrengthened by a border, which makes the door a little lefs than the infide of the cell. Thefe cells contain their young, their wax, or their honey. It is their principal care, when firt hived, to ftop up all the crannies, by a refinous gum, more tenacious than wax, called Propolis. When the bees begin to work with, it it is foft, but acquires a firmer confiltence every day; till at length it affumes a brown colour, and becomes much harder than wax. The bees carry it on their hinder legs; and fome think it is met with on the birch, the willow, and poplar.

By their teeth they model their various buildings; they begin at the top of the hive, and feveral at a time. Their combs coft them great labour, and are made by infenfible additions. Every worm, before it is an aurelia, hangs its old $\mathrm{fkin}$ around its cell : the fame cell is often tenanted by three or four worms in a fummer; and the next feafon, by three or four more : thus being lined, fix or eight deep, it becomes at laft too narrow for a new brood, and is converted into a ftore-houfe for honey.

The meal of flowers; of which their wax is formed, is one of their moft favourite repafts. On this they live during fummer; and lay up a large winter provifion of it : this is the bee-bread; without which they ftarve. Their. wax is this meal digefted, and wrought into a pafte. In April and May, the bees are bufy, from morning to evening, in gathering this meal; but when the weather becomes too hot in the midft of fummer, they work only in the morning.

The bee has a ftomach for wax, as well as honey; in which the powder is altered, digefted, and concocted into wax, then it is ejected. A comb, newly made, is white: it becomes yellow as it grows old, and almoft black when kept long. Honey is extracted from that part of the flower called the neetarium. It paffes into the firft ftomach, or honey-bag, which appears like an oblong bladder.

How numerous foever is a $\mathrm{fwarm}$, all owe their original to the queenbee : that in one fummer gives birth to twenty thoufand young: the number of her eggs appearing at one time amounts to five thoufand. She may eafsly be diftinguifhed by her fize, and the fhape of her body. She will be feen at times attended with a numerous retinue, marching 
from cell to cell, plunging the extremity of her body into many of them; and leaving one fmall egg in each; if the leave two, the latier is removed. The bees which compofe her train are thought to be males. Thefe are larger and blacker than common bees; without ftings, and without induftry. They feem formed only to tranfmit a polterity. If their queen die; the bees leave off working; and take no farther care. If another queen is prefented them, they acknowledge her for fovereign, and apply to their labour.

This fertility of the queen=bee, and the great attentions paid to ber, are controverted by more recent objervers. Tbey afert, that tbe common bees are parents themjelves; that they depofite tbeir eggs in the cells wbicb tbey bave prepared, and bring fortb a progeny wbolly tbeir awn.

The egg is fixed to the bottom of the cell, in a fingle point. A day or two after it is depofited, the worm is excluded like a maggot rolled up, and lying foftly on a bed of a whitifh coloured jelly, on which it begins to feed. The working bees attend it with the moft anxious tendernefs; and furnifh it every hour with a fupply of this whition fubftance, which is a compofition of honey and wax in their own bowels. The worm in lefs than fix days comes to full growth, and lining the walls of its apartment with a filken tapeftry, which it fpins in the manner of caterpillars, foon becomes an aurelia, exhibiting legs and wings of the future bee. In about twenty or one and twenty days the bee is completely formed, and opens its prifon, by piercing with its teeth the waxen door that confines it; but is yet moift, and incommoded : the bees flock round it, and lick it clean with their trunks; while others. feed it with honey: others cleanfe the cell that has been juft left, for a new inhabitant. The young bee quickly repays their care by its induftry; for as foon 2 its external parts are dry, it begins, the tank, which it purfues unremictingly. Inftructed only by nature, it goes in queft of flowers, choofes only thofe that yield it a fupply, rejects fuch as are barren of honey, and, when loaded, returns to the common habitation; then it gathers the mealy powder of the flower, which is converted into wax ; and the very firt day returns with large balls in its thighs.

Above a hundred are excluded in one day ; and often they are fcarcely excluded, when they are obliged, by the old bees, to feek new habitations; eve notwithftanding their refiftance; hould they attempt it. In different countries, thefe fwarms or colonies appear at different times of the year. The night before, an unufual buzzing is heard in the hive; ali labour is difcontinued; every bee is either employed in forcing; or re- 
luctantly yielding a fubmifion : at length, after fome tumult, a queen bee is chofen, to attend the young colony, which crowding round their protectrefs, fets off. The ufual time of fwarming is from ten in the morning to three in the afternoon, when the fun hines bright. They flutter a while, and fometimes undertake a diftant journey, but more frequently feek fome neighbouring afylum. In countries, where the bees are wild, and unprotected by man, they build their waxen cells in the hollow of a tree; but with us they feem improvident in their choice, and the firt green branch that ftops their flight, feems to be thought fufficient for their abode, When the queen is fettled, the reft of the fwarm foon follow. Sometime there are two or three' queens to a fwarm, and the colony is divided into parties; the bees, by degrees, defert the weakeft for the moft powerful protector. The deferted queen takes refuge underr the new monarch, and is foon deftroyed. If there fhould be a queen bee, belonging to the new colony, left in the old hive, the always fuffers the fate of the former, unlefs the hive be full of wax and honey.

At the latter end of the fummer, when the colony is fufficiently ftored with inhabitants, a molt cruel policy enfues. The drone bees, who had hitherto led a life of indolence and pleafure, impregnating the queen, and rioting on the labours of the hive, now fall a facrifice to the general refentment of the working bees, which declare war againft them; and in two or three days the ground round the hive is covered with their bodies, They even kill fuch drones as are yet in the worm ftate in the cell, and ejeet their bodies.

Sometimes upwards of forty thoufand bees are found in a fingle hive, In lefs than twenty-four hours they make combs twenty inches long, and feven or eight broad. Sometimes they will half fill their hives with wax in lefs than five days. In the firft fifteen days they always make more wax than they do during the reft of the year.

In fome parts of France and Piedmont, and Egypt, they have a kind of floating bee-houfe, well defended from accidental ftorms; and foating gently along the river. As the bees are continually choofing frefh flowery pafture along the banks, they are furnifhed with fweets before unriffed.

There are two kinds of honey, the white and the yellow. The white is taken without fire from the honey-combs. The yellow is extrakted by heat, and fqueezed through bags in a prefs. The beft honey is new, thick, and granulated, of a clear tranfparent white colour, of a foft and arcomatic fmell, and of a fweet lively tafte. Honey made in moun-' tainous countries, is preferable to that of the valley : honey made in 


\section{T H E B E E.}

the fpring, to that gathered in fummer; which yet is more raluable than that of autumn.

In Guadaloupe, the bee is leís by half than the European, and blacker and rounder; has nofting, and makes cells in hollow trees: if the hole is too large, the bees form a fort of waxen houfe, pear-Shaped; in this they lodge, ftore their honey, and lay their eggs. They lay up their honey in waxen veffels, the fize of a pigeon's egg; black or deep violet colour; and fo jointed together, that there is no fpace between them: The honey never congeals, but is Aluid, of the confiftence of oil, and amber coloured. There are found little black bees, without a fting, refembling thefe, in all tropical climates; and though thefe countries have bees, like our own, yet thofe form the moft uleful tribe in thofe parts. Their honey is more palatable, and lefs furfeiting than ours; the was is fo foft, that it is only ufed for medical purpofes, not being hard enough to form candles.

Of infects that receive the name of bees there are feveral. The HuMBLE-BEE is the largeft, equalling the firft joint of the middle finger. Thefe are feen in every field and flower. They build in holes in the ground, of dry leaves, mixed with wax and wool, defended with mofs. Each makes a feparate cell, about the fize of a fmall nutmeg, round and hollow, containing the honey in a bag. Several of thefe cells are joined, fo that the whole appears like a clufter of grapes. The females, which have the appearance of wafps, are few; their eggs are laid in cells, which the reft foon cover with wax. Uncertain whether they have a queen, but one is much the largeft, without wings or hair, all black like polinhed ebony. This views the works, from time to time, and enters the cell, as if to fee whether every thing is right. In the morning, the young humble-bees are idle, and not inclined to labour, till one of the largef thrufts half its body from a hole on the top of the neft, beats its wings, buzzing till the colony is in motion. The humble-bees gather honey, but hot fo fine, or good, as the common bees, nor the wax fo clean, or capable of fufion.

The WOOD BEE is larget than the common queen-bee; bluein black, fmooth and hining; appears at the approach of fpring, flying near walls of a warm afpect. This bee makes its neft in fome half-roiten piece of wood, which it fcoops for its purpofe; never in ftanding trees. The holes turn to one fide; their opening is fufficient to admit a finger, from whence runs the inner apartment, generally twelve or fifteen inches long. Their tetth bore thiti cavities; they ufually branch into three 
or four apartments : in each they lay eggs, to the number of ten or twelve, each feparate and diftinet; the egg is involved in a fort of pafte, at once the young animal's prorection and nourihment. The grown bees feed on fmall infects, particularly a very fmall loufe, of a reddith brown colour.

Mason-BeEs make their cells with a fort of mortar, made of earth; they build againtt a wall expofed to the fun. The mortar, which at firft is foft, foon becomes as hard as ftone, and in this their eggs are laid. Each neft contains feven or eight cells, an egg in every cell, placed regularly one over the other. If the neft remains unhurt, or wants but lictle repairs, they ufe it the year enfuing; and often three or four years. A worm with very ftrong teeth is often found to bore into their little fortifications, and devour their young.

The GROUND-BEE builds in the earth, in round holes, five or fix inches deep; the mouth narrow, juft fufficient to admit the little inhabitant. They carry out all the earth, grain by grain, to the mouth of the hole, where it forms a little hillock. Sometimes the walks of a garden are undermined by their labours ; fome of the holes running directly downward, others horizontally beneath the furface. They lay up in thefe cavities provifions fur their young, which confint of a pafte that has the eppearance of corn, and is fweetill.

LEAF CUTTING-BEES make their neft and lay theireggs among bits of leaves very artificially placed in holes in the earth, of about the length of a tooth-pick cafe. They make the bits of leaves roundifh, and with them line the inlide of their habitations. This is further lined by a reddin kind of palte, fomewhat fweet or acid. Thefe bees are of various kinds; thofe that build their nefts with cheftnut-leares are as big as drones, but thofe of the rofe-tree are fmaller than the common bee.

W ALL-BEEs make their nefts in walls, of a kind of filky membrane, with which they fill up the vacuiries between the fmall ftones which form the fides of their habitation. Their apartment confits of feveral cells, placed end to end, each in the Thape of a thimble. The weh which lines this habitation is thick, warm, tranfparent, and whition, fuppofed to be fpun from the animal's body; the males and females are of a fize, but the former are without a fling.

To thefe varieties of the bee kind might be added feveral others, which, shough different, are not fuffeciently dillinguined for particular nutice. 


\section{[ 311$]$}

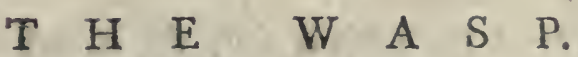

THE wafp is winged; a fting in its tail; is longer in proportion than the bee; marked with bright yellow circles round its body; fwif and active. On each fide the mouth this animal has a long toorh, notched like a faw; with thefe it cuts. Wafps live in community, fometimes ten or twelve thoufand together; fierce, voracious, and dangerous, when enraged. Wherever flefh is cutting up, they gorge themfelves with the fpoil, and fly to their nefts with their reeking prey. They make.war on every other fly, and the fpider himfelf dreads their approaches.

Wafps have frmilar occupations to bees for propagation, for nurfing and fupporting the rifing progeny. Among bees is one queen, or two in a hive; among wafps two or three hundred. Wafps are very numerous in fummer, employed in gathering provifions for their neft, if made, or in making one. The neft is contrived very artificialiy. Their principal care is to feek a hole, begun by fome animal, a field moufe, a rat, or a mole. They fometimes build on the plain, where dry, but cominonly on the fide of a bank to avoid water. Their firt labour is to enlarge the hole, carrying off the earth. They are furnithed with a trunk above their mouths, two faws un each fide, which play to the right and left againft each other, and fix trong mufcular legs. They cut the earth with their faws, and carry it out with their legs. The outline of their habitation makes a cavity of about a foot and a half every way. While fome are working, others are roving the fields to feek materials. To prevent the earth from falling down, they make a fort of roof with their glewy fubftance, to which they fix the rudiments of their building, working from, the top downwards, as if hanging a bell, which they clofe at bottom. They build their nefts of wood and glew. Thefe they faw, and divide the wood into fmall fibres, of which they take up little bundles in their claws, letting fall on them a few drops of glewy matter with which their bodies are provided, by which they knead the whole into a palte. This they tread clofe with their feet, and trowel with their trunks, going backwards as they work. Having repeated this operarion three or four i imes, the compofition is flatted out into a fmall grey leaf, much finer than paper, and pretty firm; with this, placing layer upon layer, they ftrengthen every partition. They make another entrance to their habitation, either for letting in the warmth of the fun, or for efcape. By one of thefe they PART VI. No. 3 I. 
always enter, by the other they fally forth; each being fmall, but one can pafs at a time.

The honey-comb of the wafp is fat, the mouth of every cell downwards. Thus is their habitation contrived, ftory above ftory, fupported by feveral rows of pillars which give firmnefs to the building, while the wpper ftory is flat-roofed and fmooth. The pillars are very hard and compact, largeft at each end. The cells are for the reception of young, being replete with neither wax nor honey. Each cell is hexagonal; but they are of two forts, the one larger for the production of the male and female wafps, the oither lefs for the reception of the working part of the community. The females lay their eggs, one in each cell, and ftick it in with a kind of gummy matter. This egg produces the infect in its worm-ftate, which the old females feed till it becomes large. The young worms at a certain fize fpin a very fine.filk. After this they diveft themfelves of their fkins by the ufual mode of transformation, the aurelia by degrees is emancipated from its thell, thrufts out its legs and wings, and acquires the colour and thape of its parent.

Though it gathers no honey, no animal is more fond of fweets. It will purfue the bee and the humble-bee, deftroy them with its fting, and plunder them of their honey-bag, with which it flies triumphantly loaded to its neft : but fierce battles fomerimes enfue, in which the bees make up by conduct and numbers what they want in prowefs. When there is no honey to be had, they feek the beft and fweeteft fruits. From the garden they ly to the city, to the grocers hops, and butchers Mambles: They will fometimes carry off bits of flefh half as big as themfelves, with which they fly-to their nelt. Whenever they are found, other fies defert the place immediately.

Every day in fummer adds to their numbers; and from their ftrength; agility, and indifcriminate appetite, were they as long lived as the bee, they would foon fwarm on the face of nature the moft noxious of plagues: but they live only a fingle feafon. While fummer heats continue, they are bold, voracious, and enterprifing: as the fun withdraws, they lofe their courage and activity; as the cold increafes, they become more domeitic; feldom leave the neft, make but Thort adventures, futter about at noon only, and return chilled and feeble. No longer able to provide their growing progeny a fupply, they facrifice them all to the neceffity of the times; then forfaking their nefts, they feek warmth in the corners of houfes, and artificial heat; but before the new year they wither and die; the working wafps firft, the males following, and many of the females. One or two females furvive the winter, and having been impregnated 


\section{$T H E N A S P$.}

pregnated during the preceding feafon, in fpring each lays eggs in a little hole of her own contrivance. This bundle of eggs, which is cluftered like grapes, produces two worms; thefe, when hatched, give aftiftance to the female, who is employed in hatching two more; thefe gathering ftrength, extricate themfelves from their web, and become affitants: fifteen days after, two more appear; thus the community daily increafes. The female lays in every cell a male and female: thefe foon breed in turn, till, from a fingle female, ten thoufand wafps are produced before June. Afterwards they affernble in the middle of fummer, and provide for themfelves the large and commodious habitation we have defcribed.

In the principal fpecies of the Solitary WAsp, the infect is fmaller than the working wafp. The filament, by which the corfelet is joined to the body, is longer and more diftinet, and the infect blacker than in the ordinary kinds. From May to July, this wafp is moft diligently employed, in contriving and fitting up a commodious apartment for its young, which is not to fucceed it till the year enfuing, with unwearied affiduity boring a hole into the fineft earth fome inches deep, but not wider than its own body. This gallery leads to a wider apartment for lodging its young. It always choofes a gravelly foil, where the earth is almoft as hard as ftone, digging and hollowing this apartinent by no fmall labour. This infect has two teeth, ftrong and firm, but not extremely hard: to foften that earth it is unable to pierce, it has a gummy liquor, which, emitted on the place, renders it more eafily feparable, and the whole becomes a kind of foft pafte. If the animal's liquor is exhaufted, water from fome neighbouring flower or ftream fupplies the deficiency. After much toil, a hole forme inches deep is formed, at the bottom of which is a large cavity : to this what other infect would venture, confidering the length and narrownefs of the defile? Here the folitary wafp lays its egg; and the nafcent animal continues above nine months, unattended and immured. The mother-wafp's next care is to furnith provifions to the young infect when it leaves the egg. She procures little green worms, generally from eight to twelve: this fupply laid in, the clofes the mouth of the paffage, and dies, fatisfied with having provided for her future progeny. The diminutive young glutton, juft hatched, feafts on the living fpoil without any control, till its ftock of worms is exhaufted, and the time of its transformation approaches; then fpinning a filken web, it continues fixed in its cell till the fun - calls it from its dark abode the enfuing fummer. 
Weft Indian wafps are thicker, and twice as long as the common bee grey ftriped with yellow, and have a very dangerous ftirig. Their cell refemble a honey-comb, in which the young ones are bred. They hang their nefts by threads, compofed of the fame fubftance with the cells, to the branches of trees, and the eaves of houfes, in great abundance, defcending like pears, of which thape they are, and as large as one's head. The infide is divided into three round ftories, full of hexagonal cells. In fome iflands thefe infects are fo numerous, that their nefts are fcarce two feet afunder, and fometimes no precautions can prevent their attacks : the pain of their fting is almont infupportable; the whole vifage fwells, and the features are fo disfigured, that a perfon is fcarcely known by his moft intimate acqúaintance.

\section{THE I CHNEU M O N F L Y.}

$7 \mathrm{HE}$ ichneumon $\mathrm{Ay}$ (of which there are many varieties) fears not the wafp itfelf, but enters its retreats, plunders its habitations, and takes poffeffion of its cell for its own young. The moft formidable, and beft known, is the common ichneumon, with four wings like the bee, a long nender black body, a three-forked tail, confifting of briftles; the two outermolt black, the middlemoft red. This intrument is a weapon of great force and efficacy; fcarce any fubftance it will not pierce. This is employed in deftroying its prey, and by this the animal depofits her eggs. The male has no fuch fting; the female ufes it with great force and dexterity, brandifhing it from fide to fide, and often wounding thofe who thought they held her fecurely.

All this tribe owe their birth to the deftruction of fome other infect, within whofe body they have been depofited, and upon whofe vitals they have preyed. The caterpillar, the gnat, and even the fpider, fo formidable to others, is often their unwilling fofterer. About the middle of fummer, when infects are abundant, the ichneumon is feen flying bufily about, and feeking proper objects of various kinds, upon whom to depofe its progeny. Some place their eggs in the aurelia of fome nafcent infeet, others in the neft of the walp; and as both are produced at the fame time', the young ichneumon not only devours the young wafp, but 


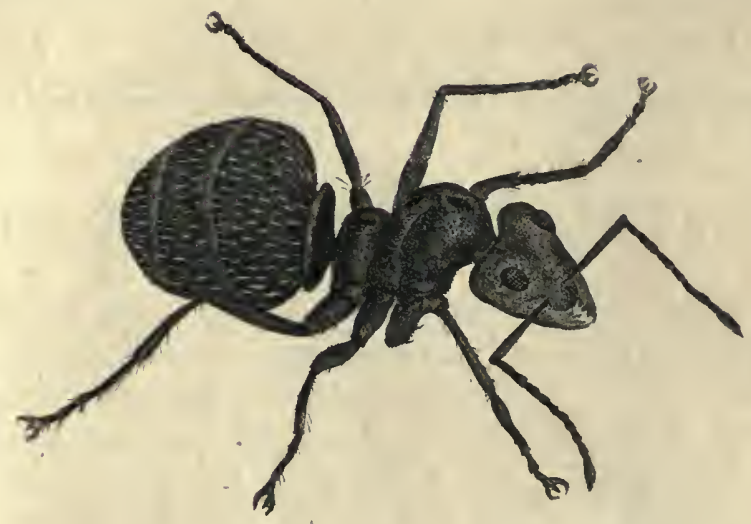

The Ant

Magnificed. 
but its who'e fupply of worms: But the greater number of the iclinet: mon tribe are produced from the back of the caterpillar; and if it furvives the worm ftate, they change into a chrgfalis, enclofed in its body. Such is this $\mathrm{Al}$, very terrible to the infect tribe, but of infinite fervice to mankind. The millions it kills in a fummer are inconceivable. Without fuch a deftroyer, the fruits of the earth would only furnifh a banquet for the infect race.

\section{T H E A N T.}

T $T$ is fomewhat furprifing, thet almoft every writer of antiquity fhould fefcribe this infect as labouring in the fummer, and feafting upon the produce during winter. It fhould feem, therefore, that in the warmer climates, where winter is mild and Thort, this occurs; but in: France and England they are torpid.

Anrs are of two or th : $\mathrm{kinds}$; fome red, fome black, fome with ftings, and others without. By their ftings fome infiet wounds; oihers fpurt from their hinder parts an acid pungent liquor, which inflames and burns the fin like neitles.

- An ant is divided into the head, breaft and belly. In the head, are the eyes, black: under the eyes two friall horns or feelers, of twelve joints, covered with a fine filly hair. The mouth has two crooked jaws, projecting outwards, ferrated like teeth. The breaft is covered with tine filky hair; from it project fix legs, ftrong and hairy, their extremities armed with two frnall claws, which the animal ufes in climbing. The belly reddifh, the body brown cheftnut colour, hining, and covered with extremely fine hair. This animal $i j$, bold and active, and fears not to attack creatures ten times its own ningnitude. In the firft fine day of April, the ant-hill fwarms with life, and myriads awaking from their annual lethargy, prepare for the occupations of the feafon. At firft none but the winglefs tribe appears; thefe are the working ants : the nales and females, that liave four large wings, are nower in their appearance. Thus, like bees, they are divided into males, females, and neutrals. The females are much the largeft; the working ants the fmalleft. The female alfo differs by the colour and fructure of her breaft, which is a little browner than the common ant, and brighter than the male. In eight or ten days after their appearance, their labours are in fome forwardnefs. 
wardnefs. The males partake not in the drudgeries of the ftate, but purfue the females with great affiduity.

In Englant, ant-hills are formed with but little regularity. In the fouth of Europe thev offer a fight highly worthy curioficy. They are generally in the neighbourhood of fome large tree and a ftream of water. The firft, as a proper place for getting food; the other, for fupplying moifture. The ant-hill refembles a fingar-loaf in thape, three feet high, compofed of leaves, wood, fand, earth, gum, and grains of corn, united compactly, with galleries to the bottom, and winding ways within. To the water, and to the tree, are many parhs worn by conftant affiduity; along thefe the bufy infects pafs and re-pafs continually from May till the autumnal bàd weather.

Their chief employment is procuring a fufficiency of food for all the community. They live on various provifion, fmall infeets, fweets of all kinds. They feldom think of the coinmunity, till themfelves are firft fatiated. Having found a juicy fruit, they fwallow what they can, then tearing it in pieces, carry home their load. If they meet with an infect above their match, feveral will fall on it at once, and each will carry off part of the fpoil, If they meet any thing that is too heavy for one, feveral will unite their force, fome dragging, others purhing. If one makes a lucky difcovery, it will give advice to others, and the whole republic will put themfelves in motion at once. If one is knled, fome will carry him off to a great diftance, to prevent obftruction to the general fpirit of induftry.

A fter a few days of fine weather, the female ants lay their eggs. They are carried, as foon as laid, to the fafeft fituation at the bottom of their hill. The egg is fo very firall, that, though laid on a black ground, it can fcarcely be difcerned. If viewed through a microfcope, it appears fmooth, polifted, and fhining; the maggot is compofed of twelve rings, is often larger than the ant itfelf, and found frequently as a white fubftance in every ant-hill. In cold weather they take them in their mouths to the very depths of their habitation; in a fine day they remove them, with equal care, nearer the furface, for the warm beams of, the fun. If a formidable enemy thould come to attack their habitation, their firt care is to fave their off:pring, each loaded with a young one, often bigger than the infect that fupports it.

When the young maggot acquires its full growth, it becomes an aurelia, which reprefents diltinctly the parts of the animal, though wirhour motion, and wrapped up. After ail its changes, it burfts this laft fkin; 
to affume the form it is to retain. The old ones very affiduounly break, open with their teeth the covering in which it is inclofed; knowing the precife time for their affiftance : if produced too foon, the young one dies of cold; if retarded too long, it is fuffocated.

When the female has done laying, her wings drop off; but the males, having no longer any occupation at home, ufe their wings, and fly away.

The working ants prepare for winter, and bury their retreats deep; their ftock of corn, and other fubftances, ferve as fences to keep off the rigours of the weather in our cold climates, not as provifions, they being torpid: but whether without any intervals may be queftioned. What has been faid miftakenly of our European ant, is true of thofe in tropical climates. They build hills with great contrivance and regularity, lay up provifions, probably live the whole year, and fubmit to regulations unknown among the ants of Europe.

In Africa are fome ants hite, others red, green, or black; the latter exceed an inch long, in every refpect formidable. Their fting is extremely painful, and their depredations fometimes extremely deftructive. Their hill is from fix to twelve feet high, made of vifcous clay, tapering pyramidally, conftructed with great artifice; the cells fo numerous and even, $a$ honey-comb farce exceeds them in number and regularity. The inhabitants feem to be under ftrict regulation. At the lighteft warning they fally out on whatever difturbs them. Sheep, hens, rats, and even large animals, are deftroyed by thefe mercilefs infects, and their flefh devoured to the bone. No anatomift in, the world can ftrip a fkeleton fo clean; no animal, how ftrong foever, when once feized, has power to refift them. When they fally forth, fifty or fixty larger than the reft head the band, and conduct them. If they have a fixed fpot where their prey. continues to refort, they form a vaulted gallery, fometimes a quarter of a mile in length; and yet they will hollow jt out in the fpace of ten or twelve hours.

The millions of thefe infects, their voracity, their union, and management, far exceeds what we can conceive : but by fuppofing our ants enlarged in fize and powers, and increafed in numbers, fo that a train might be a mile long, and very broad, we may form fome idea of the African termites, and the South American troops of infect depredators, from which fcarce any living thing can efcape but by flight. 


\section{$(318)$}

\section{T H E $\quad$ B E E $E$ T L E.}

Q $F$ the BEETLE are various kinds; all having cafes to their wings, which are the more neceffary, as the y live under the earth in holes which they dig, to prevent the injuries of their real wings, which they keep clean and even : they produce a buzzing noife, when the animal flies. Bulk for bulk, thefe infects are a thoufand times ftronger than man. Some beetles are not larger than the head of a pin, others as big as one's fift: fome are produced in a month, and in a fingle feafon go through all the ftages of their exiftence; others take near four years to their completion, and live as winged.infects another year.

The MaY-Bug, or Dorr-BeEtle, has cafes of reddinh brown colour, fprinkled with whitifh duft, which eafily comes off.' Of fome the necks are covered with a red plate, oihers with a black. The fore legs are very thort, for burrowing in the ground, where it retreats. Is well known for its evening buzz; has been known to fwarm in fuch numbers, as to eat up every vegetable production. The jexes are diftinguilhed by. the fuperior length of the tufts at the end of the horns, in the male. They unite in fummer. "The female bores a hole in the ground, to depofite her burthen, half a foot deep; here fhe places her eggs, one by the other. They are oblong, bright yellow. She afcends from her hole, to live as before, on leaves and vegetables, to buzz in the evening, and to lie hid, among the branches of trees, in the heat of the day. In three months the egr vivifies, the infect breaks its fhell, and a fmall grub or maggot crawls forth; it continues in the worm ftate more than three years, devouring the roots of plants, and making its way under ground: they. grow to the fize of a walnut, being a great whitih. yellow maggot with a red head, found frequently in new turned earth, and eagerly fought after by birds. The body confitts of cwelve fegments or joints, on each fide of which are nine breathing holes, and three red feet. The head is large, reddifh; a pincer before, and femicircular lip, with which it cuts the roots of plants, and fucks their moifture. It has no occafion for eyes, and has, none, but two feelers ferve to direet its motions. It yearly changes irs fkin.

In the fourth year, about the latter end of autumn, the grub approaches its transformation, buries itfelf, fometimes fix feet beneach the furface, and 
forms a capacious apartment, which it renders. very fmooth by the excretions of its body. It begins foon after to fhorten, fwells, and burfts its $\mathbb{R k i n}$, to become a chryfalis, at firft yellowi h, but at laft nearly red. After three months, in January, the chry?alis becomes a winged infect, but continues feeble and fickly. Its parts are foft, and its voracious nature fufpended. In May it burfts from the earth, the firt mild evening, to vifit the foftnefs of the fummer air, to choofe the fweeteft vegetables, and to drink the dew of the evening, buzzing along by thoufands, and hitting every object that intercepts their flight. At mid-day they lurk under leaves and branches, the willow particularly, in clufters. They never furvive the feafon. They unite fpeedily:

The-female bores a hole in the ground, with an inftrument at the tail, and depofites her eggs. This infeet, in its worm ftate; makes one of the chief repafts of the feathered tribe, and generally the firft nourifhment with which they fupply their young. Rooks and hogs are particularly fond of thefe worms. Of all the beetle kind this is the mont numerous, and may ferve as a fpecimen of the reft; but all are not fo long in the worm ftate, a fingle year fufficing.

That beetle which the Americans call the Tumble-Dung, is black; rounder than moft, and fo ftrong, though not much larger than the common black beetle, that if one of them be put under a brafs candleftick, it will move it backwards and forwards, as if by an invifible hand; to the admiration of thofe not accuitomed to the fight; their excellent fmelling directs them in flights to excrements juft fallen from man or beaft, on which they inftantly drop, forming round balls or. pellets, in which they lay an egg. Thefe pellets, in September, they convey three feet deep in the earth, where they lie till fpring; when the eggs are hatched, the nefts burft, and the infeets appear. They affift each other with indefatigable induftry, in rolling thefe pellets with the tail foremoft, raifing up their hinder part, and hoving along the ball with their hind feet. They are always accompanied by other beetles, larger, more elegant in ftricture and colour. The breaft covered with a crimfon hield, thining like metal; the head is crimfon mixed with green; on the crown of the head a fhining black horn, bending backward. Thefe are named kings of the beerles, but partake of the fame dirty drudgery.

The Elephant-beetle is the largeft known; inhabits South America, particularly Guiana and Surinam, and the river Oroonoko; is black, covered with a very hard fhell, full as thick and ftrong as a fmall crab. Its length four inches. The breadth of the body two inches and' $a$ quarter; the breadth of each elytron or cafe for the wings, an inch and three tenths. 
The antenne, or feelers, are horny, almoft an inch long, pointed; the probofcis is moveable at its infertion into the head, and feems to fupply the place of feelers. The probofcis an inch and quarter long, turns upwards, terminating in two horns, each near a quarter of an inch long; but not perforated at the end like the probofcis of other inlects. About half an inch above the head, next the body, is a prominence, or fmall horn, which, if the reft of the trunk were away, would caufe this part to refemble the horn of a rhinoceros. : [There is a beetle fo called, but then the horn or trunk has no fork at the end, though the lower horn refembles this.] The feet are all forked at the end, but not like lobfters claws. It is impolfible to defcribe the brilliancy of many foreign beetles; they feem compofed of all kinds of gems and precious ftones, each vying with the orhers for fplendour : their beauty is not to be diftinetly underftood without magnifyingglaffes, under which the BRAZIL BEETLE. is a moft delightful object; every part of him being ftudded with furprifing elegance; is rare, and often fold for two guineas.

To this clafs we may refer the Glow. Worm. No two infeets can differ more than the male and female. The male is a beetle, having cafes to its wings, and flying at pleafure; the female is entirely a creeping infect, and waits the approaches of her companion. The body of the female has eleven joints, a fhield breaft plate, oval; the head over this very fmall; the three laft joints of her body yellowilh : but what diftinguifhes her, in this part of the world, is the thining light the emits by night, and which is fuppofed to be an emanation of allurement to her companion. In fandy countries the ditches are ftudded on each fide of the road by her' hining fparks. If kept for fome time its light grows paler, and at laft expires. It is probable this light is eleetrical.

In tropical climates this peculiarity is very greatly exceeded : the light from fire flies, lanthorn flies (whofe light is in their head), and many others, is furprifing; it is probably for the fame purpofe, and produced on the fame principle, greatly exalted.

The Cantharis, or Spanifh Fly, is of the beetle kind, has feclers like briftles, Alexible cafes to the wings, a breaft pretty plain, and the fides of the belly wrinkled; they differ in fize, thape, and colour; the largeft are an inch long, and as much in circumference; fome are pure azure, others pure gold, others a mixture of pure gold and azure; all are very brilliant and beautifui. They are chielly natives of Spain, Italy, and Portugal: They are fond of all-leaves, and will fometimes ftrip a tree bare. Some aflirm, that they delight in fweet-finclling herbs; they are fond of honeyIuckles, lilac, and wild-cherry furubs. "The country people expect their 
return every feven years. Such numbers of thefe infects have been feen together in the air, that they appeared like fwarms of bees; they have fo difagreeable a fmell, that it may be perceived a great way off, efpecially about fun-fet, though they are not feen. When caught and dried, they are fo light, that fifty will hardly weigh a dram. They kill them with vapours of hot vinegar, after which they dry them in the fun, and keep them in boxes; they are penetrating, corrofive, and, applied to the fkin, raife blifters.

The Krrmés is produced in the excrefcence of an oak, called the berry-bearing ilex; is at firft wrapt in a membranaceous bladder, the fize of a pen, fmooth, fhining, brownin red, covered with very fine anh-coloured powder. This bladder in May or June teems with a number of reddith eggs or infects, which being rubbed emit a crimfon liquor. In A pril this infect is the fize and Thape of a pea; its eggs foon after burft from the womb, and becoming worms, run about the tree: fuch are the females. The males are a fort of flies like gnats, with fix feet, the four forward thort, the two backward long, divided into four joints, and armed with three crooked nails, two feelers on the head, moveable, ftreaked, and articulated, a quarter of an inch long; the tail very hort, forked. The whole body is covered by two tranfparent wings, and they leap about like fleas. The women gather them before fun-rifing, tearing them off with their nails, for fear there frould be any lofs from their hatching. They fprinkle them wich vinegar, and lay them in the fun to dry, where they acquire a red colour.

The Cochineal Insect is oval, the fize of a fmall pea, with fix. feei, and a fnout or trunk; brings forth its young alive; is nourifhed by fucking the juice of a plant. Its body confifts of feveral rings, and when once fixed on the plant, it continues immoveable, being fubject to no, change. There are two forts, the domeftic and the wild; the wild feeds on uncultivated trees, but the domeftic is carefully astended and removed to cultivated trees of the prickly pear-plant, and defended from other infects. Whien the rains and cold weather are coming on, they take off the leaves or branches covered with cochineal, not yet at perfection, and keep them in their houfes. Thefe leaves are very thick and juicy, and fupply them nourifhment. When milder weather returns, and they are abouc in exclude their young, the natives make them nefts of tsee-mots, nt finfe hay, or the down of cocoa-nurs, placing twelve in every intef. Thure they fix on the thorns of the prickly pear-planz; in thre: 


\section{I $\quad \mathrm{N} S \mathrm{~S}, \mathrm{E} \quad \mathrm{C} \in \mathrm{T}$.}

three or four days they bring forth their young, which leave their nefts in a few days, and creep on the branches of the plant, till the feinales are vifited by the males, which are winged infects ; they produce a new offfpring yielding a new harveft thrice a year. When gathered, they put them into holes in the ground; they are killed with boiling water, and dried in the fun, or on hot plates. From the various methods of killing them arife their different colours when brought to us.

It is evident that the foregoing (like the following) are not beetles, as they do not undergo the changes, \& $\&$ c. which belong to that tribe; yet, on the whole, this may be as convenient a place as any for them to occupy.

GÁL INsEcrs are bred in excrefcences, adhering to a kind of oak in Afra, which differ in colour, fize, roughnefs; and thape; thefe we call galls. The female of this animal is furnifhed with an implement, by which the penetrates into the bark of the tree, or into a fpot which juft begins to buid, and there fhéds a drop of corrofive fluid. She depofits lier eggs in the place. - The juice or fap fermented by the wound and fuid, turned from its natural courfe, flows round the egg; after which it is fwelled by bubbles of air. The external coat of thick $\epsilon$ :crefcence' is dried by the air, and grows like a kernel, receiving nutriment nowly. The worm that is hatched under it finds in its fubftance, which is tender, a fubfiftence till the time for its tranisformation to a nymph, and from that changes to a fly, and. rifes into the air. The gall-nut that grows in autumn if furprifed by the cold weather before the worm is transformed to a fly, the nut falls with the leaves, and the fly paffes the winter in a fhelter, where every c:ack and cranny is well ftopped up, which preferves it from the injuries of the weather. Here it acquires its perfect ftate, and, roufed by the firft heats, breaks its way through.

\section{THE GNAT AND THE T IPU.LA.}

TMHEIR differences of form are fo very minute, that it is difficult to diftinguin one from the other: they have both long legs, two wings, and flender body; their heads large, they feem hump-backed; but the tipula wants a trunk, while the gnat has a large one. The tipula harmlefs and peaceful, the; gnat fanguinary and predaceous.

The gnat proceeds from a little worm, at the bottom of ftanding waters. Its eggs, after being laid on the furface of the water, are furrounded 


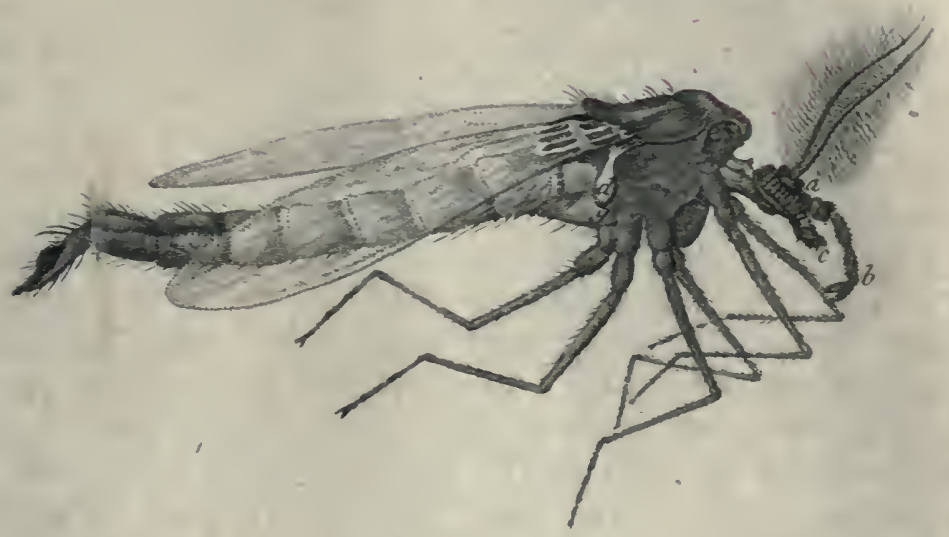

The Tufted Gnat.

Magnified 


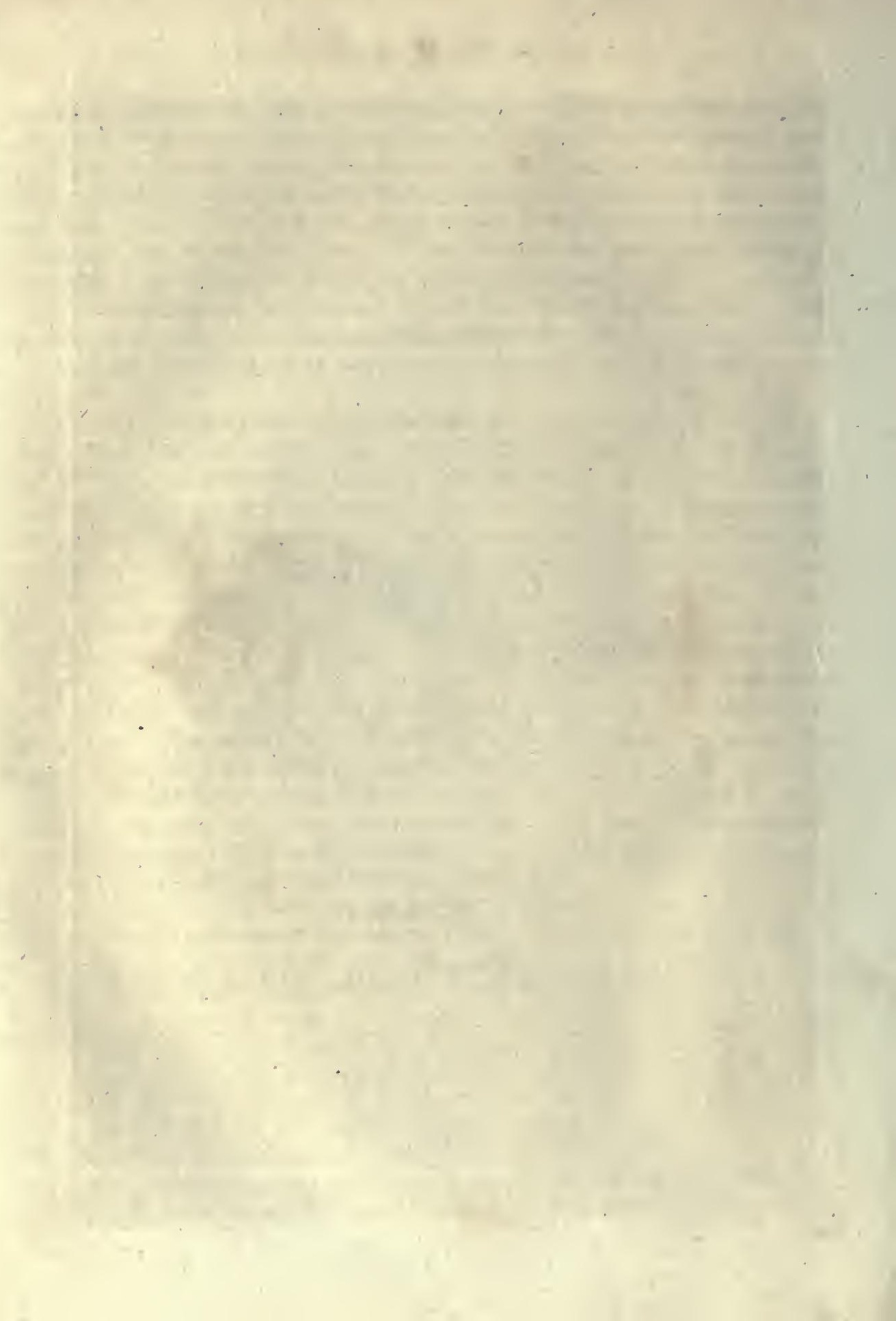


by an unctuous matter, which prevents their finking; but they are faftened with a thread to the bottom, to prevent their floating away. Thus the infects, in their egg ftate, refemble a buoy fixed by an anchor. As they come to maturity, they fink, and when they leave the egg as worms, they creep at the bottom. They make lodgments of cement, which they faften to fome folid body at the bottom, unlefs by accident they meet with a piece of chalk, which being of a foft nature, affords opportunity of finking a retreat for themfelves, where nothing but the claws, of a crayfin can pofibly moleft them. The worm afterwards appears with a large head, a hairy tail, moiftened with an oily liquor, which the ufes as a cork, to fuftain her head in the air, and her tail in the water, and to tranfport her from place to place; this liquor the difcharges out of her mouth. The gnat, in her fecond ftate, is properly a nymph, which is an entrance to a new life. In the firft place the divefts herfelf of her fecond $\mathrm{Nin}$; in the next the refigns her eyes, antennæ, and tail, and feems to expire; but from her fpoils rifes a little winged infect, whofe ftructure is a juft object of admiration. Its little head is adorned with a plume, and its whole body invelted with feales and hair. The little border of fine feathers, which graces her wings, is very curious : her trunk may juftly be deemed one of Nature's matter-pieces. It is fo very fmall, that the extremity of it can fcarcely be difcerned through the beft microlcope. That part which appears is but a long fcaly fheath under the throat. At near the diftance of two thirds of it is an aperture, through which the infect darts four ftings; one of which is the cafe in which the other three lie concealed, and run in a long groove. Their fides are harpened like twoedged fwords; they are barbed, and have a vaft number of cutting teeth toward the point, which turns up like a hook, and is furprifingly fine. Thefe darts fruck into the fleth of animals, fometimes one after another, fometimes all at once, extravafate the blood and humours. When the gnat, by the point of her cafe, which the ufes as a tongue, has tafted any fruit, fle?h, or juice, if it be fluid, the fucks it up, bue if folid, the pierces it, draws back her ftings, and by their theath, which fhe applies to the wound, extracts the juices. Winter the paffes in quarries or caverns, which the abandons at fummer, and flies to fome ford, or ftanding water, where fhe may produce her progeny, which would be foon wanhed away by the too rapid motion of any running ftream. The little brood are fometimes fo numerous, that the very water is tinged according to their colour.

Very extraordinary circumftances are reported of the gnat, and indeed P.ART VI. NO. 3 I.

barely 
barely credible. Some are oviparous; fome viviparous; fome males, and unite with the female; or females, requiring the male; fome are of neither fex, yet produce young without affiftance. A gnat inclofed alone in a glafs veffel, with air to keep it alive; thall produce young, which alfo, when feparated from each other, thall be parents of a numerous progeny, the young burfting from the body of their parents without previous impregnation. At the fixth generation this ftops, the gnat no longer produces from itfelf alone, but requires the male to beftow another fucceffion of fecundity.

In America, where the waters ftagnate, and the climate is warm, gnats are produced in multitude of multitudes; the whole air filled with clouds of all fizes, from fix inches long to minutenefs itfelf. The mid-day fun is too powerful for them; but during evening nothing can fhield the wretched inhabitants from their attacks; though millions are deftroyed, millions more fucceed, in unceafing torrents. The native Indians, who anoint their bodies with oil, and have been ufed to their depredations, find them much lefs inconvenient than Europeans; they leep covered with thoufands. If a candle be lighted in thefe places, a cloud of infects lights on the flame, and extinguifhes it; fo that they are obliged to keep their candles in glafs lanthorns. Nor is it a little extraordinary that the fame moltiplication of the gnat kind Should occur in Lapland, where thofe gentlemen who went to meafure a polar degree were extreme fufferers by heat and infeets: while thofe engaging in meafuring ain equatorial degree were perifhed by ftorms, fnows, and cold.

Such are the ways of Nature, as exemplified in the tribes of infects. We have feen other creatures transformed, but not fo often; nor after equally apparent diffolution. Among fo numerous a tribe it is difficult to form a juft felection, which may include all their various ways of obtaining life; and perhaps fome may exift whofe transformations may be yet more numerous and peculiar, their manners and properties more remarkable and wonderful: for certainly thoufands are unknown to us in countries where ftudy and learning have not penetrated, and of which our information is extremely limited; not to mention the difficulty of accurate acquaintance with thofe more immediately fubject to our notice, arifing not lefs from their modes of life, than from their unlikenefs in different ftates. 


\section{$(325)$}

\section{WORMS AND ZOOPHYTES.}

\section{T H E}

T A S great reputation for its phlebotomical fervices, being elteemed the beft of blood-letters; and as fuch known to the ancients. $P_{\text {LiNY }}$ names it the birudo fonguifuga; was ufed inftead of cupping glaffes for perfons of a full habit of body, or goutical. There are fevera: forts, all ftrongy allied to worms. In general the body oblong; moves. by affuming an arch-like form; takes its fond entirely by fuction; and what is very remarkable, has no vifible ejectory to difcharge it after digeftion; it is therefore by moft naturalifts fuppofed to pafs through the pores of its $\mathbb{k i n}$, perhaps fomewhat in the nature of perfpiration. They have been kept long in glaffes without in the leaft difcolouring the water, or caufing any fediment. Kept in glaffes they are good barometers, and predict bad weather by their reftleffnefs and perpetual change of place; they live long without food, thus kept. They inhabit ftanding waters generally, and perhaps by preference, though I have caught them in thallow running ftreams. When placed in the middle of fuch a ftream, they adhere by fuction at the tail to whatever they find; yet often the current is too ftrong for them. In fome places abroad they fwarm fo prodigiouny, as to deter the inhabitants from venturing into many pieces of water; for fuch numbers would attack them, as would drain them quickly of their blood; by their ftrong adhefion they are difficult to get rid of, and fometimes leave dangerous wounds, of which circumftance there are accounts.

The MEDICAL LEECH has a brown body, marked with fix yellow lines, belly lighter. The Horfe Leech has a fiattin body; in the bottom of the mouth certain great Tharp tubercles; is nendereft about the mouth; thickeft towards the tail; the tail nender; belly yellowin-green; back dufky. The fea furnithes a kind or two that greatly infeft fifh." That kind ufed medically is faid to faften where a fpot is rubbed with blood or milk, and to difcharge what it has fwallowed, if fprinkled with falt. In moft particulars conformable to worms, bui not capable of propagation by being cut in pieces.

\section{W $O \quad R \quad M \quad S$,}

DEING deftitute of feet, trail themfelves along on the ground, and inhabit the earth, or the water; though they creep along the earth on their bellies, yet their motions are very different from 
thole of ferpents. There is a fpiral mufcle that runs round the body, from head to tail, fomewhat refembling a wire-fpring to a bell which is hung from room to room; which, if one end.be extended and held faft, will bring the other nearer to it: by this the earth-worm; having extended itfelf, holds by the nime of the fore part of its body, then contracts itfelf and brings forward the hinder part.

Its body is armed with fmall ftiff harp burs or prickles, which it can erect or deprefs at pleafure; under the fkin lies a nimy juice, ejected as required, at certain perforations, between the rings of the mufcles, to lubricate its body, and facilitate its paffage into the earth. It has breathing-holes along the back, adjoining each ring. Deftitute of head, ears, nofe, for the moft part of eyes, and properly without feet. It has a mouth, and an alimentary canal, which runs to the very point of the tail (but in fome found in the bodies of animals, this canal opens towards the middle of the belly), filled with a very fine earth; which feems to be their nourißhment.

Without brain, but near the head is the heart, which beats diftinaly; round it are the fpermatic veffels, forming a number of little globules, containing a milky fluid, opening into the belly, not far from the head: they are alfo often found to contain eggs, which are laid in the earth, and hatched in twelve or fourteen days, by the warmth; like fnails, thefe animals unite in themfelves both fexes.

The young ones are very fmall, but perfeetly formed, and fuffer no change : how long they live is not known, certainly more than two or three feafons. During winter, they bury themfelves deep, and feem to thare the general torpidity. In fpring they revive, a moift or dewy evening brings them from their retreats, for mutual intercourfe. They chiefJy live iń a light, rich, and fertile foil, moiftened by dews or accidental fhowers, but. Thun where the water is apt to lie, or the clay is too ftiff. They avoid the mole, who feeds on them, by darting up from the earth, the inftant they feel the ground move; and fifhermen take them in numbers, by. ftirring the earth.

The EARTH. Worm continues to live, though cut in feparate parts. We owe the difcovery of this power of reproduction in animals to $\mathrm{Mr}$. Trembley, who firt obferved it in the polypus; after him, Spalarizani and others found it in the earth-worm, the fea-worm, and feveral other animals. Every earth-worm, however, did not retain the vivacious principle equally; fome, when cut in two, were deftroyed; of others, while the head was living, the tail perihed, and a new tail came at the extre- 
mity. In the fmall red-headed earth-worm, both extremities furvived the operation; the head produced a tail with the anus, the inteftines, the annular mufcle, and the prickly beards; while the tail in lefs than three months fent forth a head, heart, and inftruments of generation. This part was produced fowly, a new head taking three or four months for its completion, a new tail not fo many weeks.

The SEA-WORM, the white water-worm, and many of thofe little worms with feelers, found at the bottom of dirty ditches, are capable of the fame.

\section{THE. STAR-FISH; OR SEA-BLUBBER.}

THIS is a numerous tribe, fhapelefs and deformed, affuming at, different times different appearances; now. round like a ball, Thortly after as thin as a plate. This kind are formed of a femitranfparent gelarinous fubftance, covered with a thin membrane, and often appear like a lump of jelly, floating at random on the fea, or thrown by chance on the Thore; yet they poffefs life and motion, and thoot forth arms in every direction to feize on fuch infects as are near. Worms, fifh fpawn, even muffels, with their fhell, have been found in the ftomachs of thefe animals, which are no way injured by fwallowing fuch hard fubftances.

In fummer, when the water of the fea is warmed, they float, and in the dark einit a kind of thining light refembling phofphorus. Some call them fea-nettles, becaufe they fting the hands of thofe that touch them, like netrles. They are often feen faftened to the rocks, and to the largeft fea-fhells. If put into fpirit of wine, they will continue many years entire; but if left to the influence of the air, they are, in lefs than four and twenty hours, melted down inso limpid and offenifive water.

None poffeffes other vent for excrements but the fame paffage by which they devour their food : in general they refemble a truncated cone, its bafe applied to the rock to which they are ufually attached. Though generally tranfparent, yet they are of different colours, fome inclining to green, or red, or white, or brown. In fome, the colours appear diffufed, others are often ftreaked, and others fpotted. Many of them porfels a number of long Aender filaments, in which they entangle frnall animals, 


\section{WORMS AN-D ZOOPHYTES.}

mals, and thruft them into their enormous ftomachs, which fill the whole cavity of their bodies. The harder thells continue for fome weeks indigefted, but at length they undergo a kind of maceration, and become a part of the fubitance of the animal.

They may be cut in pieces, and every part will furvive the operation; each becoming a perfeet animal; endued with its natural rapacity.

The CUTTLE-FISH is about two feet long, covered with a very thin fkin, its flefh compofed of gelatinous fubftance, within ftrengthened by a trong bone. It has eight arms, capable of lengthening or contracting at pleafure; when dead, they become rigid. They feed on fmall fifh, which they feize with their arms; they are bred from eggs, which are laid upon the weeds along the fea-fiore.

The cuttle-fin is found on many coafts of Europe, but not, eafily caught, being furnined by Nature with a black fubftance contained in a bladder generally on the left fide of the belly, and which is ejected in the manner of an excrement. Whenever this fifh is purfued, and it finds a difficulty of efcaping, it fpurts forth a great quantity of this inky liquor, by which the water is darkened, and it efcapes, by lying clofe at the bottom.

\section{TH E P O L Y P US.}

7 HE moderns have given the name Polypus to a little frehwater creature, found at the bottom of wet ditches, or attached to the under furface of the broad-leafed plants that grow on the waters. Sea-Polypi, which were well known to the ancients, are from two feet long to three or four; and Pliny has defcribed one, whofe arms were thirty feet long. Our ditch-water. Polypi feldom exceed three parts of an inch long, and when gathered up, not a third of thofe dimenfions, but in form they refemble the larger.

To Mr. Trembley we owe the difcovery of the amazing properties and powers of this little vivacious creature : he divided this clafs of animals into four different kinds, according to their colours, green, brownifh, flefh colour, and tufted.

They appear in a wet ditch like little tranfparent lumps of jelly, the fize of a pea, flatted on one fide; the under fide of broad-leafed weeds 


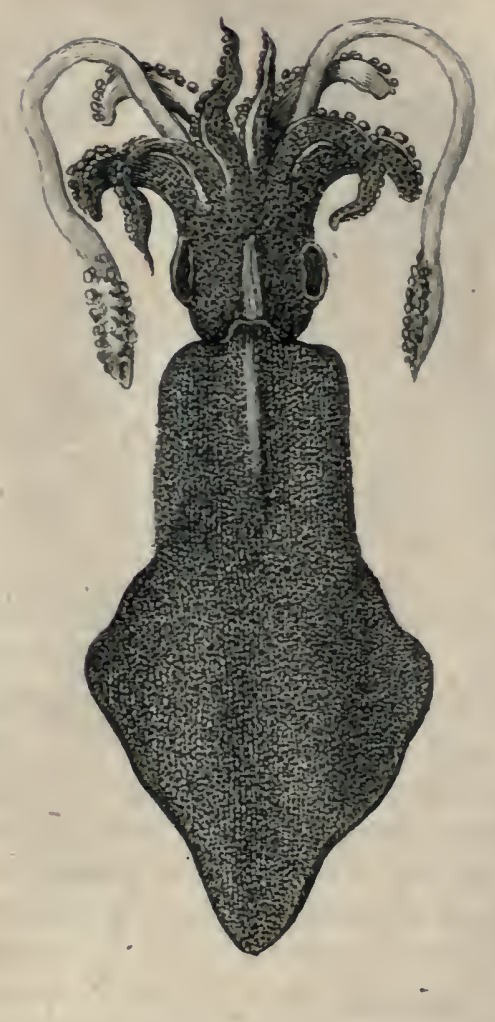

The Cuttle-fill. 


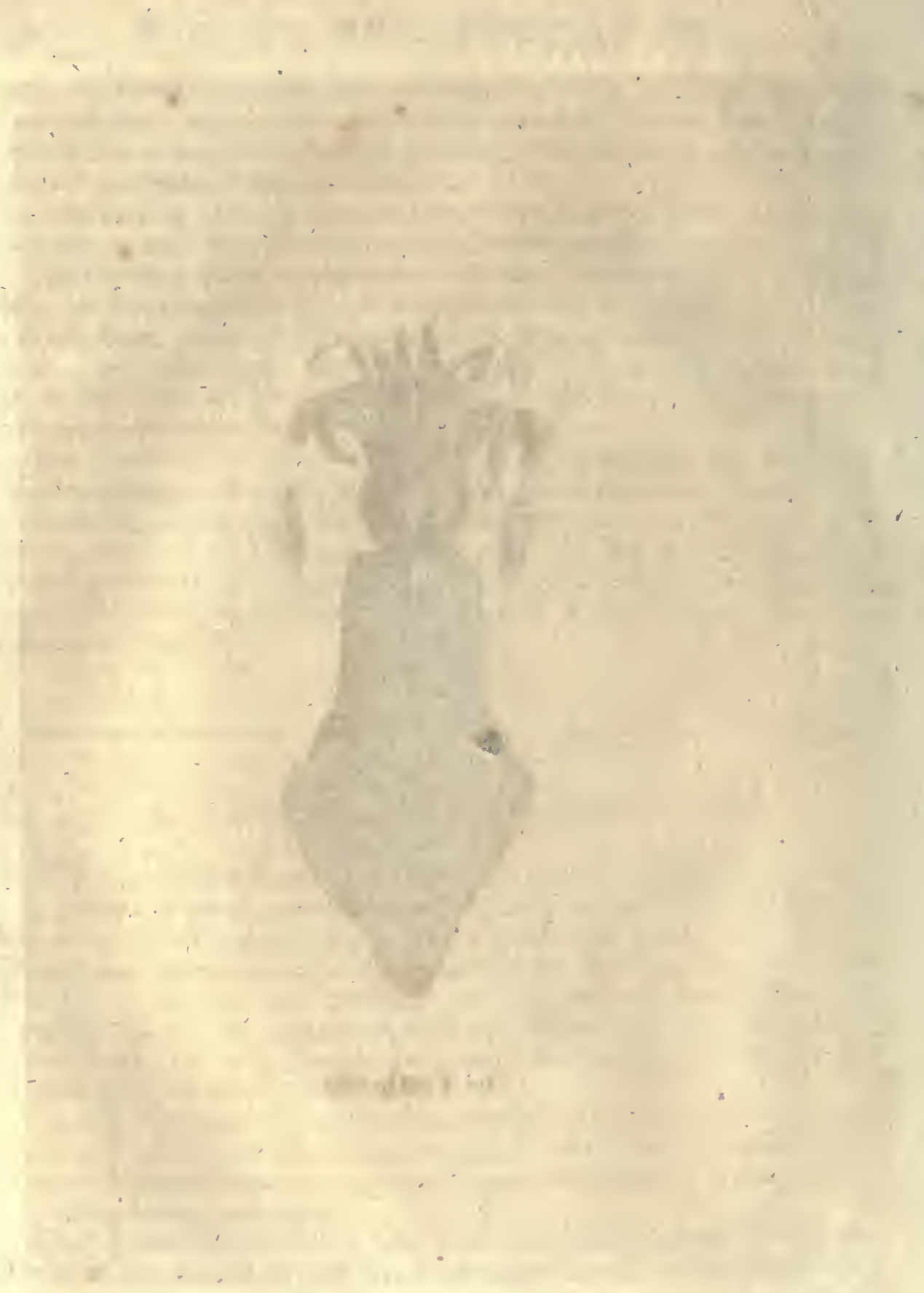


on the furface of the water, is often ftudded with a number of thefe little jelly.like fubftances, which are polypi gathered up into a quificent ftate. In action they affume a very different appearance; the finger of a glove, cut off at bottom, with feveral threads round the edge like a fringe, will give us an idea of the ftomach of the animal, and its arms or feelers. It has neither mufcles nor rings: its manner of lengthening or contracting itfelf molt refembies that of the fnail; it contracts itfelf in proportion as it is touched, or as the water is agitated. Warmth animates, and cold benumbs them; but a degree of cold approaching congelation only reduces them to perfect inativity : their arms are double (often thrice) as long as their bodies; thefe are thrown about in various directions to feize its prey; fometimes three or four are employed, while the reft are contracted, ijke the horns of a fnail, within the animal's body. It feems capable of giving what lergth it pleafes to thefe arms, and ftretches them in proportion to the remotenels of the object it would feize.

They go from one part of the bottom to another; they mount along the margin of the water, and climb the fides of aquatic plants. They often.come to the furface of the water, where they fufpend themfelves by their lower end. They advance very nowly, employ a deal of time in every action, and bind themfelves very ftrongly to whatever body they meet as they proceed; their adtefion is voluntary, and probably performed in the manner of a cupping-glas.s.

They have a remarkable attachment to turn towards light, yet no eyes have ever been difcovered by the beft microlicopes.

In the center of the arms the mouth is placed, ferving at once as a paflage for focd, and an opening for it after digeftion. The inward part of the arimal feems to be one great ftomach, open at both ends; but the purpofes of the opening at bottom are unknown, unlefs. it be of adhefion. The furface of the body of this little creature, examined with a microfcope, appears ftudded wití a number of warts, as alfo the arms, efpecially when contracted.

They chielly fubfift on infects lefs than themfelves, particularly a kind of water-millepedes, and a very fmall red worm, which they feize with great avidity. Wherever its prey is, which the animal finds by feel? ing, a touch faftens the object it would feize beyond efcape. The greater its diftance, with the greater eafe the Polypus brings the prey to its mouth. If the little object be near, though irretrievably caught, it is nor without great difficulty it can be brought to the mouth and fivallowed. PART VI. No. 3. $3 \mathrm{~K}$

When 
When the Polypus is unfupplied with prey, it teftifies its hunger by opening its mouth : the aperture, however, is fo fmall that it cannot be eanly perceived ; but when, with any of its long arms, it has feized its prey, it then opens the mouth diftinctly enough, and always in proportion to the fize of the animal it would fwallow; the lips dilate infenfibly, and precifely to the figure of their prey. Mr. Trembley found they could devour aliments of every kind, fin and flem as well as infects. When he gave one of thefe famifhed reptiles any fubftance which was improper for aliment, at firt it feized the prey with avidity, but, after keeping it fome time entangled near the mouth, let it drop again with diftinguifhing nicety.

When feveral polypi happen to leize the fame worm, they difpute their prey. Two are often feen feizing the fame worm at different ends, and dragging it at oppofite directions with great force. Often they continue fwallowing each his part, till their mouths meet; then they reft till the worm breaks; but it often happens, when the mouths of both are thus joined; the larger polypus gapes and fwallows his antagonift, which, after it has lain in the conqueror's body an hour, iffues unhurt, and often in porfeffion of the prey contended for.

They continue eating the whole year, but when the cold approaches to congelation, then they feel the general torpor, and their faculties are for two or three months fufpended. The meal of one day fuffices them feveral months. In general they devour in proportion to their fize, and their growth is quickeft as they are beft fed.

They are produced in as great a variety of manners as a vegetable. Some polypi from eggs, as plants from feed; fome by buds, as plants by inoculation; all may be multiplied by cuttings, and this to minutenefs beyond expectation.

In fummer; a polypus exhibits in different parts of its body tubercles or little knobs, which enlarge daily, and; after two or three days, take the figure of a fmall animal, refembling its parent, furnifhed with feelers, a mouth, and apparatus for feizing and digefting its prey : this daily becomes larger, like the parent, to which it continues attached; fpreads its arms to feize whatever is proper for aliment, and devours it for its own particular benefit; thus it poffeffes two fources of nourinment, that which it receives from the parent by the tail, and that which it receives from its own induftry by the mouth. The food which thefe animals reseive often tinctures the whole body, and the parent is feen communicat- 


\section{LITHOPHYTES AND SPONGES.}

ing part of its fluids to its progeny that grows on it. Several young ones are thus feen at orice, of different fizes, growing from its body; fome juft budding, others acquiring their form, and -others come to maturity, juft ready to drop from their original ftem. Young ones, while attached to their parent, propagate their own young ones alfo, each in the fame dependence on its refpective parents, and poffeffed of the fame advantages as have been defcribed.

It is indifferent whether one of them be cut into ten, or ten hundred parts, each becomes a perfect animal; but the fmaller part thus feparated will be longeft in coming to maturity. The animal has been twifted and turned into all manner of thapes; has been turned infide out, and cut in every divifion, yet ftill it continued to move, its parts adapted themfelves again to each other, and in a fhort time it became as. voracious and induftrious as before.

Befides thefe kinds mentioned by $\mathrm{Mr}$. Trembley, there are others which have been fince difcovered by the vigilance of fucceeding obfervers; fome of thefe fo Atrongly refemble a flowering vegetable in form, that they have been miftaken by many naturalifts. Mr. Hughes, in his Natural Hiftory of Barbadoes, has defcribed a fpecies of this animal, but called it a Senfitive flowering plant; he obferved it to take refuge in the holes of rocks, and, when undifturbed, to fpread forth a number of ramifications, each terminated by a flowery petal which fhrunk at the approach of the hand, and withdrew into its hole. This plant however was a polypus, not only found in Barbadoes, but on the coaft of Cornwall, and the fhores of the Continent.

\section{LITHOPHYTES AND SPONGES.}

THE animals we fee, much lefs thofe we are acquainted with, bear no proportion to thofe concealed from us. Though every leaf and vegetable in the air fwarms with animals, yet in the water they are ftill more abundant, and at fea abfolutely innumerable: the greateft part of what feem vegetables growing in the deep, are but the artificial formation of infects, and built for their own habitation.

The boitom of the fea along fome fhores, and at the mouths of feve- 
ral rivers, has the appearance of a foreft under water, millions of plants growing with their branches entangled in each other, fometimes fo ftrong'Jy as to obftruct navigation. 'The Perfian gulph, the Red fea, the Weftern coafts of America, are choaked up in many places with coraline fubltances; though hips force a paffage through them, they are impracticable to boats and to fwimmers.

Corals fometimes thoot out like branches of trees, or a broad furface.like a fan, or a large bundling head like a faggot; fometimes they refemble a plant with leaves and flowers; often the antlers of a ftag. Elfewhere in the fea are feen fponges of various magnitude, and extraordinary appearances, affuming phantaitic forms like muhrooms, mitres, fonts, flower-pots. Thefe productions feem entirely vegetable; but the ingenious $\mathrm{Mr}$. Ellis, by fagacious and diligent enquiry, determined that corals and fponges are the work of animals, and (like the honeycomb) coral was produced by an infinite number of affociates; thefe are of the polypus kind, whofe united labours fill tracts of ocean with thefe tokens of their induftry.

Should we be induced to break off a branch of the coraline fubftance from its original connection, we thall perceive its whole furface, which is very rugged and irregular, covered with a mucous fluid, almoft in every part ftudded with little jelly-like drops: thefe clofely examined prove to be of the polypus kind; have motions, arms, and appetites exactly refembling thofe already defcribed; but they foon expire when taken out of the fea.

A coraline plant, ftriftly obferved while growing, if not difturbed, the little polypi will be feen in infinite numbers, each iffuing from its cell, and in fome kinds the head covered with a little fhell, refembling an umbrella, the arms fpread abroad to feize its prey, while the hinder part remains attached to its habitation, from whence it never wholly removes. All are affiduounly employed in the fame purfuits.

Mr. Ellis examined their operations juft as they were beginning. In a neglected oyiter-bed he perceived the firt rudiments of a coraline plantation, and tufts of various kinds thooting from different parts. $\mathrm{He}$ took out the oyfters thus furnimed with coralines, and placed them in a large wooden veffel, covering them with fea-water. In about an hour he perceived the animals, which before had been contracted by handling, and had Thewn no figns of life, expanding themfelves in every direction, and employed in their own natural manner. To preferve them thus expanded, fo as to be permanent abjects of curiofity, he poured, by now degrees, 


\section{EELS IN P A S TE.}

degrees, an equal quantity of boiling water into the veffel of fea-water. He then feparated each polypus with pincers from its thell, and plunged each feparately into fmall cryftal vafes, filled with fpirit of wine mixed with water. By this means the animal was preferved entire, without having had time to contract itfelf; and chus he perceived a variety of kinds, almoft equal to that variety of productions which thefe little animals form. He perceived and defcribed fifty kinds, each poffefling its peculiar mode of conftruction, and forming a coraline none of the reft can imitate. On every coraline fubftance are a number of polypi, not refembling the erectors of the building, but a vagabond race.

In general the fame difference that fubfits between the honey-comb of the bee, and the paper-like cells of the wafp, fubfifts between the different habitations of coral-making polypi. They have been named by their likenefs to fome well-known object, fuch as coralines, fungi, madrepores, fponges, aftroites, and keratophytes. Thougk thefe differ extremely in their outward appearances, they all are formed in the fame manner by polypi of various kinds and nature. When examined chemically, corals diffolve in acids, and fponges burn with an odour ftrongly refembling that of burnt horn.

Probabiy the fubftance of coral is produced, like the fhell of a fnail, from a llimy matter, which covers its body, and hardening, becomes an habitation; feveral of thefe united, form at length a confiderable mafs.

Minute and diminutive as fome of thofe creatures feem to whofe manners we have paid attention, they are large when compared to orhers, of whom we have information, but whofe natures are greatly concealed by their fmallnefs. Among the moft remarkable of thefe are,

\section{EELS IN P A S T E.}

GLOUR and water boiled together till moderately confiftent, and expofed to the air in an open veffel, after fome days (if not mouldy) will turn four, and exhibit multitudes of long, nender, wriggling animalcula, not always invifible to the naked eye. They may be kept a year, by fupplying a drop of vinegar, or water, cccafionally; thefe are viviparous, and many young are found in the bady of the parent, each coiled up and included in its proper membrane, to the number of an hundred.

How far the former are related to enls in blighted wheas is dubious: there 
thefe are lodged in grains that appear blackinh, as if fcorched, and wher opened contain a foft white fubftance, like a number of threads lying befide each other, which, if wetted while frefh, feparate, and difcover themfelves to be living creatures. At firft their motions are languid, but gradually they become invigorated, yet always move fomewhat nowiy, and with regularity; bending their extremities fometimes differently, fomerimes alike. If the grains of wheat are dry, and opened while dry, and the thréad-like matter be put into the water, often the whole mifcarry ; but if they be previoully fteeped in water, or buried in the earth, fo that they moiften gradually, then, after being opened, and the water admitted to their contents, in the courfe of a few hours they revive, and become lively. This has been afcertained after the grains had been dry for four or more years. If the hufks be left in much water, the eels quickly die; but if removed they live feveral months, and fhould the water dry away, are revived by a frefh fupply; if left in the hußks they perin, having no powers yet known whereby to open their prifons. There are fome differences between thefe eels and thofe of pafte; what is their real relation we know not.

Pepper-water yields a great variety of minute infeets, even though the pepper has been preferved many years. Common black pepper grofsly pounded, put into an open veffel, and water poured on it, and the mixture well thaken, will in a few days be covered by a pellicle reflecting the prifmatic colours : this contains millions of creatures at firt very fmall, but increafing daily in fize and numbers, till the whole fluid feems alive. Their kinds are very various; fome are fwift and agile, feeming in continual chafe of prey, can creep as weil as fwim, are fringed all round their bodies; others have globular bodies and long tails; others refemble flounders; others worms; "of fome an hundred placed in a row would not equal in diameter a grain of 'fand.

Nor is this effect peculiar to pepper: hay, ftraw oats, barley, or any other vegetable, infufed in like manner, will furnith a fcum, which, on examination, proves to be, or to contain, living creatures in prodigious numbers; fome of the fame fort as thofe in pepper-water; others totally different, and peculiar to the plant infured; fome refembling ferpents in form and motions, coiling themfelves round in like manner. Eel-like aninals are frequent among them.

Vinegar alfo.abounds with eel-like creatures, after having ftood a few days uncovered, in the fummer feafun.. Of thefe it is remarkable, that if the vinegar be but moderately heated by the fire, they die and fall. 
to the bottom; but cold does not hurt them. If frozen and thawed repeatedly, they repeatedly revive and become brifk; if a quantity of oil be poured on the vinegar, they creep up into the oil when the vinegar begins to freeze, and return to the vinegar when that is thawed. By a few grains of fand put among them they are greatly embarraffed, and are in a manner overwhelmed by fuch huge ftones.

RAIN WATER, after ftanding a few days, exhibits fimilar appearances; water in ditches and water that drains from dunghills is often fo crowded with animals, as to feem all alive, efpecially the deep brown water from dunghills. It is probable that fome of thefe animalcula are extremely minute flies in their worm ftate, and undergo one transformation, if not more, ere they become perfect; others are unqueftionably in their perfect ftate, here breed, live, and die, without change. The infinite variety of their forms, motions, parts, and contrivances for catching prey, is unlimited. Some of them are ccrigregated in millions of millions to an inch fquare, under the appearance of mud, or weeds, or llime in ditches: of all colours, efpecially blackinh-green. Some are like worms, having membranous coverings; other Thelled like muffels, or cockles: fome feem capable of varying their forms, feeming now rounded, now lengthened, now with a long neck, now with quite a different conformation; many of them refemble fuch infects as are familiar to us, and are like them cruftaceous, have feelers, legs, tails, \&c. Ufually the microfcope fhews that their internal conformation is not altogether unlike, and we conceive of them as having the fame parts in a general idea, but inexpreffibly fmaller. Crabs and lobfters in form, and perhaps in manners (fo far at leaft as having fpawn under the tail, or in receptacles on each fide of it), are common among them; and it is not impoffible they alfo change their fkins.

In general thefe minute infeets may be referred to, (1.) Thofe which infeft other animals, for there is no animal we know but has its plague of this kind, as well fin as beafts and birds. (2.) Thofe infefting vegetables, which are as numerous and different as vegetables themfelves. (3.) Thofe found in freh waters, rivers, drains, curs, ditches, and ftanding waters; not a place without fome kind, which there inhabits and breeds; often many various kinds, whofe forms befpeak utter difimilarity. (4.) Thofe of the fea, whofe multitudes are too various to admit our knowledge.

It requires no-inconfiderable Atrength of thought and refiection, no inconfiderable mental exertion, to form any idea of this multiplied clafs of beings : if we advert to thore produced in waters around us, of which, PART VI. No. 3 I. 3 L. though 
though fome kinds feem to be nearly general, yet we find in almoft every piece of water fome peculiar to itfelf; if we eftimate the number of fuch pieces of water, and the kinds appropriate to them in our own country, in Europe, on the globe; if we remark, that in warm climates Nature feems to fport in donation of life, that the tropics prompt and haften generation. after generation (therefore we muft advance on the conception we may have formed of our own fertility), as well in kinds as in fucceffionwhen we have fo done, we fhall fall infinitely below the truth; no eftimate we can poffibly form will in any proportion approach the real fact. There exift creatures infinitely more abundant than we imagine, of kinds infinitely more diverfified than we imagine, of dimenfions infinitely fmaller than we imagine, much as are vaunted the excurfive powers of human imagination - what then fhall we fay to thofe whofe habitation is the mighty deep; who are fhrouded from our infpection amid the obfcurity of the profound abyfs? Their exiftence we cannot doubt, fince we occafionally difcover fome of their fellows, and are not ignorant of others that inhabit the verges of the receptacle of. waters.

What know we of the works of Almighty Power? Infinitely the majority is hid from us; very limited is our knowledge of what we feem to know ; their groffer properties only, or merely their exiftences, are difcerned by our natural fenfes, and little more by all the affiftance of art and reafon. Indeed our fenfes are extremely confined; but we glory that our rational powers have greatly augmented their abilities, have direeted and affifted their refearches, have demonftrated, that what feems utterly incredible may be fact, that what feems contrary to appearances may be juft, that feemingly well grounded principles muft often be admitted with hefitation, or be qualified by numerous exceptions, and that thofe who know moft are but beft inftructed how much remains unknown.

We have furveyed animals whofe bulk is enormous, whofe ftrength is prodigious, whofe voracity is tremendous: fhall we contraft them to thofe whofe fmallnefs efcapes our fight? How utterly diffimilar their dimenfions, and their powers! At that we tremble, at this we fmile; to affault one we conjoin hoftile forces-number and union overcomes might; on the others we trample without regard, and crufh myriad after myriad without reflection: thofe require valt fpaces to afford maintenance; thefe are crowded into one mafs : thofe reign tyrants of the deep or the foreft; thefe feek thelter in the moft minute crevices. Yet, if we compare fuch diftant ranks, we find; that while the enormous cachalot fupports itfelf by devouring thoufands of its prey, fo do thefe minute animacula, ever active, ever 


\section{E E I S IN P A S T E.}

vigilant, to fupply the cravings of appetite. The lion is not more terrific in the foreft than thefe in the pool; nor better provided with arms for affault, or ftrength for conqueft. What then fhall we fay to the Pill inferior creatures, their prey? If to fome a grain of fand be a rock capable of holding thoufands; if a hair be a tube capable of inclofing thoufandswhat are fuch as tremble at their afpect, fhrink from their terrors, dread their approach, and Hy from their devaftations? Atoms of life ! for what are you defigned? what end do you anfwer in the rank of exiftence? Without you were the chain of being imperfect? would there be a void, a chafm, were you' extinct? Could no power replace you but what at firft created you? Muft the fame almighty $\mathrm{fkill}$, the fame omnifcient forecaft, the fame profound contrivance, appointment, an I determination, be exércifed toward you as toward the higher ranks of creatures? Wheré then is great or fmall? where high or low? where important or fubordinate? Were you placed as mazes to perplex mankind, as labyrinths to embarrafs human thought? Yer much as you and your fellows furpafs our comprehenfion, we ourfelves furpafs it more; and when you, with all that furrounds you, the globe you inhabit, every tribe which now occupies it, which creeps or fwims, or runs or flies, when every relation which unites you, every bond that binds you, when all, all fhall terminate and be concluded, we fhall be but beginning our inceffant occupation of afcribing honour to $\mathrm{Him}$, who was, and is, and is to come. 


\section{PRINCIPLES OF VEGETATION.}

rDHE lower we defcend on the fale of life the greater is our embarraffinent, arifing from numbers and varieties of fpecies. If we fourd it ueceffary to content ourfelves with general ideas, and a mere: felection of firh and of infects, ftill greater difficulties prevent our intimate knowledge of vegetables; whofe innumerable kinds, though long the ftudy of naturalifts, are daily proving that many remain hitherto unknown an unnoticed. Nor is this furprifing, when we recollect the different firuations, foils, and expofures which they prefer; the different levels at which they grow; on plains or on mountains, on hills or on alps. A oundant throughout the globe, and every fpot producing fome peculiar to itfelf, unlefs the whole globe were explored fpot by fpot (a hopelefs fuggeftion!) how could all be known? Adapted to extremes of heat and cold, of humidity and drynefs, adapted to every climate, 'to every: region, their ftores are inexhauftible: and however human induftry may have penetrated with affiduous toil, not only among inhabited countries, but inhofpitable wilds, yet, after all endeavours, many kinds will elude refearch, though perhaps native at no great diftance, or perhaps their feafon lately part, or foon to comé; if not actually prefent, but hidden in caverns or in clefts of the earth.

Declining therefore to enter deeply into a fubject which in other hands has furnifhed many a bulky folio, and whofe nomenclature alone, when arranged and abridged with the molt perfevering fkill, forms folid volumes, we fhall felect thofe leading principles, which being common to all, may be brought to the teft of daily experience: for that learning feems molt advantageous, whofe ufefulnefs or application is perpetually recurring; that which is moft fimple, which is ever at hand, and everdelightful, is worthy our attention, and frongly claims our acquaintance. Without depreciating what may poffefs occafional ufefulnefs or pleafure, what may delight or profit on emergency, we thall prefer what may be our conftant companion and our attendant friend.

If pleafure be requefted by mankind, we have already afferted, the pureft pleafure is furnifhed by the tribes of vegetables, and human talents feem peculiarly adapted to their culiure and enjoyment. If profit be requefted, thele are an unfailing fource of profit; they fuftain life, by furnifhing food in various forms and of vairous qualities; they re- 
ftore health and counteract the progrefs of difeafe, if violent, by their activity and briknefs; if latent, by gęntle yet powerful operations : they regale the fenfes by their beauty and colours, by their odour and fragrance, by their relifh and poignancy : they raife the mind to cheerfulnefs by their combination in the flowery parterre; they difpore it to folemnity by the deep umbrage of the majeftic grove. Who feels not his fpirits exhilarated when the bending corn waves in golden ridges, courting the fickle; when the luxuriant vine, wedded to its fturdy elm, hangs in purple feftoons from bough to bough ? The glories of harveft are the true glories of man; the joy of in-gathering his real joy; the fcythe of the mower, not of war, is his trophy; and the blood of the grape, not of fellow men, his delight. $O$ were men but fenfible of real excellence and truly honourable diftinction, they would feek it, not on the enfanguined, but the cultivated plain; not in fpreading deftruction, but in diffuing life through various ranks; they "would beat their fwords into plough-fhares, and their fpears into pruning-hooks," to regulate the luxuriant earth which compofes, lupports, and awaits them.

When formerly confidering vegetables according to their ftation on the fcale of life, we thought ourfelves juftified in afferting, that "where there is growth there is life; that whatever fubject increafes or advances toward maturity, its progrefs is the confequence of a vital principle." Referring to that difcourfe for feveral fu 6 geftions which need not be repeated, we fhall enlarge on the principal idea of the paffage felected, by adverting to the generation, growth, ftructure, and nutrition of vegetables.

We poffefs fome advantages for obtaining a general idea of the generation of vegetables, from having oblerved the various modes adapted to this purpore among animals; and if, in addition to this, we keep in view our principle, that life is moft liberally beftowed as we defcend, we may perhaps juftly expect molt of the animal modes of tranfmiting life thould be found among vegetables, including the idea that fome thould be proper to themfelves. We have feen animals prolong their fpecies by the intercourfe of fexes: this is a very prevailing manner; and in the inftances of fuch as are oviparous, feems greatly coincident with the manners of many vegetables. To this effect we find parts appropriate in general, and thefe parts furnifh a ftriking method (ufually) of claffing plants; though, from the fmalinefs of fome, and the intricate fituations of others, they are not conftantly obvious. Hence we have plants yielding on one tree flowers of both fexes, and in one lower parts of both fexes; of others, each plant is but one fex; and others have no flowers. That the 
the intercourfe of the former fhould be moft frequent and certain feems natural; but the diftances which often intervene between plants of the latter $k$ ind is confiderable, and indeed furnifhes no trifling objection to the fuppofition of their intercourfe. As we have feen fome animals felfimpregnated, uniting in one individual the parts neceffary to this effect, what hould prevent the fame in plants? Again, if what is related of the defcent of impregnation in the inftance of the gnat be true, why may

not this principle alfo obtain among vegetables? So that if a plant be this year impregnated, it thall not need a repetition of this circumftance the next feafon (or next generation): and fince there may be various other departures from what is, notwithftanding, a general rule; and fince indeed among the moft general rules Nature often furprifes us with very extraordinary exceptions, I fee no reafon to deny either the affirmed fexual fyftem of plants, or the force or fact of thole inftances which, in the opinion of many, militate againft it.

Vegetables are capable no doubt of propagation by nips and cuttings, and I thould fuppofe far beyond what is related of any animal whatever, wonderful as are the facts admitted of the polypus: but whether there be any vegetable capable of propagation only by this method is not that I know of affirmed; or whether there be any vegetable entirely precluded from this method : for not only plants may, by trailing; be made to hoot from the knots, \&c. in their ftems, but branches of trees, if judiciouny managed, will become complete trees; not inferior in 'magnitude to their parents; nor are lefs remarkable the fubdivifions of vitality in the fruit of a potato, every sye of which is capable of producing a perfect plant. There is however one remarkable fingularity attending vegetables, in that; as the branches are capable of thus becoming roots, fo the roots are capable of becoming branches. Should we incline to change the fituation of thefe parts of a tree, the undertaking is feafible, and has actually been accomplifhed in fmaller fubjects, by furrounding the branches with earth in a garden-pot; and, when thêy have drawn nutriment from the earth, gradually withdrawing the root from its bed, and accuftoming it to depend for fupply on its former branches; then judiciounly choofing the time for its expolure to the air, and its production of leaves.

Grafting is a kind of planting a branch from one tree in the body of another; to this it unites, and with this it lives and profpers, or withers and derays : but it does not here unite by thooting out roots as it would were it in the rarth, for its nutritive juices are not to feek; the tree fupplies them, partly digefled too, and fic for immediate ufe. This is clearly 


\section{PRINCIPLES OF VEGETATION. 34 I}

the care where trees of a fimilar nature are united, and in thofe where curiofity has combined diffimilar natures, it has been partly the cafe; the nutriment has been in a degree forwarded toward fitnefs, and the graft has completed its deficiency. That juices thus twice frained, as it were, firft by the roots of the tree, then by the pores of the graft, fhould gain or lofe fomewhat alterative to the flavour of the fruit yielded by the graft, is not wonderful; that it thould be enriched or mellowed, thould be acidulated or foftened, feems natural, and to depend on the qualities of the tree from which it now derives its nourifhment.

But as the general propagation of vegetables is rather by feeds than by. any other mode, to them we fhall now turn our attention.

SEEDS of plants are of various figures and fizes. Moft are divided into. two lobes; though fome, as thofe of the crefs-kind, have fix; and others, as the grains of corn, are entire.

But as the effential properties of all feeds are the fame, when confidered with regard to the principles of vegetation, our defcription thall be limited to one, the great garden-bean; becaufe, after it begins to vegetate, its parts are more confpicuous than many others, and confequently better calculated for inveftigation.

This feed is covered with two coats or membranes; the outer extremely thin and full of pores, but may be eafily feparated from the inner one (which is much thicker), after the bean has been boiled, or lain a few days in the foil. At the thick end of the bean is a fmall hole vifible to the naked eye, immediately over the radicle or future root, that it may have a free paffage into the foil. When thefe coats are taken off, the body of the feed appears, which is divided in to two fmooth portions or lobes. The fmoothners of the lobes is owing to a thin film or cuticle with which they are covered.

At the bafis of the bean is placed the radicle or future root, whore trunk, juft as it enters into the body of the feed, divides into two capital branches, one to each lobe, and fends off fmaller ones in all directions through the whole fubftance of the lobes : thefe become fo extremely minute toward the edges of the lobes, that they require the fineft glaffes to render them vifible. To this Grew and Malpighius have given the name of feminal root; becaufe, by means of it, the radicle and plume, before they are expanded, derive their principal nourifhment.

The plume, bud, or germ, is enclofed in two fmall correfponding cavities in each lobe. Its colour and confiftence is much the fame, with thofe of the radicle, of which it is only a continuation; buthaving a quite PART VI. No. 3 I. 
contrary direction: for the radicle defcends into the earth; and divides into a great number of fmaller branches or filaments; but the plume afcends into the open air, and unfolds itfelf into ftem, branches, leaves, flowers, fruit, $E^{2} c$. The plume in corn thoots from the fmaller end of the grain.

The fubftance, or parenchymatous part of the lobes is not a mere concreted juice, but is curiouny organized, and confifts of a valt number of fmall bladders refembling thofe in the pith of trees.

When the feed is fown, the moifture is firft abforbed by the outer coats, which are every where furnifhed with fap and air.veffels; from thefe it is conveyed to the cuticle; from the cuticle it proceeds to the pulpy part of the lobes, where it is taken up by the mouths of the fmall branches of the feminal root, and paffes from one branch to another into the main trunk, which communicates both with the plume and radicle: then this vegetable food runs in two oppofite directions; part afcending into the plume, promotes its growth and expanfion; part defcending into the radicle, nourifhes the root and its filaments. Thus a plant is really poffeffed of two roots, both contained in the feed. The plume and radicle, when the feed is firft depofited in the earth, derive their nourihment from the feminal root; afterwards, when the radicle begins to thoot out its filaments, and to abforb fome moifture, not, however, in a fufficient quantity to fupply the exigencies of the plume, the two lobes, or main body of the feed, rife with the plume, affume the appearance of two leaves, refembling the lobes of the feed in fize and hape, but having no refemblance to thofe of the plume, for which reafon they have got the name of difimilar leaves.

Thefe diffimilar leaves defend the young plume from the injuries of the weather; and at the fame time, by abforbing dew, air, \&cc. affitt the tender radicle in nourifhing the plume, with which they haveftill a connection by means of the feminal root. But, when the radicle or fecond root has defcended deep enough into the earth, and has acquired a fufficient number of filaments or branches for abforbing as much aliment as is proper for the growth of the plume, then the feminal or diffimilar leaves, their utility being entirely fuperfeded, begin to decay and fall off.

Thus we fee, that as the egg contained not merely the foetus of an ani2 mal, but a portion of nourifhment fuitable to its powers, whereby it was fuftained, and capable of fupporting life a confiderable time; fo the feed contairis a portion of matter fitted to nourih the nafcent root, capable of beconing part of it, and of fupporting it till its own powers were competent to 
that purpofe. From this period the plant is to expect a fupply from the root, and to derive nourifhment by means of its extenfive ramifications, and their abforbent properties.

We proceed now to netice the ftructure of plants: and firft of the root:

In examining the Roor of plants, the firft thing that prefents itfelf is the $\mathrm{fkin}$, which is of various colours in different plants. Every root, after it has arrived at a certain age, has a double fkin. The firt is coeval with the other parts, and exitts in the feed; afterwards a ring fent off from the bark furms a fecond fkin; $e_{.} g$. in the root of the dandelion, towards the latter end of May, the original or outer fkin appears fhrivelled, and is eafily feparated from the new one, which is frefher, and adheres more firmly to the bark. Jereanial plants are fupplied with a new nkin every year; the outer one falls off ir the autumn or winter, and a new one is formed from the bark in the fucceeding fpring. The $\mathrm{kin}$ has numerous cells or veffels, and is a continuation of the parenchymatous part of the radicle. However, it does not confift folely of parenchyma, for the microfcope fhews that there are many tubular ligneous veffels interfperfed through it.

When the fkin is removed, the true cortical fubftance or bark appears, which is alfo a continuation of the parenchymatous part of the radicle, but greatly augmented. The bark is of very different fizes. In moft trees it is exceedingly thin in proportion to the wood and pith. 'On the other hand, in carrots, it is almoft one half of the femidiameter of the root; and in dandelion it is nearly twice as thick as the woody part.

The BARK is compoled of two fubftances, the parenchyma, or pulp, which is the principal part, and a few woody fibres. The parenchyma is exceedingly porous, and has great refemblance to a fpunge; for it thrivels confiderably when dried; and dilates to its former dimenfions wher infufed in water. Thefe pores or veffels are not pervious fo as to communicate with each other, but confift of diftinct little cells or bladders, fcarcely vifible without the affiftance of the microfcope. In all roots, thefe cells are conftantly filled with a thin watery liquor. They are generally of a fpherical figure, though in fome roots, as the buglofs and dandelion, they are oblong. In many roots, as the horfe-radifh, peony, afparagus, potato, \&c. the parenchyma is of one uniform ftructure; but in others it is more diverfified, and puts on the thape of rays running from the centre-towards the circumference of the bark. Thefe rays fometimes run quite through the bark, as in lovage; and fometimes advance toward the middle of it, as in melilor and moft of the leguminous 
and umbelliferous plants. Thefe rays generally ftand at an equal diftance from each other in the fame plant; but the diftance varies greatly in different plants. Neither are they of equal fizes : in carrot they are exceedingly fmall and fcarcely difcernible; in melilot and cherval they are thicker. They are likewife more numerous in fome plants than in others. Sometimes they are of the fame thicknefs from one edge of the bark to the other; and fome grow wider as they approach toward the ikin. The veffels with which thefe rays are amply furnimed are fuppofed to be air-veffels, becaufe they are always found to be dry, and not fo tranfparent as the veffels which evidently contain the fap.

In all roots there are ligneous veffels difperfed in different proportions through the parenchyma of the bark. Thefe run longitudinally through the bark in the form of fmall threads, tubular, as is evident from the rifing of the fap in them when a root is cut trafnverfely. Thefe ligneous fap-veffels do not run in direct lines through the bark, but, at fmall diftances, incline towards one another in fuch a manner, that they appear to the naked eye to be inofculated; but the microfcope difcovers them to be only contiguous, and braced together by the parenchyma. Thefe braces are very various both in fize and number in different roots; but in all plants they are moft numerous toward the inner edge of the bark. Neither are thefe veffels fingle tubes, but, like the nerves in animals, are bundles of twenty or:thirty fmall contiguous cylindrical tubes, which uniformly run from the extremity of the root, without fending off any branches, or fuffering any change in their fize or thape.

In fome roots, as parfnips, efpecially in the ring next the inner extremity of the bark, thefe veffels contain a kind of lymph, which is fweeter than the fap contained in the bladders of the parenchyma. From this circumitance they have got the name of lymph-ducts.

Thefe lymph-ducts fometimes yield a mucilaginous lymph, as in the comphrey; and fometimes a white milky glutinous lymph, as in the angelica, fonchus, burdock, fcorzonera, dandelion, \&c. The lymph-ducts are fuppofed to be the veffels from which the gums and balfams are fecreted. The lymph of fennel, when expofed to the air, turns into a clear tranfparent balfam; and that of the fcorzonera, dandelion, \&xc. condenfes into a gum.

The fituation of the veffels is various. In fome plants they ftand in a ring or circle at the inner edge of the bark, as in afparagus; in others they appear in lines or rays, as in borage; in the parfnip, and feveral other 
other plants, they are moft confpicuous toward the outer edge of the bark; and in the dandelion they are difpofed in the form of concentric circles.

The WoOD of roots is that part which appears after the bark is taken off, and is firmer and lefs porous than the bark or pith. It confits of two diftinet fubftances; (1) the pulpy, or parenchymatous; (2) the ligneous. The wood is connected to the bark by large portions of the bark inferted into it, moltly'in the form of rays, tending to the centre of the pith, eafily difcernible by the eye in a tranfverfe fection of moft roors. Thefe infertions, like the bark, confift of many veffels, moftly round or oval.

The ligneous veffels are generally difpofed in collateral rows running longitudinally through the root. Some of thefe contain air, others fap. The air-veffels are diftinguifhed by being whiter.

The PIтH is the centrical part of the root. Some roots have no pith, as the ftramonium, nicotiana, \&c. ; others have little or none at the extrenities of the roots, but a confiderable quantity near the top. The pith, like every other part of a plant, is derived from the feed: but in fome it is more immediately derived from the bark; for the infertions of the bark running in betwixt the rays of the wood, meet in the centre, and conftiture the pith. It is owing to this circumftance, that among roots which have no pith in their lower parts, they are amply provided with it towards the top, as in columbine, lovage, \&c.

The bladders of the pith are of very different fizes, and generally of a circular figure. Their pofjtion is more uniform than in the bark. Their fides are not mere films, but a compofition of fmall fibres or threads, which gives the pith, when viewed with a microfcope, the appearance of 2 piece of fine gauze or net-work.

We fhall conclude the defcription of roots with obferving, that their whole fubftance is nothing but a congeries of tubes and fibres, adapted by nature for the abforption of nourifhment, and of courfe the extenfion and augmentation of their parts.

In defcribing the TRUNKS of plants, it is neceffary to premife, that whatever is faid with regard to them applies equally to the branches.

The trunk, like the root, confifts of three parts; the bark, wood, and pith. Thefe, though fubltantially the fame in the trunk as in the root, are often very different in texture and appearance.

1. The $\mathrm{kin}$ of the bark is compoled of very minute bladders, interfperfed wish longitudinal woody fibres, as in the nettle, thiftle, and mort herbs. 
herbs. The outfide of the $\mathrm{kin}$ is vifibly porous in fome plants, particularly the cane.

The principal body of the bark is compored of pulp or parenchyma, and innumerable veffels much larger than thofe of the $\mathrm{fkin}$. The texture of the pulpy part, though the fame fubftance with the parenchyma in roots, feldom appears in the form of rays running towards the pith; and when thefe rays do appear, they do not extend above half way to the circumference. The veffels of the bark are very differently fituated, and deftined for various purpofes in different plants. For example, in the bark of the pine, the inmoft are lymph-ducts and exceedingly fmall; the outmoft are gum or refiniferous veffels, deftined for the fecretion of turpentine; and are' fo large as to be diftinctly vifible to the naked eye.

2. The WOOD lies betwixt the bark and pith, and confints of two parts; (I) parenchymatous, (2) ligneous. In all trees, the parenchymatous part of the wood; though much diverfified as to fize and confiftence, is uniformly difpofed in diametrical ray\$, or infertions running betwixt fimilar rays of the ligneous part.

The true wood is nothing but a congeries of old dried lymph-ducts. Between the bark and the wood a new ring of thefe is formed every year, which gradually lofes its foftnefs as the cold feafon approaches, and, towards the middle of winter, is condenfed into a folid ring of wood. Thefe annual rings, which are diftinctly vifible in moft trees when cut through, ferve as natural marks to diftinguifh their age. The rings of one year are fometimes larger, fometimes lefs, than thofe of another, probably owing to the favourablenets or unfavourablenefs of the feafon.

3. The Pith, though of a different texture, is exactly of the fame fubftance with the parenchyma of the bark, and the infertions of the wood. The quantity of pith is various in different plants. Inftead of being increafed every year like the wood, it is annually diminifhed, its veffels drying up and affuming the appearance and ftructure of wood; infomuch that in old trees there is fcarce fuch a thing as pith to be difcerned.

A ring of fap-veffels are ufually placed at the outer edge of the pith, next the wood. In the pine, fig, and walnut, they are very large. The parenchyma of the pith is compofed of fmall cells or bladders, of the fame kind with thofe of the bark, only of a larger fize. The general tigure of thefe bladders is circular; though in fome plants, as the thifle, and borage, they are angular. Though the pith is originally one connected chain of bladders; yet, as the plant grows old, they thrivel, and 
open in different directions. In the walnut, after a certain age, it appears in the form of a tegular tranlverle hollow divifion. In fome plants it is altogether wanting; while in others, as the fonchus, nettle, \&xc. there is only a tranlverfe partition of it at every joint. Many other varieties might be mentioned.

The leaves of plants confift of the fame fubftance, with the trunk. They are full of nerves or woody portions, running in all directions, and branching out into innumerable fmall threads (interwoven with the parenchyma) like fine lace or gauze.

The nin of the leaf; like that of an animal, is full of pores, which both ferve for perf́piration, and for the atorption of dews, air, \& $x$. The fe pores, or orifices, differ both in thape and magnitude in different plants, which is the caurfe of that variety of texture or grain peculiar to every plant.

The pulpy or parenchymatous part confifts of very minute fibres, wound up into fmall cells or bladders. There cells are of various fizes in the fance teaf.

Ali leaves, of whatever figure, have a marginal fibre, by which all the relt are bounded. The particular thape of this fibre decermines the figure of the leaf.

The veffels of leaves have the appearance of inofculating; but, when examined by the microrcope, they are found only to be interwoven, or laid along each other.

What is called air-veffels, or thofe which carry no fap, are vifible even to the naked eye in fome leaves. When a leaf is nowly broke, they, appear like fmall woolly fibres, connected to both ends of the broken piece.

The texture, velfels, \&ce of flowers are pretty fimilar to thofe of the leaf.

Every Alwer is perfectly formed many months before it appears outwardly; that is, the flowers which appear this year are not, properly fpeaking, fowers of this year, but of the laft. For example, mezereon generally flowers in January; but thele liowers were completely formed in the month of Auguft preceding. By feparating the coats of a tuliproot about the beginning of September, we find that the two innermoft form a kind of cell, in the centre of which ftands the young flower, which is not to make its appearance till the following April or May. In defcribing the tructure of fruits, a few examples thall be taken from fuch as are moft generally known.
PART VI. No. 32 .
$3 \mathrm{~N}$
A PEAr, 
A PEAR, befides the $\mathrm{kin}$, which is a production of the $\mathrm{kin}$ of the bark, confifts of a double parenchyma or pulp, fap, nnd air-veffels, calculary and acetary.

The outer parenchyma is the fame fubitance continued from the bark, only its bladders are larger and more fucculent.

It is every where interfperfed with fmall globules or grains and the badders refpect thefe grains as a kind of centres, every grain being the centre of a number of bladders." The fap and air-veffels in this pulp are extremely friall.

Next the core is the inner pulp or parenchyma, which confift of bladders of the fame kind with the outer, only larger and more oblong, cors refponding to thofe of the pulp, from which it feems to be derived. This inner pulp is much fourer than the other, and has none of the fmall grains interfperfed through it, and hence it has got the name of acetary.

Between the acetary and outer pulp the globules or grains begin to grow larger, and gradually unite into a hard fony body, efpecially towards the corculum, or ftool of the fruit; and from this circumptance it has been called the calculary.

Thefe grains are not derived from any of the organical parts of the tree, but feem rather to be a kind of concretions precipitated from the fap, fimilar to the precipitations from wine, urine, and other liquors.

The core is a roundin cavity in the centre of the pear, 'lined with a hard woody membrane, in which the feed is inclofed. At the bottom of the core there is a fmall duct or canal, which runs up to the top of the pear; this canal allows the air to get into the core for the purpofe of drying and ripening the feeds.

In a Lemon, the parenchyma appears in three different forms. The parenchyma of the rind is of a coarte texture, compofed of thick fibres, woven into large bladders. Thiofe neareft the furface contain the effential oil of the fruit, which burfts into a flame when the fkin is fqueezed over a candle. From this outmoft parenchyma nine or ten infertions or lamellæ are produced, which run between as inany portions of the pulp, and unite into one body in the centre of the fruit, which correfponds to the pith in trunk or roots. At the bottom and top of the Iemon, this pith evidently joins with the rind, without the intervention of any lamella. This circumftance thews that the pith and bark are accually connected in the trunk and roots of plants, though it is difficult to demonftrate the connection, on account of the clofenefs of their texture, and the minutenels of their fibres. Many veffels are differfed through.

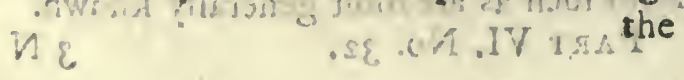


the whole of this parenchyma ; but the largeft ones ftand on the inner edge of the rind, and the outer edge of the pith, jult at the two extremities of each lamellæ.

The fecond kind of parenchyma is placed between the rind and the pith, is divided into diftinct bodies by the lamella; and each of thele bodies forms a large bag.

Thefe bags contain a third parenchyma, which is a clufter of fmaller bags, diftinct and unconneeted with each other, having a fmall ftalk by which they are fixed to the large bag. Within each of thefe finall bags are many hundreds of bladders, compofed of extremely minute fibres. Thefe bladders contain the acid juice of the lemon.

The veffels in the roots of plants abforb moifture from the earth, and convey it to the trunk, branches, leaves, \&ic. This moifture, when it firt enters the root, is crude; but as it alcends into the other parts of the plant, it undergoes feveral changes, by means of the different configurations of the veffels peculiar to each part. Thus the leaves, flowers, fruit, and feed, have all fomething peculiar in the ftructure and arrangement of their veffels, which produces confiderable changes in the nature of the fap. It is not known how thefe changes are produced : but how the ftomachs of animals make chyle from animal and vegetable fubftances, or how urine, faliva, bile, \&c. is fecireted from the common mafs of blood, is as little known. The fap likewife moves in a lateral or horizontal direction.

Philofophers were greatly divided about the circulation of the fap. Some contended that it returns to the root betwixt the bark and wood. But Hales, who has made many accurate experiments on the fubject, has Thown, that it does not circulate, but afcends and defcends in the fame veffels; that it alcends in hot weather, and defcends in cold, like the fpirits in a thermometer.

Vegetables begin to abforb fap about the beginning of fpring, and foon after hoot out their buds, leaves, and flowers.

When plants are in a ftate of vegetation, efpecially in hot weather, there is a great deal of fuperfluous fap abforbed; but the fuperfluity is carried off by tranfpiracion. Every part of a plant tranfpires, but the greateft quantity paffes by the leaves.

Some have affigned the tranfpiration of plants as the caufe of the motion of the fap. It is undoubtedly one caufe of this motion; becaufe, if the tranfpiration be ftopped, at a time when all the veffels are full, the motion of the fap muft ftop of courfe. But then there is a previous and 
principal caufe, viz. that power in the veffels, whatever it is, that firft puts the fap in motion before tranfpiration has commenced.

Heat, moifture, and air, are the three chief circumitances that promote the afcent of the fap. Hence nothing is more favourable to vegetation than warm weather, accompanied with rain: on the other hand, cold dry weather is its greateft enemy. In a wet cold feafon every thing rots; and in hot dry weather every thing is parched. But the circumftances molt favourable to vegetation are cloudy hot weather, inclinable to thunder, fucceeded by plentiful rains.

It would appear very improbable, that the fame matter could nourif fuch a variety of plants, differing fo effentially in fmell, tafte, figure, \&c:. Much, however, may depend on the internal ftructure and arrangement of the veffels. If the veffels in any plant be uncommonly frnall, parts will be rejected by that plant which would be abforbed by one whofe veffels are larger. Nay, changes may be made in the crude homogeneous nourifhment, by a fmall difference in the figure or action of the veffels.

One plant will ftarve another by robbing it of its nourifhment, either by extending its roots, and requiring a greater quantity of nourifhment, or by abforbing the peculiar food which is neceffary for the growth of the other plant.

That a poifonous plant and its antidote will grow in the fame foil, may be owing either to thefe plants imbibing different juices from the earth, or to peculiarities in the ftructure and action of their veffels.

A ftalk of a lemon, grafted on a branch of an orange-tree, grew, ripened its fruit, and preferved the figure and all the other qualities belonging to a lemon. This plainly indicates, that the organization of the lemon had given a different modification to the juices of the orange, through the intervention of which it received its nourihment.

It is alfo certain, that the different parts of the fame plant have frequently various fmells, taftes, \&c. although the nourifhment derived from the root mult be the fame. This is an evidence, that the different ftructure of parts in the fame plants is capable of producing very fenlible changes in the nature and quality of the fap.

Repeated experiments thow, that many plants of very oppofite qualities, and even trees, have been nourinhed and brought to maturity by water alone.

The roots of plants are fitted to abforb every fluid that comes within their reach, They have been found by experiment to imbibe fluids 


\section{PRINCIPLES OF OVEGETATION. BI}

fiuids that actually poifon them. From this circumftance it may be fairly concluded, that they have not, like animals, the fagacity of choofing the food that is moft proper for-nourifhing them, and rejecting that which is either noxious or lefs nourifhing.

6in That the earth may fupply a variety of juices is undeniable; that a platit may have pores too narrow to admit fome is alfo undeniable: but it feems to me that fomewhat alfo is to be attributed to that kind of juice to which the plant has been accuftomed; for we know that if a number of thorted threads be hung in a bafon of oil, fo that they abforb the oil, and it run through them, they will not in like manner imbibe water ; the oif they contain forbids it; if they are fqueezed never fo dry, fo that apparently the oil were gone from them, yet what little remains, will unfit thofe threads for the ablorption of water : the fame occurs if they had been' iniblied wich water, they will refúfe to tranfmit oil. May it not then te, that one effect of the pulpy part of the feed has been to accuftom the fibres of the feminal roat to fuch a juice as fuits its nature? or have not thofe fibres drawn from (perhaps through) that pulp a juice tinged or contaminated with its own properties, and thereby partly, concocted for the aliment of the plant? to which being habituated and thoroughly. drenche ${ }^{2}$ in it, it ever after admits paffage to thofe only which are of a fimilar nature. Thus a poifonous feed accuftoms its offspring-fibres to a poilonous juice, and perpetuates their properties. In an earth which does not furnifh fuch a juice; the plant will not thrive, if it will live; which perhaps it may, by affimilating fuch innocent juices as it procures, fo far as it can, to its own nature, which yet may not be far enough to perfectits properties: whence that may be deadly in one foil which in another is only noxious, or that noxious in one which in another is only Infipid; and with this feems to agree the analogy of moft vegetable poifons, which often by tranfplantation lo their moft lively properties; and the variation of plants, corn, \&c. Which in one foil fourith, perhaps improve, in another degeneraie; this caufe then traces their properties to their origin, and thews the nature impreffed upon them, which probably is preferved by a greater or lefs number of each plant refpectively always occupying a portion of earth where it meets with juices adapted to its maintenance in fúll vigour. It is natural to fuppofe that after havirg paffed through fo great a number of canals and paffages between the root and the branches (and perhaps acquiring a tinge from many ing its progrefs), it thould be highly impregnated ere it arrive at the fruit? where, ahd épecially in the feeds of that fruit, it dhould undergo, the s.:.0? 
Jaft tage of exaltation, and be ripened into qualities perfectly correfponding to thiofe of the tree.

That plants partake of the nature of the foil whereon they grow is notorous, and this in no trifling degree: plants which in a free foil haveno nitre in them, yet yield nitre when they grow on a nitrous foil, as is often experienced in the nitre-works if France.

Though 1 have faid plants may live by affimilating fuch juices as they can procure, yet I apprehend if there be an abfolute deartlof fuch as are proper to them, though there be plenty of others in the foot where they grow, they will pine, languilh, and die. Hence water plants cannot fupport a dry foll, and heath plants are rotted by humidity. Nevertheles it is afferted, that as the defert plains of Africa, where, a parched and fandy foil prohibits regetation, yiefd'only moffes and lichens, to the higheft Alpine rgholts, and the moft rigorous northern climates, yield only moffes and qichens alfo: Strange, that the fame plants fould fupport extremes of heat and cold' yet tefure to hourin in temperate climates and richerifoils?

I have heretofore confidered irritability as an indefinitely lower degree of fenfibility ; for $\mathrm{I}$ confefs $\mathrm{I}$ am unable to draw any line whereat to diftinguifh thefe principles. ? The irritability of plants is a curious fubject. but not yet entirely elucidated. It is not always alike, but capable of increafe and decreafe ; fajd to be greateft in the morning, less at noon, fili lefs in the evening; greateft in fpring, Jefs in fummer, ftill less in autumn: "whether it be recruited by winter torpidity, therefore molt abundant in fprifig, or by nightly repole, therefore moft abundant in the mornitg; or whether it may not depend on the different itates of the atmophere, which in fpring and morning is humid and cool, is fub. mitted. That humidity is grateful to plants is clear; that coolnefs conftricts their fibres, as heat renders them flaccid, loofe, and therefore probably inert, by reafon of a fmaller degree of tenfion, is allo clear. Whether this latter caufe may not influence thofe plants which apparently follow the fun has been doubfedi: for ifthofe parts of the item whereon his rays fall moft immediately are thereby rendered weaker than thole not expored to his' ray's, doubtlefs they will give way, and the flower will bend. to that fide. If this be granted, then, that coolnels fhould coptriet the fibres of plants, that conftiction thould act principally on thole parts which had been expanded, 2. . the fowers, is natiral. That coolness obtains before rain, and in the evening, is certain; and on this principle, the clofure of certain plants and flowers is thus accounted for: but as that 
fome are opening and clofing at all times (infomuch that Linnaus, by obferving their ftate, informs us iwe may know the hour of the day, and hence calls them Flara's Watcb), and as others open only during night, this caule feems in adequate to fo great variety of effects. What is termed the fleep of plants, is fuppofed to proceed from exhauftion of irritability, and is molt obfervable in young plants, and in fpring.

The Mimofa, or Senfitive Plant (of which Linnæus reckons forty-fix fpecies) is the great inltance of irritability; as, befide contracting its leaves in the evening, it may be made to contract them at any time, by the touch of the hand, the fumes of volatile alkali, the electric fpark, mufk, or opium : and this contraction is fo powerful, that, on its taking place, the leaves may be eafier broken than re-expanded; but the plant will regain its natural ftate after an interval of from ten minutes to half an hour. Immerfion in water does not produce thefe effects. Their gerieral progrefs is according to the force or quantum of ftimulus engaged on the plant, affecting firt one leaf, then its fellow or pair on the ftalk, then the pedicle or foot-ftalk, moving upwards, then all the leaves on that branch, then the branch to the very ftem of the plant. A fhaking motion affects the whole plant; but it is pofible to affect the branches and not the leaves.

That plants are greatly affeeted by the impulfe of light, appears not only from what we have faid when treating of light, but from the inftance of this very plant. A fenfitive plant, placed in a dark cave, was twenty-four hours before it expanded, and then very partially; fuffered no change at night or morning; but being placed in the open air, recovered its natural ftate and irritability. A nother, kept in a dark room during fome hours after day.break, did not expand; but, reftored to the light, expanded without delay.

According to the ftructure of plants they fhew their irritability in various manners : the Dionea Muscipula, or Venus's Ay-trap, is fo called, becaufe, if an infect enter iss flower, defigning to tafte its fweets, the leaves clofe upon him, and hold him beyond his powers to extricate himfelf.

Parafitical plants, which grow on other trees, as the miffeltoe, or which climb on other trees, as the ivy, and numberlefs others, are a curious clafs of plants; many of which never drew nourihment from morher earth, but from their fupporting tree, which they often ftrargle and defroy. In hot countries thefe are often fo noxiouny abundant, no art can exterminate them.

$$
\text { PART'VI. No. } 32 \text {. }
$$


Vegetables are greatly expofed to the depredations of infects : almoft every plant has numbers attached to itfelf, and many fuffer by feveral in fuccefion; being while juft fprouting the favourite food of fome, when further advanced of others, and when mature of others. To this caufe has been attributed the blight of corn.

Vegetables, when decayed, compofe that kind of earth or mould, which of all earths is beft adapted to nourin vegetable life, and indeed without which no fertility can be expected. Hence, if in a fandy foil that plant which can fupport fuch a foil be cultivated, and left to rot, then another crop of the fame fucceed, and be ploughed in, by degrees the fandy foil will become mixed with vegetable earth, and after a while will be capable of nourihing whatever plants are committed to its bofom.

Vegetation is no lefs ftrong in the water than on land; in the ocean than on the plains : nor is it confined to plants, but produces large trees of folid wood. Of thefe we mutt expect to continue ignorant, except as accident difclofes them. Can thofe which grow in perpetual darknels be ftimulated by light? Have thofe variations of irritability which dwell in a medium invariably cold and denfe, often perhaps ftagnant and motionlefs?

Thus we have endeavoured to illuftrate the generation, growth, ftruc. ture, and nutrition of vegetables : their numbers forbid extending our difquifitions, and their properties are various as their numbers; however, we hall, juft obferve, that fome are poifonous, and in certain inftances fo ftrongly as to poifon the air around them. 'We have an extraordinary relation of a great tree of this nature in Japan, to which only condemned criminals are fent to gather its gum : they approach the tree to windward, yet few return to claim exemption from further punithment. Another and a well authenticated inftance is the manchineel tree, undei: whofe branches fhould an unwary traveller take refuge, the drops of rain falling from them would at leaft corrode and blifter his fikin, if he efcaped fo. Our own yew has fimilar, though very greatly inferior, reputation among fome. Nor hould opium be forgotten, which is yielded by the white poppy, cultivated for that purpofe in the Eaft: in finall quantities this promotes neep; in large quantities fatal neep. By habit the Eaftern people can eat it in lumps, and drinking a glafs of cold water after it, experience merely intoxication; yet gradually it fhortens their days, produces decrepitude, and undermines the natural powers. The number of plants having poifonous qualicies is confiderable; and 
much difcretion, or rather knowledge, is requifite to diftinguifh fome of them from falutary herbs. Many of them are berry-bearing, and their berries delude the eyes of children not without rifque.

Mankind, expofed to inclement feafons, will ever be beholden to vegetables for Thelter : hence our obligations to timber trees of all forts, from the ftately oak of which hips are conitrueted, to the Aender ofier which yields only wattles: this is too obvious to require enlargement; and even fuppofing they furnih no edible fruit for our fupport, or that of animals for our ufe. But by fruit-bearing trees we are doubly accommodated, not only with Thelter but with food, not only with wood but with provifion: hence the apple, pear, plum, peach, cherry, and many others, are highly valuable; they furnith our tables with a deffert, and delight our palates with their vivacity and selith. The vine, indeed, boafts no wood for beams, or for furniture, but its fruit is noble, and, temperately ufed, invaluable. All nations have had recourfe for cheering drinks to infufions, or to the fap, of vegetables. I fhall not enlarge on the variety of fruits; on their fucceffions, each in its feafon; on their qualities of prefervation, and indeed improvement by keeping; nor on their profit, in that what is not fit for our ufe has many animals awaiting its donation, to whom it is grateful though imperfect.

Grain is a part of our provifion, on which we depend with the utmolt affurance; whofe abfence nothing can fupply; whofe lofs nothing can compenfate. Happy for us not only that it is fertile and productive, but that, after many years keeping, its nutritive qualities are not impaired.

Garden vegetables, preferve us in health : they unite delicacy of tafte to falubrity; they offer us choice either of roots or plants, either of pulfe or herbs; fome for prefent ufe, others for ftores. If we quit the kitchen garden for the parterre, we are enlivened at the fight of blooming flowers, and regaled by their odours: fometimes they yield us ornament, fometimes perfume, fometimes a remedy, always a moral. Some we fubmit to the Itill, of fome we extract the effences, of fome we preferve the forms, and others, which we cannot preferve, we imitate. Such delight have we ever taken in flowers!

For perfonal accommodation we praife the flax, whofe beaten fibres yield elegance and health: nor let us forget the hemp, whofe hardy ftalks furnifh our thips with wings. The moft immenfe fail is but an union of hempen threads; the ftrongeft cable is but a combination of twifts, weak afunder, but their united ftrength refifts the rolling waves: 


\section{6

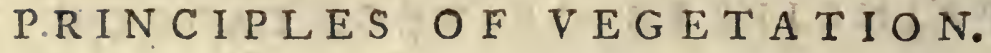

enfuring fecurity to the adventurous mariner, amid the fwellings of the mighty deep.

It is evident; that to underttand, though but remotely, the relations of thefe fo different fubjects, difcrimination is both defirable and neceffary: fince they are not alike, we may juftly feparate the different, and combine the fimilar; to accomplifh which purpofe is the defign of botanical fyltems.

Smell and talte give us fome intimation of the nature and qualities of plants. An agreeable tafte or fmell is feldom accompanied with noxious qualizies; on the other hand, when thefe fenfes are difagreeably affected, the qualities are generally moie or lefs noxious, being either purgative, emetic, or poifonous. Plants that have a fweet tafte are generally nutritive; thofe that have a falt tafte are warm and fimulant. Plants of an acrid tafte are corrofive; but, when deprived of their acrimony by drying, fome of them become fit for food. Bitter plants are alkaline, ftomachic, and fometimes of a fufpicious nature. Acid plants are cooling, and, allay thirft; but thofe of an auftere tafte are aftringent.

The colour and afpect of plants throw fome light upon their nature. Flowers or fruit of a red colour are generally acid. Yellow flowers indicate a bitter tafte. 'Plants that have green flowers are crude; thofe of a pale colour are commonly infipid; thofe of a white colour are generally fweet; and thofe whofe flowers have a gloomy and difmal afpect, are moftly poifonous.

In order to bring the numerous tribes of vegetables under certain claffes or denominations, various methods have been adopted by different authors. Some have claffed them by the figure of their roots; fome by the caulis or ftems; fome by the leaves. Linnæus has preferred the parts of fructification, becaufe thefe are not only. the moft effential, but likewife the molt univerfal.

This method of clafing is preferable to any that has been propofed, on many accounts. It is found by experience, that plants which are diftinguifhed by the fame characters in the flower and fruit, have the fame qualities, though not always in an equal degree as to ftrength or weaknefs; fo that, upon infpection of the flower and fruit, a botanift can determine à priori the effects that will refult from the plant when'taken into the ftomach.

This methad of reducing plants to claffes, genera, and fpecies, is founded upon the fuppofition that vegetables propagate their fpecies in a manner fimilar to that of animals. Linnæus endeavours to fupport this hypothefis 


\section{PRINCIPLES OF VEGETATION. 357}

hypothefis by the many analogies that fublift between plants and animals. From this circumftance Linnaus's fyttem of botany has got the name of the fexual fyftems. The names of his claffes, orders, \&c, are all derived from this theory. He calls the ftamina of fowers the males; the piftils fenales. Plants whofe flowers contain both male and female parts, are faid to be bermapbrodites, \&c. His claffes, orders, and genera, are all derived from the number, fituation, proportion, and other circumftances attending thofe parts.

Twenty-four claffes comprehend every known genus and fpecies. It is an eafy matter to clafs a plant belonging to any of the firft eleven claffes, as they all depend on the number of ftamina or male parts, without regard to any other circumftance. The I 2 th clafs requires more attention. When the ftamina amount to above 20, particular regard muft be had to the infertion of the ftamina. If they are inferted into the calix or cup, the plant belongs to the icofandria clafs, if to the receptacle or balis of the Bower, it belongs tothe polyandria.

The $4^{\text {th }}$ clafs is likewire in danger of being confounded with the $4^{\text {th. }}$. In the $4 \mathrm{th}$, the number of ftamina is the fame with that of the 14 th. But, in the $14^{\text {th }}$, two of the ftamina are uniformly much fhorter than the other two; at the fame time each particular ftamen belonging to the different pairs ftands directly oppofite to one another.

The ${ }^{1} 5^{\text {th }}$ clats may be miftaken for the 6th, as they confift of the fame number of ftamina. But in the $15^{t h}$, four of the ftamina are uniformly longer ihan the other two; and thefe two are always oppofite to each other. 
$\cong$

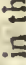

$\stackrel{2}{3}$

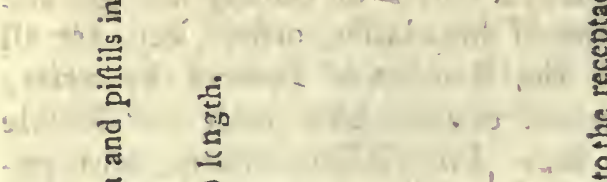

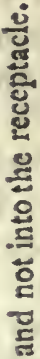

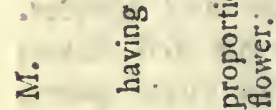

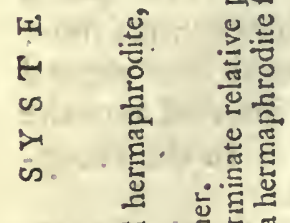

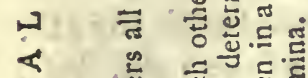

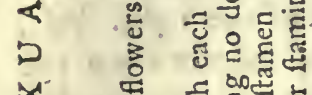

শั

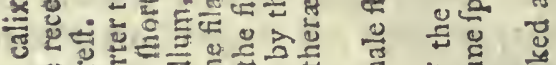

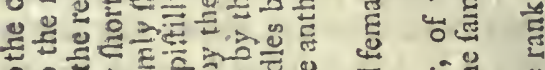
욜

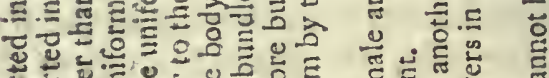

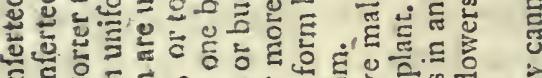
ఏ.

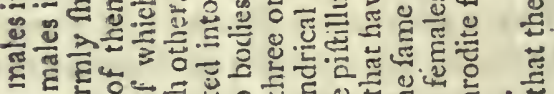
位: * प

म $\quad \vec{z}$ च

w $H$ 己

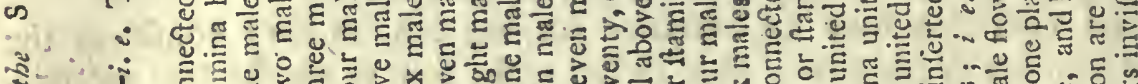

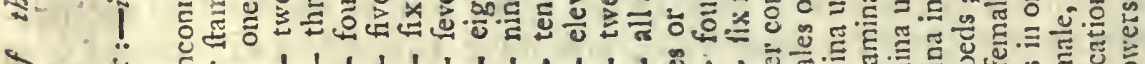
จ $\quad$ 节 出

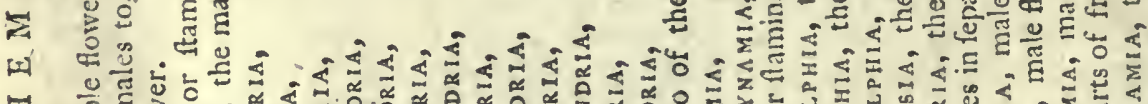

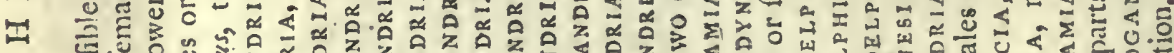

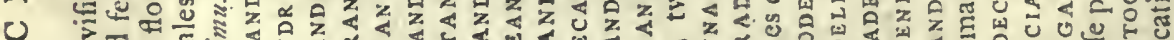
0 ⿰ $\therefore$ 进

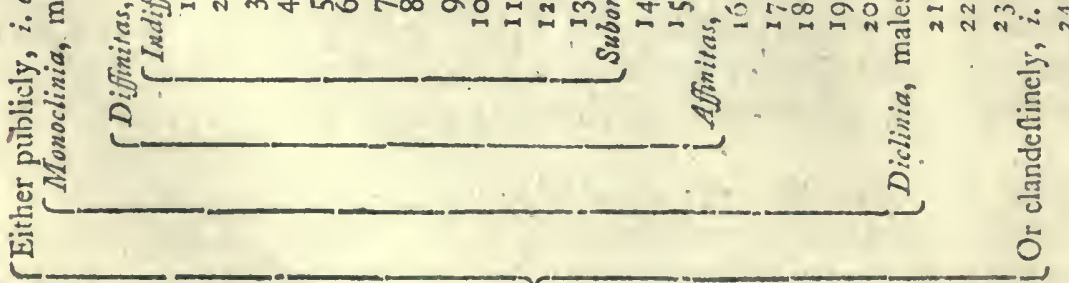

PJ!กน อมE SLNVTd 



\section{GARDEN BEAN}
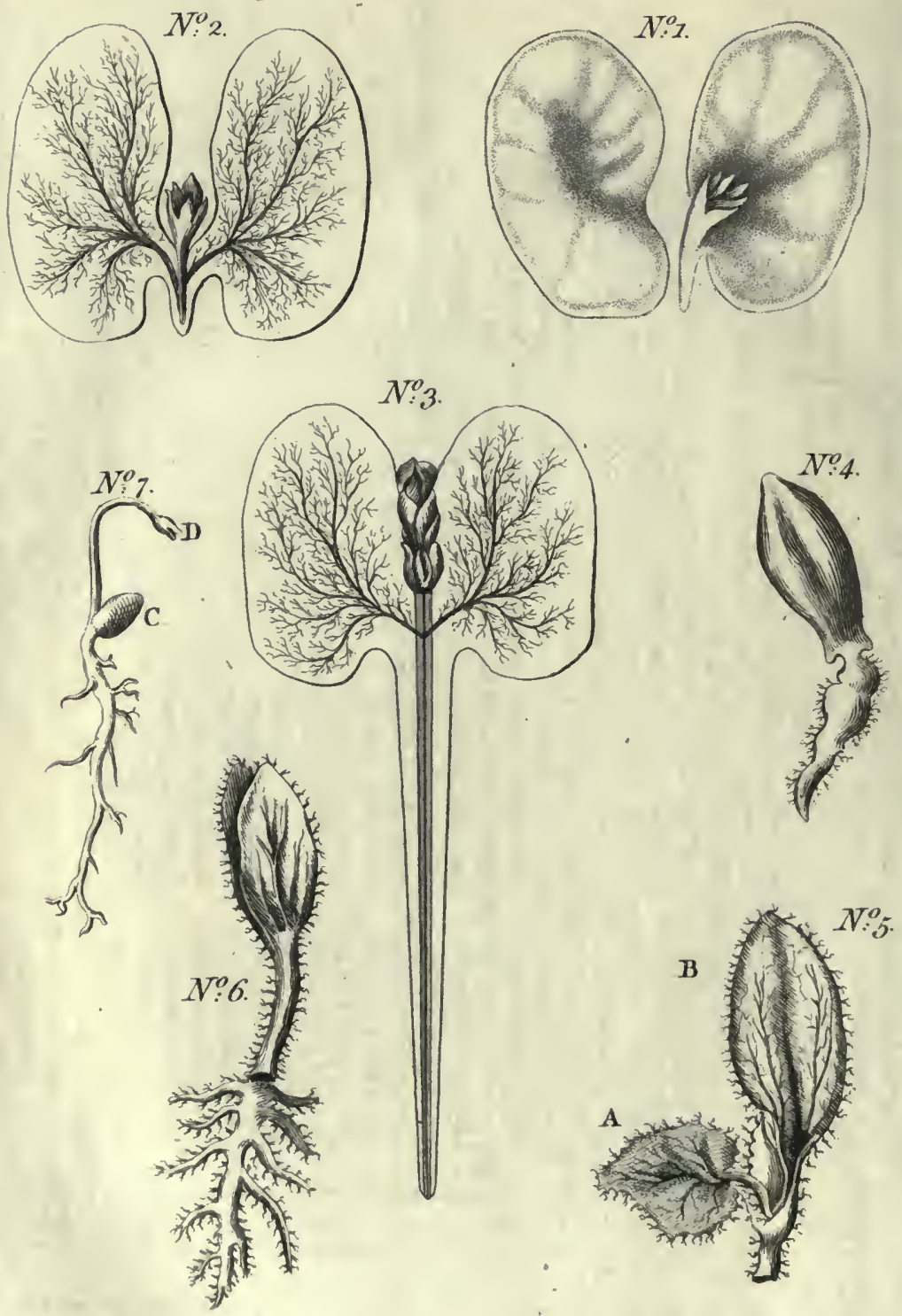
F.

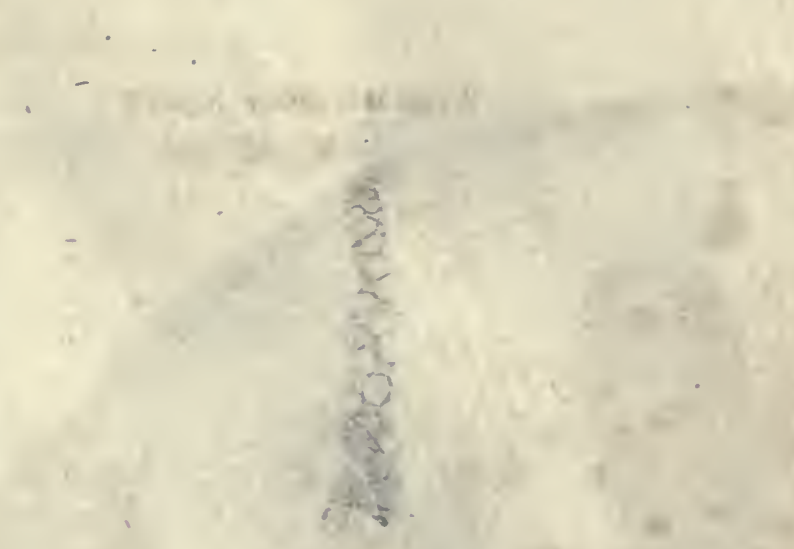

- 
WORMWOOI ROOT

$\times 02003$ Magnified

$\times 0,0000000538$

0100000030503

$3000 \%$ m

$001 \ldots$

1 .

ono

$0003 \%$ m

.000

$\infty$

sor

roo

000

ino

)

nove

ox

mo

oró

log

ox

or

10

- a

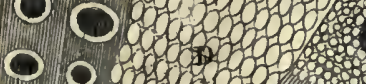

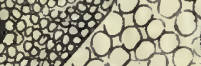

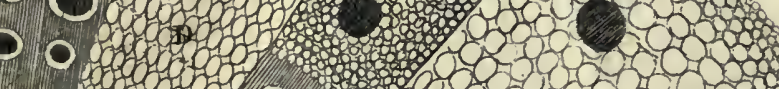

- 5050050 O

- 0.530505

- 300305

(.)

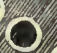

- 00000003000

I)
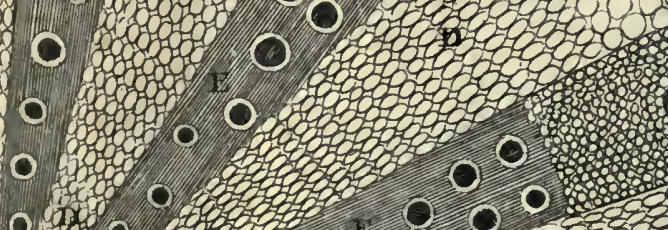

ix

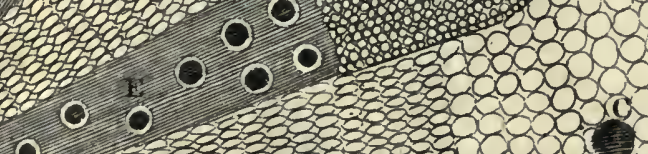

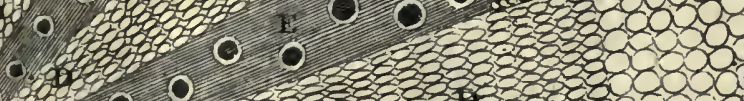

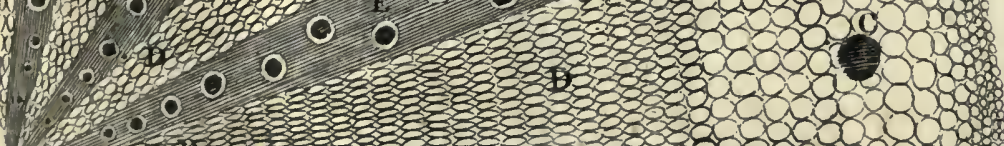
1.1.

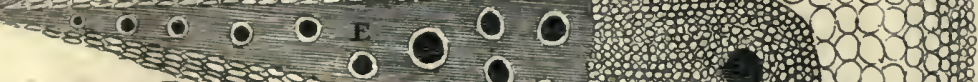

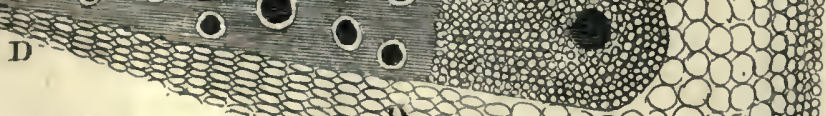

$$
\begin{aligned}
& \text { avis: }
\end{aligned}
$$

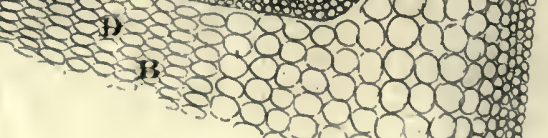




\section{O B S E R A T I O N S \\ ON THE}

\section{PLATES belonging to the DISCOURSE:}

\section{G A R D E N B E A N.}

JUMBER I. Shews the ftate of this feed previous to its being com1 mitted to the earth : the future plant is very apparent, and furrounded by the pulpy matter that is afterwards to afford it nutriment. That a fimilar plant occurs in other feeds, is evident to whoever will open plums, cherries, \&cc. carefully.

No. 2. The feed having been a few days in the earth, the germ is beginning to thoot upward, and draws nourifhment from a fyftem of minute veffels, diftributed throughout the pulpy part of the feed.

No. 3. The root thooting ftrongly downward in fearch of nourithment, which it may contribute in addition to that furnifhed by the minute ramifications difperfed throughout the pulp.

No. 4. Is the ftate of the bud of a gourd when it has been fome time in the earth, fhewing the root ftriking into the ground.

No. 5. Shews the little plant iffuing from between the two feminal leaves $(\mathrm{AB})$; the feminal leaf $\mathrm{A}$ being bent downward: the root is cut off.

No. 6. Shews the root making further advances into the earth, and mooting deeper, while the feminal leaves are rifing into the air.

No. 7. The kernel of an orange in a progrefive ftate. C, the feminal leaf having done its duty, now about to become rotten.

\section{WOR M WOD ROOT, magnified.}

A. The fkin with its veffels; fmall and clofe.

B, B. The bark, exhibiting a regular fyftem of little cells and fapveffels.

PART VI. NO. 32 . 
C, C, C. Lymph ducts in the bark.

D, D, D. Parenchymatous infertions from the bark, with the cells, \&c. E, E, E. The rays of the wood, wherein the holes are air-veffels. N.B. This root has no pith.

A. The bark.

\section{A S H B A N C H, magnified.}

$\mathrm{B}, \mathrm{B}, \mathrm{B}$. An arched ring of fap-veffels, adjoining the $1 \mathrm{kin}$.

C, C. The parenchyma of the bark, with its cells, and another ring of fap-veffels anfwering the former, but fituated more internally.

D. A line of lymph-ducts immediately adjoining the fecond arched ring of fap-veffels.

E, E. The wood.

F. The firt year's growth.

G. The fecond year's growth.

H. The third year's growth.

I. The true wood.

K. The great air-veffels.

L. Leffer air-veffels.

M, M, M. Parenchymatous infertions of the bark, radiating to the centre.

N. The pith.

O. Its bladders or cells.

N. B. T'be $G$ in the centre Sould bave been $O$.

VINE LEA F, magnified.

Fig. 1. The appearance of the air-veffels to the eye, in a vine-leaf gently drawn afunder.

Fig.2. A fmall piece of that leaf.

Fig. 3. The fame magnified, in which the veffels have the appearance of a fcrew.

Fig. 4. The appearance of thefe veffels as they exift in the leaf before they are ftretched out. 
VEGETATION

\section{VINE LEAF}

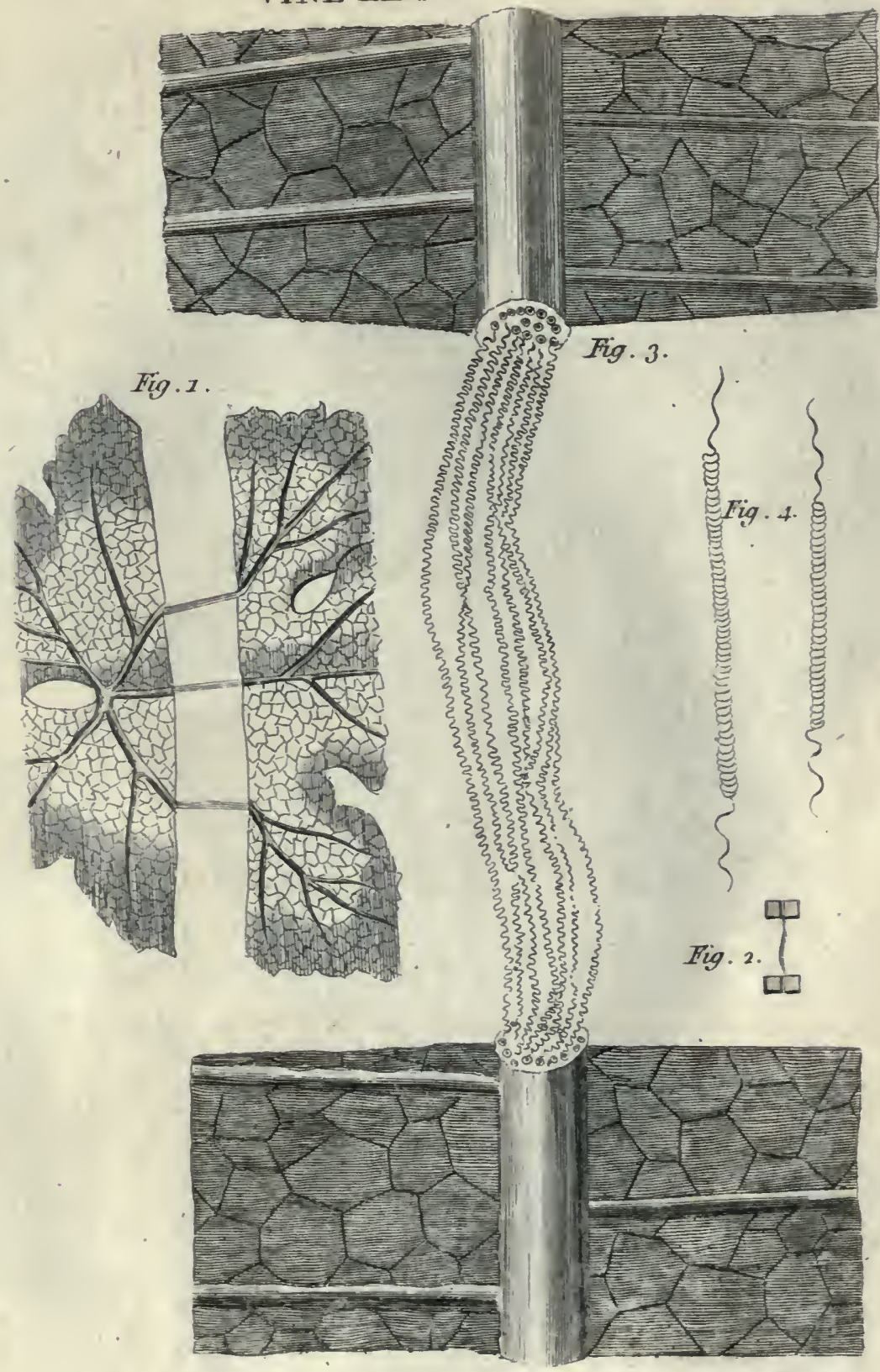




\section{$24+4 x \times 1 \%$}
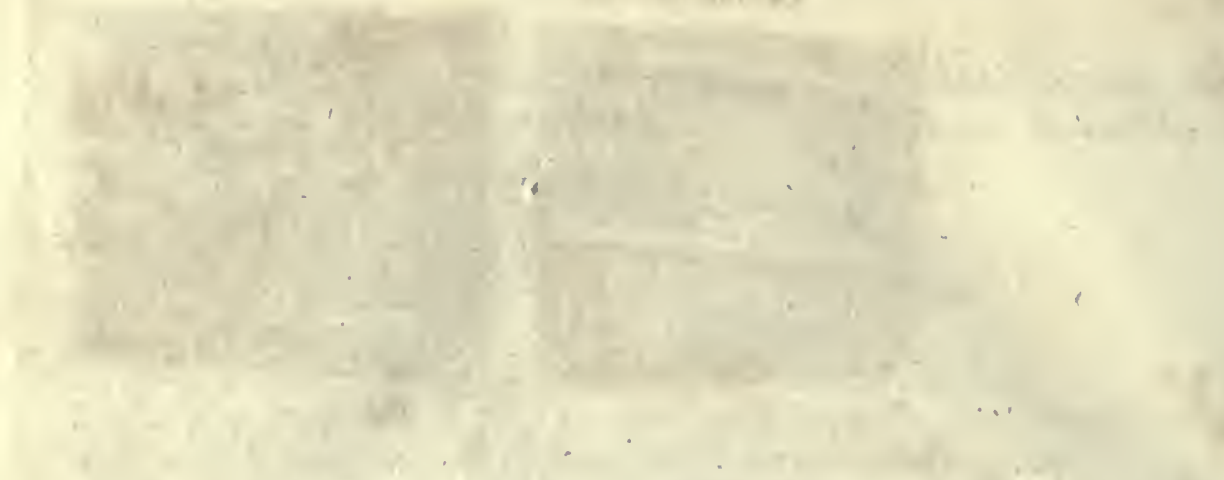
Part of an ASH BRANCH Magnified.

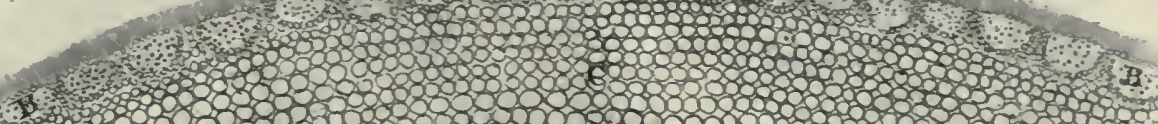

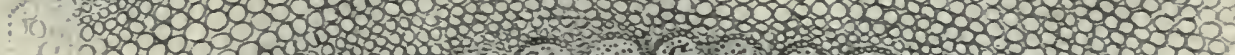

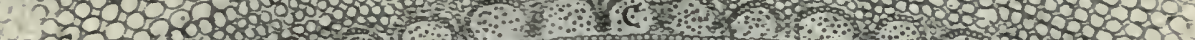

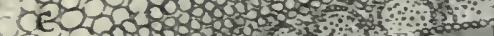

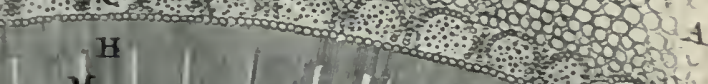

A

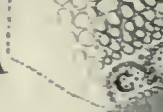

D
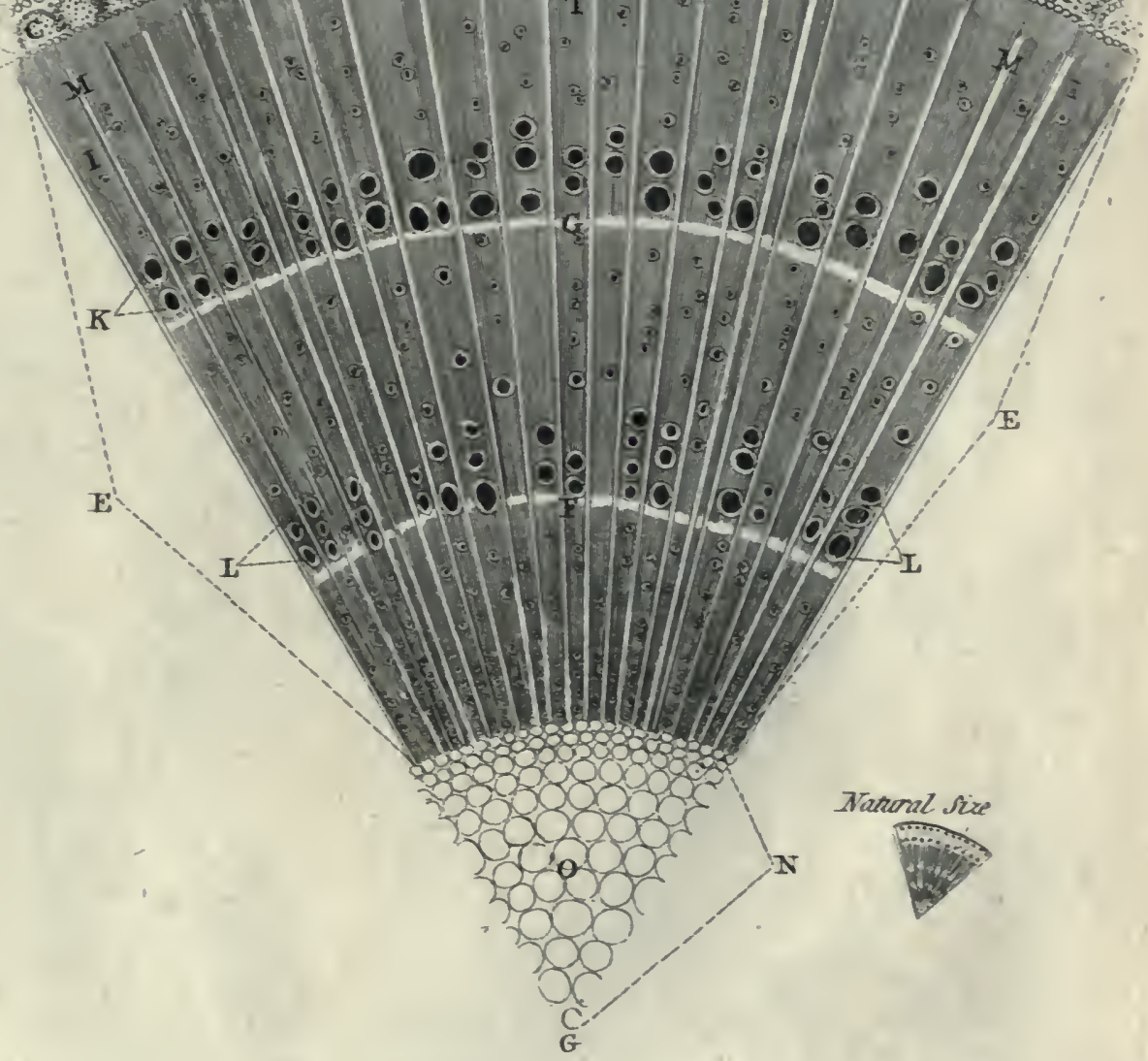


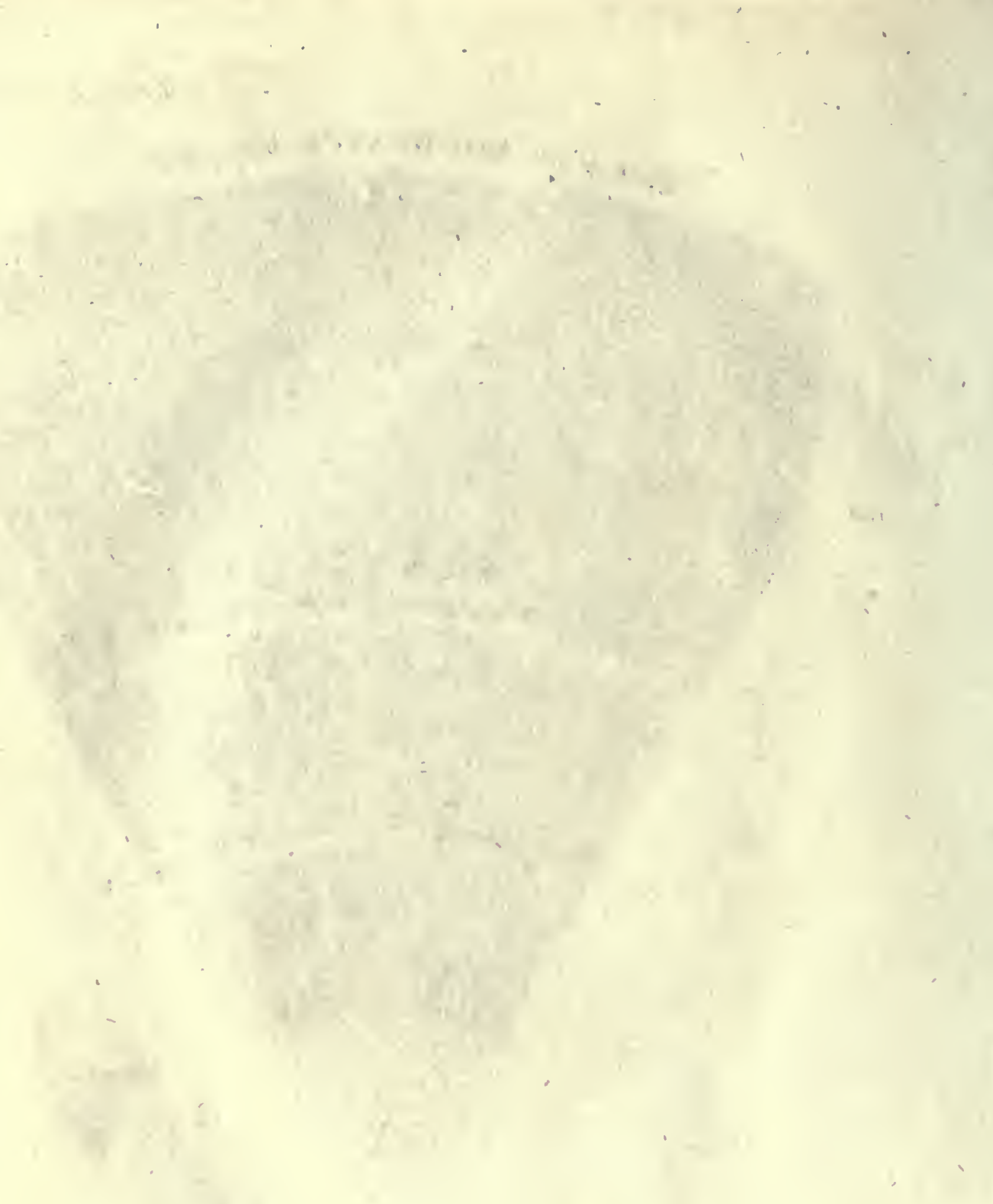




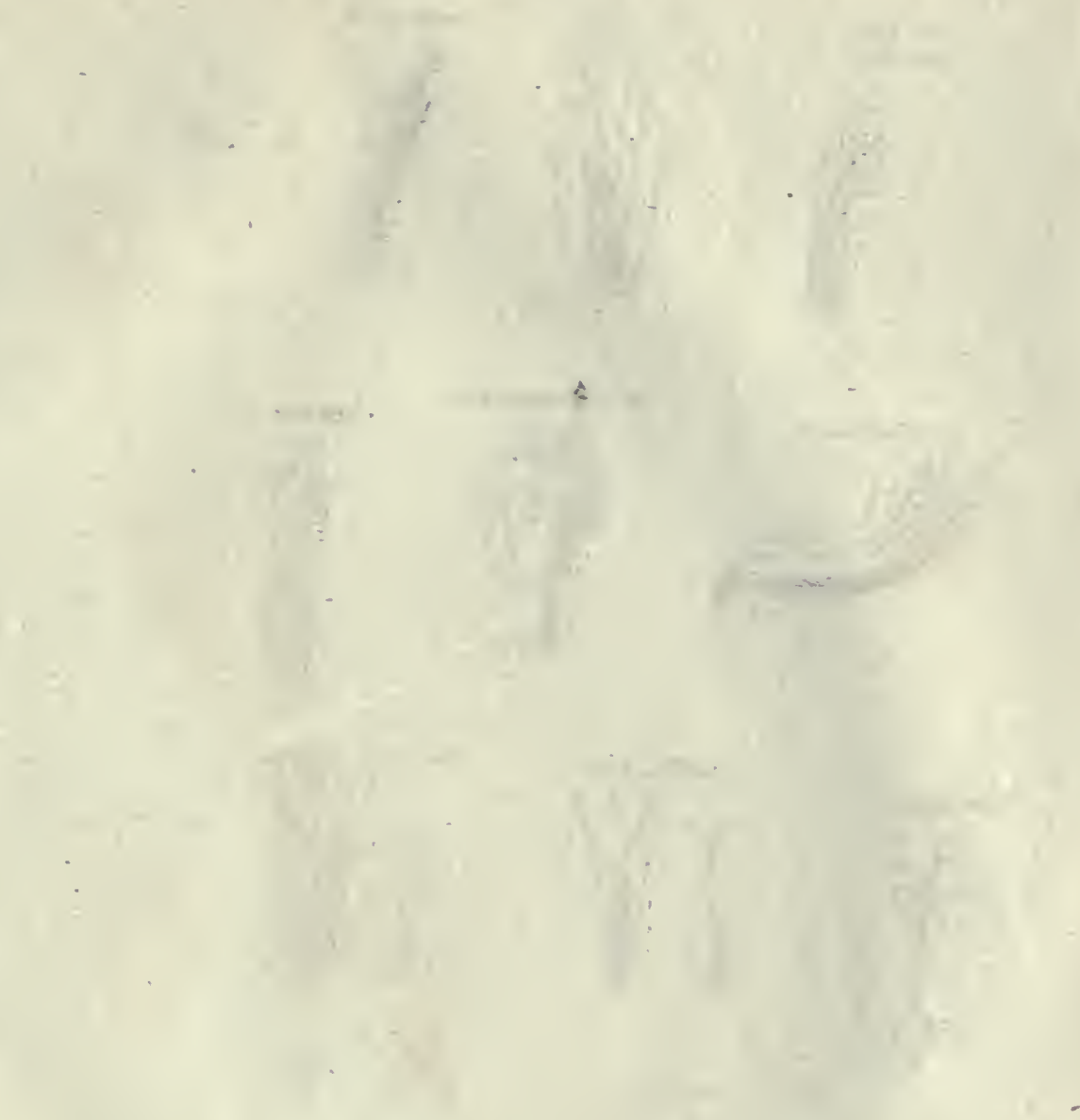


Plate II.

\section{FLOWER S.}

4 two long

G- 4 long

bivtherhood
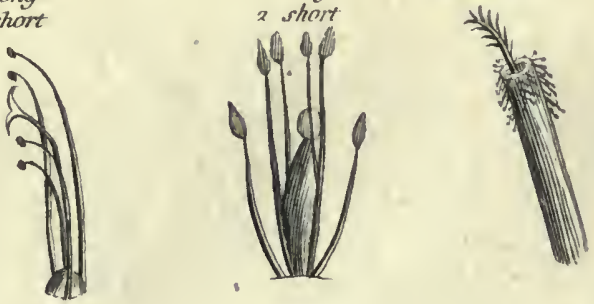

two brotherhoods

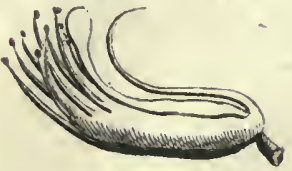

many" Brotherhoods

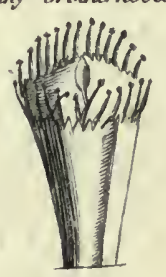

Syngenesia
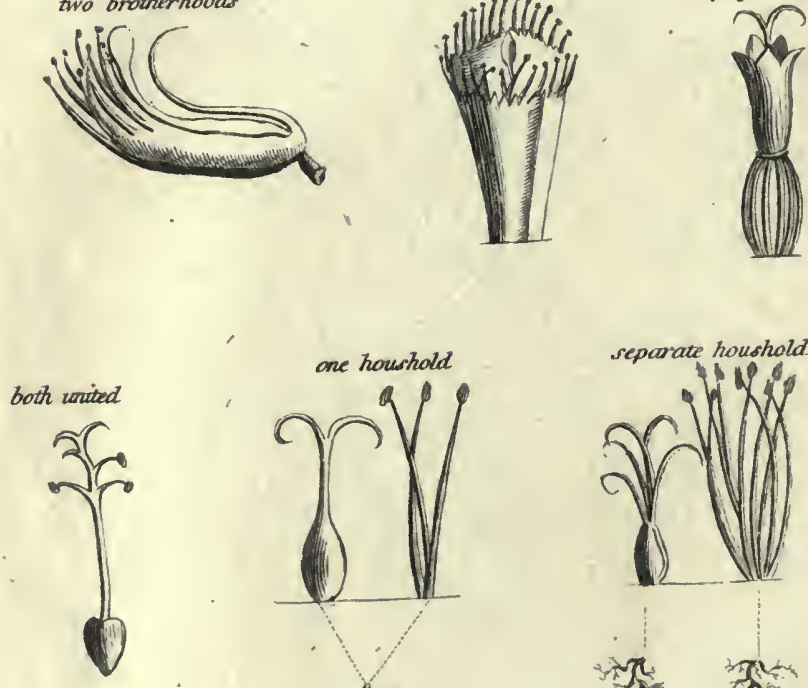

$\min _{\rightarrow \text { तो }}$

separate houshold
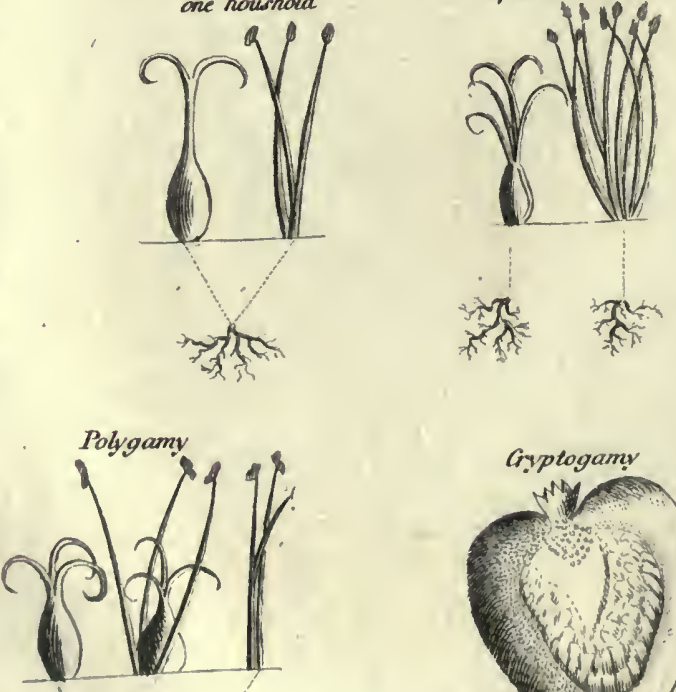

㛢

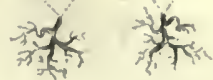

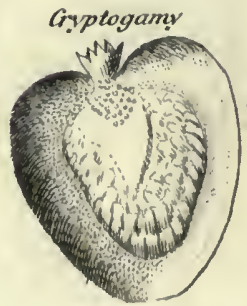




$$
\therefore 1 ; 1=610+1
$$
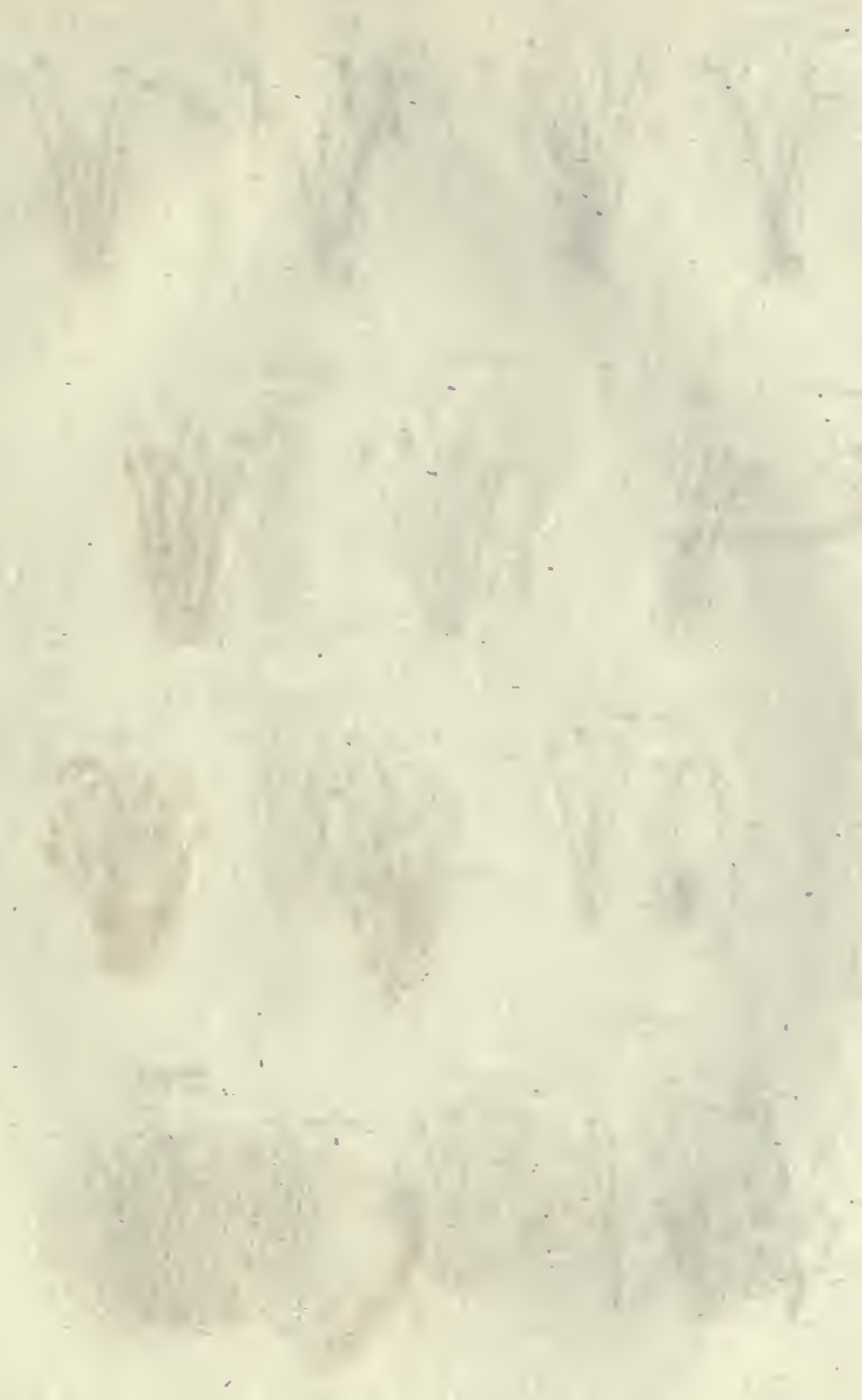
FLOWERS.
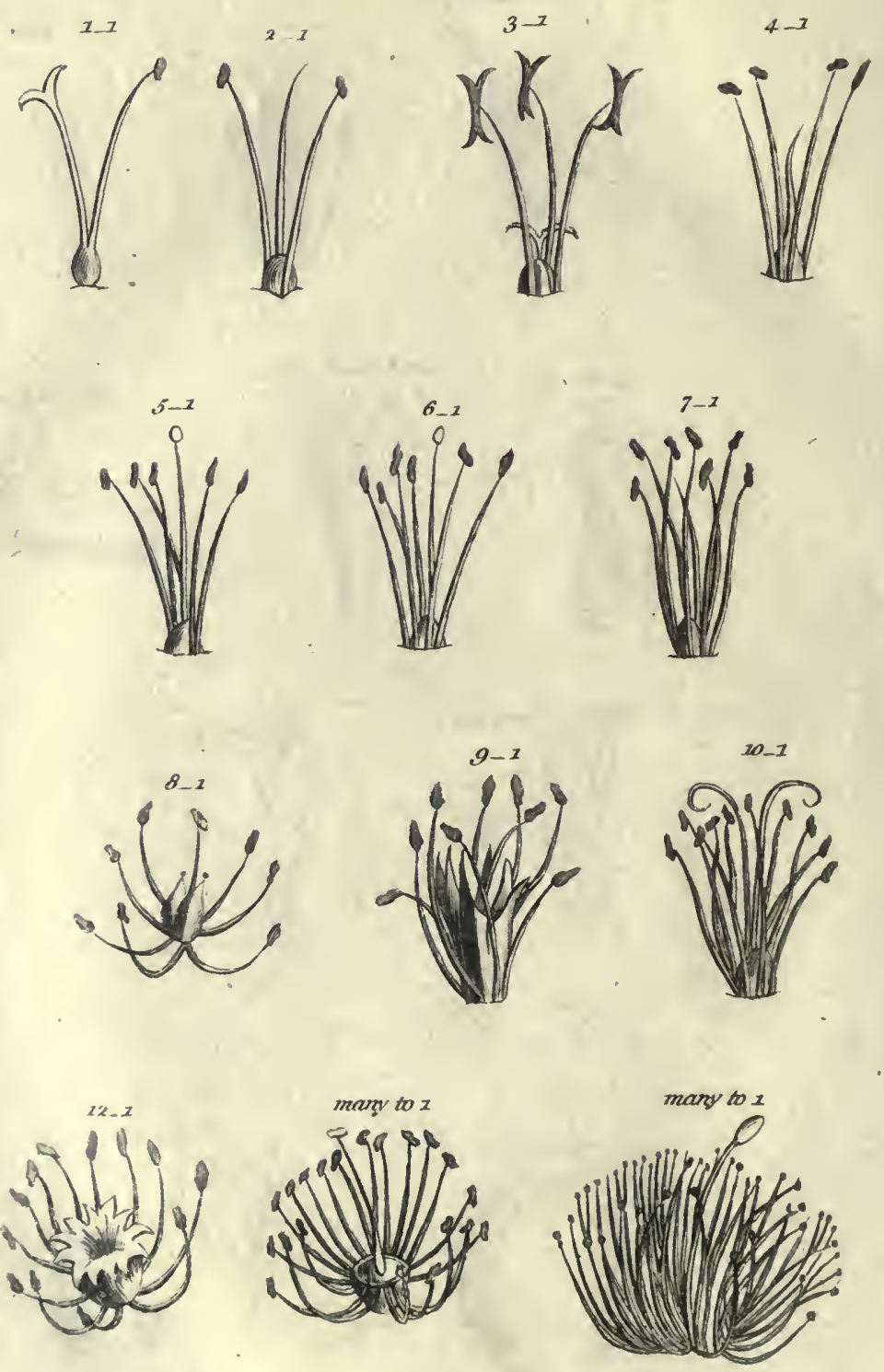


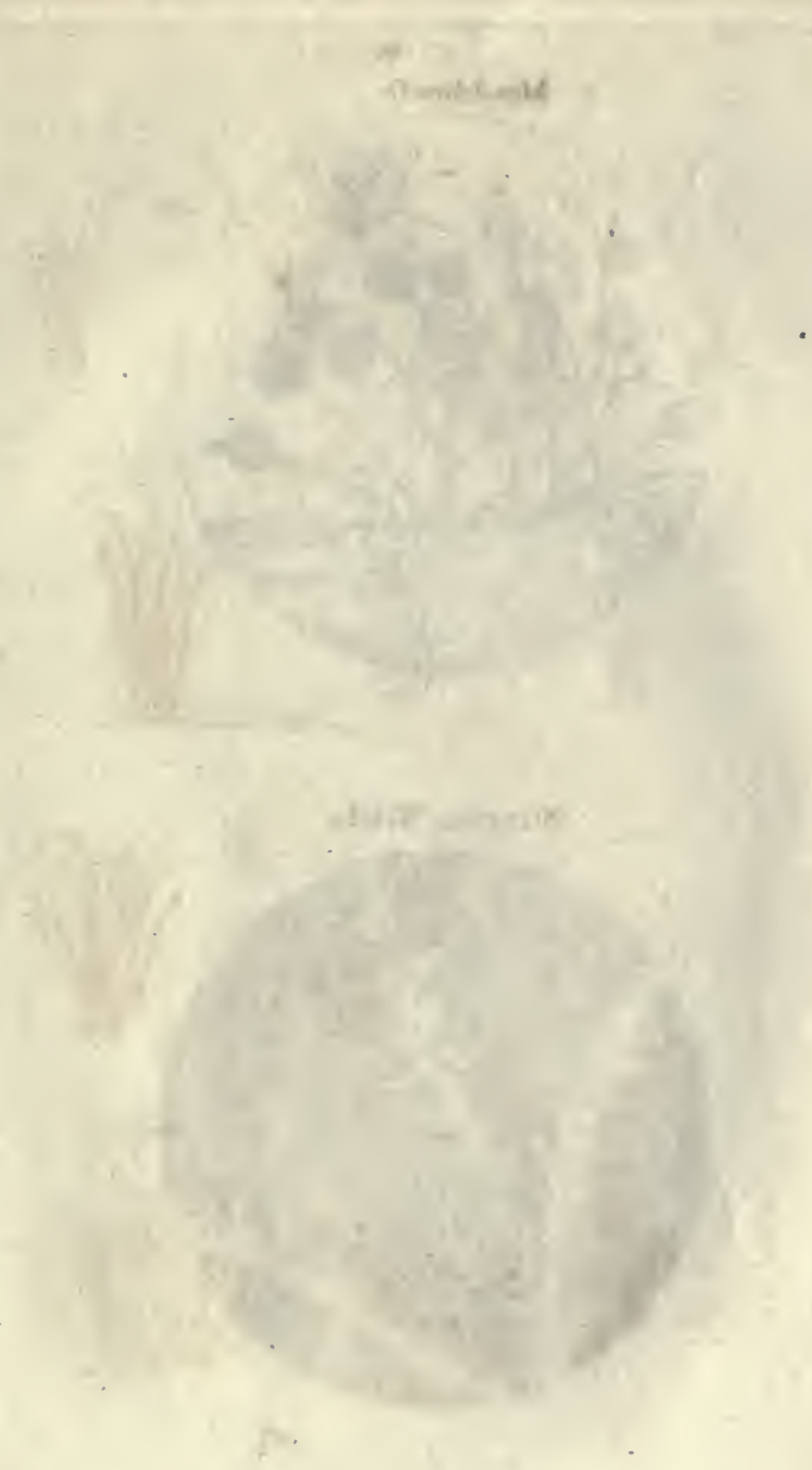




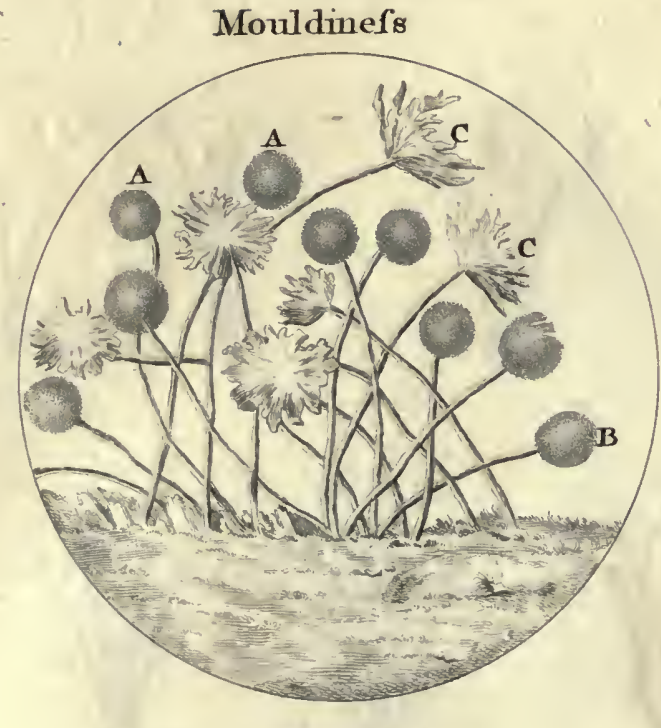

Stinging Nettle

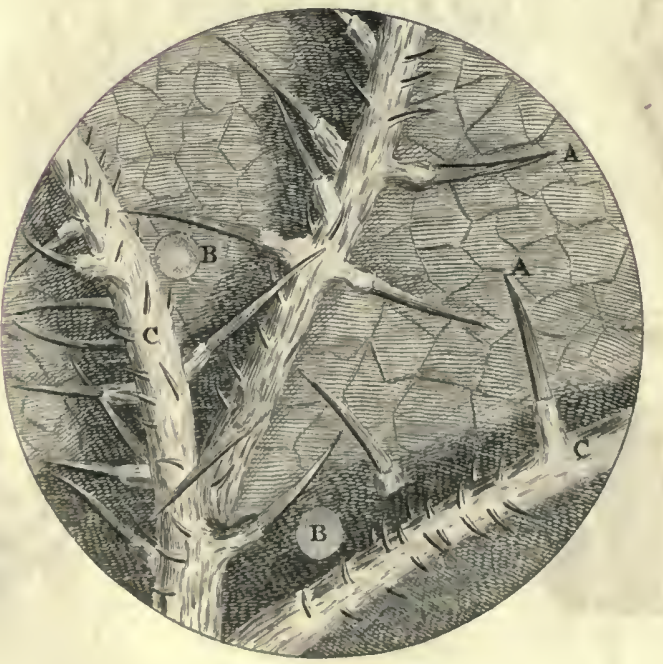


1.
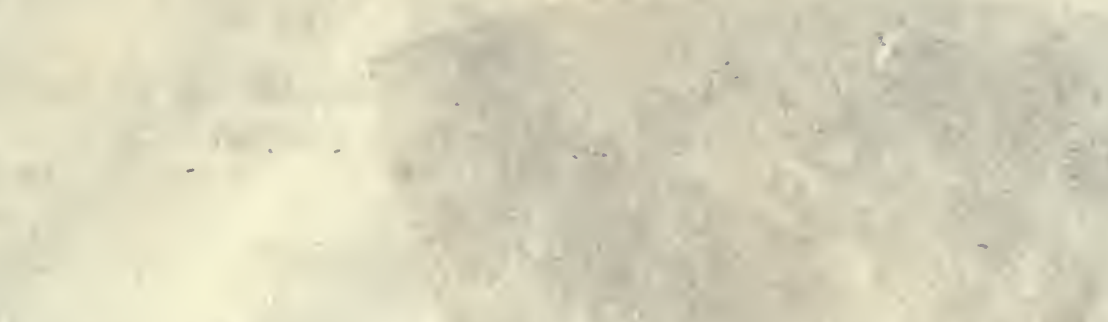

(1)
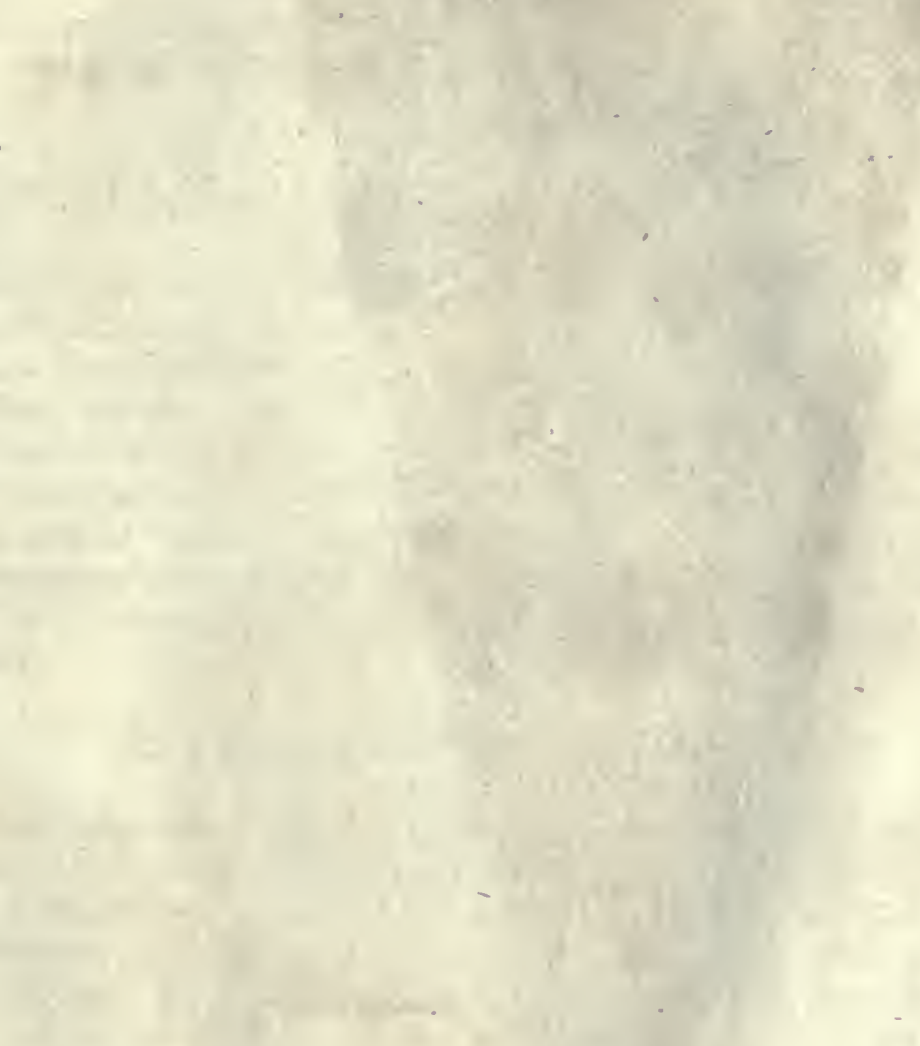

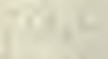

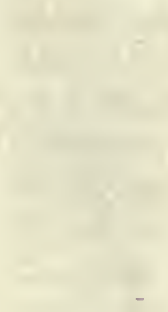




\section{Part of a PEAR Magnified}
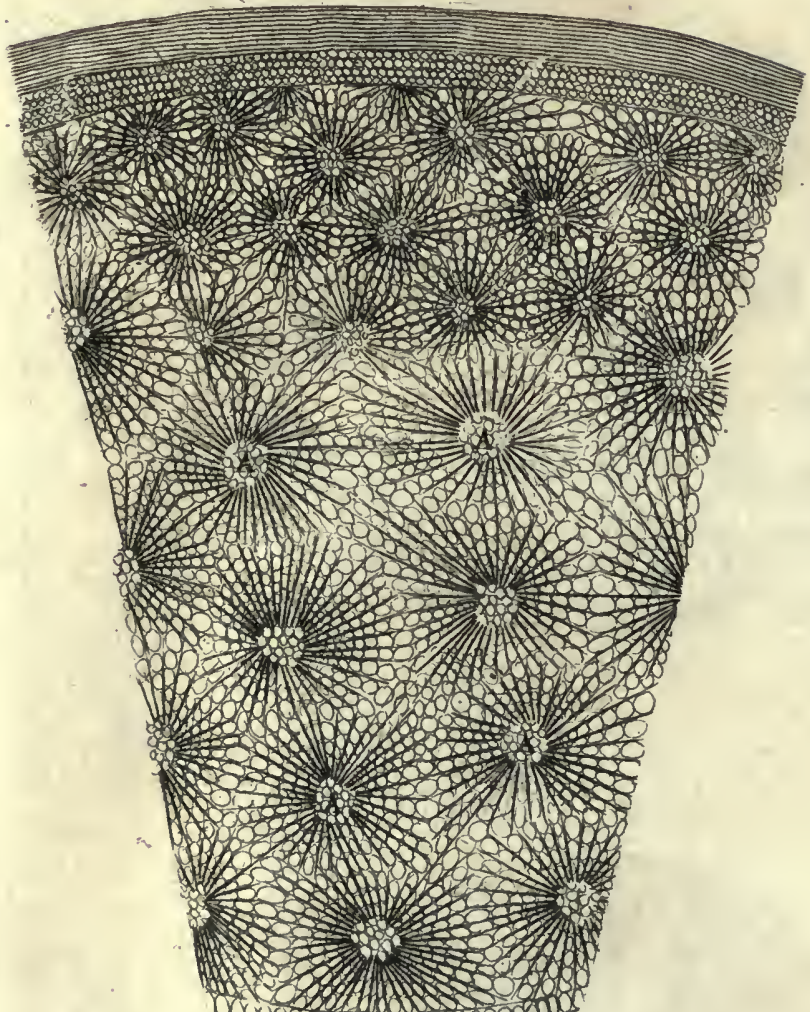

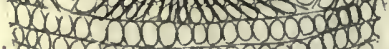

ous 000000001000

$\$ 1000000000000$

10000000000

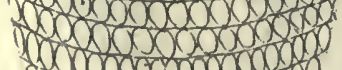

imomatromoro 0

monomónorou

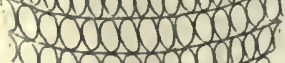

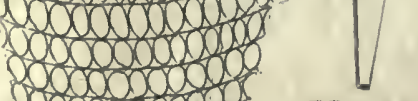

isoosonosos

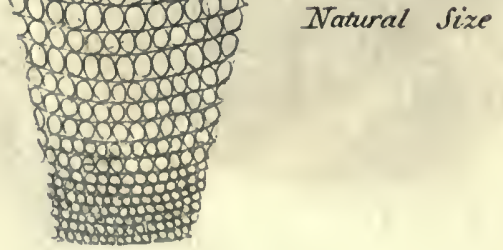




\section{PLATES TO THE DISCOUR
PART OF A PEAR, magnified.}

Shewing the rind and its veffels, the calculary and acetary. them.

A, A, A. The litcle grains or globules, with the veffels radiating from

\section{F L O W E R S,}

Two plates; are fully explained by the method of clafification ac. cording the fexual fyftem in page $35^{8}$.

\section{O U L D I}

This plate exhibits the minuteners of vegetation, and thews, that what we call mouldinefs is in reality only a colonty of plants. This figure was a fpot found on the red. Theep-fkin cover of a book. The plant has long flender ftalks, furmounted by a knob or ball: many of thele were round and fmooth, as A A; others Imooth, but not round, as $B$; others broken and expanded in various degrees, as C C. The whole was tender, and in fubftance like the common musroom. This plant is part of a very numerous tribe, whofe limits of duration perhaps are but fhort, but which compenfate this brevity by furprifing fecundity and rapid maturity.

\section{STINGING NETTLE.}

This therys the whole furface of the leaf, thickly fet with fharp thorns and prickles, A A, each confifting of two parts; one harp and tapering to a point; the other thicker, being a cavity containing a liquor to be ejected from the point into the wound it has made, in the fame manner as a viper's fang. $B$, is a fort of pearl-like tranfparent globules that grow interfperfed on the leaf, much like oak-apples on the leaves of the oak. C C; the ribs or fap-canals, whence all the prickles iffue, and which furnifh the juice they emit. The fmaller prickles have no juice. 


\section{OBSERVATIONS on fundry PLATES}

Belonging to the SECOND VOLUME of the

\section{S UR V E Y S OF N A T UR E.}

THE LAPLANDER is reprefented clothed in $n$ kins, and holding a Rein deer.

The CHINese is dreffed in filks, be-dragoned, according to the cuftom of his country, as are alfo his flat fword and his little queue of hair.

The AFrICAN is diftinguifhed as well by his colour as his woolly hair.

The Hotrentors are in two groups : that below from Kolben's account of the Cape of Good Hope; that above from an original (with remarks) by Dr, Spaarman.

The NORTH AMERICAN claims Mr. Weft as its author; the high feathered head, the bow, and the belt of wampum, diftinguifh him.

Wallachian Sheep exhibit a remarkable diverfity of horns, little to be expected by the fpecimens of this animal in our country: this race is faid to be conftant in Crete.

The Brack Wolf, here reprefented, was native of Canada, and lefs than the Alpine wolves.

The FlYing SeUirRil of this plate is native of India. His attitude fhews the membranous expanfion between his hind and fore legs, $\mathrm{cn}$ which his flight depends; (vide the Bat). He is larger than the kinds mentioned P. 99; but differs in little elfe, though his colours and fpots vary.

The CoAIta is given as exhibiting not only a remarkable formation in the hands, but alfo as an example of a prehenfile tail.

The White BeAR is the great Greenland bear, not the terreftrial white bear.

The ANT-BEAR. The fnout of this animal is ton long by a quarter its length, (ftuffed nkins are apt to occafion fuch miftakes); allo it fhould taper more at the end:"the ftreaks on the back are too diftinet.

The BAT, fig. I: Reprefents this creature in a ftate of repofe. The front-arm $(A C)$ is very long, extending obliquely downwards and forwards to the nofe; the knuckle (C) refts on the ground, and the thumb only (D) appears; the knce (B) is elevated up to the back (E); the leg is vertical, and the five toes $(G)$ of the lind leg are of equal length 


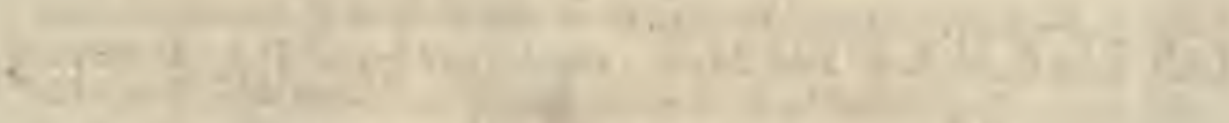
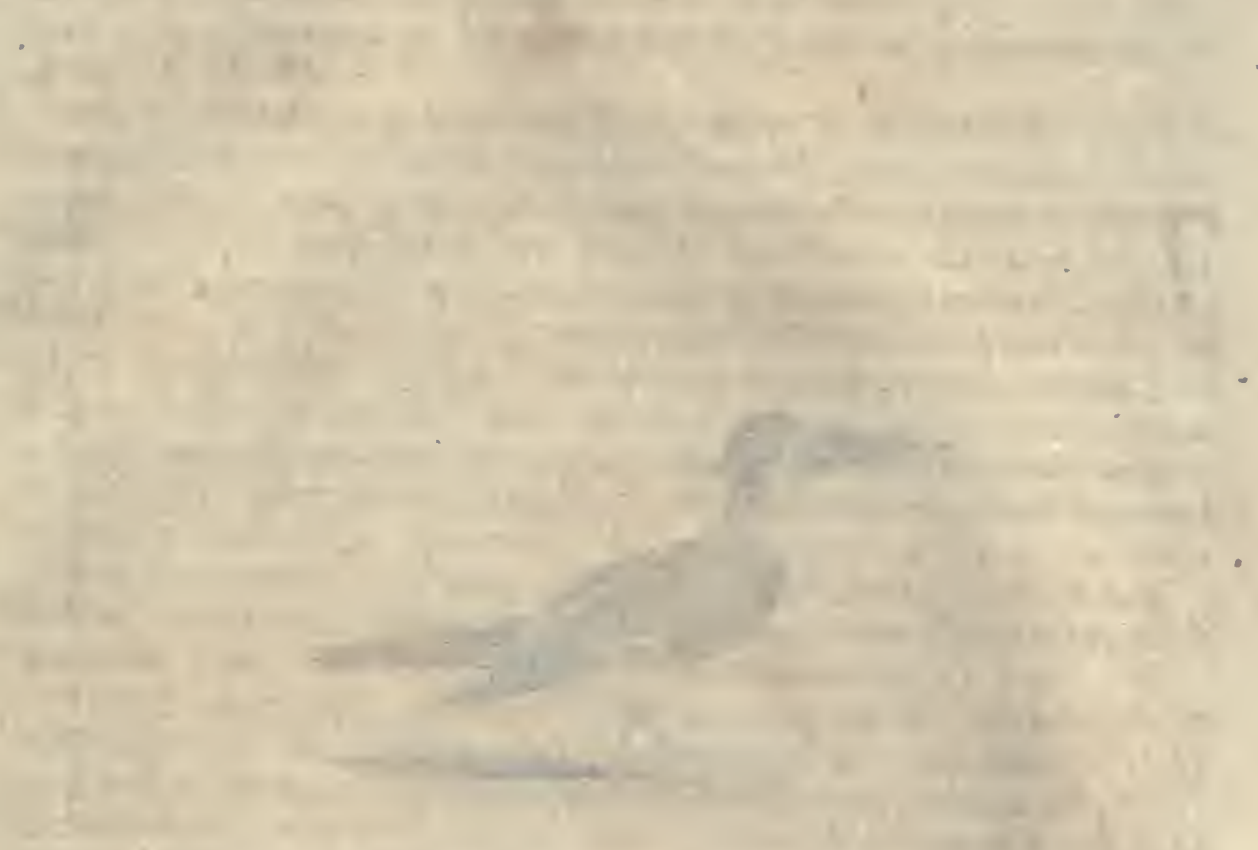

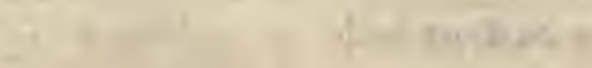
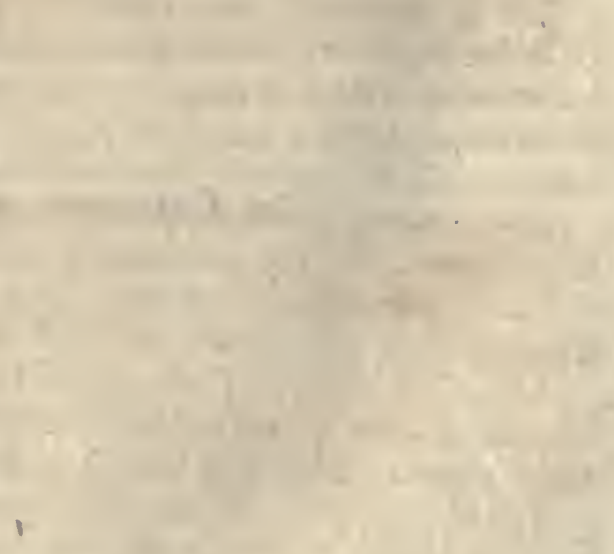


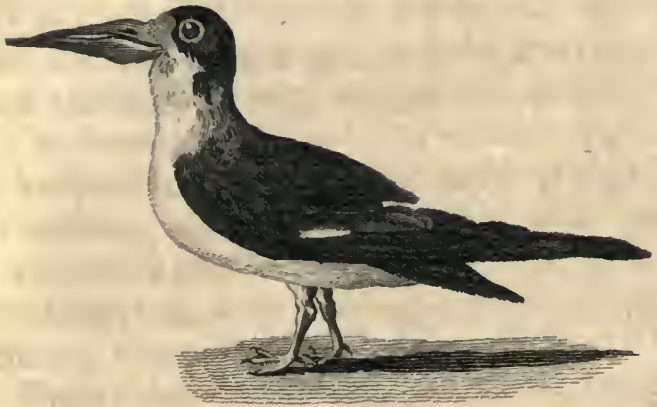

The Cut-water or Scifsor-bill 


\section{OBSERVIATIONS, \&C.}

and diverging. In this view many parts are hidden by others coming before them. That by this almoft contradictory conformation of parts, the bat fhould be a heavy walker, and indeed rather drag itfelf along than walk, is no wonder; his gait is tottering, and he is often in danger of falling fideways.

Fig. 2. Shews this animal in a lying ftate; to accomplifh which he fpreads his fingers (or thofe long radii from $\mathrm{M}$ ), and extends his membranous fides, which are fo thin they are almoit tranfparent, yet very ftrong. A the arm, $B$ the fore arm, $M$ the thumb, C, D, E, F, the extended fingers, which are further feparated from each other in the order mentioned; the membrane between thefe affumes a bollowed form, $G$, $\mathrm{H}, \mathrm{I}, \mathrm{K}$ (near the tail L). When the bat ceafes flying, he Thuts the fingers clore on the fore-arm, thereby folding the membrane into a fmall compafs, and prefenting to the air a lefs furface, yet equal weight, he defcends and repofes. Other flying creatures have no fuch long radii of fingers (vide Flying Squirrel).

The Flamisgo. The head of fome is rather fmaller in proportion.

The Avocetra. All birds bills of this kind do not turn up equally, but fome more, fome lefs, and are not of equal length.

The CoMBATANT is given in both ftates, to exhibit the remarkable diffimilarity of this bird when full feathered and when moulred.

The CUT-W A TER: This bird, from the conformation of his bill, which is compofed of two very unequal pieces, can neither peck nor gather his food: his upper mandible falls into his lower, like the blade of a razor into its haft, fo that the bird is reduced to glide over the furface of the fea, and with his lower mandible furrow the water, in order to catch fuch filh as are near, or on, the furface; hence his name. The point of his bill is black; near the head red, as are his feet : fize of a fmall fea-mew. The upper part of his body, the front of his neck, and forehead, white; fome white on his wings; the reft of his plumage black, or brown-black, more or lefs. Inhabits Carolina and Guyana; go in troops; almolt always on the wing: their wings are long, yet they fly nowly, the better to perceive and feize their prey.

The Ostrich. The neck of fome is rather longer in proportion.

The Crocodile given in the plate, is the long-frouted crocodile; or that of the Ganges; which is fimilar to the Siamefe defcribed in page $15 \mathrm{I}$.

The Guano. His pouch is in its fwelled ftate; the rifings on his back are rather too ftrongly marked, and rather too much in lines.

The CAMELEON is in his puffed-up ftate. 
The RATTLE-SNAKE, plate II. Shews the peculiar parts of this reptile, feparated and diftinct.

The bead. At the extremity are the noftrils (A); between them and the eyes are (B) two orifices furpected to be the organs of hearing, but which lead into a bone, hollow, but not peforated $C$, Nhews the teeth of this ferpent feated in each jaw. D, the fangs through which the poifon paffes, placed forward in the mouth: only the firt (which is the largeft) fixed to the bone; the others to teridons; their mechanifm has been defcribed. E, the fituation of the bladders of poifon. F, the larynx, not with a variety of cartilages, but formed to as to make' a nit for the admiffion of air ; whence the hifing gs ferpents. G, the forked tongue, compofed of two round bodies, joined two thirds of its length; the part outfide the Sheath is black, that within it red : the under jaw is here divided (as at I) for its readier paffage, and the teeth in this jaw (H) are on each fide this divifion, that they may not injure the tongue.

The Rattle. The formation of the firft rattle. $a$, the latter vertebra of the tail: $b$, the mufcle on which the rattle is faftened: $c$, a fingle rattle, Thewing its rifings whereby it is held by following rattles, being inferted into their hollows; alfo its hollows whereby it holds the rifings of the following rattles : $d$, five rattles joined together, viewed as they appear externally.

The poifonous fangs are given at large, that their orifices, form, and conftruction may appear more plainly.

The SWORD-FISH frequents our coafts, but is more abundant in the Mediterranean, where its firhery is a confiderable object, efpecially on the coaft of Sicily, near Italy. . It is much efteemed by the Sicilians. The feafon is in fummer. They are ftruck with a fpear; are faid to be very voracious, and great enemies to the tunny, who are affirmed to be terrified at the fight of them, probably for the fame reafon as the whale is at the faw-fifn. It grows very large : the head and pectoral fins of one weighing feventy.pounds; the fnout three feet long, rough and hard, but not enough to penetrate thips. The fnout is the upper jaw greatly prolonged; it is compreffed at top and botton, fharp at the point: the under jaw is tharp but fhort; no teeth: the $\mathrm{kin}$ is rough but very thin : colour of the back dufky; the belly filvery. 


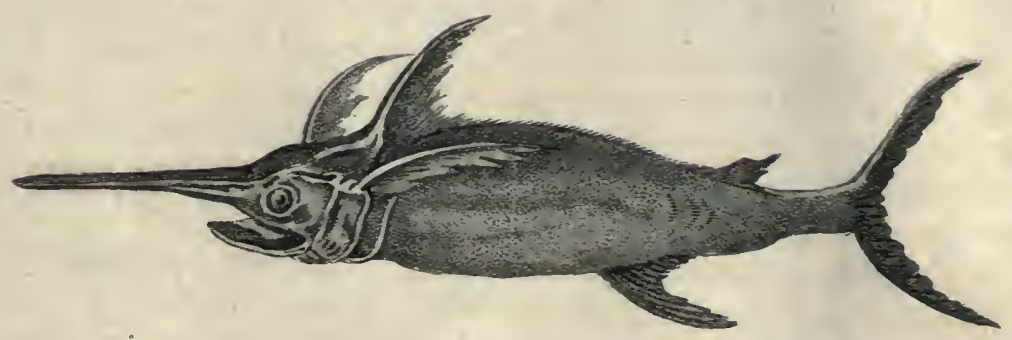

The Sword-fifh. 


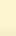



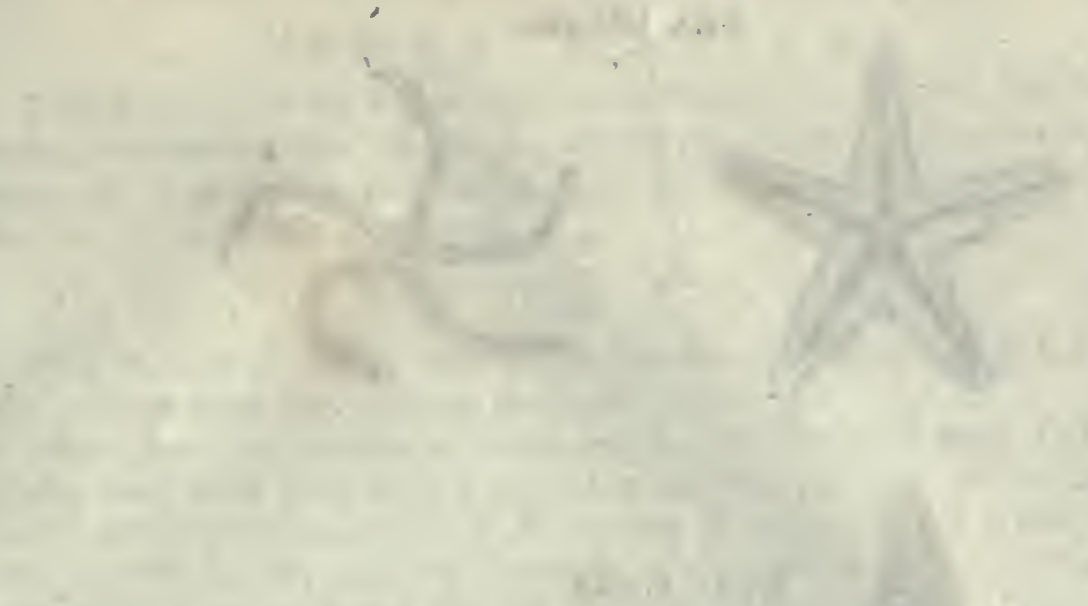


\section{SEA S TARS}
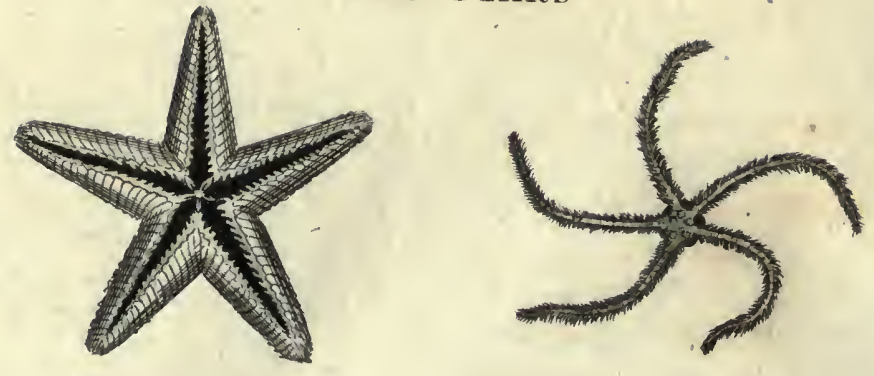

SEA PENS

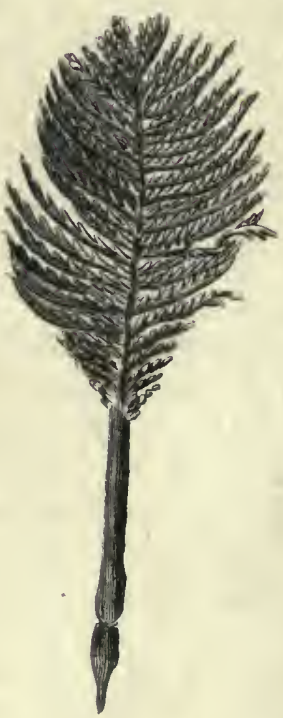




\section{TO SURVEYS OF NATURE:}

\section{P I N N A M A R I N A.}

This is of that kind whofe edges are rounded; it is the larget known, being ufually two feet in length, fometimes more: it attaches itfelf to rocks by long ftrings not unlike filk, which are called by fous, and ufed for making fome kinds of ftuffs.

\section{P $\mathrm{H} O \mathrm{~L}$ A $\mathrm{A}$ E.}

This clats of thell-fifh vary in the number of pieces which form their Thell; fome have four, others five, and fome eight.

This figure is: compofed of eight pieces, viz. two large ones, D D; two others/long and thin.EE, placed toward the opening of the thell; a very fmall one indicated by $F$ F, uniting the above; and a long nip. $G$ adjoining to $F$, and running down the fhell: befide thefe are two others channelled, and running down the internal face of the fhell. This thell is entirely white; the two large pieces nightly channelled.

\section{N A. U T I I L U U S.}

This figure reprefents the fhell internally and externally. The chambers of the firlt deferve our notice : they are feparated by thin partitions, pierced, each in its centre, by an orifice of communication running throughout the whole. The colour of this inell is yellowinh, with crols bands deeper coloured, and almo:t brown.

\section{S E A S T TIA R, S}

Are marine animals divided into many poirts or rays, but generally five; they are covered by a fkin, more or lefs tough, hard, or leathery. If one of their rays be broken off, they regain the deficiency in a litcle time, fometimes growing from the place of the old one, fometimes from one fide of it. - The under face in almoit all kinds is different from the upper, and concave or lollow; while the upper is convex, and molly fmooth, having no channels. The mouth is in the under face.

Of the firt of thefe the rays are divided by deep channels, fringed as it were by points, thin and flatted; the whole of this face is covered by little grains the fize of a' fmall pin's head. Inhabits molt feas.

The fecond has much thinner rays, with longer fringes, cylindrical and pointed; the part between is covered above and below by little thin plates, difpofed like the fcales of a fifh; the centre or body is granulated, extremely finely, both above and below. The colour of this fubject is brown: Is found at' St. Domingo.

PART VI. No. 32. 


\section{S E A P E N S}

Are a kind of marine infects, denominated from their refemblance to a writing pen : the middle, which correfponds to the quill of the pen, is a cartilaginous fubftance, in colour a clear brown; the featbers of the pen are whitin, hollow like the body, but lefs folid, and partly allied to the rays of fea ftars. The flen of the animal occupies the whole; is at leaft the fize of a pen, often more. Is found in the Eaft Indies.

The fecond differs from the former in having its lateral branches or fearthers furnithed with other fmaller filaments, very thin : its colour varies from red to white; the reddeft are molt defired. Is found as. well in the European as Indian feas.

\section{SEA UR CHIN S}

Are diftinguifhed from fea ftars by not being divided into rays, but having numerous fpikes iffuing from fmall knobs difpofed over the furface. If one of thefe points or fpikes be broken off, they regain the deficiency. It has been hinted by fome, that poffibly they change their Thell like crabs, \&c.: : it is certain that, when broken or pierced, they quickly reftore it. : Some are quite flat, and have no points. The mouth is on one fide, the anus on the other, commonly directly oppofite.

No. I. Is not round, but approaching to oval, flat on one fide, convex on the other: its convex fide is reprefented; its mouth is on the other fide : colour brown. It has a great number of very fine and thort afhcoloured points: four deep fiffures on its convex fide, none on its flat fide. Found at St. Domingo.

No. 2. Is feen on that fide where its mouth is (which has five teeth): this urchin has two forts of points, one fhort, flatted, fmooth, and whitim; the other much longer, of an unequal or roughifh furface, and reddith colour. Is found in America.

No. 3. Has a very great number of points, principally on the convex face and fides; is of a fine violet colour. Found in the Mediterranean.

No. 4. Is very convex on one of its faces'; the opening feen is the anus. The colours of this urchin are ftripes of green and white alternately. The little knobs which cover its furface have ufually each a little fpike of a quarter of an incls long; fome green, fome white: thefe break off eafily when the animal is dead. Native of the Weit Indies.

No. 5. Is extremely thin and Aat ; thickert in the middle, thinneft towârd 


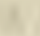

,

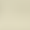

$\checkmark$ 


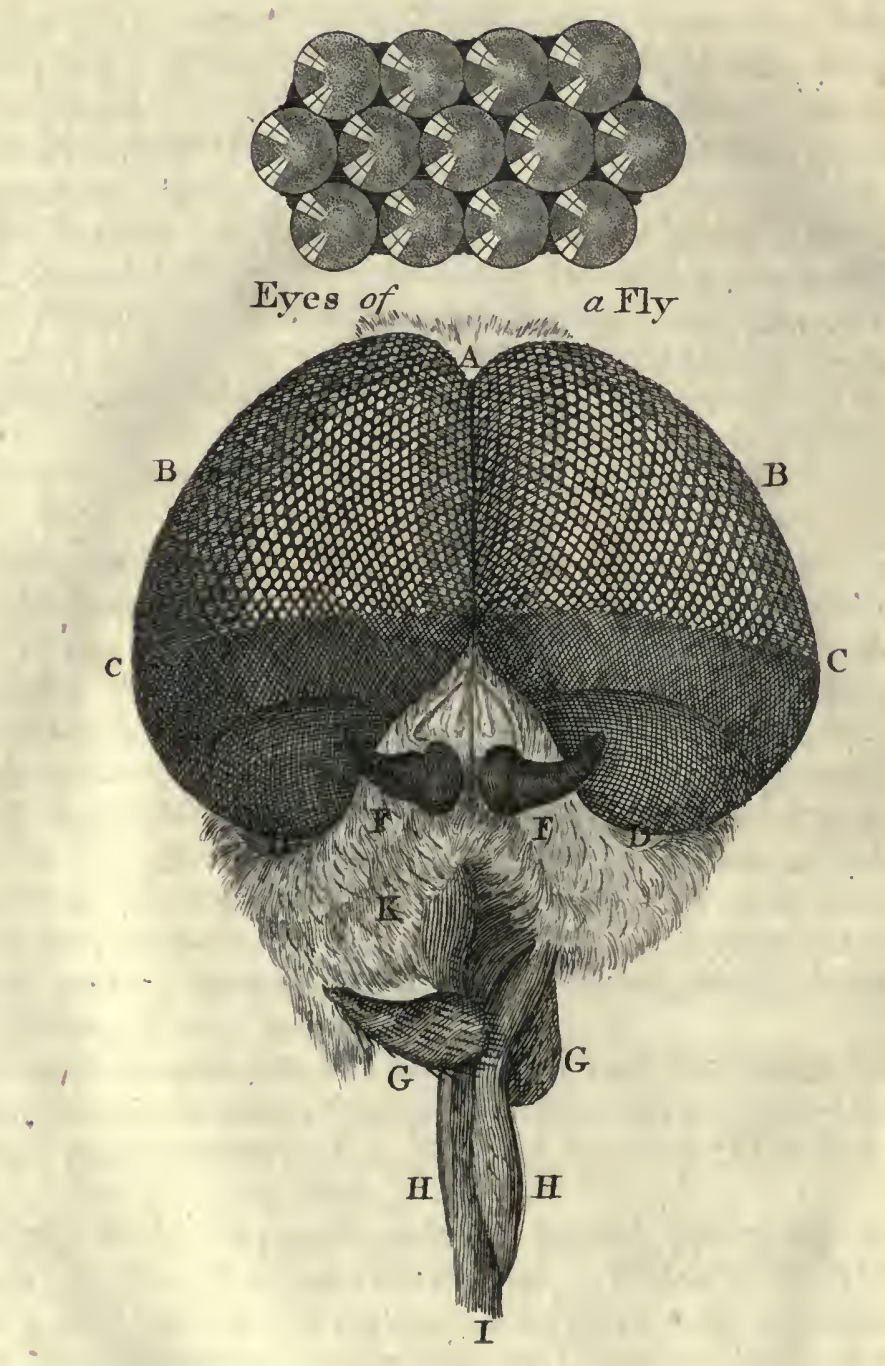




\section{TO SURVEYS OF NATURE.}

toward the edge: the mouth and anus are both on the fame face, and near together. On the upper face the figure of a five-petaled flower: around it fix oval openings, having no apparent communication with the internal parts; points only within thefe openings. Native of the Weft Indies.

No. 6. Is white and lat; like the foregoing; differs by a kind of incifions which almolt refemble the appearance of a fringe; in other refpects is fimilar.

\section{The Head and Eyes of a Drone Fly, niagnified.}

This infect is remarkable for a large head and clufters of eyes : the greatelt part of the head confifts of two femi-circular protuberances or eyes, A, B B, C C, D D; whole furfaces are replete with minute hemifpheres difpofed triagonally, forming exact and equi-diftant rows, with little channels between them. Thofe in the upper divifons $A, B, C$, much larger than thofe in the lower divilions $C, D$. Every one of thefe feems very nearly an exalt hemifphere, reflecting the images of furrounding objeets; infomuch that houfes, trees, \&c. within a certain diftance, appeared depicted on it, in the fame manner as the windows are on the figure above.

There were 14,000 pearls or hemifpheres in thefe clufters; 3000 of the larger kind, 4000 of the fmaller kind, in each protuberance. Each pearl is an eye, having the neceffary humours, \& c. yet probably the creature has vifion only of fuch objects whofe rays of light fall nearly coincident with the axis of the hemifphere; and of thefe fome may engage its attention more than others.

In the Libella, or Dragon Fly, Mr. Leuenнов keckoned I 2,544 pearls in each eye, placed hexangularly; he alío numbered 6236 pearls in a Silksoorm's two eyes when in a fly ftate; $3^{1} 8 \mathrm{i}$ in each eye of a Beetle; and 8000 in the two eyes of a common Fly.

In fies and aerial animals the pearls are placed in triangular rows; in Crabs, Lobfters, Sbrimps, and other ciuftaceous water animals (whore eyes are lefs pearled) they are ranged in a quadrangular order: the lofs in number being compenfated by a fmall power of moving their eyes when infpecting objects.

F F. The horns.

G G. The fmellers or feelers.

H H.I...The probofcis.

K. Hairs and briftes. 


\section{The BLUE-BOT TLE FLY, magnified.}

a. Its protuberant pearled eyes.

b. The forehead, fcaly and prominent between the eyes, furnifhed with ftrong black briftles; from this grow two oblong parts $d d$, having joints into the forehead. Thefe in the head of the drone fly were called borns.

e e. Tufts of buhy briftles or feathers growing from $d d$.

$f f$. Four ftrong briftles placed in pairs, and bending toward each other juft above the opening of the mouth.

$g b i$. The trunk or probofcis iffuing from the middle of the mouth, apparently hollow; and by its joints projected or withdrawn at pleafure. From $b$ to $i$ feems divided into two lips, covered with hairs; thefe lips open or thut eafily, and hold little pieces of folid food; but when the fly fucks liquid, the fpreads them open, and applies their hollow part to the body on which fuch liquid is, as on fruit, \&c. whereby they become a kind of pump.

$k \cdot k$. Two little hairy oblong projections growing within the mouth, on each fide the probofcis; thought by Dr. Hooke to be the organs of frnelling or feeling (as $G \mathrm{G}$, in the foregoing plate).

The thorax of this fly is cruftaceous, ftrongly made, its briftles ftanding backward like the quills of a porcupine; has fix legs, covered with a hairy thell, each having eight joints, at the end of which are its claws, and foles which are fpungy.

Of thefe fix legs the fly leldom employs more than four to walk with; the two foremolt anfwering many of the purpofes of arms and hands.

\section{The TUFTED GNA T, nagnified.}

a. Its head, fmall in proportion to its body, confifting chiefly of two cluiters of pearled eyes : juft over thefe eyes, and fomewhat between them, are two black balls, from whence, iffue two long horns, tapering and jointed like the horns, of a lobiter : from thefe joints arife fmall ftiff hairs in a regular order.

b. Is two ocher jointed horns, or feclers, projecting over the probofcis $c$, which is a cafe covered with long fcales, and, when not in ufe, concealed under the throat: its fide opens, and emits four darts occafionally, one being a heath to the other three: they are barbed toward the point. This head, with its appurtenances, is united to the thorax by 2. Thort neck. 


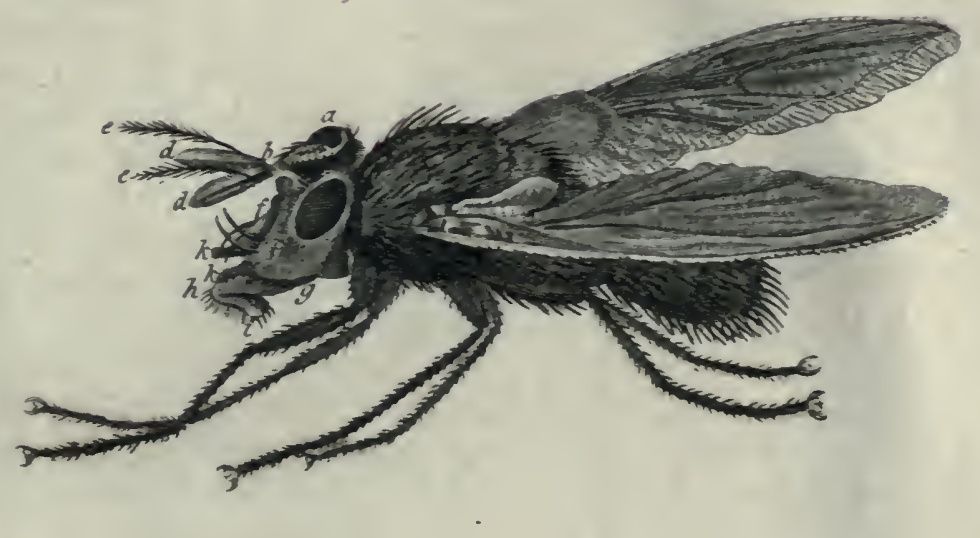

The Blue-bottle Fly

Magnified 


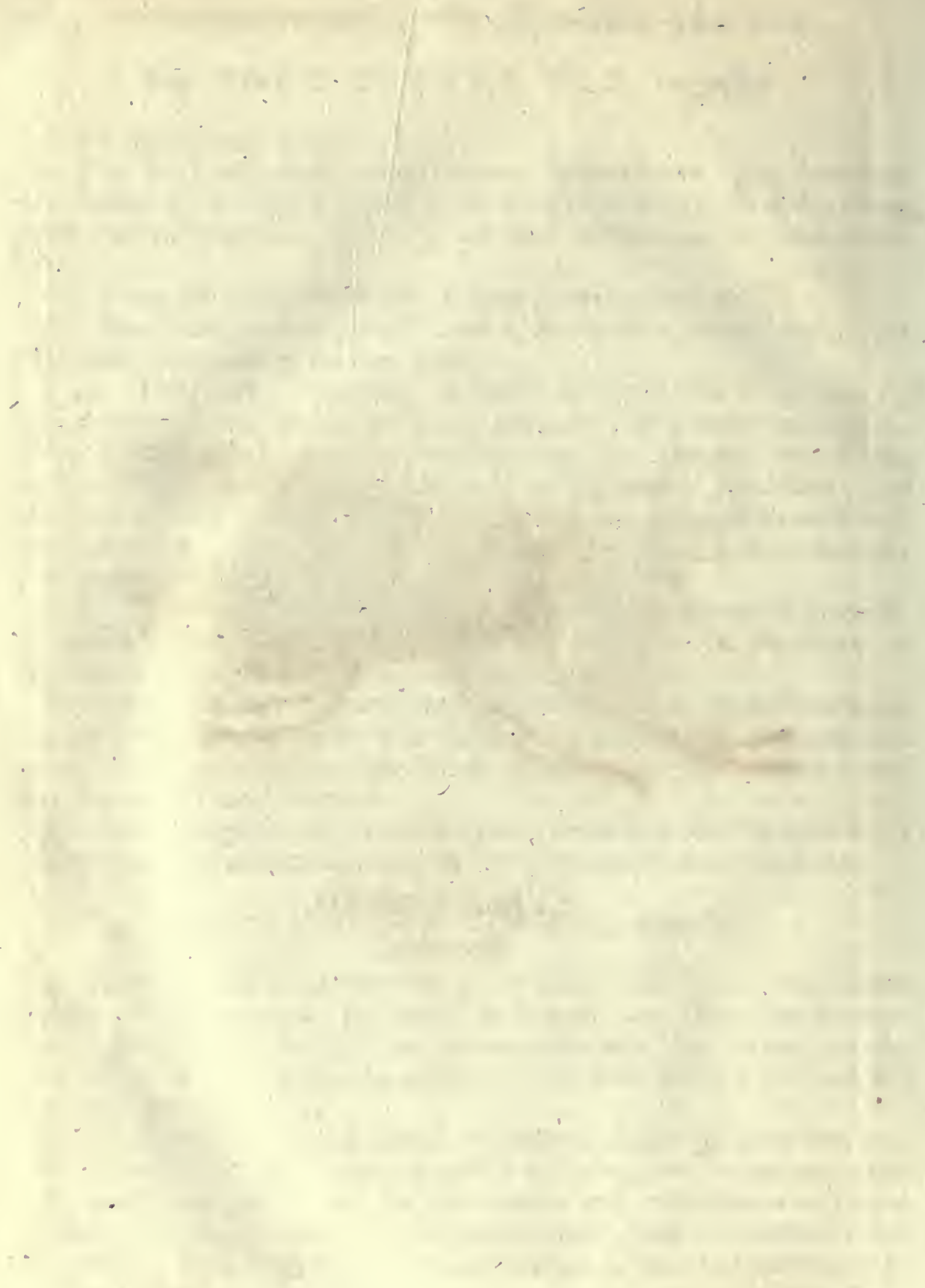




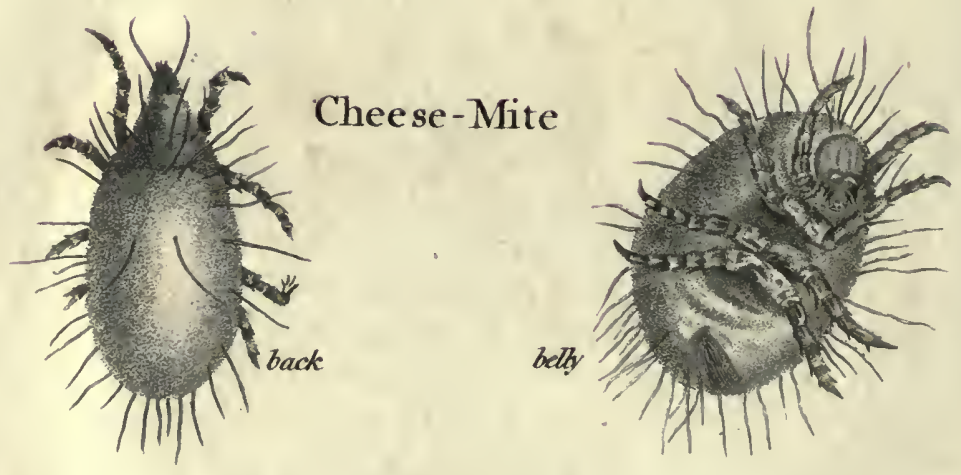


$\sqrt{2}+x^{2}$

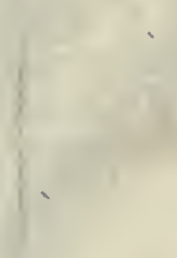

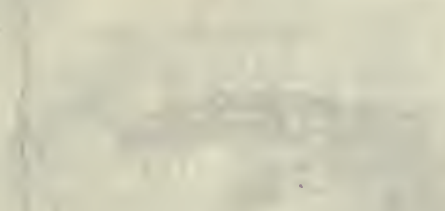
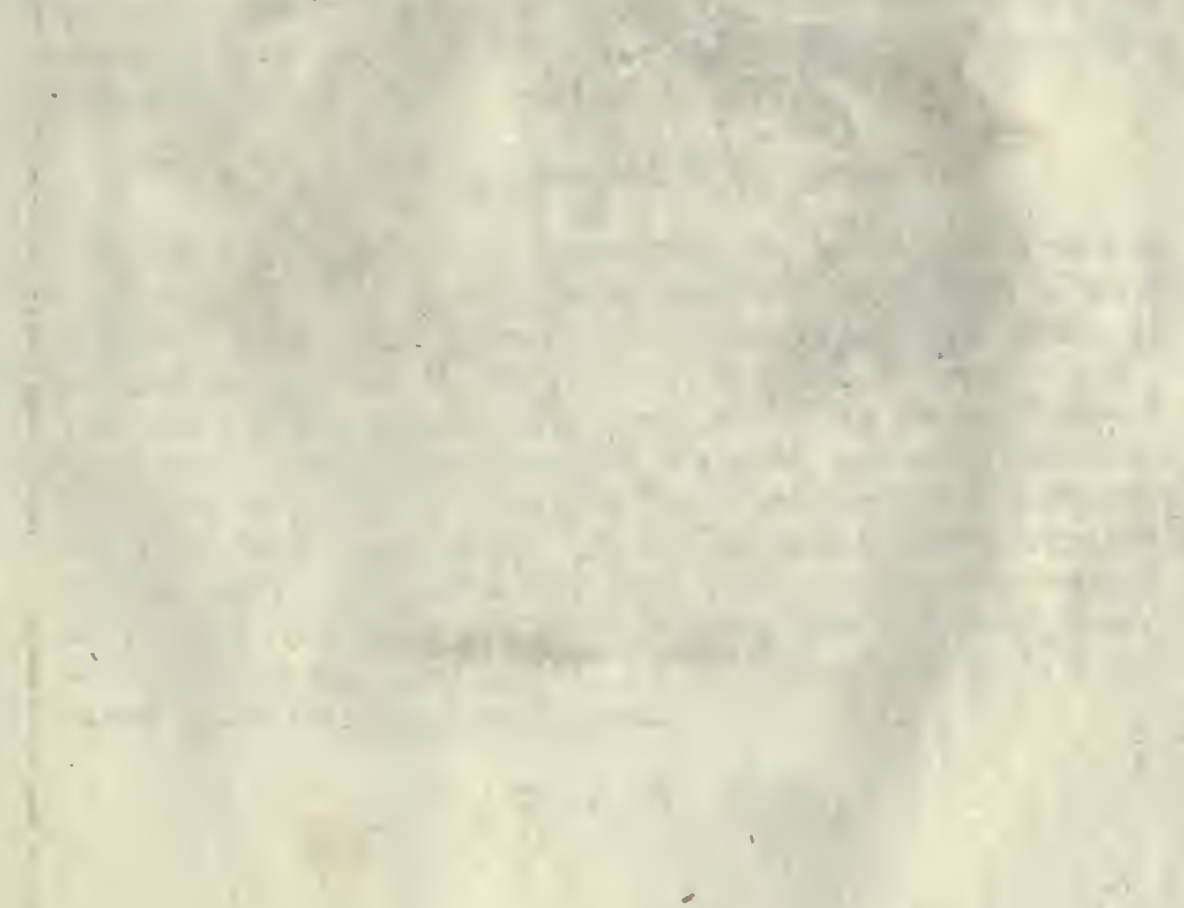


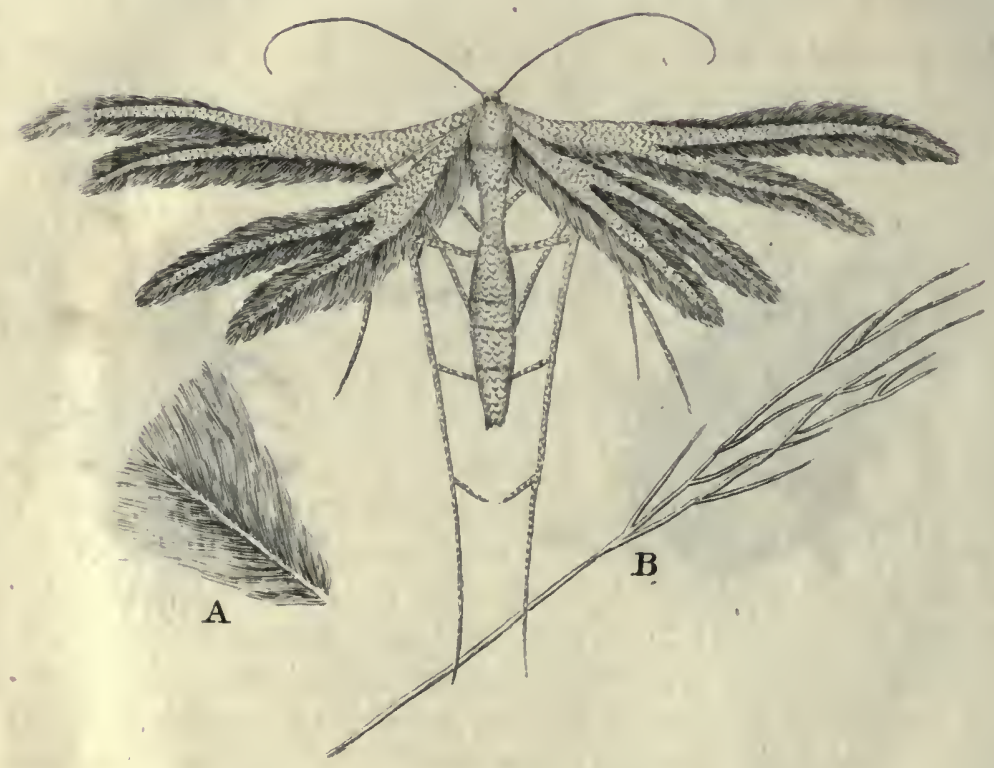

Feather-winged Moth 


\section{TO SURVEYS OF NATURE.}

The legs are long and flender, in number fix, and having fix joints; the feet are feathered, in a manner refembling the fcales of a fifh, with many briftles interfperfed : the wings are edged with a fringe of feathers; under each wing appears a projecting body, thought to be a poife or balance $d$, rounding at its extremity and under the wing. The belly of the creature is long, in nine divifions; fix of them tranfparent, the other three at the end opake. A fmall, clear, white part $g$ is feen beating like the heart in large animals.

\section{The FEATHER-WINGED MOTH, magnified.}

This is a fmall white moth, fometimes found on the nettle: it has four wings, each divided, very elegantly fringed on both fides with exceeding finall white hairs, their ftems inclining backward and downward. The body, legs, horns, and ftems of the wings, are covered over with feathers of different thapes and lizes, which come off when touched. A, reprefents one of thefe feathers; $B$, one of thofe ftalks which fringe the edges of the wings.

\section{CHEESE MITE, magnified.}

BAck. Shape nearly oval, but obtufe; the back covered with one entire thell, fo curiouny polined that it reflects the pictures of all objects around it. The upper parts of the creature are diftinct thells, and capable of being drawn in or thruft out; as is alfo its fnout.

BELI.Y. This thews the under parts of a mite; the head is fmall, has two eyes; the mouth refembles that of a mole, appearing red within; has briftles at the fnout; is fometimes feen munching and chewing the cur, like a Guinea-pig : has eight legs covered with a very tranfparent fnell; each has eight joints, and a very tharp hook or claw at the end; four of thefe legs move the body forward, the other four backward, when neceffary : they are male and female, are oviparous, thed their Rins feveral simes, but never change their forms.

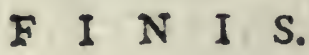


$\sin$

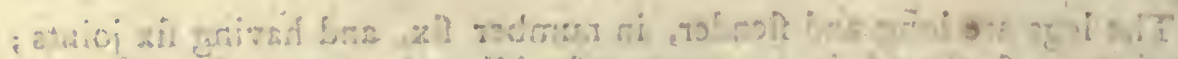

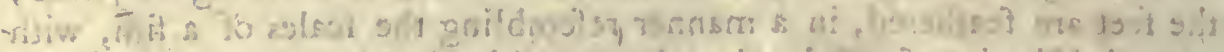

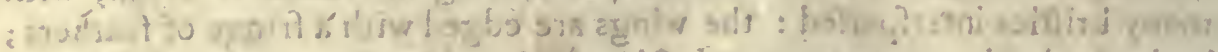

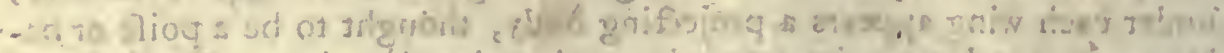

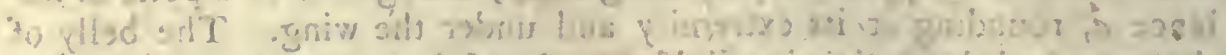

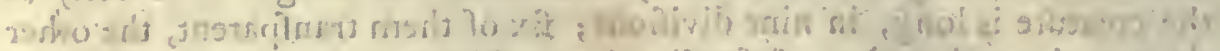

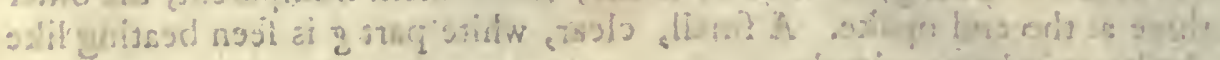

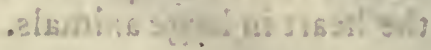

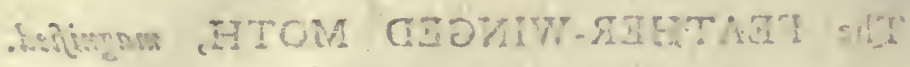

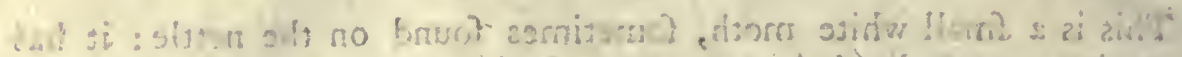

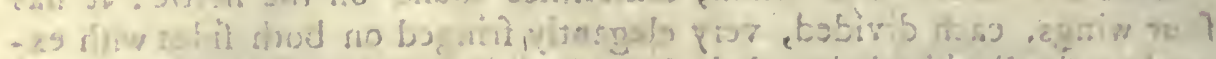

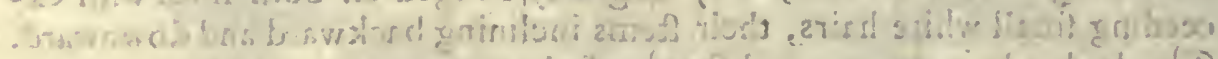

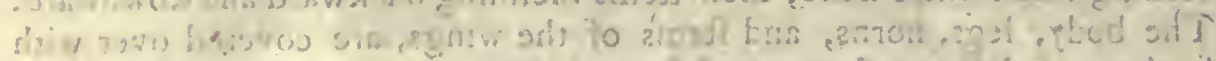

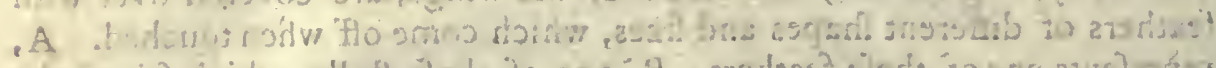

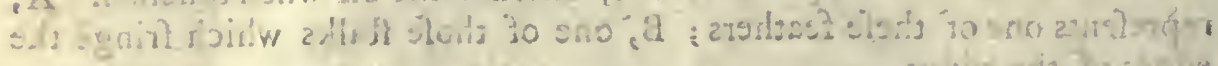

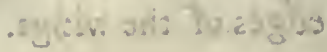

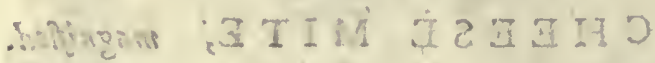

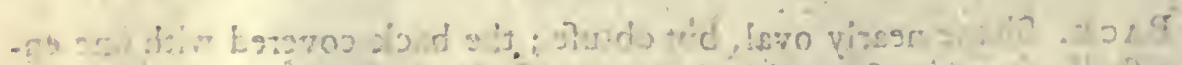

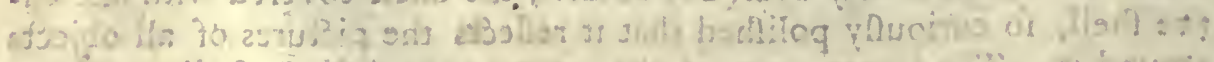

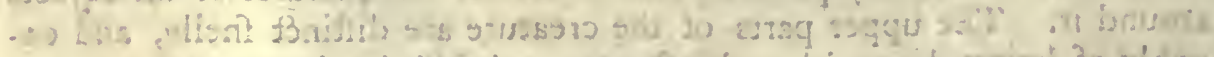

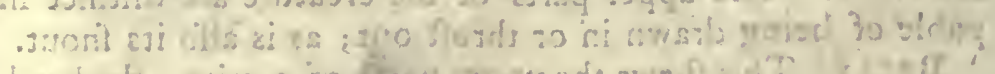

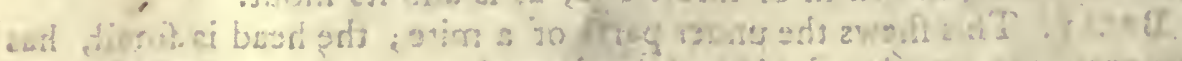

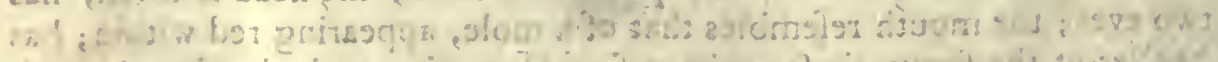

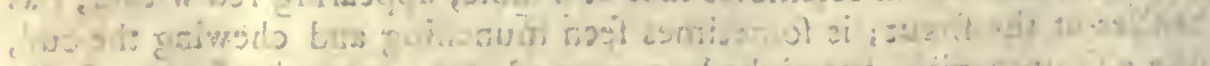

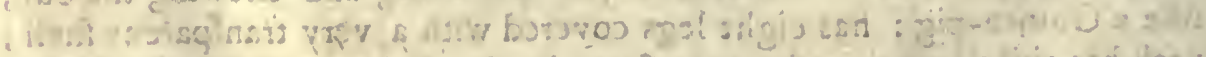

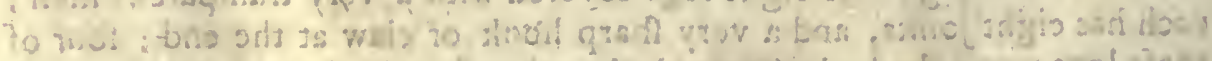

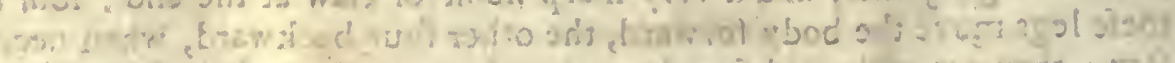

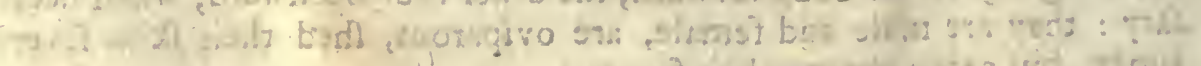

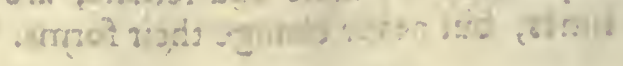

\section{. I. Y I}




\title{
I N \\ D \\ E \\ X
}

T 0 TH

P L A T E S.

\author{
A. Vor. I.—B. Vor. II.
}

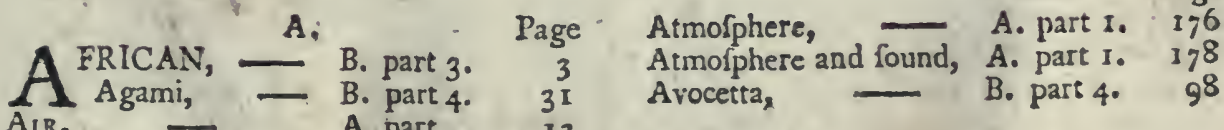
$A_{I R}, \quad$ A. part 12 Ant, - B. part 6. 315 Ants, North-American, Ant-bear, B. part 3. Ant-eater, B. part 3. $=139$ " Bear (white) Antipodes and Horizon, Anhinga, B. part 3. 140 Ape (the long-armed) A. part I. 152 Armadillo, B. part 4. 112 Autums, B. part 3. II3 An-branch A. part 1. 345 Atmofphere and twilight, A, part I. $17+$ B. part 3. 130 Vọ. I. Avocetta,

B.

\begin{tabular}{|c|c|c|c|}
\hline $\begin{array}{l}\text { Bat, } \\
\text { Bear (white) }\end{array}$ & & $\begin{array}{l}\text { B. part 3. } \\
\text { B. part 3. }\end{array}$ & $\begin{array}{l}143 \\
136\end{array}$ \\
\hline Beaver. & - & B. part 3 . & 123 \\
\hline Birds bills, & - & B. part 4 . & 10 \\
\hline Birds feet, & - & B. part 4 . & 10 \\
\hline ck Wolf, & $\longrightarrow$ & B. part i3. & 54 \\
\hline Bluebortle Fly, & & B. part & $3^{68}$ \\
\hline Booby, & & B. part 4. & 118 \\
\hline & & B. part 50 & 197 \\
\hline$A$ & & & $p_{* g}$ \\
\hline
\end{tabular}




\section{$1 \mathrm{~N}$ D E X.}

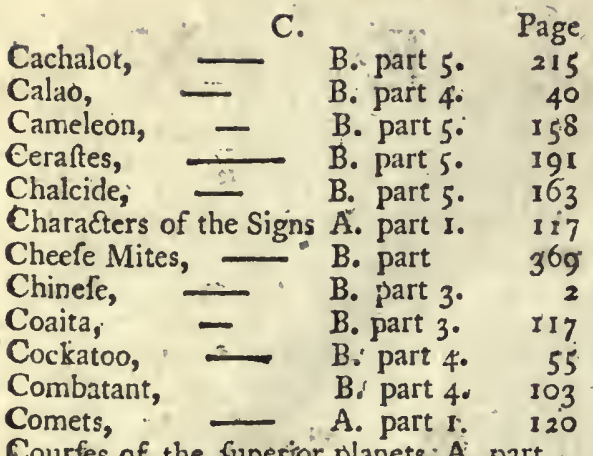

Courfes of the fuperior planets; $A$. part 1, - 108

Courfes of the inferior planets, A. part

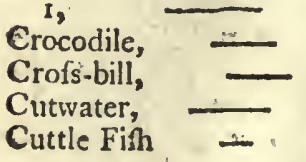

B. part 5. 104

B. part 4. 72

B. part $46 \quad 363$

D.

Diodon, or Glube Mole, B. part 5."

Diver,

B. part 4 .

Dragon;

B. part 5 .

Dromedary, -

Duke (Great):

B. part 3 .

B. part 4 .

E.

Eagie (Great) -

Ear, A. part $2 . \quad{ }_{23} 3 \mathrm{~S}$

EARTH, A. part s. 267 Eclipfes, Lecture.3, plate 4, A. part i. $5^{8}$ Eclipfes of Jupiter's Mloons; Lecture 5, A.: part i.

Eclipfes (and Parallax) Leetnre 3 ; plate

Elephant,

Erchins (Sea)... -

Eye,

Eyes of a Fly,

A part 1.

B.' part 3.

B. part 5 .

A. part.2.

B. part 6 .

F.

Feather-winged Moth,

FEELING,

FIRE,

Flaningo, -

Flea, .. -

Flowers, plate 1.
B. part,

A. part 2.

A. part 1.

B. part 4 .

B. part 6.

B. past 6 .
124

Flowers, plate-2.

Fly (Bluebottle)

Flying Fifl,

Flying Squirrel (Great)

Frog (Tree)

B. part 6.

36

B. part 6. 368

B. part 5. $\quad 238$

B. part 3. $\quad 99$

B. part 5. 172

G.

Gjleote, B. part 5. 157

Garden-bean (Vegetation) B. part 6. 359

Gecko, B: part 5: $16 \mathrm{I}$

Giraffe, - $\quad$ B. part 3. 335

Glacieres; 2 plates; A. part 2. 235

Globe Mole (or Diodon) B. part 5. 229

Gpat (Tufted) B. part 6: 322

Great Eagle,

Great Flying Squirrel,

Great Shark,

B. part 4.

II

Great Duke,

B. part 3 .

99

Guano (or Iguana)

B. part 5.

219

19

155

H.

Halo and Magnet,

Harvert Moon,

B. part 4.

B. part 5 .

A. part i: 35 I

Hainmer-headed Shark, B. part 5 .

Hedge-Hog (Sea)

HEARING,

B. part 5 .

232

230

39

19

Heron, ans

Hottentots,

A. part 2 .

196

Hyena,

B. part 4 .

94

Htimming Birds;

B. part 3 .

3

$6 z$

76

I. $\begin{array}{llr}\text { Jacana, } & \text { R. part 4. } & 107 \\ \text { Jabiru, } & \text { 13. part 4. } & 85 \\ \text { Iguana (or Guano) } & \text { B. part 5. } & 155 \\ \text { Jbis (White) } & \text { B. part.4. } & 84 \\ \text { Jupiter (views of) } & \text { A. part 1. } & \text { s10 }\end{array}$

$5^{6}$

132

257

$23^{6}$

367.

Kamichi,

th.

King of the Vultures,

B. part 4.

86

Laplander, L.

B. part 4 .

B. part 3 .

Leclure 4, plate 5. (Joould. bave, been maxrked LCt. .3, plate 5.) A. part I.

Leciure 14, plate $20^{\circ}$

A. part 1.

280

Lectare: 14 , plate 3 .

A. part $\dot{x}$.

Leclure 14, plate, 4 .

A puist $r$.

A. part $\mathrm{x}$.

Leciure 14, plate 5 .

l.cngth of day and night, A. part $t$. 


\section{$I^{\cdots} \mathrm{N} \quad \mathrm{D} \quad \mathrm{E} \quad \mathrm{X}$}

tong-armed Monkey, B. part 3i Page

\% $\quad \mathbf{M}$.

Nagqt,

Mercury (views of)

Mole (Quadruped)

Mole (Finh)

Monkey (Long-armed)

Morle,

Moth (Feather-yinged) B. part

Mouldinels, — B. part

N.

Nature, front Vol. I.

Night Raven,

North American;

Nautilus, -

B. part $40^{\circ}$

B. part 3.

A. part 18

B. part 3.

B. part 5 .

113

B. part 3 .

B. part 5.

97

3

251

Opoffum, O.

Orb (Sea)

B. part 3.

B. part 5.

Orbit of the Moon and Eclipfes, part $\mathrm{I}$.

Oftrich,

B. part 4 .

A.

I 19

230

54

I3 I

P.

Pangolin,

B. part 3 :

129

Pear (regetation)

Pelican,

B. part 6 .

361

B. part 4 .

Perpective view of the orbit of Satzrn during bis courfe, Lecture 5. A. part

Phafes of the Moon,

A. part t.

114

Phoca (or Seal) -

B. part 3 .

Pinna Mariua, Pholade, B. part 5.

Pipal

B. part 5.

Plan of the Solar Syftem, A. part $\pi$.

Porcupine,

B. part 3 .

Prifmatic colours,

A. part I.

R.

Ratile Snake, pl. I.

Rattle Snake, pl. 2.

Refraction,

Rhinoceros,

Ray,

Rotation of the Earth, A. part 1.

Silamander (ihree-fingered) D. part ;. 16 ? Siturn (views off)
B. "part 5.

B. part 5.

A. part I.

B. part 3 .

B. part 5.

$\mathrm{S}$.

A. part 1. 116

199

199

$33 \mathrm{~S}$

135

223

157

Saw-fifl,

Scorpion;

Sea Hedgehog,

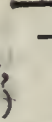

Seal (or Phoca)

Sea Stars,

Sea-orb,

Seasurchins,

Seafons, Leet. vil. pl. 3.

Seafons, Lect. vii. pl. 6 .

Secretary,

SeEIng,

Shark (great)

Shark (Hammer headed)

Shape of the Earth,

Sheep (Wallachian)

Sloth,

SMeiling,

Solar Syftem (plan of)

Spatula (or Spoon-bill) B. part 4,90

Spots in the Sun, Lect. ii. pl. 1.

Spots in the Sun, Lect. ii.

pl. 2.

SPRING,

Springs,

Squirrel (Great Flying)

Summer,

Sword-fifh,

B. part 5,212

B. part $6,=74$

B. part 5,222

B. part $3,1=3$

B. part 3,365

B. part 5,250

B. part 5, 257

A. part I, I 53

A. part $I, I ; S$

B. part 4, 87

A. part 2, 176

B. part 5,219

B. part 5,222

A. part 1, 150

B. part 3,18

B. part 3, 140

A. part 2, 208

A. part 1,75

B. part 4,90 B. part 5, 192 A. part 1, 33

A. part 1,34 A. part $1,1+4$ A. part I, 260 B. part $3, \quad 99$

A. part I, 145 B. part 364

T.

Tasting, $\quad$ A. part 2, $22 \mathrm{I}$

Tides, A. part 1, 264

Three-fingered Salamander, B. part 5, 167

Tortoife, B. part 5, I 4 I

Torpedo, - B. part 5, 223

$75^{\circ}$ Toucan, $\longrightarrow$ B. part 4,4 ,

rog Tree-frog, B. part 5, I72

$3 f^{1}$ Tufted Gnat, $\quad$ B. part 6, 322

V.

Vegetation, (Afh-branch) B. part 6, 360 Vegetation,(Wormwood root)B. part 6, 359 Vegetation, (Pear) B. part 6, $36 \mathbf{1}$ Vegetation, (Vice leaf) B. parr 6, 360 Vegetation, (Garden bean) B. part 6, 359 Views of Jupiter,

Views of Mcrcury,

A. past, 1:0

Views of Venus,

A. part ', 107

Views of Saturn,

A. part 1,107

Vultures, (King of)

A. part i, 116

B. pait is I5 $\because \therefore T=3$, 


\section{$\begin{array}{lllll} & N & D & E & X\end{array}$}

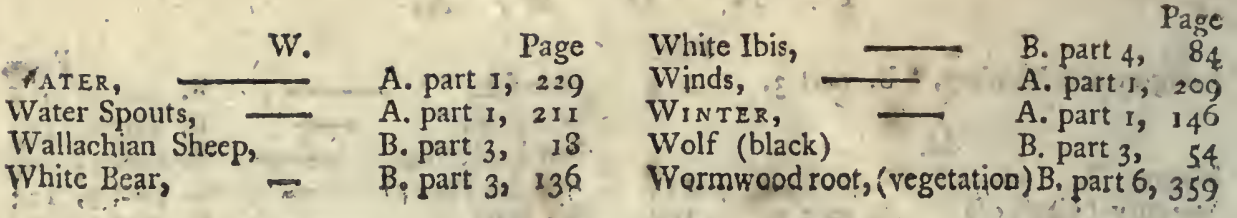



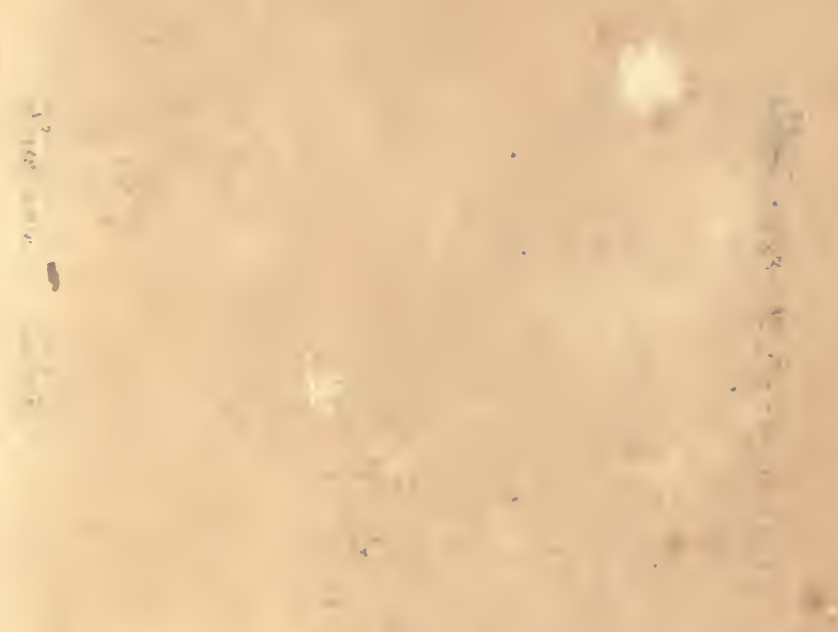

n.
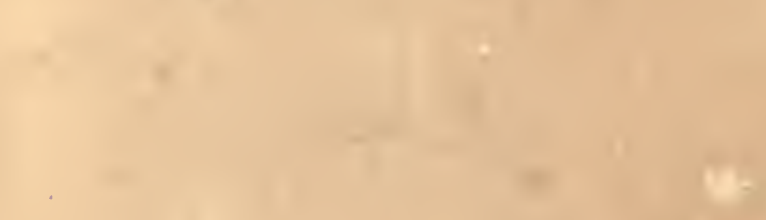

1 1.

$=$

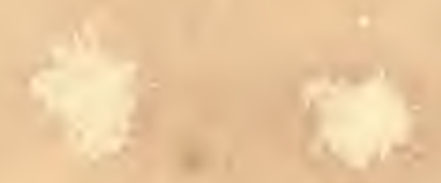




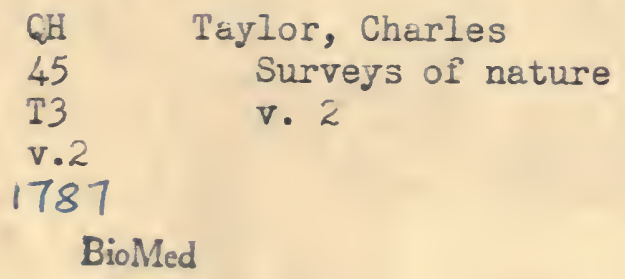

\section{PLEASE DO NOT REMOVE SLIPS FROM THIS POCKET}

\section{UNIVERSITY OF TORONTO LIBRARY}


6.

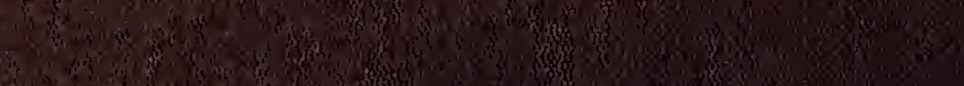

S.

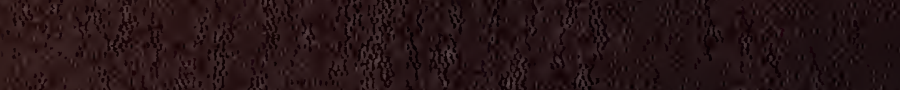

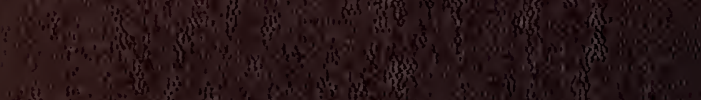

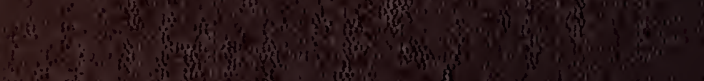

(1)

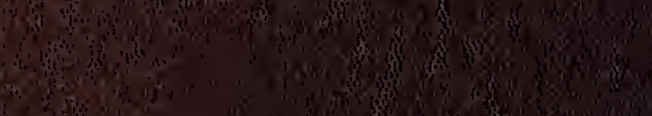

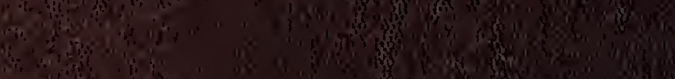

and

2.

7.

(4)

2

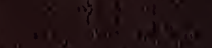

